DEPARTMENT OF THE INTERIOR

UNITED STATES GEOLOGICAL: SURVEY

CHARLES D. WALCOTT, DiRECTOR

\author{
TH E
}

\title{
TRIASSIC CEPHALOPOD GENERA OF AMERICA
}

BY

ALPHEUS HYATT AND JAMES PERRIN SMITH

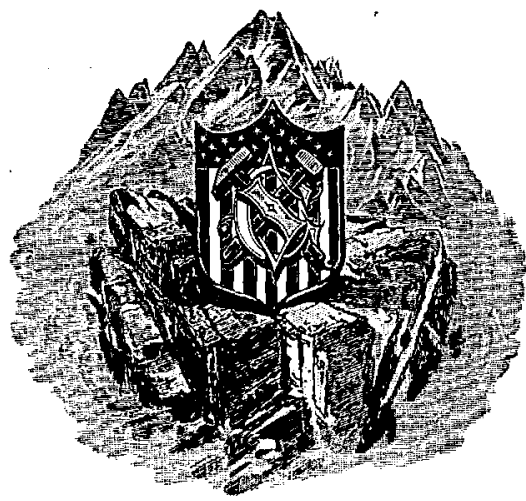

WASHINGTON

GOVERNMENT PRINTING OFEICE

1905 



\section{CONTENTS.}

Letter of transmittal . . . . .

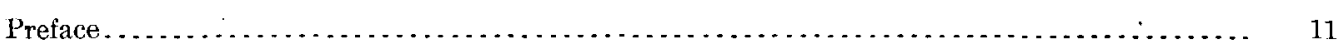

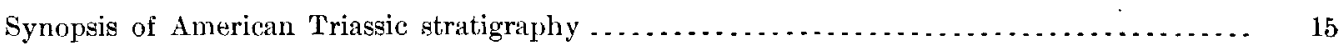

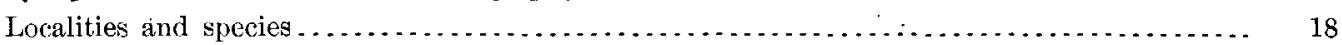

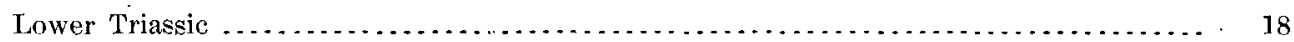

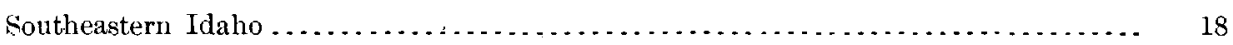

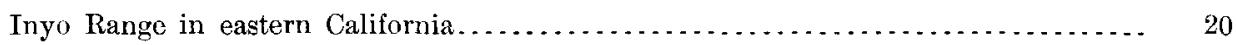

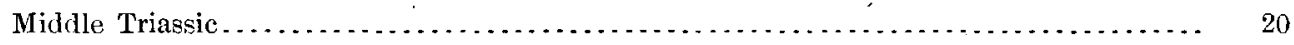

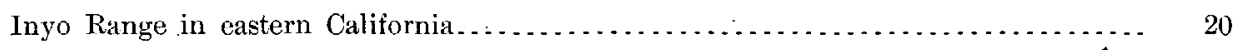

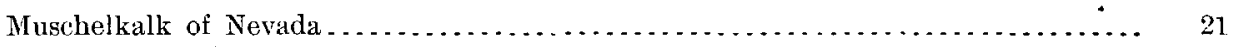

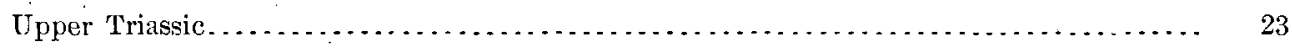

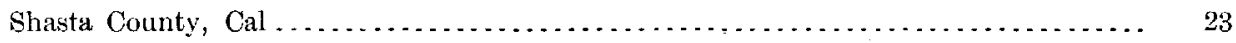

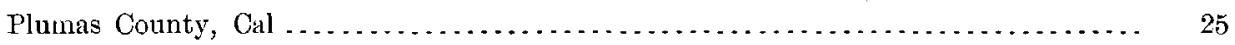

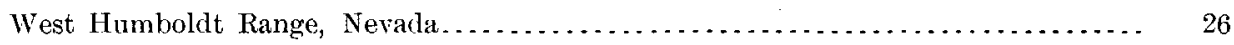

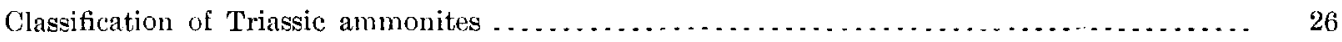

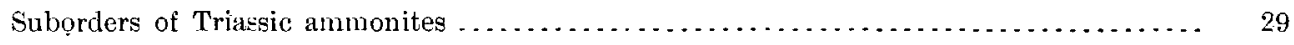

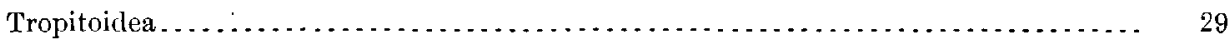

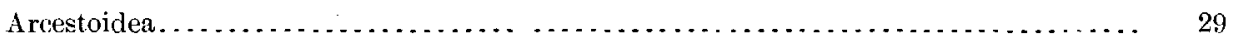

Ptychitoidea. . . . . . . . . . . .

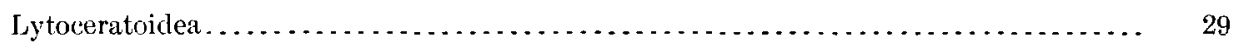

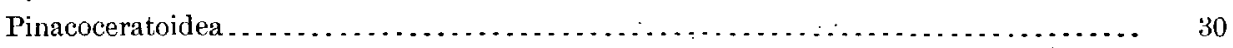

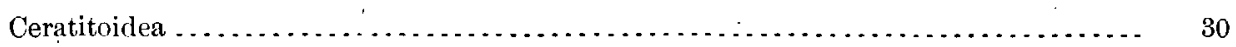

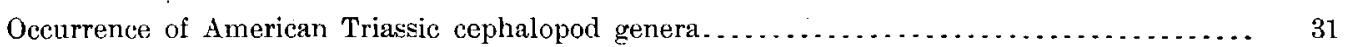

Table showing the relation of Triassic to Paleozoic genera of cephalopods........ 34

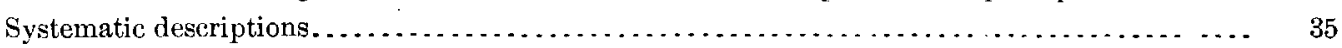

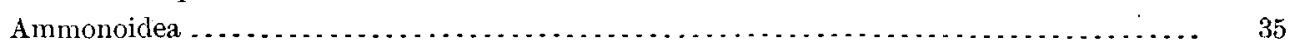

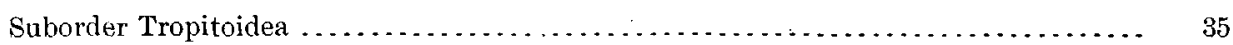

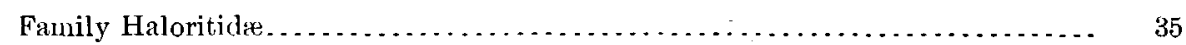

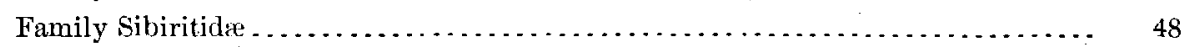

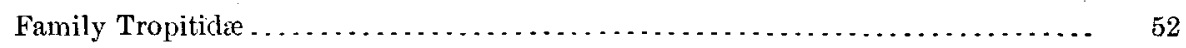

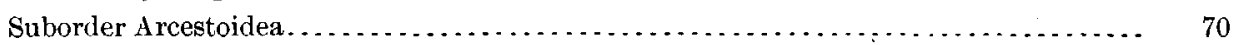

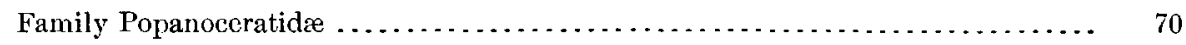

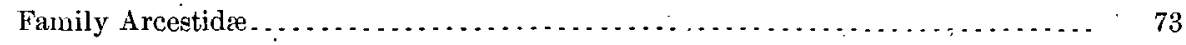

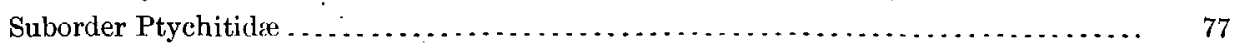

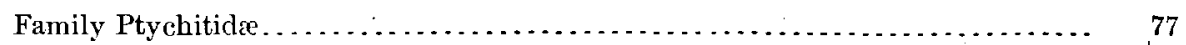

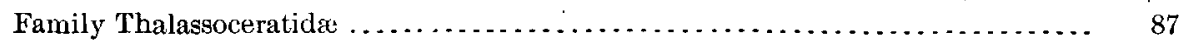


Systematic descriptions-Continued. $\quad$ Page.

Ammonoidea-Continued.

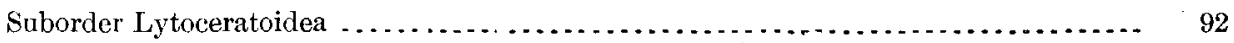

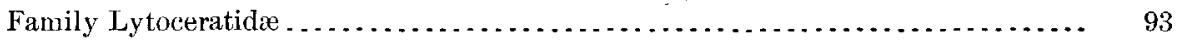

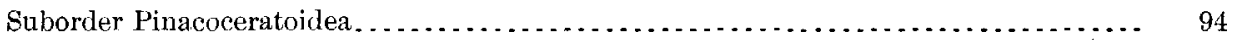

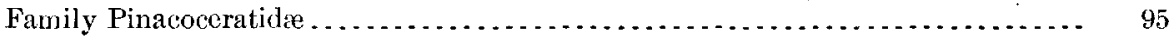

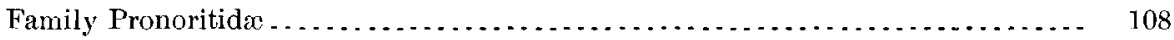

Suborder Ceratitoidea ................................................. 114

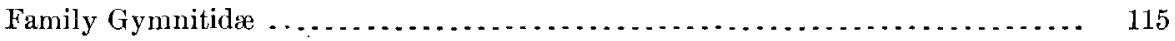

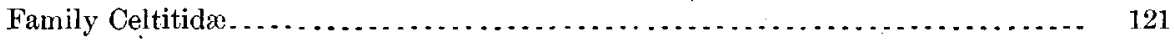

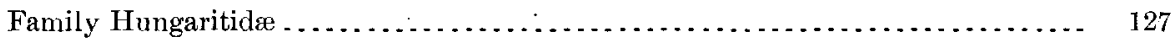

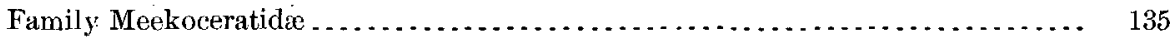

Family Ceratitidæ ............................................... 156

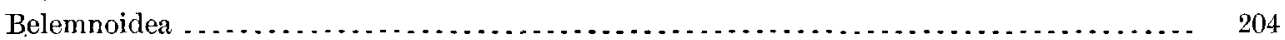

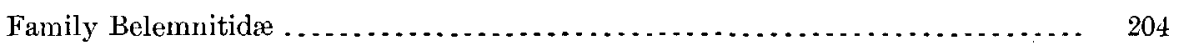

Nautiloidea ..................................................... 205

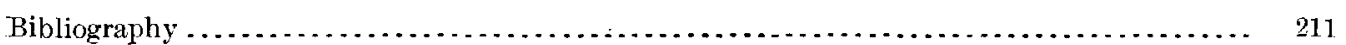

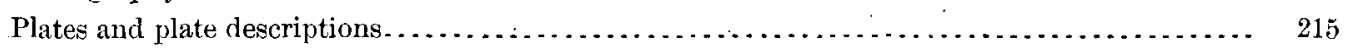

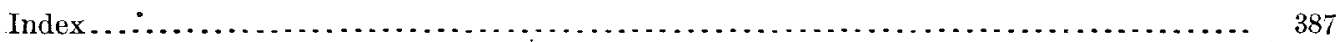




\section{ILLUSTRATIONS.}

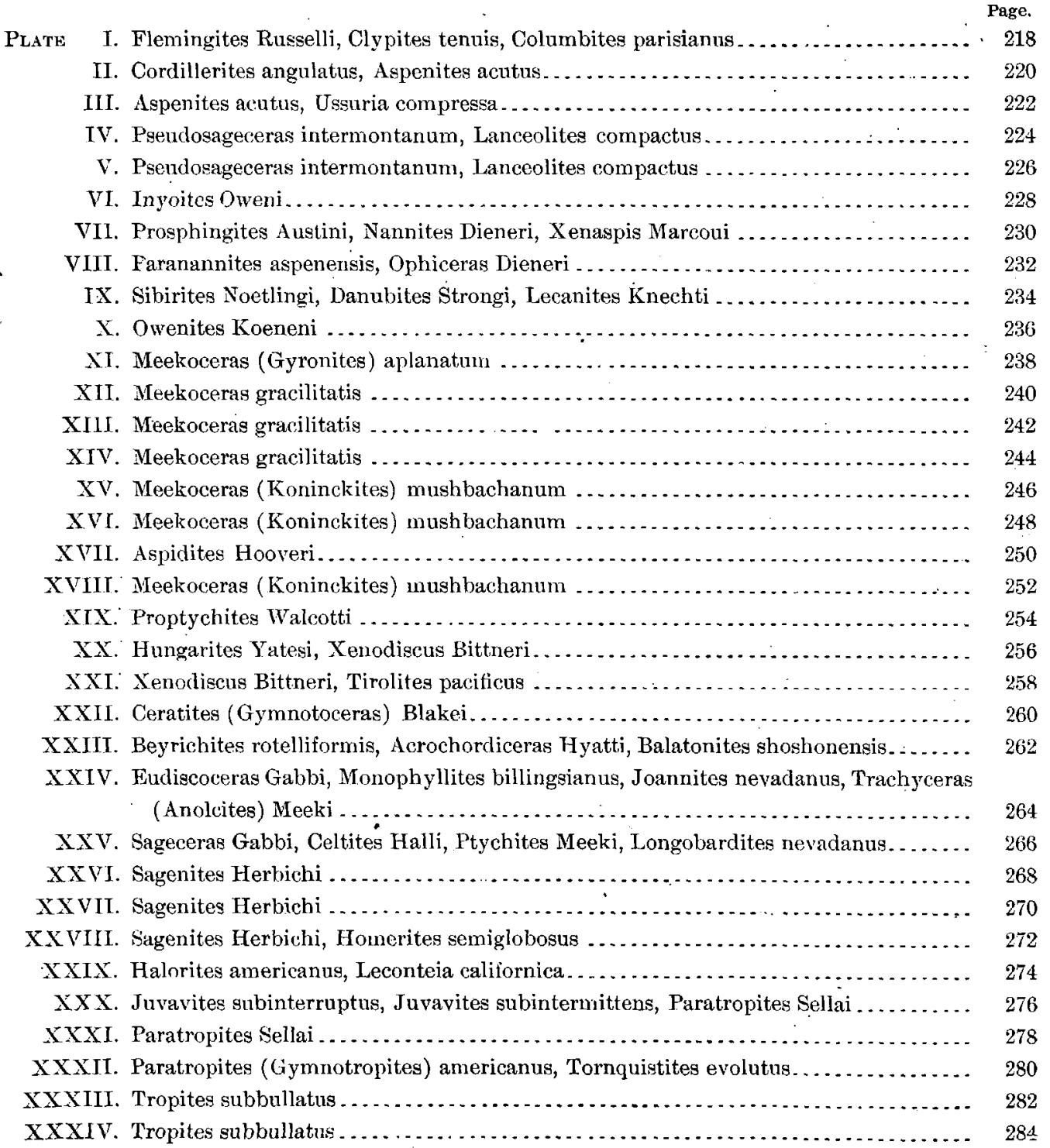




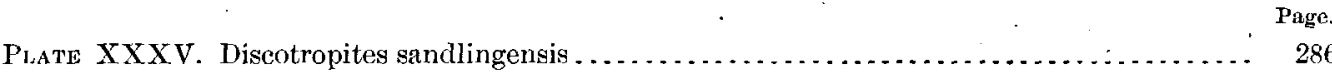

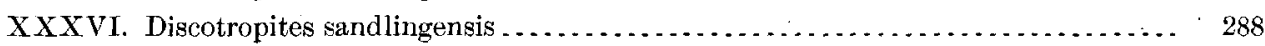

XXX VII. Arcestes pacificus, Hauerites Ashleyi, Dieneria A rthabcri . . . . . . . . . . . . . 290

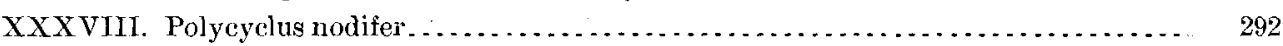

XXXIX. Arpadites Gabbi . . . . . . . . . . . . . . . . . . . . . . . . . . . . . . . . . 294

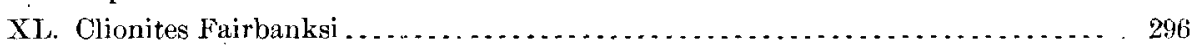

XLI. Clionites Fairbanksi, Clionites (Stantonites) rugosus . . . . . . . . . . . . . . . . 298

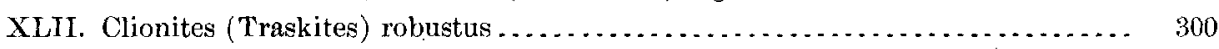

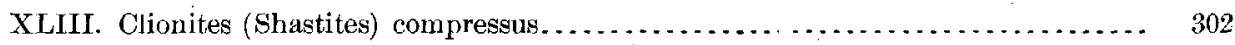

XLIV. Trachyceras (Protrachyceras) Lecontei ......................... 304

XLV. Trachyceras (Protrachyceras) Lecontei . ......................... 306

XLVI. Trachyceras (Protrachyceras) Lecontei, Sirenites Lawsoni . . . . . . . . . . . . . 308

XLVII. Sirenites Lawsoni, Sandlingites Andersoni, Rhabdoceras Russelli . . . . . . . . 310

XLVIII. Atractites Philippii, Orthoceras shastense, Mojsvaroceras Turneri .......... 312

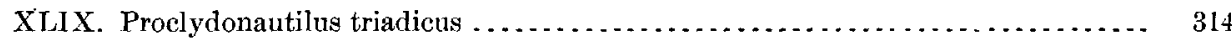

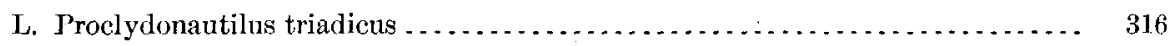

LI. Cosmonautilus Dilleri ..................................... 318

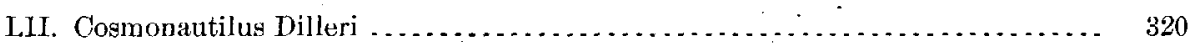

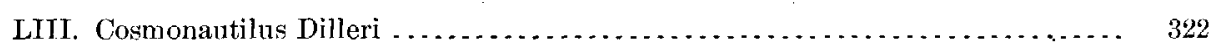

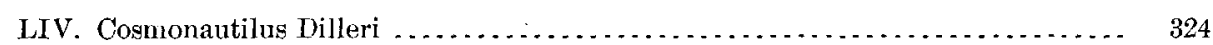

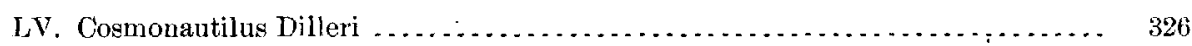

LVI. Arcestes Andersoni, Placites humboldtensis, Rhabdoceras Russelli . . . . . . . . 328

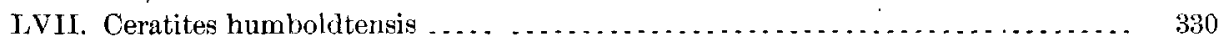

LVIII. Beyrichites rotelliformis, Longobardites nevadanus................... 332

LIX. Trachyceras (Anokites) Meeki . . . . . . . . . . . . . . . . . . . . . . . . 334

LX. Dinarites bonæ-vistce, Futomoceras Laubei, Lecanites Vogdesi $\ldots \ldots \ldots \ldots \ldots . .336$

LXI. Columbites parisianus .................................. 338

TXII. Ophiceras Spencei, Meekoceras (Prionolobus) Jacksoni . . . . . . . . . . . . . . 340

LXIII. Pseudosageceras intermontanum, Meekoceras pilatum . . . . . . . . . . . . . . . 342

LXIV. Paralecanites Arnoldi, Meekoceras aplanatum . . . . . . . . . . . . . . . . . . . . 344

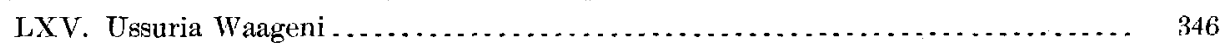

LXVI. Ussuria Waageni . . . . . . . . . . . . . . . . . . . . . . . . . . . . . . . . 348

I,XVII. Ussuria Waageni, Hedenstrømia Kossmati . . . . . . . . . . . . . . . . . . 350

LXVIII. Cordillerites angulatus. . . . . . . . . . . . . . .

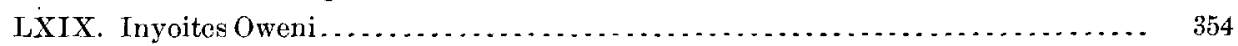

LXX. Flemingites Russelli, Meekoceras gracilitatis, Meekoceras mushbachanum.... 356

LXXI. Cordillerites angulatus, Pronorites praepermicus, P. mixolobus, Sicanites Mojsvari, Propinacoceras Beyrichi........................... 858

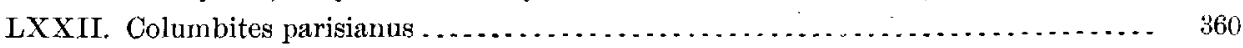

LXXIII. Paranannites aspenensis . . . . . . . . . . . . . . . . . . . . . . . . . . . $\quad 362$

LXXIV. Trachyceras Meeki, Sageceras Gabbi, Sibyllites Louderbacki .............. 364

LXXV. Celtites Halli, Lougobardites nevadanus, Lecanites Vogdesi, Sageceras Gabbi . . 366.

LXXVI. Popanoceras Haugi . . . . . . . . . . . . . . . . . . . . . .

LXX VII. Meekoceras aplanatum, Meekoceras(Prionolobus) Waageni, Paralecanites Arnoldi 370

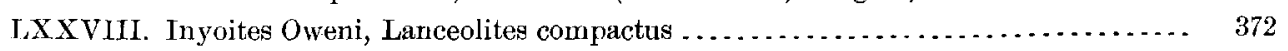


PLate LXXIX. Tropites subbullatus, Tardeceras parvum . . . . . . . . . . . . . . . . . . . 374

LXXX. Tropiceltites Frechi, Paraganides californicus . . . . . . . . . . . . . . . 376

LXXXI. Arcestes pacificus, Dieneria Arthaberi. . . . . . . . . . . . . . . . .

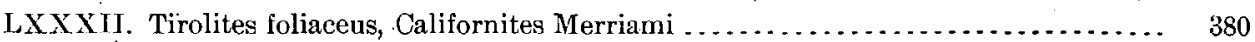

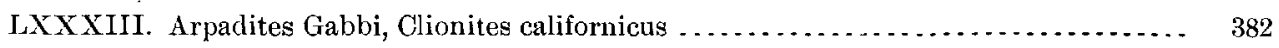

LXXXIV. Hedenstromia Kossmati .................................... 384

IXXXV. Ussuria Waageni, Thalassoceras Phillịpsi, T. Gemmellaroi, Dimorphoceras atratum, D. Gilbertsoni, Ussuria Iwanowi, Cordillerites angulatus . . . . . .... 386

FIG. 1. Table showing the relation of Triassic to Paleozoic genera of cephalopods ............. 34 



\section{LETTER OF TRANSMITTAL.}

\section{Department OF THE INT'TERToR, United States Geological Survey, Waskington, July 21, 1904.}

SIR: I transmit herewith the manuscript of. a paper by Alpheus Hyatt and James Perrin Smith, entitled "The Triassic Cephalopod Genera of America," and request that it be published as a professional paper.

In this paper every genus of cephalopods known to occur in the Triassic of America is described, and a representative species under each genus is described and figured. Most of the material herein described is new, largely collected by Professor Smith, but all the available collections. in the United States have been utilized.

Very respectfully,

$$
\begin{gathered}
\text { C. W. HaYes, } \\
\text { Geologist in Charge of Geology. }
\end{gathered}
$$

Hon. Charles D. Walcott,

Director United States Geological Survey. 



\section{P RE F A CE.}

For the last twelve years the authors have been working on the Triassic faunas of America, both in the field and in the museum. They have visited nearly all the localities in the United States where Triassic cephalopods have been found. Collections were made by Professor Hyatt in the Lower 'Triassic of the Aspen Ridge in southeastern Idaho, in the Middle Triassic of the West Humboldt Range of Nevada, and in the Upper Triassic of the Genesee Valley, Plumas County. Collections have been made by the writer in the Lower Triassic of the Aspen Ridge, Idaho, and in the Inyo Range, Inyo County; in the Middle Triassic of the Inyo Range, California, and of the West Humboldt Range of Nevada; and in the Upper Triassic of Plumas and Shasta counties, Cal., and of the West Humboldt Range of Nevada.

In addition to the above collections, fossils have been collected by Dr. C. D. Walcott and Mr. H. W. Turner from the Triassic of the Inyo Range, California, and by Dr. H. W. Fairbanks, from the Upper Triassic of Shasta County, Cal.

The Museum of Comparative Zoology has loaned the Triassic ammonites in the Whitney collection, from Nevada and California, and the United States National Museum has given the use of the material collected by various official surveys from the Lower Triassic of Idaho, the Middle Triassic of Nevada, and the Upper Triassic of Shasta and Plumas counties, Cal.

In addition to the field and museum studies of the authors in America, Professor Hyatt spent three weeks in 1897 studying the Triassic ammonites in the museum of the Geological Survey of Austria in Vienna, under the guidance of Dr. E. von Mojsisovics, and was thus enabled to make a careful comparison of the American and European faunas that were available at that time.

The work of writing the descriptions of genera and species has fallen to the writer, but the inspiration and general supervision of the work was Professor Hyatt's contribution. His sudden death before the completion of the work prevented his taking the active part, in the preparation that he had hoped to do. This work will therefore be found to have many shortcomings that more extended consultation with Professor Hyatt would probably have prevented. 
- It will be noted that the classification of Triassic ammonites here used differs materially from that proposed by Professor Hyatt in Eastman's translation of Zittel's Text-book of Palcontology (1900); but that classification was elaborated before Professor Hyatt had seen much of the material treated in the present work, and it was found inadequate to express the relations of the American faunas. With characteristic generosity Professor Hyatt freely consented to use the classification adopted in this paper, of the progress of which he was kept constantly informed by correspondence. The writer desires to acknowledge his gratitude to Professor Hyatt for his kindly criticism, his open-hearted attitude toward ideas differing somewbat from his own, and his generosity as a collaborator. His great learning only made him all the more modest and ready to make a friendly. compromise in settling disputed points.

The writer desires to acknowledge his indebtedness to the following gentlemen:

Hon. Charles D. Walcott, Director of the United States Geological Survey, for the collections of Triassic ammonites from Inyo County, Cal.;

Dr. T. W. Stanton, of the United States Geological Survey, and Mr. Charles Schuchert, of the United States National Museum, for the use of the collections of those institutions;

Mr. H. W. Turner, for the collections of Triassic fossils made by him in Inyo County, Cal.;

Dr. H. W. Fairbanks, of Berkeley, Cal., for the use of the collection of Triassic fossils made by him in Shasta County, Cal.;

Dr. E. von Mojsisovics, of Vienna, Austria, for valuable assistance in comparing ' the American with the Triassic faunas;

Dr. John C. Merriam, of the University of California, for access to the Triassic fossils in the University Museum, and for assistance in the field;

Mr. Frank M. Anderson, of the California Academy of Sciences, for assistance in the field and for the use of Triassic fossils collected by him in Nevada;

Mr. A. M. Strong, of Independence, Cal., for assistance in the field and for the use of collections made by him in Inyo County, Cal.;

Dr. Ralph Arnold, of the United States Geological Survey, for assistance in the field.

Special acknowledgment is due the artists of the United States Geological Survey for the skill and fidelity with which they have prepared the illustrations for this paper. It was not possible in all cases for the artist to sign the plate, for drawings by several artists are included in many of the plates. The drawings were made by Mr. H. Chadwick Hunter, Miss Mary King Sumner, Miss Maud Baggett, Mr. H. Hobart Nichols, and Miss Marion Page. 
Since the completion of a final report on all the marine Triassic faunas will consume a long time, and since the ammonites are the most abundant elements of these faunas, it has been thought desirable to make the results of these studies available for geologists. In this work every genus of cephalopods known to occur in American Triassic strata is described, and a representative species under each one is described and figured.

James Perrin Smith.

Stanford Universiti, Californa, July, 1904. 



\title{
THE TRIASSIC OEPHALOPOD GENERA OF AMERICA.
}

\author{
By Alpheus Hratt and J. P. Sмith.
}

\section{SYNOPSIS OF AMERICAN TRIASSIC STRATIGRAPHY.}

The marine Triassic section of America is unusually complete, and its thickness compares favorably with that of any other region. All three subdivisions-Lower, Middle, and Upper Triassic--are represented by calcareous deposits, aggregating approximately 4,000 feet in thickness. Of this amount, about 800 feet belong to the Lower Triassic, about 1,000 feet to the Middle Triassic, and about 2,000 feet to the Upper Triassic.

The entire section is not represented at any one locality, nor is the thickness of each division constant. Furthermore, the marine Triassic is not everywhere developed as a calcareous formation. In the United States the Triassic system is represented by marine deposits only in the Western States, in Idaho, Nevada, Oregon, and California.

The Lower Triassic is known only in Idaho and southeastern California, where about 800 feet of shales and limestones contain fossils characteristic of this series. The most important genera are Meekoceras, Danubites, Cohumbites, Flemingites, Aspidites, Lecanites, Ophiceras, Nannites, Ussuria, Pseudosageceras, Hedenstromia, Cordillerites, Tirolites, and Proptychites, most of which are represented by closely related species in the Lower Triassic of India and Siberia.

The Middle Triassic occurs chiefly in Nevada and southeastern California. In the Inyo Range, southeastern California, about 200 feet of shaly limestones contain the following genera characteristic of the lower horizon of the Middle Triassic: Acrochordiceras, Xenodiscus, Hungarites, Ptychites, Tirolites, Ceratites, and Parapopanoceras.

In central Nevada, in the West Humboldt Range, the higher beds of the Middle Triassic are represented by about 800 feet of shaly limestones, in which the most 
characteristic genera are Ceratites, Anolcites, Dinarites, Danubites, Celtites, Hungarites, 'Beyrichites, Acrochordiceras, Balatonites, Eutomoceras, I'tychites, Joannites, Lecanites, and Atractites among the cephalopods, Daonella among pelecypods, and Cymbospondylus among vertebrates.

The Upper Triassic is best represented in northern California, where the Hosselkus limestone and the shales below and above this formation contain characteristic fossils. The Hosselkus limestone and the interbedded shales have a thickness approximating 500 feet. Fossils are very abundant throughout this formation, although much better preserved near the base. The best known fauna belongs to the zone of Iropites subbullatus, and contains as its most important members the following genera: Tropites, Paratropites, Discotropites, Juvavites, Sagenites, Leconteia, Trachyceras, Clionites, Arpadites, Polyoyclus, Metatirolites, Hauerites, Dieneria, Arcestes, Paraganides, Proclydonautilus, Cosmonautilus, and Atractites among cephalopods, Halobia among pelecypods, and Shastasaurus among the vertebrates.

Above the Hosselkus limestone lie the Pseudomonotis slates, of unknown thickness, characterized by Halorites, Rhabdoceras, Arcestes, and Pseudomonotis.

In the West Humboldt Range in Nevada the Star Peak limestone, about 1,200 feet thick, appears to represent the Hosselkus limestone, although very few fossils have ever been found in it. Above the limestones lie the Pseudomonotis beds, about 800 feet of shales and shaly limestones, in which are found Pseudomonotis subcircularis, Rhabdoceras, Halorites, Placites, and Arcestes, an association characteristic of the Noric horizon. 
$\approx$

Table showing relations of Americun Triassic faunts.

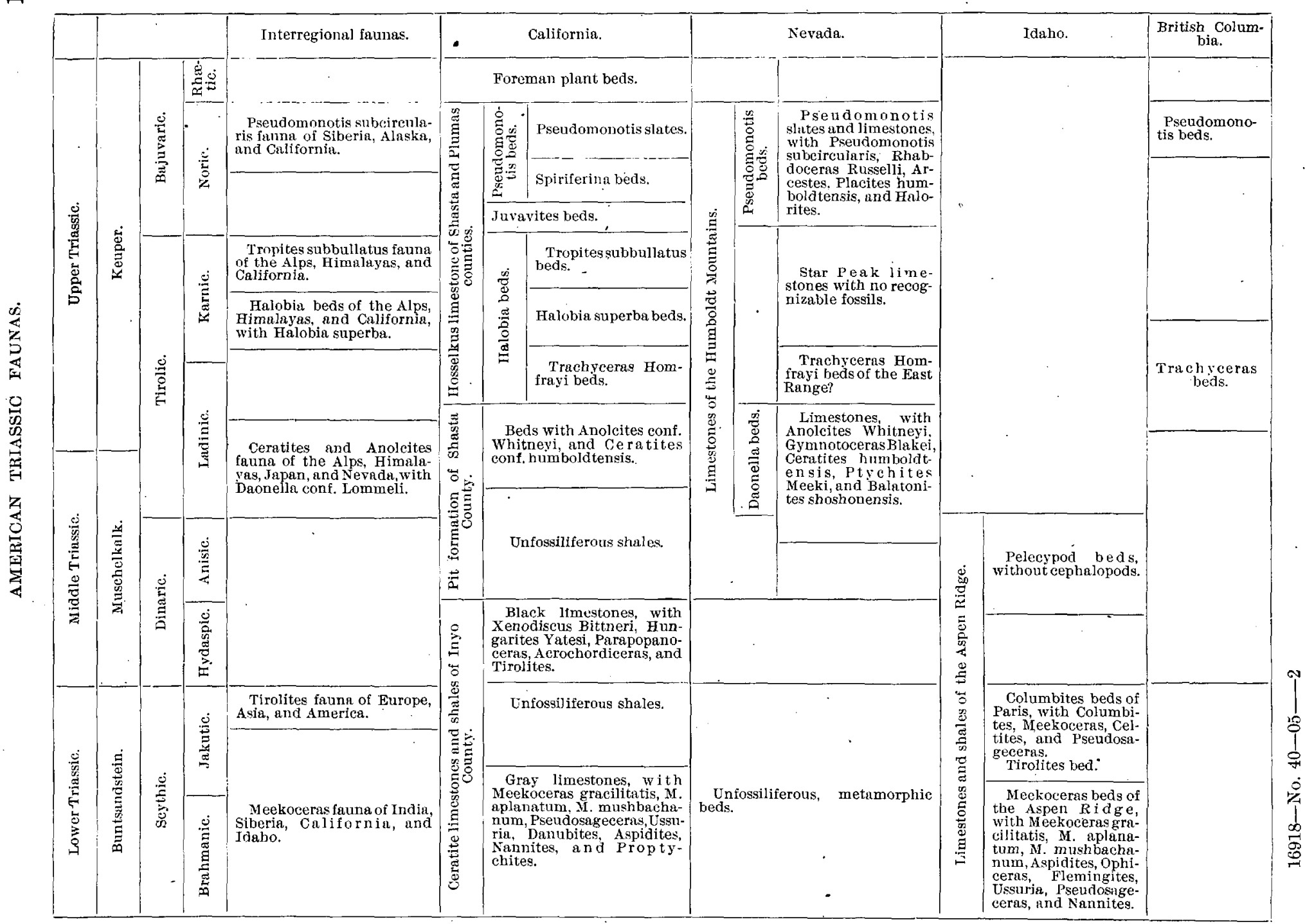




\section{LOCALITIFS AND SPECIES. \\ LOWER TRIASSIC.}

Southeastern Idaho.-Many years ago Dr. A. C. Peale discovered in southeastern Idaho and southwestern Wyoming a series of fossiliferous beds lying below the Red Beds and above the Carboniferous limestone. The fossils found in this formation were described by Dr. C. A. White, ${ }^{a}$ and assigned to the Lower Triassic. Cephalopods were found at two places: Locality No. 1, in southeastern Idaho, 65 miles north of the Utah line, 18 miles west of the Wyoming line, and 5 miles south of John Gray's Lake; locality No. 2, 15 miles east of south from locality No. 1.

The section at locality No: 1, according to Dr. C. A. White, is as follows:

Section near John Gray's Lake, Idaho.

A. (Uppermost beds.) Limestones and shales, with Terebratula semisimplex White, T, angustata) Feet.

Hall, and Aviculopecten idahoensis Meek..................................... 1,000

B. Limestones, with Eumicrotis curta and Aviculopecten idahoensis . . . . . . . . . . . . . . . . .

C. Greenish and reddish shales and sandstones, with Aviculopecten Pealei White............. 850

D. Bluish-gray limestones, fossiliferous at the base, with Meekoceras gracilitatis White, M. mush-

bachanum White, Arcestes ? cirratus White .............................. 700

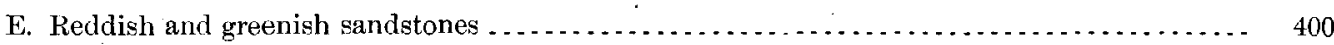

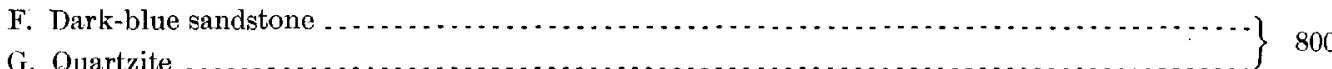

H. Massive gray limestone ...........

At locality No. 2 Meekoceras gracilitatis White and M. aplanatum White were found in limestone similar to that marked $D$. in locality No. 1. This part of the section unquestionably belongs to the Lower Triassic, although it is not likely that the entire thickness of beds there is referable to this division.

In 1888 Alpheus Hyatt discovered a third locality for Lower Triassic ammonites in the same region, in the Aspen Ridge, Wood Canyon, near the divide, about 9 miles east of Soda Springs. In 1900 and $1903 \mathrm{~J}$. P. Smith also visited the same locality, which lies only a few miles southwest of locality No. 2 of White. All species listed here were taken out of a bed of limestone not more that 15 feet thick. The joint collection of Hyatt and Smith yielded the following ammonites in addition to a large number as yet unnamed:

a Contrib. to Invert. Pal. No. 5; Triassic fossils of southeastern Idaho: Twelfth Ann. Rept. U. S. Geol, and Geog. Surv. Terr., pt. 1, 1880, pp. 105-118. 
Species found in the Meekoceras beds, Aspen Ridge, Idaho.

Meekoceras gracilitatis White.

Meekoceras, 3 new species.

M. (Koninckites) mushbachanum White.

M. (Gyronites) aplanatum White.

M. (Gyronites), 2 new species.

Aspidites sp. nov.

Paralecanites Amoldi Hyatt and Smith.

Flemingites Russelli Hyatt and Smith.

Ophiceras Dieneri Hyatt and Smith.
Lanceolites compactus Hyatt and Smith. Clypites tenuis Hyatt and Smith.

Cordillerites angulatus $\mathrm{H}$ yatt and Smith.

Pseudosageceras intermontanum Hyatt and Smith.

Aspenites acutus Hyatt and Smith.

Hedenstromia Kossmati Hyatt and Smith.

Paranannites aspenensis Hyatt and Smith.

Nannites sp. nov.

Ussuria Waageni Hyatt and Smith.

This fauna is intimately related to the Lower Triassic faunas of India and eastern Siberia, with several species that may even be identical with those from Asia. It contains several genera hitherto known only from the Lower Triassic of India, and others previously found only in the Proptychites beds of Ussuri Bay in Siberia; it is therefore referred with certainty to the upper part of the Brahmanic, or the Ceratite marls and the lower part of the Ceratite sandstone of the Salt Range of India.

Mr. R. S. Spence has recently collected some Lower Triassic ammonites at a locality 1 mile west of Paris, Bear Lake County, southeastern Idaho. These fossils were sent to J. P. Smith for identification. J. P. Smith also visited this locality, and the joint collections yielded the following species, besides several as yet unnamed:

$$
\text { Species from the Columbites beds, at Paris, Idaho. }
$$

Columbites parisianus Hyatt and Smith.

Meekoceras pilatum Hyatt and Smith.

Prionolobus Jacksoni Hyatt and Smith.

Pseudosageceras intermontanum Hyatt and Smith.

Ophiceras Spencei Hyatt and smith.
Celtites sp. nov.

Pseudomonotis idahoensis White.

Rhynchonella sp. nov.

Lingula sp. nov.

At the same locality, but in the underlying Meekoceras beds, were found:

Meekoceras gracilitatis White.

M. (Gyronites) aplanatum White.

Meekoceras mushbachanum White.

Ussuria Waageni Hyatt and Smith.
Paranannites aspenensis Hyatt and Smith.

Flemingites cirratus White.

Pseudosageceras intermontanum Hyatt and Smith. Some undetermined brachiopods and pelecypods.

The Columbites beds form the highest horizon known in the Lower Triassic of America, and are probably comparable to the Olenek limestone of northern Siberia, and the Hedenstromia beds of India. A few feet below them, and about 100 feet above the Meekoceras beds are found shales, in which occur:

Tirolites aff. cassianus Quenstedt. Tirolites aff. Smiriagini Mojsisovics.
Tirolites aff. Haueri Mojsisovics.

Pseudomonotis jdahoensis Meek. 
Inyo Range in eastern California:-All the Lower Triassic species from California were collected in the Inyo Range on the east side of Owens Valley, Inyo County, $1 \frac{1}{2}$ miles east of the Union Spring, near the McAboy trail over the Union Wash, leading into the Salinas Valley. This locality is about 3 miles east of Skinner's ranch and 15 miles southeast of Independence. The fossils were all found in a thin bed of gray limestone not more than 12 feet thick that outcrops on the south side of the canyon near the trail.

Species collected from Lower Triassic rocks of Inyo Range, California.

Sibirites Noetlingi Hyatt and Smith. Prosphingites Austini Hyatt and Smith. Nannites Dieneri Hyatt and Smith. Owenites Koeneni Hyatt and Smith. Proptychites Walcotti Hyatt and Smith. Ussuria compressa Hyatt and Smith. Aspenites acutus Hyatt and Smith. Pseudosageceras intermontanum Hyatt and Smith. Lanceolites compactus Hyatt and Smith. Xenaspis Marcoui Hyatt and Smith.
Inyoites Oweni Hyatt and Smith. Paralecanites Arnoldi Hyatt and Smith. Lecanites Knechti Hyatt and Smith. Meekoceras gracilitatis White. M. (Gyronites) aplanatum White. M. (Koninckites) mushbachanum White. Prionolobus Waageni Hyatt and Smith.

Prionolobus Jacksoni Hyatt and Smith. Aspidites Hooveri Hyatt and Smith. Danubites strongi Hyatt and Smith.

Besides these were found severa ceras, Ophiceras, Aspidites, etc.

This fauna has a number of species and most of the genera in common with that of the Aspen Ridge in southeastern Idaho, and may be correlated with the Meekoceras beds. The differences are slight and not greater than might well exist between the faunas of two beds of the same age in the same province but separated by 600 miles.

The beds assigned to the Lower Triassic in Inyo County have a thickness approximating 800 feet, while the corresponding beds in Idaho are about 700 feet thick.

MIDDLE TRIASSIC.

The Inyo Range in eastern California.-This locality is on the east side of Owens Valley, Inyo County, a mile east of the Union Spring, on the south side of the McAboy trail leading over the Union Wash to Salinas Valley. This locality is about 3 miles east of Skinner's ranch, and 15 miles southeast of Independence. The fossils were all taken from a bed of dark limestone, which is not over 4 feet thick and which lies abont 800 feet above the stratum from which the Lower Triassic fossils were collected, in a series of calcareous shales conformable with the Lower Triassic. The fossiliferous outcrops are on the south side of the canyon, and are a few hundred feet above the trail. The species described from that place and horizon are:

Parapopanoceras Haugi Hyatt and Smith. Xenodiscus Bittneri Hyatt and Smith.
Hungarites Yatesi Hyatt and Smith. Tirolites pacificus Hyatt and Smith. 
Muschelkalk of Nevada.-The geological survey of California, under J. D. Whitney, discovered in the Humboldt Range of Nevada some fossiliferous limestones containing ammonites, referred by W. M. Gabb ${ }^{a}$ to the Upper Triassic, and correlated by him with the St. Cassian formation of the Alps. Most of the species were obtained in the canyons on the eastern tlanks of the West Humboldt Range, especially in Cottonwood and Buena Vista canyons, although the stratigraphic data concerning these fossiliferous strata given by Gabb are exceedingly meager.

About ten years later the United States Geological Exploration of the Fortieth Parallel brought to light a considerable number of new species and genera from the same region. These were described by F. B. Meek, ${ }^{b}$ and referred to the St. Cassian formation of the Upper 'Triassic, although Alpheus Hyatt, who also examined the collection, always adhered to the opinion that the fauna belonged to the Muschelkalk.

The general section of the Triassic of Nevada, as determined by the United. States Geological Exploration of the Fortieth Parallel, is as follows:

General section of Triassic of Nevada.

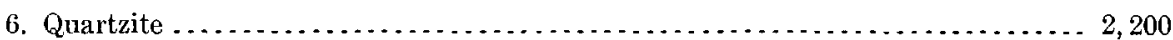

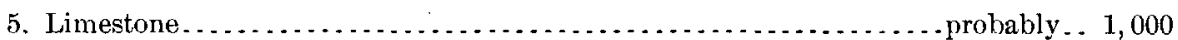

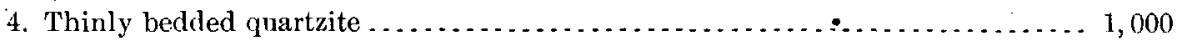

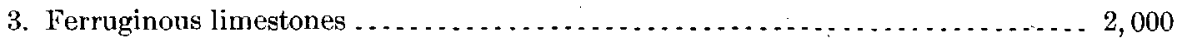

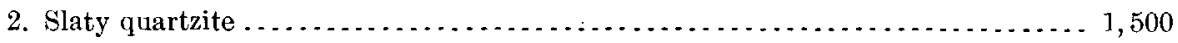

1. Argillaceous limestones, full of fossils . . . . . . . . . . . . . . . . . . . 1,500

Metamorphic Koipato group, unfossiliferous ........................ 6,000

All the Triassic fossils described by Meek from the Humboldt region came from near the base of the limestone No. 1. But of those cited by Gabb, from that region, "Ammonites Ramsaueri," Ammonites Homfroyi, and Pseudomonotis subcircularis came from higher beds, toward the top of the Triassic.

The section as given above is by no means correct, nor is the section constant over the region. No such thickness of limestone as 4,500 feet is visible anywhere in the region, for faulting has caused the same beds to be counted more than once in making the estimate.

In 1888 Alpheus Hyatt visited the West Humboldt Range and made collections from the Daonella beds (limestone No. 1). These, together with the original Whitney collection and those of the United States Geological Exploration of the Fortieth Parallel, were studied by J. P. Smith. Much undescribed material was found.in them, sufficient to make certain the Muschelkalk age of at least part of the series. 
In several publications Dr. E. von Mojsisovics ${ }^{a}$ has referred the Humboldt fauna to the Upper Triassic, correlating the beds with the Fassanic substage of the Tirolic series and comparing them more especially with the Buchenstein beds of the Alps. But Dr. A. Tornquist ${ }^{b}$ has shown that the group of Ceratites nodosus, diagnostic of the upper Muschelkalk, is found in the Buchenstein beds and that these must be classed with the Muschelkalk and not with the Upper Triassic. This makes it necessary to refer the Ceratite beds of Nevada to the Middle Triassic. Fven without this evidence the occurrence in the Humboldt region, in the same beds, of Plychites, Hingarites, Beyrichites, Acrochordiceras, Ceratites, Anoleites, and Balatonites would be enough to make the reference cortain, as none of these genera in their typical forms occur higher up than the Muschelkalk.

In May and June, 1902, and in July, 1903, J. P. Smith visited the West Humboldt Range to determine the association of the Middle Triassic fauna. He made extensive collections from the lower limestone, the fossiliferous portion of which was found to be not more than 200 feet thick.

In Buena Vista Canyon, near Unionville, the following species were found:

Species found in Buena Vista Canyon, Nev.

Gymnotoceras Blakei Gabb.

Beyrichites rotelliformis Meek.

Acrochordiceras Hyatti Meek.
Ptychites ? perplanus Meek.

Dinarites bonæ-vistæ. Myatt and Smith.

Balatonites sp. indet.

In the same formation, on the north side of Cottonwood Canyon near the Lucky Dog mine, were found the following:

$$
\text { Species found in Cottonwood Canyon, Nev. }
$$

Daonella dubia Gabb.

Daonella conf. Lommeli Wissmann.

Orthoceras Blakei Gabb.

Fudiscoceras Gabbi Meek.

Anolcites Meeki Mojsisovics.

Gymnotoceras Blakei Gabb.

Ceratites aff. trinodosus Mojsisovies.

Trachyceras Whitneyi Gabb.

Ceratites humboldtensis Hyatt and Smith.

Longobardites nevadanus Hyatt and Smith.
Acrochordiceras Hyatti Meek.

Beyrichites rotelliformis Meek.

Ptychites perplanus Meek.

Arcestes Gabbi Meek.

Celtites Halli Mojsisovics.

Japonites sp. indet.

Atractites sp. indet.

Encrinus stems.

Saurian bones, probably referable to Cymbospondylus teidy.

A new locality was visited by J. P. Smith on the divide between Troy Canyon and the south fork of American Canyon, 4 miles south of Foltz post-office, and about

"Arktische Triasfaunen, p. 149, and Obertriadischen Cephalopoden-Faunen des Himalaya, p. 695

${ }_{b}$ Zeitschr. Deutsch. geol. Gesell, Berlin, vol. 50, pt. 4, 1898, p. 691. 
5, wo feet above sea level. The shaly limestone is here literally full of fossils in a fair state of preservation, and the beds in which they occur are not over 50 feet in thicknews."

At this locality were found the following species:

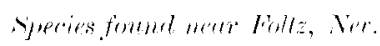

[ Somella dubia (iab)h.

latemella ront. Lonmoli Wissmann.

Grthoremas Blakei (ab).

Trathyeeras Meeki Mojwisovics.

Trahyeras Whitneyi cahb.

(aratites homboldtensis I yatt and smith.

Ceratites Vogdewi smith.

Ceratites ant. trinodoners Mojsisovies.

Ceratites cont. planus Arthaber.

Iongolardites nevalanus Ilyatt and Smith.

Beyrichites rotellifomis Meck.

Beyrichites spe nox.

1.eranites Vogdesi Ilyatt and smith.

Areestes Gabbi Merk.

\author{
Entonoceras Lanbei Moek. \\ Sareecras ciabli Mojoisovies. \\ Celtites Inalli Mojsimovior. \\ Celtites sur. nov \\ J)anulites spe inclet. \\ Dinarites spe indet. \\ Acrochordiceras aff. Ityati Treek. \\ Ptychites? perplanes Meck. \\ Gymnotereras Blakej ciabh. \\ Gymnotoceras (seroral new speseces). \\ Atrudites sp. indet. (very abuulant). \\ Nantilus Whituey dahb. \\ Saurian bones, probably cymbospondylus Teidy.
}

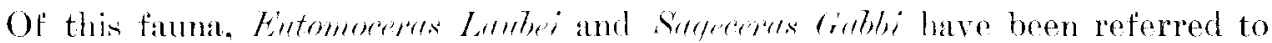
by Mojwisories" as probably oceurring in the Lpper Triamic, but .J. P. Smith found them in the same bed with the others. This fauna undoubtedly belongs to the Musehelkalk, and even the upper part of the zone of firutites frimodowes may be represented in it as well as the lower Ladinie.

Besides the species listed above. the Whitney collection rontained also the following species from the same formation:

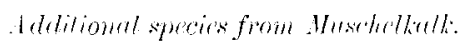

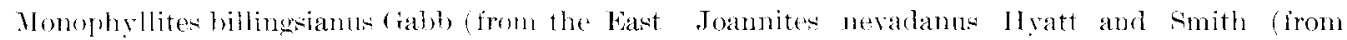
Ifumboldt Range, possibly Tpper Triassice). Volcano, Nevala).

Balatonites shoshonensis Hyatt and smith (From Ptyehites Meeki Ilyatt and smith (from star the showhone Range). Canyon).

UPPER TRIASSIC.

Sheste comenty, arl. The bent locality for Lpper Triassic fossils in America is in Shastal County, on the divide between Fiqua Creek and Pit River, 3 miles ant of Madison's ranch and one-half mike north of the trail leading to Brock's ranch. This locality is a miles northeast of the Bully Ifill mine. The fossils are very

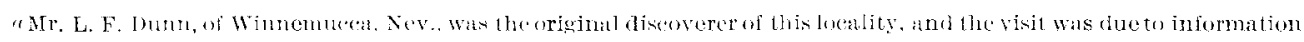
grivelu by hin.

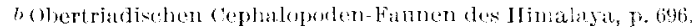


abundant in the lower beds of the Hosselkus limestone. The following species from the locality are described in this paper:

Triassic fossils from Brock Mountain, Shasta County, Cal.

Leconteia californica Hyatt and Smith.

Sagenites (Trachysagenites) Herbichi Mojsisovics.

Halorites (Homerites) semiglobosus Hauer.

Tardeceras parvum Hyatt and Smith.

Juvavites subinterruptus Mojsisovics.

J. (Anatomites) subintermittens Hyatt and Smith.

Paratropites Sellai Mojsisovics.

P. (Gymnotropites) americanus Hyatt and Smith.

Tropiceltites Frechi Hyatt and Smith.

Tornquistites evolutus Hyatt and Smith.

Discotropites sandlingensis Hauer.

Tropites subbullatus Hauer.

Arcestes (Proarcestes) pacificus Hyatt and Smith. Paraganides californicus Hyatt and Smith.

Hauerites Ashleyi Hyatt and Smith.

Dieneria Arthaberi Hyatt and Smith.

Tirolites (Metatirolites) foliaceus Dittmar.
Arpadites Gabbi Hyatt and Smith.

Californites Merriami Hyatt and Smith.

Clionites Fairbanksi Hyatt and Smith.

C. (Shastites) compressus Hyatt and Smith.

C. (Stantonites) rugosus IIyatt and Smith.

C. (Traskites) robustus Hyatt and Smith.

C. (Neanites) californicus Hyatt and Smith.

Trachyceras (Protrachyceras) Lecontei Hyatt and Smith.

Sirenites Lawsoni Hyatt and Smith.

Sandlingites Andersoni Hyatt and Smith.

Polycyclus nodifor Hyatt and Smith.

Atractites Philippii Hyatt and Smith.

Proclydonautilus triadicus Mojsisovics.

Cosmonautilus Dilleri Hyatt and Smith.

Mojsvaroceras Turneri Hyatt and Smith.

Orthoceras shastense Hyatt and Smith.

Besides the species listed above, the following species were found in the Karnic horizon:

Tropites torquillus Mojsisovics.

Tropites Dilleri Smith.

T. Morloti Mojsisovics.

Paratropites Dittmari Mojsisovics.
Halobia superba Mojsisovies.

Shastasaurus pacificus Merriam, and several other species of Ichthyosauridre.

In addition to the described species there was found a large number of new species of Tropites, Paratropites, Trachyceras, Clionites, brachiopods and pelecypods.

In the shales above the Hosselkus limestone was found Pseudomonotis subcircularis Gabb.

The general section of the Shasta County Triassic worked out by J. P. Smith, is as follows: 


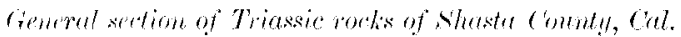

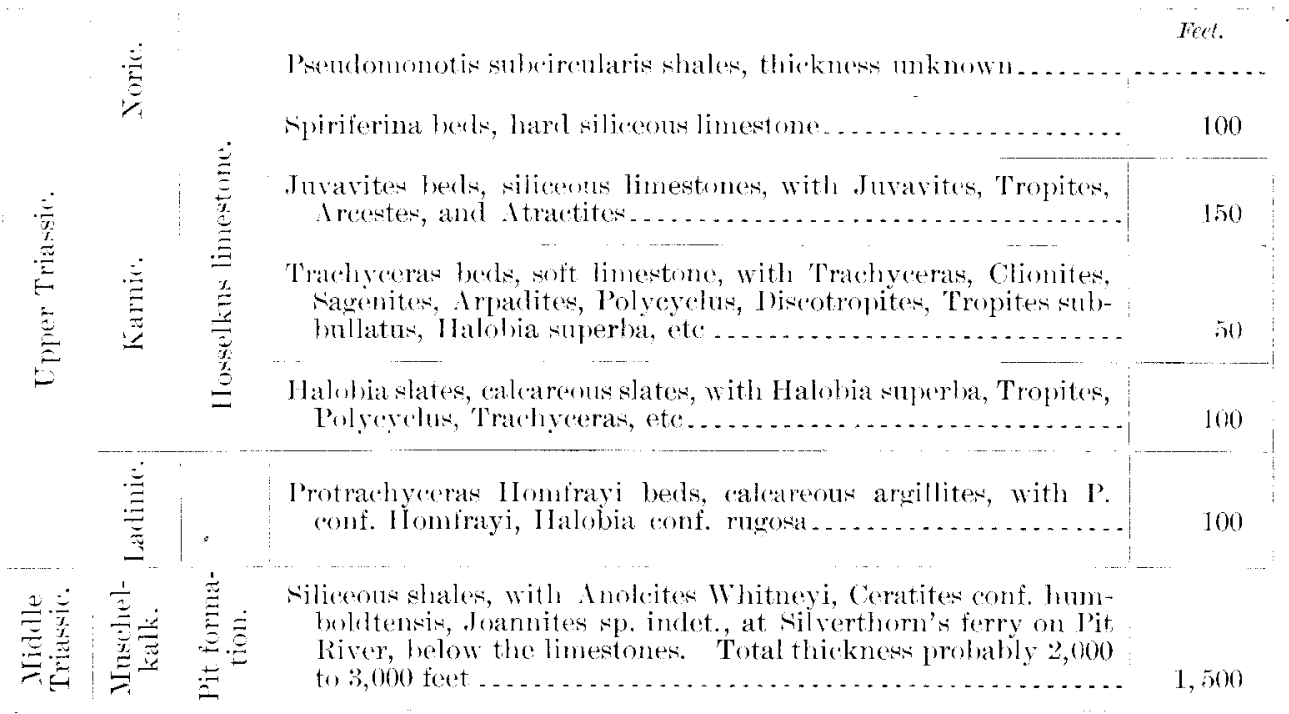

The Ilalobia slates, the Trachyeras beds, and the Juvarites beds make up the zone of Tropites sublbullate; the spiriferina beds, and probably the top of the Iuvavites beds constitute the lower Noric horizon, of which the Pseudomonotis shales constitute the upper horizon.

The Hosselkus limestone outrops continuously for albout 20 miles, from Brock's ranch on Pit River northward to the North Fork of Squaw Creek. Fossils are abundant in it almost everywere.

J. P. Smith found an irolated outcrop of the Ltomelkus limestone on Bear Mountain, 2 miles northwest of Sherman's ranch, 18 miles northeast of Redding. The fauna of the beds here is the same as at the other localities, being characterized

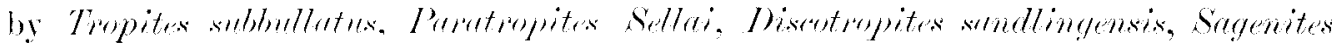

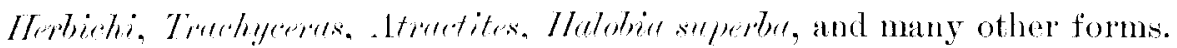

Plumes Comenty. Cal. - The Triassic of California was tirst discovered in Plumas County, in Genesee Valley, on Indian Creek, near Robinson's ranch. The section there is very much the same as in shasta County, except that nothing older than the Halobia slates is known, and the Hossolkus limestone is not nearly so thick nor so rich in fowils as in the squaw Creek section. The massive limestone, corresponding to the Trachyceras beds of Shasta county, is harren of fossils, while on the other hand the Pseudomonotis heds are better oxposed and richer in fossils. 
The Genesee section of the Triassic is as follows:

Section of Triassic rocks in Genesee Valley, Californïa.

\begin{tabular}{|c|c|c|}
\hline \multirow{3}{*}{ 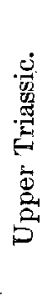 } & 它 & $\begin{array}{l}\text { Pseudomonotis shales and limestones (Swearinger slates) with Pseudomonotis } \\
\text { subcircularis, Halorites wmericanus, Rhabdoceras Russell, Arcestes conf. Ander- } \\
\text { soni, Atractites sp. indet., and a few other forms. }\end{array}$ \\
\hline & \multirow{2}{*}{ 莣 } & $\begin{array}{c}\text { Massive limestone without fossils (probably corresponding to the Trachyceras } \\
\text { beds of Shasta County). }\end{array}$ \\
\hline & & Halobia slates, with Halobia superba, Tropites conf. subbullatus. \\
\hline
\end{tabular}

This section agrees with that observed by J. P. Smith in Shasta County, Cal., and in the Muttleberry Mountains, West Humboldt Range, Nevada.

West Humboldt Range, Nevada.--In the West Humboldt Range, in Nevada, the Upper Triassic is but little known. The limestone of Star Peak, about 1,000 feet in thickness, probably corresponds in part to the Hosselkus limestone of California, for on the north side of Star Canyon .T. P. Smith found what secmed to be Halobia superba about 800 feet above the Daonella beds of the Middle Triassic. Above the Star Peak limestone is a series of slates and slaty limestones aggregating 800 fect in thickness. These are poorly exposed near the head of Star Canyon, where Gabb has listed Pseudomonotis subcircularis. These same beds are much better exposed in Muttleberry Canyon, in the road, about 8 miles southeast of Lovelock. At this locality ${ }^{a}$ fossils are abundant, although usually poorly preserved. J. P. Smith found in the Pseudomonotis slates of Muttleberry Canyon the following forms:

$$
\text { Fossils from Muttleberry Canyon, Newada. }
$$

Pseudomonotis subcircularis Gabb.

Placites humboldteńsis Hyatt and Smith.

Myophoria sp. indet.

Halorites conf. americanus Hyatt.

Rhabdoceras Russelli Hyatt.

A reestes Andersoni Hyatt and Smith.

Above the Pseudomonotis beds lie Jurassic limestones with Arietites (Caloceras) aff. nodotianus d'Orbigny, a form diagnostic of the Lias.

A plain unconformity separates the two formations. The Pseudomonotis beds, therefore, form the highest horizon of marine Triassic known in this region, or anywhere in America.

\section{CTASSIFICATION OF TRIASSIC AMMONITES.}

Mojsisovics's classification of Triassic ammonites as Trachyostraca and Leiostraca, however convenient it may be for the Upper'Triassic, can not be applied to the Lower Triassic. It is purely artificial, classing together groups of very different origin, 
and separating groups that are nearly related. Families that are smooth-shelled in the Lower Triassic often become rough-shelled in the Upper Triassic.

This classification was considered to have a phylogenic significance as long as it was thought that the rough-shelled fanilies come from the Glyphioceratide and the smooth-shelled from the Prolecanitide. But now it has been demonstrated that both rough-shelled and smooth-shelled families have developed out of both Paleozoic phyla, and even in the same family one genus might be leiostracan while another was trachyostracan. E. Haug, in Les Ammonites du Permien et du Trias, ${ }^{a}$ attempted to revise the classification elaborated by Mojsisovics, but in that paper he merely changed the name of the Trachyostraca to the phylum of the. Glyphioceratidie and the Leiostraca to the phylum of the Prolecanitidæ. In his later work, Etudes sur les Goniatites, ${ }^{b}$ Haug has revised and improved this classification, but in this paper he still includes heterogeneous elements in the same group.

W. Waagen, in Fossils from the Ceratite Formation, ${ }^{c}$ attempted an elaborate classification of the Triassic anmonites, but the forms he described are almost exclusively confined to the Lower Triassic, so that his taxonomic scheme does not take in more than a small part of the early Mesozoic genera.

The most satisfactory treatment of the Triassic cephalopods is that of C. Diener, ${ }^{d}$ who described a large series of ammonites from the Lower and Middle Triassic. His grouping of the families and genera from this system is simple and seems to agree more nearly with the phylogeny of the ammonoids than any other scheme yet proposed.

Essential advances in the taxonomy of the ammonoids have been made by G. von Arthaber, ${ }^{e}$ who has described a large series of forms from the Permian and Middle Triassic, clearing up many doubtful points in the history of the Ceratitida and allied groups, bringing out especially the intimate relationship of many so-called Leiostraca to that group.

F. Frech ${ }^{f}$ has done much to simplify the classification of the late Paleozoic and early Mesozoic ammonites. He proposes to include in a suborder Ceratitoidea the Ceratitide, Meekoceratidæ, Ptychitide, Tropitidx, and Xenodiscinæ. Under this latter group he includes Xenodiscus, Xenaspris, Otoceras, and Hungarites. The writers have accepted this scheme, with the exception of leaving out the Tropitidie and the Ptychitidx, both of which families show in their development that they did not come from the same phylum as the Ceratitidie.

\footnotetext{
. a Bull. Soc. géol. France, 3 d ser., vol. 22, 1894

b Mém. Soc. géol. France, No. 18, 1898.

c Salt Range Fossils, yol, 2, 1895, p. 236: Mem. Geol. Survey India, Pal. Indica, ser: 13.

dHimalayan Fossils, vol. 2, pt. 1, 1897, Cephalopoda of the Lower Trias.; and pt. 2, 1895, Cephalopoda of the Muschelkalk; Mem. Geol. Survey India, ser. 13.

e Die Cephalopoden der Reiflinger Kalke, vol. 1 and 2, 1896; and Das Jüngere Palæozoicum aus der Araxes-Enge bei Djulfa, 1900.

$f$ Die Dyas: Lethæa Palæonoica, Bd. 2, Lieferung 3, 1901.
} 
J. P. Smith ${ }^{a}$ has recently given a revision of the later Paleozoic ammonites, and traced their development into Triassic genera where the available data warranted it. On Pl. I, in the work cited, is given a phylogenic table of the Paleozoic ammonoids, and their probable relationships with Triassic families. This was based on studies in the ontogeny of characteristic species in most of the important genera of the Triassic. While the results of this study are not in harmony in every case with the commonly accepted classification, it must not be forgotten that in many instances the taxonomy of Triassic genera has been based on mere conjecture, and not on studies in the ontogeny of the species, nor on a complete phylogenic series of mature forms These investigations showed that all the suborders recognized in the present work were already distinctly separated in the Paleozoic.

For convenience of reference this table is reproduced in the present work, with such additions as the subject demands.

Frech $^{b}$ has recently published a revision of the ammonites of the Permian and Lower Triassic, in which he proposes to group together all the forms with ceratitic lobes under the subfamily Xenodiscinæ, thus abandoning the families Hungaritidæ, Celtitidæ, Meekoceratidæ, and Gymnitidæ for the ammonites of those faunas. He also drops the genus Meekoceras entirely, dividing the species formerly assigned to that genus between Ophiceras, Aspidites, Prionolobus, and Ceratites. The writers, however, consider these changes as unwarranted, and, while they would welcome a simplification of the classification of Permian and Lower Triassic ammonites, still believe that the laws of priority must rule in such changes as are necessary in taxonomy.

Frech also assumes that the Permian age of the Otoceras beds of India and the Proptychites beds of Siberia is demonstrated. This may be true of the zones of Otoceras Woodwardi and of Ophiceras tibeticum in India, but is certainly not true of the Siberian beds with Ophiceras, Meekoceras, Pseudosageceras, and Ussuria, for in California and Idaho the writers have found all these genera, with the exception of Otoceras, in the zone of Meckoceras gracilitatis, represented by species very closely allied to the Asiatic species and in beds of which the Lower Triassic age can not be questioned.

In the present work the writers have attempted to unite all the good points in the schemes of all these authors, modifying them as little as possible, and only where it was necessary in treating such a variety of genera as are represented in the entire Triassic of America.

a The Carboniferous Ammonoids of America: Mon. U. S. Geol. Survey, vol. 42, 1903. $b$ Lethæa Palæozoica, Bd. 2, Lieferung 4, 1902, pp. 628-639. 


\section{SUBORDERS OF TRIASSIC AMMONITES.}

The ammonites of the Triassic may be divided into six suborders: Tropitoidea, Arcestoidea, Ptychitoidea, Ly toceratoidea, Pinacoceratoidea, and Ceratitoidea; under each of these divisions several families may be recognized, and under most of them several superfamilies or phyla. But each suborder is fairly homogeneous and may be traced to forms already characteristically specialized in the Paleozoic.

Tropitoidea.-Under this group are the Tropitidæ, Haloritidæ, and Sibiritidæ, all apparently derived from the gastrioceran branch of the Carboniferous Glyphioceratidæ. In this paper the ontogeny of Tropites, Paratropites, Discotropites, under the Tropitide, that of Leconteia and Sagenites under the Haloritide, and that of Columbites, under the Sibiritidæ, are fully described and illustrated. In all cases the ontogeny points clearly to a gastrioceran ancestry, probably through Schistoceras and Paralegoceras. The Sibiritidæ embrace the oldest forms of this group, and Columbites, of the Lower Triassic of America, is the most primitive member of the Sibiritidæ. This genus may not be the ancestral radicle of the Tropitoidea, but it retains many of the characters that the primitive ancestral radicle must bave possessed.

Arcestoidea.-Under this group are the Popanoceratidæ, Cyclolobidx; Arcestidæ, and Cladiscitidæ. The Popanoceratide and Cladiscitidæ appear to have been derived from Adrianites of the Permian. J. P. Smith ${ }^{a}$ has already shown that the Cyclolobida are derived from the gastrioceran branch of the Glyphioceratida, through Schistoceras and Shumardites. The Arcestidis s. str. probably came partly from the Cyclolobidie and partly from the Popanoceratide, but it is not yet possible to assign each genus to its proper place in the phylogenic tree.

In this paper the complete ontogeny of Parapopanoceras and Arcestes, subgenus Proarcestes, is described and illustrated, showing clearly a derivation from Adrianites as the prinitive member of the Arcestidæ, and connecting through Agathiceras with the Glyphioceratide of the Carboniferous.

Ptychitoidea.-To this group belong the Ptychitidx and the Thalassoceratide. In this paper the complete ontogeny of Nannites, Paranamites, and Paraganides under the Ptychitide is described and illustrated. This points to a derivation of the family from the Aganides stock of the Glyphioceratidx, probably through Pronannites.

Under the Thalassoceratide the writers describe the development of Ussuria, which goes through stages corresponding successively to Dimorphoceras, Thalassoceras, and Ussuria, and probably connecting ultimately with Aganides.

Lytoceratoidea.- Under this group the writers recognize two families, Lytoceratidx, and Phylloceratida, of uncertain origin, but probably derived from the Paleo- 
zoic genus Nomismoceras. Of these the Lytoceratidx appear to be the more primitive in development, and if not the parent branch, they at any rate have retained more of the characters that must have belonged to the primitive stock.

Pinacoceratoidea.--Under this group are three phyla: Pinacoceratide, Pronoritidæ, and Noritidæ, which had diverged from each other certainly as early as the Carboniferous. But because of the general resemblance preserved in parallel development from kindred stocks, it is thought best to keep them together in classification.

The Pronoritide are represented in the Triassic, although it is now claimed that Medlicottia, which was described by Diener from the Lower Triassic of India, really came out of Permian beds. The genera Cordillerites. and Lanceolites appear to come from the Pronoritida. Cordillerites in its development goes through stages corresponding. successively to Prolecanites, Pronorites, Sicanites, and Cordillerites.' The young stages of Lanceolites are not well known, but they indicate a similar history.

The young stages of most of the Noritidæ have not been studied, so their systematic position is in doubt, but they are regarded as a parallel development with the Pronoritide from Paraprolecanites.

The Pinacoceratidæ are abundantly represented in the American Triassic, and the writers describe the partial ontogeny of several typical gencra. This points to a derivation from the Gephy roceratide through the Beloceratide, though probably not from Beloceras itself. Some of the forms appear to be genetically connected with Prodromites, while others show greater kinship with Timanites.

It is possible that the characters chosen by Wagen and Mojsisovics in defining the Pinacoceratidæ may belong to several parallel branches, or even that they may have developed in branches not closely allied. This family may then be merely a group of morphological equivalents; but the number of known forms is too small, and the ontogeny of those few has been too little studied for any settlement of this question to be possible now. $\Lambda$ fter all, this family is probably not more heterogeneous than most other so-called families.

Ceratitoidea.-Under this group the writers class the Ceratitidæ, Hungaritidæ, Meekoceratidæ, Celtitidx, and Gymnitidæ. The development of characteristic species under each of these groups is described and illustrated in this paper. It appears that they are all closely allied and came from a common stock, Paralecanites, through which they are connected with Prolecanites of the Carboniferous.

The development of several genera under the Meekoceratidæ points to Lecanites as the family radicle, but the Gymnitidx, Celtitidæ, and Hungaritidæ appear to have branched off from the main stock further down. The Ceratitidx, while closely resembling the Hungaritidæ and the Meekoceratidæ, appear to be more closely allied with the Celtitidx. 


\section{OCCURRENCE OF AMERICAN TRIASSIC CEPHALOPOD GENERA.}

The following table shows the occurrence of the American Triassic cephalopod genera in America, Asia, and Europe:

Table of occurrence of American Triassic cephalopod genera.

$[x$, very rare; $x \times$, rare; $x \times x$, common. $]$

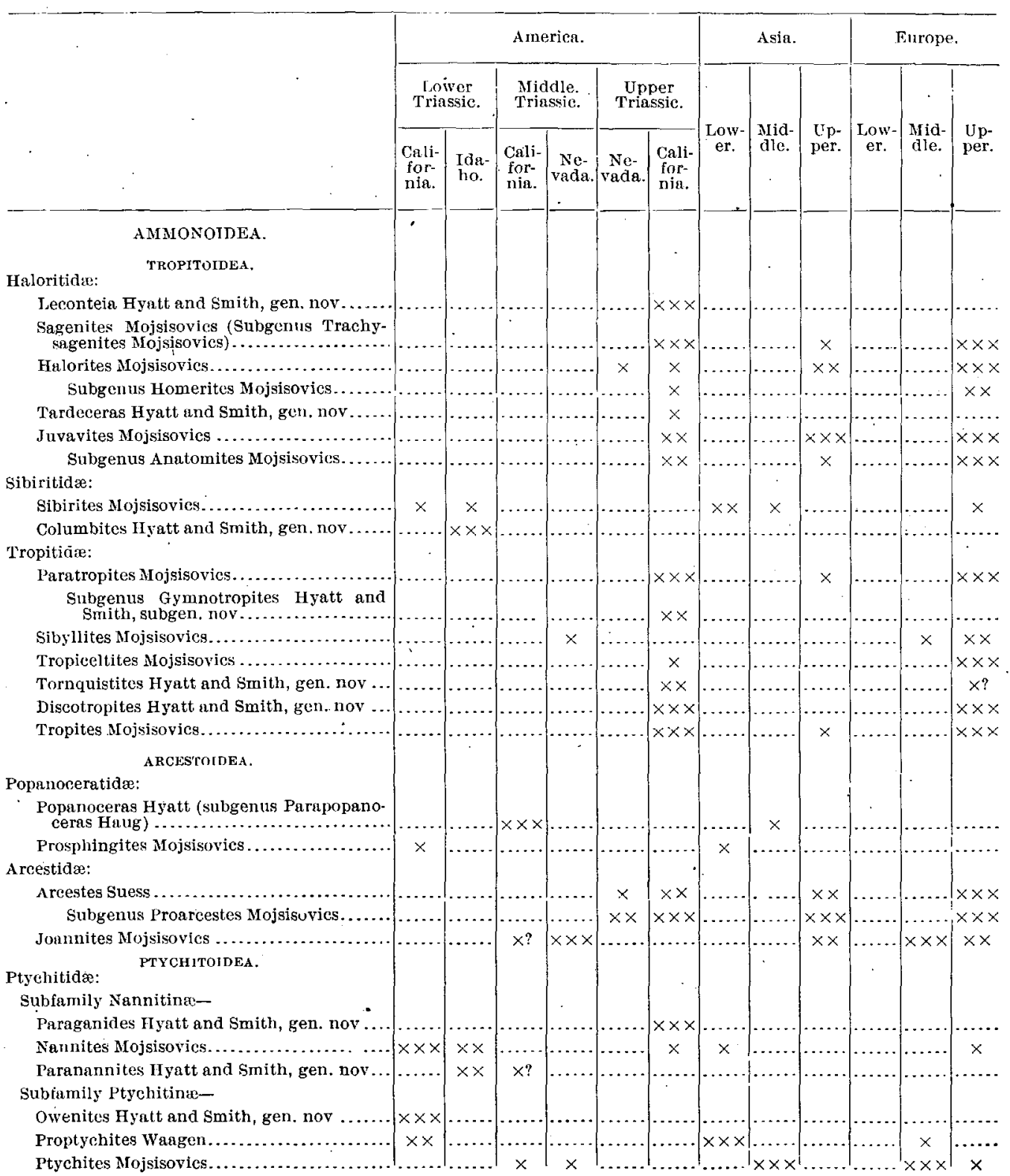


Table of occurrence of American Triassic cephalopod genera-Continued.

$[x$, very rare; $x \times$, rare; $x \times x$, common.]

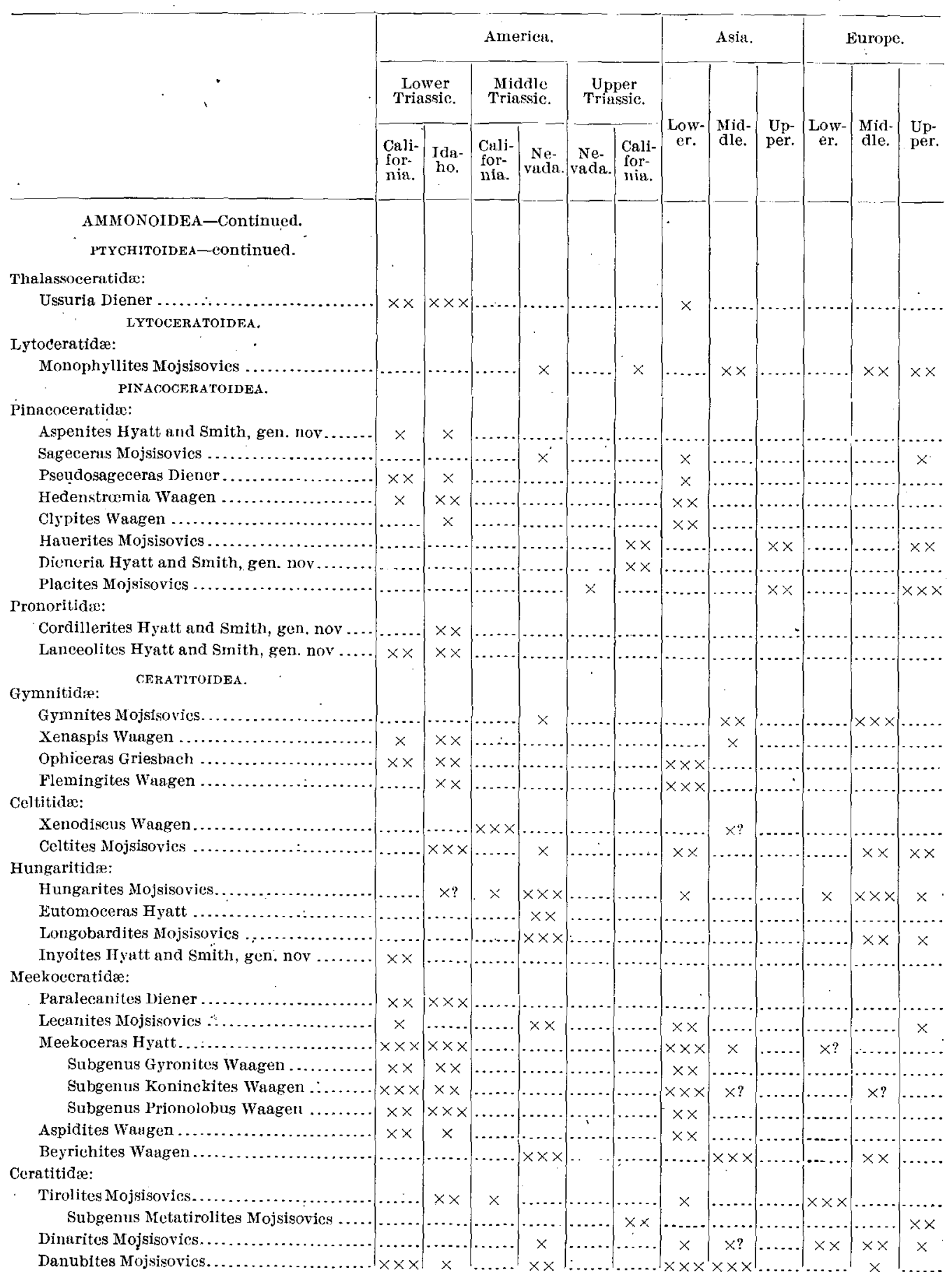


Table of occurrence of American Triassic cephalopod genera-Continued.

$[\times$, very rare; $x \times$, rare; $x \times x$, common. $]$

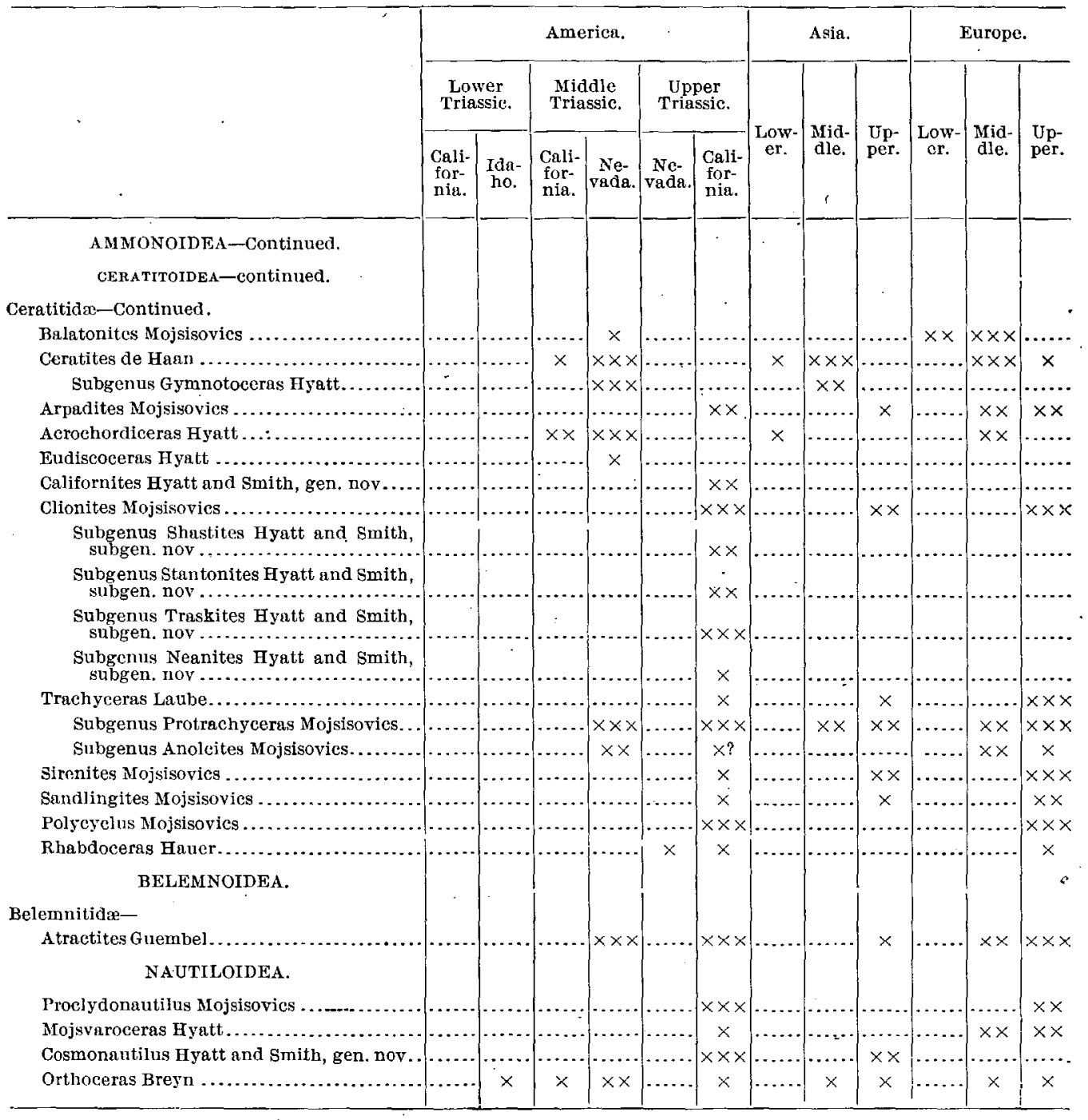

16918-No. $40-05-3$ 
TRIASSIC CEPHALOPOD GENERA OF AMERTCA."

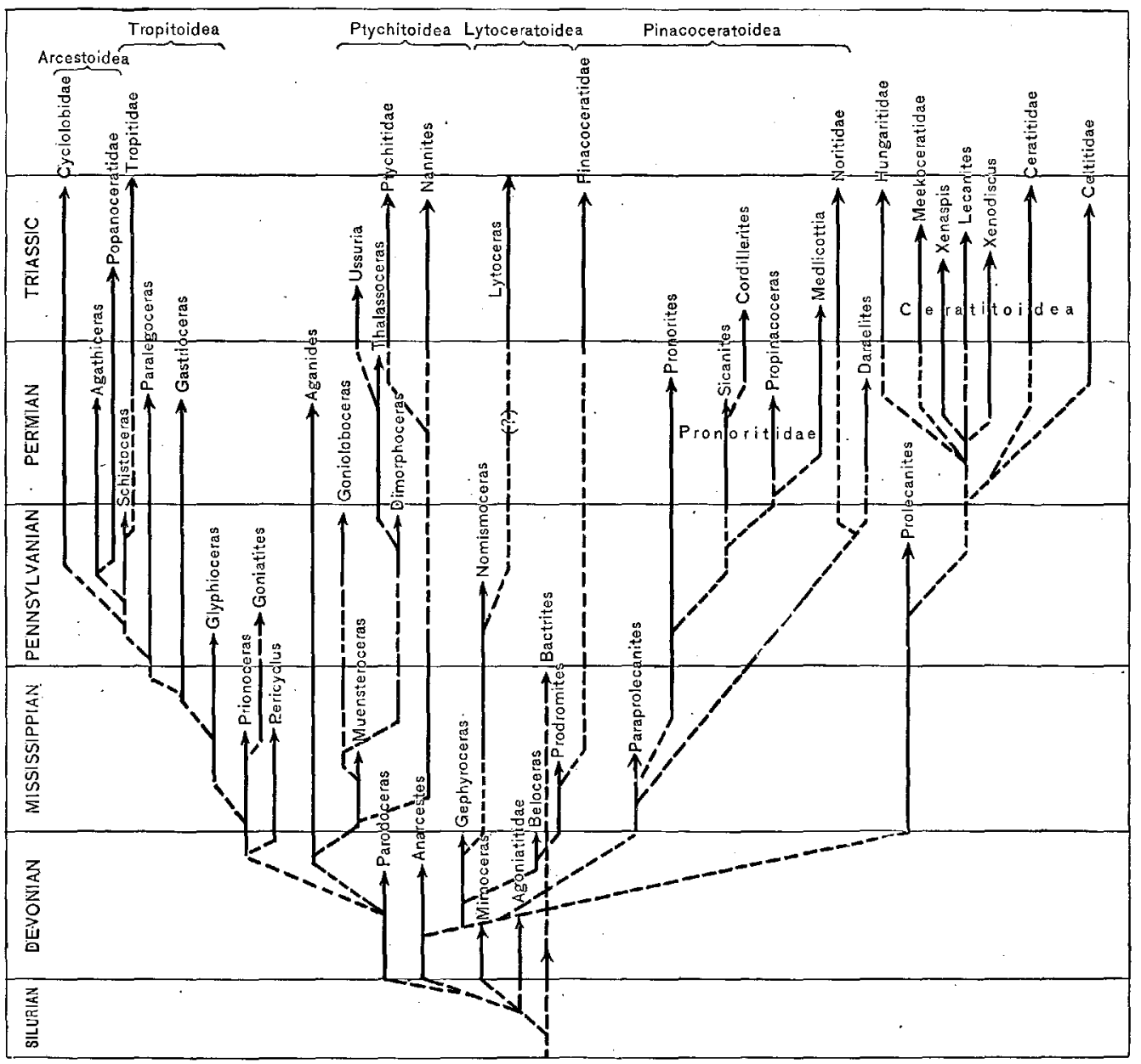

FIG. 1.-Table showing the relution of Triassic to Paleozoic genera of cephalopods. 


\title{
SYSTEMATIO DESCRIPTIONS.
}

\author{
AMMONOIDEA. \\ Suborder TROPITOIDEA.
}

Forms with long body chamber, ammonitic, rarely goniatitic, simple septa, strong sculpture, either lateral ribs, or spines, or ventral keel. The young are involute and subglobose, resembling in form and septa the Carboniferous family Glyphioceratidæ. Under this group are included Haloritidæ, Tropitidæ, and Sibiritidæ.

\section{Family HALORITIDA Mojsisovics.}

Subglobose, involute genera, with lateral ribs, often crossing the venter, and in some groups with spines or knots on the ribs. No keels nor ventral furrows are known in this group, but the interruption of the ribs on the venter sometimes gives the appearance of a furrow.

The septa are ammonitic, dolichophyllic, or ceratitic. The young of this family resemble the Glyphioceratidæ, and more especially the genus Pericyclus Mojsisovics, of the Carboniferous.

This family was formerly classed by Mojsisovics under the Tropitidæ, but it did not come from the main stock, being rather a parallel development from the same Carboniferous radicle, but probably from different branches of the same family.

The Haloritidæ are known only from the Upper Triassic, and chiefly from the Karnic and Noric stages, in the Alpine province, the Himalayas, and western America. They are represented in America by Leconteia Hyatt and Smith. Sagenites Mojsisovics, Halorites Mojsisovics, Tardeceras Hyatt and Smith, and Juvavites Mojsisovics, all confined to the Upper Triassic.

$$
\text { Genus LECON'NEIA IIyatt and Smith, gen. nov. }
$$

Type.-Leconteia californica Hyatt and Smith.

Whorls involute, subglobose, deeply embracing, and deeply indented by the inner volutions. Sides convex, rising to the highly arched venter without any abdominal shoulder. Umbilicus narrow, becoming wider at maturity. Body chamber long, at least a revolution. Septa ceratitic; external lobe narrow, goniatitic, divided by a small siphonal notch into two sharp branches; lateral lobe and auxiliary broad, shallow, and serrated. External saddle high, rounded and 
entire; lateral saddle similar but lower; antisiphonal lobe long, narrow, and entire, flanked by a shorter internal lateral lobe. Internal saddles similar to the externals. Surface ornamented with strong straight or gently flexuous ribs which pass without interruption across the venter, but become much wider on that portion of the shell. The ribs are not all of equal height, every third or fourth one being stronger and higher than the intervening ones, which at maturity may become nearly obsolete. On the outer shell these ribs are smooth, without nodes, but internal casts show the ribs slightly interrupted by a ventral furrow, bounded by rows of knots on the ends of the ribs.

This genus resembles Heliotites and Polycyclus, but differs from them in the greater involution and the long body chamber. The young of Leconteia are not like those of the Ceratitide, but subglobose like those of Sagenites. For these reasons the genus is assigned to the Haloritidx of the Tropitoidea.

Leconteia is named in honor of the late Prof. Joseph Le Conte. This genus is characteristic of the zone of Tropites subbullatus in the Upper Triassic of California, and at present is known only in that province. Besides the species described in this paper only one other, as yet undescribed, is known, occurring in the same beds.

LECONTEIA CALIFORNICA Hyatt and smith, sp. nov.

Pl. XXIX, figs. 3-21.

Form involute, subglobose. Whorls deeply embracing, and deeply indented by the inner volutions; highly arched, rounded, with no.abdominal shoulders. Cross section crescentic. Umbilicus narrow, almost closed, concealing the inner whorls. Umbilical shoulders abruptly rounded, with steep inner walls. The height of the whorl is one-half of the total diameter, the width is about one and a quarter times the height, and it is indented to more than one-third of its height by the inner whorl.

The surface is ornamented with simple coarse ribs that run nearly straight up the sides from the umbilicus, and across the venter without interruption. These ribs are broad and rounded, much wider than the narrow deep intercostal furrows; they show on the cast as strongly as on the outer shell, but are interrupted by a shallow median furrow, bounded by a row of tubercles at the ends of the ribs. At maturity the ribs grow very much coarser and some become obsolete, or nearly so. At this stage also the whorl becomes somewhat compressed laterally, so that it resembles Lobites. The body chamber is long, at least a revolution.

The septa are ceratitic; the external lobe is divided by a small siphonal noteh into two sharp branches; the lateral lobe is longer, broader; and serrated. The auxiliary is shallow, broad, and serrated. The antisiphonal lobe is long, narrow, simple, and pointed, flanked by a. similar internal lateral on each side. The saddles, both internal and external, are all entire, broad, and rounded. 
The development of this species is extremely simple, the young stages being very like the mature forms. In the larval stage the shell is evolute, low-whorled with wide umbilicus, and broad whorl with trapezoidal cross section, like Gastrioceras. At the diameter of $1.6 \mathrm{~mm}$. strong tubercles appear on the umbilical shoulders, still further increasing the resemblance to that Carboniferous genus, and the septa also are of that type. The glyphioceran constrictions appear at frequent intervals on the shell. At diameter of $4 \mathrm{~mm}$. the ribs cross the venter and the constrictions cease, but the form is still like Gastrioceras. At diameter of $4.5 \mathrm{~mm}$. the median furrow with the marginal tubercles appears on the inner cast, and at $5 \mathrm{~mm}$. the lateral lobe becomes ceratitic. This species preserves in its ontogeny an unusually perfect record of its race history, since even at maturity so many glyphioceran characters are still visible, and in its larval and adolescent stages such perfect resemblance to Paleozoic goniatite genera may be seen.

Leconteic californica has an external resemblance to Polycyclus nasturtium, but is much more involute, and has a long body chamber. Also the young stages point to the Glyphioceratidæ as the Paleozoic radicle from which it came, while Polycyclus is supposed to belong to the stock of Ceratitidæ.

While Leconteia is classed in the Haloritidæ, it is much simpler than any other members of that stock, being much nearer the parent family. It is not a reversionary form, but a persistent ancestral type, such a genus as one would expect to find in the Lower Triassic or Permian. It is a connecting link between the Haloritide and the Glyphioceratidæ.

Horizon and locality._Leconteia californica is common in the Upper Triassic zone of Tropites subbullatus of Shasta County, Cal., 3 miles east of Madison's ranch, and one-half mile north of the trail from Madison's to Brock's ranch on Pit River. It was also found in the same horizon on Bear Mountain, near Sherman's ranch, south of Pit River, 2 miles north of the road from Redding to Copper City, and at several other places on the divide between Squaw Creek and Pit River. It has not yet been found outside of Shasta County.

The figured specimens all came from Brock Mountain, on the divide between Squaw Creek and Pit River, 3 miles east of Madison's ranch, and one-half mile north of the trail from Madison's to Brock's ranch, Shasta County, Cal.

$$
\text { Genus SAGHNITES Mojsisovics. }
$$

1879. Sagenites, Mojsisovies, Vorläufige kurze Uebersicht der Ammoniten-Gattungen, etc.: Verhandl. K.-k geol. Reichsanstalt, Wien, p. 141.

1893. Sagenites, Mojsisovics, Cephalopoden der Hallstätter Kalke: Bd. 2. Supplement-Heft, Abhandl. K.-k. geol. Reichsanstalt, Wien, vol. 6, pt. 2, p. 155.

1896. Sagenites, Mojsisovics, Beitr. Kenntniss der obertriadischen Cephalopoden-Faunen des Himalaya: Denkschr. K. Akad. Wiss., Wien, vol. 63, p. 608. 
Type-Ammonites reticulatus Hauer, Ueber neue Cephalopoden aus den Marmorschichten von Hallstatt und Aussee. Haidinger's Naturwiss. Abhandl. vol. 3, 1849, p. 16, Pl. V, figs. 1-3; and E. von Mojsisovics, Cephalopoden der Hallstätter Kalke, vol. 2, 1893, p. 173, Pl. C, fig. 1.

Subg]obose, somewhat compressed laterally, sides rounded, venter highly arched; no abdominal shoulders. Involute, deeply embracing, whorls increasing rapidly in height. Umbilicus narrow, but open and deep. Body chamber long.

Sculpture consisting of dichotomous folds or ribs which cross the venter, but become weaker on that part of the shell. In addition to these radial folds there may be also spiral lines or ridges, and in one group there occur short spines arranged in spiral rows on the ribs.

Septa ammonitic, complex and deeply digitate.

Mojsisovics (loc. cit.) divides Sagenites into three groups: (1) Sagenites inermes, (2) Sagenites reticulati, and (3) Sagenites spinosi, which latter group he designates as the subgenus Trachysagenites. The Sagenites inermes and Trachysagenites appear in the Karnic horizon of the Upper Triassic, Trachysagenites becoming extinct with the end of this stage, and Sagenites inermes living on into the Noric stage, in which the group of Sagenites reticulati appears for the first time. 'The genus Sagenites s. str. is not known in America, but is represented by the subgenus Trachysagenites.

$$
\text { Subgenus TRACHYSAGENITES Mojsisovics. }
$$

1893. Trachysagenites, Mojsisovics, Cephalopoden der Hallstätter Kalke: Abhandl., K.-k. geol. Reichsanstalt, Wien, vol. 6, pt. 2, p. 156.

1904. Trachysagenites, J. P. Smith, The Comparative Stratigraphy of the Marine Trias of Western America: Proc. California Acad. Sci., 3d ser., vol. 1, p. 399.

Type.-Ammonites erinaceus Dittmar, Zur Fauna der Hallstätter Kalke, Geogn.palaeont. Beitr. von Benecke, Schlönbach und Waagen, 1886, vol. 1, p. 380, Pl. XVII, figs. 15-17, and E. von Mojsisovics, Cephalopoden der Hallstätter Kalke, Abhandl. K.-k. geol. Reichsanstalt, Wien, vol. 6, pt. 2, 1893, p. 179, Pl. C, figs. 2-4.

Long body chamber, subglobose whorls. Rounded sides and venter. No abdominal shoulders. Umbilicus narrow.

Surface ornamented with radial dichotomous ribs, running nearly straight across the venter, and provided with numerous rows of short spines arranged in regular spiral rows at short intervals.

Septa ammonitic, deeply digitate.

Trachysagenites closely resembles Trachyceras, from which it differs in the subglobose whorls, rounded venter, and absence of ventral furrow and long spines. The septa are very similar in both genera. But this resemblance is purely external, and does not betoken close relationship, for the development of Trachysagenites 
points to a glyphioceran ancestry, in common with the Tropitidx, while that of Trachyceras points to a derivation from the stock of Prolecanitidæ.

But three species of Trachysagenites are known, all confined to the Upper Triassic, upper Karnic stage, zone of Tropites subbullatus, in the Alpine province, in which horizon T. Herbichi Mojsisovics occurs also in the Himalayas. In California Trachysagenites erinaceus Dittmar, and T. Herbichi Mojsisovics occur in the same horizon, associated with Tropites subbullatus, in the Hosselkus limestone of Shasta County.

SAGENITES (TRACHYSAGENITES) HERBICHI Mojsisovics.

Pl. XXVI, figs. 1-2; Pl. XXVII, figs. 1-4; Pl. XXVIII, figs. 1-18.

1893. Sageniies (Trachysagenites) Herbichi, Mojsisovics, Cephalopoden der Hallstätter Kalke, Bd. 1: Abhandl. K.-k. geol. Reichsanstalt, Wien, vol. 6, pt. 2, p. 180, Pl. CI, fig. 3; Pl. CII, figs.1-6.

1904. Sagenites (Trachysagenites) Herbichi, J. P. Smith, Comparative Stratigraphy of the Marine Trias of Western America: Proc. California Acad. Sci., 3d ser., vol. 1, p. 399, Pl. XLVI, figs. 7 and 8; Pl. XLVII, figs. 5 and 6.

Form subglobose, somewhat compressed laterally, robust, involute. Whorl highly arched, high, helmet-shaped, deeply embracing, increasing rapidly in height, and not deeply indented by the inner volutions. Sides convex, curving to the broad venter without any marked abdominal shoulders. Umbilical shoulders abruptly rounded, with the inner walls steep. Umbilicus deep and narrow, but exposing the umbilical shoulders of the inner whorls and becoming wider with age. Body chamber long, apparently comprising an entire revolution.

Surface ornamented with numerous closely set small radial ribs, that run nearly straight from the umbilicus across the venter, usually dividing on the flanks. On these ribs are spiral rows of short spines or knots, varying from nine to thirteen rows on each half of the shell, showing only on the outer shell and not on the cast. This sculpture is the same over all parts of the whorl, and there is no interruption on the venter, nor any ventral furrow. This character easily distinguishes . Trachysagenites from Trachycerces, with which it is associated, and the spiral arrangement of the spines separates it from Halorites.

The septa are ammonitic, deeply digitate, more so than is usual with the Tropitoidea. The external lobe is divided by a shallow siphonal saddle into two short narrow branches. The first lateral lobe is long, moderately broad, and divided into two branches at the end. The second lateral lobe is shorter and narrower, but also digitate. On the umbilical shoulder is a distinctly individualized auxiliary lobe, not unlike the second lateral, but smaller. There are three lateral saddles, all narrow, but long and deeply digitate. The antisiphonal lobe is long and narrow, flanked by two similar internal laterais on each side. This species grew to a very large size, the specimen figured on PI. XXVI, figs. 1 and 2 having a diameter of $110 \mathrm{~mm}$, and 
being broken at the very beginning of the body chamber, so another revolution must have been added to its size, which would make the total diameter of the completed whorl more than $200 \mathrm{~mm}$. The dimensions of this chambered specimen are as follows:

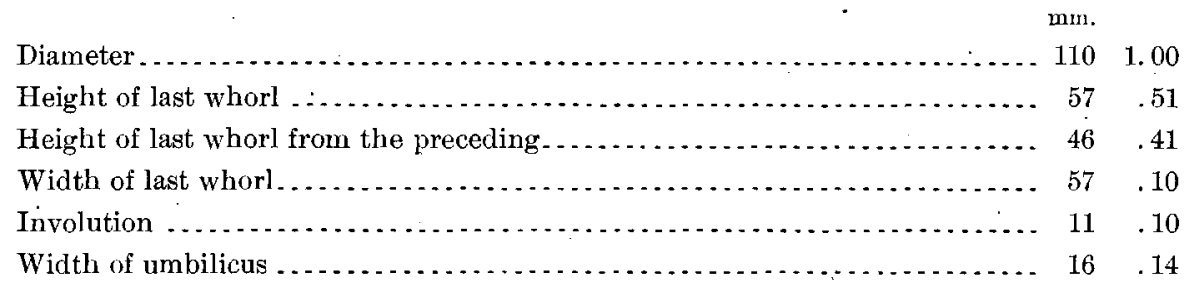

The greatest width is at about one-third of the height of the whorl. The height and breadth of the whorl are equal, and slightly more than one-balf the total diameter. The outer volution conceals three-fourths of the inner, and is indented to less than one-fifth of the height by it. These dimensions are remarkably constant from adolescence to maturity, as the measurements of a small specimen show:

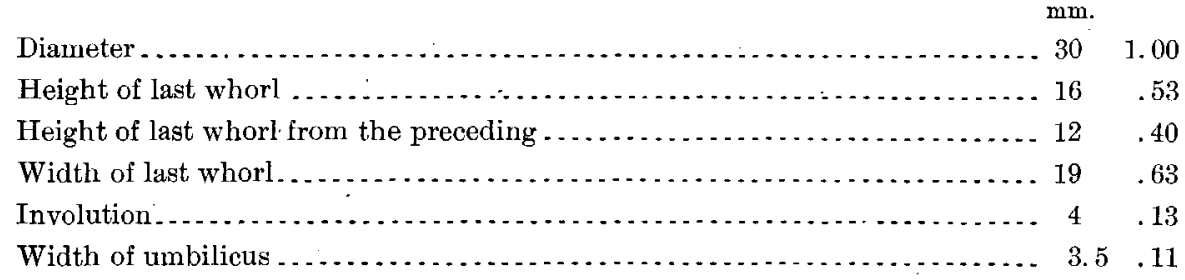

In the adolescent shell the whorl is broader, the involution slightly less, and the umbilicus somewhat narrower.

The septa shown on Pl. XXVII, fig. 2, were taken from a specimen at the diameter of $80 \mathrm{~mm}$, and are necessarily much more complex than those figured by Mojsisovics, ${ }^{a}$ which were taken from a specimen at the diameter of $35 \mathrm{~mm}$. At this size the septa of the Californian specimens are like those shown on the specimens from the Alps.

The young of Sagenites Herbichi are subglobose, and very like the adults in form, except that the whorl is proportionally broader and the umbilicus wider. At this larval stage the young are like the Carboniferous Glyphioceratide in form and septa, and probably correspond to Gastrioceras.

The lateral ribs appear at diameter of $4 \mathrm{~mm}$. and the spiral rows of knots at $5 \mathrm{~mm}$. The septa pass from the goniatite to the ammonite stage of development at diameter of $2.8 \mathrm{~mm}$. From then on there is little change in the characters except in increasing lateral compression and complexity of septation.

a Cephalopoden der Hallstïtter Kulke: Abhandl. K.-k. geol. Reichsanstalt, Wien., vol. 6, pt. 2, 1893, PI. CI, fig. 3 
Sagenites Herbichi is very like $S$. erinaceus Dittmar, as figured by Mojsisovies, ${ }^{a}$ but differs from that species in its greater lateral compression, more numerous spiral rows of knots, and much more numerous and final radial ribs; also in $S$. erinaceus the lobes are shorter and broader, the second lateral is small and scarcely divided, while the auxiliary is represented only by a small notch on the umbilical shoulder.

Horizon and locality.-Sagenites Herbichi Mojsisovics is common in the upper Triassic of the Alps, zone of Tropites subbullatus. In California it is abundant in this same horizon, associated with S. erinaceus, Tropites subbullatus, Discotropites sandlingensis, and Halobia superba, and a number of other species characteristic of the Alpine province.

The figured specimens were collected by J. P. Smith on the divide between Squaw Creek and Pit River, 3 miles east of Madison's ranch, and 6 miles northeast of the Bully Hill mine, Shasta County, Cal.

Genus HAIORITES Mojsisovies.

1878. Halorites, Mojsisovics, Die Dolomitriffe von Südtirol und Venetien, Wien, p. 50.

1879. Halorites, Mojsisovics, Vorläufige kurze Uebersicht der Ammoniten-Gattungen, etc.: Verhandl. K.-k. geol. Reichsanstalt, Wien, p. 136.

1893. Halorites, Mojsisovics, Cephalopoden der Hallstätter Kalke: Abhand]. K.-k. geol. Reichsanstalt, Wien, vol. 6, pt. 2, p. 11.

1896. Halorites, Mojsisovics, Obertriadischen Cephalopoden-Faunen des Himalaya: Denkschr. K. Akad. Wiss., Wien, p. 578.

Type-Ammonites Ramsaueri Quenstedt (1846), in F. von Hauer, Die Cephalopoden des Salzkammergutes, p. 22, Pl. VIII, figs. 1 and 2.

Subglobose, involute, deeply embracing, and deeply indented by the inner whorls. Umbilicus very narrow, often closed. Sides convex, venter high-arched and broadly rounded.

Surface ornamented with cross ribs like those of Juvavites, or with rows of knots running diagonally across the shell.

The body chamber is long and contracted, and also shows egression or departure from the normal spiral.

The septa are ammonitic, dolichophyllic, not deeply digitate.

Of the Halorites s. str. only the group with the diagonal rows of knots, the Catenati, occurs in America, where it is found in the Upper Triassic, probably in the Noric stage, associated with Rhabdoceras and Pseudomonotis. Halorites is confined in the Alpine province and in India to the Noric stage. In America it is represented only by Halorites americanus Hyatt.

a Cephalopoden der Hallstätter Kalke: Abhandl. K.-k. geol. Reichsanstalt, Wien, vol. 6, pt. 2, 1893, Ṗl. C, figs. 2, 3, and 4. 


\section{HALORITES AMERICANUS Hyatt.}

Pl. XXIX, figs. 1 and 2.

1864. Ammonites Ramsaueri, Gabb (not Quenstedt), Geol. Survey California, Palæontology, vol. 1, p. 27, Pl. III, figs. 21 and $21 \mathrm{a}$.

1892. Halorites americanus, Hyatt, Bull. Geol. Soc. America, vol. 3, p. 398.

(Not 1846. Ammonites Ramsaueri, Quenstedt (in F. von Hauer), Die Cephalopoden des Salzkammergutes, p. 32, Pl. VIII, figs. 1 and 2.)

Subglobose, involute, deeply embracing; whorls highly arched, with convex sides and rounded broad venters. Umbilicus closed.

Surface ornamented with distinct ribs that start from the umbilicus and run, without interruption, straight across the venter. On these ribs are tubercles, closely arranged, which do not seem to be in regular spirals.

Septa unknown.

Gabb compared this species to Halorites Ramsaneri, but it is not a member of that group of Acatenati; its nearest affinities are with the group of Halorites catenati, although on account of the imperfect preservation of the Californian specimens no direct comparison with any European species may be made.

Horizon and locality.-Found by the Geological Survey of California in the Pseudomonotis beds, Upper Triassic, of the Genesee Valley, Plumas County, Cal., near Robinson's ranch (formerly called Gifford's ranch). A similar form; possibly the same species, was found by J. P. Smith in the Pseudomonotis beds of the Muttleberry Canyon, West Humboldt Range, Nevada, associated with Pseudomonotis subcircularis, Rhabdoceras Russelli, Arcestes Andersoni, and other forms similar to those found with Halorites americanus in Plumas County.

Subgenus HOMERITES Mojsisovics.

1893. Homerites, Mojsisovics, Cephalopoden der Hallstätter Kalke: Abhandl. K.-k. geol. Reichsanstalt, Wien, vol. 6 , pt. 2, p. 13 .

Type.-Ammonites semiglobosus Hauer (1855), Beitr. Kennt. Cephalopoden der Hallstätter Schichten, p. 155, Pl. IV, figs. 10-13, and E. von Mojsisovics, Cephalopoden-Fauna der Hallstätter Kalke, p. 57, Pl. LXXXIX, figs. 1-6.

Dwarf forms, involute, deeply embracing, subglobose whor]s; umbilicus closed, sides convex, whorl highly arched with rounded venter. Inner whorls rounded and with the sculpture of Halorites, but at the beginning of the body chamber at maturity the whorl becomes flattened and higher, and the sculpture grows rougher. There are then strong dichotomous ribs that bend forward on the flanks across the rounded abdominal shoulders and end on the venter in rows of knots on each side of a weak central keel. These knots do not occur at the end of every rib, but usually on alternating ribs. 
The septa are ceratitic, the saddles being only occasionally serrated.

Homerites occurs only in the zone of Tropites sublullatus of the Alpine province. In California it was found only in the upper part of the Upper Triassic above the zone of Tropites subbullatus, but in the same limestone bed with that species. Homerites is represented in America only by Homerites semiglobosus Hauer.

\section{HALORITES (HOMERITES) SEMIGLOBOSUS Hauer.}

Pl. XXVIII, figs. 19-24.

1855. Ammonites semiglobosus, Hauer, Beitr. Kennt. Cephalopoden-Fauna Hallstätter Schichten: Denkschr. K. Akad., Wiss., Wien, vol. 9, p. 155, Pl. IV, figs. 10-13.

1893. Homerites semiglobosus, Mojsisovic's, Cephalopoden der Hallstätter Kalke: Abhandl. K.-k. geol. Reichsanstalt, Wien, vol. 6, pt: 2, p. 57, Pl. LXXXIX, figs. 1-6.

1860. Ammonites semiglobosus, Haner, Nachtrag zur Kenntniss der Cephalopoden-Fauna der Hallstätter Schichten: Sitzungsber. K. Akad. Wiss., Wien, vol. 41, p. 145, Pl. IV, figs, 8-10.

Shell small, robust, involute, subglobose, deeply embracing, and deeply indented by the inner whorls. Whorl somewhat compressed laterally, highly arched, with convex sides and rather broad venter.

The surface is ornamented with radial ribs that run nearly straight up the sides. In the middle of the venter there is a weak keel, bounded by a row of spines on each side. These spines are usually at the ends of the lateral ribs, but may also occupy intermediate spaces. They begin with a large pair of horn-like protuberances at the beginning of the body chamber. The inner whorls are rounded, with ribs, like those of Halorites, running from the umbilicus across the low and arched venter, with no interruption. On the chambered part of the shell there are no spines and no keel, so that the appearance of the rough sculpture marks the mature stage of the body chamber.

The septa are ceratitic; the external lobe is divided by a siphonal notch into two short simple branches. The first and second laterals are serrated. The saddles are all rounded and entire. Inner septa not seen. The California specimens agree with those figured and described by Mojsisovics from the Alpine province.

Horizon and locality.-Homerites semiglobosus was found by J. P. Smith in the Upper Triassic of Shasta County, Cal., 3 miles north of Kelly's ranch, on the west side of the North Fork of Squaw Creek, 18 miles northeast of the Bully Hill mine. The horizon in which it was found is the upper part of the Hosselkus limestone, about 150 feet above the beds with Tropites subbullatus. It was also found by H. W. Furlong, 2 miles northwest of Brock's ranch, on the divide between Squaw Creek and Pit River, in the same horizon as at the first-named locality. In the Alpine province this species is associated with Tropites subbullatus, but in California it is somewhat later than that species. 
Type.-Tardeceras parvum Hyatt and Smith.

Involute, laterally compressed, robust, deeply embracing whorls; sides flattened, abdominal shoulders rounded, and venter flattened. Umbilicus closed. Strong umbilical nodes that are prolonged in ribs that run up the sides across the abdominal shoulders, and become weaker on the venter, which is nearly smooth. Body chamber long. Septa simple, slightly ceratitic. The ventral lobe is divided by a siphonal notch, the lateral lobe is slightly serrated; there is a small, shallow, entire auxiliary lobe on the umbilical shoulder.

The young of this genus are like Stephanites or Acrochordiceras. Tardeceras resembles Sibirites, but is more involute than that genus, and also differs in its smooth venter. It also resembles Juvavites, but differs in its lateral ribs, ceratitic septa, and smooth venter. Tardeceras is known only from the Upper Triassic zone of Tropites subbullatus, of Shasta County, Cal., where it is represented by the single species Tardeceras parvum Hyatt and Smith.

TARDECERAS PARVìM Hyatt and Smith, sp. nov.

Pl. LXXIX, figs. 11-20.

Dwarf form; involute, deeply embracing; whorl laterally compressed, with flattened sides, rounded abdominal shoulders, and rather broad, flattened venter.. Umbilicus very narrow, almosit closed, concealing the inner volutions.

: Surface ornamented with fine dichotomous ribs that start from bundles on the umbilical shoulder, and run nearly straight up the sides and across the abdominal shoulders. They become much weaker on the venter, but are still visible.

The septa are weakly ceratitic; the external lobe is divided by a siphonal notch; the lateral lobe is broad, shallow, and slightly serrated; the second lateral is small, rounded, and entire. The saddles are all entire.

This species rescmbles Sibirites, but is too involute, and the sculpture on the venter is too faint for that genus. It also resembles Juvavites, but the character of the sculpture, the flattened sides and venter, and the simple ceratitic septa forbid a reference to that genus.

In its early youth this species has a low, broad trapezoidal whorl, and umbilical ribs, with occasional constrictions and nearly smooth venter, as in Gastrioceras.

Then the form in adolescence resembles Stephanites Waagen, after which the ribs are prolonged until they cross the venter.

Horizon and locality.-Tardeceras parvum was found by J. P. Smith in the Upper Triassic zone of Tropites subbullatus, of Shasta County, Cal., three miles east of Madison's ranch, on the divide between Squaw Creek and Pit River, and one-half mile north of the trail across to Brock's ranch. 
Genus JUVAVITES Mojsisovics.

1879. Juvavites, Mojsisovics, Vorlüufige kurze Uebersicht der Ammoniten-Gattungen der Mediterranen und Juvavischen Trias.: Verhandl. K.-k. geol. Reichsanstalt, Wien, p. 136.

1893. Juvavites, Mojsisovics, Cephalopoden der Hallstätter Kalke: Abhandl. K.-k. geol. Reichsanstalt, Wien, vol. 6, pt. 2, p. 74 .

1896. Juvavites, Mojsisovics, Obertriadischen Cephalopoden-Faunen des Himalaya: Denkschr. K. Akad. Wiss., Wien, vol. 63, p. 603 .

Type--Ammonites Ehrlichi Hauer, Beitr. Kennt. Cephalopoden-Fauna der Hallstätter Schichten, 1855, p. 155, Pl. IV, figs. 14 and 15 (not figs. 16-18); and E. von Mojsisovics, Cephalopoden der Hallstätter Kalke, 1893, p. 79, Pl. LXXXIX, fig. 11.

Involute, laterally compressed, with convex sides and rounded venter. Umbilicus narrow. Whorls deeply embracing, and deeply indented by the inner whorls. Form subglobose, but sometimes flattened to subdiscoidal.

Surface ornamented with dichotomous ribs thát extend over the rounded abdomen, although they may be interrupted along the siphonal area. Besides these ribs, constrictions usually occur at frequent intervals.

Septa ammonitic, but not deeply digitate. The external lobe is divided by a siphonal saddle; there are two principal lateral lobes present, and usually two small auxiliaries.

E. von Mojsisovics ${ }^{a}$ divides the genus into five groups, forming three subgenera:

1. Continui $\{$ Interrupti $\}$ Juvavites s. str.

3. Scissi

4. Intermittentes $\}$ Subgenus Anatomites.

5. Dimorphi. Subgenus Dimorphites.

In the Oontinui the ribs run uninterrupted across the venter. In the Interrupti the ribs are interrupted in the center of the siphonal area, and alternate on opposite sides. Both of these groups appear to lack constrictions. In the Scissi and the Interirittentes the ribs are interrupted by a slight ventral furrow, but do not alternate on opposite sides. On both groups periodic constrictions of the shell, with an elevation or: rib parallel to this constriction, appear. Neither the constrictions nor the ribs parallel to the constrictions are interrupted by the ventral furrow, but run across the abdomen. In the Intermittentes the constriction divides the sculpture into distinct fields, in which a bundling of the ribs is visible.

The Dimorphi are laterally compressed with high whorls, narrow venters, and lack the constrictions. The ribs cross the venter, forming abdominal shoulder angles.

a Cephalopoden der Hallstätter Kalke: Abhandl. K.-k. geol. Reichsanstalt, Wien, 1893, vol. 6, pt. 2, p. 74. 
The groups of Scissi and Intermittentes make up the subgenus Anatomites Mojsisovics, for which no type was cited, but of which Juvavites rotundus Mojsisovies (Cephalopoden der Hallstätter Kalke, pt. 2, (1893), p. 98, PI. LXXX, figs. 6-8; Pl. CXXVI, fig. 11; Pl. CXCV, fig. 11) is first described under the group Scissi.

Juvavites s. str., and Anatomites are both characteristic of the Upper Triassic, Karnic, and Noric horizons, in which they are found in the Alpine province, in the . Himalayas, and in California. Besides the species described in this paper there are several as yet undescribed in the American Triassic.

\section{JUVAVITES SUBINTERRUPTUS Mojsisovics.}

Pl. XXX, figs. 1 and 2 .

1893. Juvavites subinterruptus, Mojsisovics, Cephalopoden der Hallstätter Kalke: Abhandl. K.-k. geol. Reichsanstalt, Wien, vol. 6, pt. 2, p. 90, Pl. LXXXIX, fig. 13; Pl. XC, figs. 2 and 3; Pl. CXXVI, fig. 16 .

Form robust, involute, laterally compressed. Whorl bigh with flattened convex sides, sloping abdominal shoulder's, and bighly arched venter. Deeply embracing, and deeply indented by the inner whorls. Umbilicus narrow, almost closed, showing none of the interior volutions. The height of the whorl is somewhat more than one-half of the total diameter, and it is indented to one-half its height by the inner volution. The width of the whorl is slightly less than the height, and the point of greatest width falls just above the umbilical shoulders.

The surface is ornamented with radial dichotomous ribs that branch at a point about one-third of the height of the whorl, and often a second time on the abdominal shoulders. These ribs are interrupted on the venter and alternate on the two sides. There is no ventral furrow, and no constrictions have been seen.

The septa are ammonitic, deeply digitate. The external lobe is divided by a siphonal saddle into two rather short branches. The first lateral lobe is long and wide, followed by a similar, but smaller, second lateral. There are also three auxiliaries. The antisiphonal lobe is long and narrow, flanked by five internal laterals on each side, growing smaller and simpler toward the umbilicus.

The Californian specimens agree exactly with those described by Mojsisovics from the Alpine province. This species differs from Juvavites interruptus Mojsisovics in its greater thickness, more complex sopta and greater curvature of the ribs on the abdominal shoulders.

Horizon and locality.-Juvavites subintermutus was first found in the Alps in the Upper Triassic, middle Karnic stage, below the zone of Tropites subbullatus. It was found by J. P. Smith in the Upper Triassic, Karnic stage, zone of Tropites subbullatus, of Shasta County, Cal, near Terrup-chetta (Cottonwood Flat), on Squaw Creek, 9 miles northeast of the Bully Hill mine, and 6 miles above Madison's ranch; 
also on Brock Mountain about 3 miles east of Madison's ranch, on the divide between Squaw Creek and Pit River, Shasta County, Cal. The figured specimens were collected near Terrup-chetta, on the divide between Squaw Creek and Pit Kiver, Shasta County, Cal.

\section{Subgenus ANATOMITES Mojsisovics.}

1893. Anatomites, Mojsisovics, Cephalopoden der Hallstätter Kalke: Abhandl. K.-k. geol. Reichsanstalt, Wien, vol. 6, pt. 2, p. 74.

1896. Anatomites, Mojsisovics, Obertriadischen Cephalopoden-Faunen des Himalaya: Denkschr. K. Akad. Wiss., Wien, vol. 63, p. 31.

Type.-Probably Juvavites rotundus Mojsisovies, Cephalopoden der Hallstätter Kalke (1893), p. 98.

Subglobose, involute, deeply embracing, convex sides and highly arched, rounded venters.

Surface ornamented with dichotomous ribs interrupted along the siphonal area, and with periodic constrictions. This latter character is the sole distinction between this subgenus and fuvavites s. str.

Besides the species described below one or two undescribed species have been found in Califormia.

\section{JUVAVITES (ANATOMITES) SUBINTERMITTENS Hyatt and Smith, sp. nov.}

Pl. XXX, figs. 3-5.

Involute, laterally compressed, deeply embracing, and deeply indented by the inner whorls. Sides somewhat flattened, venter rounded and narrow, without .prominent abdominal shoulders. Umbilicus narrow, exposing none of the interior volutions.

Surface ornamented with radial dichotomous ribs which divide about midway up the flanks and again at the abdominal shoulders, curving gently forward. These ribs are interrupted in the middle of the venter, and alternate on the two sides, but there is no furrow. There are also three or four deep constrictions to each revolution, dividing the sculpture into well-marked periods.

The septa are ammonitic, divided into a number of lobes and saddles, but. they could not be made out in sufficient detail to draw.

Juvavites subintermittens is nearest of kin to Juvavites intermittens Mojsisovics, ${ }^{a}$ but differs from that species in the greater lateral compression of the whorl, and the coarser ribs.

Horizon and locality.--Juvavites subintermittens was found by J. P. Smith in the Upper Triassic Karnic stage, upper part of the Tropites subbullatus beds, of

a Cephalopoden der Hallstiatter Kalke: Abhandl. K.-k. geol. Reichsanstalt, Wien, vol. 6, pt. 2, 1893, p. 112, Pl. XCIII, figs. $6-10$. 
Shasta County, Cal., near Terrup-chetta, on Squaw Creek, about 9 miles northeast of the Bully Hill mine, and 6 miles above (northeast) Madison's ranch. It was also found by J. P. Smith on the west side of the North Fork of Squaw Creek, Shasta County, 3 miles north of Kelly's ranch, and 15 miles northeast of Madison's.

The figured specimen was collected on the divide between Squaw Creek and Pit River, near Terrup-chetta, Shasta County, Cal.

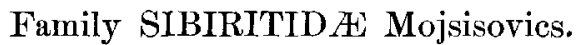

Body chamber long, whorl somewhat evolute, laterally compressed; umbilicus open, usually wide. Sides ornamented with ribs, which usually cross the venter. Septa goniatitic or weakly ceratitic.

This group is the oldest known of the Tropitoidea, but this does not necessarily mean that it is the ancestral family of the suborder, for none of the others in development go through a Sibirites stage of growth. Being the oldest known family of Tropitoidea, it has preserved somewhat more of the remote ancestral characters than the others. The differentiation of the Sibiritida from the other members of the Tropitoidea must have taken place in the Paleozoic, for Sibirites is already characteristically developed in the Lower Triassic, in which formation the Haloritidæ and Tropitidæ are as yet unknown.

The Sibiritidæe are represented in America by Sibirites, known in this region only in the Lower Triassic, although in the Mediterranean region it is found also in the Upper Triassic, and by Columbites Hyatt and Smith, known only in the Lower Triassic of southeastern Idaho.

Columbites appears to possess more of the primitive characters of the Tropitoidea : . than any other genus of the group, and hence is either the ancestral radicle of the suborder, or is very like that primitive form. It seems to be a connecting link between the Tropitoidea and the Glyphioceratide of the Paleozoic.

$$
\text { Genus SIHIRITHS Mojsisovios. }
$$

1886. Sibirites, Mojsisovies, Arktische Triasfaunen: Mém. Acad. imp. sci. St.-Pétersbourg, sér. 7, tome 33 , No. 6 , p. 58 .

1893. Sibirites, Mojsisovics, Cephalopoden der Hallstätter Kalke: Abhandl. K.-k. geol. Reichsanstalt, Wien, vol. 6 , pt. 2, p. 327.

1895. Sibirites, Waagen, Fossils from the Ceratite Formation: Salt Range Fossils, vol. 2, p. 104: Men. Geol. Survey India, Pal. Indica, ser. 13.

1895. Sibirites, Diener, Cephalopoda of the Muschelkalk: Himalayan Fossils, vol. 2, pt. 2, p. 37, Mem. Geol. Survey India, Pal. Indica, ser. 15.

Type-Sibirites pretiosus Mojsisovics, Arktische Triasfaunen, p. 61, Pl. X, fig. 10 . 
Body chamber long; whorl moderately evolute, robust, widely umbilicate; sides rounded; whorls not increasing rapidly in height.

Surface ornamented with strong ribs that run straight up to the venter from the umbilicus, usually dividing on the abdominal shoulders. The typical species have the ribs alternating on the two sides, as in Schlotheimia; later species may develop thorns and tubercles at the point of division of the ribs, as in Cocloceras.

It seems very doubtful to the writers whether the species assigned by Waagen to Sibirites, really belong in that genus, but the material collected in California is not sufficent to settle the question. At any rate it is certain that several species from the Meckoceras beds of California are congeneric with Waagen's Indian species, and for the present they are assigned to Sibirites.

This genus is known at present in the Lower Triassic of northern Siberia; Lower Triassic Meekoceras beds, of Inyo County, Cal.; and base of the Middle Triassic in the Salt Range. Three species have been found in California, Sibirites Noetlingi, and two as yet undescribed.

SIBIRITES NOETLINGI Hyatt and Smith, sp. nov.

Pl. IX, figs. 1-3.

Shell moderately involute, laterally compressed. Whorl deeply embracing, increasing slowly in height, not deeply indented by the inner volutions. Sides flattened, umbilical shoulder subangular, venter broad and flattened. Umbilicus moderately wide and deep, showing all the interior volutions. The height of the last whorl is about three-sevenths of the total diameter, and it is indented to slightly more than one-fourth of its height by the inner volution. The width of the whorl is more than three-fourths of the height. The width of the umbilicus is one-fourth of the total diameter.

Surface ornamented with radial flexuous ribs, fine and coarse ribs alternating. These begin, without knots, on the umbilicus, curve gently forward high up on the flanks, and then run straight across the venter. There is a faint suggestion of nodes where the ribs cross the abdominal shoulders.

The septa are unknown.

Sibirites Noetlingi is nearly allied to $S$. hircinus Waagen ${ }^{a}$ from the upper Ceratite limestone of India, but differs from that species in its fine sculpture, and more numerous ribs. 'They both, however, belong to the same group.

Horizon and locality.-Sibirites Noetlingi was found by J. P. Smith in the Lower Triassic Meekoceras beds of the Inyo Range, Inyo County, Cal., $1 \frac{1}{2}$ miles

a Fossils from the Ceratite Formation: Salt Range Fossils, vol. 2, 1895, p. 123, Pl. LX, fig. 4: Mem. Geol. Survey India, Pal. Indica, ser. 13.

16918-No. $40-05-4$ 
east of the Union Spring, on the old McAboy trail across to the Salinas Valley. This locality is on the east side of Owens Valley, and about 15 miles southeast of Independence.

Genus COLUMBITES IIyat and Smith, gen. nov.

Type.-Cohumbites parisianus Hyatt and Smith.

Form evolute, discoidal; whorls little embracing, and little impressed by the inner volutions, low and increasing slowly in height. Cross section helmet shaped. Umbilicus wide. Body chamber at least one revolution in length.

Surface ornamented with lateral ribs, spiral strix, and frequent varices.

Septa consisting of a divided ventral lobe, a principal lateral lobe, and an auxiliary. Internal septa consisting of a narrow antisiphonal Iobe flanked by a similar lateral on each side. The divided ventral lobe and the principal lateral are slightly serrated, the other lobes and all the saddles are goniatitic, except the auxiliary lateral lobe, which is occasionally serrated.

In adolescence the whorl is trapezoidal in shape and is much broader and more depressed than at maturity. At this stage the septa are goniatitic and all the characters resemble Gastrioceras of the Carboniferous and Permian, from which genus Columbites seems to have originated; and it is probably a connecting link between the Tropitidæ of the Triassic and the Glyphioceratidx of the Carboniferous.

Columbites greatly resembles Dinarites spiniplicatus Mojsisovics ${ }^{a}$ (Olenelictes Hyatt), but differs from that group in its more trapezoidal adolescent whorls, its frequent varices, and its long body chamber. Dinarites spiniplicatus and its allies are said to have short body chambers and are considered as the ancestors of the group of Ceratites subrobustius (Keyserlingites Hyatt). Columbites appears to have given rise to Tropites, the young of which greatly resemble the broader and more trapezoidal species of Columbiles.

Columbites also resembles Danubites Mojsisovics, but differs from that genus in its trapezoidal gastrioceran young, in its longer body chamber, its varices, and fewer lobes. Columbites differs from Xenodiscus in its broader whorls and smaller number of lobes, but more especially in the character of the young, which in Xenodiscus point to the Prolecanitidæ as Paleozoic ancestors.

For a long time Celtites has been regarded by some paleontologists as the ancestor of the Tropitidæ, in spite of the fact that no certain members of the latter group have young stages in any way resembling Celtites. This was because the ontogeny of the Tropitidx points to an evolute ancestor with long body chamber and lateral ribs, and destitute of keel and abdominal furrows. Columbites 
meets these requirements, and is like the young stages of the more primitive species of Tropites, while Celtites is not like them.

Occurrence.-Columbites is known at present only in the Lower Triassic of southeastern Idaho, where it is represented by Columbites purisianus Hyatt and Smith, and four undescribed species. Its horizon is above the zone of Meekoceras. gracilitatis, although at least two species of the Meekoceras'gracilitatis fauna were found in the beds with Columbites.

COLUMBITES PARISIANUS Hyatt and Smith, sp. nov.

Pl. I, figs. 9-14; Pl. LXI, figs. 1-21; Pl. LXXII, figs. 1-24.

This species is the type of Columbites Hyatt and Smith, gen. nov.

Form evolute, discoidal, laterally compressed. Whorls little embracing and little indented by the inner volutions. Cross section high helmet shaped, the width being about two-thirds of the height of the whorl. The sides are convex, curving without marked shoulders to the rounded venter. The indentation is shallow, being less than one-fourth of the height of the whorl. The outer whorl embraces about three-eighths of the inner. The height of the whorl is somewhat less than one-third of the entire diameter of the shell.

The umbilicus is broad and shallow, being about three-eighths of the entire diameter of the shell.

At maturity the sculpture is weak, consisting of low umbilical folds, which extend up the sides and occasionally across the venter, being much weaker on the ventral portion of the whorl. These folds curve sharply forward on the flanks, forming a broad sinus on the venter. Parallel with them are frequent weak varices, which are distinct on the cast, but scarcely visible on the outer shell. The surface of the shell is ornamented with fine cross stria of growth parallel with the folds, and weaker spiral striæ.

The body chamber was seen on several specimens to be at least a complete revolution in length, and the sculpture persists on the body whorl as well as on the chambered portion of the shell.

The septa consist of a ventral lobe divided by a deep saddle into two narrow branches, a principal lateral lobe in the middle of the flank, and a short, narrow auxiliary on the umbilical shoulder. There are also a narrow antisiphonal lobe and a single small internal lateral. The ventral lobe, the principal lateral, and the auxiliary are slightly serrated, and the internal lobes are goniatitic. All the saddles are rounded and entire.

The foregoing description applies only to the mature shell, for up to the diameter of $20 \mathrm{~mm}$. the whorl is low and trapezoidal in cross section, sloping outwardly to the angular ventral shoulders, where the umbilical ribs end in 
knots. At this stage the sculpture is almost obsolete on the venter, but the varices are more strongly marked than at maturity. The spiral stria are also very distinct, and the septa are all goniatitic. Up to the diameter of $15 \mathrm{~mm}$. the shape, ornamentation, and septa are exactly like Gastriocercs of the Carboniferous, from which genus Columbites appears to have been derived, by increasing the involution and height of the whorl and by the slight serration of the ventral and lateral lobes. This is just such a transition as one would expect to find in the upper Permian or the lowest Triassic, and the beds in which Columbites was found are in the Lower Triassic, but that they belong to the Mesozoic is shown by the association of Meekoceras, Prionolobus, Celtites, and Pseudosageceras, of which the species are in part identical with forms from the zone of Meekoceras gracilitatis which lies below the Columbites beds.

Columbites parisianus bears some resemblance to Dinarites avisianus Mojsisovics $^{a}$ of the Middle Triassic Ladinic horizon, of the Mediterranean region, but differs from the European species in its greater evolution, in its weaker sculpture at maturity, its stronger ornamentation in adolescence, and its long body chamber.

Columbites parisianus resembles externally Danubites Strongi Hyatt and Smith, but differ's from that species in its stronger sculpture, especially in the young whorls, in its varices, longer body chamber, and in lacking a third lateral lobe. The young stages of the two genera are so unlike that they must belong to different stogks, in spite of their convergence in appearance at maturity.

Horizon and locality.-Columbites parisianus was found by, Mr. R. S. Spence 1 mile west of Paris, Bear Lake County, southeastern Idaho, associated with Pseudosageceras intermontanum Hyatt and Smith, Prionolobus Jacksoni Hyatt and Smith, Meekoceras, sp. nov., Ophiceras Spencei Hyatt and Smith, Celtites, sp. nov., three or four other species of Columbites, and some other undetermined forms This bed lies above the beds with Meekoceras gracilitatis, which outcrop near by, but it still belongs to the Lower Triassic, and is the probable equivalent of the Olenek horizon of northern Siberia.

\section{Family TROPITID A Mojsisovies.}

Form evolute or involute, whorls usually laterally compressed, but in some genera depressed. Surface with lateral ribs and ventral keel, usually bounded by depressions or furrows. Spines are usually confined to the umbilicus or the margin, but may be present on the sides. Body chamber long. Septa ammonitic, dolichophyllic in all except some reversionary or primitive genera, in which they are goniatitic. The young stages of the Tropitidæ all are robust, helmet-

a Cephalopoden der Mediterranen Triasprovinz: Abhandl. K.-k. geol. Reichsanstalt, Wien, rol. 10, 1882, p. 13, I'l. XXVII, figs. $17-21$ 
shaped, with smooth sides, ventral keel, and goniatitic septa, resembling the genus Styrites, which may then be thought to have preserved the primitive characters of the family. Below the Styrites stage the young resemble Gastriocercas of the Glyphioceratide, from which group the Tropitide probably descended. Columbites is probably the connecting link with the Glyphioceratida.

Characteristic nembers of the Tropitide are not known below the Upper Triassic, but Sibyllites occurs in Nevada in beds that belong to the Middle Triassic. The greater part of this family is confined to the Karnic stage of the Upper Triassie, in which horizon Tropitidie are abundant in the Alpine province, in the Himalayas, and in California.

The Tropitide are represented in the American Triassic by Tropites, Paratroptes, Sityllites, Tropiceltites, Discotropites, and Tornquistites, all confined to the Upper Triassic, with the exception of Sityllites, which is found in Nevada only in the Middle Triassic.

Genus PARA'TROIITHS Mojsisovics.

1893. Paratropites, Mojsisovics, Cephalopoden der Hallstätter Kalke: Abhandl. K.-k. geol. Reichsanstalt, Wien, vol. 6 , pt. 2 , p. 184.

1904. Paratropites, J. P. Smith, The Comparative Stratigraphy of the Marine Trias of Western America, Proc. California Acad. Sci., 3d ser., vol. 1, p. 395.

Mojsisovics gave this name to what he considered a subgenus under Tropites, and did not name any type nor mention any species under the diagnosis. The first species described by him under this group, Paratropites bidichotomus Mojsisovics (Ceph. Hallstätter Kalke, p. 234, Pl. CXXVII, fig. 11), would then according to usage become the type, but it is neither characteristic nor well known. The commonest and best known species of the group, Paratropites Saturnus Dittmar, would seem much better as the basis for the generic diagnosis, and this form, along with Paratropites Sellai Mojsisovics, must have served the author as prototype of the group.

The form is laterally compressed, deeply embracing, and deeply indented by the inner whorls. The sides are flattened-convex, the venter narrow, and the whorls usually much higher than wide. The umbilicus is narrow, the inner volutions usually being concealed. Umbilical knots are present on most species, and from these dichotomous ribs run with gentle forward curve up the flanks and bend forward on the abdominal shoulders. On the venter is a distinct central keel, usually with furrows on each side, at which the lateral ribs end. The keel is smooth and not crenulated by the ribs. No spines occur, and knots only on the umbilicus. Constrictions have not been observed on any of the numerous species of the group.

The septa are ammonitic but not deeply digitate, dolichophyllic, of the Tropites type. The ventral lobe is divided by a shallow siphonal saddle; there are usually 
two principal laterals and an auxiliary present; but in some species there is only one principal lateral, and the second must be regarded as an auxiliary. The body chamber is long, and at maturity shows a tendency to obsolescence of the ribs, also an egression of the whorl.

Most species of this group are compressed laterally, and high-whorled, but some are subglobose in shape. Paratropites seems to be equally as nearly related to Discotropites as to Tropites, and may possibly be a connecting link between them; or, more properly speaking, it seems to have departed less from the ancestral type than they. This is emphasized by the fact that in Paratropites the adult whorls differ little from the youthful stages, while in Tropites and Discotropites great changes take place in growth.

Under this genus two groups of species may be recognized: (1) Group of Paratropites Sellai Mojsisovics, characterized by the strong lateral ribs, Paratropites s. str. (2) Group of Paratropites americanus Hyatt and Smith, characterized by obsolescence of the ribs, which persist faintly only in early youth, subgenus G'ymnotropites Hyatt and Smith.

Paratropites appear in the Mediterranean region, in India, and in California in the Karnic stage of the Upper Triassic, and, according to our present knowledge, is entirely confined to that horizon.

In the zone of Tropites subbullatus of Shasta County, Cal. Parutropites is represented by two species identical with Alpine forms, P. Sellai Mojsisovics, and $P$. Dittmari Mojsisovics, besides a large number of new species closely related to Alpine forms. These species will be described in a later paper.

The subgenus Gymnotropites is not recorded outside of California, although Paratropites Marii Mojsisovics, of the Alpine province, may be a transition to this group.

\section{PARATROPITES SELLAI Mojsisovics.}

PI. XXX, figs. 6-10; PI. XXXI, figs. 1-26.

1893. Tropites (Paratropites Sellai) Mojsisovics, Cephalopoden der Hallstätter Kalke: Abhandl. K.-k. geol. Reichsanstalt, Wien, vol. 6, pt. 2, p. 242; Pl. CXIV, figs. 2, 4-10; Pl. CXV, figs. 5, 6, 9; 10, 11; Pl. CXIII, fig. 23.

1866. Ammonites Saturnus (pars), A. von Dittmar, Zur Fauna der Hallstätter Kalke: Geognost.palæont. Beitr., vol. 1, p. 367, Pl. XVI, figs. 4, 5, 6, 8; not figs. 1, 2, 3, 7 .

Form involute, robust, somewhat compressed laterally; whorl high, deeply embracing, and deeply indented by the inner whorls. In youth the whorl is highly arched, with convex sides, and rounded venter, but in age the sides become flattened, the abdominal shoulders pronounced, and the venter somewhat flattened. The umbilicus is narrow, concealing the inner volutions; its breadth varies from one-eighth to one-twelfth of the diameter of the shell. The outer whorl is 
about one-half of the diameter of the shell, and approximately as wide as high; the greatest breadth is at the base of the whorl, just above the umbilical shoulders. It is indented to one-half its height by the inner whorl, and conceals the inner whorl entirely. In the younger stages the form is subglobose, and the umbilicus virtually closed. On the venter there is a low median keel, bounded by shallow but distinct marginal furrows; these furrows are very distinct on the cast, but less so on the shell.

Surface ornamented with radial ribs that begin in bundles on the umbilical border, run up the sides with a forward curve, and bend abruptly forward on the umbilical shoulder to the margins of the keel furrows. These ribs are usually dichotomons, the division taking place at one-third of the beight of the whorl; they are broad and rounded, much wider than the intercostal spaces. In old age the ribs become weaker, and the shell is nearly smooth, only the keel remaining distinct.

Septa ammonitic, but simple, not deeply digitate. The external lobe is divided by a rectangular siphonal saddle into two short branches; the first lateral lobe is larger, and the second lateral about as large as the external; the auxiliary lobe on the umbilical shoulder is distinctly individualized, but smaller than the second lateral. The antisiphonal lobe is flanked by three internal laterals and an auxiliary on each side.

'The larval stages of Paratropites Sellai resemble Gastrioceras in their wide umbilicus and low helmet-shaped whorls. The keel appears at diameter of $2 \mathrm{~mm}$., while the lateral ribs do not develop until the diameter of $3.5 \mathrm{~mm}$. is reached. The septa begin to be ammonitic at diameter of $4 \mathrm{~mm}$. The development of the species is unusually simple for such a highly specialized ammonite, and the little change that takes place from the larval period to maturity shows that this genus has departed very little from its ancestral characters. It is therefore highly probable that in the early adolescent stage of Paratropites is seen a good indication as to what the ancestor of Tropites was like, involute, robust, with highly arched whorl, rounded abdominal shoulders, strong keel without bordering furrows, obscure umbilical ribs, and simple goniatitic septa. No mature form is yet known possessing these characters, but they are seen also in the young of Tropites and Discotropites, and many of them are preserved, although considerably modified, in mature forms of Styrites and Tropiceltites.

Paratropites Sellai is most nearly related to P. Saturnus Dittmar, but, according to Mojsisovics, differs from that species in having one more lateral lobe in the straighter lateral ribs and the fewer and weaker umbilical nodes. The figures of the two species given by Mojsisovics are indistinguishable, and from a careful examination of the original specimens of the two, one of the writers (A. Hyatt) is convinced that there are intergradations between P. Sellai and P. Satumus. Among 
more than fcur hundred American specimens of this species, however, the writers could find none with the characters attributed to $P$. Satumaus, and they have retained the name proposed by Mojsisovics.

This species is also closely related to $P$. Dittmari Mojsisovics, with which it is associated both in the Alps and in California, but differs from that species in its more robust, thicker whorl, $P$. Dittmari being thinner and more discoidal.

Horizon and locality.-Paratropites Sellai is very common in California in the the Karnic stage, Upper Triassic zone of Tropites subbullatus, of Shasta County. The figured specimens all came from Brock Mountain, on the divide between Squaw Creek and Pit River, about $2 \frac{1}{2}$ miles northeast of Madison's ranch, 6 miles northeast of the Bully Hill mine. It was found in this horizon in the Hosselkus limestone at several places along Squaw Creek, always in the same association, with . Tropites subbullatus Hauer, Discotropites sandlingensis Hauer, Proclydonautilus triadicus Mojsisovics, Sagenites Hertichi Mojsisovies, and Halobia superba Mojsisovics.

Subgenus GYMNOTROPITES Hyatt and Smith, subgen. nov.

Type--Paratropites americanus Hyatt and Smith.

Involute, laterally compressed, discoidal, deeply embracing, and deeply indented by the inner whorls. Sides flattened, venter narrow, surmounted by a keel, with little or no marginal furrows. Umbilicus narrow. Sides almost smooth, ornamented only with cross stria. In some forms transitional to Paratropites s. str. there are in the adolescent stages obscure rudiments of the lateral ribs.

Septa ammonitic; external lobe divided by a siphonal saddle. There are usually two laterals and a small auxiliary lobe.

This subgenus is distinguished from Paratropites s. str. only by its smooth shell, the other characters being identical; it is connected with that group by transitional species, and undoubtedly developed out of Paratropites. It also resembles Styrites, but differs from that genus in its more robust form and ammonitic septa.

Gymnotropites is known only from the Upper Triassic of Shasta County, Cal., zone of Tropites subbrillatus, where it is represented by several species, of which only one is described in this paper.

PARATROPITES (GYMNOTROPITES) AMERICANUS Hyatt and Smith, sp. nov.

PI. XXXII, figs. 1-10.

Involute, discoidal, laterally compressed. Whorl deeply embracing and deeply indented by the inner whorl. Sides flattened, venter narrow with obscure abdominal shoulders, and low median keel, without bordering furrows. Cross section of whorl high and narrow. Umbilicus closed, unbilical shoulders abruptly 
rounded. The height of the whorl is one and a third times the width and slightly more than one-half of the total diameter of the shell. The outer whorl cover's the inner almost entirely, and is indented by it to nearly one-half the height.

Surface of the shell nearly smooth, ornamented only with fine cross strix, which are bundled into faint folds.

The septa are ammonitic, both lobes and saddles being weakly digitate. The divided external lobe is flanked by two laterals and an auxiliary, decreasing in size toward the umbilicus. The antisiphonal lobe is flanked by three internal laterals and an auxiliary. In the young stages the folds are stronger, forming true ribs like those of Paratropites, indicating the origin of this group of smooth forms. This species resembles Paratropites Marii Mojsisovics, but is thinner and smoother. It has a stronger external resemblance to Styrites Reinischii Mojsisovics, ${ }^{a}$ but differs from that species in having ammonitic instead. of goniatitic septa.

Horizon and locality.-Paratropites (Gymnotropites) americanus Hyatt and Smith was found by J. P. Smith in the Upper Triassic zone of Tropites subbullatus, of Shasta County, Cal., 3 miles east of Madison's ranch, on the divide between Squaw Creek and Pit River, one-half mile north of the trail from Madison's to Brock's ranch on Pit River. This locality is about 6 miles northeast of the Bully Hill mine.

Genus SIBYLLITHS Mojsisovies.

1893. Sibyllites, Mojsisovics, Cephalopoden der Hallstätter Kalke: Abhandl. K.-k. geol. Reichsanstalt, Wien, vol. 6 , pt. 2 , p. 314.

Type.-Sibyllites tenuispinatus Mojsisovics, Cephalopoden der Hallstätter Kalke, p. 314, Pl. CXX, figs. 1 and 2.

Evolute, widely umbilicate; inner whorls with rounded venter, becoming sharpened in age into a sort of keel.

Sculpture on the inner whorls in form of ribs or knots, which become weaker with age. Fine spiral lines on the outer shell. Body chamber more than one revolution long.

Septa ammonitic, but not really digitate; the serration extends uniformly to lobes and saddles alike. 'There is a small divided ventral lobe, a large first lateral, small second lateral, and usually a small auxiliary lobe.

This genus is largely confined to the Upper Triassic of the Mediterranean region, where only a few species are known. It is represented in America by only a single species, Sibyllites Louderbacki Hyatt and Smith, from the Middle Triassic of Nevada

a Cephalopoden der Hallstiitter Kaike: Abhandl. K.-k. geol. Reichsanstalt, Wien, vol. 6, pt. 2, p. 281, Pl. XXI, fig. 3. 
Form evolute, discoidal, whorls low and broad, increasing slowly in height, rather deeply embracing and moderately indented by the inner volutions. Sides rounded, and sloping gently to the acute venter, without abdominal shoulders. Umbilical shoulders abrupt and subangular. Umbilicus wide and deep, exposing the broad umbilical margins of the inner whorls.

Surface almost smooth, but with faint umbilical folds parallel with the lines of growth. The shell was not sufficiently preserved to show the spiral lines.

The septa are ammonitic, but very simple, lobes and saddles slightly serrated all around, but not really digitate. The divided external lobe is small, the first lateral broad and rather shallow, the second lateral much smaller; there is probably an auxiliary lobe on the umbilical shoulders, but that could not be determined. This species is not like those assigned by Mojsisovics to Sibyllites, but is nearer to Sibyllites planorbis Hauer, "from the Middle. Triassic zone of Ceratites trinodosus, of Bosnia. But the American species has weaker sculpture and simpler septa.

Horizon and locality.-Sibyllites Louderbacki was found by J. P. Smith in the Middle Triassic of Nevada, on the divide between Troy Canyon and the South Fork of American Canyon, associated with Anolcites Whitneyi, Ceratites humboldtensis, Beyrichites rotelliformis, and many others. The specific name is given in honor of Dr. G. D. Louderback, of Reno, Nev.

Genus TROPIOFLTITES Mojsisovies.

1893. Tropiceltites, Mojsisovies, Cephalopoden der Hallstiitter Kalke: Abhandl. K.-k. geol. Reichsanstalt, Wien, vol. 6, pt. 2, p. 369.

Type.-Tropiceltites rotundus Mojsisovics, Cephalopoden der Hallstätter Kalke, p. 370 , Pl. CXX, tig. 9.

Dwarf forms. Evolute, little embracing, discoidal, depressed whorls, of which the breadth is usually greater than the height. Cross section low helmet-shaped. Umbilicus wide. Venter rather broad, and provided with a sharp central keel.

Sides ornamented with ribs, either simple or bifurcated, that start out from the umbilical shoulders and run nearly straight up the flanks, bending forward and becoming obsolete on the abdominal shoulder.

Septa goniatitic.

Mojsisovics divides this genus into three groups: (1) Tropiceltites costati, (Tropiceltites s. str.) characterized by absence of keel-furrows, by the inflated whorls, strong ribs becoming obsolete on the venter, and by the total absence of

$a$ Cephalopoden aus der Trias von Bosnien: Denkschr. K. Akud. Wiss., Wien, vol. 63, pt. 2, p. 271, PI. XII, figs. 1-8. 
knots or spines; (2) Tropiceltites laeves, characterized by the obsolescence of the lateral sculpture; (3) Tropiceltites arietiformes characterized by the very numerous volutions, the strong lateral sculpture, and the deep furrows bordering the central keel. The Tropiceltites laeves and $T$. arietiformes together make up the subgenus Arnioceltites Mojsisovics.

Only Tropiceltites s. str. is known in America, in the Upper Triassic, zone of Tropites subbullatus, of Shasta County, Cal. This group appears in Europe in the lower Karnic stage, and persists until the Noric. Only a single species is known in America.

TROPICELTITES FRECHI Hyatt and Smith, sp. nov.

Pl. LXXX, figs. 1-11.

Moderately involute, with inflated whorls, highly arched, and somewhat compressed laterally, becoming relatively narrower with age. Abdominal shoulders rounded, venter broad, provided with a distinct low keel at maturity. Umbilicus rather narrow and deep.

Surface ornamented with strong lateral ribs which at maturity cross the keel in folds, but in adoleseence become obsolete on the abdominal shoulders. In the young shells there are only umbilical ribs without the keel. There are no keel furrows at any stage.

Septa goniatitic; the external lobe is divided into two narrow, short branches; the lateral and the auxiliary are larger. The body chamber is at least a revolution in length. In the young stages there is neither keel nor ventral ribs; the form is depressed and broad, and resembles Stephanites Waagen, which may be the parent for'm of this group. Tropiceltites Frechi in all essential characters agrees exactly with the group of $T$. rotundus.

Horizon and locality.--Tropiceltites Frechi was found by J. P. Smith in the upper Triassic, zone of Tropites subbullatus, of Shasta County, Cal., on Bear Mountain, near Sherman's ranch, about 18 miles northeast of Redding, and 2 miles north of the road from Redding to Copper City. One specimen was also found in the limestone belt on the divide between Squaw Creek and Pit River, about 3 miles east of Madison's ranch. It was also found by J. P. Smith in the same horizon in Bear Cove, about 2 miles northeast of the last locality.

The figured specimens all came from Bear Mountain, Shasta County, Cal., near Sherman's ranch.

Genus TORNQUISTITES Fyatt and Smith, gen. nov.

Type.-Tornquistites evolutus Hyatt and Smith, sp. nov.

Evolute, discoidal, little embracing, laterally compressed, low whorls increasing very slowly in height. Cross section of whorl belmet-shaped; sides flat convex, 
venter narrowly rounded. Umbilicai very wide and shallow. At maturity there is a faint thread-like central elevation, which is the rudiment of a keel that is prominent in the adolescent period.

Surface ornamented with fine ribs that are sigmoidal on the sides and cross the venter.

Septa apparently goniatitic, but showing under the lens a faint serration of the lateral lobe.

The young stages of this genus are more involute, with higher whorls, and a distinct ventral keel; like Styrites Mojsisovics. This genus resembles Lecanites Mojsisovics, but differs from it in the faint serration of the lateral lobe and in the young stag'es.

Tornquistites is represented by two species in the zone of Tropites subbullatus, of Shasta County, Cal. One European species probably belongs under this genus,' "Isculites" obolinus Dittmar, described as Isculites by Mojsisovics (Cephalopoden der Hallstätter Kalke, p. 66; Pl. LXXXVI, fig. 4), but obviously unlike the type of that genus. Only one specimen is known of it, and the young stages were not studied, but this showed the thread-like elevation on the venter, the faint lateral sculpture, and the weakly ceratitic lateral lobe. The generic name is given in honor of Prof. Alexander Tornquist.

TORNQUISTITES EVOLOTUS Hyatt and Smith, sp. zov.

Pl. XXXII, figs. 11-21.

Evolute, laterally compressed, widely umbilicate. Whorls laterally compressed, low, and increasing slowly in height, little embracing, and little indented by the inner whorl. Cross section of the whorl elongate-oval, with rounded abdominal shoulders, and narrow, arched venter. In the middle of the venter is a faint thread-like elevation, which is the remnant of a keel, which is prominent in the young stages. The height of the whorl is slightly less than one-third of the total diameter, and the width is about two-thirds of the height. The indentation is about one-eighth of the height. The width of the umbilicus is about one-third of the diameter of the shell. The body chamber is at least one revolution long.

The surface of the shell and of the cast is ornamented with weak folds that bend sharply forward on the abdominal shoulders, forming a narrow sinus on the venter.

Septa faintly ceratitic, the first lateral lobe being slightly serrated, all the others being goniatitic. The external lobe is divided by a small siphonal notch into two short branches; the first lateral lobe is larger, and occasionally shows under the lens faint traces of serration; the second is smaller and entire; on the umbilical shoulder is a very small auxiliary. The antisiphonal lobe is long and 
narrow, flanked by a single short internal lateral on each side. This species is nearest to "Isculites" obolinus Dittmar, which probably belongs to the same genus but differs from it in the greater evolution and stronger sculpture.

Horizon and locality.-Tornquistites evolutus is rather common in the Upper Triassic, zone of Tropites subbullatus, of Shasta County, Cal., 3 miles east of Madison's ranch, on the divide between Squaw Creek and Pit River. It was most abundant at a place one-half mile north of the trail from Madison's to Brock's ranch on Pit River.

Gemus DISCORTOPITHSS Hyatt and Smith, gen. nov.

1879. Eutomoceras, Mojsisovics, Vorläufige kurze Uebersicht der Ammoniten-Gattungen der Mediterranen und Juvavischen Trias: Verhandl. K.-k. geol. Reichsanstalt, Wien, p. 136.

1893. Eutomoceras, Mojsisovics, Cephalopoden der Hallstätter Kalke: Abhandl. K.-k. geol. Reichsanstalt, Wien, vol. 6, pt. 2, p. 283.

(Not 1877. Eutomoceras, Meek., U. S. Geol. Explor. 40th Par., vol. 6, p. 126.)

Type-Ammonites saindlingensis Hauer.

Involute, discoidal, laterally compressed; whorls deeply embracing, and deeply indented by the inner whorls. Sides flattened; venter narrow, acute, and surmounted by a high keel, which in some species is hollow and in others is solid.

Surface ornamented with dichotomous sickle-shaped ribs, which bend forward on the flanks and become obsolete at the base of the keel; in some species the enlargement of these ribs on the abdomen forms rounded shoulders. Umbilical knots are always present, and knot or rudimentary spines may be present on the ribs but are not numerous. Besides the ribs the shell is ornamented with distinct spiral lines, giving a reticulated aspect to the surface. No constrictions or varices are known.

The septa are ammonitic, lobes and saddles being digitate, but not deeply so. The external lobe is long and deeply divided by a siphonal saddle; there is only one principal lateral lobe present; one well-developed auxiliary, and a second smaller auxiliary on the umbilical shoulder. The body chamber is long, comprising the last volution.

This genus is nearest to Paratropites Mojsisovics, from which it differs in the more compressed form, the usual absence of abdominal shoulders, and the extremely high keel. The spiral lines of Discotropites appear also on the shell of the group of Tropites subbullatus and in some other members of the Tropitoidea, and hence can not be considered as distinctive of this genus.

The young of Discotropites are of the Tropites type, almost exactly like those of the more compressed forms, and especially like those of Paratropites, which may be considered as the connecting link with the parent stock. And even in mature forms there is an almost unbroken series from the compressed 
Discotropites to the cylindrical Tropites bullati, so that there can be no question as to the propriety of classing these seemingly very different forms in the same family.

In classifying the ammonites of the European Triassic, E. von Mojsisovics ${ }^{b}$ assigned Ammonites sandlingensis Hauer to Hyatt's genus Futomoceras, which was based on a single imperfect specimen from the Middle Triassic of Nevada. Later collections made in the West Humboldt region of Nevada show that Eutomoceras Laubei Meek, ${ }^{b}$ the type of the genus, has ceratitic lobes, and belongs to the Ceratitoidea, being much more closely allied to Hungarites than to the Tropitida. The generic diagnosis of Eutomoceras given by Mojsisovies ${ }^{c}$ was based entirely on Ammonites sundlingensis Hauer, and kindred species in the Upper Triassic, Karnic stage, of the Austrian Alps, and not on Eutomoceras Laubei Meek. Mojsisovics divides the European species assigned to Eutomoceras into two groups: (1) Eutomocerata striata; including E. sandlingense Hauer, E. Theron Dittmar, E. Plinii Mojsisovics, E. acutum Mojsisovies, E. denudatum Mojsisovics. (2) Eutomocerata punctata; including E. punctetum Mojsisovics, E; Sengeli Mojsisovics.

The American species, $E$. Laubei Meek, was assigned to the group of Eutomocerata punctata.

The first group (Eutomoceras sandlingense) was characterized by the presence of umbilical knots but none on the flanks, and a hollow keel. The second group was characterized by lateral in addition to the umbilical knots, and by the supposed possession of a solid keel.

None of the species assigned by Mojsisovics to Eutomoceras agrees with Eutomoceras Laubei Meek, but all have the general characters of Ammonites sandlingensis Hauer, and clearly belong to the Tropitidæ, with which the American type species has no affinity. This group, however, is generically distinct, and therefore the writers propose for it the name Discotropites Hyatt and Smith, gen. nov., with "Ammonites" sandlingensis Hauer as the type. Discotropites is known only in the Upper Triassic, Karnic stage; in Europe it is represented by the species assigned by Mojsisovies to Eutomoceras. In America it is represented in the zone of Tropites subbullatus by Discotropites sandlingensis Hauer, and by several other . species, of which one belongs to the group defined by Mojsisovics as Eutomocerata punctata and the others to the Eutomocerata striata, all closely allied to their European congeners.

a Vorläufige kurze Uebersicht der Ammoniten-Gattungen der Mediterranen und Juvavischen Trias: Verhandi. K.-k, geol. Reichsanstalt, Wien, 1879, p. 136.

$b$ U. S. Geol. Explor. 40th Par., vol. 4, 1877, p. 126, Pl. X, figs. 8 and 8 a.

c Cephalopoden der Hullstätter Kalke: Abhandl. K.-k. geol. Reichsanstalt, Wien, vol. 6, pt. 2, 1893, p. 283. 
DISCOTROPITES SANDLINGENSIS Haner.

Pl. XXXV, figs. 1-12; Pl. XXXVI, figs. 1-26.

1849. Ammonites sandlingensis, Hauer, Ueber neue Cephalopoden aus den Marmorschichten von Hallstatt und Aussee: Haidinger's Naturwiss. Abhandl., vol. 3, p. 10, Pl. III, figs. 10-12.

1866. Ammonites sandlingensis, Dittmar, Zur Fauna der Hallstütter Kalke: Geognost--palaeont. Beitr., vol. 1, p. 370.

1893. Eutomoceras sandlingense, E. von Mojsisovics, Cephalopoden der Hallstätter Kalke: Abhandl. K.-k. geol. Reichsanstalt, Wien, vol. 6, pt. 2, p. ${ }^{\circ 285}$, Pl. CXXX, figs. 11-13; Pl. CXXXI, figs. 1-11.

1904. Eutomoctras sandlingense, J. P. Smith, The Comparative Stratigraphy of the Marine Trias of Western America: Proc. California Acad. Sci., 3d ser., vol. 1, p. 397, Pl. XLVI, fig. 10; and PI. XLVIII, figs. 5-6.

Type--Discotropites, gen. nov., Hyatt and Smith.

Involute, laterally compressed, discoidal, deeply embracing and deeply indented by the inner volution. Umbilicus narrow, one-eighth of the diameter of the shell, but exposing the umbilical shoulders of the inner whorls. Umbilical shoulders abruptly rounded. Sides flattened-convex, curving gently to the acute venter, with hardly any abdominal shoulders. Venter narrow and acute, surmounted by a high hollow keel, which is thinner at the base than at the top, and without bordering furrows. The outer whorl is one-half the diameter of the shell, and its breadth is one-half of the height. It is indented to one-third of its height by the inner volution, and conceals three-fourths of that volution.

Surface ornamented with numerous fine but distinct sickle-shaped ribs that show in the middle of the flanks a gentle backward curve, and then bend forward to the base of the keel, where they become obsolete. These ribs are either single or dichotomous, the division taking place nearly halfway up the flanks. The ribs are rounded, low, and narrower than the intercostal spaces; there are about sixty to a revolution on the mature shell. In addition to the ribs there are numerous fine spiral lines, which crossing the ribs give to them a beaded appearance. Both ribs and spiral lines show distinctly on the cast as well as on the shell. Around the umbilicus there is a row of small knots, the remnant of coarse umbilical ribs in the Tropites stage of growth.

Septa ammonitic but comparatively simple, lobes and saddles all digitate, but not deeply so. External lobe divided by a shallow siphonal saddle into two short branches. First lateral broader and deeper; second lateral less than half the size of the first; auxiliary shallow and composed of two or three indentations on the umbilical shoulder. The antisiphonal lobe is flanked by three internal laterals.

Mojsisovics described the second lateral as an auxiliary, but it is too well developed to be considered as such, especially since the occurrence of the real auxiliary 
on the umbilical shoulder makes such a definition incorrect. The septa figured by Mojsisovics were taken from a small specimen on which the auxiliary was not yet distinctly developed.

The young of Discotropites sandlingensis are robust and not discoidal, resembling Paratropites; they can, however, be distinguished from that genus by their sharper venter. In the earlier stages the sculpture is much rougher than at maturity, resembling that of Tropites; but in Discotropites sandlingensis the ribs appear before the keel at the diameter of $0.9 \mathrm{~mm}$., while the keel does not appear until a diameter of $2.7 \mathrm{~mm}$. is reached. In all.species of Tropites and Paratropites examined by the writers the keel appears before the lateral ribs are developed. From the development of this species it is clear that Paratropites was the parent stock, and that Discotropites has departed less from that radicle than has Tropites. The earlier larval stages of this species are like Gastrioceras, which is shown by two specimens figured on Pl. XXXVI, figs: 10-13, 17 and 18, of the following dimensions:

Dimensions of two specimens of Discotropites.

mm. mm.

\begin{tabular}{|c|c|c|}
\hline Diameter. & 1. 36 & \\
\hline Height of last whorl. & .52 & 1.32 \\
\hline Height of last whorl from the preceding .... & .37 & .92 \\
\hline Width of last whorl $\ldots \ldots \ldots \ldots \ldots \ldots$ & .70 & 1.92 \\
\hline Involution $\ldots . . . .$. & .15 & .40 \\
\hline Width of umbilicus & .43 & .65 \\
\hline
\end{tabular}

This gastrioceran stage makes it evident that Discotropites developed out of the Glyphioceratidx, probably from Gastrioceras itself, and the transition to the tropitoid characters teaches us to look for, in the Lower Triassic, some form with - lateral ribs, highly arched, acute venter, incipient keel, and simple goniatitic septa. Such a genus is as yet unknown, but the young stages of Discotropites, Paratropites, and Tropites show what it is like. Styrites fills part of these requirements, but bas lost the ribs, become more involute, and is thus itself highly specialized in most respects. Tropiceltites, too, has preserved many of the characters of the unknown primitive form, but has also acquired some that the primitive form could not have possessed. These two genera are known only from the Upper Triassic and could hardly be expected to preserve all the ancestral characters, but they are valuable in interpreting the meaning of the young stages of Discotropites.

The Californian specimens of Discotropites sandlingensis show as much variation as those from the Alps, there being no constancy in the size and number of the ribs. They also show in some prematurely adult specimens the development of abdominal shoulders, where the ribs thicken just as they bend forward near the base of the keel, giving a decided resemblance to Harpoceras. 
The agreement with the figures and descriptions given by Mojsisovics of Discotropites sandlingensis, of the Alpine province, is as perfect as could be wished for. The only possible difference is in the development of a distinct auxiliary lobe, and the figure of the septa given by Mojsisovies was taken from a small specimen, where the auxiliary lobe would not have been developed. Many of the Californian specimens are certainly more like the type than some of the figures given by Mojsisovics are like each other.

Mojsisovics assigned Ammonites sandlingensis Hauer to Eutomoceras Hyatt, which was based on a single imperfect specimen from the Middle Triassic of Nevada. Further collections of the type, Eutomoceras Laubei Meek, have shown that its septa are ceratitic, and that it belongs to the Ceratitoidea, being closely allied to Hungarites. The generic diagnosis of Eutomoceras given by Mojsisovics was based on Ammonites sandlingensis, and therefore this group needs a new name. The writers have called it Discotropites, with Ammonites sandlingensis Hauer as the type.

Dimensions of the specimens figured on $P l . X X X V$, figs. 1 and $\mathscr{Q}$.

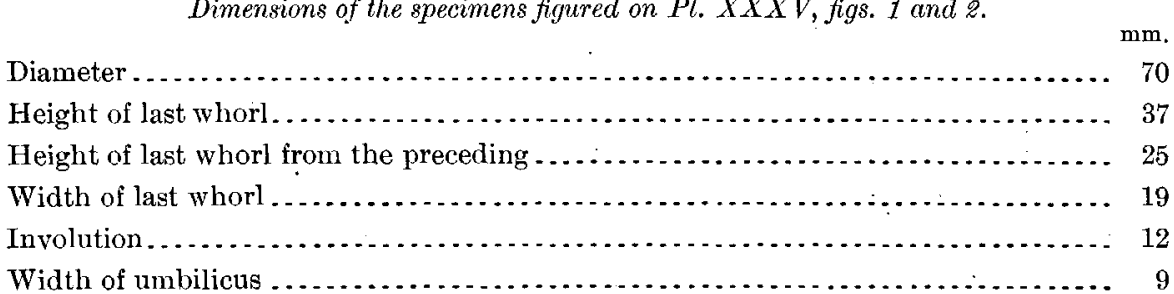

Horizon and locality.-Discotropites sandlingensis is common in the Upper Triassic of Shasta County, Cal., zone of Tropites subbullatus, 3 miles east of Madison's ranch, on the divide between Squaw Creek and Pit River. This locality is 6 miles northeast of Winthrop, and one-half mile north of the trail from Madison's to Brock's ranch on- Pit River. In the Alps this species is common in the same horizon and in the same association as in California.

Genus TROPITHS MOjsisovies.

1875. Tropites (pars), Mojsisovics, in M. Neumayr, Die Ammoniten der Kreide und die Systematik der Ammonitiden: Zeitsch. Deutsch. geol. Gesell., vol. 27, p. 889.

1879. Tropites (pars), Mojsisovics, Vorläufige kurze Uebersicht der Ammoniten-Gattungen der Mediterranen und Juvavischen Trias: Verhandl. K.-k. geol. Reichsanstalt, Wien, p. 136.

1893. Tropiles (pars), Mojsisovice, Cephalopoden der Hallstätter Kalke: Abhandl. K.-k. geol. Reichsanstalt, Wien, vol. 6, pt. 2, p. 184.

1896. Tropites (pars), Beitr. Kennt. der Obertriadischen. Cephalopoden-Faunen des Himalaya: Denkschr. K. Akad. Wiss., Wien, vol. 63, p. 39.

1904. Tropites, J. P. Smith, The Comparative Stratigraphy of the Marine Trias of -Western America: Proc. California Acad. Sci., 3d ser., vol, 1, p. 392.

16918-No. $40-05-5$ 
Type-Ammonites subbullatus Hauer, Ueber nene Cephalopoden aus den Marmorschichten von Hallstatt und Aussee: Haidinger's Naturwiss. Abhandl, vol. 3, 1849, p. 19, Pl. IV, figs. 1-4 (not 5-7); also E. von Mojsisovics, Cephalopoden der Hallstätter Kalke, 1893, p. 187; Pl. CVI, figs. 1, 2, 3, 5, 7; Pl. CVIII; Pl. CX, fig. 6 .

Moderately evolute whorls, not deeply embracing, and not deeply indented by the inner whorls. Umbilicus open and deep, with steep walls. Whorls usually broader than high, with angular prominent umbilical shoulders, and arched venter, which may be broad and flattened, or helmet-shaped. At maturity the whorls are often contracted, showing egression, so that the body whorl is lower and narrower than the inner volution. 'The cross section is usually trapezoidal, and in the typical forms there are no flanks, for the venter is flattened so that it begins at the umbilical shoulders.

Surface ornamented with strong umbilical knots, from which dichotomous ribs start out, curving gently across the sides to near the center, upon which a strong keel is developed, usually with marginal furrows at which the lateral ribs end. The surface of the shell also has spiral lines, which are not visible on the cast. - No constrictions appear on the shell, and no knots except on the umbilical shoulders.

The septa are ammonitic, but not deeply digitate. The external lobe is divided by a siphonal saddle into two broad, shallow branches. The lateral lobe is still broader, and there aro usually several auxiliaries, which in the type species are on the steep umbilical walls. Since the height of the whorls varies greatly, there is a corresponding variation in the number of the lateral lobes. The body chamber is long, at least a revolution in length.

E. von Mojsisovies ${ }^{a}$ divides Tropites into five groups: (1) Tropites bullati (Tropites s. str.); (2) Tropites spinosi (subgenus Anatropites); (3) Tropites labiati (subgenus Paulotropites); (4) Tropites rquabiles (subgenus Puratropites); (5) Tropites galeoli (subgenus Microtropites).

Tropites bullati have the general characters of the type species, the robust, broad, little embracing whorls, with prominent umbilical shoulders and low, broad venter, with knots on the umbilicus as the starting place of the ribs.

Tropites spinosi have spines instead of knots on the umbilical angles of the inner whorls, and have only very low, narrow whorls, increasing slowly in height.

Tropites labiati are characterized by the obsolescence of the umbilical knots, and by the occurrence on the body chamber of paulostome-like contractions which replace, in part, the normal sculpture of the flanks.

a Cephalopoden der Hallstätter Kalke: Alhandl. K.-k. geol. Reichsanstalt, Wien, vol, 6, pt. 2, 1893, p. 184. 
Tropites requabiles are characterized by the laterally compressed, high, involute whorls, by the similarity of the mature forms to the youthful stages, and by the narrower umbilicus. These differences are so striking that the writers prefer to regard Paratropites as an independent genus, especially since subgenera under it may also be distinguished. These characters will be treated fully under the head of Paratropites.

Tropites galeoli are characterized by dwarfed, involute forms, on which the sculpture shows a tendency to become obsolete, and the whorl shows a decided egression on the body chamber. These are all marks of degeneration in this family.

The genus Tropites appears, unheralded by known ancestors, in the Upper Triassic, Karnic stage, in the Mediterranean region, in the Himalayas, and in California. A few remnants live on into the Noric stage, but bere the entire genus becomes extinct, without leaving any descendants, so far as our present knowledge extends. The Tropites that has been cited from the Lower Jura of the southern Alps does not belong to this genus, but to the Arietidæ.

The sudden appearance of the typical Tropitidæ, with apparently many identical species, in three remote regions in the Karnic stage is one of the most striking and puzzling events in the history of Triassic ammonite faunas. Somewhere in the world this group must have differentiated in the Middle Triassic, but it was not in the Mediterranean region, nor in the Himalayas, nor in western America, the only places where Upper Triassic faunas are well known. Up to this time no species of Tropites has ever been described from America, but in the Tropites subbullatus beds of Shasta County, Cal., were found T. subbullatus Hauer, T. torquillus Mojsisovics, and a large number of undescribed species of this genus.

TROPITES SUBBULlatUS Haner.

Pl. XXXIII, figs. 1-7; Pl. XXXIV, figs. 1-14; PI. LXXIX, figs. 1-10.

1849. Ammonites subbullatus, Hauer (pars). Ueber neue Cephalopoden aus den Marmorschichten von Hallstatt und Aussee: Haidinger's Naturwiss. Abhandl., vol. 3, p. 19, Pl. IV, figs. 1-4; (not 5-7).

1893. Tropites subbullatus, Mojsisovics, Cephalopoden der Hallstätter Kalke: Abhandl. K.-k. geol. Reichsanstalt, Wien, vol. 6, pt. 2, p. 187, Pl. CVI, figs. 1, 2, 3, 5, 7; Pl. CVII; Pl. CVIII; Pl. CX, fig. 6.

Form subglobose, broad, evolute; cross section trapezoidal. Whorl broad, arched, but depressed, rising with gentle curve from the umbilicus to the venter, without any marked abdominal shoulders. Umbilical shoulders abrupt and angu lar, with the inner walls steep. Umbilicus wide and deep, exposing the umbilical margins of the inner whorls, forming a funnel-shaped cavity with spiral row of knots, marking the edges of the inner volutions. The breadth of the whorl is nearly equal to the diameter of the shell, and is about twice the height. The 
whorl is indented to about one-fourth its height by the inner volution. The width of the umbilicus is about three-eighths of the total diameter.

The venter is surmounted by a strong, low, median keel, bordered by shallow furrows. The umbilical margin is ornamented with a row of blunt nodes, and from these branch out the radial ribs that run with a forward curve across the whorl to the keel furrows. These ribs are faint, but always present, and usually dichotomous, the division taking place about halfway between the umbilical margin and the keel. At maturity the keel becomes depressed and the ridges sometimes cross it, giving to it a beaded appearance. The keel furrows are obscure in adolescence, but become distinct at maturity. There are faint spiral lines on the outer shell, stronger on the venter than on the sides.

The septa are ammonitic but not deeply digitate, the lobes more so than the saddles. The external lobe is divided by a nearly rectangular siphonal saddle into two narrow and short monacanthian lobes. The first lateral lobe is deep and broad; the second lateral, just above the umbilical margin, is broad and shallow. On the inner slope of the umbilical walls there are two distinctly individualized auxiliaries. The first and second lateral saddles are narrower than the lobes, and much narrower at the top than at the base. The antisiphonal lobe is narrow, flanked by a pair of similar laterals on each side.

At maturity the spiral becomes wider, and the whorl does not keep up its rate of increase, showing the phenomenon of egression, so that not only the umbilical margins of the inner whorls but also part of their flanks may be scen in the umbilicus. At this stage also the umbilical nodes usually become obsolete.

The young stages of Tropites subbullatus are keg-shaped, with broad umbilicus, sharp umbilical margins, no flanks, and very low whorls. The innermost volutions are nearly globose, but the whorl soon begins to flatten, and the umbilical margin becomes angular; they have constrictions, but no other sculpture. The keel appears at diameter of $2 \mathrm{~mm}$. The umbilical nodes and the spiral strix appear at the diameter of 5 or $6 \mathrm{~mm}$. A specimen, figured on Pl. XXXIV, figs. 12-14, showing the beginning of the umbilical nodes, gave the following dimensions:

Dimensions of specimen figured on Pl. XXXIV, figs. 12-14.

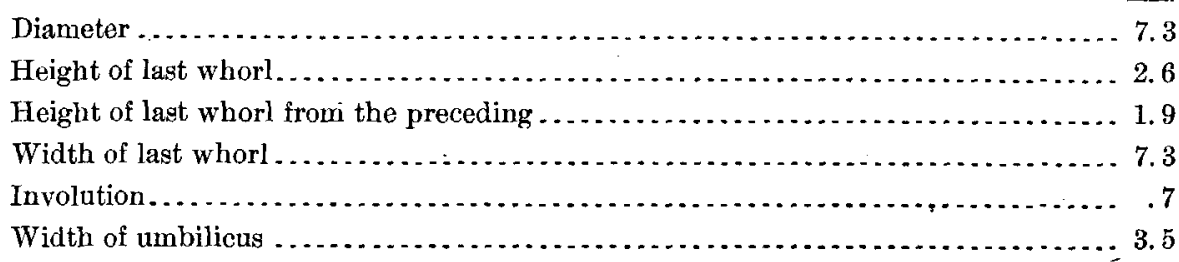

The septa pass from the goniatite to the ammonite stage at diameter of $4.5 \mathrm{~mm}$.; and the nodes begin to be prolonged as ribs on the venter at diameter of 7 or $8 \mathrm{~mm}$. 
At the diameter of about $10 \mathrm{~mm}$. the venter begins to arch, and from then on there is a steady progression toward mature characters. An adolescent specimen, figured on Pl. XXXIV, figs. 6-8, gave the following dimensions:

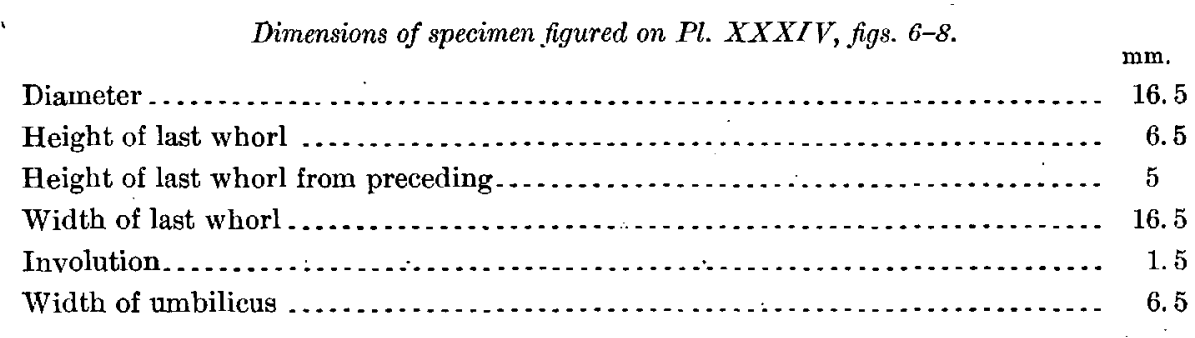

Dimensions of specimens of Tropites subbullatus.

Successively larger specimens gave the following dimensions:

\begin{tabular}{|c|c|c|c|c|}
\hline Diameter & $\begin{array}{r}\mathrm{mm} . \\
25\end{array}$ & $\begin{array}{r}\mathrm{mm} . \\
40\end{array}$ & $\begin{array}{r}\mathrm{mm} . \\
60\end{array}$ & $\begin{array}{r}\mathrm{mm} . \\
80\end{array}$ \\
\hline Height of last.whorl $\ldots \ldots \ldots \ldots \ldots \ldots$ & 10 & 15.5 & 22 & 32 \\
\hline Height of last whorl from the preceding. . & 7 & 11 & 15 & 19 \\
\hline Width of last whorl... & 25 & 37 & 44 & 56 \\
\hline Involution.. & 3 & 4.5 & 7 & 13 \\
\hline Width of umbilicus. & 7.5 & 14.5 & 25 & 30 \\
\hline
\end{tabular}

These measurements show that the whorl increases slowly in height, but becomes more highly arched, while the relative width of the last whorl decreases. The umbilicus widens with age, and shows egression, exposing the shoulders of the inner whorls as the spiral widens. This egression takes place at a diameter of between 40 and $60 \mathrm{~mm}$., when full maturity is reached. At $80 \mathrm{~mm}$. the shell is already senile, and shows degeneration in loss of distinct sculpture.

The Alpine specimens of Tropites subbullatus are extremely variable, so that it is almost impossible to define the limits of the species. The same thing is true of the Californian specimens. There are, however, some slight differences, such as the stronger spiral lines, deeper keel furrows, and broader whorl, which seem to be characteristic of the American types, and it was not possible to separate these from those identical in every other particular with the European forms.

Horizon and locality.-Tropites subbullatus is characteristic of the upper Karnic horizon of the Upper Triassic in the Tyrolian Alps; in California it is common in the same horizon and in the same faunal association in the Hosselkus limestone, in Shasta County, Cal., on the ridge between Squaw Creek and Pit River, about 3 miles east of Madison's ranch, where it was first discovered by Dr. H. W. Fairbanks. The specimens figured in this paper were collected at i,hat locality by J. P. Smith, who also found it on Bear Mountain, near Sherman's rar , h, about 18 miles northeast of Redding. A species probably identical with this has luen found by the geological survey of India in the Upper Triassic of the Himalayas. 


\section{Suborder ARCESTOIDEA.}

Forms with long body chamber, smooth, subglobose whorls, and septa either goniatitic, ceratitic, or ammonitic, of the brachyphyllic type. The Arcestoidea seem to be derived from the gastrioceran branch of the Glyphioceratidæ, probably from Adrianites or Agathiceras: Under this group belong the Popanoceratidæ, Cyclolobidæ, Arcestidæ, and Cladiscitidæ. The Popanoceratide are known in the Carboniferous and Triassic; the Cyclolobidæe only in Carboniferous; the Arcestidæ and Cladiscitidæ only in the Triassic. Only the Popanoceratidæ and Arcestidæ are represented in the American Triassic.

\section{Family POPANOCERATIDAE Hyatt.}

Subglobose, involute, smooth forms, with long body chamber, and triænidian or prionidian septa. This group is the chief representative of the Arcestoidea in the Lower Triassic, where it is common. In the American Triassic the Popanoceratidæ are represented only by Prosphingites and Popanoceras, which are merely survivors of Permian types, not even so highly specialized as kindred forms already developed in the Paleozoic.

\section{Genus POPANOCERAS IMyatt.}

1883. Popanoceras, Hyatt, Genera of Fossil Cephalopods: Proc. Boston Soc. Nat. Hist., .vol. 22, p. 337. 1886. Popanoceras, Mojsisovies, Arktische Triasfaunen: Mém. Acad. imp. sci. St.-Pétersbourg, sér. 7. tome 33 , No. 6 , p. 65 .

1894. Parapopanoceras, Haug, Les Ammonites du Permien et du Trias: Bull. Soc. géol. France, sér, 3 , tome 22 , p. 395 .

1901. Popanoceras, F. Frech, Lethæa Palæozoica, Bd. II, Lieferung 3, p. 512.

Type.-Goniatites kingianus Murchison, Verneuil, and Keyserling, Geology of Russia in Europe and the Ural Mountains, 1845, vol. 2, p. 374, Pl. XXVII, fig. $5, a, b, c$.

Whorls involute, subglobose, but laterally compressed; venter flattened, but with rounded shoulders. Sides provided with fine flexuous ribs, with a backward bend on the venter. Umbilicus very narrow. Septa divided into numerous lobes and saddles, of which the former are either bifid or trifid, and the latter entire. This genus has been extended so far beyond what Hyatt included in his original description that many subgenera have been established for the various groups. Popanoceras, in the strict sense, has not been found in the Triassic, but some of its descendants are common in that formation. 
Subgenus PARAPOPANOCERAS Haug.

1894. Parapopanoceras, Hang, Les Ammonites du Permien et du Trias: Bull. Soc. géol. France, sér. 3 , tome 22, p. 395 .

Type--Popanoceras Verneuili Mojsisovies, Arktische Triasfaunen, p. 65, Pl. XV, figs. 5-9, from the Middle Triassic of Spitzbergen.

Form subglobose, moderately involute; whorls compressed and deeply embracing; umbilicus open, deep, and rather narrow.

Sculpture, consisting of varices and strie, running nearly straight across the venter, instead of bending sharply backward.

Septa distinctly prionidian instead of being merely triænidian, as in Popanocercs s. str., of the Permian. The serrations run far up on the sides of the saddles, showing that the form is transitional to Arcestes.

Haug called the division a genus, but the species cited do not differ further from the type of Popanoceras than do many species in large genera. The writers therefore prefer to class this as a subgenus, in order that the taxonomic groups may be more uniform.

As defined by Haug, Parapopanoceras is known only in the Middle Triassic of northern Asia and California. E. von Mojsisovics ${ }^{a}$ proposes to restrict the name Parapopanoceras to Popanoceras Hyatti Mojsisovics, and to give the subgeneric name Dienerites Mojsisovics to Popanoceras Verneuili, notwithstanding the fact that the latter species was selected by E. Haug as the type of Parapopanoceras. It is clear that the same species can not be chosen as the type of two genera, and that the species expressly named by the author as the type must remain so, whether it is the most characteristic species or not.

POPANOGERAS (PARAPOPANOCERAS) HAUGI Hyatt and Smith, sp. nov.

\section{Pl. LXXVI, figs. 1-22.}

Subglobose, sides rounded, laterally compressed; venter highly arched, helmetshaped. Umbilical shoulders abrupt. Umbilicus rather wide, one-fourth of the diameter of the shell. Whorl deeply embracing, covering two-thirds of the inner whorl, and indented by it to one-fourth the height. Height of whorl, twothirds of the breadth and about two-fifths of the total diameter.

Surface destitute of sculpture, only cross striæ being seen on the shell.

Septa of the Arcestes type, with many lobes and saddles; the lobes are digitate, and the serrations run high up on the sides of the saddles, but the tops are always rounded and entire. The external lobe is divided by a short and narrow siphonal

a Cephalopoden der Hallstütter Kalke, Supplement-Heft: Abhandl. K.-k. geol. Reichsanstalt, Wien, vol. 6, pt. 1, 1902, p. 258. 
saddle into two short and narrow lobes. The first lateral lobe is broader and longer, the second smaller than the first; following these is a series of three small auxiliaries, of which the last is directly on the umbilical suture. The internal septa consist of an antisiphonal lobe, long and narrow, flanked by two laterals and an auxiliary on each side.

This species in early youth resembles Adrianites, then it passes through a distinct Popanoceras stage, with trifid principal lobes and bifid auxiliaries. Even at maturity the trifid nature of the lobes may still be seen. This form is a connecting link between Popanoceras and Arcestes, and in its ontogeny gives a transition from the Glyphioceratidæ to the Arcestidæ.

Horizon and locality. - Parapopanoceras Haugi is common in the Middle Triassic of the Union Wash, one mile east of the Union Spring, Inyo Range, east side of Owens Valley, and 15 miles southeast of Independence, Inyo County, Cal.

Genus PROSPHINGITUAS Mojsisovios.

1886. Prosphingites, E. von Mojsisovics, Arktische Triasfaunen: Mém. Acad. imp. Sci. St.-Pétersbourg, sér. 7 , tome 33 , No. 6 , p. 64 .

Type--Prosphingites Czekanowskii Mojsisovics, p. 64, Pl. XV, figs. 10-12.

Subglobose, laterally compressed, with belmet-shaped whorls and highly arched venter. Umbilicus deep and showing the inner volutions.

Surface smooth, except the cross strix of growth.

Septa consisting of an external and two lateral serrated lobes, and a fourth lobe, goniatitic in character, on the umbilical border. Internal lobes consisting of a long, serrated, antisiphonal, and two or more narrow laterals on each side.

Occurrence.-Prosphingites is known only in the Lower Triassic, and up to the present only from the Arctic-Pacific regions. A single species has been found in the Lower Triassic of California, and a doubtful one, as yet undescribed, in the Middle Triassic of Nevada.

PROSPHINGITES AUSTINI Hyatt and Smith, sp. nov.

Pl. VII, figs. 1-4.

Shell subglobose, rather involute, with helmet-shaped whorls, impressed to about one-half their height by the inner coils. Surface smooth except for the periodic constrictions or varices that occur to the number of six or eight to a volution. External septa consisting of a divided antisiphonal lobe, and two principal laterạls, all serrated, and a third lateral or auxiliary, goniatitic. The external lobe is narrow, and the first and second laterals are broad and shallow. The saddles are entire, rounded, and broader than the lobes. The internal lobes consist of a short antisiphonal, tlanked by three laterals. 
Horizon and locality.-In the Lower Triassic, Meekoceras beds, on the Union Wash, 3 miles east of Skinner's ranch, Inyo Range, Inyo County, Cal. Named in honor of Mr. S. W. Austin, of Independence, Cal.

\section{Family ARCESTID A Mojsisovics.}

Subglobose, involute, smooth forms, with long body chamber, and ammonitic septa, both lobes and saddles digitate. Surface ornamented only with constrictions or varices. The young are like the Permian Adrianites, and later resemble the Popanoceratidæe, although it is quite probable that some of the Arcestidæ have developed out of the Carboniferous Cyclolobidæ. This group is very common in the Alpine Upper Triassic, but is little represented below that stage.

In America the Arcestide are represented in the Middle Triassic by the genus Joannites, and in the Upper Triassic by Arcestes and the suibgenus Proarcestes. The rarity of this group in the American region is one of the strongest contrasts with the Mediterranean fauna, where it forms one of the most important elements of the ammonite fauna.

$$
\text { Genus ARCHistes Suess. }
$$

1865. Arcestes (pro parte), Suess, Ueber Ammoniten: Sitzungsber. K. Akad. Wiss., Wien, vol. 52, p. 76, 1869. Arcestes (pro parte), Laube, Fauna der Schichten von St. Cassian: Denkschr. K. Akad. Wiss., Wien, vol. 30, p. 86 .

1873. Arcestes (pro parte), E. von Mojsisovics, Das Gebirge um Fallstatt: Abhandl. K.-k. geol. Reichsanstalt, Wien, vol. 6 , pt. 1, p. 71.

1879. Arcestes, Mojsisovics, Vorläufige kurze Uebersicht der Ammoniten-Gattungen, etc: Verhandl. K.-k. geol, Reichsanstalt, Wien, p. 134.

1882. Arcestes, Mojsisovics, Cephalopoden der Mediterranen Triasprovinz: Abhandl. K.-k. geol. Reichsanstalt, Wien, vol. 6, p. 153.

1893. Arcestes, Mojsisovics, Cephalopoden der Hallstätter Kalke: Abhandl. K.-k. geol. Reichsanstalt, Wien, vol. 6, pt. 2, p. 785.

1896. Arcestes, Mojsisovics, Beitr. Kennt. der Obertriadischen Cephalopoden-Faunen des Himalaya: Denkschr. K. Akad. Wiss., Wien, vol. 63, p. 79.

1902. Arcestes, Mojsisovics, Das Gebirge um Hallstatt, Cephalopoden der Hallstätter Kalke: Supplement-Heft, Abhandl. K.-k. geol. Reichsanstalt, Wien, vol. 6, pl. 1, p. 261.

Type.-Group of Arcestes galeati. Arcestes in the limited sense is constituted by the groups of $A$. galeati, $A$. coloni, and $A$. intuslabiati.

Body chamber long, more than the last revolution; form globose or subglobose, involute, deeply embracing, closed umbilicus; helmet-shaped whorls, with rounded venter.

Surface smooth, excepting the periodic varices, which may be quite numerous. The body chamber is often contracted and differs considerably in shape from the rest of the whorls. 
The septa are deeply divided, ammonitic. Mojsisovics divides them into an external lobe, two laterals, and an anxiliary series; but the division is artificial, for the numerous auxiliaries are just as large and important as the two so-called principal laterals.

Arcestes in the stricter sense occurs only in the Upper Triassic, although nearly related forms are found in older beds. This group is represented in America by two or three undescribed forms from the Upper Triassic of California, and by Arcestes Andersoni, described in this paper, from the Upper Triassic of Nevada.

\section{ARCESTES ANDERSONI Hyatt and smith.}

Pl. LVI, figs. 1-9.

Form globose, involute, whorls depressed, deeply embracing and deeply indented by the inner volutions. Umbilicus narrow, and apparently closed in age. Venter broad and slightly flattened, flanks curving from the umbilicus without any ventral shoulders̀; umbilical shoulders abruptly rounded.

Surface smooth, but on the inner whorls there are about four constrictions to a revolution; these constrictions bend gently forward, making a broad shallow sinus on the venter. The surface of the outer whorl seems to be free from constrictions.

The septa are extremely complex, deeply and finely digitate, divided into a large number of nearly equal lobes and saddles. There are 5 external and 5 internal lateral lobes.

The height of the whorl is about one-half of the total diameter of the shell, the width is about one and four-fifths times the height, and the indentation is about three-fifths of the height.

This species belongs to the group of Arcestes coloni, characteristic of the Upper Triassic, especially of the Noric stage.

Horizon and locality.-Arcestes Andersoni was found first by Mr. F. M. Anderson in the Upper Triassic Pseudomonotis beds of Muttleberry Canyon, West Humboldt Mountains, in the road 8 miles southeast of Lovelock, Nev. J. P. Smith found along with it Pseudomonotis subcircularis Gabb., Rhabdoceras Russelli Hyatt, Placites humboldtensis Hyatt and Smith, Halorites sp. indet.

The writers' thanks are due Mr. Anderson for the loan of the type specimen.

$$
\text { Subgenus PROARCESTES Mojsisovics. }
$$

1893. Proarcestes, Mojsisovics, Das Gebirge um Hallstatt: Abhandl. K:-k. geol. Reichsanstalt, Wien, vol. 6, p. 785 .

1896. Proarcestes, Mojsisovics, Obertriasdischen Cephalopoden-Faunen des Himalaya: Denkschr. K. Akad. Wiss., Wien, vol. 63, p. 655.

1902. Proarcestes, Das Gebirge um Hallstatt, I Abtheil; Cephalopoden der Hallstätter Kalke: Supplement-Heft. Abhandl. K.-k. geol. Reichsanstalt, Wien, vol. 6, pt. 1, p. 259. 
Type--Arcestes Bramantei.

The general description of Arcestes applies to the subgenus, of which the especial characteristic is that the inner whorls are like the outer; the umbilicus usually closed, and varices occur on both inner and outer whorls. This group is represented in America by Arcestes pacificus sp. nov., and several undescribed forms.

ARCESTES (PROARCESTES) PACIFICUS Hyatt and Smith, sp. nov.

Pl. LXXXI, figs. 1-9; Pl. XXXVII, figș. 1-9.

Involute, globose; whorls broad, helmet-shaped, deeply embracing, and deeply indented by the inner volutions. Umbilicus very narrow, almost closed, umbilical shoulders abruptly rounded. Venter broad with low arch, and broadly rounded abdominal shoulders. The height of the whorl is about one-half of the total diameter of the shell, and about two-thirds of the width; it is indented by the inner volution to three-fifths of the height.

The surface is ornamented with fine radial strix of growth, and with strong constrictions that occur about four to a revolution, and are visible on both cast and shell. These constrictions curve gently forward on the flanks, forming a broad, shallow crest on the venter. The body chamber is long, more than a revolution.

The septa are divided into numerous lobes and saddles, ammonitic, but not deeply digitate. There is a divided ventral lobe, four principal lateral lobes, and an auxiliary; all except the latter are of about the same size and shape, being long and narrow.

In the youthful stages this species illustrates clearly its phylogeny. The smallest stage that could be correlated with any known genus is at the diameter of $1.7 \mathrm{~mm}$., when the form and septa correspond to Adrianites Gemmellaro, of the - Permian. The septa are goniatitic, tongue-shaped, and with numerous lobes and saddles. At $2.16 \mathrm{~mm}$. the lobes become slightly digitate at the end as in Prpanoceras of the Permian. At diameter of $3 \mathrm{~mm}$. the septa are more complex, as in Stacheocercs Gemmellaro. At $5 \mathrm{~mm}$. the septa already are characteristic of Arcestes, The constrictions begin at diameter of about $1 \mathrm{~mm}$. and continue throughout life; the whorl also undergoes little change in shape.

Horizon and locality.-Very common in the Upper Triassic zone of Tropites subbullatus of Shasta County, Cal, on divide between Squaw Creek and Pit River, 3 miles east of Madison's ranch and one-half mile north of the trail to Brock's ranch. It is also common in the limestone east of Squaw Creek, near Terrup-chetta (Cottonwood Flat), a place about 6 miles north of the first-mentioned locality, in the same beds and in the same association of fossils. 
1879. Joannites, Mojsisovics, Vorlüufige kurze Uebersicht der Ammoniten-Gattungen, etc.: Verhandl K.-k. geol. Reichsanstalt, Wien, p. 134.

1882. Joannites, Mojsisovics, Cephalopoden der Mediterranen Triasprovinz: Abhandl. K.-k. geol. Reichsanstalt, Wien, vol. 10, p. 166.

1896. Joanniles, Mojsisovics, Obertriadischen Cephalopoden-Faunen des Himalaya: Denkschr. K. Akad. Wiss., Wien, vol. 63, p. 656.

No type is expressly cited, but under the synonymy of the genus the group of Arcestes cymbiformes is first mentioned by Mojsisovics, which makes it certain that to him the chief species of this group, Joannites cymbiformis Wulfen, was the type. This species is figured by Mojsisovics, in Das Gebirge um Hallstatt, vol. 1, 1875, p. 85, Pl. LXI, figs. 1 and 5; Pl. LXII, fig. 1; Pl. LXV.

Form subglobose, laterally compressed, involute, inner coils completely covered by the outer. Umbilicus narrow and often closed by a callous.

Surface smooth, but with numerous varices. Body chamber very long.

Septa of the Arcestes type, but with the saddles bifid and deeply digitate. The lobes are not so complex as in the typical Arcestes, and preserve somewhat more of the primitive character of the family. The genus ranges from the upper Muschelkalk to the middle Karnic horizon; it is found in the Alpine region,.in India, and in Nevada. It is represented in America by Joannites Gabbi Meck and J. nevadanus sp. nov.

JOANNITES NEVADANUS Hyatt and Smith, sp. nov.

\section{Pl. XXIV, figs. 5-7.}

Involute, subglobose, laterally compressed. Whorl highly arched, with broadly rounded venter, deeply embracing and deeply indented by the inner whorl. The point of greatest breadth is at one-half the distance between the base of the whorl and the top of the next inner whorl. The height of the whorl is slightly less than one-half the total diameter, and the width is equal to the height; it is indented to somewhat more than one-half its height by the inner whorl. The umbilicus is open and deep, but narrow, being only slightly more than one-sixth of the total diameter, and exposing only the umbilical shoulders of the inner whorls.

The surface is smooth except for the constrictions, which occur about four to a revolution. These constrictions curve gently forward on the flanks, and then sharply forward on the venter, forming a broad and deep sinus.

The septa are complex, ammonitic, lobes and saddles all deeply digitate. The external lobe is rather deeply divided by a siphonal saddle. There are eight lateral lobes on each side, decreasing in size toward the umbilicus, but it is hardly possible to separate these into principal and auxiliary series. 
This species is most nearly related to "Arcestes" Gabbi Meek (Ammonites ausseeanus Gabb, not Hauer), but differs from that species in its wider umbilicus more strongly digitate septa, and greater lateral compression.

Horizon and locality.-Middle Triassic, upper Muschelkalk, Volcano, Nevada, J. D. Whitney collection, Harvard University.

\section{Suborder PTYCHITOIDEA.}

Forms with short body chamber, laterally compressed, involute, smooth whorls; surface ornamented only with constrictions, weak folds, or spiral strie. Septa goniatitic in the primitive genera, ceratitic in some later forms, and ammonitic in the more highly specialized genera.

All the Ptychitoidea seem to have developed out of the Carboniferous family Glyphioceratidæ, with Aganides as the more remote radicle.

This suborder may be divided into Ptychitidx and Thalassoceratidæ, both of which stocks were already differentiated in the Carboniferous. Both are represented in the American Triassic.

\section{Family PTYCHITID \& Mojsisovies.}

The description of the suborder Ptychitoidea may be applied to this family with the exception of the spiral strix, which do not occur in this group.

The Ptychitide are represented by the subfamily Nannitinæ, with Nannites, Paranannites, and Paraganides; and the subfamily Ptychitinæ, with Ptychites and Proptychites. The former are largely confined to the Lower Triassic, while of the latter Proptychites is confined to the Lower Triassic, and Ptychites is characteristic of the Middle Triassic.

\section{Subfamily NANNITIN $A$ Diener.}

Involute, robust, subglobose; body chamber short; surface nearly smooth, but ornamented with periodic constrictions. Septa goniatitic or weakly ceratitic. Found throughout the entire Triassic.

This subfamily is composed of the following genera: Paraganides Hyatt and Smith, Nannites Mojsisovics, and Paranannites Hyatt and Smith, all represented in the American Triassic.

Genus PARAGANIDES Hyatt and Smith, gen. nov.

Type--Paraganides californicus Hyatt and Smith, sp. nov.

Dwarf forms; involute, laterally compressed, deeply embracing, umbilicus narrow, all the inner whorls being concealed by the outer. Sides flattened, whorl proportionally high, with somewhat narrowly rounded venter. 
Surface nearly smooth, but ornamented with faint ribs which bifurcate on the umbilical shoulders and run nearly straight up the sides and across the venter, without interruption. No constrictions have been observed on this group.

The septa are goniatitie, lobes and saddles all short, one principal lateral, and a second lateral or auxiliary on the umbilical shoulders. The antisiphonal (internal) lobe is like the external, and is flanked by a pair of short laterals.

This genus differs from Nannites only in the individual external lobe. It is probably a descendant of Aganides Montfort, of the Carboniferous, and is either a persistence of the ancestral stock, or a reversion to that stock by arrested development. It differs from Aganides chiefly in the possession of the second lateral lobe.

Paraganides is known only from the Upper Triassic zone of Tropites subbullatus, of Shasta County, Cal., where' it is represented by a single species.

PARAGANIDES CALIF0RNICUS Hyatt and Smith, sp. nov.

Pl. LXXX, figs. 12-21.

Involute, robust, laterally compressed. Umbilicus closed. Whorl high-helmet shaped, with flattened sides, and rounded venter, with rounded but distinct abdominal shoulder's. The height of the whorl is slightly more than one-half the total diameter, and the width is about two-thirds of the height. It is indented to one-half its height by the inner whorl. The body chamber is at least a revolution long.

The surface is ornamented with weak radial folds that start from the umbilical shoulders and run nearly straight across the venter without interruption. These are parallel to the fine cross strix of growth.

The septa are goniatitic. The external lobe is undivided and rounded; there are two laterals very like the external, and the antisiphonal lobe is flanked by a pair of internal laterals, as is the case with Nannites.

The young stages of this species are subglobose, with open umbilicus.

Horizon and locality.-Paraganides californicus is rather common in the Upper Triassic zone of Tropites subbullatus, of Shasta County, Cal, on the limestone belt on the divide between Squaw Creek and Pit River, about 3 miles east of Madison's ranch.

\section{Genus NANNITES Mojsisovics.}

1881. Nannites, Mojsisovics, Jahrbuch, K.-k. geol. Reichsanstalt, Wien, p. 264.

1882. Nannites, Mojsisovics, Dic Cephalopoden der Mediterrauen Trias provinz: Abhandl. K.-k. geol. Reichsanstalt, Wien, vol. 10, p. 210.

1897. Nannites, Diener, The Cephalopoda of the lower Trias: Himalayan Fossils, vol. 2, pt. 1, p. 66: Mem. Geol. Survey India, Pal. Indica, ger. 15. 
Type.-" Goniatites" spurius Muenster, Beiträge zur Geogn. und Petrifaktenkunde des südöstlichen Tirols, 1843, p. 127, Pl. XIV, fig. 7.

Subglobose rather involute, with highly arched helmet-shaped whorls, open deep umbilicus, steep umbilical shoulders, and rounded sides. Surface ornamented only with constrictions or varices.

Septa simple, goniatitic, consisting of an external lobe divided by a siphonal notch, a lateral, $c i c$ an auxiliary, all short and rounded. The internal antisiphonal lobe is undivided, and flanked by two pairs of laterals. This group of forms bears a decided resemblance to the Carboniferous Glyphioceratidæ, from which it has been artificially separated on account of : 's occurrence in Triassic strata. In Nannites are only dwarf forms, which are either a survival of an ancient radicle, or a case of reversion by retardation.

Mojsisovics and Diener have referred this genus to the Ptychitidæ, and this reference seems entirely correct, for the young of all the Ptychitidæ that have been studied go through a Nannites stage of growth. On this account Diener makes this genus the type of a subfamily, Nannitinæ, to include the more primitive members of the stock.

Nannites is known at present from the Upper Triassic of the Alps, the Lower Triassic of the Himalayas, and the Lower Triassic Meekoceras beds of the Aspen Ridge in Idaho and the Inyo Range in California. Besides the species described below, there are several new species in the same formation.

\section{NANNITES DIENERI Hyatt and Smith, sp. nov.}

Pl. VII, figs. 5-25.

Form subglobose, involute, deeply embracing; whorls depressed, helmet shaped, wider than high, indented more than half of the height by the preceding whorl. Breadth of whorl slightly greater than its height, 9:7. Umbilicus narrow, deep, one-tifth of the total diameter of the shell. Venter broadly rounded. Umbilical shoulders abrupt, and umbilical slope steep. Body chamber long, comprising about the last volution.

Surface nearly smooth in youth, but marked with varices and constrictions that become more numerous as the shell grows older, until there are as many as ten to a revolution. Between the principal constrictions and varices intervene minor cross ribs, and the entire shell is ornamented with fine radial striæ, like those in the Glyphioceratidæ.

Septa goniatitic, external lobe divided by a small siphonal notch into two sharp pointed lobes; lateral lobe broader and not so deep; shallow auxiliary on the umbilical slope. The two lateral saddles are broadly rounded. The internal anti- 
siphonal lobe is narrow and short, the lateral is similar, and there is a smaller auxiliary inside of the umbilical suture. The internal saddles are broadly rounded.

This species is most nearly related to Nannites hindostanus Diener (Cephalopoda of the Lower Triassic, p. 68, Pl. VII, figs. 3 and 12), but differs from the Indian species in being broader and having fewer contractions of the shell. The divisions of the ventral lobe are also somewhat sharper. The contractions are as distinctly marked on the shell as on the cast, while on $N$. hindostanis iie, are visible chiefly on the cast.

These differences would be considered by the writers not to have a greater than varietal im itance, if Diener had not used even smaller differences to separate his $N$. Herberti from $N$. hindostanus. But in small shells with few distinctive characters, those marks that are seen should be accorded greater importance in classification than on shells with many characters.

This species grew to the diameter of at least $24 \mathrm{~mm}$.

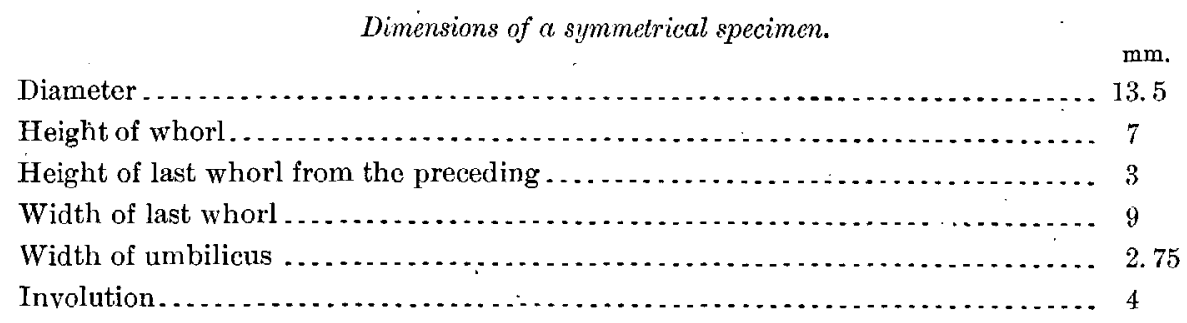

Horizon and locality. - Nannites Dieneri is named in honor of Prof. Carl Diener, of Vienna. It is common in the Lower Triassic Meekoceras beds of the Union Wash, about $1 \frac{1}{2}$ miles east of the Union Spring, Inyo Range, east side of Owens Valley, California, about 15 miles southeast of Independence.

Genus PARANANNITHS Hyatt and Smith, gen, nov.

Type.-Paranannites aspenensis Hyatt and Smith, sp. nov.

Form subglobose, laterally compressed, sides convex, venter broadly rounded. Umbilicus narrow; whorls involute deeply embracing.

Surface nearly smooth, or ornamented only with radial folds, or constrictions.

Septa ceratitic, lobes partly serrated, saddles all rounded and entire. The external lobe is divided by a small siphonal notch into two short branches. The lateral lobe is broad and serrated; the small auxiliary is serrated on the type species. The internal septa are goniatitic, and consist of a rather long antisiphonal lobe flanked by a pair of laterals on each side.

The form and surface ornamentation are exactly like those of Nannites, from which the new genus can be distinguished only by its ceratitic septa. It is probably an intermediate form between Nannites and the true Ptychitidæ. 
Paranannites is known at present only from the Lower Triassic Meekoceras beds of southeastern Idaho, where several species of it occur associated with Nannites, Meekoceras, Flemingites, Pseridos̆ageceras, Ophiceras, and other genera characteristic of the Lower Triassic.

PaRANANNITES ASPENENSIs Hyatt and smith, sp. nov.

Pl. VIII, figs. 1-15; Pl. LXXIII, figs. 1-30:

Form robust, involute, somewhat compressed latérally. Whorl highly arched, with flattened sides and rather broadly rounded venter. Abdominal shoulders indistinct. The umbilicus is very narrow, and the whorl is deeply embracing, and deeply indented by the inner volution. The height of the whorl is one-half of the total diameter of the shell; the breadth is slightly less than the height; the indentation is somewhat more than one-half of the height. The width of the umbilicus is about one-eighth of the diameter of the shell.

The surface is nearly smooth, but has faint cross striæ of growth visible only on the shell, which is rarely preserved. These striæ become later on weak folds, giving a sculpture like that of the Glyphioceratidæ. There are also occasional constrictions, visible on the cast.

The septa are ceratitic, but comparatively simple. The external lobe is divided by a siphonal notch into two narrow branches with serrated ends. The lateral lobe is broad and deep, with four or five serrations; the auxiliary is similar, but smaller, and also serrated. The antisiphonal lobe is long and narrow, not divided, flanked on each side by a pair of similar smaller internal laterals.

In the young stages this species is a typical Nannites, the serration of the lobes beginning at the diameter of $5 \mathrm{~mm}$. In the Nannites stage the varices are much more frequent, and the form is more robust than in later life.

Horizon and locality.-In the Lower Triassic Meekoceras beds of the Aspen Ridge, Wood Canyon, southeastern Idaho, about 9 miles east of Soda Springs.

\section{Subfamily PTYCHITINAE.}

Subglobose, laterally compressed, involute forms, with short body chamber, and surface ornamented only with obscure folds. Septa either ceratitic or ammonitic. Venter rarely acute, forming a sort of keel, more commonly arched.

All members of this group go through a Nannites stage of growth in their youth, but the separation from the parent stock must have taken place in Paleozoic time, for typical members of the Ptychitinæ are present in the Lower Triassic of Asia and America.

This subfamily is represented in the American Triassic by three genera: Owenites Hyatt and Smith, known only in the Lower Triassic of California; Pro16918-No. $40-05-6$ 
ptychites Waagen, known in America only from the Lower Triassic of California, but commion in the same formation in Siberia and India, rare in the middle Triassic of the Alpine province; Ptychites, characteristic of Middle Triassic in America, Asia, and Europe.

Genus OWENITES Hyatt and Smith, gen. nov.

Type.-Owenites Koeneni Hyatt and Smith, sp. nov.

Body chamber long, comprising the last volution. Form lenticular, involute, deeply embracing, with closed umbilicus, rounded sides, and acnte venter, without any real keel or shoulder angles.

Surface smooth, or ornamented with radial folds; occasionally with bundled ribs, which run straight up the sides and become obsolete on the venter.

Septa ceratitic, the saddles mostly rounded, the lobes serrated. The siphonal saddle may occasionally be digitate, but is usually entire. There are no adventitious lobes. The external and the two principal laterals are similar, usually short and rather wide. Some species have a third lateral before the auxiliary series, which is composed of two or more denticulations, becoming with age independent auxiliaries, but never serrated. The internal lobes and saddles are also very numerous. This genus resembles IIungarites, but differs in lacking the abdominal shoulder angles, and in having the young globose and involute, with Nannites form and septa. It is therefore classed in. the Ptychitide as a descendant of Nannites. The young also possess rather strong radial ribs and constrictions, wholly unlike the young stages of any of the true Ceratitoidea. F. Toula ${ }^{a}$ has described from the lower Muschelkalk of Asia Minor some species which he assigned to Hungarites, but which are said to have globose young. In form and septa they resemble Owenites, and it is quite possible that this genus has lasted into the Middle Triassic in that region.

Owenites has a strong external resemblance to Dalmatites Kittl, ${ }^{b}$ which that author assigned to the Iungaritidæ. But the European genus differs from the American in lacking the auxiliary lobes. Kittl regarded Dalmatites as nearly related to the radicle of the Hungaritidx. But the ontogeny of Owenites shows that it does not belong to the Hungaritidæ. The development of Dalmatites is unknown.

Owenites is known at present only from the Lower Triassic Meekoceras beds of the Inyo Range, Inyo County, Cal., where several undescribed species have been found, besides Owenites Koeneni, described below.

a Eine Muschelkalkfauna am Golfe von Ismid in Kleinasien: Beitr. Pal. und Geol. Oesterreich-Ungarns und des orients, vol. 10, pt. 4, 1896, p. 176. 1903 , p. 72 .

$b$ Kittl, E., Die Cephalopoden von Mue in Daimatien: Abhandl. K..k. geol. Reichsanstalt, Wien, vol. 20, pt. 1, 
OWENITES KOENENI Hyatt and Smith, sp. nov.

(Pl. X, figs. 1-22.)

Form involute, laterally compressed, lenticular. Whorl deeply embracing and deeply indented by the inner volutions; sides flattened-convex, curving without abdominal shoulders to the acute venter. There is no keel, but the abdomen grows gradually narrower until it resembles a keel. Umbilicus narrow, growing wider with age. The height of the last whorl is one-half of the total diameter, and the indentation or involution is one-half of the height. The width of the whorl is threefifths of the height. The width of the umbilicus is about one-sixth of the total diameter.

The surface of the shell and of the cast is smooth at maturity, being destitute of ribs, constrictions, or other ornamentation.

The septa are ceratitic, the saddles are all rounded and entire, the lobes all serrated. The external lobe is divided by a siphonal notch or saddle into two short branches; the first lateral is similar, but larger; the second lateral similar to the first, but only two-thirds of its size. First auxiliary bifid, each of the small divisions being serrated; second auxiliary undivided, but serrated. Antisiphonal lobe narrow and undivided, flanked by five internal lobes on each side.

In the young stages the whorl is rounded, robust, with rounded venter, constrictions, and radial ribs. In this stage it resembles Nannites in form and the simple septa. The venter becomes acute at the diameter of about $6 \mathrm{~mm}$; the constrictions cease and the ribs less distinct at $8 \mathrm{~mm}$., and the septa cease to be goniatitic and become serrated at about $10 \mathrm{~mm}$. From this stage on ward no change in development takes place, except in the widening of the umbilicus at maturity.

Owenites Koeneni resembles IIungarites, but differs externally from that genus in its merely sharpened venter, without abdominal shoulder angles. But the inner volutions show still greater differences, being involute and rounded like Nannites, the radicle of the Ptychitidæ, instead of evolute and discoidal, like the young of the Ceratitoidea.

Thère is no described species with which Owenites Koeneni may be compared, the only other known members of the group being some undescribed species from the same formation.

Horizon and locality.-Owenites Koeneni was found by J. P. Smith in the Lower

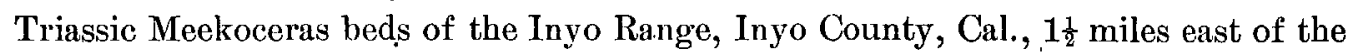
Union Spring, on the old McAboy trail across to Salinas Valley. This locality is about 15 miles southeast of Independence. 
1892. Proptychites, Waagen, Records Geol. Survey India, vol. 25, p. 183.

1892. Proptychiles, Waagen, Jahrb. K.-k. geol. Reichsanstalt, Wien, vol. 42 , p. 379.

1895. Proptychites, Waagen, Fossils from the Ceratite Formation: Salt Range Fossils, vol. 2, p. 162: Mem. Geol. Survey India, Pal. Indica, ser. 13.

1895. Proptychites, Diener, Triadische Cephalopoden-Faunen der ostsibirischen Küstenprovinz: Mém. Com. géol., St.-Pétersbourg, vol. 14, No. 3, p. 31.

1897. Proptychites, Diener, Himalayan Fossils, vol. 2, pt. 1, p. 70: Mem. Geol. Survey India, Pal. Indica, ser 15.

1902. Aspidites (pars), F. Frech, Lethsea Palscozoica, Bd. II, Lieferung 4, p. 637.

Type.—"Ceratites" lawrencianus de Koninck, Quart. Jour. Geol. Soc. London, vol. 19, 1863, p. 14, Pl. VI, fig. 3, from the Lower Triassic of the Salt Range.

Form, thickly lenticular, robust, with narrow umbilicus, flattened sides, and broadly rounded venter. Surface smooth, or ornamented with faint radial folds. Septa distinctly ceratitic, the saddles long, narrow, and rounded, the lobes usually broader and serrated. There is-usually an external lobe divided by a rather deep siphonal saddle, two principal laterals, and an auxiliary series, which may consist of a single ceratitic lobe or a series of denticulations, some of which may become individualized into secondary lobes. The internal septa consist of an antisiphonal lobe, with a single lateral.

E. von Mojsisovics (Arktische Triasfaunen, p. 79), classes P. lawrencianus under Meekoceras, while Griesbach classes it with Ptychites. But the young of Proptychites are said to be always globose, of the Nannites type, and the mature forms always have ceratitic septa, which characters distinguish it from those two genera. Waagen considers this genus as the ancestor of Ptychites, although he knew of no transitional forms between the two. This intermediate place may be filled by "Arcestes" perplanus Meek ${ }^{a}$ from the Middle Triassic of Nevada, which on account of its form might be classed with Proptychites, and on account of its slightly ammonitic septa with. Ptychites. These septa were not figured by Meek, but the type in the United States National Museum shows them.

Frech ${ }^{b}$ proposes to drop the genus Proptychites and to assign all the species of this group to Aspidites. The writers are of the opinion that this view is probably correct, but a further study of the ontogeny of the two genera would be necessary before such a reference could be decisive. Waagen was of the opinion that Proptychites was an ancestral form of the Ptychitidæ, while Frech believes that this family was not differentiated before the Middle Triassic. But Mojsisovics, Diener, and the writers agree in regarding Nannites as the ancestor of Ptychites.

Proptychites is almost exclusively confined to the Lower Triassic, being found 
in that horizon in the Salt Range and the Himalayas in India, at Ussuri Bay in eastern Siberia, and in the Meekoceras beds of Inyo County, Cal. Proptychites Walcotti, sp. nov., and one other undescribed form are the only ones known to occur in America.

\section{PROPTYCHITES WALCOTTI Hyatt and Smith, sp. nov.}

Pl. XIX, figs. 1-7.

Robust, involute, deeply embracing, laterally compressed, abdomen rounded so that there are no shoulders. Outer whorl twice as high as broad, embracing about one-half of the inner, and being indented to about one-fourth the height by it. Umbilicus narrow, being only about one-sixth of the diameter. Umbilical shoulders abrupt, almost angular.

Surface smooth, so far as known.

Septa ceratitic, with rounded, entire, and constricted saddles and serrated lobes. External lobe divided into two very broad branches by a broad digitate siphonal saddle; the first lateral lobe is twice as long as the external, and serrated not only on the ends, but also more than halfway up its sides; second lateral about the size of the external; auxiliary series consisting of four or five denticulations forming a broad lobe, somewhat after the manner of $\dot{A}$ spidites, but perfectly regular. Internal septa not seen in detail, but consisting of a large antisiphonal and one smaller lateral. The form and septa greatly resemble those of "Paranorites" ambiensis Waagen, ${ }^{a}$ differing in being more robust, having narrower umbilicus, and having fewer denticulations on the auxiliary series. This species might well be assigned to Paranorites, but that genus is probably based merely on a highly specialized form of Proptychites. The present species also resembles somewhat Proptychites khoorensis Waagen, ${ }^{b}$ but has the septa much more specialized, since the ventral saddle is digitate, and the serrations are not confined to the ends of the lobes. This sort of digitation of the lobes and the bases of the saddles is quite common in Proptychites, but does not seem to be transitional to Ptychites. The writers have not yet had the opportunity to study the complete ontogeny of this genus, but are of the opinion that it will turn out to be a member of the Meekoceratida, which it so greatly resembles that even Mojsisovics has not been able to draw a line between them. It seems to be more nearly related to Aspidites than to any other member of the group, and may be the ancestral form of that genus.

Horizon and locality.-Proptychites Walcotti was found by J. P. Smith in the Lower Triassic Meekoceras beds of the Union Wash, Inyo Range, east side of Owens Valley, about 15 miles southeast of Independence, Inyo County, Cal., associated with Meekoceras gracilitatis White, $M$. (Gyronites) aplanatum White, $M$. (Koninckites) mushbachanum White. 
1875. Ptychites, Mojsisovics (in Neumayr's Systematik der Ammonitiden): Zeitschr. Deutsch. geol. Gesell., vol. 27, p. 882.

1882. Ptychites, Mojsisovics, Cephalopoden der Mediterranen Triasprovinz: Abhandl. K.-k. geol. Reichsanstalt, Wien, vol. 10, p. 244.

1886. Ptychites, Mojsisovics, Arktische Triasfaunen: Mém. Acad. imp. sci. St.-Pétersbourg, sér. 7, tome 33, No. 6, pi 88.

1888. Ptychites, Hauer, Cephal. des Bosnischen Muschelkalk von Han Bulog bei Sarajevo, p. 38 .

1892. Ptychites, Haner, Beitr. Kennt. Cephalopoden der Trias von Bosnien: Denkschr. K. Akad. Wiss., Wien, vol. 59, p. 284.

1895. Ptychites, Diener, Cephalopoda of the Muschelkalk: Himalayan Fossils, vol, 2, pt. 2, p. 62: Mem. Geol. Survey India, Pal. Indica, ser. 15.

1896. Plychites, Toula, Fine Muschelkalkfauna am Golfe von Ismid in Kleinasien: Beitr. Pal. und. Geol. Oesterreich-Ungarns und des Orients, vol. 10, p. 174.

1896. Ptychites, Mojsisovics, Beitr. Kennt. Obertriadischen Cephalopoden-Faunen des Himalaya: Denkschr. K. Akad. Wiss., Wien, vol. 63, p. 668.

1896. Ptychites, Arthaber, Die Cephalopodenfauna der Reiflinger Kalke: Beitr. Pal. und Geol. Oesterreich-Ungarns und des Orients, vol. 10, p. 95.

1898. Ptychites, Tornquist, Neuere Beiträge zur Geol. und Pal. der Umgebung von Recoaro, etc. : Zeitschr. Deutsch. geol. Gesell., vol. 50, p. 659.

1900. Ptychites, Diener, Die Triadische Cephalopoden-Fauna der Schiechlinghöhe bei Eallstatt: Beitr. Pal. und Geol. Oesterreich-Ungarns und des Orients, vol. 12, p. 27.

Ptychites is variable in form, ranging from subglobose to laterally compressed and acute venter. The umbilicus is narrow, and the form is involute, deeply embracing, whorls concealing most of the inner volutions, and deeply indented by them. In the most typical forms the whorl has rounded sides and highly arched rounded venter. The surface is sculptured with low folds running nearly straight up the sides and becoming faint or nearly obsolete on the venters. These folds may be strongly flexuous, but never become strong ribs. They do not form bundles on the umbilicus as in most of the Trachyostraca.

The body chamber is three-quarters of a rolution in length.

The septa are thoroughly ammonitic but of comparatively simple pattern, not deeply digitate. The external lobe is short and divided by a shallow siphonal saddle. The first lateral lobe is deep, the second smaller, and the auxiliaries decrease in size and complexity toward the umbilicus. The unusually long first lateral saddle and first lateral lobe are the most salient characters.

I'tychites is most characteristic of the Middle Triassic, being found in that horizon in the Alps, Siberia, the Himalayas, and one species has been found in the Middle Triassic of Nevada. The genus is also found sparingly in the Upper Triassic. 
PTYCHITES MEEKI Hyatt and Smith, sp. nov.

Pl. XXV, figs. 6-12.

Form robust, involute, laterally compressed. Whorl highly arched, with broadly rounded venter; deeply embracing and deeply indented by the inner whorl. The height of the whorl is one-half the diameter of the shell, and the width is equal to the height. It is indented to two-fifths of the height by the inner whorl, and conceals the inner whorl almost entirely. The umbilicus is deep, has steep inner walls and the breadth is somewhat less than one-fourth of the total diameter of the shell.

The surface is ornamented with fine radial folds that run from the umbilicus nearly straight across the venter. This sculpture is stronger on the young than on the mature shell. There are no constrictions visible, and no knots or spines.

The septa are ammonitic but comparatively simple, not deeply digitate. The external lobe is divided by a small siphonal saddle; the first and second lateral lobes are of about the same size, and there is a smaller auxiliary on the umbilical shoulder. The body chamber is one revolution long.

Dimensions of the type specimen, figured on Pl. XXV, figs. 6-8.

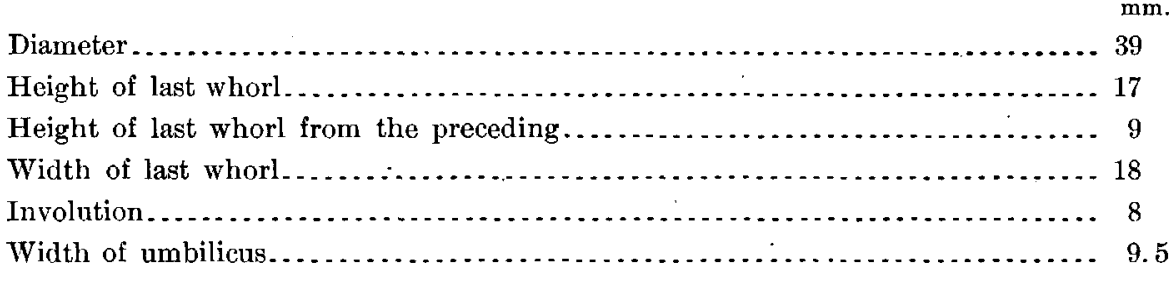

Horizon and locality.-Middle Triassic, lower Ladinic stage, Star Canyon, West Humboldt Range, Nevada. Whitney collection, Harvard University.

\section{Family 'THALASSOCERATID AE.}

Form involute, with laterally compressed, high-arched whorls, and narrow, rounded venters. Surface smooth, or ornamented with spiral strix. Septa ammonitic, but in the more primitive forms the saddles are entire, although the digitations run high up on the sides of the saddles.

In this family are included Thalassoceras Gemmellaro, Ussuria Diener, and Sturia Mojsisovics. The two former genera are commonly accepted as standing in genetic connection, and as having been derived from the Carboniferous genus, Dimorphoceras. Sturia has hitherto been assigned to the Ptychitidæ, but a species has been found in the Lower Triassic of California that seems to connect Ussuria 
with it, and this necessitates classing both with the Thalassoceratidæ, with which they are clearly more closely allied than with the Ptychitidx.

Thalassoceras is known only from the Permian of the Mediterranean region; Ussuria only from the Lower Triassic of Siberia, California, and Idaho; and Sturia only from the Middle and Upper Triassic of the Alpine province and the Middle Triassic of the Himalayas.

Genus USSURIA Diener.

1895. Ussuria, Diener, Triadische Cephalopodenfaunen der ostsibirischen Küstenprovinz: Mém. Com. géol., St.-Pétersbourg, vol. 14, No. 3, p. 23.

1902. Ussuria, F. Frech, Lethæa Palæozoica, Bd. 2, Lieferung 4, p. 659.

Type-Ussuria Iwanowi Diener, op. cit. p. 27, Pl. III, fig. 5.

Compressed, involute, deeply embracing, whorls increasing rapidly in height. Umbilical shoulders broadly rounded, sides gently convex up to the narrow and rounded venter. Umbilicus narrow and deep. Surface without ribs or constrictions, but provided with fine spiral striæ (seen on specimens from California).

Septa, both lobes and saddles ammonitic, digitate, and highly specialized. The external lobe is divided by a broad digitate siphonal saddle, and each side of the lobe is deeply trifid, with secondary indentations on the prongs. There are two or three principal lateral lobes, wide, deep, and deeply digitate; the auxiliaries, of which there are as many as three or more, are smaller, but also digitate. The internal lobes have not been observed in detail, but broken whorls show that there is a long, narrow antisiphonal lobe, flanked by a pair of laterals on each side.

Diener considers this genus as a descendant of Thalassoceras Gemmellaro (Fauna dei calcari con Fusulina, 1887, p. 69), which has somewhat simpler, though ammonitic, septa, in which there are two digitate lateral lobes, and a single simple auxiliary. Thalassoceras has a depressed subglobose form, with the whorls usually broader than high, while the adults of Ussuria are high whorled and compressed. But the young of the latter genus are robust and subglobose, resembling Thatassoceras both in form and septa, and the still younger stages are like Dimorphoceras. These observations have been made only on an Ussuria Waigeni Hyatt and Smith from the Meekoceras beds of Idaho, no young stages of Ussuria compressa Hyatt and Smith having been seen. Thalassoceras is supposed to have been derived from Dimorphoceras, but this is based on the resemblance of the adults, no observations having been made on its ontogeny.

Ussuria bèars a certain resemblance to Sturia Mojsisovics, commonly assigned to the Ptychitidx, in itś compressed form, spiral striæ, and complex septa, and a relationship between the two genera is by no means unlikely, in spite of the difference in complexity of the septa. 
Hyatt $^{a}$ classed Ussuria in a new family Ussuritidæ, under the suborder Phylloceratida, but this was before any observations had been made on the ontogeny of the genus or any: species of it was known except the Siberian forms.

Ussuria is known at present only in the Lower Triassic, Proptychites beds of Ussuri Bay in eastern Siberia, and in the Meekoceras beds of the Aspen Ridge in southeastern Idaho, and in the same formation in the Inyo Range of California, in all three places associated with Meekoceras, Pseudosageceras, Ophiceras, and Danubites, with closely allied species.

USSORIA COMPRESSA Hyatt and Smith, sp. nov.

$$
\text { Pl. III, figs. 6-11. }
$$

Form compressed, involute, discoidal; whorls deeply embracing, and increasing rapidly in height, the outer whorl being indented to one-fourth of its height by the inner. Umbilicus closed, umbilical shoulder's broadly rounded. Sides gently convex, with greatest breadth opposite the top of the inner volution. Venter rounded, but very narrow. The whole form is thus seen to be lenticular, with the greatest thickness of the lens exactly in the middle, and one-third of the diameter.

The surface of the cast is perfectly smooth, devoid of ribs, constrictions, or other ornamentation; but in a few places the outer shell was preserved, adhering to the cast, and on this were observed fine spiral lines like those on the shell of Sturia.

The septa are very complex, both lobes and saddles being thoroughly ammonitic, much more complex than those of Ussuria Schamaræ Diener and $U$. Iwanowi Diener. The ventral lobe is divided by a broad, siphonal saddle, which in turn is broken up by several small, short digitations, almost becoming adventitious lobes; the two lateral lobes are deeply digitate, the first being much more complex than the second. The auxiliary series consists of four or five small lobes scarcely individualized, and inclined backward to the umbilical margin. The internal septa could not be observed in detail, but broken whorls showed a large antisiphonal lobe, flanked by a pair of principal internal laterals on each side.

Ussuria compressa has more compressed whorls than either of the Siberian species and has also greater complexity of the septa, but undoubtedly belongs to the same genus with them.

$$
\text { Dimensions of the type specimen. }
$$

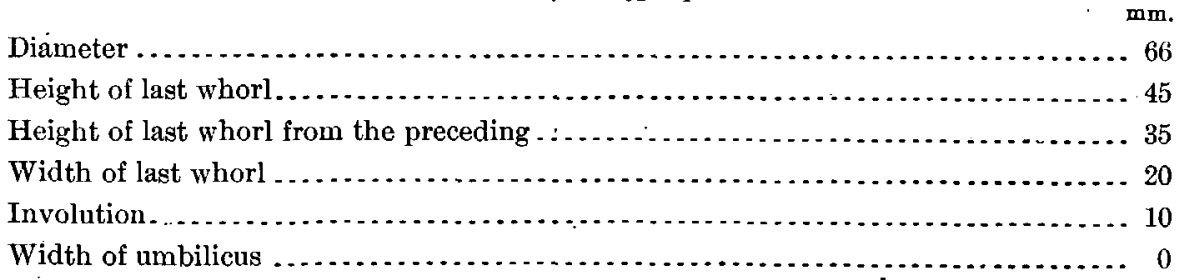


This specimen was chambered throughout, and the species probably grew to twice this diameter.

Morizon and locality.-In the Lower Triassic Meekoceras beds of the Union Wash, near the Union Spring, about 15 miles southeast of Independence, Cal., collected by J. P. Smith.

USSTURIA WAAGENI Hyatt and Smith, sp. nov.

Pl. LXV, figs. 1-5; Pl. LXVI, figs. 1-12; PI. LXVII, figs. 1 and 2; Pl. LXXXV, figs. 1-8.

Discoidal, involute, laterally compressed. Whorls high and increasing rapidly in height, deeply embracing, and deeply indented by the inner whorls. Sides flattened, with narrow rounded venter, and no marked umbilical shoulders. The umbilicus is very narrow, being somewhat less than one-tenth of the entire diameter of the shell. The height of the last whorl is more than one-half of the diameter of the shell, the width slightly more than one-half of the height of the whorl, and it is indented to nearly one-seventh of its height by the inner whorl.

The shell at maturity has the following proportions:

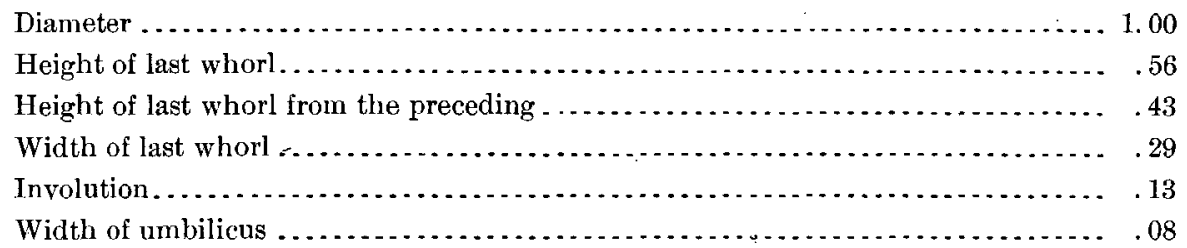

The greatest width of the whorl lies at a point about balfway up the flanks, some distance above the contact with the inner volution. The surface is nearly smooth, showing neither ribs nor constrictions, but faint radial folds and striæ of growth. No spiral lines were seen on the shell, as was the case with Ussuria compressa, but the surface was poorly preserved, and they may have been destroyed by weathering.

The septa are very complex, consisting of a rather small external lobe divided by a siphonal saddle, a small first lateral lobe, larger second lateral, and smaller third lateral, besides a long series of auxiliaries, decreasing in size and complexity toward the umbilicus. The external and the lateral lobes are deeply digitate, while the auxiliaries are much simpler in form. The saddles are all narrower than the lobes and somewhat phylloid.

These septa are more complex than those of Ussuria Schamaræ Diener and $U$. Iwanowi Diener from Siberia, and of Ussiria compressa Hyatt and Smith from California, but show that the species is congenerie with them. It must also be taken into account that the Idaho species is very large, and that the Siberian species may 
have reached the same complexity of septation if such large specimens of them had been found.

The foregoing description applies only to the mature shell, for the young stages differ very much from the adult. An unusually good series of young stages was obtained, and as they show clearly the phylogeny of the genus they have been fully illustrated. The mature shell was found up to diameter of $150 \mathrm{~mm}$. fully septate, and the complete shell must have been nearly $300 \mathrm{~mm}$. in diameter.

The smallest stage obtained has diameter of $5.5 \mathrm{~mm}$., is evolute, little embracing, with low broadly rounded whorls, with simple goniatitic septa. The form and septa correspond to the Carboniferous genus Dimorphoceras. The change from glyphioceran septa to those characteristic of Dimorphoceras may be observed on the outer volution of this specimen, which is figured on Pl. LXXXV, figs. 5-8. For comparison with this the septa of Dimorphoceras Gilbertsoni Phillips and D. atratum Goldf uss, of the Carboniferous, are figured on Pl. LXXXV, figs. 11 and 12.

At the diameter of $11 \mathrm{~mm}$. the shell shows a transition from Dimorphoceras to Thalassoceras. In the beginning of the digitation of the lobes, the whorl becomes higher at this stage, but not yet flattened as at maturity. This stage is figured on Pl. LXXXV, figs. 1-4. For comparison with it, the septa of Thalassoceras Gemmellaroi Karpinsky and T. Phillipsi Gemmellaro are figured on Pl. LXXXV, figs. 9 and 10.

At the diameter of $13 \mathrm{~mm}$. the form and septa are more like the highly specialized species of Thalassoceras known from the Permian; this stage is figured on Pl. LXVI, figs. 10-12.

At the diameter of $17 \mathrm{~mm}$. the shell and septa show a transition from Thalassoceras to Ussuria in the flattening of the sides, increased height of whorl, greater complexity of lobes, and pronounced development of the auxiliary lobes. This stage is shown on Pl. LXVI, figs. 7-9.

At diameter of $30 \mathrm{~mm}$. the stage of development of the septa agrees with that of Ussuria Schamaræ Diener and $U$. Iwanowi Diener, from the Lower'Triassic of Siberia. It is possible, however, that the species described by Diener may have been based on young individuals. This stage of Ussuria Waageni is figured on Pl. LXVI, figs. 4-6.

At diameter of $35 \mathrm{~mm}$. the shell and septa already show the most important characters of maturity, but are not yet so complex as in the larger specimens. This is shown on Pl. LXVI, figs. 1-3.

The fully mature shell is figured on PI. LXV, figs. 1-5, and Pl. LXVII, figs. 1 and 2. The septa of Ussuria Iwanowi Diener, from the Lower Triassic of Siberia, are figured for comparison on Pl. LXVI, fig. 25.

The development of Ussuria Waageni is remarkable, in that we can trace the species in its ontogeny through stages corresponding successively to some glyphio- 
ceran form of the Carboniferous; then through the stage corresponding to the simpler species of Dimorphoceras in the Mississippian; then to the more complex species of Dimorphoceras of the Coal Measures; then to the simpler species of Thalassoceras of the lower Permian or Artinsk stage; then to the more complex Thalassoceras of the upper Permian; and lastly through gradually increasing complexity into Ussuria. The stages come in the exact order of the geologic sequence of mature genera, so that the agreement of phylogeny and ontogeny is perfect.

Of course this is what we should expect in Lower Triassic species, for the time of the Meekoceras fauna is not greatly removed from that of the Permian faunas of Sicily and the Artinsk stage, nor yet very remote from even the Carboniferous. But such close correlation of individual development and geologic history is rare even in Lower Triassic species, and especially in such complex forms, where the adult differs so markedly from the young.

Comparison with other species.-Ussuria Wageni Hyatt and Smith differs from Ussuria Iwanowi Diener and U. Schamarx Diener in the greater complexity of its septa, but agrees with them in the general plan of lobes and saddles. It agrees in general with Ussuria compressa Hyatt and Smith, from the Lower Triassic Meekoceras beds of California, but differs from that species in the more robust whorl in all stages observed. The saddles in both the American species are more digitate than in the Asiatic forms, and the subdivision of the lobes is more complex. It has been suggested by F. Frech" that the Siberian species of Ussuria did not occur in the Lower Triassic, as Diener supposed, but in the Permian. It is more likely, however, that the Siberian as well as the American species of this genus belong to the Lower Triassic, and that their greater simplicity of development is due to their occurrence in a lower horizon of the Triassic.

Horizon and locality.-Ussuria Waageni is rather common in the Meekoceras beds, Lower Triassic, at the head of Wood Canyon, 9 miles east of Soda Springs, Aspen Ridge, southeastern Idaho. It was associated with Meekoceras gracilitatis White, M. mushbachanum White, M. aplanatum. White, Pseudosageceras intermontanum Hyatt and Smith, Flemingites Russelli Hyatt and Smith, Hedenstroemia Kossmati Hyatt and Smith, Ophiceras Dieneri Hyatt and Smith, Paranannites aspenensis Hyatt and Smith, Cordillerites angulatus Hyatt and Smith, Aspidites, Danubites, and many other forms characteristic of this horizon.

The specific name is given in honor of the late Prof. W. Waagen.

\section{Suborder LXTOCERATOIDEA.}

This suborder includes the families. Lytoceratidæ and Phylloceratidæ, which are so various that a single short diagnosis can hardly cover both and include characters

a Die Dyas: Lethæu Palæozoica, Bd. 2, Lieferung 4, p. 659. 
possessed by all genera of both families. The forms may be either evolute or involute, high whorled or low. But they all agree in having the shell nearly smooth, ornamented only with varices or cross strix of growth, without keels, knots, or strong lateral sculpture. The septa are always phylloid in digitation; in the primitive forms the saddles are rounded and entire, but in the more specialized the saddles are also digitate, although not so much so as the lobes.

The Phylloceratidæ appear to have developed out of the Lytoceratidæe in the Upper Triassic. The Lytoceratida are first known in the Lower Triassic, but beyond that their. ancestry is in doubt. They are commonly supposed to have been derived from Nomismoceras of the Carboniferous, but there are no connecting links. Only the Lytoceratidæ are represented in the American Triassic.

\section{Family LYTOCERATID}

Forms evolute, laterally compressed, surface smooth, ornamented only with constrictions or low folds. Septa phylloid, saddles entire in more primitive forms, and digitate in more specialized forms.

The Lytoceratidæ are represented in the American Triassic only by Monophyllites, which occurs in both the Middle and the Upper Triassic.

Genus MONOPHYLIITHS Mojsisovios.

1879. Monophyllites, Mojsisovics, Vorläufige kurze Uebersicht der Ammoniten-Gattungen der Mediterranen und Juvavischen Trias: Verhand1. K.-k. geol. Reichsanstalt, Wien, p. 135.

1882. Monophyllites, Mojsisovics, Cephalopoden der Mediterranen Triasprovinz: Abhandl. K.-k. geol. Reichsanstalt, Wien, vol. 10, p. 204.

1886. Monophyllites, Mojsisovics, Arktische Triasfaunen: Mém. Acad. imp. sci. St.-Pétersbourg, sér. 7, tome 33 , No. 6 , p. 72 .

1895. Monophyllites, Diener, Cephalopodenfaunen der ostsibirischen Küstenprovinz: Mém. Com. géol., St.-Pétersbourg, vol. 14, No. 3, p. 29.

1895. Monophyllites, Diener, Cephalopoda of the Muschelkalk: Mem. Geol: Survey India, Pal. Indica, ser. 15 , p. 106.

Type.-Monophyllites Suessi Mojsisovics, Cephal. Medit. Triasprovinz, p. 205, Pl. LXXIX, fig. 4.

Evolute, discoidal, whorls increasing slowly in height, and little embracing; umbilicus wide and shallow. Surface nearly smooth, but ornamented with cross stria, and on some forms with varices, especially on the inner whorls.

Septa ammonitic, but simple. Saddles phylliform, lobes digitate, triænidian in plan. The external lobe is divided by a narrow, simple siphonal saddle; the laterals are two or three in number, decreasing in complexity toward the umbilicus; and there is an auxiliary series, usually of two or three small lobes of which the innermost may be goniatitic. 
Monophyllites is characteristic of the Middle Triassic of the Alps, Spitzbergen, Siberia, and Nevada, but has also been found in the Upper Triassic of the Alps and California.

The only American species yet described is $M$. billingsianus Gabb.

\section{MONOPHYLLITES BILLINGSIANUS Gabb.}

Pl. XXIV, figs. 3 and 4 .

1864. Ammonites billingsianus, Gabb, Geol. Survey California, Palrontology, vol. 1, p. 26, Pl. V, fig. 20. 1870. Ammonites billingsianus, Gabb, Am. Jour. Conchol, vol. 5, p. 8, Pl. V, fig. 3.

Form evolute, laterally compressed. Whorl low, and increasing slowly in height, little embracing, and not deeply indented by the inner volution. Sides somewhat flattened, venter rounded, with indistinct abdominal shoulders. Umbilicus wide and shallow, exposing the greater part of the inner volutions. Umbilical shoulders abruptly rounded. The height of the whorl is more than one-third of the total diameter of the shell, and the breadth is about three-fourths of the height of the whorl. The width of the umbilicus is about one-third of the total diameter. of the shell.

The surface is smooth, so far as known, and destitute of any kind of ornamentation.

The septa are monophyllic, the saddles rounded, entire, contracted at the base, and the lobes are digitate. The external lobe is divided by a narrow siphonal saddle into two bifid divisions; the first lateral is distinctly and symmetrically trifid; the second lateral unsymmetrically trifid. The auxiliary consists of three small secondary divisions of the umbilical lobe. Internal septa unknown. The septa as figured by $\mathrm{Gabb}^{a}$ are not correct, as he represents the first lateral lobe as bifid. The septa as represented in this paper were drawn from a specimen in the Whitney collection, on which the septa were not visible until prepared by the writers.

Horizon and locality. - Monophyllites billingsiunus Gabb was found by the Geological Survey of California in the Middle Triassic of the East Humboldt Range, Nevada. The specimen figured on Pl. XXIV, figs. 3 and 4, was loaned from the Whitney collection of Harvard University.

\section{Suborder PINACOCERATOIDEA.}

Involute, discoidal, laterally compressed. : Surface smooth, septa lanceolate, goniatitic, ceratitic, or ammonitic, divided into numerous lobes and saddles, and usually with adventitious lobes.

E. von Mojsisovies formerly included in this group such diverse families as Lytoceratidæ, Ptychitidæ, Hungaritidæ, and Meekoceratidæ. Cleared of these 
foreign elements the suborder retains only the Pinacoceratidx, Pronoritidæ, and Noritide, all of which bave much in common in form and septation. The divergence of these three families from a common stock must have taken place in the Devonian, but they developed on parallel lines, so that the resemblance persisted even in the Triassic. Only a single Carboniferous genus of the Pinacoceratidæ is known, Prodromites Smith and Weller; the Pronoritida are confined to the Paleozoic, with the exception of Medlicottia, which ranges from the Permian into the Lower Triassic, and Cordillerites Hyatt and Smith, and Lanceolites Hyatt and Smith, of the Lower Triassic; the Noritide are confined to the Triassic, with the exception of Darælites Gemmellaro, of the Permian, and Schuchertites Smith, of the Pennsylvanian. The grounds on which Waagen separated the Noritida from the Pinacoceratidæ do not seem to the writers to be valid; but since no certain members of the Noritidæ occur in the American Triassic there is no need of further discussion.

\section{Family PINACOCERATID A.}

Involute, laterally compressed, discoidal. Short body chamber; narrow venter, either flattened with angular margins, or channeled, or with central keel. Surface smooth or ornamented only with spiral ridges, or low folds. Septa lanceolate, either dicranidian, prionidian, or ammonitic, but always with adventitious lobes.

This family probably connects with Beloceras Hyatt, of the Devonian, but the only intermediate genus yet known is Prodromites Smith and Weller, ${ }^{a}$ from the Mississippian ("Lower Carboniferous") of America. In the Lower 'Triassic this family is represented by Aspenites Hyatt and Smith, Clypites Waagen, Sageceras Mojsisovics, Hedenstroemia Waagen, and Pseudosageceras Diener; so that many members of the family may be looked for in the Permian. In the Middle and Upper Triassic the chief members are Pinacoceras, Arthaberites, Carnites, Placites, and Sageceras.

Genus ASPENITES Myatt and Smith, gen. nov.

Type.-Aspenites acutus Hyatt and Smith, sp. nov.

Form compressed, involute, deeply embracing, discoidal; sides flattened, a'. domen acute and surmounted by a keel, umbilicus closed. Surface ornamented with fine, strong radial folds.

Ventral lobe narrow and short, divided by a short siphonal notch; that is, one small adventitious lobe on each side; three laterals, which are larger than the others, and distinctly serrated. Following these is a short auxiliary series of goniatitic lobes. The internal septa are unknown, also the length of the body chamber.

Aspenites is most nearly related to Clypites Waagen, but differs from that genus in the simpler lobes and in the possession of a keel. It shows also a certain resem-

a Prodromites, a new ammonite.genus from the Lower Carboniferous: Jour. Geol., vol. 9, 1901, No. 3, p. 255. 
blance to Prodromites Smith and Weller from the Mississippian, but is entirely too simple to have been a descendant of that highly specialized genus. Its form and septa suggest a derivation from Timanites of the Devonian.

Aspenites is known at present only from the Lower Triassic Meekoceras beds of southeastern Idaho and of the Inyo Range, in Inyo County, Cal. One species only was found, A. acutus sp. nov.

ASPENITES ACUTUS Hyatt and Smith, sp: nov.

Pl. II, figs. 9-13; Pl. III, figs. 1-5.

Form discoidal, involute, deeply embracing, laterally compressed. Whorls high and narrow, with flattened sides, and acute venter. Umbilicus closed. The height of the last whorl is nearly three-fifthis of the total diameter of the shell; its width is somewhat more than one-third of its height, and it is indented to about three-eighths of its height by the inner volution.

The surface is nearly smooth, but ornamented with fine radial folds, visible on the cast, stronger near the umbilicus, and becoming obsolete high upon the flanks.

The septa are lanceolate, consisting of an adventitious series, a lateral and an auxiliary series. The saddles are all entire and rounded, the lobes of the adventitious and of the auxiliary series are simple and pointed, while the laterals are serrated. The external lobe consists of a short bifid ventral, flanked by a single longer and pointed adventitious lobe on each side. The first lateral is short and slightly serrated, the second is longer and broader, the third short like the first, but broader. The auxiliary series consists of two or three short-pointed lobes with broadly rounded saddles.

The form and the septa suggest a derivation from Timanites Mojsisovics of the Devonian, as described by E. Holzapfel. ${ }^{a}$ Aspenites differs from Timanites in the development of the adventitious series, and the serration of the laterals, but its young stages are remarkably like the mature forms of the Devonian genus. Timanites is placed by some writers in the Prolecanitidæ, by others in the Primordialidæ, but its true position will probably be found to be along with Beloceras, as an offshoot from the Primordialidie.

Horizon and locality.-Aspenites acutus was found by Alpheus Hyatt in the Lower Triassic Meekoceras beds of Wood Canyon, near Soda Springs, Idaho, and by J. P. Smith in the same formation on the Union Wash, near the Union Spring, in the Inyo Range, California, about 15 miles southeast of Independence.

$a$ Die Cephalopoden des Domanik im südlichen Timan: Mem. Com. géol., St.-Pêtersbourg, *ol. 12, No. 3, 1899. 
Genus SAGHOHRAS Mojsisovics.

1872. Sageceras, Mojsisovics, Ueber die Entwicklung von Ammoniten in der Carbonischen Formation Indiens: Verhandl. K.-k. geol. Reichsanstalt, Wien, p. 316.

1873. Sageceras, Mojsisovics, Das Gebirge um Hallstatt: Abhandl. K.-k. geol. Reichsanstalt, Wien, vol. 6, pt. 1, p. 69 .

1879. Sageceras, (pars) Waagen, Salt Range Fossils, vol. 1, p. 37: Mem. Geol. Survey India, Pal. Indica, ser. 13.

1882. Sageceras, Mojsisovics, Cephalopoden der Mediterranen Triasprovinz: Abhandl. K.-k. geol. Reichsanstalt, Wien, vol. 10, p. 187.

Type.- "Goniatites" Haidingeri Hauer, Neue Cephalopoden aus dem rothen Marmor von Aussee, Haidinger's Naturwiss. Abhandl., vol. 1, 1847, p. 264, Pl. VIII, figs. 9-11.

Discoidal involute, laterally compressed, umbilicus very narrow; whorls thin, deeply embracing, and increasing rapidly in height. Venter narrow with furrow bounded by two sharp shoulder angles. Sculpture consisting of fine radial strix, and fine spiral lines.

Septa lanceolate, divided into a great number of long and narrow tongue-shaped entire saddles and bifid lobes. These increase in length from the short adventitious lobes near the venter to the larger principal lateral lobes near the middle, and then decrease again to the small auxiliary lobes outside of the umbilicus. The increase and decrease are so gradual that no line can be drawn between adventitious, principal, and auxiliary lobes.

The oldest known member of this genus is Sageceras hauerianum de Koninck, from the Lower Triassic of the Salt Range; the next is $S$. Gabbi, Mojsisovics, of the Middle Triassic of Nevada; the other two known species occur in the Upper Triassic of the Alps.

\section{SAGECERAS GABBI Mo sisovics.}

Pl. XXV, figs. 1-3; Pl. LXXIV, figs. 8 and 9; Pl. LXXV, figs. 14 and 15.

1864. Goniatites Haidingeri, Gabb, Geol. Survey California, Palæontology, vol. 1, p. 22, Pl. V, figs: 8 and 10 (27 and 28).

1873. Sageceras Gabbi, Mojsisovics, Das Gebirge um Hallstatt: Abhandl. K.-k. geol. Reichsanstalt, Wien, vol. 6 , pt. 1, p. 71.

(Not 1864. Goniatites Haidingeri, Gabb, Geol. Survey California, Palæontology., vol. 1, Pl. IV, fig. 10.) (Not 1847. Goniatites Haidingeri, Hauer, Neue Cephal. aus dem rothen Marmor von Aussee, Haidinger's Naturwiss. Abhandl., vol. 1, p. 264, Pl. VIII, figs. 9-11.)

Involute, discoidal, laterally compressed, whorls narrow, high, deeply embracing, and deeply indented by the inner volutions. Umbilicus very narrow, but exposing the inner volutions. The umbilical shoulders are abruptly rounded, the sides flattened, the venter narrow, channeled, with bicarinate edges.

16918-No. $40-05-7$ 
The septa are lanceolate, divided into numerous long and narrow lobes and saddles. The saddles are rounded and entire, while the lobes are bifid, increasing in size from the venter toward the middle of the flanks, and then decreasing again toward the umbilicus.

Gabb included in his description of this species (p. 22, Pl. IV, fig. 10), a young specimen of Longobardites, under the mistaken idea that it was the young of Sageceras. This explains the anomaly in Gabb's description where it is stated that the septa of the young shell are serrated, while those of the mature shell are only bifid, without serrations.

This species is nearly akin to Sageceras Haidingeri Hauer, but, as Mojsisovics points out, it has fewer lobes at the same size.

Horizon and locality.-Middle Triassic, Humboldt mining region, Nevada, collection Geological Survey of California; and on the divide between the South Fork of American Canyon and Troy Canyon, West Humboldt Range, collection of J. P. Smith.

The specimen figures on Pl. LXXIV, figs. 8 and 9; Pl. LXXV, figs. 14 and 15, are from Troy Canyon, and are in the collection of J. P. Smith; Pl. XXV, figs. 1-3, are copied from the Palæontology of California, vol. 1, Pl. V, figs. 8-10.

Genus PGEUDOSAGHCH:RAS Dicnex.

1895. Pseudosageceras, Diener, Triadische Cephalopodenfaunen der'ostsibirischen Küstenprovinz: Mém. Com. géol., St.-Pétersbourg, vol. 14, p. 28, No. 3.

1902. Pseudosageceras, F. Frech, Lethæa Palæozoica, Bd. 2, Lieferung 4, p. 659.

1905. Pseudosageceras, Noetling, Untersuchungen über den Bau der Lobenlinie von Pseudosageceras multilobatum Noetling: Palæontographica, vol. 51, pp. 155-260.

Type--Pseudosageceras sp. indet. Diener, Triadische Cephalopodenfaunen der ostsibirischen Küstenprovinz, p. 28, Pl I, tig. 8.

Shell compressed, involute, discoidal, deeply embracing, umbilicus closed, sides flattened; venter narrow and angular, with a low sharp keel surmounting the venter.

Surface smooth, so far as known.

Septa consisting of numerous long and narrow lobes and saddles; the saddles are all entire, and the lobes all divided; near the venter there is a series of shorter adventitious lobes chiefly bifid, and on the flanks a series of several laterals, chiefly trifid, but with secondary divisions. Below the chief laterals is a series of bifid auxiliaries outside the umbilicus.

This genus resembles Sageceras Mojsisovics, but has more complex septa, and can not possibly be the ancestor of it, since in Sageceras the lobes are always bifid, the trifid stage never being reached. $\Lambda$ near relative and possible ancestor of Peudosageceras may be found in Prodromites Smith and Weller (Jour. Geol., vol. 9, p. 257) from the Mississippian (Lower Carboniferous), which may be a connecting link with Beloceras Hyatt, of the Devonian, for Prodromites has the same involute, 
compressed, acute form, and the numerous serrated lobes with a long auxiliary series, but it has not developed the numerous adventitious lobes characteristic of Beloceras and Pseudosageceras; the writers, however, do not consider the adventitious lobes of primary importance in classification, since they are developed in other groups that have no near relationship with the Pinacoceratidæ.

This genus is known only from the Lower Triassic of Ussuri Bay, in eastern Siberia, from the Lower Triassic of India, and from the corresponding beds of the Aspen Ridge in southeastern Idaho and the Inyo Range in California.

Frech ${ }^{a}$ assumes that two geologic horizons are represented in the Proptychites beds of Ussuria Bay, and that Ussuria and Pseudosageceras came out of Permian strata, while Meekoceras came out of Lower Triassic beds. This is, however, unlikely, for J. P. Smith has found both Ussuria and Pseudosageceras in the Inyo Range of California and in the Aspen Ridge of Idaho associated with Meekoceras gracilitatis and numerous other species of Meekoceras, and other forms equally characteristic of the Lower Triassic. But it is extremely probable that both genera will eventually be found in the Permian, for the stocks to which they belong are already well differentiated in the Carboniferons.

PSEUDOSAGECERAS INTERMONTANUM Hyatt and Smith, sp. nov.

Pl. IV, figs. 1-3; Pl. V, figs. 1-6; Pl. LXIII, figs. 1 and 2.

Shell compressed, involute, discoidal, deeply embracing, with closed umbilicus, and flattened sides, with gentle convex curve up to the venter, which is narrow, with small furrow and two fine bordering keels. On this rests a central keel, which, however, is usually broken off.

Septa consisting of numerous lanceolate lobes and saddles, the saddles all entire; and the lobes mostly divided. Next to the venter is a series of two adventitious lobes on each side of the short undivided ventral, of which the first is short and undivided, the second longer and bifid. Then follows a series of four principal lateral lobes, of which the first is bifid, with a secondary notch on the upper prong, the second unsymmetrically bifid, with notches on both prongs, the third unsymmetrically trifid, all the prongs being indented, and a fourth deeply and unsymmetrically bifid. After the principal lateral lobes follows a series of six irregular auxiliaries, of which the first and third are bifid, and the others apparently entire. This septation is seen to be more complex than on Diener's type species, but is of the same general character. Also Diener's specimen was very imperfect, and if better preserved might have shown these same characters, so that the two are certainly congeneric.

The length of the body chamber is unknown, as all the specimens were septate, but imperfect individuals of $115 \mathrm{~mm}$. diameter have been found.

a Lethæa Palæozoica, Bd. 2, Lieferung 4 (1902), p. 659. 
Dimensions of the type specimen, from the Lower Triassic Meekoceras beds of Wood Canyon, near Soda Springs, Idaho.

$\mathrm{mm}$.

Diameter.

93

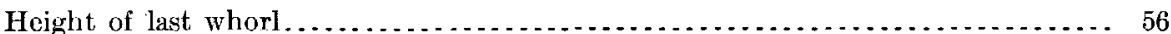

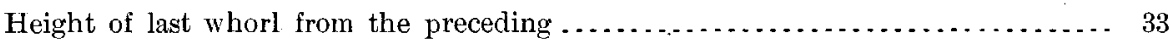

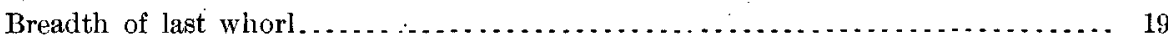

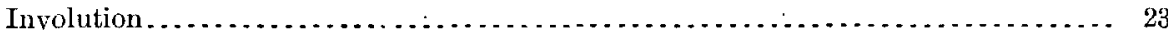

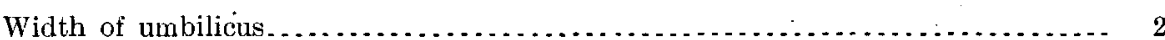

The whorl is indented to nearly one-half its height by the inner coil, and the greatest breadth lics just opposite this point.

Horizon and locality.-Lower Triassic Meekoceras beds of Wood Canyon, 9 miles east of Soda Springs, Aspen Ridge, soutbeastern Idaho; and the same formation on the Union Wash, 3 miles east of Skinner's ranch, Inyo County, Cal., near the old McAboy trail from Owens Valley over the Inyo Range to Salinas Valley. In both Idaho and California it is associated with Meekoceras gracilitatis White, M. (Gyronites) aplanatum White, and M. (Koninckites) mushbachanum White, and many other species common to the two beds, enough to make certain the correlation of the Meekoceras beds in. California and Idaho. It was also found by Mr. R. S. Spence in the Columbites beds, 1 mile west of Paris, Bear Lake County, Idaho, associated with Columbites parisianus Hyatt and Smith, Prionolobus Jacksoni Hyatt and Smith, Ophiceras Spencei Hyatt and Smith, Celtites sp. nov., Meekoceras pilatum Hyatt and Smith, etc.

\section{Genus HEDENSTRCEMIA Waagen.}

1895. Hedenstrcemia, Waagen, Fossils from the Ceratite Formation: Salt Range Fossils, vol. 2, p. 140: Mem. Geol, Survey India, Pal. Indica, ser. 13.

1897. Hedenstræmia, Diener, Cephalopoda of the lower Trias: Himalayan Fossils, vol. 2, pt. 1, p. 60: Mem. Geol. Survey India, Pal. Indica, ser. 15.

1900. Hedenstromia, Hyatt, Cephalopoda (in Eastman's translation of Zittel's Text-Book of Palæontology, vol. 1), p. 555 .

1900. Anahedenstromia, Hyatt, Cephalopoda (in Eastman's translation of Zittel's Text-Book of Palæontology, vol. 1), p. 555.

Type-Ceratites Hedenstromi Keyserling, Bull. Acad. imp. sci. St.-Pétersbourg, vol. 5, No. 11, p. 166, Pl. II, figs. 5-7; and E. von Mojsisovies, Arktische Triasfaunen, p. 80.

Form involute, discoidal, laterally compressed. Whorls high, narrow, deeply embracing, and deeply indented by the inner volutions. Sides flattened, venter narrow, bounded by distinct angles, with slight ventral furrow.

Surface smooth, so far as known. Umbilicus narrow, almost closed. 
Septa complex, consisting of one or two adventitious lobes. Three or more laterals, and a long auxiliary series. The lobes are all serrated and the saddles entire.

Hedenstromia resembles Pseudosagecerces, with which it is associated, in form, but differs from that genus in lacking the lanceolate type of lobes. It also resembles Cordillerites Hyatt and Smith, but does not have the complexity of the lateral lobes, nor the tongue-shaped bifid lobes of the auxiliary series that are characteristic of Cordillerites.

The type species of Hedenstromia was assigned by Mojsisovics to Meekoceras, but that genus never has adventitious lobes, nor a long series of auxiliaries, and therefore Waagen placed it in a new genus under the subfamily Hedenstrœminæ in the Pinacoceratidæ. . This has been accepted by C. Diener, ${ }^{a}$ who added another species, II. Mojsisoviosi Diener. Meekoceras furcatum Mojsisovics was also included by Waagen and Diener in Hedenstromia, but E. $\mathrm{Haug}^{b}$ assigned it to Norites, to which genus it has a certain resemblance in form. E. von Mojsisovics ${ }^{c}$ has recently chosen this species as the type of a new genus Tellerites, under the family Noritidæ, thus leaving only two accepted species under Hedenstræmia, H. Hedenstromi, and H. Mojsisovicsi.

Occurrence.-Hedenstromia has been found up to the present time only in the upper part of the Lower Triassic in northern Siberia and in the Himalaya Mountains in India. It has.recently been found by J. P. Smith in the Meekoceras beds of the Lower Triassic of southeastern Idaho and eastern California, in both cases associated with Meekoceras gracilitatis, and many other characteristic forms.

\section{HEDENSTREMIA KOSSMATI Hyatt and Smith, sp. nov,}

P1. LXVII, figs. 3-7; Pl. LXXXIV, figs. 1-10.

Involute, discoidal; whorls laterally compressed, high and increasing rapidly in height. Venter narrow, triangular, and with slight ventral depression between the shoulder angles. Umbilicus narrow, almost closed. Surface smooth on both shell and cast.

The septa are complex, consisting of an adventitious series of lobes, laterals, and a long auxiliary series. The first adventitious lobe is short and narrow, less than one-half the size of the second lateral; the first lateral slightly longer and about twice as broad as the adventitious lobe, and the second lateral shorter, and nearly as broad. The third lateral is shallow, but shaped like the second. These are all distinctly

a Cephalopoda of the lower Trias: Himalayan Fossils, vol. 2, pt. 1, p. 60: Mem. Geol. Survey India, Pal. Indica, ser. 15

$b$ Les Ammonites du Permien et du Trias: Bull. Soc. géol. France, ser. 3, tome 22, 1894, p. 393.

c Cephalopoden der Hallstätter Kalke, Supplement-Heft (1902), p. 311: Abhandl. K.-k. geol. Reichsanstalt, vol, 6, pt. 1 (1902), p. 311. 
serrated. Then follows a long series of short tongue-shaped auxiliaries, growing smaller toward the umbilicus.

In the later adolescent stage the ventral furrow is distinct, but disappears before maturity.

In the earlier adolescent stage the venter is rounded, the whorl proportionally more robust, and the surface is sculptured with lateral ribs. The young stages are absolutely unlike those of the Meekoceratida, but resemble those of Cordillerites. Both genera probably come from a common ancestor.

Hedenstrcemia Kossmati is evidently closely allied to H. Mojsisovicsi Diener ${ }^{a}$ of the Lower Triassic of India, from which it differs chiefly in the narrowness of the umbilicus, the shape of the whorl, the smooth surface, and character of the septa being virtually identical in the two species. It is thought best, however, for the present to keep them separate, until sufficient material of the Indian and the American forms should be found to show whether they are perfectly similar at the same size.

Occurrence--Hedenstromia Kossmati was found by J. P. Smith in the Lower Triassic Meekoceras beds, at the head of Wood Canyon, 9 miles east of Soda Springs, in the Aspen Ridge in southeastern Idaho, associated with Meekoceras gracilitatis White, M. mushbachanum White, M. aplanatum White, Flemingites, Ussuria, Cordillerites, Nannites, Ophiceras, Aspenites, Pseudosageceras, and many other forms characteristic of the Lower Triassic. Probably the same species was found by J. P. Smith in the Meekoceras beds of Union Canyon, in the Inyo Range, about 15 miles southeast of Independence, Inyo County, Cal., associated with virtually the same fauna.

It would seem that Hedenstromia, in both Asia and America, is characteristic of the upper horizon of the Lower Triassic, the Flemingites beds, or what was formerly called by Diener the Subrobustus beds, for the associated faunas are very similar in India, Siberia, Idaho, and California. The specific name is given in honor of Dr. Franz Kossmat, of the Imperial Geological Survey of A ustria.

\section{Genus OLYPILHS Waagen.}

1895. Clypites, Fossils from the Ceratite Formation: Salt Range Fossils, vol. 2, p. 142: Mem. Geol. Survey India, Pal. Indica, ser. 13.

1902. Aspidites (pars), F. Frech, Lethrea Palæozoica, Bd. 2, Jieferung 4, p. 637.

Type-Clypites typicus Waagen, Fossils from the Ceratite Formation, p. 143,. Pl. XXI, figs. $7 \mathrm{a}$ and $\mathrm{b}$.

Involute, laterally compressed, deeply embracing, inner whorls concealed by the outer; umbilicus narrow; sides flattened; venter flattened, narrow, with sharp

a Cephalopoda of the lower Trias: Himalayan Fossils, vol. 2, pt. 1, 1897, p. 63, Pl. XX, fig. 1: Mem. Geol. Survey India, Pal. Indica. ser. 15 . 
abdominal shoulder angles, which may even almost form lateral keels bordering an abdominal furrow.

Surface smooth except the faint radical folds and strie.

Septa ceratitic, external lobe divided by a broad saddle, which is broken up by adventitious lobes and saddles; first lateral lobe strongly developed; second lateral lobe sometimes not differentiated, auxiliary series long, consisting of small, irregular lobes and saddles, as in Aspidites, but usually simpler than in that genus.

Clypites is closely related to Hedenstromia Waagen, but in the latter genus both the adventitious and the auxiliary series of lobes and saddles are much more individualized. Another near relative is Aspenites Hyatt and Snith, but this genus has a sharp venter, with a keel, and is much more compressed laterally. All these forms, however, seem to be closely related to Prodromites Smith and Weller, of the Mississippian (Lower Carboniferous), which may be a connecting link between them and Beloceras.

Clypites is known only from the Lower Triassic Ceratite formation, of the Salt Range in India, and Alpheus Hyatt found one species in the Lower Triassic Meekoceras beds of the Aspen Ridge, southeastern Idaho.

CLYPITES TENUIS Hyatt and Smith, sp. nov.

$$
\text { Pl. I, figs. 4-8. }
$$

Form involute, discoidal, laterally compressed, deeply embracing. Whorl high and narrow, with flattened sides, and narrow-channeled venter, with biangular margins. Umbilicus closed. Surface cast smooth, shell unknown.

Septa lanceolate, with auxiliary, lateral, and adventitious series. The external lobe is divided by a small siphonal notch into two short ventrals; the adventitious lobes consist of a single pair of serrated lobes; the two laterals are broader, longer and more distinctly serrated; the auxiliary series consists of several short, pointed lobes, with broadly rounded saddles.

In youth the venter is biangular, without the channel; the ventral lobe is undivided, thus forming, with the two adventitious lobes, a trifid exteinal.

The septa are simpler than on any of the species described by Waagen, but the resemblance is sufficient to class them in the same genus. This species has a considerable resemblance to Aspenites Hyatt and Smith, but differs in its biangular instead of acute venter. The septa are almost identical on the two.

Horizon and locality.-In the Meekoceras beds, about 9 miles east of Soda Springs, Idaho, in Wood Canyon, near the divide, associated with Meekoceras gracilitatis, M. mushbachanum, and $M$. aplanatum. Collected by A. Hyatt, 1888. 
1893. Iauerites, Mojsisovies, Cephalopoden der Hallstätter Kalke: Abhandl. K.-k. geol. Reichsanstalt, Wien, vol. 6 , pt. 2, p. 517.

1896. Hauerites, Mojsisovics, Obertriadischen Cephalopoden-Faunen des Himalaya: Denkschr. K. Akad. Wiss., Wien, vol. 63, p. 645 .

Type-Ammonites rarestriatus Hauer, Neue Cephalopoden aus den Marmorschichten von Hallstatt und Aussee; Haidinger's Naturwiss. Abhandl., vol. 3, 1849, p. 11, Pl. V, fig. 10; Pl. VI, figs. 4 and 5; and E. von Mojsisovics, Cephalopoden der Hallstätter Kalke, p. 529, Pl. CL, fig. 5.

Involute, discoidal, laterally compressed, deeply embracing, and deeply indented by the inner whorls. Umbilicus narrow, concealing the inner whorls. Sides flattened-convex, curving without abdominal shoulders up to the narrow venter, which is deeply channeled and bounded by narrow keels.

Sides ornamented with fine sigmoidal fold-like ribs, and with strix parallel to these. Body chamber short.

Septa ammonitic, not deeply digitate, and very little above the ceratitic stage of development. They consist of a series of adventitious lobes, an external lobe, a first and second lateral, and an auxiliary series. The adventitious lobes are formed by secondary division of the siphonal and first lateral saddle.

This genus was first described by Mojsisovics as a subgenus of Cyrtopleurites, but he afterwards gave it independent rank. It was classed by him with the Ceratitidæ, but the character of the septa and the ontogeny of the group forbid such a classification. The young stages of this genus bear no resemblance to Dinarites or Tirolites, but do resemble the genus Ambites, supposed by Waagen to be one of the stock forms of the Noritidx. The characters of the septa are such that this genus must be placed in Waagen's group of Pinacoceratidæ, although, according to the opinion of the writers, this group is not homogeneous.

Hauerites is known only from the Upper Triassic, Karnic, and Noric stages of the Alpine province; Karnic stage of the Himalayas; and the same formation in California, where it is represented by two species, H. Ashleyi, sp. nov., and one undescribed species.

HAUERITES ASHLEYI Hyatt and Smith, sp. nov.

Pl. XXXVII, figs. 10-12.

Involute, discoidal, laterally compressed. Whorl high, with flattened-convex sides, and narrow venter, -slightly concave, bounded by sharp marginal shoulder angles. Deeply embracing, and deeply indented by the inner whorl. Umbilicus narrow, almost closed, not exposing any of the interior volutions. The height of the whorl.is three-fifths of the total diameter, and the width is one-half of the height. It is indented to slightly more than one-third of the height by the inner whorl. The 
width of the venter between the marginal angles is $2.5 \mathrm{~mm}$. on a specimen of $40 \mathrm{~mm}$. diameter. The surface ornamented with rather strong sigmoidal ribs and parallel cross striæ, that bend sharply forward in the middle of the flanks, and then backward toward the abdominal shoulders, where they again curve forward, slightly crenulating the shoulder angles.

The septa are ammonitic, but very little above the ceratitic stage of development, the lobes being only slightly digitate, and the saddles slightly serrated. The external lobe is divided by secondary saddles into a series of adventitious lobes, all short and acute; the first lateral is long and wide, somewhat digitate, the second lateral is much smaller and simpler. The auxiliary lobe is divided into several small lobes.

Hanerites Ashleyi is most rearly related to II. Esculapii Mojsisovics, ${ }^{a}$ but differs in its flatter and broader venter, shallower ventral furrow, weaker crenulation of the marginal shoulder angles, and less complex septa. Also in $I$. Asculapii the first lateral saddle is unsyiumetrically divided, which is not the case with $I I$. Ashleyi .

There is no other described species. with which this form may be compared, but in California it is accompanied by an undescribed species that is smoother, flatter, thinner, lacks crenulations on the shoulder angles, and has more complex septa. 'The two' species can, however, easily be distinguished from each other.

Horizon and locality.-Hanerites Ashleyi was found by J. P. Smith in the Upper Triassic zone of Tropites subbullatus, of Shasta County, Cal,, 3 miles east of Madison's ranch; in the limestone beds on the divide between Squaw Creek and Pit River, and one-half mile north of the trail across the divide.

Genus DIENWRIA Iyatt and Smith, gen. nov.

Type--Dieneria Arthaberi Hyatt and Smith, sp. nov.

Involute, laterally compressed, discoidal deeply embracing whorls, deeply indented by the inner volutions. Sides flattened, venter narrow, with angular margins, and without furrow or keel. Umbilicus very narrow, exposing but little of the inner whorls. Surface smooth, ornamented only with flexuous lines of growth. Septa very simple, just in the transition from goniatite to ceratitic stage. The external lobe is divided by a shallow siphonal notch; the first lateral lobe is broad, shallow, and slightly serrated; the second lateral is smaller and entire; following this the septum runs in a nearly straight line to the umbilical suture, with the auxiliary lobes indicated only by undulations.

This genus resembles greatly Ambites Waagen, from which it differs in the slightly serrated first lateral lobe, which in Ambites is entire. The young are exactly like Ambites.

- Dieneria is known only from the Upper Triassic zone of Tropites subbullatus, of Shasta County, Cal., where it is represented by a single species.

a Cephalopocien der Hallstiatter Kalke: Abhandl. K.-k. geol. Réichsanstalt, Wien, vol. 6, pt. 2, p. 527, P1. CLIX, fig.7. 
DIENERIA ARTHABERI Hyatt and Smith, sp. nov.

Pl. XXX YII, figs. 13-16, Pl. LXXXI, figs. 10-25.

Form involute, discoidal, laterally compressed. Whorl high, and increasing rapidly in height; deeply embracing, and deeply indented by the inner whorls. Umbilicus very narrow, almost closed, exposing only the umbilical shoulders of the inner whorls. Sides almost flat; venter narrow and flat, bounded by angular margins; without ventral furrow or keel.

The height of the whorl is seven-twelfths of the total diameter, and the width is about one-third of the height. The indentation or involution is less than onethird of the beight of the whorl.

The surface is smooth, ornamented only with fine, flexuous cross striæ of growth.

Septa very simple, only the first lateral lobe being slightly serrated, all the other lobes and the saddles boing entire. The external lobe is divided by a shallow siphonal notch into two small branches; the first lateral is broader, deeper, and weakly serrated; the second lateral is small and entire; the auxiliary series is represented by a nearly straight line, with only slight undulations on the flank just above the umbilicus.

The young of this species is more robust than the mature shell, and has rounded venters, without abdominal marginal angles. The septa are goniatitic, and are like those of Ambites Waagen, from which Dieneria probably descended. Dieneria Arthaberi has a strong external resemblance to Hauerites Ashleyi Hyatt and Smith, but differs in its less complex septa, in the absence of lateral ribs, and abdominal furrow.

The abdominal angles appear at diameter of $3.5 \mathrm{~mm}$, and the first lateral lobe becomes serrated at $8 \mathrm{~mm}$.

The young stages of Hauerites are like the mature forms of Dieneria, and both genera in the young stages resemble also Beneckeia tenus Seebach; but the mature form of Dieneria Arthaberi differs from that species in lacking a ventral keel, and in having the septa simpler. On Beneckeia both the first and the second lateral lobes are serrated, and the auxiliary series has distinct lobes.

The genus Ambites, to which the young stages of Dieneria are compared, is assigned by Waagen to the Noritidx, but the writers think this group should be assigned to the Pinacoceratidx.

Dimensions of a young specimen in the Ambites stage, figured on Pl. LXXXI, figs. 15-18.

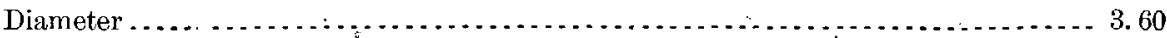

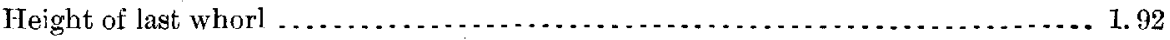

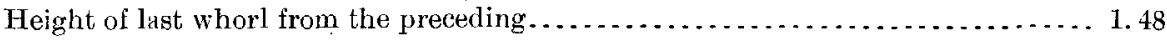

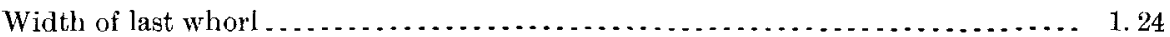

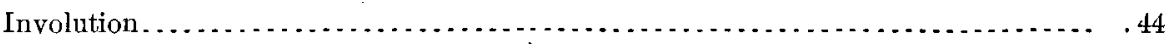

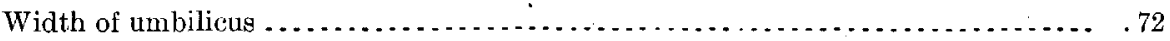


Dimensions of the type specimen.

Diameter $\mathrm{mm}$.

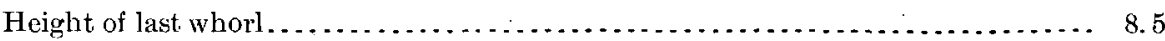

Height of last whorl from the preceding............................ 6

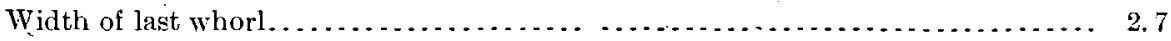

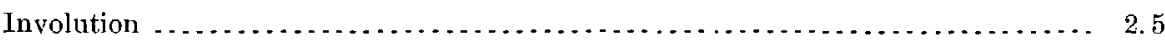

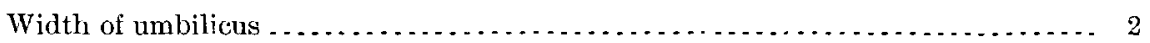

Horizon and locality.-Dieneria Arthaberi was found by J. P. Smith in the Upper Triassic, zone of Tropites subbullatus, of Shasta County, Cal., 3 miles east of Madison's ranch, on the divide between Squaw Creek and Pit River, one-half mile north of the trail from Madison's to Brock's ranch. It was associated with a large number of typical species of the upper Karnic horizon.

Genus PLACITES Mojsisovios.

1896. Placites, Mojsisovics, Ueber den chronologischen Umfang des Dachsteinkalkes: Sitzungsber. K. Akad. Wiss., Wien, vol. 105, pt. 1, p. 18.

1896. Placites, Mojsisovics, Obertriadischen Cephalopoden-Faunen des Himalaya: Denkschr. K. Akad. Wiss., Wien, vol. 63 , p. 663 .

Type.-Group of Pinacoceras platyphyllum Mojsisovics.

Form involute, laterally compressed, discoidal, whorls deeply embracing and deeply indented by the inner volutions; sides flattened, venter narrow and rounded.

Surface smooth, destitute of all ornamentation.

Septa complex, digitate, with an external, two principal lateral lobes, and a series of auxiliaries. At maturity the external lobe is secondarily divided into a short adventitious series.

This genus is characteristic of the Upper Triassic of the Mediterranean and Oriental regions, having its beginning in the Karnic stage, but becoming much more common in the Noric. In America it is represented by a single species, in the Noric stage, of Nevada.

PLACITES HUMBOLDTENSIS Hyatt and Smith, sp. nov.

Pl. LVI, figs. 10-25.

Involute, discoidal, laterally compressed; whorl high and narrow, increasing rapidly in height, deeply embracing, and deeply indented by the inner volutions; venter narrow and rounded.

Surface smooth. Length of body chamber unknown.

Septa complex, deeply digitate, showing an external, two principal lateral lobes, and a short auxiliary series. The external lobe is divided into small branches that might be termed an adventitious series, but the septa do not resemble those of the undoubted Pinacoceratoidea. 
Placites humboldtensis Hyatt and Smith is a very near ally of $P$. Sakuntala Mojsisovics, ${ }^{a}$ of the Noric stage of India, but differs from that species in the greater complexity and deeper digitation of the lobes and saddles.

Dimensions of the type specimen.

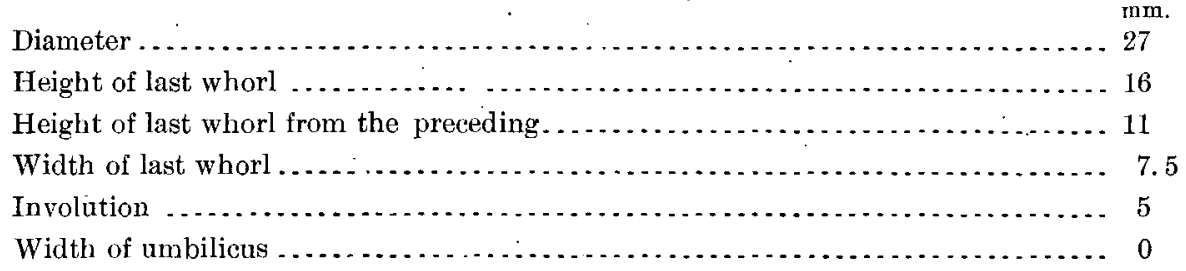

Horizon and locality.-Muttleberry Canyon, West Humboldt Mountains, on road 8 miles southeast of Lovelock, Nev., associated with Pseudomonotis subcircularis Gabb, Arcestes Andersoni, sp. nov., Rhabdoceras Russelli Hyatt, and Halomites sp. Collected by J. P. Smith, May, 1902.

\section{Family PRONORITIDA.}

Under this head the writers group all forms closely allied with Pronorites; these are characterized by compressed whorls, little sculpture of the shell, rather short body chambers, and lanceolate septa, with pronounced development of the auxiliary, and little development of the adventitious series of lobes. Karpinsky ${ }^{\circ}$ has given almost a monograph of this family, and has traced the ontogeny of several Paleozoic genera, so that a comparison of later forms is easy, and the relations between phylogeny and ontogeny are clear. This is one of the few families in which we can trace with certainty a series of forms leading up from those with simple goniatitic lobes to those with complex ammonitic septa; and in which in the ontogeny of each genus we can find its family history repeated in abridged from.

This family includes Pronorites Mojsisovics, Sicanites Gemmellaro, Propinacoceras Gernmellaro, Medlicottia Waagen, of the Paleozoic, and Cordillerites and Lanceotites Hyatt and Smith, of the Lower Triassic; Medlicottia has also been cited by C. Diener, ${ }^{c}$ from the Lower Triassic of India, but later researches have made it probable that this species came from the upper Permian. Karpinsky has shown that Pronorites in its development can be traced back to Prolecanites; that Sicanites, Propinacoceras, and Medlicottia all show in their ontogeny their origin in Pronorites. In this paper the writers describe the ontogeny of Cordillerites, which genus goes through stages corresponding in succession to Prolecanites, Pronorites, Sicanites, and Cordillerites. The ontogeny of Lanceolites is only imperfectly known, but it a Obertriadischen Cephalopoden-Faunen des Himalaya: Denkschr. K. Akad. Wiss., Wien, vol. 63, 1896, p. 665, Pl. XIX, figs. 3-5.

${ }^{b}$ Ammoneen der Artinsk-Stufe: Mém. Acad. imp. sci. St.-Pétersbourg, sér. 7, tome 37, No. 2, 1889.

cephalopoda of the lower Trias.: Fimalayan Fossils, vol. 2, pt. 2 (1897), p. 58, Mem. Geol. Survey India, Pal. Indica ser. 15. 
points to the Pronoritidx of the Paleozoic as the ancestral stock of the genus. Both of the American representatives of the Triassic Pronoritidæ are so primitive in their stage of evolution that they appear to be rather little modified survivors of Permian types than characteristic Lower Triassic ammonites.

C. Diener ${ }^{a}$ has described, from the Middle Triassic of the Alps, a genus Arthaberites, which apparently is closely allied with Cordillerites, on account of its tripartite external lobe and the lanceolate characters of its lobes and saddles. It differs from the rest of the Triassic members of the Pronoritida in the minor development of the adventitious series. This is the only geñus above the Lower Triassic that is thought to represent the stock of Pronorites.

Gènus CORDILLFRTTES Fyatt and Smith, gen. nov.

Type.-Cordillerites angulatus Hyatt and Smith, Lower Triassic.

This genus is compressed, involute, deeply embracing, robust, with flattened sides, flat angular venter, and narrow umbilicus. The only surface sculpture visible on the casts consists of faint radial folds and strix of growth. The septa are lanceolate, with rounded saddles, and lobes partly serrated. The external or siphonal lobe is tripartite, as in Pronorites. There is a short series of lanceolate simple or bifid adventitious lobes, a series of laterals that are partly bifid and partly trifid, and a long series of auxiliaries, of which those nearest the umbilicus are undivided. The general plan of the septa is very like that of Pseudosageceras, but the lobes are not nearly. so complex nor so numerous. There is a closer resemblance to Arthaberites Diener (Die Triadische Cephalopoden-Fauna der Schiechlinghöhe bei Hallstatt, ${ }^{b}$ p. 17, Pl. II, figs. 4, a-c), but the lobes of Arthaberites are uniformly trifid, and are of simpler plan tban those of Cordillerites.

An equally close resemblance exists with Prodromites Smith and Weller, of the Mississippian (Lower Carboniferous), but Cordillerites has a flattened venter and no keel, and the general plan of the septa, while superficially similar, in important details is quite dissimilar.

The ontogeny of the only known species of Cordillerites shows clearly the origin of the genus. The earliest observed stage resembles Prolecanites, having a somewhat compressed moderately involute form, with an undivided ventral lobe, and two or more lanceolate lateral lobes. After this follows a stage in which the ventral lobe becomes tripartite, corresponding to Paraprolecanites. The outline of the whorl then becomes subquadrangular, and the first lateral lobe becomes bifid, corresponding to Pronorites. Shortly after this, the first lateral lobe becomes tripartite, still corresponding to Pronorites, as some species of that genus have this character.

a Die Triadische Cephalopoden-Fauna der Schiechlinghöhe bei Hallstatt: Beitr. Pal. und Geol. Österreich-Ungarns und des Orients, vol. 13, p. 17, Pl. II, fig. 4, a-c.

$b$ Beitr. Pal. und Geol. Österreich-Ungarns und des Orients, vol. 13 (1900). 
Then the second lateral lobe becomes bitid, and the form is transitional from Pronorites to Sicanites. Next, the first lateral saddle becomes indented, the beginning of the adventitious series, which develops with great rapidity, though not reaching the number of the auxiliaries, which began earlier; that is, with the Pronorites stage.

The large tripartite lateral lobe of Cordillerites corresponds to the bifid or tripartite lateral of Pronorites; the adventitious lobes are made by subdivision of the first lateral saddle, and at maturity may number as many as three. The second lateral lobe at maturity is tripartite, and just before maturity is bitid. The third lateral lobe becomes bifid at maturity, and before maturity is undivided. The auxiliaries decrease in size and complexity toward the umbilicus, as they do in all genera of the Pronoritidæ.

This development shows the intimate kinship of Cordillerites with Medlicottia, from which it differs only in the form of the external lobe, the exaggerated development of the lanceolate adventitious lobes, and the tripartite laterals. Medlicottia in its ontogeny goes through stages corresponding successively to Prolecanites, Paraprolecanites, Pronorites, and Sicanites, just as does Cordillerites, but diverges in the peculiar development of the siphonal lobe and the external saddle.

Cordillerites is known only from the Lower Triassic Meekoceras beds of the Aspen Ridge, in southeastern Idaho, where it is represented by a single species.

CORDILLERITES ANGULATUS Hyatt and Smith, sp. nov.

Pl. II, figs. 1-8; Pl. LXVIUI, figs. 1-10; Pl. LXXI, figs. 1-6; Pl. LXXXV, figs. 14-20.

Form compressed, involute, discoidal, deeply embracing, the outer whorl being indented to one-third of its height by the preceding whorl. Umbilicus closed. Sides with rather abrupt umbilical shoulders, and gentle convex curve up to the abdominal shoulder angles. Venter flat and rather broad, with abdominal furrow in youth, which disappears in age. Surface ornamentation consisting of obscure radial folds and stria of growth. The length of the body chamber is unknown.

Septa lanceolate, with rounded saddles, and tongue-shaped lobes mostly either bifid or trifid. The ventral lobe is rather short and tripartite. Near the abdominal shoulders is a series of three adventitious lobes, increasing in size away from the venter; the first of these is undivided, the second and third bifid. The third adventitious lobe is very large, deeply bifid, and occurs. well down on the flanks; from its size and position it might well be called a lateral lobe, if it were not a secondary development out of the external saddle. Its nature as an adventitious lobe would not even be suspected if one could not trace its gradual growth from a mere notch in the external saddle. 
The true lateral lobes are two in number; the first is regularly and deeply tripartite, and longer and broader than the third adventitious lobe; the second is irregularly tripartite, with the prong nearest the venter longer than the other two, which are separated only by a shallow notch.

After this follows a long series of auxiliary lobes, growing smaller toward the umbilicus; the first three are distinctly bifid, the others, two in number, are apparently simple. The details of the internal septa could not be seen, but there is a long antisiphonal lobe, flanked by at least five internal laterals.

Stages of grovth.--In its ontogeny Cordillerites angulatus shows its history and derivation from Pronorites. In the youngest stage seen, at a diameter of 2.5 $\mathrm{mm}$, the whorl is moderately involute, rounded and somewhat compressed laterally. The septa consist of an undivided ventral lobe and two laterals. This stage corresponds to Prolecanites of the Devonian and Carboniferous.

At a quarter of a revolution farther on, diameter $3.5 \mathrm{~mm}$, , the ventral lobe begins to divide, and becomes indistinctly tripartite, and at the same time a third lobe is added outside of the umbilicus.

At the diameter of $4 \mathrm{~mm}$, two septa farther on, and about one-eighth of a revolution more, the first lateral lobe begins to divide. This is the beginning of the Pronorites stage, and the likeness is made greater by the accompanying development of the auxiliary series.

A quarter of a revolution farther on, at a diameter of $5.5 \mathrm{~mm}$., the second lateral lobe becomes bifid, and the first is distinctly tripartite. Pronorites never had this character, but a descendant of that genus, namely, Sicanites of the Permian, did have it. This stage may, therefore, be said to be transitional from Pronorites to Sicanites. 'It lacks, however, a character that was distinctive of Sicanites, the division or notching of the external saddle.

At the diameter of about $7 \mathrm{~mm}$. this notching of the exterual saddle begins, and the development of the adventitious series of lobes is inaugurated. Even then this stage can not be said to correspond absolutely with Sicanites, for the parallelism is obseured by the earlier inheritance in the larva of the tripartite principal lateral lobe, a character that Sicanites never acquired. This merely means that we have occurring simultaneously in this stage of growth some characters that were characteristic of Sicanites, along with others that were characteristic of descendants of that genus.

The Sicanites stage of growth is very short, just as was the life of that genus in the geologic succession; and very soon it is obscured by the appearance of characters that belonged to the mature stage. This follows naturally from the unequal acceleration of characters in inheritance.

When the adolescent stage is well advanced there is a single adventitious lobe, 
but this is soon followed by the appearance of a second smaller lobe nearer the venter, by further division of the external saddle. The first adventitious lobe by this time has become bifid, and the second soon becomes so.

At diameter of $10 \mathrm{~mm}$. the septa correspond to Sicanites, and at $12 \mathrm{~mm}$. they resemble those of the more primitive species of Propinacoceras, in the development of two distinct adventitious lobes.

At the diameter of $17 \mathrm{~mm}$. the first adventitious lobe is divided, the second still simple, and the third is just beginning to form. No change has taken place in the first lateral lobe, but the second has become tripartite instead of bifid, and the first auxiliary has become bifid. The other auxiliaries remain simple, as they do through life. At this stage there is a simultaneous occurrence of characters that belonged to Propinacoceras and Cordillerites.

The only advance to be made now is the development of the third adventitious lobe by a further division of the external saddle. This takes place at diameter of $30 \mathrm{~mm}$., and the species has attained its full generic characters, although not yet mature size.

It is easy to trace this development because the first lateral lobe is constant from the Pronorites stage until maturity, and the new elements are added, and changes introduced into the lobe on both sides of it. The adventitious lobes are of simple character, and progress but little beyond the development attained in Sicanites and Propinacoceras. The same thing is true of the auxiliary series. The advance over those two genera is made chiefly in the prominence and special development of the two lateral lobes.

Pronorites of the Carboniferous and the Permian progressed up to the stage shown on PI. LXXI, figs. 7 and 8 , and stopped. Sicanites of the lower Permian went through the Pronorites stages and began the formation of the adventitious series by indentation of the external saddle. "Propinacoceras of the Permian went through all the stages of Pronorites and Sicanites, and advanced beyond them in the formation of two distinct adventitious lobes in the same way. Cordillerites in the Lower Triassic went through all the.stages corresponding to Pronorites, Sioanites, and Propinacoceras, and went beyond them in the further development of the adventitious series, and in the greater complexity of the first and second lateral lobes.

The septa of these forms, showing their gradual advance, are figured on $\mathrm{Pl}$. LXXI. In the development of Cordillerites we see a species going through in its ontogeny all the stages gone througb by its Paleozoic ancestor's and in the same succession as did the genetic series of mature forms.

Horizon and locality.-Cordillerites angulatus is not uncommon in the Lower Triassic Meekoceras beds of Wood Canyon, 9 miles cast of Soda Springs, Aspen Ridge, southeastern Idaho. It was accompanied by Meekoceras gracilitatis, 
M. mushbachanum, M. aplanatum, Flemingites Russelli, Ophiceras Dieneri, Pseudosageceras intermmtanum, Parcinannites aspenensis, Ussuria Waageni, Lanceolites compactus, Aspidites, Danubites, Paralecanites Arnoldi, and̄ many other forms characteristic of this horizon. These forms were all collected by the writers in the same bed, so there can be no doubt about the association of species.

Genus IANCFOLITES Hyatt and Smith, gen. nov.

Type.-Lanceolites compactus Hyatt and Smith, Lower Triassic Meekoceras beds.

Form compact, laterally compressed, sides flattened, venter flattened with sharp shoulder angles. Involute, deeply embracing, closed umbilicus. In youth the flat venter bas a broad shallow furrow, but this disappears at maturity. The form is thus seen to be exactly similar to that of Cordillerites, but the septa would distinguish the two genera at once. In Lanceolites the septa are complex, digitate, and lanceolate. There is a short adventitious series of simple lobes, two laterals, of which the first is deeply digitate, and the second less so; and a series of tongueshaped auxiliaries. The saddles are divided as well as the lobes. The septa suggest an intimate relationship with Cordillerites, but that genus, while it has lanceolate septa, still has a more complex plan for its lobes. They may be parallel developments from the same stock, and in both cases this radicle seems to be the group of Pronorites.

Lanceolites is known only from the Meekoceras beds of the Lower Triassic in the Aspen Ridge of southeastern Idaho, and the same horizon in the Inyo Range, eastern California, where the species described below, and one urdescribed form were found.

LANCEOLITES COMPACTUS Hyatt and Smith, sp. nov,

Pl. IV, figs. 4-10; Pl. V, figs. 7-9; Pl. LXXVIII, figs. 9-11.

Form involute, discoidal, laterally compressed. Whorl deeply embracing, and deeply indented by the inner yolution. Umbilicus completely closed. Sides of whorl flattened, gently convex, abdominal shoulders angular, venter narrow, flat, or even slightly depressed below the shoulder angles. The height of the last whorl is two-thirds of the diameter of the shell, and the breadth is one-half of the height. The width of the venter is one-third of the greatest thickness of the shell, which occurs just above the umbilical shoulders.

The surface is nearly smooth, no ribs or spines being visible, but there are faint radial folds visible on the cast. The shell is not preserved on any specimen found. Length of body chamber unknown.

The septa are complex, with lanceolate digitation of the lobes. The external lobe is divided by a narrow siphonal saddle into two broad digitate branches. The 16918-No. $40-05-8$ 
first lateral lobe is broad and deep, with long linguiform digitations. The second lateral lobe is narrower and shallow, also digitate. There is an auxiliary series of several tongue-like small lobes above the umbilicus.

The form of this species is exactly like that of Cordillerites angulatus, but the septa show fundamental differences. The septa in the young stages show some resemblance to the Pronoritidx, which may have been the ancestral stock. The form and the arrangement of the septa show some resemblance to Clypites, which may have been derived from a common stock with it.

Horizon and locality.-Lower Triassic Meekoceras beds of Wood Canyon, Aspen Ridge, Idaho, 9 miles east of Soda Springs; also in the Inyo Range, Inyo County, Cal., $1 \frac{1}{2}$ miles east of the Union Spring, near the trail over the Union Wash to Saline Valley, 15 miles southeast of Independence.

\section{Suborder CERATITOIDEA.}

Form evolute or involute, laterally compressed; body chamber usually short, but long in some genera; surface usually ornamented with ribs, sometimes with knots, or spines. Septa goniatitic in some primitive forms, ceratitic in most, and ammonitic in a few higbly specialized genera.:

The Ceratitoidea are a remarkably homogeneous group, but it is so various that, while the relationship is plain, it becomes exceedingly difficult to give a diagnosis that will include all the families and genera: Frech ${ }^{a}$ first used this name for the group, but he included also the Ptychitidx and the Tropitidæ in it. With the exclusion of these foreign elements, however, the group, as he established it, appears to be phylogenetically homogeneous, altbough they may differ as widely from each other in appearance as they do from members of other suborders. The Hungaritidæ, Meekoceratidæ, and Gymnitidæ had been previously classed as Leiostraca, and the Celtitidæ as Trachyostraca, an arbitrary separation, based on the character of the sculpture in some forms. Frech showed that rough-shelled and smooth-shelled genera might occur in any of the families, and represented only development stages. The more primitive members of each family are smooth shelled; while most of the highly specialized member's become rough shelled.

The young stages of all the Ceratitoidea, so far as known, are evolute, discoidal, little embracing, resembling Paralecanites Diener, which may be considered as the radicle of the group, and the connecting link with the true Prolecanitidæ of the Carboniferous. Some few of the primitive types persist until the Triassic, as Lecanites, which lived on until:the Upper Triassic, and the retrograde genera revert to this type.

Under the Ceratitoidea are included the Ceratitidx, the Hungaritida, the

$a$ Die Dyas: Lethæa Palæozoica, Bd. 2 , Lieferung 3 (1901), p. 478. 
Meekoceratidæ, the Celtitidæ, and the Gymnitidæ, all of which families are characteristic of the Lower and Middle Triassic, although some genera of each occur in the Upper Triassic, the Hungaritidæ, Gymnitidse, and Celtitidæ are also represented sparingly in the Permian. It is certain that all these families had differentiated in the Paleozoic, for typical members of each are found in the lowest beds of the Triassic.

\section{Family GYMNITID $A$.}

Evolute, laterally compressed, discoidal forms, with shells either smooth, or ornamented with low folds or spiral ridges. The septa are ceratitic in the more primitive genera and ammonitic, deeply digitate, in the more specialized forms.

This family has usually been regarded as a subfamily under the Ptychitidæ, but the young stages of all genera in it are like the genus Xenaspis of the Permian, which may be regarded as the radicle of the family, and the connecting link with the parent of the Ceratitidx, probably Paralecanites. It is true that some species of Gymnites become rather involute, and then resemble some compressed species of Ptychites, but this is purely convergence, and does not indicate any relationship, for the young stages are very unlike.

In the American Triassic the family Gymnitidæ is represented by Xenaspis, Ophiceras, and Flemingites, all of which have ceratitic lobes, and are confined to the Lower Triassic Meekoceras beds, although in Asia Xenaspis ranges into the Middle 'Triassic. Recently Gymnites has been found in the Middle Triassic of Nevada.

Genus XFiNASPIS Waagen.

1895. Xenaspis; Waagen, Fossils from the Ceratite Formation: Salt Range Fossils, vol. 2, p. 161: Mem. Geol. Survey India, Pal. Indica, ser. 13.

1895. Xenaspis, Diener, Triadische Cephalopodenfaunen der ostsibirischen Küstenprovinz: Mém. Com. géol., St.-Pétersbourg, vol. 14, No. 3, p. 38.

1897. Xenaspis, Diener, Cephalopoda of the lower Trias: Himalayan Fossils, vol. 2, pt. 1, p. 83 Mem. Geol. Survey India, Pal. Indica, ser 15.

1902. Xenodiscus (pars), F. Frech, Lethæa Palæozoica, Bd. 2, Lieferung 4, p. 634a.

1903. Proceratites, E. Kittl, Die Cephalopoden von Muc in Dalmatien: Abhandl. K.-k. geol. Reichsanstalt, Wien, vol. 20, pt. 1, p. 28

Long body chamber, whorl evolute, little embracing, discoidal, wide shallow umbilicus, caused by the slow increase in height and thickness of the whorls. Lateral sculpture faint, the inner volutions being smooth. Septa ceratitic, lobes and saddles short, the two laterals longer than the external. The internal septa consist of a short, bifid antisiphonal lobe, flanked by a lateral on the umbilical suture, which might be considered as an auxiliary lobe. Waagen ${ }^{a}$ first assigned this to his genus Xenodiscus, and then separated it from that group on account of

$a$ Productus Limestone Fossils: Salt Range Fossils, vol. 1, p. 35: Mem. Geol. Survey India, Pal. Indica, ser. 13. 
its faint lateral sculpture, as contrasted with the strong folds of Xenodiscus plicatus Waagen, the type of the genus.

As thus defined Xenaspis is known in the upper Permian of the Salt Range and the Himalayas in India; the Lower Triassic Meekoceras beds of the Inyo Range in California; and the Middle Triassic of eastern Siberia, and India. Most of the smooth, evolute Triassic species formerly assigned by Waagen to Xenodiscus seem to have short body chambers, and are therefore classed under Gyronites.

But one American species is here described, Xenaspis Marconi Hyatt and Smith, sp. nov.

Frech, ${ }^{a}$ in his revision of the ammonites of the Permian, drops the genus Xenaspis as insufficiently differentiated from Xenodiscus. The writers have, however, retained the genus as Waagen defined it, because it seems to have given rise to the Gymnitidx, while Xenodiscus seems to have been the radicle of many of the highly ornamented ammonites of the -Triassic. This separation is artificial, but not more so than is the case in many groups of Triassic ammonites. The confusion existing at present would not be helped by assigning all the evolute discoidal ceratitic ammonities of the Permian and Lower Triassic to Xenodiscus and Ophiceras, for the differentiation of these two genera is just as artificial and difficult as that of Xenaspis from Xenodisous.

The Gymnitidx, Celtitidæ, Meekoceratidx, and Ceratitidæ were certainly differentiated from each other in the Lower Triassic, and it is probable that evolute discoidal ceratitic genera of all four families ought to be recognized in the Permian. Waagen's classification is an attempt to do this, and while it may be wrong, the writers prefer to follow it until it is proved to be wrong.

XENASPIS MARCOUI Hyatt and Smith, sp. nov.

Pl. VII, figs. 26-33.

Evolute, discoidal, laterally compressed. Whorl little embracing, and little indented by the inner volution. Sides flattened convex, venter narrow and rounded. Umbilicus wide and shallow. The height of the last whorl is threeeighths of the diameter of the shell, and the width is two-thirds of the height. It is indented to about one-fourth of its beight by the inner whorl. The width of the umbilicus is one-third of the total diameter.

The surface is ornamented with low radial folds, never forming ribs. The body chamber is at least a revolution long.

The septa are ceratitic. The ventral lobe is divided by a shallow siphonal saddle into two short goniatitic branches. The first and second laterals are ser- 
rated, and the auxiliary lobe is goniatitic. The antisiphonal lobe is long, narrow, and entire, flanked by a similar internal lateral on each side.

Xenaspis Marcoui differs from $X$. carbonaria Waagen in the flattening of the whorl, and in having the external lobe goniatitic instead of serrated. It differs from Gyronites in its long hody chamber.

Horizon and locality. - This species was found by J.P. Smith in the Meekoceras beds, Lower Triassic of the Inyo Range, Inyo County, Cal., on the Union Wash, $1 \frac{1}{2}$ miles east of the Union Spring, 15 miles southeast of Independence. It was associated with Meekoceras gracilitatis, M. aplanatum, M. mushbachanum, Pseudosageceras intermontanum and many other species characteristic of the Lower Triassic.

Genus OPHICH:RAS Griesbach.

1880. Ophiceras, Griesbach, Palæontological notes on the lower Trias of the Himalayas: Records Geol. Survey India, vol. 13, p. 109.

1895. Ophiceras, Diener, Triadische Cephalopodenfaunen der ostsibirischen Küstenprovinz: Mém. Com. géol., St.-Pétersbourg, vol. 14, No. 3, p. 43.

1897. Ophiceras, Diener, Cephalopods of the lower Trias: Himalayan Fossils, vol. 2, pt. 1, p. 100 : Mem. Geol. Survey India, Pal. Indica, ser. 15.

1902. Ophiceras, F. Frech, Lethæa Palæozoica, Bd. 2, Lieferung 4, p. 636.

Type.-Ophiceras tibeticum Griesbach, Records Geol. Survey India, vol. 13, p. 109, Pl. III, figs. 1-7.

Evolute, little embracing; whorls increasing slowly in height; umbilicus wide, and moderately deep. Surface ornamented with faint folds and cross striæ, sometimes with coarse lateral ribs in age. The inner casts are ornamented with a delicate spiral striation, formed by the inner pearly layer of the shell, and unknown on any other group of ammonites, although Flemingites, Sturia, and sometimes Ceratites and Tropites, have the external striation. On account of this peculiar sculpture Diener classes this genus with the Gymnitinæ, along with Flemingites.

The septa are ceratitic; the lobes and saddles usually long and narrow, there being the usual number, the divided external, the two laterals, and the small auxiliary on the umbilical shoulder. F. von Mojsisovics ${ }^{a}$ described under the name of Xenodiscus Karpinskyi a species that may belong to Ophiceras, although it may be a Gyronites. Waagen ${ }^{b}$ thought that of the species described by Griesbach as Ophiceras, only $O$. tibetioum could remain under that genus, and that the others should be classed under Gyronites. Mojsisovics, ${ }^{c}$ at first considered Ophiceras merely as a synonym of Xenodiscus. In a later work he still considered most species of that genus to belong to Xenodiscus, but $O$. himalayanum Griesbach and $X$. plicatus Waagen he placed in the group of Ceratites obsoleti, to which he afterwards gave the name of Danubites.

\footnotetext{
a Arktische Triasfaunen: Mém. Acad. imp. sci. St.- Pétérsbourg, sér. 7, tome 33, No. 6, (1886), p. 75.

$b$ Fossils from the Ceratite Formation: Salt Range Fossils, vol. 6, pt. 2, p. 209: Mem. Geol. Survey India, Pal. Indica ser. 13.

c Die Cephalopoden der Mediterranen Triasprovinz: Abhandl. K.-k. geol. Reichsanstalt, Wien, vol. x (1882), p. 232.
} 
It will be seen from this that this genus has been variously misinterpreted or else ignored; and Waagen's recognition of even one species was due to his mistake of supposing that there was an adventitious lobe. This lobe has bcen shown by Diener not to exist on the type, and Waagen's error was due to a poor drawing.

Ophiceras resembles Danubites, from which it is distinguished by its spiral sculpture on the inner layer of the shell; from Xenaspis it is distinguished in the same way, also by its shorter body chamber; from Xenodiscus by these same characters and by its fainter sculpture on the inner whorls. Gyronites is much more difficult to separate from Ophicercs because of the uncertainty of its characters; many species that were assigned by Waagen to Gyronites may belong to Ophiceras, but the diagnostic mark, the spiral striation, appears only on the cast, as that disappears when the shell is preserved, and also when the specimen is poorly preserved. Ophiceras is characteristic of the Lower Triassic, being known in that horizon in India, eastern Siberia, the Meekoceras beds in the Aspen Ridge of Idaho, and the same formation in the Inyo Range of California.

Ophiceras is described from America for the first time in this paper, in O. Dieneri, sp. nov., but several other species have been collected by J. P. Smith in the Lower Triassic of California and Idaho.

F. Frech" assigns the Ophiceras beds of India and Siberia to the upper Permian, but the writers have found gennine species of Ophiceras in the Meekoceras beds of the Lower Triassic in California and Idaho.

\section{OPHICERAS DIENERI Hyatt and Smith, sp. nov.}

PI. VIII, figs. 16-29.

Evolute, discoidal, laterally compressed, widely umbilicate. Whorls little embracing and little indented by the inner volution. The height of the whorl is less than one-third of the total diameter of the shell, and the width is three-fourths of the height. It embraces about one-third of the inner volution. The width of the umbilicus is nearly one-half of the total diameter of the shell. The umbilical shoulders are rounded, with gentle inward slope; the flanks are convex, with the greatest width at one-half of the height of the whorl. The abdominal shoulders are abrupt, subangular; the venter flat and rather narrow. There are no ribs on the shell, but only low radial folds. The surface is ornamented with fine spiral lines, which are seldom preserved. This is the distinguishing character of the genus.

The septa are ceratitic. The external lobe is divided by a short, narrow, siphonal saddle into two small unserrated lobes; first lateral lobe long and narrow, second lateral very small. Both lateral lobes are slightly serrated; on the umbilical suture there is a small auxiliary, unserrated. 
This species is most nearly related to Ophicerrs demissum Oppel as figured by C. Diener in Cephalopoda of the Lower 'Trias, p. 121, Pl. XIV, figs. 1-7. But in the India species the radial sculpture is stronger and the spiral lines weaker than on Ophiceras Dieneri. The faunal association of the two is the same, and the differences here noted are not greater than are often found between varieties of the same species.

Horizon and locality.-In the Lower Triassic Meekoceras beds of the Aspen Ridge, Wood Canyon, southeastern Idaho, 9 miles east of Soda Springs. Associated with it were Meekoceras gracilitatis, $M$. aplanatum, and $M$. mushbachanum, besides Flemingites, Aspidites, Hedenstromia, Nannites, Danubites, and many other forms - characteristic of the Lower Triassic.

OPHICERAS SPENCEI Hyatt and Smith, sp. nov.

Pl. LXII, figs. 1-10.

Evolute, discoidal, laterally compressed. Whorl of medium beight, but increasing slowly. Deeply embracing, and deeply indented by the inner volutions. Umbilical shoulders abruptly rounded, sides flattened; venter rounded, bordered by rounded but rather abrupt abdominal shoulders. The outer whorl envelops a little over one-half of the inner and is indented to one-fourth of its height. The height of the whorl is two-fifths of the total diameter of the shell, and the width is fiveeighths of the height. The umbilicus is wide and shallow, being slightly less than one-third of the total diameter of the shell.

The surface is ornamented with numerous weak forward-curving constrictions, visible chiefly on the cast, and with fine cross strie of growth, visible only on the outer shell.

Septa ceratitic, with entire saddles, a divided external lobe, two principal laterals and an auxiliary, all serrated.

The form greatly resembles that of Prionotobus Jacksoni, from which Ophiceras Spencei may easily be distinguished by the sculpture and the individualized auxiliary lobe. This species also resembles Ophiceras ptychodes Diener, of the Lower Triassic Otoceras beds, of India, but has slightly weaker sculpture than the Indian species, the folds being weaker and more strongly curved.

The two species agree in outer form, septa, and in having the folds on the cast and only the cross striæ of growth visible on the outer shell. The two species might well be considered as only varieties of the same form, if the association in the two cases were not different. The Otoceras beds in India, in which Ophiceras ptychodes occurs, are now regarded as Permian; but the associated species in the Idaho beds make such a reference extremely improbable, especially since several of the species are also common in the Meckoceras gracilitatis horizon, of the age of 
which there can be no question. The specific name is given in honor of $\mathrm{Mr}$. R. S. Spence, of Paris, Idaho, who discovered this fauna.

Horizon and locality.-Ophiceras Spencei is rare in the Lower Triassic, 1 mile west of Paris, Bear Lake County, Idaho, in brownish bituminous limestones, associated with Columbites parisianus, Meekoceras pilatum, M. (Prionolobus) Jacksoni, Pseudosageceras intermontanum, Celtites sp. nov., and many others less characteristic. The horizon lies above that of Meekoceras gracilitatis, which occurs near by in gray limestones like those of the Aspen Ridge near Soda Springs.

Genus FIEMINGITES Waagen.

1892. Flemingites, Waagen, Records Geol. Survey India, vol. 25, pt. 4, p. 184.

1892. F'lemingites, Waagen, Jahrb. K.k. geol. Reichsanstalt, Wien, vol. 42, pt. 2, p. 380.

1895. Flemingites, Waagen, Fossils from the Ceratite Formation: Salt Range Fossils, vol. 2, p. 185: Mem. Geol. Survey India, Pal. Indica, ser. 13.

1897. Flemingites, Diener, Cephalopoda of the lower Trias: Himalayan Fossils, vol. 2, pt. 1, p. 90: Mem. Geol. Survey India, Pal. Indica, ser. 15.

1902. Flemingites, F. Frech, Lethæa Palæozoica, Bd. 2, Lieferung 4, p. 638.

1902. Flemingites, F. Frech, Ueber Trias-Ammoniten aus Kaschmir: Centralblatt für Min. Geol. und Pal., vol. 3, no. 5, p. 134.

1904. Flemingites, J. P. Smith, The Comparative Stratigraphy of the Marine Trias of Western America: Proc. California Acad. Sci., 3d ser., vol. 1, p. 377.

Type._-"Ceratites" Alemingianus de Koninck, Quart. Jour. Geol. Soc., London, vol. 19, p. 10, Pl. VII, fig. 1, from the Lower Trias of the Salt Range.

Form evolute, little embracing, wide shallow umbilicus, whorls robust, usually a little higher than wide, increasing very slowly in size, sides rounded, venter somewhat flattened and usually considerably narrower than the greatest breadth of the whorl. Strong, lateral cross ribs or folds, which are never dichotomous and do not cross the venter, are often present. Strong, fine spiral ridges on all parts of the external shell, appearing also on the casts.

Septa distinctly ceratitic, with rounded entire saddles, and long serrated lobes, of which there are an external lobe divided by a broad siphonal saddle, two principal laterals and an auxiliary. In more specialized forms the siphonal saddle is broken up by secondary divisions that almost reach the importance of adventitious lobes.

Waagen compares this genus with Ceratites, but notes that the form is more evolute and the spiral lines stronger than on that genus, also that the lateral sculpture does not break up into knots or dichotomous ribs. He places Flemingites in the Leiostraca, in spite of the coarse ribs that oceur on most species of the genus, although it is hard to see what relationship it can have to Gymnites. No observations have been made on its ontogeny, and its true systematic position is unknown. 
Flemingites, according to our present information, is confined entirely to the Lower Triassic, being found in that horizon in the Himalayas and the Salt Range in . India, and in the Meekoceras beds of southeastern Idaho, where several species have been found.

\section{FLEMINGITES RUSSELLI Hyatt and Smith, sp. nov.}

Pl. I, figs. 1-3; Pl. LXX, figs. 1-3.

1904. Fiemingites Russelli (Hyatt and Smith ms.), J. P. Smith, The Comparative Stratigraphy of the Marine Trias of Western America: Proc. California Acad. Sci., 3d ser., vol. 1, p. 378, Pl. XLII, fig. 5 , and Pl. XLIIJ, figs. 5 and 6 .

Evolute, discoidal, laterally compressed, wide umbilicus; whorls not deeply embracing, outer whorl covering only one-third of the inner, and being indented by it to about one sixth of its height. This shows that while the form is evolute, the increase in height of whorls is great.

Umbilicus shallow, and umbilical shoulders rounded; sides gently convex. Whorls twice as high as broad; venter narrow and somewhat rounded.

Sides ornamented with strong folds in mature shell, nearly smooth in young shells. Surface of cast ornamented with fine, distinct spiral lines. Septa ceratitic, four serrated lobes and three rounded entire saddles on each side. The external lobe is broad, divided by a deep siphonal saddle. The first lateral is twice as long as the external, and has about four serrations; the second lateral is narrow, and the auxiliary series consists of four or five denticulations, forming a broad lobe. The saddles are all similar in shape and brodider than the lobes.

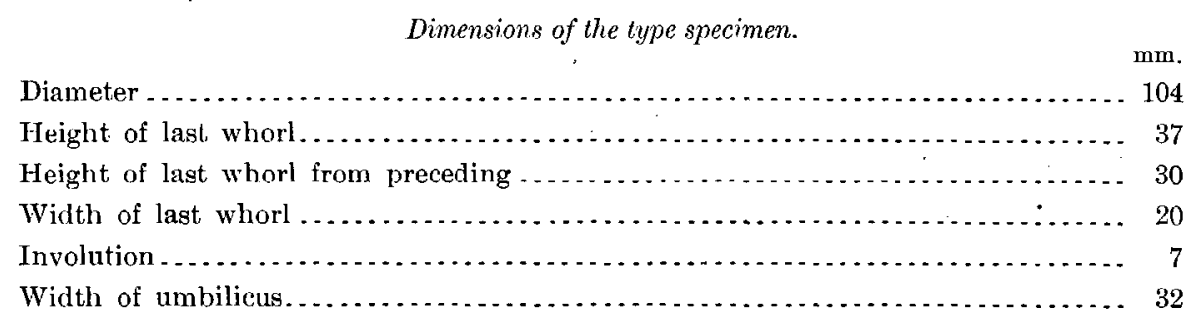

Horizon and locality.-In the Lower Triassic Meekoceras beds of Wood Canyon, Aspen Ridge, 9 miles east of Soda Springs, Idaho. Found associated with Pseudosageceras, Meekoceras gracilitatis White, M. (Gyronites) aplanatum White, M. (Koninckites) mushbachanum White.

\section{Family CELTITIDAE.}

Form evolute, discoidal, laterally compressed. Body chamber long. Surface ornamented with lateral ribs or folds. Septa goniatitic or ceratitic.

The Celtitidx have commonly been regarded as a subfamily under the 
'Tropitide, purely on account of their lateral ribs and long body chamber. But no member of the Tropitidæ has young stages in any way resembling Celtites, and the characters on which that reference was based occur in other groups. The Celtitide can not have descended from the Glyphioceratidx, in which group the ancestors of Tropites are to be sought, but from some member of the Prolecanitidx. The kinship of this group with the primitive members of the Ceratitidx, Hungaritidæ, and Meckoceratidæe is evident and acknowledged by all. Frech probably had this family in mind when he included the Tropitida in his suborder Ceratitoidea, and the writers are of the opinion that his reference was correct, although the true Tropitide can not have any kinship with it.

The Celtitidæ are known in the Permian of Asia, in the genus Xenodiscus; in other parts of the world they are not known below the Triassic. In America they are known in the Middle Triassic in the genera Xenodiscus and Celtites, and several undescribed species of Celtites have recently been found in the Lower Triassic of Idaho.

\section{Genus XIUNODISCUS Waagen.}

1879. Xenodiscus (pars), Waagen, Productus Limestone Fossils: Salt Range Fossils, vol. 1, p. 32. Mem. Geol. Survey India, Pal. Indica, ser. 13.

1895. Xenodiscus, Waagen, Fossils from the Ceratite Formation: Salt Range Fossils, vol. 2, p. 161. Mem. Geol. Survey India, Pal. Indica, ser. 13.

1902. Xenodiscus, F. Frech, Lethæa Palæozoica, Bd. 2, Lieierung 4, p. 634a.

1903. Proceratiles, E. Kittl, Die Cephalopoden von Muć in Dalmatien: Abhandl. K.-k. geol. Reichsanstalt, Wien, vol. 20 , p. 28.

(Not 1886. Xenodiscus, Mojsisovies, Arktische Triasfaunen, p. 74.)

(Not 1895. Xenodiscus, Diener, Cephalopoda of the Muschelkalk, Himalayan Fossils, vol. 2, pt. 2, p. 110.)

Type.-Xenodiscus plicatus Waagen, Salt Range Fossils, vol. 1, 1879, p. 34, Pl. II, figs. 1 ; $1 \mathrm{a}, 1 \mathrm{f}$.

Evolute, discoidal, little embracing, increasing slowly in height, widely umbilicated, laterally compressed. Body chamber long. Lateral sculpture strong, even on inner whorls, consisting of strong folds running from the umbilicus up the sides. Venter abruptly rounded. Septa ceratitic, lobes and saddles short.

When this genus was first named, Waagen placed it under the Leiostraca, in close relationship with Gymnites. Further study, however, convinced him that this would apply to one species classed under Xenodiscus, which he afterwards separated under the name of Xenaspis carlomaria Waagen. The type, Xenodisous plicatis, was then classed under the Celtitine, subfamily of the Tropitidæ. In the meantime E. von Mojsisovics, ${ }^{a}$ under the supposition that "Ceratites" carbo- 
narius was the type of Xenodiscus, classed X.plicatus under the group of Ceratites obsoleti, which he afterwards designated by the subgeneric title Danubites. All the Siberian species assigned by Mojsisovics to Xenodiscus fall partly under Meekoceras and partly under Dainubites. The Middle Triassic species classed by Diener under Xenodiseus belong to Xenaspis. Thus only the type X. plicatus Waagen remains under this genus. It becomes therefore extremely easy to determine the generic characters. It is not so easy to determine the systematic position: Waagen considered it to be intermediate between Paraceltites and Celtites, but this view has nothing to sustain it. The possession of a long body chamber alone is not sufficient to place this genus in the Tropitidæ, for the writers have demonstrated that members both of the Ptychitidæ and of the Ceratitidæ may have body chambers at least a revolution long.

Frech, in Lethon Geognostica, Bd. 2, Lieferung 3, page 478, classes Xenodiscus, Xenaspis, Ilungarites, and Otoceras together as subfamily Xenodiscinæe under the Ceratitoidea. Leaving out the two latter genera this is a proper classification, for the two former are certainly related to the general group of ceratitic ammonites, either as ancestors or as survivals of ancestral types; while Hungarites and Otoceras are more specialized, and have no more right to be classed in the ancestral group than Gyronites or Lecanites. It is highly probable that the Meekoceratidæ, the Hungaritidæ; the Ceratitidæ, and the Celtitide all sprang from a common stoek-the Xenodiscina-and that this group took its origin from some primitive form like Paralecanites. But this differentiation must have taken place before the upper Permian, for there we have Xenodiscus, Xenaspis, Paralecanites, Otoceras, and Hungarites all flourishing simultaneously.

Up to the present time. Xenociscus has been known only from the upper Permian of India; but recently $\mathrm{Mr}, \mathrm{H}$. W. Turner bas found it in the lower beds of the Middle Triassic, on the Union Wash, Inyo Range, Inyo County, Cal, associated with Fungarites, Metatirolites, Popanoceras, Acrochordiceras, in beds supposed to be the equivalents of the upper Ceratite limestone of the Salt Range.

XENODISCUS BITTNERI Hyatt and Smith, sp. nov.

Pl. XX, figs. 5-15; P1. XXI, figs. 1-13.

Evolute, discoidal, little embracing, and little indented by the inner volutions. Whorl low and increasing slowly in height; sides flattened, venter rather narrow and highly arched, with indistinct abdominal shoulders. The height of the whorl is one-third of the total diameter of the shell, the width is two-thirds of the beight, and the indentation by the inner volution is one-tenth of the height. The umbilicus is wide and shallow, being two-fifths of the entire diameter of the shell. 
The shell is ornamented with distinct radial plications that begin on the abrupt umbilical shoulders and run nearly straight up the sides, bending forward at the abdominal shoulders. These plications become faint on the venter at maturity, but are very distinct in the adolescent stages; they are accompanied by frequent constrictions, which become nearly obsolete at diameter of $20 \mathrm{~mm}$.

The specimens are usually too much broken to show the length of the body chamber, but on two specimens it was seen to be about one revolution in length.

The septa are ceratitic; the external lobe is divided by a short siphonal saddle into two short slightly serrated branches; the first lateral is longer and wider, distinctly serrated; the second lateral is similar, but much smaller; the auxiliary lobe is small and undivided, standing on the umbilical shoulder. The internal lobes on sist of a goniatitic antisiphonal, flanked by a single internal lateral on each side. The external and internal saddles are rounded, and much wider than the lobes.

In the young stages the lobes are goniatitic, the whorls are low with almost rectangular cross section, and the radial sculpture much stronger in proportion to the size of the shells. The septa make the transition from the goniatitic to the ceratitic stage at the diameter of about $7 \mathrm{~mm}$. The adolescent, unserrated stage probably corresponds to Paraceltites Gemmellaro.

Xenodiscus Bittneri has a close resemblance to Danubites himalayanus Griesbach, as figured by Diener, ${ }^{a}$ but has the ribs more numerous than on that species, and they cross the venter, which is unknown on any species of Danubites. It has a

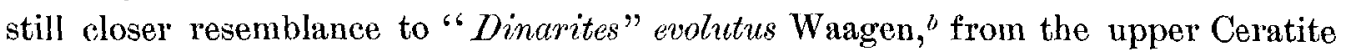
limestone of the Salt Range. Waagen's specimen seems to show a long body chamber, but the inner whorls are described as being smooth, which is not the case with Xenodisous Bittneri. Certainly neither species has anything to do with Dinarites.

In this species we have a survival of the Permian genus Xenodiscus in the bottom of the Middle Triassic, which in itself is not improbable, since its kindred form Xenaspis has also been found in the same horizon in Asia.

Horizon and locality. - In the lowest beds of the Middle Triassic, Inyo Range, east side of Owens Valley, California, on the Union Wash, about a mile east of the Union Spring, about 800 feet above the Meekoceras beds, which occur on the sides of the same canyon. This locality is about 15 miles southeast of Independence. This species was first discovered by Mr. H. W. Turner. The specimens figured in this paper were collected by J. P. Smith. The specific name is given in honor of the late Dr. Alexander Bittner.

$a$ Cephalopoda of the lower Trias; Himalayan Fossils, vol. 2, pt. 1, p. 41; P1. XIV, fig. 14, a, b, c: Mem. Geol. Survey India, Pal. Indica, ser. 15 .

$b$ Fossils from the Ceratite Formation: Salt Range Fossils, vol. 2, p. 32, Pl. X, fig. 3: Mem. Geol. Survey Indiä, Pal. Indica, ser. 13. 
SYSTEMATIC DESCRIPTIONS-SUBORDER CERATITOIDEA.

Genus CHI rPTFES Mojsisovios.

1882. Celtites, Mojsisovics, Cephalopoden der Mediterranen Triasprovinz: Abhandl. K.-k. geol. Reichsanstalt, Wien. vol $10, \dot{p} .145$.

1892. Celtites, Hauer, Beitr. Kennt. Cephalopoden der Trias von Bosnien: Denkschr. K. Akad. Wiss., Wien, vol. 59, pt. 1, p. 273.

1893. Celtites, Mojsisovics, Cephalopoden der Hallstätter Kalke: Abhandl. K.-k. geol. Reichsanstalt, Wien, vol. 6, pt. 2, p. 346.

1895. Celtites, Waagen, Fossils from the Ceratite Formation: Salt Range Fossils, vol. 2, p. 69: Mem. Geol. Survey India, Pal. Indica, ser. 13.

Type._-"Trachyceras" epolense Mojsisovies Dolomitriffe von Südtirol, 1878, p. 57; and Cephalopoden der Mediterranen Triasprovinz, 1882, p. 149, PI. XXIX, figs. 1 and 2; Pl. XXXVIII; fig. 13.

Whorls evolute, little embracing, low, increasing very slowly in height. Cross section quadratic, sides fiattened, abdominal shoulders abruptly rounded, venter flattened. Sides ornamented with simple straight ribs that become obsolete at the shoulders. Fine spiral lines appear on the venters of some species, and occasionally the sculpture crosses the venter in old age. Body chamber long. Septa goriatitic, or slightly serrated. Ventral lobe usually divided, but sometimes undivided. There are usually two laterals and an auxiliary. Antisiphonal lobe undivided.

Celtites ranges from the bottom to the top of the Triassic. In America it has been found in the Middle Triassic of the West Humboldt Range of Nevada, one species having been described from that place. Several undescribed species occur in the Lower Triassic of southeastern Idaho.

\section{CELTITES haLII Mojsisovics.}

Pl. XXV, figs. 4, 4a, 5, 5a, and 5b; Pl. LXXV, figs. 1-5.

1896. Danubites Halli, Mojsisovics, Obertriadischen Cephalopoden-Faunen des Himalaya: Denkschr. K. Akad. Wiss., Wien, vol. 63, p. 124.

? 1864. Goniatites levidorsatus, Gabb (not Haner), Geol. Survey California, Palæontology, vol. 1, p. 21, Pl. III, figs. 6 and 7.

1877. Clydonites levidorsatus, Meek (not Hauer), U. S. Geol. Explor. 40th Par., vol. 4, p. 109, Pl. X, figs. 7 and $7 \mathrm{a}$.

Form evolute, discoidal, laterally compressed, widely umbilicate. Whorls low, increasing very slowly in height; little embracing and little indented by the inner volutions. The umbilicus is very wide and shallow. The height of the whorl is about one-fourth of the total diameter of the shell, the width slightly greater than the height, and the indentation about one-sixth of the height. The width of the umbilicus is slightly more than one-half of the total diameter of the shell. The outer whorl conceals about one-third of the next inner one. This ratio does not hold good for the inner volutions, which are more evolute than the outer ones. 
Surface ornamented with strong lateral ribs which run obliquely forward from the umbilical shoulders and become obsolete high up on the flanks. Occasionally weak folds may be observed crossing the venter.

Septa consisting of a divided ventral lobe and two small laterals, all goniatitic except the first lateral lobe, which is serrated. Body chamber more than one revolution in length.

This species is more robust than Celtites læovidorsatus Haner, with which it was compared by Gabb and Meek, and the accompanying faunas are not the same.

Mojsisovics $^{a}$ said that the species described by Meeis was different specifically and generically from Gabb's "Goniatites lievidorsatus," and that the former belonged to Danubites; accordingly he renamed Meek's figures Danubitcs Halli. Recently, however, J. P. Smith has visited the localities where both Meek's and Gabb's specimens came from, and had collected numerous specimens at both places. They are probably identical, Gabb's figure being based on a shell somewhat flattened by pressure. It must also not be forgotten that Gabb's drawings are often hardly more than diagrammatic, hence the basing of species on his drawings alone can not be too strongly condemned.

Horizon and locality.-Celtites Halli Mojsisovics was first described from the Humboldt mining region of Nevada, exact locality not given, but probably Cottonwood Canyon in the West Humboldt Range. The United States Geological Exploration of the Forticth Parallel found it in the Middle Triassic Daonella beds, of Buena Vista Canyon, West Humboldt Range. J. P. Smith (1902) found it to be abundant in the Middle Triassic Daonella beds, West Humboldt Range, Cottonwood Canyon, and on the divide betwcen Troy Canyon and South Fork of American Canyon. In both places it was associated with Daonella dubia, Beyrichites rotelliformis, Cerutites humboldtensis, Anolcites Whitneyi, A. Meeki, Ceratites (Gymnotoceras) Blakei, Longobardites nevadanus, Eutomoceras Laubei, Joannites Gabbi, and other species characteristic of the Middle Triassic.

Gabb also cites this species from the east side of Owens Valley, 3 miles north of Owens Lake; but the Lower Triassic, which occurs at that locality, has been carefully collected by J. P. Smith (1900) and Celtites Halli was not found in that fauna, although Danubites Strongi Hyatt and Smith, which is very abundant in Inyo County, Cal., does resemble Celtites Halli externally, differing chiefly in its more complex septa and more robust whorls. Gabb also cites $C$. Halli from Eldorado Canyon, near Dayton, Nev., but was in doubt as to the identity.

The foregoing deseription and all the figures in this paper are based on specimens collected by J. P. Smith in the Middle Triassic divide between Troy Canyon and the South Fork of American Canyon, West Humboldt Range, Nevada.

a Obertriadischen Cephalopoden-Faunen des Himalaya: Denkschr. K. Akad. Wiss., Wien, vol. 63 (1896), p. 124. 


\section{Family HUNGARITID 2 E.}

Forms involute, laterally compressed, discoidal, venter narrow, and surmounted by a keel. Septa ceratitic. Surface either smooth, or ornamented with folds or ribs.

The Hungaritidæ have usually been regarded as a subfamily of the Ptychitidæ, but differ from that group in baving evolute, discoidal young, while the Ptychitide are always subglobose in the young stages. The Hungaritide have usually been regarded as Loiostraca, in spite of their close resemblance to Ceratites, but G. von Arthaber $^{a}$ has shown that the group is inseparable from the Ceratitoidea.

The Hungaritidæ are known first from the Permian of Armenia, where they are represented by Frungarites and Otoceras, both of which genera occur also in the Triassic, the former being especially characteristic of the Middle Triassic and the latter not being found in later beds than the very lowest horizon of the Triassic. In America the family is represented by only four genera, Inyoites Hyatt and Smith in the Lower Triassic and ITungarites, Longobardites, and Eutomoceras in the Middle Triassic.

$$
\text { Genus HUNGARITHés Mojsisovios. }
$$

1879. Hungarites, Mojsisovics, Vorläufige kurze Uebersicht der Ammoniten-Gattungen, etc.: Verhandl. K.-k. geol. Reichsanstalt, Wien, p. 140.

1882. Hungarites, Mojsisovics, Cephalopoden der Mediterranèn Triasprovinz: Abhandl. K.-k. geol. Reichsanstalt, Wien, vol. 10, p. 221.

1886. Hungarites, Mojsisovics, Arktische Triasfaunen: Mém. Acad. imp. sci. St.-Pétersbourg, sér. 7, tome 33, No. 6, p. 87 .

1896. Hungarites, Mojsisovies, Obertriadischen Cephalopoden-Fiannen des Himalaya: Denkschr. $\mathrm{K}$. Akad. Wiss., Wien, vol. 63, p. 669.

1897. Hungarites, Diener, Cephalopoda of the lower Trias: Himalayan Fossils, vol. 2, pt. 1, p. 150: Mem. Geol. Survey India, Pal. Indica, ser. 15.

1898. Hungarites, Tornquist, Neuere Beiträge zur. Geol, und Pal., Umgebung von Recoaro, \&c: Zeitșchr. Deutsch. geol. Gesell., vol. 50, p. 653. . . .

1899. Hungarites, Diener, Mittheilung Cephalopoden-Arten aus der Trias des südl, Bakony: p. 9.

1900. Hungarites, von Arthaber, Dạs jüngere Palæozoicum aus der Araxes-Enge bei Djulfa: Beitr Pal, und Geol. Oesterreich-Ungarns und des Orients, vol. 12, p. 220.

1901. Hungarites, F. Frech, Lethæa Palæozoica; Bd. 2 Lieferung 3, p. 474.

1902. Hungarites, F. Frech, Lethæ̇a Palæozoica, Bd. 2, Lieferung 4, p 635.

Type.-"Ceratites" Mojsisovicsi Boeckh, Jahrbuch K. ungarischen geolog. Anstalt, vol. 2, 1873, p. 150; also in Mojsisovics, Cephalopoden der Mediterranen Triasprovinz, 1882, p. 229, Pl. VII, fig. 6; Pl. VIII, fig. 3.

Laterally compressed, involute, discoidal. Narrow umbilicus, inner whorls concealed. Whorls high, increasing rapidly in height, and deeply indented by

« Das jüngere Palæozoicum aus der A raxes-Enge bei Djulfa; Beitr. Pal. und Geol. Oesterreich-Ungarns und des Orients, vol. 12 , pt. $4(1900)$, p. 220 . 
the inner whorls. Abdomen narrow, with sharp central keel, flanked by sharp abdominal shoulder angles or secondary keels. Sides nearly smooth, ornamented only with faint radial folds, which may begin with umbilical knots.

Septa distinctly ceratitic, lobes all serrated, saddles all rounded. The external lobe is divided by a shallow siphonal saddle, and besides this there are two principal laterals, and one or more auxiliaries.

The shells are always compressed, never globose even in youth, and hence can not be placed in the Ptychitidx, where they have commonly been classed. Frech ${ }^{a}$ classes under the suborder Ceratitoidea the Ceratitidx, Meekoceratidx, Ptychitidæ, and Tropitidæ. The older ceratites of the Permian, Xenodiscus, Xenaspis, Otoceras, and Hungarites he classes. together under the subfamily Xenodiscina. With the exclusion of the Ptychitide and the Tropitidx, this is the most satisfactory classification we have, for the near relationship of the Meekoceratidæ, Hungaritidx, and Ceratitidæ is manifest to all that have studied them, in spite of the fact that they have been separated into two great artificial divisions, Truchyostraca and Leiostraca. These divisions can not be recognized in the Lower Triassic and the Permian, and no doubt rough-shelled and smoothshelled forms originated out of the same stocks. Frech also rightly disregards the length of the body chamber in his classitication, for there can be no doubt that forms with long body chamber and forms with short body chamber have had a common origin, and that this character should not be accorded prime importance in taxonomy. Such classifications on the basis of rough-shelled or smooth-shelled, longidome or brevidome, can not be biogenetic, but have the value merely of convenient keys in identification of species.

The oldest species of Itungarites, H. Raddei Arthaber, ${ }^{b}$ from the upper Permian of Armenia, is so little specialized that a strict construction of the generic diagnosis would not admit it, since the external lobe is goniatitic; there is but a single lateral, and the auxiliary series consists merely of a row of serrations, not yet individualized into lobes. And this shows that artificial definitions of genera or other groups can not have a place in an evolutionary classification. The best discussion of ITungarites and the associated genera is given by Dr. G. von Arthaber in the work cited, in which the relationship to Otrceras and Ceratites is clearly stated and the gradual evolution of Hungarites from the Permian to the top of the Middle Triassic is shown in graphic form. Hungarites has also been cited as late as the middle of the Upper Triassic, but the later forms are no longer characteristic, and the genus is most common in the Muschelkalk, in which formation

$a$ Lethæa Gcognostica, Bd. 2, Liefcrung 3, p, 478.

b Das jüngere Palæozoicum aus der Araxes-Enge bei Djulfa, in F. Freeh und G. von' $A r t h a b e r$, Ueber dis Palæozoicum in Hocharmenien und Persien, Beitr. zur Pal. und Geol. Osterreich-Ungarns und des Orients, vol. 12 (1900), pt. 4, p. 234, Pl. XVIII, figs. 6-8. 
it is represented in America by one species, Itungarites Yatesi Hyatt and Smith, sp. nov., from the lowest beds of the Middle Triassic of California, and by two or three doubtful undescribed forms.

HUNGARITES YATESI Hyatt and Smith, sp. nov:

Pl: $\mathrm{XX}$, figs. $1-4$.

Compressed, involute, discoidal, deeply embracing, umbilicus closed, concealing the inner whorls, which indent the outer to two-fifths of the height. Sides fiattened, greatest breadth a little less than half the height of the whorl and at a point just above the rounded umbilical shoulder. Venter narrow, surmounted by a sharp central keel, flanked by sharp abdominal shoulder angles, above which the central keel rises distinctly. Surface ornamented with gently flexuous falcate ribs or folds and lines of growth, which bend forward gently to the shoulder angles. Septa ceratitic, lobes all serrated, saddles all rounded and entire; external lobe short, divided by a moderately deep siphonal saddle; first and second lateral lobes deeper; besides these there is one auxiliary on the sides and another on the umbilical shoulder. Internal septa not seen.

This species nearest to $H$. Pradoi Verneuil, as figured by E. von Mojsisovies ${ }^{a}$ from the Middle Triassic of Spain, but is not so highly sculptured, has the auxiliary series shorter, and has the abdomen narrower than on $H$. Pradoi. The name is given in honor of Dr. L. G. Yates, in recognition of his contributions to the geology of California.

Horizon and locality.-ITungarites Yatesi was found by H. W. Turner in the Middle Triassic, on the Union Wash, about one mile east of the Union Spring, Inyo Range, Inyo County, Cal., about 15 miles southeast of Independence, associated with Parapopanoceras, Xenodiscus, Acrochordiceras, Ceratites, and Tirolites. This bed is about 800 feet above the Meekoceras beds of the Lower Triassic, which outcrop on the sides of the same canyon.

Genus FUTOMOCFRAS Hyatt.

1877. Eutomoceras, A. Hyatt, U. S. Geol. Explor. 40th Par., vol. 4, p. 126.

(Not 1879. Eutomoceras, F. von Mojsisovics, Vorläufige kurze Uebersicht der Ammoniten-Gattungen der Mediterranen und Juvavischen Trias: Verhandl. K.-k. geol. Reichsanstalt, Wien, p. 136.) (Not 1893. Eutomoceras, E. von Mojsisovics, Cephalopoden der Hallstätter Kalke: Abhandl. K.-k. geol. Reichsanstalt, Wien, vol. 6, p. 283.)

Type.-Eutomoceras Laubei Meek, U. S. Geol. Explor. 40th Par., vol. 6, p. 126, Pl. X, figs. 8:and 8a.

a Cephalopoden der Mediterranen Triasprovinz: Abhandl. K.-k. geol. Reichsanstalt, Wien, vol. 10, 1882, p. 225, Pl. XXXII, figs. 7 and 8; PI. XXXIII, figs. 1 and 2.

16918-No. $40-05-9$ 
Involute, discoidal, laterally compressed, with flattened sides, narrow umbilicus, distinct umbilical shoulders, and narrow acute renter, surmounted by a sharp, solid keel without marginal furrows. Surface ornamented with radial dichotomous ribs that branch out from knots on the umbilical shoulders, curve upward on the sides, and bend sharply forward on the shoulders to the keel: Besides the knots on the umbilical shoulders, small knots occur on the ribs at irregular intervals, not arranged in spiral lines.

The septa are ceratitic, consisting of a divided ventral lobe, two principal laterals, and several smaller auxiliaries. The saddles are all rounded and entire, while the lobes are distinctly serrated. Internal septa unknown. Length of body chamber unknown. This genus greatly resembles ITungarites Mojsisovics, and differs from that group chiefly in the distinct sickle-shaped ribs, the irregular knots, and the extremely high keel. It has very probably developed out of Hungarites, for its young stages are almost identical with the mature forms of that genus.

The foregoing description is based partly on Meek's type specimen, which was imperfect, but chiefly on specimens collected in the West Humboldt Range by J. P. Smith.

E. von Mojsisovies ${ }^{a}$ accepted this genus and assigned to it several European species from the Upper Triassic of the Hallstatt region, Eutomoceras sundlingense Hauer, E. Theron Dittmar, E. Plinï Mojsisovics, E. acutum Mojsisovics, E. denudatum Mojsisovics, E. punctatum Mojsisovics, E. quinquepunctatum Mojsisovics, E. Sengeli Mojsisovics, and E. Laur: Mojsisovics. Not one of these species agrees with the type E. Laubei Meek, all baving ammonitic septa instead of ceratitic, so far as they are' known, and all clearly belonging to the Tropitide. Mojsisovics's generic description of Eutomoceras was based wholly on Ammonites sandlingensis ${ }^{b}$ Hauer, and does not apply at all to Eutomoceras Laubei Meek.

As restricted to the type of $E$. Laubei, Eutomoceras does not occur in Europe, and is known only in the Middle Triassic of Nevada, where it is represented by E. Laubei Meek, E. Dunni Smith, and one undescribed species.

The group "Eutomoceras" sandlingense, which is also well represented in America, but only in the Upper Triassic, has boen renamed by the writers Discotropites. These species have no relationship with Eutomoceras, but belong to the Tropitida, as their ontogeny clearly shows. The true Eutomoceras, on the other hand, belongs to the Ceratitoidea, and is so closely allied to Hungarites that a separation of the two is uncertain. In fact, it is not impossible that

a Vorläufige kurze Uebersicht der Ammoniten-Gattungen der Mediterranen und JuvavisehenTrias: Verhandl. K.-k. geol. Reichsanstalt, Wien, p. 136.

$b$ Cephalopoden der Hallstätter Kalke: Abhandl. K.-k. geol. Reichsanstalt, Wien, vol, 6, pt. 2, p. 283. 
Hungarites is scarcely more than a subgenus of Eutomoceras, since the charcicters of the two are so similar, and Eutomoceras must take precedence because it was named first.

\section{EUTOMOCERAS LAOBEI Meek.}

Pl. LX, figs. 7-11.

1877. Eutomoceras Laubei, F. B. Meek, U. S. Geol. Explor. 40th Par., vol. 4, p. 126, Pl. X, figs. 8, 8 a.

Form involute, discoidal, laterally compressed. Whorls high, and increasing rapidly in height, deeply embracing, and deeply indented by the inner whorls. Sides flattened, sloping from the abrupt umbilical shoulders to the distinct ventral angles. Abdoninal shoulders narrow and angular, surmounted by a high sharp ventral keel, not bordered by marginal furrows. The keel is solid and shows on the cast almost as high as on the shell. The umbilicus is narrow, but open, with the greatest wilth of the whorl at the umbilical shoulders.

Surface of shell and cast ornamented with ribs and knots; the ribs bundle in twos and threes on knots on the umbilical shoulders, and bifurcate a second time half way up the flanks, bending sharply forward at the point of bifurcation, and extending to the abdominal shoulders. There are knots on these ribs at irregular intervals, becoming more frequent in age.

The septa are ceratitic, consisting of a short divided ventral lobe, large first lateral, smaller second lateral, and three smaller auxiliary lobes, growing smaller and simpler toward the umbilicus. All the lobes are serrated, and all the saddles rounded and entire. The internal septa are unknown.

The height of the whorl at maturity is one-half of the total diameter of the shell, the width three-fifths of the height, and the impression one-fourth of the height. The width of the umbilicus is slightly more than one-fifth of the total diameter of the shell.

The sculpture resembles somewhat that seen on Iungarites, with which genus Eutomoceras is very closely allied.

Horizon and locality.-Eutomoceras Laubei was found by .J. P. Smith in the Middle Triassic Daonella beds, on the divide between 'Troy Canyon and the South Fork of American Canyon, West Humboldt Range, Nevada, at a point about 1,000 feet above the valley and 4 miles south of Foltz post-office. It was associated with Ceratites humboldtensis Hyatt and Smith, C. nevadanus Mojsisovics, Gymnotoceras Blakei Meek, Beyrichites rotelliformis Meek, Anolcites Meeki Mojsisovics, Acrochordiceras Iyatti Meek, Sageceras Gabbi Mojsisovics, Tongobardites nevadanus Hyatt and Smith, Daonella dubia Gabb, and many other species characteristic of the Middle Triassic. The figured specimens are in the collection of J. P. Smith. This 
species was first discovered by the Geological Exploration of the Fortieth Parallel at New Pass, in the Desatoya Mountains, Nevada, associated with Acrochordiceras

. Hyatti Meek, and the single imperfect specimen found was chosen as the type of the genus Eutomoceras.

\section{Genus LONGOBARDTTES Mojsisovics.}

1882. Longobardites, Mojsisovies, Cephalopoden der Mediterranen Triasprovinz: Abhandl. K.-k. geol. Reichsanstalt, Wien, vol. 10, p. 184.

Type.-Longobardites breguzzanus Mojsisovics, Cephalopoden der Mediterranen Triasprovinz, p. 185, Pl. LII, figs. 1 and 2.

Form involute, discoidal, laterally compressed; with high whorls and flattened sides. Umbilicus closed. Venter acute, with no real keel, and without perceptible shoulder angles. Surface ornamented only with striæ of growth, destitute of ribs, knots, or constrictions.

Septa ceratitic, consisting of an adventitions series, a lateral series, and an auxiliary series. The adventitious lobes are two in number, increasing in size down the sides; the second adventitious lobe being really the first lateral. The third lobe from the venter, or first lateral, is the largest, and from then down the sides the lobes decrease in size and increase in simplicity. The auxiliary lobes may be all goniatitic, or the first one or two may be serrated; they number from three to five or six.

Length of body chamber unknown.

Mojsisovies classed this group with the Pinacoceratide under the subfamily Pinacoceratine. But the affinities of the genus appear to be rather with Hungarites, from which it differs in, the possession of the adventitious lobes and in lacking the shoulder angles or keels.

'This genus is known only in the upper part of the Middle Triassic and the lower part of the Upper Triassic. Only two European species are known.

In America it is known only in the Middle Triassic Daonella beds of Nevada, where it is represented by a single species, Longobardites nevadanus Hyatt and Smith.

LONGOBARDITES NEVADANUS Hyatt and Smith, sp. nov.

Pl. XXV; figs. 13-18; Pl. LVIII, figs. 16-20; Pl. LXXV, figs. 6-9.

Form involute, discoidal, laterally compressed. Whorls narrow, high, and increasing rapidly in height, completely embracing, and deeply indented by the inner volutions. Sides flattened convex, curving gently to the narrow venter. Umbilical shoulders rounded and scarcely perceptible. Abdominal shoulders 
scarcely developed, without shoulder angle. Venter acute, forming a sort of keel. The height of the whorl is slightly more than half the total diameter of the shell, the width is less than one-half of the beight, and the indentation is about one-third of the height. The umbilicus is almost completely closed.

The surface of both shell and cast is smooth, being ornamented only with faint. undulations on the shell parallel with the cross stria of growth.

The septa are ceratitic, the saddles all rounded and entire, and the principal lobes are serrated. The external lobe is divided by a rather narrow and shallow siphonal saddle into two short, narrow branches; the first lobe on the side is broader and longer. These two may be considered as the adventitious series. The third lube on the side may be considered as the first principal lateral, being much larger and longer than the others. The fourth lobe is smaller than the second adventitious lobe, but serrated. The fifth is still smaller but also serrated. The sixth is slightly bifid, and the two remaining auxiliary lobes are goniatitic.

In the early adolescent stage all the lobes are goniatitic, but they are nearly as numerous as at maturity; also even in the early mature stages there is no differentiation into an adventitious and a lateral series.

Longobardites nevadanus resembles L. Zsigmondyi Boeckh, as figured by Mojsisovics, ${ }^{a}$ but is somewhat more robust than its Mediterranean congener, has fewer true auxiliaries and more complex lobes. The close resemblance is emphasized by the associations of the two forms, the geologic horizon being the same for each, and the accompanying faunas very closely related.

Horizon and locality.-The geological survey of California, under J. D. Whitncy, found this species in the Middle Triassic of New Pass, Desatoya Mountains, Nevada. A small specimen of this was figured by $\mathrm{Gabb}^{b}$ as the young of Ceratites Haidingeri (= Sayeceras Gabbi Mojsisovics), but it has no kinship with Sagecercs nor even any resemblance.

Longobardites nevadanus was found by J. P. Smith in the Middle Triassic Daonella beds on the divide between Troy Canyon and the South Fork of American Canyon, 4 miles south of Foltz post-office, West Humboldt Range, associated with Ceratites lumboldtensis, sp. nov., Anolcites Whitneyi, A. Meeki, Celtites Halli, Beyrichites rotelliformis, Gymnotoceras Blakei, Eutomoceras Laubei, Sageceras Gabbi, Daonella dubia, and other characteristic fossils.

J. P. Smith also found L. nevadanus near the "Lucky Dog" mine in Cottonwood Canyon, West Humboldt Range Nevada, in the same beds, and in the same association.

a Cephalopoden der Mcditerranen Triasprovinz: Abbandl. K.-k. geol. Reichsanstalt; Wien, vol. 10, p. 185, Pl. LII, fig. 4 , an and b.

b Geol. Survey California, Palacontology, vol. 1, Pl, IV, fig. 9. 
Type--Inyoites Oweni Hyatt and Smith, sp. nov.

Body chamber long, comprising an entire volution; form compressed, evolute, little. embracing; wide shallow umbilicus, flattened sides, acute venter with high hollow keel. Strong lateral ribs which run straight from the umbilical shoulder toward the venter.

Septa ceratitic, consisting of rounded entire saddles and serrated lobes. The external lobe is divided by a siphonal saddle; the two principal laterals are about of the same size as the external, and there is a single serrated auxiliary. The long body chamber, the lateral ribs, and the high keel resemble Eutomoceras, but that genus is involute and has knots on the lateral ribs.

This genus has a certain resemblance to Clinolobus Gemmellaro, from the Permian of Sicily, but differs in its lateral sculpture and ceratitic lobes.

Inyoites is classed with the Hungaritida on account of its evolute form, ceratitic septa, and acute venter; it differs from Hungarites in the possession of a Iong body chamber and high hollow keel and in lacking the abdominal shoulder angles. This genus is at present represented by a single species in the Lower Triassic Meekoceras beds of the Inyo Range, Inyo County, Cal.

INYOITES OWENI Hyatt and smith, sp. nov.

Pl. VI, figs. 1-16; Pl. LXIX, figs. 1-9; Pl. LXXVIII, figs. 1-8.

Laterally compressed, evolute, discoidal. Whorls thin, flattened, with acute venter and high hollow keel. Little embracing and not deeply indented by the inner volutions. Umbilicus wide and shallow, exposing the inner whorls. The height of the whorl is twice the width and about one-third of the entire diameter. The indentation or involution is one-fourth of the height. The width of the umbilicus is onethird of the total diameter.

The surface is ornamented with fine strong lateral ribs that run from the umbilicus straight up the sides and disappear below the base of the keel, and also with fine straight radial striæ that run higher up on the sides than the ribs.

The septa are ceratitic, saddles all rounded and entire, lobes all distinctly serrated. The external lobe is divided by a small siphonal saddle, the tirst and second laterals are of about the same size as the external; the auxiliary lobe is smaller, but still serrated. The body chamber is long, at least one revolution.

The young of this species are robust, with low evolute whorls, and coarse lateral ribs.

Horizon and locality.-Inyoites Oweni was found by Dr. C. D. Walcott in the Lower Triassic Meekoceras beds of the Inyo Range, Inyo County, Cal., on the old 
McAboy trail, $1 \frac{1}{2}$ miles above the Union Spring, east side of Owens Valley, and about 3 miles east of the Reward mill. This locality is about 15 miles southeast of Independence. This species was associated with Meeloceras gracilitatis, M. mushbachanum, M. aplanatum, Pseudosageceras intermontanum, and many other forms characteristic of the Lower Triassic.

\section{Family MEEKOCERATID $\notin$.}

Form laterally compressed, discoidal, evolute in the primitive genera, involute in more specialized groups. Surface smooth or ornamented with weak folds, more rarely with distinct ribs. Body chamber short. Septa goniatitic or ceratitic, becoming slightly ammonitic in a few species. The Meekoceratidæ have commonly been regarded as a subfamily under the Ptychitidæ, but they differ from the latter group in their more compressed form and evolute discoidal young, which resemble the genus Lecanites, the probable radicle of the family.

W. Waagen ${ }^{a}$ was the first to class this group as an independent family, on account of the large number of genera or subgenera in it, and the evident phylogenetic relationship between them. This family, as Waagen defines it, is the most homogeneous among Triassic ammonites, the most perfect gradation existing between the genera composing it, so much so that Diener has regarded all the Meekoceratide as belonging to the genus Mcekoceras, with the exception of Lecanites and Kymatites.

The Meekoceratidæ are composed of Lecanites, Tymatites, Parakymatites, Meekoceras (with the subgenera Gyronites, Koninckites, and Prionolobus), Kingites, Aspidites, and Beyrichites, all occurring in the Lower Triassic, except Beyrichites, and all confined to that division except Lecanites, which is also found in the Upper Triassic of the Alps, and Meekoceras, which is found rarely in the Middle Triassic. Beyrichites is characteristic of the Middle Triassic of the Alps, India, and America. The Meekoceratide are characteristic of the Lower Triassic of western America, Siberia, and India, and, with the exception of Beyrichites and Lecanites, are scarcely known outside of these regions.

Frech ${ }^{b}$ has recently proposed to abandon altogether the family Meekoceratidx and the genus Meekoceras, dividing the species assigned to this group between Prionolobus, Ophiceras, and Aspidites. But this is not in accordance with the rules of priority nor with the relationships of the species concerned.

\footnotetext{
a Fossils from the Ceratite Formation: Salt Range Fossils, vol. 2 (1895), p. 236: Mem. Geol. Survey India, Pal. Indica, ser. 13.

b Lethæa Palæozoica. Bd. 2, Lieferung 4, p. 630.
} 
1897. Paralecanites, C.·Diener, Sitzungsber. K. Akad. Wiss., Wien, vol. 106, p. 66.

1901. Paraceltites (pars), Frech, Lethæa Palæozoica, Bd. 2, Lieferung 3, p. 552.

1901. Paralecanites, C. Diener, Ueber die systematische Stellung der Ammoniten des südalpinen Bellerophonkalkes: Centralblatt für Min. Geol. und Pal., 1901, No. 14, p. 436.

Type.-Paralecanites sextensis Diener.

This genus, which up to the present has been represented by a singlo species, is characterized by its evolute, little embracing, low whorls, wide umbilicus, almost total absence of sculpture, and goniatitic scpta. The ventral lobe is divided, and there is but a single lateral, with no auxiliary lobe. The internal lobes are unknown on the type, but presumably would consist of an antisiphonal lobe flanked by an internal lateral, as this is the case with all primitive ammonites of this group.

These characters agree in all essentials with the genus Lecanites Mojsisovics, except in the absence of the auxiliary lobe, and Diener regards Paralecanites as the stock from which sprang Lecanites and the Meekoceratide.

Frech ${ }^{a}$ regards Paralecanites as synonymous with Paraceltites Gemellaro, disregarding the sculpture and the shape of the external lobe in the latter genus; which apparently is more closely related to Celtites.

Occurrence.-Paralecanites is known, up to this time, only from the Permian of the Alps, but a species agreeing in all essentials with the generic characters of the type has been found in the Lower Triassic Meekoceras beds of southeastern Idaho, associated with a typical Lower Triassic fauna. It is therefore to be regarded as a survival of an ancestral type.

\section{PARALECANITES ARNOLDI Hyatt and smith, sp. nov.}

Pl. LXIV, figs. 1-16; Pl. LXXVII, figs. 9-12.

Form evolute; whorls subquadratic in cross section, slightly higher than wide, low and increasing very slowly in beight; little embracing, and scarcely indented by the inner whorls. The sides and venter are flattened, the umbilical shoulders are rounded, and the ventral shoulders subangular, this character being more pronounced in the late adolescent stages than at maturity.

The umbilicus is vory wide and shallow, being nearly one-half of the entire diameter of the shell.

The septa are goniatitic, consisting of a divided ventral lobe, a large first lateral lobe, and a small second lateral just above the umbilical shoulder. There is no auxiliary lobe, but the internal lateral is visible, on account of the evolution of the shell, outside the umbilical suture. The antisiphonal lobe is long and divided. 
The septa are exactly like those of Lecanites except in the lack of an auxiliary lobe, there being only eight lobes in Paralecanites and ten in Lecanites.

The surface at maturity is nearly smooth, ornamented only with nearly obsolete low radial folds. In early youth, up to a diameter of about $5 \mathrm{~mm}$. the folds are Much stronger, and the cast is marked with distinct constrictions that run from the "imminticus across the venter. At this stage, also, the cross section of the whorl is rounded instead of subquadratic, and the ventral lobe was undivided, the division takking place at a diameter of a little more than $5 \mathrm{~mm}$.

"irfifis early adolescent stage of Paralecanites is like that of Xenodiscus, as described and figured in this paper, and the mature form is very like the larval stages of Meekoceras. This points to Paralecanites as the radicle of the Meekoceratidæ, which family must have developed in the Permian, for highly specialized representatives are known at the very bottom of the Triassic, and, indeed, in a formation considered by some authorities to be upper Permian. Paralecanites Arnoldi can not, therefore, be the radicle, but is merely a-little modified survival of the ancestral form.

It is highly probable that Paralecanites, or some similar form, was the family radicle, not only of the Meekoceratidæ; but also of all the true Ceratitoidea. It is is also probable that this form came directly from the earlier Paleozoic genus Prolecanites. This would make the Ceratitoidea descendants of the direct line of Prolecanitidæ, while Medlicottia and its allies are descended from a side branch of the same stock.

Horizon and locality.-Meekoceras beds, Lower Triassic, Wood Canyon, Aspen Ridge, 9 miles east of Soda Springs, Idaho, associated with Meekoceras gracilitatis, M. mushbachanum, Mr. aplanatum, Pseudosageceras intermontanum, Hedenstrocmia Kossmati, Cordillerites angulatus, Paranannites aspenensis, Fieningites Russelli, and many other forms characteristic of the Lower Triassic. The specific name is given in honor of Dr. Ralph Arnold, of the United States Geological Survey.

Genus IHACANITHS Mojsisovics.

1882. Lecanites, Mojsisovics, Cephalopoden der Mediterranen Triasprovinz: Abhandl. K.-k. geol. Reichsanstalt, Wien, vol. 10, p. 199.

1895. Lecanites, Waagen, Fossils from the Ceratite Formation: Salt Range Fossils, vol. 2, p. 275: Mem. Geol. Survey India, Pal. Indica, ser. 12.

1897. Lecanites, Diener, Cephalopoda of the lower Trias.: Himalayan Fossils, vol. 2, pt. 1, p. 146: Mem. Geol. Survey India, Pal. Indica, ser: 15.

1902. Lecanites, F. Frech, Lethra Palæozoica, Bd. 2, Lieferung 4, p. 634.

Type.- "Ceratiles" glaucus Muenster, Neues Jahrbuch für Mineralogie, 1834, p. 11, Pl. I, fig. 1; also in E. von Mojsisovics, Cepbalopoden der Mediterranen Triasprovinz, p. 200, Pl. XXX, figs. 1-6; Pl. LIII, fig. 14. 
Evolute, discoidal; little embracing whorls, laterally flattened, and higher than wide. Wide umbilicus, whorls increasing slowly in height. Abdomen narrow, eitber flattened or rounded.

Surface smooth, or sculptured with radial folds. Body chamber short, not more than one-half revolution.

Septagoniatitic, lobes and saddles all entire. The external lobe is aliways divided by a siphonal saddle. There are always two lateral lobes present and often a small auxiliary.

The form and septa are exactly like Gyronites Waagen, except that the lobes are never serrated and the whorls are a little more evolute than most species of Gyronites.

Lecanites is known in the Lower Triassic of India and California, in the Middle Triassic of Nevada, and in the Upper Triassic of the Alps.

LECANITES KNECHTI Hyatt and Smith, sp. nov.

Pl. IX, figs. 11-16.

Evolute, discoidal, laterally compressed, wide shallow umbilicus; sides flattened, umbilical shoulders broadly rounded; venter rather broad and rounded so that there are no distinct abdominal shoulders. Whorls increasing slowly in height and little embracing, concealing only about one-third of the inner volution and being indented to only one-sixth of the height by it. The width of the whorl is nearly three-fourths of the height.

Surface smooth, only casts being known, showing no ribs nor folds.

Septa goniatitic, external lobe divided into two narrow short branches, which fall on the abdominal shoulders; first lateral longer and much broader; second lateral nearly as broad as the first, but much shorter. Auxiliary lobe lacking entirely. Internal septa consisting of a long antisiphonal lobe and a short shallow lateral, just inside the umbilical suture. The form and septa are exactly like those of the young of Meekoceras aplanatum, but the lobes of Meekoceras become serrated at a very early adolescent stage, while those of Lecanites remain goniatitic.

Lecanites Knechti belongs to the group of $L$. gangeticus de Koninck, characterized by the possession of rounded instead of angular and flattened venters, and in shape it is most nearly related to the Indian Salt Range species, but differs in lacking: the auxiliary lobe and not having any varices on the shell.

$L$. Knechti also resembles $L$. glaucus Muenster, the type of the genus, but is somewhat more evolute than that species, and lacks the auxiliary, which is present on the type species.

There are in the Lower Triassic of America scveral species of Meekoceras (Gyronites) that agree closely with this species of Lecanites, except that they possess 
ceratitic lobes, and thus are more highly developed, either out of it or some similar member of the same genus.

IIorizon and locality.-Lecanites Knechti was found by J. P. Smith in the Lower Triassic Meekoceras beds of the Inyo Range, Inyo County, Cal., on the Union Wash, about $1 \frac{1}{2}$ miles east of the Union Spring, about 15 miles southeast of Independence. It was associated with Meekocerces gracilitatis White, $M$. aplanatum White, $M$. mushbachanum White, and many other characteristic species of the Lower Triassic. The specific name is given in honor of Mr. C. E. Knecht, who assisted in collecting this fauna.

Relatine dimensions of the type.

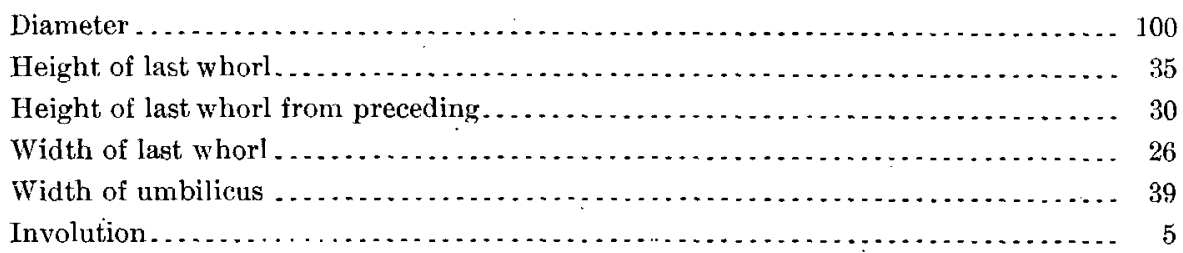

Actual diameter of the type specimen $30 \mathrm{~mm}$.

LECANITES VOGDESI Hyatt and Smith, sp. nov.

Pl. LX, figs. 12-22; Pl. TXXV, figs. 10-13.

Shell evolute, discoidal, laterally compressed, not deeply embracing and not deeply indented by the inner whorls. Whorl low and increasing slowly in height, concealing about two-fifths of the inner volution, and being indented to about onesixth of its height by that volution. Umbilicus wide and shallow, somewhat more than one-third of the entire diameter of the shell.

The surface of both shell and cast is ornamented with rather coarse umbilical ribs, which bend forward and reach about halfway up the flanks, but become obsolete before the abdominal shoulder is reached. At maturity these ribs become finer and sigmoidal in curvature, reaching to the ventral shoulders.

Length of body chamber at least three-quarters of a revolution. Septa goniatitic, lobes and saddles all rounded and entire. The ventral lobe is short, divided by a shallow siphonal saddle; the first lateral lobe is deep and wide; the second lateral small and shallow. The first and second lateral saddles are large, almost equal in size, and broadly rounded. The internal septa consist of a large undivided antisiphonal lobe, flanked by a smaller internal lateral on each side.

In the young stages the whorl is more robust, and the sculpture proportionally stronger, so that the young shell bears some resemblance to Dinarites, but it never has any of the umbilical knots which Dinarites is said always to have. Even in youth Lecanites Vogdesi is more compressed laterally than any species of Dinarites. The characters all point to the Meekoceratidæ rather than to be the Ceratitidæ. 
In the larval stage Lecanites Vogdesi corresponds to the genus Paralecanites Diener, as shown on Pl. LXXV, figs. 11-13, where a young specimen in this stage of growth shows the following dimensions:

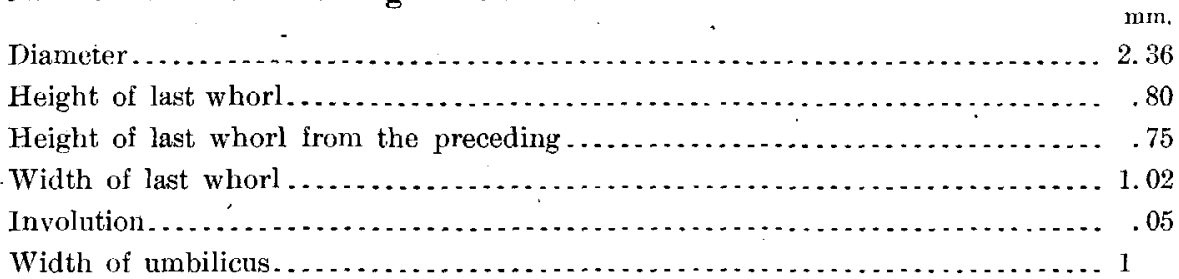

At this stage the whorl is very low, and square in cross section, and the septa are exactly like those of Paralecanites.

Horizon and locality.-Lecanites Vogdesi was found by J. P. Smith in the Middle Triassic Daonella beds, on the divide between 'Troy Canyon and the South Fork of American Canyon, West Humboldt Range, Nevada, associated with Ceratites humboldtensis, Beyrichites rotelliformis, Acrochordiceras Hyatti, Anolcites Whitneyi, Daonella dubia, and many other species characteristic of the Middle Triassic. The figured specimens are in the collection of J. P. Smith. The specific name is given in honor of Col. A. W. Vogdes, U. S. Army, in recognition of his services to Californian paleontology.

\section{Genus MEETOCFRAS Hyatt.}

1879. Meekoceras, Hyatt (in C. A. White), Fossils of the Jura-Trias of southeastern Idaho: U. S. Geol. and Geog. Surv, Terr., vol. 5, p. 111.

1880. Meekoceras, Hyatt (in C. A. White), Contributions to Invertebrate Palæontology, No. 5: U. S. Geol. and Geog. Surv. Terr., vol. 12, pt. 1, p. 112 .

1882. Meekoceras (pars), Mojsisovics, Cephalopoden der Mediterranen Triasprovinz: Abhandl. K.-k. geol. Reichsanstalt, Wien, vol. 10, p. 213.

1886. Meckoceras (pars), Mojsisovics, Arktische Triasfaunen: Mém. Acad. imp. sci. St.-Petersbourg, sér. 7, tome 33, No. 6, p. 79.

1895. Meekoceras, Waagen, Fossils from the Ceratite Formation: Salt Range Fossils, vol. 2, p. 236: Mem. Geol. Survey India, Pal. Indica, ser. 13.

1895. Meekoceras, Diener, Triadische Cephalopodenfaunen der ostsibirischen Küstenprovinz: Mém. Com. géol., St.-Pétersbourg, vol. 14; No. 3, p. 46.

1897. Meekoceras, Diener, Cephalopoda of the Iower Trias: Himalayan Fossils, vol. 2, pt. 1, p. 126 : Mem. Geol. Survey India, Pal. Indica, ser. 15.

1900. Wyomingites, Hyatt, Cephalopoda: Text-Book of Palæoontology by K. A. von Zittel, p. 556. (Translated by C. R. Lastman.)

1903. Meekoceras, E. Kittl, Die Cephalopoden von Muc in Dalmatien: Abhandl. K.-k. geol. Reichsanstalt, Wien, vol. 20, pt. 1, p. 69.

(Not 1895. Meekoceras, Diener, Himalayan Fossils, vol. 2, pt. 2, p. 40: Mem. Geol. Survey India, Pal. Indica, ser. 15.)

1904. Meckoceras, J. P. Smith, The Comparative Stratigraphy of the Marine Trias of Western America: Proc. California Acad. Sci., 3d ser., vol. 1, p. 367. 
Type-Meekoceras gracilitatis White, Fossils of the Jura-Trias of southeastern Idaho, 1879, p. 111; and Contributions to. Invertebrate Palæontology, No. 5, 1880, p. 112, Pl. XXXI, fig. 2, a-d.

Form compressed, discoidal, involute or evolute, sides flattened; venter narrow, either flattened or rounded, no keels nor furrows; umbilicus narrow or wide. Body chamber short. Surface smooth, or ornamented with lateral folds; no tubercles, spines, nor spiral ridges. Septa ceratitic, with rounded entire saddiles and serrated lobes. The external lobe is short and divided by a siphonal saddle; the two lateral lobes are longer, and there is an auxiliary series present in most forms, consisting either of a single lobe (serrated or goniatitic), or of a series of denticulations, some of which may be partly individualized into lobes. The internal septa consist of a divided antisiphonal lobe, flanked by a single lateral, although in some cases there may be internal auxiliaries.

Perhaps no other genus of ammonites has been so variously treated as Meekoceras, for the reason that it is very variable, and also because in the first description no type was expressly given, and three species, differing in essential respects, were simultaneously described, Meekoceras aplanatum White, M. mushbachanum White, and $M$. gracilitatis White, in the order given. But in the diagnosis of the genus, Hyatt first mentions M. gracilitatis. Thus, according to usage, either M. aplanatum or $M$. gracilitatis might be chosen as the type. Of these the latter alone agrees with the generic diagnosis, since it has the fourth lobe as an auxiliary series of denticulations, and does not have a distinct saddle between this lobe and the umbilical suture.

Besides the three species mentioned, Hyatt also included in his generic diagnosis previously described species that have since been assigned to Balatonites, Hungarites, Xenaspis, and Celtites, whicb clearly bave no relationship to the typical members of the genus. The writers regard all forms that agree with any one of the three species, M. aplanatum, M. mushbachanum, or M. gracilitatis, as belonging to Meekoceras in the broader sense.

Mojsisovics ${ }^{a}$ was the next to treat of this genus, in which he included a number of forms now assigned to Proptychites and Beyrichites, thus giving Meekoceras an unwarranted extension beyond the limits assigned by Hyatt. In a later paper Mojsisovics ${ }^{b}$ still further extended the genus in one direction to take in forms now assigned to Hedenstræmia, but limited it on the other to involute forms. All evolute, open-coiled forms were assigned along with $M$. aplanatum to Xenodiscus Waagen, although Mojsisovics confessed that this was purely because Xenodiscus seemed to be the ancestor of Gymnites. None of the forms assigned by Mojsisovics to Xenodiscus agree with Waagen's genus, and they are no longer classed with it.

a Cephalopoden der Mediterranen Triasprovinz. Abhandl. K.-k. geol. Reichsanstalt, Wien, vol. 10, 1882, p. 213. b Arktisehe Triasfaunen, Mém. Acad. imp. sci. St.-Pétersbourg, sér. 7, tome 33, No. 6, 1886, p. 79. 
Meekceeras was next treated by Waagen, ${ }^{a}$ who regarded $M$. gracilitatis as the type, and placed all other kindred but dissimilar forms under different genera, thus restricting the genus to narrower limits than was intended by Hyatt. The evolute forms without the auxiliaries, such as $M$. aplanatum, were placed under a new genus Gyronites, which would include most of the forms assigned by Mojsisovics to Xenodiscus. Species with a fourth lateral lobe followed by an auxiliary series were classed under the genus Koninckites Waagen; while forms in which the auxiliary series is not individualized, but consists of only a few denticulations, were placed under Kingites Waagen.

Diener ${ }^{b}$ regards Kingites and Koninckites merely as subgenera of Meekoceras, in which conclusion the writers agree with him. In a still later work Diener ${ }^{c}$ includes also Aspidites Waagen, and Beyrichites Waagen as subgenera under Meekoceras. But these two types are different from any species included by Hyatt under the original description, and it scems best to the writers to let them stand as independent genera.

As thus defined Meekoceras in the broader sense would include all species similar to the three typical forms, and the species nearest to $M$. gracilitatis White would be classed in Meekoceras in the limited sense.

Since $M$. aplanatum White bas all the characters of Gyronites Waagen, all species similar to it are placed in the subgenus Gyronites under Meekoceras.

Examination of the types in the United States National Museum has shown that M. mushbachanum has all the characters assigned by Waagen to Koninckites, and since this species was one of the types of Meekoceras all species similar to M. mushbuchanum are classed in the subgenus Koninckites, under Meekoceras in the broader sense. Aspidites and Beyrichites are regarded by the writers as independent genera. The systematic position of Prionolobus is somewhat doubtful, but it should probably be placed as a subgenus under Meekoceras.

Frech ${ }^{d}$ has recently proposed to drop the family Meekoceratidæ, dividing the species belonging to that genus between Ophiceras, Prionolobus, and Aspidites, although all the genera mentioned were described after Meekoceras, which was first described in 1879, and described and fully illustrated in 1880. Frech's reasons for - these changes were that Hyatt included in his original description of Meekoceras not only the three American species that differ in certain important characters, but also foreign species later assigned to Balatonites, Xenaspis, Hunganites, and Celtites.

Of course it was a mistake to include these elements in Meekoceras, but the citation of them as species under that genus does not make any confusion as to the

a Fossils from the Ceratite Formation: Salt Runge Fossils, vol, 2, 1895, p. 236: Mem, Geol. Survey India, Pal. Indica, ser. 13.

$b$ Triadische Cephalopodenfaunen der ostsibirischen Küstenprovinz: Mém. Com. géol., St.-Pétersbourg, 'vol. 14, No. 3,1895, p. 46 .

c Himalayan Fossils, vol. 2, pt. 1, 1897, p. 126: Mem. Geol, Surviey India, Pal. Indica, ser. 15.

$d$ Lethæa Palæozoica, Bd. 2, Lieferung 4 (1902), p. 630. 
limits of the group. Three American species were fully described and figured, and one of the three was certainly the typo. ${ }^{a}$ The fact that later writers have extended the genus Meekoceras to take in heterogeneous elements does not invalidate it. If any such rule in nomenclature should be accepted almost every genus of ammonites would be thrown out and new names substituted.

As restricted in this paper, Meekoceras is entirely confined to the Lower Triassic, in which horizon it is very abundant in California, Idaho, India, and Siberia.

Genus MFEIKOCHRAS s. str. Hyatt.

This genus is represented in America by Meekoceras gracilitatis, and by a large number of undescribed forms.

\section{MEEKOCERAS GRAGILITATIS White.}

Pl. XII, figs. 1-13; Pl. XIII, figs. 1-18; Pl. LXX; figs. 4-7; Pl. XIV, figs. 1-8.

1879. Neekoceras gracilitatis, White, U. S. Geol. and Geog. Surv. Terr., vol. 5, p. 114.

1880. Meekoceras gracilitatis, White, U. S. Geol. and Geog. Surv. Terr., vol. 12, pt. 1, p. 115, Pl. XXXI, fig. 2 a-d.

1902. Prionolobus gracilitatis, F. Frech, Lethæa Palæozoica, Bd. 2, Lieferung 4, p. 631, fig. a.

1904. Meekoceras gracilitatis, J. P. Smith, The Comparative Stratigraphy of the Marine Trias of Western America: Proc. California Acad. Sci., 3d ser., vol. 1, p. 370, Pl. XLII, figs. 1-4; Pl. XLIII, figs. 3 and 4 .

Shell compressed, involute, discoidal, deeply embracing, outer wholl concealing three-fourths of the inner, and being indented to one-third of its beight by the inner whorl.

Umbilicus narrow but open and rather shallow, the width being about one-sixth of the diameter of the sbell. The whorl increases rather rapidly in height, the altitude being slightly more than twice the breadth of the whorl, and one-half of the total diameter. The sides are gently convex, from the abruptly rounded umbilical shoulder; the greatest thickness of the whorl lies at a point even with the top of the inner whorl, thus giving a lenticular appearance to the shell. Venter flattened, biangular, with broad flat space and sharp adominal shoulder angles.

Surface ornamented with low folds and radial striæ of growth, which in age cross the venter in faint corrugations. No true ribs nor spines are ever present.

Septa ceratitic, saddles all rounded and entire, lobes all serrated. Ventral short, divided by a broad, shallow siphonal saddle; first lateral broad and deeper; second lateral narrow as the ventral; auxiliary series consisting of a short, straight row of denticulations following the third lateral saddle, forming merely an unindividualized lobe, which, however, is sharply distinguished from the saddle. The inner septa consist of a rather short divided antisiphonal lobe, with a single lateral.

a Professor Hyatt told Mr. Smith in June, 1900, that he had regarded Meekoceras gracilitatis as the type of the genus. 
The young shells are much more involute than mature forms, the umbilicus growing wider with age, and the whorls less deeply embracing. The relative width of the umbilicus, however, seems to be variable, also the abruptness or roundness of the umbilical shoulders... Diener ${ }^{a}$ thinks that White has confused two species in his figures of $M$. gracilitatis, and that Pl. XXXI, fig. $2 \mathrm{~b}$, in White's paper represents a different species from 2 a. But the difference lies rather in the drawing than in the oliginal specimens. The septa on White's original are as in PI. XXXI, fig. 2 d, of. White's paper, except that the denticulations are not sufficiently strongly marked in the drawing, and the innermost saddle is more sharply defined from the auxiliary denticulations than in the figure. In some unfigured specimens, however, there does not seem to be any separation at all of the saddle and the auxiliary series. These specimens in all other respects seem to belong to $M$. gracilitatis, and were probably the cause of the ambiguities in Hyatt's and White's descriptions. These forms would fall under Waagen's genus Kingites, but they are probably nothing more than individual variations of $M$. gracilitatis, but for the present they are not included in the specific diagnosis, since it is essential to establish the exact meaning of this species.

$M$. gracilitatis White is nearly related to $M$. boreale Diener of the Lower Triassic of India and Siberia, but differs in not having the auxiliary series individualized, also in the slightly wider umbilicus. There are, however, in the American Lower Triassic, species with the umbilicus as narrow or even narrower than on $M$. boreale, but on all of them the auxiliary serics is unindividualized.

Morizon and locality.-Meekoceras gracilitatis. White was found by. Dr. A. C.

Peale in the Lower Triassic of southeastern Idaho, at two places, 5 miles south of John Gray's Lake, and about 15 miles a little west of south from this lake. Alpheus Hyatt also found this species in Wood Canyon, about 9 miles east of Soda Springs, Idaho, associated with $M$. aplanatum White, M. mushbachanum White, Pseudosagecoras intermontanum Hyatt and Smith, Flemingites Russelli Hyatt and Smith, Ussuria Waageni, and other characteristic species. J. P. Smith found M. gracilitatis in the Meekoceras beds of the Union Wash, near the Union Spring, east side of Owens Valley, Inyo Range, Inyo County, Cal., about 15 miles southeast of -Independence, associated with all the above-mentioned forms except Flemingites.

MEEKOCERAS PILATUM Hyatt and smith, sp. nov.

Pl. LXIII, figs. 3-9.

Form involute, laterally compressed; whorls high, with flattened sides, broadly rounded venter, without distinct abdominal shoulders. Umbilical shoulders abrupt 
and somewhat angular. Whorls deeply embracing, and deeply indented by the inner volutions. The height of the whorl is slightly less than one-half of the total diameter of the shell, and the width is one-half of the height. The whorl is indented to one-fourth its height by the preceding volution. The width of the umbilicus is onefourth of the total diameter of the shell.

The surface of both shell and cast is ornamented with coarse radial ribs, which run from the umbilicus straight up the flanks and become obsolete on the shoulders. In addition to these there are the usual curved strie of growth, showing only on the surface of the shell.

The septa are of the usual Meekoceras type, with the saddles all rounded and entire and the lobes all serrated. The external lobe is short and narrow, divided by a small siphonal saddle; the first lateral lobe is broad and deep; the second lateral narrow and long; the auxiliary lobe is not individualized but resembles that of Meekoceras gracilitatis.

Horizon and locality. - In the Lower Triassic Columbites beds, 1 mile west of Paris, Idaho, locality No. 1981, United States Geological Survey, associated with Columbites parisianus, Pseudosageceras intermontanum, Prionolobus Jacksoni, Ophiceras Spencei, etc., collected by R. S. Spence.

\section{Subgenus GYRONITES Waagen.}

1892. Gyronites, Waagen, Records Geol. Survey India, vo'. 25, p. 183.

1892. Gyronites, Waagen, Jahrb. K.-k. geol. Reichsanstalt, Wien, vol. 42, p. 379 .

1895. Gyronites, Waagen, Fossils from the Cerat te Formation: Salt Range Fossils, vol. 2, p. 288: Mem. Geol. Survey India, Pal. Indica, ser. 13.

1900. Wyomingites, Hyatt, Cephalopoda: Text-book of Paleontology by K. von Zittel, p. 556. (Translated by C. R. Eastman.)

1902. Ophiceras (pars), F. Frech. Lethæa Palæozoica, Bd. 2, Jieferung 4, p. 631.

1904. Gyronites, J. P. Smith, The Comparative Stratigraphy of the Marine Trias of Western America: Proc. California Acad. Sci., 3d ser., vol. 1, p. 372.

Type.-Gyronites frequens Waagen, Fossils from the Ceratite Formation, 1895, p. 292, Pl. XXVII, figs. $1-4$.

Evolute, discoidal, laterally compressed, little embracing; wide, shallow umbilicus; whorls increasing slowly in height, and covering but a small portion of the inner volutions. Venter narrow, either biangular or rounded. Surface smooth or ornamented only with radial strix and low folds. Body chamber supposed to be generally short, but little is known about this character.

Septa partly ceratitic, all the saddles and some of the lobes being entire. The external lobe is divided into two unserrated branches by the siphonal saddle. The first lateral lobe is always serrated, the second usually not so; and there is sometimes a short auxiliary series of denticulations, or an unserrated scarcely individ16918-No. $40-05-10$ 
ualized auxiliary lobe. The internal septa consist of a rather short divided antisiphonal lobe, with a single lateral.

Diener ${ }^{a}$ says that this genus would coincide chiefly with Meekoceras, and that the other species assigned to it by Waagen would fall partly in with Ophiceras, and partly with Danubites. Mojsisovics and Waagen formerly clussed the species of Gyronites under Xenodiscus. Certainly the amount of involution should not be regarded as sufficient reason for generic separation, and only the development stage can excuse such a separation. Now, since Meekoceras aplanatum. White, one of the original types of Meekocercs in the broad sense, has all the characters of Gyronites, the writers prefer to retain this name as a subgeneric title for species of the group of M. aplanatum. Gyronites is found only in the Lower Triassic of India, Siberia, Idaho, and California, where it is represented by Meekoceras (Gyronites) aplanatum, and several new species, as yet undescribed.

\section{MEEKOCERAS (GYRONITES) APLANATUM White}

Pl. XI, figs. 1-14; Pl. LXIV, figs. 17-22; Pl. LXXVIT, figs. 1 and 2.

1879. Meekoceras aplanatum, White, U. S. Geol. and Geog. Surv. Terr., vol. 5, p. 112.

1880. Neekoceras aplanatum, White, U. S. Geol. and Geog. Surv. Terr., vol. 12, pt. 1, p. 112, Pl. XXXI, fig. 1 a, b, and d (not fig. $c$, which is Danubites whiteanus Waagen).

1886. Xenodiscus aplanalus, Mojsisovics, Arktische Triasfaunen: Mém. Acad. imp. sci. St.-Pétersbourg, sér. 7 , tome 33 , No. 6, p. 75 .

1895. Xenaspis? aplanata, Waagen, Fossils from the Ceratite Formation: Salt Range Fossils, vol. 2, p. 290: Mem. Geol. Survey India, Pal. Indica, ser. 13.

1900. Wyomingites aplanatus, Hyatt, Cephalopoda: Text-book of Palæontology by K. A. von Zittel, p. 556. (Translated by C. R. Eastman).

1902. Ophiceras aplanatum, F. Frech, Lethæa Palæozoica, Bd. 2, Lieferung 4, p. 631, fig: e.

1904. Meekoceras aplanatum, J. P. Smith, The Comparative Stratigraphy of the Marine Trias of Western America: Proc. California Acad. Sci., 3d ser., vol. 1, p. 373, pl. XLI, figs. 4-6.

Evolute, discoidal, laterally compressed; wide, shallow umbilicus; whorls increasing slowly in height, little embracing, outer whorl concealing but little of the inner, and being indented to less than onc-fourth of its height by it. Breadth of whorl a little over one-half its height, and one fifth of the diameter of the shell; height of whorl a little more than one-third of the total diameter. Width of umbilicus equal to height of the whorl. Umbilical shoulders abruptly rounded, but not angular. Sides gently rounded, greatest breadth of whorl at a point halfway between the base and the venter. Abdomen flattened, narrow, with subangular abdominal shoulders.

Surface ornamented with cross striæ and folds, which may become quite strong on the body chamber.

a Cephalopoda of the Lower Triassic: Himalayan Fossils, vol. 2, pt. 1, 1897, p. 30: Mem. Geol. Survey India, Pal., Indica, ser. 15. 
Septa ceratitic, saddles all rounded and entire, lobes partly serrated, partly entire. The external lobe is divided by a shallow siphonal saddle into two narrow branches, which are slightly denticulate, though usually entire. 'These divisions of the lobe fall upon the abdominal shoulder angles. The first lateral lobe is distinctly serrated, longer than the external, and much wider; the second lateral is usually entire, although occasionally it may be slightly denticulated. There is no auxiliary series. The internal septa consist of a short bifid antisiphonal lobe and a short, shallow entire lateral, just inside the umbilical suture. These septa are very like those of Xenaspis Waagen, except in the difference in the sizes of the lobes. This resemblance becomes more important when it is known that $M$. aplanatum has a body chamber at least three-quarters of a revolution in length. The writers regard Xenaspis and Gyronites as being closely related, and it is by no means impossible that $M$. aplanatum may eventually be shown to belong to the former genus.

M. aplanatum White resembles in form Gyronites frequens Waagen," but differs from that in lacking the auxiliary lobe. It also agrees in septa with Gyronites nangaensis $W$ aagen, ${ }^{b}$ but is slightly more involute than that species and has the lobes not so long.

The relative dimensions of $M$. aplanatum are as follows:

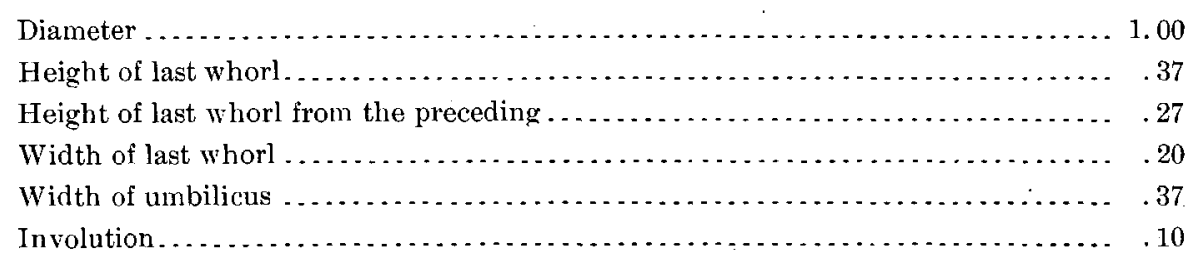

In small specimens the whorl is more robust, broader in proportion to its beight, and more deeply embracing, although the form is always evolute, even in the early stages of growth. The young whorls are rounded, the angular shoulders being a character of adolescence. The adolescent shell agrees in all respects with Lecanites; and this species gives a transition from that genus to Mekioceras. On this account the writers prefer to recognize Gyronites as a subgenus or transitional group.

Hyatt (in Cephalopoda, 1900, p. 556) took M. aplanatum as the type of a new but undescribed genus Wyomingites, but this statement was intended to refer to the form described by Waagen as Gyronites whiteanus, and not to the typical M. aptanatum. It was unknown to Hyatt that Waagen had already renamed this form.

Horizon and locality.-Meekoceras aplanatum White was found by the United States Geological Survey in the Lower Triassic Meekoceras beds in southeastern

a Fossils from the Ceratite Formation: Salt Range Fossils, vol. 2, p. 292, Pl, XXXII, figs. 1-4: Mem. Geol. Survey India, Pal. Indica, ser. 13.

b Op. cit., p. 297, Pl. XXXII, fig. 5 a-c. 
Idaho, about 5 miles south of John Gray's Lake, and also about 15 miles a little west of south from the lake. Alpheus Hyatt also found it in Wood Canyon, 9 miles east of Soda Springs, Aspen Ridge, Idaho. J. P. Smith found it in the Lower Triassic Meekoceras beds of the Inyo Range, east side of Owens Valley, on the Union Wash, near the Union Spring, about 15 miles southeast of Independence. .

\section{Subgenus KONINCKITES Waagen.}

1895. Koninckites, Waagen, Fossils from the Ceratite Formation: Salt Range Fossils, vol. 2, p. 258: Mem. Geol. Survey India, Pal. Indica, ser. 13.

1895. Koninckites, Diener, Triadische Cephalopodenfaunen der ostsibirischen Küstenprovinz: Mém: Com. géol., St.-Pétersbourg, vol. 14, No. 3, p. 53.

1896. Koninckites, Toula, Eine Muschelkalkfauna am Golfe von Ismid in Kleinasien: Beitr. Pal. und Geol. Osterreich-Ungarns und des Orients, vol. 10, p. 177.

1897. Koninckites, Diener, Cephalopoda of the lower Trias: Himalayan Fossils, vol. 2, pt. 1, p. 139: Mem. Geol. Survey India, Pal. Indica, ser. 15.

1902. Aspidites (pars), F. Frech, Lethra Palæozoica, Bd. 2, Lieferung 4, p. 637.

1904. Koninckites, J. P. Smith, Comparative Stratigraphy of the Marine Trias of Western America: Proc. California Acad. Sci., 3d ser., vol. 1, p. 375.

Type-Koninckites vetustus Waagen, Fossils from the Ceratite Formation, p. 261, Pl. XXVII, figs. 4 and 5 .

Evolute, discoidal, laterally compressed, narrow venter, either flattened or rounded. Sides flattened, and entire form not robust. Umbilicus wider than in typical members of Meekoceras s. str. and lateral ornamentation often stronger, in the form of coarse radial ribs or folds.

Septa as in Meekocercas s. str., but the auxiliary lobe is individualized, followed by a distinct auxiliary saddle, and this by a series of denticulations, forming a second auxiliary lobe on the umbilical shonlder. This subgenus embraces a number of species from the Lower Triassic of the Salt Range, the Himalayas, Ussuri Bay, and the mouth of the Olenek River in northern Siberia. It was not known to Waagen that Meekoceras mushbachanum White possessed all the essential characters of Koninckites, for the figure of the septa of that species is not exact. But since this is the case, and since M. mushbachanum was one of the three species given as typical members of Meekoceras, this group of species characterized by the greater evolution, the more rugose shell, and the fourth lobe with the auxiliary denticulations, is regarded merely as a subgenus. There are in the American Triassic, both in Idaho and California, several species that will fall into this division, but M. mushbachanum White is the only one described.

Frech ${ }^{a}$ proposes to drop Koninckites, referring the species described by Waagen under that name to Aspidites. While this is, no doubt, correct for some of those 
species, it is not correct for the type, nor for species like the type, one of which is Meekoceras (Kioninckites) mushbachanum White.

MEEKOCERAS (KONINCKITES) MUSHBACHANUM White.

Pl. XV, figs. 1-9; Pl. XVI, figs. 1-3; Pl. XVIII, figs. 1-7; Pl. LXX, figs. 8-10.

1879. Meekoceras mushbachanum, White, U. S. Geol. and Geol. Surv. Terr., vol. 5, p. 113.

1880. Meelioceras mushbachanum, White, U. S. Geol. and Geog. Surv. Terr., vol. 12, pt. 1, p. 114, Pl. XXXII, fig. 1 a-d.

1902. Prionolobus mushbachanus, F. Frech, Lethea Palæozoica, Bd. 2, Lieferung 4, p. 631, fig. c.

1904. Meeloceras mushbachanum, J. P. Smith, Comparative Stratigraphy of the Marine Trias of Western America: Proc. California Acad. Sci., 3 ser., vol. 1, p. 376, Pl. XLI, figs. 1-3; Pl. XLIII, figs. 1 and 2 .

Compressed, involute, discoidal, whorls rather deeply embracing, covering nearly three-fifths of the inner volution and being indented to one-fourth of its height by it. Umbilicus wide, shallow, umbilical shoulders abruptly rounded. Sides more flattened than in $M$. gracilitatis White, gently convex up to the abruptly rounded narrow venter. Height of whorl twice its breadth, and nearly one-half of the entire diameter. Width of umbilicus nearly one-fourth of the entire diameter of the shell. Greatest breadth of whorl at a point halfway between base and venter.

Surface ornamented with sharp cross striæ, slightly curved, and faint low folds, especially in age.

Septa ceratitic; saddles all rounded and entire, lobes all serrated. Ventral lobe divided by a broad, shallow siphonal saddle, the two divisions being serrated with about five denticulations; the first lateral is somewhat deeper and broader; the second lateral about half as deep as the first, and about two-thirds its width; the first auxiliary is small, shallow, provided with several denticulations; then follows a distinct auxiliary saddle, with a row of denticulations between that and the umbilicus. The internal septa consist of a moderately long antisiphonal lobe, and a single lateral.

Horizon and locality.-Meekoceras (Koninckites) mushbachanum White is rather common in the Lower Triassic of southeastern Idaho, where it was found at a point 5 miles south of John Gray's Lake, and at another place 15 miles a little west of south from that lake. Alpheus Hyatt also found it at Wood Canyon, about 9 miles east of Soda Springs. J. P. Smith found it in the Lower Triassic Meekoceras beds of the Inyo Range, Inyo County, Cal,, on the Union Wash, near the Union Spring, east side of Owens Valley about 15 miles southeast of Independence. In both Idaho and California it was associated with Meekoceras gracilitatis White, M. aplanatum White, Pseudosageceras intermontanum Hyatt and Smith, Ussuria, and many other forms characteristic of the Lower Triassic of the regions around the Pacific. 
1895. Prionolobus, Waagen, Fossils from the Ceratite Formation: Salt Range Fossils, vol. 2, p. 306 : Mem. Geol. Survey India, Pal. Indica, 'ser. 13.

1897. Prionolobus, Diener, Cephalopoda of the lower Trias: Himalayan Fossils, vol. 2, pt. 1, p. 149: Mem. Geol. Survey India, Pal. Indica, ser. 15.

1902. Prionolobus (pars), F. Frech, Lethæa Palæozoica, Bd. 2, Lieferung 4, p. 637.

Type.-Prionolobus atavus Waagen, Fossils from the Ceratite Formation, p. 309, Pl. XXIV, fig. 4 a-b; Pl. XXV, fig. 4 a-b.

Discoidal, evolute, laterally compressed, little embracing, wide umbilicus. Body chamber short. Sculpture consisting of faint radial folds.

Septa always ceratitic, consisting of a divided external lobe, two laterals, and an auxiliary series composed of a long, straight row of denticulations.

This group is very like Lecanites, but that genus always has goniatitic lobes. It is also nearly related to Gyronites, from which it differs only in the possession of the straight row of auxiliary denticulations. Gyromites would seem to be an intermediate link between this group and Leconites.

Since these differences are so slight, the writers prefer not to consider the group as an independent genus, for this narrowness of generic lines would not be in keeping with the rest of the classitication of Triassic ammonites. It is, therefore, placed as a subgenus under Meekoceras in the broạder sense, along with Gyronites and Koninckites. Prionolobus is known at present only from the Lower Triassic of India, and the Meekoceras beds of the Inyo Range in California, where it is represented by a single species, Prionolobus Waageni sp. nov., and the Aspen Ridge.in Idaho, where it is represented by several new species.

MEEKOCERAS (PRIONOLOBUS) WAAGENr Hyatt and Smith, sp. nov.

Pl. LXXVII, figs. 3-8.

Evolute, discoidal, laterally compressed. Whorls little embracing and little indented by the inner volutions. Sides flattened convex, venter narrow and rounded; greatest width at a point on a level with the top of the inner whorl. Umbilical shoulders gently rounded, umbilicus wide and shallow.

Surface ornamented only with low, radial folds, visible only on the shell.

Scpta ceratitic; external lobe divided by a siphonal noteh into two short branches; first lateral long; second lateral about two-thirds of the size of the first. Auxiliary series consisting of a straight row of denticulations on the umbilical slope. The antisiphonal lobe is flanked by a single internal lateral. The height of the last whorl is about twice its width and two-fifths of the total diameter. It is impressed by the inner whorl to one-fourth of its height, and conceals slightly 
more than one-half of the inner whorl. The width of the umbilicus is two-fifths of the total diameter of the shell.

Horizon and locality.-Prionolobus Waageni was found by A: M. Strong in the Liower Triassic Meekoceras beds of the Inyo Range, Inyo County, California, $1 \frac{1}{2}$ miles east of the Union Spring, on the old McAboy trail across to Salinas Valley. This locality is about 15 miles southeast of Independence.

MEEKOCERAS (PRIONOLOBUS) JACKSONI Hyatt and Smith, sp. nov.

Pl. LXIT, figs. 11-21.

Form evolute, discoidal, laterally compressed. Whorls of moderate height, but increasing slowly in height; rather deeply embracing, and deeply indented by the inner volutions. Sides flattened, umbilical shoulders gently rounded, venter highly arched and narrow; no ventral shoulders perceptible. Umbilicus wide and shallow. The height of the whorl is about two-fifths of the total diameter of the shell, and the width one-half of the height. The indentation is somewhat less than one-third of the height. The width of the umbilicus is about three-tenths of the total diameter of the shell.

The surface is smooth, ornamented only with cross strix of growth and very fine spiral lines. The septa are ceratitic, lobes all serrated, and saddles all rounded and entire. The general character of the septa is the same as that of Meekoceras s. str., but there is no fourth lateral lobe; instead there is a long, straight row of denticulations. This character of the septation at once distinguishes Prionolobus from Ophiceras and Gyronites, which are both very similar to it in form and character.

Prionolobus Jacksoni differs from $P$. Waageni in being more robust and involute and in the more rapid increase in height of the whorls. It differs from ophiceras Spencei in the character of the septa and in lacking the constrictions that occur on the cast of Ophiceras. It does not resemble closely any of the Indian species ascribed by Waagen to Prionolobus, but agrees with them all in having the straight row of denticulations instead of the auxiliary lobe.

Horizon and locality.-Prionolobus Jacksoni is common in the Lower Triassic Columbites beds above the Meekoceras beds 1 mile west of Paris, Idaho, locality No. 1981, United States Geological Survey, associated with Columbites parisianus, Meekoceras pilatum, Pseudosageceras intermontanum, Ophiceras Spencei, Celtites sp. nov., and many others. What is probably the same species was found in the Meekoceras gracilitatis beds in Wood Canyon, 9 miles east of Soda Springs, Idaho, and in the same horizon on the Union Wash, in the Inyo Range, $1 \frac{1}{2}$ miles east of the Union Spring, 15 miles southeast of Independence, Cal. 
The figured specimens all came from the locality near Paris, Idaho, and are the property of the United States Geological Survey.

The specific name is given in honor of Prof. R. T. Jackson.

$$
\text { Genus ASPIDITHS Waagen. }
$$

1895. Aspidites, Waagen, Fossils from the Ceratite Formation: Salt Range Fossils, vol. 2, p. 215: Mem. Geol. Survey Tndia, Pal. Indica, ser. 13.

1397. Aspidites, Diener, Cephalopoda of the lower Trias: Himalayan Fussils, vol. 2, pt. 1, p. 145: Mem. Geol. Survey Indica, Pal. Indica, ser. 15.

1902. Aspidites (pars), F. Frech, Lethrea Palæozoica, Bd, 2 Lieferung 4, p. 637.

1903. Aspidites, G. von Arthaber, Neue Funde in den Werfener Schichten, etc.: Resultate der Wissenschaftlichen Erforschung des Balatonsees, vol. 1, pt. 1, p. 18.

Type.-Aspidites superbus Waagen, Fossils from the Ceratite Formation, p. 218, Pl. XXIII; Pl. XXIV, fig. 1 a-b.

Laterally compressed, discoidal, involute; whorls deeply embracing, and deeply indented by the inner whorls, increasing rapidly in height. Sides only slightly convex, sloping up to the rather narrow venter, which may be either angular or rounded, but never provided with keels or furrows. Umbilicus usually narrow. Surface smooth, or ornamented with radial stria and folds. No ribs 'visible at any stage of growth. Body chamber short, as in most discoidal shells.

Septa distinctly ceratitic, with rounded saddles, and serrated lobes. The external lobe is divided into two branches by a siphonal saddle which may itself in some cases be serrated, but not to the extent of forming adventitious lobes. The first and second laterals are large and deep, and the denticulations may run high up on the sides of the saddles. The auxiliary series is very long and complicated, consisting of several denticulations united into a broad auxiliary lobe, followed by a number of irregular lobes of greater or less size, not individualized. The saddles are usually long and narrower than the lobes. The internal septa consist of a divided antisiphonal lobe, with a principal internal lateral, and an auxiliary series inside the umbilical suture.

This genus greatly resembles the subgenus Koninckites, but differs in the greater involution, and the greater complexity of the auxiliary series, both external and internal; it may very likely have developed out of Koninckites. Another genus with which it may be compared is Clypites, which, however, has adventitious lobes, and also has the auxiliary series much simpler; also Clypites is usually more involute than Aspidites, although this character alone would not be sufficient,for separation.

Aspidites, up to the present, has been found only in the Lower Triassic of the Salt Range and the Himalayas in India, and in Hungary. But Alpheus Hyatt 
found it in the Meckoceras beds of the Aspen Ridge, near Soda Springs, in southeastern Idaho, and J. P. Smith found it in the same formation in the Inyo Mountains of Inyo County, Cal., in both cases associated with Meekoceras gracilitatis White. In addition to the species described below, there are at least two other species, both apparently new.

ASPIDITES HOOVERI Hyatt and Smith, sp. nov.

Pl. XVII, figs. 1-12.

Form compressed, discoidal, involute, deeply embracing, inner whorls almost completely concealed by the outer, and indenting the outer to nearly half its height. Umbilicus narrow, the umbilical shoulders of the succeeding whorls being so gently rounded and meeting each other at so nearly the same angle that the umbilicus makes a deep and crater-like conical depression. Sides gently convex, from the crater-like walls of the umbilicus to the rounded and rather narrow venter. Greatest breadth of the whorl at a point balfway from base to venter.

Surface ornamented with fine cross strie, which are visible only in the few places where the shell is preserved. The body chamber appears to have been two-thirds of the last revolution.

Septa ceratitic, but some of the saddles have become slightly ammonitic. The external lobe is broad, and divided into the broad branches by a shallow siphonal saddle, which is digitate, but not to the extent of forming adventitious lobes.

The first lateral lobe is equally broad and twice as deep; the second lateral lobe about two-thirds the depth as the first. Then comes the auxiliary series, consisting of a small, somewhat individualized, first auxiliary, followed by a long, irregular series of denticulations, making more or less distinct lobes and saddles, but smaller than the first.

The first lateral saddle is long, narrow, and denticulate to the apex on the apper side; the second is similar in shape, but longer and entire; the third, which separates the second lateral lobe from the auxiliary series, is shallow, broad, and denticulate all around. The septa are more highly specialized than those of any other known species of Aspidites, being more like those of Proptychites ammonoides Waagen. ${ }^{a}$ But in Aspidites Hooveri the saddles are narrower, the first lateral saddle denticulate only on the upper side, and the secondary lobes in the auxiliary series much smaller and more distinct. Also the first and second lateral lobes are not rounded at the end, but square, and the denticulations fewer. Proptychites ammonoides is quite robust, the whorl being nearly twice as thick proportionally as in Aspidites Hooveri.

«Fossils from the Ceratite Formation: Salt Range Fossils, vol. 2, 1895, p. 171, Pl. XviI, fig. a-c: Mem. Geol. Survey India, Pal, Indica, ser. 13. 


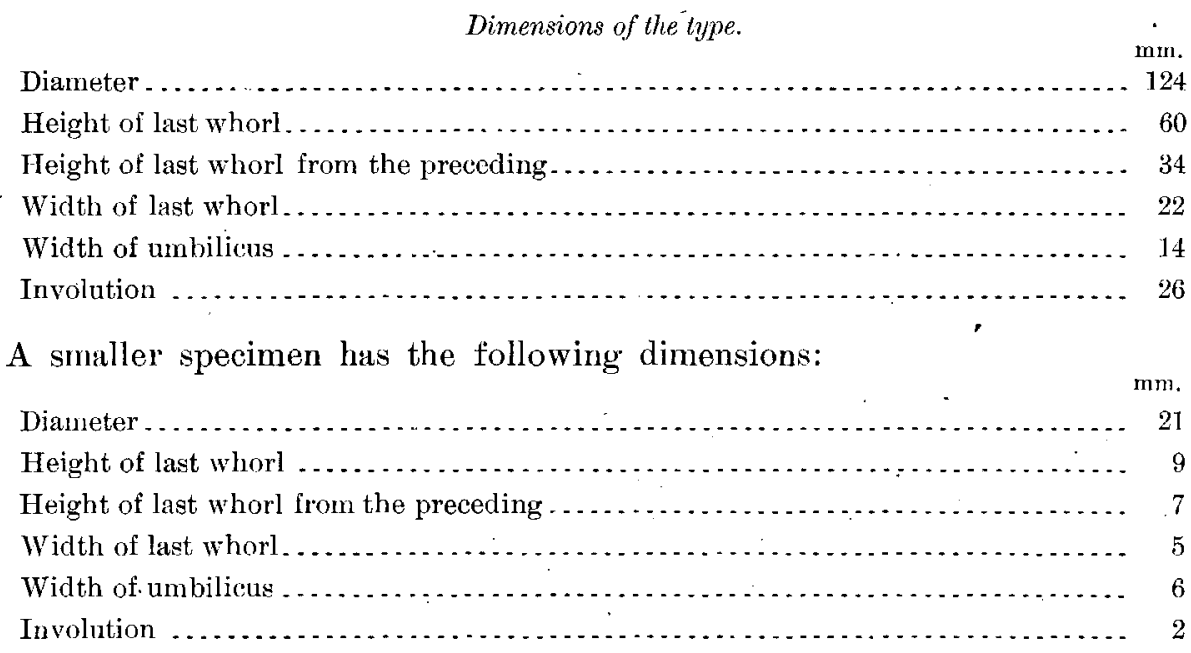

This specimen was broken so as to expose the inner whorls, and at the diameter of $5 \mathrm{~mm}$. showed a distinct Lecanites stage, similar to that of Meekoceras gracilitatis and $M$. aplanatum. No other proof is needed of the relationship and derivation of this genus.

The specific name is given in honor of Mr. 'T. J. Hoover, a mining engineer, who assisted in collecting this fauna.

Horizon and locality.-Aspidites Hooveri was found by J. P. Smith in the Lower Triassic, Meekoceras beds, of the Inyo Range, east side of Owens Valley, Inyo County, Cal., on the Union Wash, about $1 \frac{1}{2}$ miles east of the Union Spring and 15 miles southeast of Independence. It was associated with Meekoceras gracilitatis White, Meelocenas aplanatum White, and Meekoceras mushbachanum White, besides many others.

Genus IBFYRICHITHS Waagen.

1895. Beyrichites, Waagen, Fossils from the Ceratite Formation: Salt Range Fossils, vol. 2, p. 160: Mem. Geol. Survey India, Pal. Indica, ser. 13.

1896. Beyrichites, Arthaber, Cephalopodenfaunen der Reiflinger Kalke: Beitr. Pal. und Geol. OsterreichUngarns und des Orients, vol. 10, pt. 2, p. 228.

1896. Beyrichites, Toula, Fine Muschelkalkfauna am Golfe von Ismid in Kleinasien: Beitr. Pal. und Geol. Osterreich-Ungarns und des Orients, vol. 10, pt. 4, p. 172.

1897. Beyrichites, Diener, Cephalopoda of the lower Trias: Himalayan Fossils, vol. 2, pt. 1, p. 74 : Mem. Geol. Survey India, Pal. Indica, ser. 15.

1898. Beyrichites, Tornquist, Nenere Beiträge zur Geol. und Pal., Umgebung von Recoaro, etc.: Zeit. Deutsch. geol. Gesell., vol. 50, pt. 4, p. 658.

1904. Beyrichites, J. P. Smith, Comparative Stratigraphy of the Marine Trias of Western America: Proc. California Acad. Sci., 3d ser., vol. 1, p. 378.

Type. "Anmonites" reuttensis Beyrich, 1867, Cephalopoden aus dem Muschelkalk der Alpen: Abhandl. K. Akad. Wiss., Wien, 1866, p. 113, Pl. I, fig. 4. 
Involute, laterally compressed, deeply embracing, umbilicus narrow, sides slightly convex, venter narrowly rounded. Sides ornamented with weak ribs which usually have a falciform bend. Septa of the ceratitic type but with even the saddles slightly denticulated, just in the transition to becoming ammonitic. Waagen established this genus to include "Meekoceras" reuttense Beyrich, M. Khanikofi Oppel, and $M$. maturum Mojsisovics, of the Muschelkalk of the Alps, but he placed these in the family Ptychitidæ.

Diener $^{a}$ shows.that Beyrichites does not belong to the Ptychitidæ, but he goes to the other extreme and classes it as a subgenus under Meekoceras.

On account of the specialization shown by its sculpture and denticulated saddles as well as ceratitic lobes, the writers prefer to consider this as an independent genus.

E. von Mojsisovics ${ }^{b}$ says that Beyrichites belongs to the Ceratitidx, and that it developed out of Dinarites, which conclusion may very probably be correct.

As thus defined this genus is confined to the Middle Triassic of the Alps, Asia Minor, India, and Nevada. Beyrichites is represented in America by B. rotelliformis, but J. P. Smith has found in the Middle Triassic of Nevada several other forms of this genus all apparently new.

BEYRICHITES ROTELLIFORMIS Meek.

Pl. XXIII, figs. 1-11; Pl. LVJII, figs. 1-15. •

1877. Gymnotoceras rotelliforme, Meek, U. S. Geol. Explor. 40th Par., vol. 4, p. 111, Pl. X, figs. 9 and 9a. 1904. Beyrichites rotelliformis, J. P. Snith, Comparative Stratigraphy of the Marine Tras of Western America: Proc. California Acad. Sci., 3 d ser., vol. 1, p. 379, Pl. XLV, figs. 5; Pl. XLIII, figs. 13 and 14.

Involute, discoidal lenticular, laterally compresșed. Whorl high and increasing rapidly in height, with flattened convex sides and narrowly rounded venter. Umbilicus narrow, umbilical shoulders abruptly rounded, with very steep inner walls. The height of the whorl is slightly greater than one-half of the total diameter and the width is two-thirds of the height. It is indented to about twosevenths of its height by the inner whorl. The width of the umbilicus is about onesixth of the total diameter of the shell.

Surface ornamented with numerous fine flexuous ribis and radial striæ of growth, with sigmoidal curve on the flanks, and a sharp forward bend just below the abdominal shoulders. These ribs are strongest on the flanks, and become obsolete near the venter. The ribs do not become obsolete on the mature shell, although they are stronger on the young sbell.

a Cephalopoda of the lower Trias: Himalayan Fossils, vol. 2, pt. 1, p. 74: Mem. Geol. Survey India, Pal. Indica, ser. 15. $b$ Cephalopoden der Hallstïtter Kalke; Bd. I, Supplement Heft: Abhandl. K.-k. geol. Reichsanśtalt, Wien, vol. 6, pt. 1, 1902, p. 331. 
The septa are ceratitic but the saddles are slightily indented; the lobes are all distinctly serrated. The internal lobe is divided by a short siphonal saddle; the first lateral is large, slightly digitate; the second lateral smaller and simpler; this followed by a smaller third lateral; the true auxiliary series consists only of denticulations below the auxiliary saddle. The septa are not like those of Ceratites (Gymnotoceras) Blakei Gabb, with which species Gabb united it. The young shells are much more evolute, robust, and have rougher seulpture.

This species was erroneously assigned by Hyatt to his genus Gymnotoceras, but has not the least kinship with that group; it agrees in all respects with Waagen's genus Beyrichites.

Horizon and locality.-Beyrichites rotelliformis was found by the United States Geological Exploration of the Fortieth Parallel in the Middle Triassic limestone, Buena Vista Canyon, West Humboldt Range, Nevada, from which place came the type; the Whitney Survey found it at New Pass, Nevada. J. P. Smith found it very common in the Middle Triassic of Cottonwood Canyon, near the Lucky Dog mine, West Humboldt Range, and on the divide between 'Troy Canyon and the Sonth Fork of American Canyon, about 4 miles south of Foltz post-office, in Spring Valley, in both places associated with Anoleites Whitneyi, Ceratites humboldtensis, Celtites IIalli, Acrochordiceras Hyatti, Gymnotoceras Blakei, Daonella dubia, and many other molluses.

\section{Family CERATITIDA.}

Form usually evolute, but involute in some groups; laterally compressed, robust. Surface usually ornamented with ribs, or spines, and sometimes, with ventral keels. Body chamber short in most genera, but in some few it is long. Septa ceratitic in nearly all genera, but goniatitic in some primitive, and in some reversionary genera; ammonitic in some highly specialized forms.

The Ceratitidie formerly included all ammonites with ceratitic septa, but it was gradually found out that most Triassic families contained genera with this sort of septation, and so the group was finally restricted to those in the development series of Ceratites nodosus. Even with this restriction the family has been large and unwieldy, for many genera having little kinship with the type resemble it greatly, and many others that are closely related to it genetically do not resemble it at all. The classification of this family, therefore, can not be based on mere resemblance, but on development series, and on ontogenic studies of the various genera.

The most primitive members of the family are all evolute little embracing forms with very simple scpta, and the young stages of all the genera, except the most specialized, are of this type. This indicates that the family radicle is to be sought in an evolute form with simple septa. More than this, all the earliest known mem- 
bers of the family have little sculpture, and the adolescent stages of most genera, except the highly specialized later forms, are nearly smooth. This indicates that this family had a common origin with the Meekoceratide and the Hungaritida, in some genus with the characters of Lecanites. While the later genera of all three families can easily be distinguished from each other, the earlier ones can not; and, further, the young stages of all three groups are very similar, which is sufficient justification for placing all three in the suborder Ceratitoidea.

The most elaborate and systematic classification of the Ceratitide has been attempted by E. von Mojsisovics, ${ }^{a}$ who divided the family as follows:

$\begin{aligned} \text { Subfamily Dincritine. } & \left\{\begin{array}{c}\text { Phylum I. Dinaritea, containing Dinarites, Ceratites, and Arpadites, with a num- } \\ \text { ber of subgenera, or subordinate genera. } \\ \text { Phylum II. Heraclitea, containing Heraclites and Cyrtopleurites. } \\ \text { Phylum III. Orthopleuritea, containing Polycyclus, Choristoceras, Rhabdoceras, } \\ \text { and Cochloceras. }\end{array}\right. \\ \text { Subfamily Tirolitine. } & \left\{\begin{array}{c}\text { Phylum I. Tirolitea, containing Tirolites and Badiotites. } \\ \text { Phylum II. Distichitea, containing Distichites and Ectolcites. } \\ \text { Phylum III. Trachyceratea, containing Trachyceras, Eremites, Sandlingites, Cly- } \\ \text { donites, and Sirenites. }\end{array}\right.\end{aligned}$

The Dinaritinæ were supposed to develop out of Dinarites and the Tirolitinæ out of Tirolites, and both were thought to have come from Xenodiscus or some related genus. This subdivision of the family is, then, not merely a convenient arrangement, but an attempt at a phylogenic classification. All the later work of Diener, Waagen, and others has substantiated the classification in all essentials, although some of the details must be modified.

The writers have studied the ontogeny of Danubites, Ceratites, Arpadites, and Clionites, of the Dinaritinæ, and have found the young stages to be like Tirolites; so it becomes probable that Tirolites is the ultimate family radicle of both divisions of the Ceratitide. The parent form of Tirolites can not have been either Xenodiscus or Xenaspis, but rather Lecanites, which differs only very slightly from the earlier species of Dinarites, Danubites, and Tirolites. Lecanites itself was probably derived from Paralecanites of the Permian and Lower Triassic, through which the Ceratitida were probably derived from the Prolecanitidie of the Carboniferous. By the Prolecanitide the writers do not mean the phylum or suborder as the term has been used by Karpinsky and Haug, but the group of Prolecanites.

At the time Mojsisovics selected Xenodiscus as the probable radicle of the Ceratitide it was the only Permian ammonite genus known that could possibly have been the ancestral form. But the later work of Diener and Wagen has shown that the characters of this genus and its kindred form Xenctspis are too highly specialized

a Cephalopoden der Hallstiitter Kalke: Abhandl. K.-k. geol. Reichsanstalt, Wien, vol. 6, pt. 2, 1893, p. 395. 
for either onerto have been the family radicle, and that there are other similar but more primitive genera in the lowest beds of. the Triassic, that may with more probability be regarded as the ancestors of the Ceratitidx.

No Ceratitide are as yet known certainly below the Lower Triassic, although in this formation Danubites is known in the very lowest beds, and must have developed in the Permian. Even Lecanites itself is not yet known in the Permian, although Xenodiscus, Xenaspis, Mungarites, and Otoceras, which must have developed out of Lecanites, are known in the upper Permian. Our knowledge of the ammonites of the Carboniferous and Permian is still very fragmentary, and until more discoveries are made all our classifications will stand on an insecure basis. At present the ontogeny of the principal genera is the only criterion, and that is uncertain, because of the imperfection of the material and its scarcity.

In America the Ceratitidæ are represented in the Lower Triassic by Danubites; in the Middle Triassic by Dinarites, Danubites, Ceratites, Tirolites, Acrochordiceras, Balatonites, Trachyceras (Protrachyceras and Anolcites), and Eudiscoceras; in the Upper Triassic by Tirolites, Clionites, Arpadites, Trachyceras (Protrachyceras), Sandlingites, Sirenites, Polycyclus, and Rhabdoceras.

\section{Genus TIROLIIES Mojsisovios.}

1878. Tirolites, Mojsisovies, Dolomitriffe von Südtirol und Venetien, Wien, p. 43.

1879. Tirolites, Mojsisovics, Vorläufige kurze Uebersicht der Ammoniten-Gattungen der Mediterranen und Juvavischen Trias: Verhandl. K.-k. geol. Reichsanstalt, Wien, p. 138.

1882. Tiroliles, Mojsisovics, Cephalopoden der Mediterranen Triasprovinz: Abhandl. K.-k. geol. Reichsanstalt, Wien, vol. 10, p. 64.

1893. Tirolites, Mojsisovics, Cephalopoden der Hallstätter Kalke: Abhandl. K.-k. geol. Reichsanstalt, Wien, vol. 6 , pt. 2, p. 588 .

1902. Tirolites, Mojsisovics, Cephalopoden der Hallstätter Kalke, Supplement-Heft: Abhandl. K.-k. geol. Reichsanstalt, Wien, vol. 6, pt. 1, p. 324.

1903. Tirolites, E. Kittel, Die Cephalopoden von Muć in Dalmatien: Abhandl. K.-k. geol. Reichsanstalt, Wien, vol. 20, p. 29.

7ype.- "Ceratites" idrianus Hauer, Cephalopoden der Unteren Trias der Alpen: Sitzungsber. K. Akad. Wiss., Wien, vol. 52, 1865, p. 610, Pl. I, figs. 4 and 5 ; and in Mojsisovics, Cephalopoden der Mediterranen Triasprovinz, 1882, p. 67, Pl. I, fig. 1.

Evolute, little embracing, robust, laterally compressed whorls, with wide, shallow umbilicus. Venter flattened, and without central furrow or other seulpture. Sides ornamented with ribs, which end on the syuare abdominal shoulders in long spines. Body chamber short. Septa simple; external lobe divided by a shallow siphonal prominence; the two branches of this lobe are goniatitic. The lateral lobe is broad and shallow, and may be weakly serrated, although in some forms it is goniatitic. An auxiliary lobe may be faintly indicated on the umbilical shoulder. 
This genus was regarded by Mojsisovics as the radicle of the Tirolitine, a subfamily of the Ceratitide, including Tirolites, Balatonites, Trachycerces, and Sirenites as its chief representatives. But the writers are inclined to go further, and regard this as the radicle of all the typical Ceratitidæ, for a distinct Tirolites stage has been observed in most of the genera of this family of the so-called Dinaritinæ, as well as Tirolitine.

Tirolites s. str. is characteristic of the Werfen beds of the Lower Triassic of the Mediterranean region, and occurs in this horizon also in India and in Idaho. In California it is represented by the subgenus Metatirolites Mojsisovies, which occurs in the Upper Triassic, by one species of Tïrolites spinosi, in the Middle Triassic of California, and by several species clesely allied to Tirolites cassianus in the Tirolites beds of the Lowêr 'Triassic of Idaho.

TIROLITES PACIFICDS Hyatt and Smith, sp. nov.

Pl. XXI, figs. 14-18.

Evolute, widely umbilicate; whorls robust, subquadrate, low, and increasing slowly in height, little embracing, and little indented by the inner volutions. Sides of the whorls narrow, and subangular; venter flattened; abdominal shoulders abrupt. The height of the whorl is one-third of the total diameter of the shell, the width is slightly greater than the height, and the indentation is only one-ninth of the height of the whorl. 'The width of the umbilicus is four-ninths of the total diameter of the shell.

The surface is ornamented with fine radial ribs which cross the venter, and with strong spines on the abdominal shoulders.

The septr are slightly ceratitic; the ventral lobe is divided by a small siphonal notch into two narrow, slightly serrated divisions. There is a serrated lateral lobe on the abdominal shoulders, and an unserrated small second lateral on the umbilical slope. 'The latter is narrow, pointed, and unserrated. This species has all the characters of the group of Tirolites spinosi, but is distinct fron any described species in the development of the auxiliary lobe, in which character it agrees with Metatirolites.

Tirolites pacificus was found by J. P. Smith in the upper limestone beds, base of Middle Triassic, on the Union Wash, Inyo Range, Inyo County, Cal., about 15 miles southeast of Independence. It was associated with Hungarites, Ptychites, Xenodiscus, Acrochordiceras, Parapopanoceras, in beds 800 feet above the Meekoceras beds. 
1893. Metatirolites, Mojsisovics, Cephalopoden der Hallstätter Kalke: Abhandl. K.-k. geol. Reichsanstalt, Wien, vol. 6 , pt. 2, p. 588 .

Type.-Ammonites foliaceus Dittmar, Zur Fauna der Hallstätter Kalke: Geognost. - ' palæont. Beitr., von Benecke, etc., vol. $` 1,1866$, p. 358, Pl. XV, figs. 10-12, and Mojsisovics, Cephalopoden der Hallstätter Kalke, p. 590, Pl. CXL, figs. 1-5̃.

Evolute, little embracing, robust whorls, with wide umbilicus. Cross section quadratic, sides flattened, abdominal shoulders square, venter flattened and broad, without any central furrow. A row of spines is seen on the abdominal shoulders as in Tirolites s. str. The septa consist of a divided external lobe, serrated first lateral, and a distinct auxiliary lobe on the umbilical shoulder. This latter character is the only mark of distinction from Tirolites, from which this subgenus undoubtedly descends.

Metatirolites is found in the Upper Triassic, Karnic stage, zone of Tropites subbullatus, in the Mediterranean region, to which it has been supposed, up to the present, to be confined. J. P. Smith found Metatirolites foliaceus Dittmar in the Upper Triassic of Shasta County, Cal., associated with Halobia superba Mojsisovics, Discotropites sandlingensis Hauer, Sagenites Herbichi Mojsisovics, Tropites subbullatus Hauer, and many other species characteristic of the upper Karnic.

TIROLITES (METATIROLITES) FOLIACEUS Dittmar.

Pl. LXXXII, figs. 1-10.

866. Ammonites foliaceus, Dittmar, Zur Fauna der Hallstittter Kalke: Geognost.-palæont. Beitr., von Benecke, Schlœenbach und Waagen, vol. 1, p. 358, Pl. XV, figs. 10-12.

1893. Metatirolites foliaceus, Mojsisovics, Cephalopoden der Hallstïtter Kalke: Abhandl. K.-k. geol. Reichsanstalt, Wien, vol. 6, pt. 2, p. 590, Pl. CXL, figs. 1-5.

Form evolute, robust, little embracing, and little indented by the inner volutions. Whorls low and increasing slowly in height, trapezoidal in shape; sides flattened and sloping outward, with square, angular abdominal shoulders and flattened broad venter. Umbilical shoulders rounded, umbilicus wide and deep, exposing the inner volutions. The beight of the whorl is about equal the width and one-half of the total diameter. The width of the umbilicus is about one-third of the diameter of the shell.

On the abdominal shoulders is a row of strong but blunt knots, which are the remnants of the Tirolites spines. In addition to these, the surface is ornamented with fine radial strixe, which run nearly straight up the sides, and bend sharply forward at the marginal knots, forming a broad and deep sinus on the venter. On the venter are seen also fine spiral lines, which give a somewhat reticulated appear- 
ance to this portion of the shell. On the sides are low folds which become stronger on the venter, bending forward, parallel to the cross striæ.

The septa are ceratitic; the external lobe is narrow and divided by a small siphonal notch; the lateral lobe is larger, distinctly serrated, and falls on the abdominal shoulder angle; on the umbilical slope there is a small but distinct second lateral or auxiliary lobe. The antisiphonal lobe is narrow, and flanked by a single short internal lateral on each side.

'There is no other species with which Tirolites foliaceus may be compared, but the Californian specimens agree. exactly with the figures and descriptions of those from the Alps, and there can be doubt of the identity of those from the two regions, in spite of their geographic separation, for the horizon and faunal association are the same in both places.

Horizon and locality.-Tirolites (Metatirolites) foliaceus was first found in the Upper Triassic, zone of Tropites subbullatus, of the Alps. In California it was found in the same horizon in Shasta County, 3 miles east of Madison's ranch, between Squaw Creek and Pit River, associated with Tropites subbullatus, Paratropites Sellai, Sagenites Herbichi, Discotropites sandlingensis, Halobia superba, and many other species characteristic of this zone.

Gemus DINARITHS Mojsisovios.

1882. Dinarites, E. von Mojsisovics, Cephalopoden der Mediterranen Triasprovinz: Abhandl. K.-k. geol. Reichsanstalt, Wien, vol. 10, p. 5 .

1886. Dinarites, E. von Mojsisovics, Arktische Triasfaunen: Mém. Acad. imp. sci. St.-Pćtersbourg, sér. 7, tome 33, No. 6, p. 9 .

1895. Dinarites, W. Waagen, Fossils from the Ceratite Formation: Salt Range Fossils, vol. 2, p. 23: Mem. Geol. Survey India, Pal. Indica, ser. 13.

1895. Dinarites, C. Diener, Triadische Cephalopodenfaunen der ostsibirischen Küstenprovinz: Mém. Com. géol., St.-Pétersbourg, vol. 14, No. 3, p. 11.

1895. Dinarites, W. Salomon, Geol. und Pal. Studien über die Marmolata: Palæontographica, vol. 42, p. 179.

1900. Aplococeras, A. Hyatt, Cephalopoda: Text-book of Palæontology, by K. von Zittel, p. 556. (Translated by C. R. Eastman.)

1900. Plococeras, A. Hyatt, Cephalopoda: Text-book of Palcontology, by K. von Zittel, p. 556. (Translated by C. R. Lastman.)

1900. Protophiceras, A. Hyatt, Cephalopoda: Text-book of Palæontology, by K. von Zittel, p. 556. (Translated by C. R. Eastman.)

1900. Pseudodinarites, A. Hyatt, Cephalopoda: Text-book of Palceontology, by K. von Zittel, p. 559. (Translated by C. R. Eastman.)

1902. Dinarites, E. von Mojsisovics, Cephalopoden der Hallstätter Kalke, Supplement-Feft: Abbandl. K.-k. geol. Reichsanstalt, Wien, vol. 6, pt. 1, p. 324 .

1903. Dinarites, E. Kittl, Die Cephalopoden von Muć. in Dalmatien: Abhandl. K.-k. geol. Reichsanstalt, Wien, vol. 20, p. 12.

16918-No. 40-05-11 
Type-Ceratites dalmatinus Hauer, figured by E. von Mojsisovics in Cephalopoden der Mediterranen Triasprovinz, p. 8, Pl. I, figs. 7 and 8.

Form evolute, somewhat compressed laterally, not deeply embracing nor deeply indented by the inner volutions. Whorl higher than wide, usually helmet-shaped, with rounded sides and convex venter, without keel or furrow.

Mojsisovies divided this genus into two groups on the basis of the sculpture: The Nudi, in which the shell remained almost smooth through life; and the Circumplicati, in which there are strong umbilical ribs or nodes, which reach up the sides and frequently cross the venter. This latter group is the most characteristic, and was regarded as the direct ancestor of Ceratites, while the Nudi were considered by Mojsisovics as the ancestors of Klipsteinia. In Dinarites the sculpture is largely confined to the umbilical region, and the whorl is helmet-shaped, in contradistinction with Tirolites, in which the nodes are marginal, and the cross section of the whorl trapezoidal. At maturity the sculpture of Dinarites may be almost obsolete, but it is always distinct in the adolescent stages.

The septa are slightly ceratitic, the saddles all entire, and the principal lobes usually serrated. The external lobe is divided by a siphonal saddle into two branches; there is but a single principal lateral lobe, and a very small auxiliary just outside of the umbilicus. The internal septa show a slender antisiphonal lobe, flanked on each side by a single lateral.

The body chamber is said to be short, but as it is usually incomplete there is no certainty that it may not have been long in the extremely evolute forms.

Dinarites occurs in the Lower, Middle, and Upper Triassic of the Mediterranean region, in the Lower Triassic of eastern Siberia, and it has been cited from the Ceratite sandstone of India, although the species figured under that name probably do not belong to Dinarites. In America it has been found only in the Middle Triassic of Nevada.

DINARITES BONE-VISTE Hyatt and Smith, sp. nov.

Pl. LX, figs. 1-6.

Form evolute, discoidal, laterally compressed. Whorls low and increasing slowly in height. Sides flattened, with abruptly rounded umbilical shoulders, and narrow, rounded venter. Abdominal shoulders like the ventral, but less abrupt.

The involution is very slight, being less than one-tenth of the height of the whorl. The umbilicus is wide and shallow. The height of the whorl is one-third of the total diameter of the shell and the width is three-fifths of the height. The width of the umbilicus is two-tifths of the diameter of the shell.

The surface is ornamented with both ribs and varices. The ribs begin on the umbilical shoulders and run nearly straight up the sides and across the venter 
without interruption, although they become weaker at the abdominal shoulders. They divide into pairs at a point about halfway up the sides, and also new ribs are frequently introduced by intercalation, although at irregular intervals. The constrictions or varices are parallel with the ribs, and occur about eight to a revolution. This ornamentation shows on the cast as distinctly as on the shell.

The septa consist of a divided ventral lobe, a principal lateral lobe, and a small auxiliary. The lobes are slightly serrated, the saddles entire.

The length of the body chamber is unknown, but is at least two-thirds of a revolution.

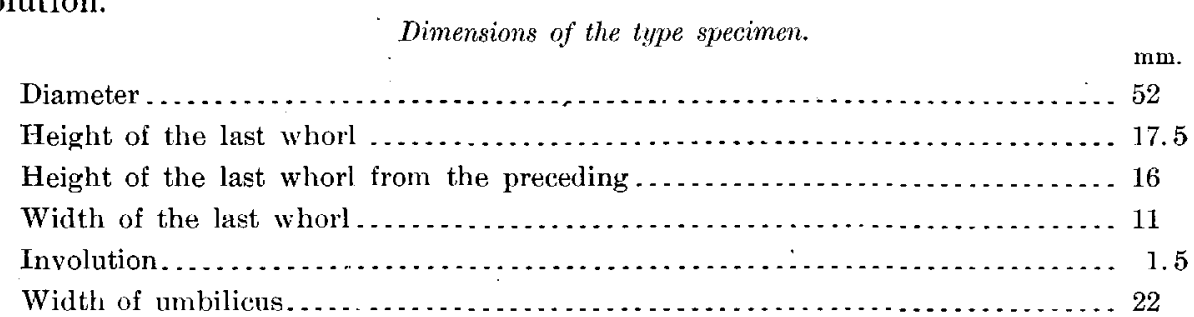

Dinarites bonie-vista belongs to the group of Dinarites circumplicati, but is unlike most other species of this genus. A similar species, Dinarites ornatus, has been described by von Hauer" from the upper Muschelkalk zone of Ceratites trinodosus. In describing this species von Hauer says that it may possibly belong to another genus, on account of the varices, which are usually lacking on typical Dinarites. It is, however, nearer to this than to any other genus, and the writers prefer not to found a new genus on such slight differences.

Horizon and locality. - Dinarites bonze-vistio was found in the Middle Triassic upper Muschelkalk, at Unionville, Buena Vista Canyon, West Humboldt Range, Nevada, associated with Acrochordiceras Hyatti, Beyrichites rotelliformis, and other species characteristic of that horizon.

The type is in the collection of J. P. Smith.

A single specimen of this species was also found in the same horizon and association in the Star Canyon, near the Sheba mine, in the West Humboldt Range.

$$
\text { Genus DANUBITHS Mojsisovias. }
$$

1893. Danubites, Mojsisovics, Die Cephalopoden der Hallstätter Kalke: Abhandl. K.-k. geol. Reichsanstalt, Wien, vol. 6 , pt. 2 , p. 398.

1897. Danubites, Diener, Cephalopoda of the lower Trias: Himalayan Fossils, vol. 2, pt. 1, p. 24. Mem. Geol. Survey India, Pal. Indica, ser. 15.

1900. Florianites, Hyatt, Cephalopoda: Text-book of Palæontology, by K. von Zittel, p. 558. (Translated by C. R. Eastman.)

1902. Danubites, Mojsisovies, Cephalopoden der Hallstätter Kalke, Supplement-Heft: Abhandl. K.-k. geol. Reichsanstalt, Wien, vol. 6, pt. 1, p. 323.

a Cephalopoden der Trias von Bosnien: Denkschr. K. Akad. Wiss., Wien, vol. 59, 1892, p. 259, Pl, II, fig. 6 a-d. 
Type.-_"Celtites" Floriani Mojsisovies, Cephalopoden der Mediterranen Triasprovinz, p. 145 .

Evolute, little embracing, robust whorls, slowly increasing in size; umbilicus very wide; shape of cross section subquadratic; body chamber short. Sculpture of the circumplicate type, consisting of simple, rarely bifurcating, ribs running straight from the umbilicus up the sides to the abdominal shoulders, but always interrupted on the somewhat rounded venter. Occasionally there is a thread-like keel in the center of the siphonal area, but this is usually smooth and flattened.

Septa ceratitic, an external, two lateral, and an auxiliary, lobe present. In one species the septa seem to remain through life in the goniatitic stage, and in others the auxiliary lobe remains entire, but usually all four are serrated.

Mojsisovics at first included the type species under his genus Celtites, which is characterized by goniatitic lobes and long body chamber. Afterwards, when its characters became better known, he placed it under the group of Ceratites obsoleti, for which he established the subgenus Danubites, with this species as the type. But since this group is not derived from Ceratites, and is probably not the ancestor of that genus, the writers prefer to consider it as an independent genus.

Waagen "assigns to his genus Gyronites a number of species that, on account of their sculpture, ought to be classed with Danubites. In the same work Waagen also ascribes several species to Celtites that ought to be referred to Danubites.

Hyatt $^{b}$ took Celtites Floriani as the type of a new genus Florianites, having overlooked the fact that it was already used as the type of another genus:

Species that may belong to Danubites have already been described from the .American Triassic. "Clydonites" lavidorsatus Meek" (not Hauer and not Gabb) is said by Mojsisovics ${ }^{d}$ to belong to Danubites, $\dot{D}$. Halli Mojsisovics, and to be different from the form ascribed by Gabb to the same species. White ${ }^{e}$ figures a species from the Lower Triassic of Idaho under Meekoceras aplanatum, which Waagen has shown can not belong to that species, and renames Gyronites whiteanus Waagen (Fossils from the Ceratite Formation, p. 291). Diener ${ }^{\prime}$ suggests that this species should rather be classed with Danulites. An examination of the original specimen in the United States National Museum confirms this, for the shell and cast are wholly destitute of spiral striation, and the radial ribs might well belong to Danubites.

This genus is common in the Lower Triassic of India, Siberia, Idaho, and

$a$ Fossils from the Ceratite Formation: Salt Range Fossils, vol. 2, 1895, p. 288: Mem. Geol. Survey India, Pal. Indica, ser. 13 .

$b$ Cephalopoda: Text-Book of Pulacontology, by Zittel, 1900, p. 558; translation by C. R. Eastman.

c U. S. Geol. Explor, 40th Par., vol, 4, p. 109, Pl. X, fig. 7.

a Obertriadischen Cephalopoden-Faunen des Himalaya: Denkschr. K. Akad. Wiss., Wien, vol. 63, 1896, p. 124.

eU. S. Geol. and Geog. Surv. Terr., vol. 12, 1880, Pl, XXXI, fig. $1 \mathrm{c}$ (not $1 \mathrm{a}$, b, d, which is the true Meekoceras aplanatum).

$f$ Cephalopoda of the lower Trias: Himalayan Fossils, vol. 2, pt. 1, 1897, p. 28. Mem. Geol. Survey India, Pal. Indica, ser. 15 . 
California, and in the Middle Triassic of Siberia, Japan, and Nevada. Danubites Strongi, sp. nov. is the only form described from America that certainly belongs to Danubites.

\section{DANOBITES STRONGI Hyatt and Smith, sp. nov.}

Pl. IX, figs. 4-10.

Evolute, robust, discoidal, somewhat compressed laterally, widely umbilicate. Whorls low and increasing slowly in height, covering about ono-half of the inner volution, and indented by it to one-fifth of the height. The height of the whorl is a little more than one-third of the diameter of the shell. The umbilicus is shallow and wide, being nearly one-half of the total diameter. The surface is ornamented only with coarse, rounded, straight, radial ribs, that start from the uinbilical shoulders and run up the flanks to the rounded abdominal shoulders, where they become obsolete. The venter is highly arched, helmet-shaped, and smooth.

The septa are ceratitic, the saddles are all rounded and entire, and the lobes serratcd. The ventral lobe is divided by a short siphonal saddle into two very short narrow branches, the first lateral lobe is broader and longer, the second lateral about the size of the external, and there is a small shallow entire auxiliary on the umbilical shoulders. The body chamber seems to have been short, but no perfect specimens were found to illustrate this point.

Horizon and locality.-Lower Triassic Meekoceras beds, of the Inyo Range, east side of Owens Valley, Inyo County, Cal., $1 \frac{1}{2}$ miles east of the Union Spring, and 3 miles east of Skinner's ranch, on the McAboy trail leading over the Union Wash to Salinas Valley. This locality is about 15 miles southeast of Independence, and this species was associated with Meekoceras gracilitatis, M. aplanatum, and M. mushbachanum, and many others characteristic of the Lower Triassic. The specific name is given in honor of $\mathrm{Mr}$. A. M. Strong, who assisted in collecting this fauna.

\section{Genus BALATONITES Mojsisovics.}

1879. Balatonites, Mojsisovies, Vorlüufige kurze Uebersicht der Ammoniten-Gattungen der Mediterranen und Juvavischen Trias: Verhandl. K.-k. geol. Reichsanstalt, Wien, p. 139.

1882. Balatonites, Mojsisovics, Cephalopoden der Mediterranen Triasprovinz: Abhandl. K.-k. geol. Reichsanstalt, Wien, vol. 10, p. 7 :

1887. Balatonites, Hauer, Cephalopoden des Bosnischen Muschelkalkes: Denkschr. K. Akad. Wiss., Wien, vol. 54, p. 29.

1889. Arniotites, Hyatt, in Whiteaves, Fossils of the Triassic Rocks of British Columbia: Contributions Canadian Palæontology, Geol. Nat. Hist. Survey Canada, vol. 1, pt. 2, p. 144.

1892. Balatonites, Hauer, Cephalopoden der Trias von Bosnien: Denkschr. K. Akad. Wiss., Wien, vol. 59 , pt. 1, p. 270.

1896. Balatonites, Arthaber, Cephalopodenfaina der Reiflinger Kalke: Beitr. Pal. und Geol. OsterreichUngarns und des Orients, vol. 10, pt. 1, p. 60, and pt. 2, p. 198. 
Type.-Ammonites balatonicus Mojsisovics, Verhandl. K.-k. geol. Reichsanstalt, Wien, 1872, p. 190, and Abhandl. K.-k. geol. Reichsanstalt, Wien, vol. 10, p. 78, Pl. IV, figs. $2-6$; Pl. XXX, fig. 20.

- Body chamber short; whorls evolute, little embracing, laterally compressed, increasing slowly in size. Umbilical shoulders abrupt, sides somewhat flattened, umbilical shoulders strongly marked, abdomen narrow and surmounted by a keel which may be either smooth or beaded, or even serrated. Umbilicus wide and ishallow.

Lateral sculpture strongly marked, consisting of strong ribs which run from umbilical knots straight up the sides to the abdominal shoulders, where they bend abruptly forward, but in some forms do not reach the keel. These ribs are usually provided with knots or short spines arranged in spiral rows, at short intervals. The angular abdominal shoulders have a strong row of these knots, as does also the keel in the most typical forms.

Septa ceratitic, saddles entire, and four serrated lobes, a divided external, two laterals and an auxiliary.

Mojsisovics " divided this genus into three groups: The Balatonites gemmati, $B$. arietiformes, and $B$. acuti, of which only the first belong to Balatonites in the stricter sense, the second being the subgenus Judicarites Mojsisovics, and the third having been shown by Arthaber ${ }^{b}$ to belong chiefly to Hungarites. The groip of $B$. gemmati is always provided with the knots arranged in spiral lines, spines on the abdominal shoulders, and serrated kecls. The young of this group resemble Tirolites, and indicate a derivation from that genus. The mature forms show an approach to Trachyceras, but differ in the evolute form, the ceratitic septa, and the central keel with it.s row of knots.

Hyatt $^{c}$ named a genus Arniotites, based on a species from the Triassic of British Columbia, and in this group he included the Balatonites arietiformes. It is, however, very doubtful whether the type species is a Balatonites at all, and certain that the $B$. arietiformes (Judicarites) do not belong to Arniotites.

The only authentic members of Balatonites in the American region are found in the Middle Triassic of Nevada, where B. shoshonensis, sp. nov., and two other species, as yet undescribed, were found. This genus is characteristic of the Middle Triassic of the Mediterranean region, but it as yet unknown in the Oriental and Arctic regions.

a Cephalopoden der Mediterranen Triasprovinz: Abhandl. K.-k. geol. Reichsanstalt, Wien, vol. 10, 1882, p. 77. $b$ Das jüngere Palcozoicum aus der Araxes-Enge bei Djuifa: Reitr. Pal. und Geol. Osterreich-Ungarns und des Orients, vol. 12 , pt. 4,1900, p. 200.

c. Whiteaves, J. F., Fossils of the Triassic Rocks of British Columbia: Contributions Canadian Paleontology, Geol Nat. Hist. Survey Canada, vol. 1, pt. 2, 1889, p. 144. 
BALATONITES SHOSHONENSIS Hyatt and smith, sp. nov.

Pl. XXIII, figs. 12 and 13.

Evolute, discoidal, widely umbilicate, laterally compressed. Whorls little embracing, and little indented by the inner volution; low, and increasing slowly in height. The beight of the whorl is about one-third of the total diameter, and the width about two-thirds of the height. The width of the umbilicus is nearly one-half of the diameter-of the shell. The umbilical shoulders are abrupt, the flanks slightly convex, with obtusely angular abdominal shoulders, and rather narrow venter, rising to the central angular ridge. The surface is ornamented with radial bifurcating ribs that run nearly straight across the venter, beading the central ridge. There is a row of knots at the beginning of these ribs on the umbilical shoulders, a second row of much larger knots on the middle of the flanks, and a third, less prominent, on the abdominal shoulders. The central ridge is also provided with a row of small knots. This form, therefore, belongs to the group of Balatonites gemmati.

The septa could not be seen in detail; being mostly covered by the shell; the saddles are certainly rounded, but the serrations on the lobes could not be made out.

This species does not seem to be nearly related to any known European form, but has all the marks of the genus.

Horizon and locality.-In the Middle Triassic, of the Shoshone Mountains, Nevada, from longitude $117^{\circ} \mathrm{W}$., collected by the Whitney expedition. Only a single specimen was found, and this was loaned to the writers from the Whitney collection, in the Museum of Comparative Zoology of Harvard University. The exact locality was not recorded, but it was associated with typical Middle Triassic forms.

Genus CHRATITHS de Haan.

1825. Ceratites, de Haan, Monographiæ Ammoniteorum et Gonit. Specimen, p. 39.

1879. Ceratites (pars), Mojsisovics, Vorläufige kurze Uebersicht der Ammoniten-Gattungen der Mediterranen und Juvavischen Trias: Verhandl. K.-k. geol. Reichsanstalt, Wien, p. 198.

1882. Ceratites, Mojsisovics, Cephalopoden der Mejditerranen Triasprovinz: Abhandl. K.-k. geol. Reichsanstalt, Wien, vol. 10, p. 18.

1886. Ceralites, Mojsisovics, Arktische Triasfaunen: Mém. Acad. imp. sci. St.-Pétersbourg, sér. 7, tome 33, No. 6 , p. 19.

1887. Ceraties, Hauer, Cephalopoden des Bosnischen Muschelkalkes: Denkschr. K. Akad. Wiss., Wien, vol. 54, p. 24.

1888. Ceratites, Mojsisovics, Ueber einige Japanische Trias Fossilien: Beitr. Pal. und Geol. OsterreichUngarns und des Orients, vol. 6, p. 168.

1892. Ceratites, Haner, Beitr. Kennt. Cephalopoden der Trias von Bosnien: Denkschr. K. Akad. Wiss., Wien, vol. 59 , pt. 1, p. 260 . 
1893. Ceratites, Mojsisovies, Die Cephalopoden der Hallstätter Kalke: Abhandl. K.-k. geol. Reicheanstalt, Wien, vol. 6, pt. 2, p. 397:

1895. Ceratites, Waagen, Fossils from the Ceratite Formation: Salt Range Fossils, vol. 2, p. 34: Mem: Geol. Survey India, Pal. Indica, ser. 13.

1895. Cerctites, Diener, Cephalopoda of the Muschelkalk: Himalayan Fossils, vol. 2, pt. 2, p. 5: Memı: Geol. Survey India, Pal. Indica, ser. 15.

1895. Ceratites, Arthaber, Die Cephalopodenfauna der Reiflinger Kalke: Beitr. Pal. und Geol. Oesterreich-Ungarns und des Orients, vol. 10, pt. 1, p. 43.

1896. Ceratites, Hauer, Beitr. Kennt. Cephalopoden Trias von Bosnien: Denkschr. K. Akad. Wiss., Wien, vol. 63, pt. 2, p. 251.

1896. Ceratites, Toula, Eine Muschelkalkfauna am Golfe von Ismid in Kleinasien: Beitr. Pal. und Geol. Osterreich-Ungarns und des Orients, vol. 10, pt. 4, p. 166.

1897. Ceratites, Diener, Cephalopoda of the lower Trias: Himalayan Fossils, vol. 2, pt. 1, p. 20: Mem. Geol. Survey India, Pal. Indica, ser. 15.

1898. Ceratites, Tornquist, Neuere Beitrüge zur Geol. und Pal., Umgebung von Recoaro, etc.: Zeitschr. Deutsch. geol. Gesell. vol. 50, pt. 14, p. 59.

1900. Ceratites, Diener, Die Triadische Cephalopoden-Fauna der Schiechlinghöhe bei Hallstatt: Beitr. Pal. und Geol. Osterreich-Ungarns und des Orients, vol. 13, p. 5.

1901. Ceratites, Philippi, Die Ceratiten des oberen deutschen Muschelkalkes: Pal. Abhandl. von Dames und Koken (Neue-Folge), vol. 4, pp. 347-458.

1902. Ceratites, Mojsisovics, Das Gebirge um Hallstatt, Abtheil I, vol. 1, Supplement-Heft, p. 326.

1904. Ceratites, J. P. Smith, Comparative Stratigraphy of the Marine Trias of Western America: Proc. California Acad. Sci., 3d ser., vol. 1, p. 382.

Type.- "Ammonites" nodosus Brugiere, figured by de Haan in his Monographix Ammoniteorum et Goniatiteorum Specimen, 1825, p. 39.

This genus, which is the commonest and most widely distributed. of Middle Triassic ammonites, as well as the most characteristic, is the most difficult of all to define. After de Haan introduced the name Ceratites, all ammonites with ceratitic septa were assigned to this genus, thus including species from the most diverse genera and even families. The type species is common in the Germanic basin, but until recently unknown outside of that province, and so most of the writers that have dealt with Ceratites have described species from other provinces and other regions. It could not be expected that they would all agree with the type, and hence these writers have had free rein to extend the genus as pleased them. They have thus extended the generic limits, which is allowable and necessary, but there has been little uniformity in their extensions. Further than this they have overlooked the fact that the original type must be the typical form, and in many cases have come to regard the group of Ceratites nodosi as exceptional and the Alpine and Asiatic forms as normal, which is unwarranted.

Waagen's ${ }^{a}$ monograph was the first to give a comprehensive, elastic, and exact definition of the genus Ceratites, and even his work was based entirely on Asiatic

\footnotetext{
$a$ Fossils from the Ceratite Formation: Salt Range Fossils, vol, 2, 1895: M $\mathrm{cm}$, Geol. Survey India, Pal. Indica, ser. 13.
} 
species, which depart considerably from the Germanic prototypes. Dr. A. Tornquist was the first to make a systematic comparison of the Germanic ceratites with the Alpine and other groups, and to him is due the reestablisbment of the group of Nodosi in its real importance as the typical and normal forms.

The group of Nodosi embraces forms of moderate involution, not deeply. embracing, but increasing rather rapidly in diameter, thus causing the umbilicus to be wide. The whorls are subquadratic in cross section, usually higher than wide, with square abdominal shoulders and flattened venter.

The sculpture consists of ribs starting out from knots on the umbilicus and running nearly straight up the sides, either single or bifurcating. These ribs do not usually extend beyond the abdominal shoulders, which separate the sculptured sides from the ventral portion usually destitute of all sculpture; in a few groups a low central ridge is present. The umbilical and abdominal shoulders are provided with strong knots, which may also occur on the ribs on the sides. These knots, however, are not set close together as in Balatonites and Trachyceras.

The septa consist of rounded saddles and serrated lobes; the external lobe is divided by a siphonal saddle into two rather narrow branches. There are two laterals and a series of several small auxiliaries, which may be reduced to mere denticulations of a nearly straight saddle. The internal (intisiphonal) lobe is long, narrow, and bifid, flanked by a lateral and an auxiliary series, corresponding closely with the outside septa. In the more specialized forms the lobes may be weakly ammonitic. The body chamber is rather short, being not more than three-quarters of a revolution in length.

Ceratites bears the greatest resemblance to Hungarites, from which it differs in the rugose sculpture, the greater evolution, the absence of abdominal shoulder keels, and almost total absence of a ventral keel. The two genera agree exactly in septation, and this resemblance indicates their kinship. Hungarites is the older and more primitive form, and may be the ancestor of Ceratites, although this is not likely. E. von Mojsisovics has always regarded Dinarites as the radicle of this group, but this genus appears not to have existed in the older part of the Lower Triassic, in beds older than those containing Ceratites, while Hungarites occur's even in the Permian. This latter genus is usually classed with the Eeiostraca, but this artificial classification can not separate groups that are manifestly closely related.

As to the more remote ancestor of Ceratites, all species of this group go through a stage resembling Tirolites, which is probably the primitive radicle, not only of Ceratites, but also of the entire family Ceratitida. The group has been usually derived from the goniatite family Glyphioceratida, to which the young of Ceratites have no resemblance. The typical members of the Ceratitide in their adolescent and late larval stages resemble the Prolecanitidæ, and are probably connected with that group through Paralecanites. 
E. von Mojsisovics ${ }^{a}$ attached to the genus Ceratites a multitude of so-called subgenera, most of which bear little resemblance to the group of Nodosi, and probably have little kinship with it; but as they do not occur in the American Triassic the writers can not enter into a critical discussion of them.

Ceratites is characteristic of the Middle Triassic of the Mediterranean, Oriental, Arctie, and American regions, but in India and Siberia it is also found in the upper part of the Lower Triassic. And it has also been described by Mojsisovics from the Upper Triassic of the Alpine province, although the forms ascribed to Ceratites are greatly modified from the original type of the Nodosi, and probably not congeneric with it.

It has been found by J. P. Smith to be abundant in the Middle Triassic of the W est Humboldt Range of Nevada, represented not only by Ceratites humboldtensis, the species described in this paper, but also by a large number of new species, closely allied to forms from the Muschelkalk of Europe and Asia, and some that may even be identical with Mediterranean forms.

CERATITES HUMBOLTENSIS Hyatt and Smith, sp. nov.

Pl. LVII, figs. 1-23.

Moderately involute, deeply embracing, the outer whorl concealing about thrcefifths of the inner, and being indented to about one-fifth of its height by it. Whorl of moderate height, nearly one-half of the diameter of the shell, and the width is four-fifths of the height. Greatest width at a point one-third of the distance above the base of the whorl. Cross section trapezoidal. Sides convex, widening to the lateral row of knots, then sloping steeply to the square abdominal shoulders. Venter broad and flattened, but with a low central ridge. Width of the venter one-half of the height of the whorl. Umbilical shoulders abrupt, inner slope vertical. Umbilicus wide and deep, the width being one-fourth of the diameter of the shell.

Surface ornamented with coarse ribs that start from the umbilical shoulders without distinct umbilical knots, branch at the strong lateral knots at one-third of the beight of the whorl, then bend gently forward to the abdominal shoulders, where they end in strong marginal knots. At first these marginal knots lie opposite each other, but in old age they occupy alternate positions. Some of the ribs do not bifurcate, and have no lateral knots, but there is no regularity in the alternation, about every third rib being single. The full length of the body chamber could not be determined, but it is at least two-thirds of a revolution.

The septa are ceratitic, the saddles being slightly wavy and the principal lobes serrated. The external lobe is divided by a short, narrow siphonal notch into two short branches. The first lateral- lobe, which lies just below the shoulder, is

a Die Cephulopoden der Hallstätter Kalke: Abhandl. K.-k. geol. Reichsanstalt, Wien, vol. 6, pt. 2, 1893, p. 397. 
much wider and longer; the second lateral lobe is about one-half as large as the first and also serrated. These are followed by three small auxiliary lobes on the umbilical shoulder. The antisiphonal lobe is long, flanked by two internal laterals on each side. The external saddle lies on the abdominal shoulder, the first lateral saddle lies in the middle of the flank, and the second lateral lies on the row of lateral knots.

The foregoing description applies only to the mature shell. The young stages descrited and figured were broken out of large characteristic specimens, to avoid the danger of confusion with the other numerous'species of Ceratites with which C. humboldtensis is associated.

The earliest stage obtained was 4.5 millimeters in diameter; it is evolute, with depressed broad, half-moon-shaped whorls, wide umbilicus, and surface ornamented only with a few straight umbilical ribs. This stage seems to correspond with Tirolites.

At diameter of $8 \mathrm{~mm}$. the whorl is as high as broad, the sides begin to flatten, and the ribs are much more numerous, still single, but they curve slightly at the round ventral shoulders. This stage is already adolescent and resembles Dinarites.

At $13 \mathrm{~mm}$. the flanks are differentiated in shape and sculpture from the slightly flattened venter. The ribs show the beginning of bifurcation, and form incipient marginal knots at their ends on the shoulders.

At $18 \mathrm{~mm}$. the marginal knots become strong, the lateral knots begin to be distinct, and the ventral ridge begins to show. The shell at this stage is broader proportionally than at maturity; the umbilicus is wider, being one-third of the diameter.

At $28 \mathrm{~mm}$. the whorl has become higher than wide, and the marginal knots are as distinct as at maturity. The lateral sculpture is not yet so rough as it becomes later, and this may be considered as marking the end of the adolescent stage.

At $33 \mathrm{~mm}$. the sculpture has taken on mature characters, although the saddles are still rounded and entire. This is considered as the beginning of maturity.

Ceratites humboldtensis is closely related to C. brembanus Mojsisovics (Cephalopoden der Mediterranen Triasprovinz, p. 38, Pl. X, figs. 1-4), of the Alpine Muschelkalk, but differs from that species in its more robust whorl, coarser lateral sculpture, and in lacking distinct, umbilical knots. From C. trinodosus Mojsisovics, of the same group, it differs in its greater evolution, coarser sculpture, and more robust whorl.

Its nearest European relative is Ceratites subnodosus Mojsisovics (Cephalopoden der Mediterranen Triasprovinz, p. 33, Pl. X, figs. 9-11), from which it differs in its fainter umbilical and stronger lateral knots. The ribs, shape of the whorl, general sculpture, and involution are the same in both species. The associations of both 
species are virtually the same, and Ceratites humboldtensis may be considered as the American representative of $C$. subnodosus.

Horizon and locality.-Middle Triassic Daonella beds, on the divide between Troy Canyon and the South Fork of American Canyon, in the saddle nearest to the Star Valley, 4 miles south of Foltz post-office, West Humboldt Range, Nevada, associated with numerous other species of Ceratites, $C$. conf. trinodosus, $C$. conf. planus, etc., Anolcites Whitneyi, A. Meeki, Beyrichites rotelliformis, Celtites Halli, Longobardites nevadanus, Gymnotoceras Blakei, Eutomoceras Laubei, Sageceras Gabbi, Acrochordiceras Hyatti, Daonella dubia, and many other forms characteristic of the Middle Triassic. Ceratites humboldtensis was found by J. P. Smith to be very common at the above-mentioned locality, and also in Cottonwood Canyon near the "Lucky Dog" mine, West Humboldt Range, in the same association. The horizon might very appropriately be named after this characteristic species. J. P. Smith also found at Silverthorn's ferry on Pit River, Shasta County, Cal., some poorly preserved Ceratites that probably belong to this species.

Subgenus GYMNOTOCERAS Hyatt.

1877. Gymnotoceras, Hyatt, in F. B. Meek, U. S. Geol. and Geog. Explor. 40th Par., vol, 4, p. 110.

Type-Ammonites Blakei Gabb, Geological Survey California, Palieontology, 1864, vol. 1, p. 24, Pl. IV, figs. 14-15; and F. B. Meek, U. S. Geol. Explor. 40th Par., vol. 4, 1872, p. 113, Pl. X, figs. 10, 10a, 10b, 10c. (not Pl. XI, fig. 6).

Involute, laterally compressed, robust whorls, deeply embracing, but not deeply indented by the inner volutions. Sides convex, abdominal shoulders rounded, venter high and raised in the middle in a keel-like ridge. Umbilicus moderately narrow, but exposing the inner whorls.

Surface ornamented with sigmoidal ribs, which branch on the sides and swing sharply forward across the rounded shoulders to the median ridge. There are no umbilical nodes and none on the flanks, but in old age the ends of the ribs tend to form knots on the shoulders, although these are never prominent. The body ehamber seems to be long, nearly a revolution, but the genus can not be classed with the Tropitidæ on account of its ontogeny, which is that of the Ceratitidæ.

Septa ceratitic, lobes serrated, saddles rounded and slightly denticulated. The septa figured by Gabb in Geol. Survey California, Palæontology, vol. 1, Pl. IV, fig. 15; were taken probably from a weathered specimen, and hence are not correct in detail.

Mojsisovics ${ }^{a}$ says that Gymnotoceras is merely a synonym of the group of Ceratites geminati, characteristic of the Arctic Triassic. It seems to the writers,

a Arḱtische Triasfaunen: Mém. Acad. imp. sci..St.-Pétersbourg, sér. 7, tome 33, No. 6, 1886, p. 23. 
however, that the characters are sufficiently distinct from those of Ceratites nodosus to warrant giving subgeneric rank to this group, which would then include the Ceratites geminati. As thus characterized, Gymnotoceras is characteristic of the Middle Triassic of Nevada and northern Siberia. It is very common in the Middle Triassic of the West Humboldt Range, Nevada, where it is represented by Gymnotoceras Blakei and several undescribed speciès.

\section{CERATITES (OYMNOTOCERAS) BLAKEI Qabb.}

Pl. XXII, figs. 1-23.

1864. Ammonites Blakei, Gabb, Geol. Survey California, Palæontology, vol. 1, p. 24, Pl. IV, figs. 14 and 15.

1877. Gymnotoceras Blakei, Meek, U. S. Geol. and Geog. Explor. 40th Par., vol. 4, p. 113, Pl. X, figs. 10, 10a, 10b, 10c. (not Pl. XI, fig. 6).

Form involute, robust, latcrally compressed. Whorl deeply embracing, but not deeply indented by the inner volution. Sides flattened-convex, venter high and narrowed to a median keel. Abdominal shoulders narrow and sloping in early maturity, more abrupt later in life. Umbilicus rather narrow and deep, umbilical shoulders abruptly rounded, with steep inner walls. The height of the whorl is about one-half of the total diameter, and the width is three-fourths of the height. The indentation is one-fourth of the height. The width of the umbilicus is about one-fifth of the total diameter.

The surface is ornamented with strong, radial, dichotomous ribs, that branch on the flanks one-third of the way up from the umbilicus and bend sharply forward on the abdominal shoulders, becoming obsolete at the median ridge or keel.

The septa are ceratitic, the lobes being serrated, the saddles rounded and slightly serrated. The septa figured by Gabb, in Geological Survey California Palæontology, vol. 1, Pl. IV, fig. 15, and by. Meek in U. S. Geol. Explor. 40th Par., vol. 4, Pl. X, fig. 10c, were probably not drawn from a weathered specimen, and are not correct in detail. Meek copied the septa from Gabb. The young shell is much more evolute than the mature form, as shown in the young specimens figured.

In the young the cross section of the whorl is nearly circular, with the exception of the impressed zone; the ribs are fine, and much straighter than at maturity, and in the earliest stages are present only on the umbilical shoulders.

The body chamber is nearly or quite a complete revolution in length, and increases the resemblance to Paratropites, but the young stages are not like those of the Tropitidæ. 
G. von Arthaber ${ }^{a}$ has described, in the genus Reiflingites, a. somewhat similar group, that resembles Ceratites in form and septa, but has a. long body chamber. The writers, however, are not of the opinion that the length of the body chamber has the paramount taxonomic value that is commonly ascribed to it. The form figured by Meek, U. S. Geol. Survey 40th Par., vol. 4, Pl. XI, fig. 6, does not belong to Gymnotoceras.

Horizon and locality.-Ceratiles (Gymnotoceras) Blakei Gabb was found by the Geological Survey of California under Whitney in the Middle Triassic limestone, Daonella beds, near Star City, West Humboldt Range, Nevada. It was found by J. P. Smith to be very abundant in the Middle Triassic Daonella beds, of the West Humboldt Range, in Cottonwood Canyon, near the "Lucky Dog" mine; and on the divide between the South Fork of American Canyon and Troy Canyon, about 4 miles south of Foltz post-office, associated with Geratites humboldtensis, Beyrichites rotelliformis, Anolcites Whitneyi, Daonella dubia, and many other species characteristic of the Middle Triassic.

Genus ARPADITHe Mojsisovios.

1879. Arpaditts, Mojsisovics, Vorläufige kurze Uebersicht der Ammoniten-Gattungen der Mediterranen und Juvavischen Trias: Verhandl. K.-k. geol. Reichsanstalt, Wien, p. 140.

1882. Arparlites, Mojsisovies, Cephalopoden der Mediterranen Triasprovinz: Abhandl. K.-k. geol. Reichsanstalt, Wien, vol. 10, p. 52.

1893. Arpadites (pars), Mojsisovics, Cephalopoden der Hallstätter Kalke: Abhandl. K.-k: geol. Reichsanstalt, Wien, vol. 6, pt. 2, p. 450.

1898. Arpadiles, Tornquist, Zeitschr. Deutsch. geol. Gesell., vol. 50, pt. 4, p. 647.

Type--Ammonites Arpadis Mojsisovics, Beitr. Kennt. Cephalopoden-Fauna der Oenischen Gruppe, 1870, p. 109, PI. V, fig. 6, and Cephalopoden der Mediterranen Triasprovinz, 1882, p. 54, Pl. XXV, fig. 29;

As originally defined, Arpadites embraced rather evolute, discoidal, laterally compressed forms, with wide shallow umbilicus, flattened sides, and narrow venters. The whorls are not deeply' embracing, but are higher than wide. The venter has a furrow bounded by ridges or keels; may be either smooth or crenulated. There are umbilical knots from which ribs extend toward the shoulder keels, often becoming fainter on the sides, on which a few tubercles may be developed.

The septa are ceratitic, with rounded narrow entire saddles, and serrated lobes, of which there are four, the divided external, the two laterals, and a small auxiliary on the umbilical shoulder.

Arpadites is clearly a descendant of Ceratites, from which it differs in the greater lateral compression, the narrow venter, the ventral furrow bounded by shoulder keels, and the absence of the elongated auxiliary series of lobes.

a Cephalopodenfauna der Reitlinger Kalke: Beitr. Pul, und Geol. Osterreich-Ungarns und des Orients, vol. 10, 1896 , p. 72 . 
This genus is known at present from the upper Muschelkalk, Middle Triassic of the Alps, and the lower part of the Upper Triassic of the Alps, India, and California, where it is represented by Arpadites Gabbi, sp. nov. and one undescribed species.

ARPADITES GABBI Hyatt and Smith, sp. nov.

Pl. XXXIX, figs. 1-17; PI. LXXXIII, figs. 1-13.

Laterally compressed, involute, discoidal, deeply embracing, and deeply indented by the inner volutions. Whorls high and narrow, increasing rapidly in height. Umbilical shoulders abruptly rounded, sides flattened-convex. Venter narrow, channeled, bounded by marginal ridges slightly beaded. The height of the whorl is a little more than one-half of the total diameter; the breadth of the whorl is three-sevenths of the height. The outer whorl covers seven-eighths of the inner, and is indented to two-sevenths of the height by it. The umbilicus is narrow, but open, exposing the umbilical shoulders of the inner whorls in steps; its width is one-eighth of the diameter of the shell. The surface of the shell is ornamented with umbilical knots which are extended up the sides in low folds, made up of bundles of sigmoidal striæ. These folds are faint on the sides, but become strong again at the abdominal marginal ridges, giving to them a beaded appearance. This sculpture shows on the cast as well as on the shell.

The septa are ceratitic, saddles all rounded and entire, lobes all serrated. The ventral lobe is divided by a shallow siphonal notch into two short narrow branches with three serrations. The first lateral lobe is broad and deep, terminating in fine serrations. The second lateral is smaller, less than one-half the size of the first, and trifid. The auxiliary series is composed of two small lobes, bardly more than notches, on the umbilical shoulder. Antisiphonal lobe rather long and narrow, flanked by a shorter lateral.

The foregoing description applies only to the mature shell, for the young stages are absolutely unlike the adults. The inner coils, up to a diameter of $2.5 \mathrm{~mm}$, are evolute, broad, low-whorled, with wide umbilicus, genuine Tirolites in shape, with depressed volutions, and somewhat flattened venter, and strong marginal tubercles, but no furrow. The ventral lobe is undivided, narrow, and there is but a single lateral, with a very small auxiliary on the umbilical shoulder. The antisiphonal lobe is flanked by a small lateral, hardly larger than the external auxiliary.

The larval stage just before the appearance of the furrow has the following dimensions:

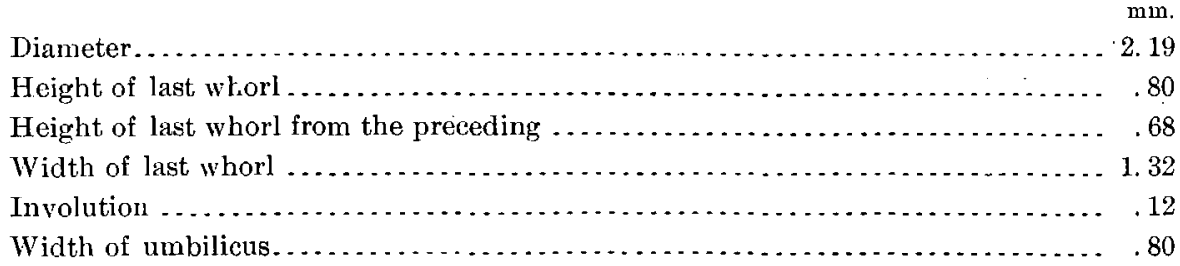


At the diameter of $2.5 \mathrm{~mm}$. the ventral furrow begins, but the Tirolites shape persists for one-half of a revolution farther to the dianeter of $4 \mathrm{~mm}$. At this size the whorl becomes higher, and the sides developed. 'The tubercles are no longer lateral but umbilical, and the stage corresponds to Dinarites with the exception of the ventral furrow. Two specimens in this stage had the following dimensions:

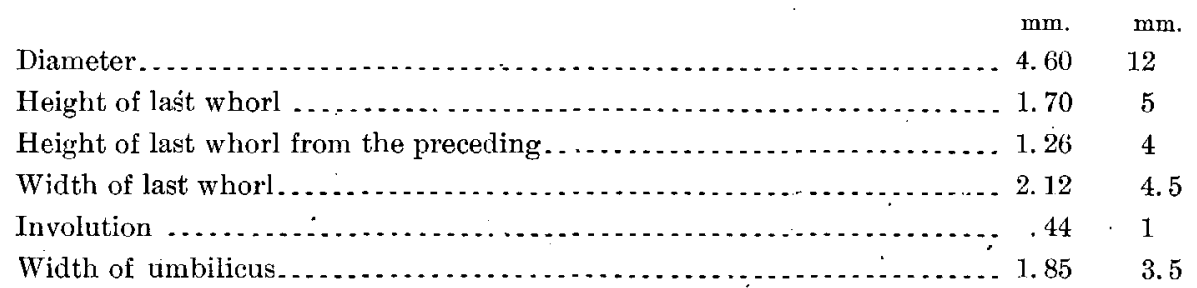

These dimensions show the whorl to be proportionally higher and the umbilicus narrower than in the Tirolites stage; the marginal knots have become umbilical ribs, which are extended up the sides, but do not yet reach the abdominal shoulders. This stage lasts to the diameter of $11 \mathrm{~mm}$. At this size the whorl increases rapidly in height, and becomes laterally compressed. The shell is now analogous to Ceratites, in which stage it remains to the diameter of about $20 \mathrm{~mm}$. A specimen in this stage showed the following dimensions:

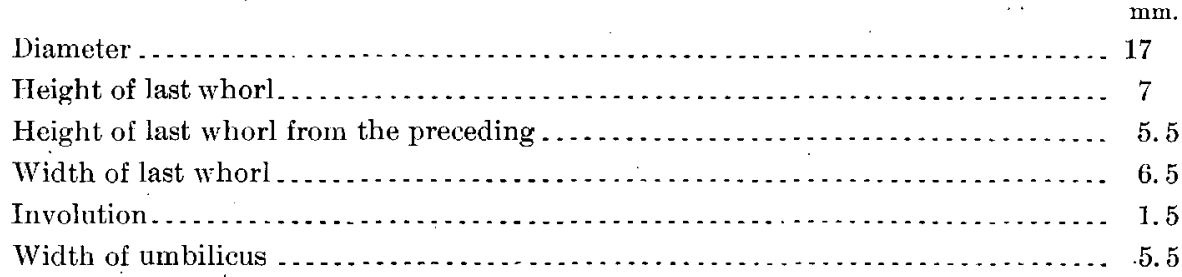

The shell then gradually makes the transition to the Arpadites stage, becoming more involute, the lateral ribs less pronounced, and the ridges bordering the ventral furrow are beaded by the ends of the lateral ribs.

Arpadites $G a b b i$ is more involute than any other described species of this genus. Its nearest relative is $A$. cinensis Mojsisovics (Cephalopoden der Mediterranen Triasprovinz, 1882, p. 56, Pl. XXVI, figs. 3-15), but A. Gabbi differs from the Alpine species in its greater involution, narrower umbilicus, higher whorl, crenulated abdominal ridges, and in its more complex septa. The late adolescent stages, of $A$. Gabbi are very like the mature form of $A$. cinensis, which is in keeping with the later age of the American species.

Horizon and locality.-Arpadites Gabbi was found by J. P. Smith in the Upper 'Triassic zone of Tropitcs subbullatus, in Shasta County, Cal., on the divide between Squaw Creek and Pit River, 3 miles east of Madison's ranch and a half mile north of the trail from Madison's to Brock's ranch on Pit River. This locality is about 6 
miles northeast of Winthrop. It was associated with Tropites subbullatus Hauer, T. torquillus Mojsisovies, Paratropites Sellai Mojsisovics, Sagenites Herbichi Mojsisovics, Discotropites sandlingensis Hauer, Halobia superba Mojsisovics, and many other forms characteristic of the upper Karnic horizon.

Genus ACROCHORDICHRAS Hyatt.

1877. Acrochordiceras, Hyatt, U. S. Geol. and Geog. Explor. 40th Par., vol. 4, p. 124.

1879. Acrochordiceras, Mojsisovice, Vor]äufige kurze Uebersicht der Ammoniten-Gattungen der Mediterranen und Juvavischen Trias: Verhandl. K.-k. geol. Reichsanstalt, Wien, p. 139.

1880. Acrochordiceras, Noetling, Zeitschr. Deutsch. geol. Gesell., vol. 32, p. 334 .

1882. Acrochordiceras, Mojsisovics, Cephalopoden der Mediterranen Triasprovinz: AbhandI. K.-k. geol. Reichsanstalt, Wien, vol. 10, p. 140.

1887. Acrochordiceras, Hauer, Cephalopoden des Bosnischen Muschelkalkes von Han Bulog bei Sarajevo: Denkschr. K. Akad. Wiss., Wien, vol. 54, p. 22.

1892. Acrochórdiceras, Hauer, Beitr. Kennt. Cephalopoden der Trias von Bosnien: Denkschr. K. Akad. Wiss., Wien, vol. 59, pt. 1, p. 272.

1895. Acrochordiceras, Waagen, Fossils from the Ceratite Formation: Salt Range Fossils, vol. 2, p. 89: Mem. Geol. Survey India, Pal. Indica, ser. 13.

1895. Acrochordiceras, Diener, Cephalopoda of the middle Trias.: Himalayan Fossils, vol. 2, pt. 2, p. 35: Mem. Geol. Survey India, Pal. Indica, ser. 15.

1895. Acrochordiceras, Diener, Triadische Cephalopodenfaunen 'der ostsibirischen . Küstenprovinz: Mém. Com. géol., St.-Pétersbourg, vol. 14, No. 3, p. 22.

1896. Acrochordiceras, Arthaber, Cephalopodenfauna der Reiflinger Kalke: Beitr. Pal. und Geol. Oesterreich-Ungarns und des Orients, vol. 10, pt. 1, p. 79, and pt. 2, p. 226.

Type-Acrochordiceras Hyatti Meek, U. S. Geol. and Geog. Explor. 40th Par., vol. 4, p. 124, Pl. XI, figs. 5 and 5 a.

Whorls robust, laterally compressed, higher than wide, moderately involute, deeply embracing, but not deeply indented by the inner whorls. Umbilicus open, deep and moderately wide. Umbilical shoulders abrupt, sides convex, somewhat flattened, venter rounded and highly arched.

Surface ornamented with strong ribs that bundle on umbilical knots and then, without further division, run nearly straight across the venter. 'The septa are ceratitic, but complex; the saddles are all rounded and entire, but the digitations of the lobes run high upon the sides of the saddles. The external lobe is divided into two narrow branches by the siphonal saddle; the principal lateral lobe is very long and broad, deeply digitate, with four or five long branches; there are usually two auxiliary lobes present, of which the first might be considered as a second lateral, except that it is so much smaller and simpler than the principal lateral. In some species the second auxiliary is lacking, although it is present on the type Acrochordiceras Hyatti. The body chamber is long, about one revolution. This genus resembles 16918-No. $40-05-12$ 
Juvavites Mojsisovies, from which it differs in the very strong umbilical knots, the simplicity of the coarse ribs, and in the ceratitic septa. Acrochordiceras is usually classed in the Tropitidie because of this resemblance, but the writers have studied the young of an undescribed species and found them to resemble Ceratites in development, and to be absolutely unlike the young of Tropites or any of the group. On this account it is classed under the Ceratitidæ.

The genus Acrochordiceras is confined to the Middle Triassic except in the Salt Range in India, where it has been found in the Lower Triassic. It is represented in America by Acrochordiceras Hyatti Meek, and one or two undescribed species.

\section{ACROCHORDICERAS HYATTI Meek.}

PI. XXIII, figs. 8-11.

1877. Acrochordiceras IIyatti, Meek, U. S. Geol. and Geog. Explor. 40th Par., vol. 4, p. 124, Pl. XI, figs. 5 and $5 \mathrm{a}$.

Form robust, somewhat compressed laterally, moderately evolute. Whorl with flattened-convex sides, highly arched and broadly rounded venter, deeply embracing but not deeply indented by the inner whorl. The umbilicus is broad and deep, exposing nearly half of each of the inner whorls. The height of the whorl is one-half of the total diameter of the shell, and the width is four-fifths of the height. The indentation is one-fifth of the height. The width of the umbilicus is one-fourth of the total diameter of the shell.

The surface is ornamented with coarse, rounded ribs, that run from the umbilicus straight across the venter, without interruption. There are strong nodes on the flanks just above the umbilical shoulders, formed by the junction of two or three of the ribs. Between these nodes there are usually two ribs not joined, but the interval is irregular.

The septa are ceratitic, the saddles being rounded and entire, while the lobes are digitate. The external lobe is divided by a triangular siphonal notch into two short and narrow branches; the first lateral lobe is more than twice as long and very wide, digitate, with five long branches. The second lateral, or first auxiliary, is about half the length and breadth of the first, with four branches. On the umbilical shoulder is a second auxiliary smaller and simpler than the first.

Horizon and locality.-Meek's type specimen came from the Middle Triassic limestone of New Pass, Desatoya Mountains, Nevada; the specimen figured on Pl. XXIII, figs. 8-11, came from the same horizon, in the Shoshone Mountains, Nevada. J. P. Smith found it to be common in the Middle Triassic of the West Humboldt Range, Nevada, in Cottonwood Canyon near the "Lucky Dog" mine, associated with Gymnotoceras Blakei, Beyrichites rotelliformis, Anolcites Whitneyi, Daonella dubia, and many other species. 
Genus FUDiscoChras Hyatt.

1877. Fudiscoceras, Hyatt, in F. B. Meek, U. S. Geol. and Geog. Explor. 40th Par., vol. 4, p. 128.

Type.-Eudiscoceras Gabbi Meek, U. S. Geol. and Geog. Explor. 40th Par., vol. 4 , p. $128, \mathrm{Pl}$. XI, figs. 3 and $3 \mathrm{a}$.

Discoidal, involute, laterally compressed, deeply embracing, high whorled. Venter narrow, with a central keel, bordered by two furrows and abdominal shoulder keels. Umbilicus moderately wide. Surface ornamented with flexuous dichotomous ribs, which end at the shoulder ridges, and form knots on them. Septa unknown.

This genus seems to belong to the Ceratitidæ in the group allied to Arpadites, but, on acconnt of the imperfect condition of the type, its true relationship is unknòwn.

It is known only in a single species from the Middle Triassic of the West Humboldt Range, Nevada.

\section{Eddiscoceras GaBBI Meek.}

Pl. XXIV, figs. 1 and 2.

1877. Eudiscoceras Gabbi Meek, U. S. Geol. and Geog. Explor. 40th Par., vol. 4, p. 128, Pl. XI, figs. 3 and $3 a$.

Discoidal, involute, laterally compressed. Whorls high, and increasing rapidly in height; narrow, with high cross section; sides gently convex, venter narrow, with marginal keels, and a central keel in the median depression. The last whorl is deeply embracing, concealing about two-thirds of the inner volution; its height is three-sevenths of the total diameter of the shell. The umbilicus has abrupt inner walls, is shallow, and its width is about three-tenths of the total diameter.

The surface is ornamented with flexuous ribs, which end in small knots, beading

- the marginal keels; these ribs become finer as the shell grows older. The septa are unknown.

The shape and ornamentation suggest relationship or identity with Arpadites, but the specimen is too imperfect to warrant any definite opinion. The septa and the young stages have not been seen, so it is not known certainly that this species belongs to the Ceratitidæ.

Horizon and locality.-In the Middle Triassic, Cottonwood Canyon, West Humboldt Range, Nevada, the only specimen known being the original type in the United States National Museum.

Genus CAIIFORNITHS Hyatt and Smith, gen. nov.

Type-Californites Merriami Hyatt and Smith.

Evolute, low whorled, little embracing, scarcely impressed by the inner volutions. Umbilicus wide, umbilical shoulders abrupt, cross section trapezoidal, 
with flattened sides sloping outwardly to the angular abdominal shoulders. Venter low-arched, nearly smooth, and with distinct central furrow. Sides ornamented, with straight ribs that have short knots on them, and end in strong spines on the abdominal shoulders. The venter is nearly smooth. The septa are ceratitic, consisting of a divided external lobe, a principal lateral, and a small auxiliary on the umbilicus. The body chamber is short.

This genus is the direct descendant of Tirolites, and differs from it chiefly in the ventral furrow. It is of especial importance in the phylogenetic history of the group of Clionites, for all spinose members of that group go through a distinct Californites stage, and some persist in it almost until maturity.

Californites is known only from the Upper Triassic, zone of Tropites subbullatus, of Shasta County, Cal., where the species described below and one other form have been found.

\section{CALIFORNITES MERRIAMI Hyatt and Smith, sp. nov.}

\section{Pl. LXXXII, figs. 11-23.}

Form evolute, robust, low whorled. Whorl little embracing and little indented by the inner volution; low, and increasing slowly in height. Cross section trapezoidal, wider at the top. Sides flattened, sloping outward. Abdominal shoulders abrupt and square, venter flattened and broad. The beight of the whorl is less than one-third of the total diameter of the shell; the width is slightly greater than the height, and the indentation is only one-ninth of the height. The width of the umbilicus is three-sevenths of the total diameter of the shell.

The surface is ornamented with coarse ribs that start from a row of knots on the umbilical shoulders and run straight up the sides, ending in strong spines on the abdominal shoulders. From these marginal spines finer ribs extend obliquely forward on the venter. There is a strong median furrow on the venter, bounded by low, rounded ridges, at which the fine ventral ribs become obsolete.

The septa are ceratitic, all the saddles being entire. The external lobe is divided by a small siphonal notch into two narrow, short, simple lobes, which fall upon the ridges bounding the median furrow. The lateral is larger and serrated, and falls upon the abdominal shoulder. On the flank, just above the umbilical shoulder, is the small, simple auxiliary lobe. The first and second lateral saddles are large and broadly rounded.

The young stages of this species are exactly like Tirolites, and the mature form differs from that genus only in the second lobe on the flank and the median furrow. The median furrow appears at the diameter of about $6 \mathrm{~mm}$.

All species of Clionites of which the young stages have been studied go through a Californites stage of growth, and therefore this genus is regarded as the ancestor of Clionites and the connecting link with Tirolites. 
Horizon and locality.-Californites Merriami Hyatt and Smith was found by J. P. Smith in the Upper Triassic, zone of Tropites subbullatus, of Shasta County, Cal., in the limestone belt on the divide between Squaw Creek and Pit River, about 3 miles east of Madison's ranch and one-half mile north of the trail from Madison's to Brock's ranch on Pit River. This locality is 6 miles northeast of the Bully Hill mine.

The specific name is given in honor of Dr. John C. Merriam.

Genus OLIONITHS Moisisovios.

1893. Clionites, Mojsisovics, Cephalopoden der Hallst.itter Kalke: Abhandl. K.-k. geol. Reichsanstalt, Wien, vol. 6 , pt. 2 , p. 451.

1896. Clionites, Mojsisovirs, Obertriadischen Cephalopoden-Faunen des Himalaya: Denkschr. K. Akad. Wiss., Wien, vol. 63, p. 624 .

Type-Clionites angulosus Mojsisovics, Cephalopoden der Hallstätter Kalke, 1893, pt. 2, p. 465, Pl. CXXII, fig. 10.

Evolute, little embracing, whorl low, breadth usually equal to the height, inereasing slowly in height. Umbilicus wide and shallow. Umbilical shoulders abrupt, sides flattened, venter somewhat flattened, with distinct abdominal shoulders. Surface ornamented with strong ribs, usually dichotomous, which run nearly straight up the sides, and usually bifurcate just below the shoulders and then bend sharply forward. There is a central furrow, bounded by ridges made by the ends of the ribs. These ridges are rows of knots or spines, and the ribs are provided with similar knots arranged in spiral rows from the umbilical shoulders to the ridges bordering the furrow. Although these spines are present on most species of this group, they are lacking on the first species mentioned and described by Mojsisovics, $C$. angulosus, and therefore this form is only technically the type.

The body chamber is short, as is usually the case with the Ceratitidæ.

The septa are ceratitic, the external lobe is divided by a shallow siphonal saddle into two short narrow branches, which may be either entire or slightly serrated; the lateral lobe is larger and always serrated; there is also an auxiliary lobe on the umbilical shoulder. The saddles are all rounded and entire.

Mojsisovics regarded this group as a subgenus of Arpadites, from which it differs in the greater evolution and the strong spiny ribs and the ventral furrow bounded by rows of knots instead of continuous marginal keels, and also in having one lobe fewer on the sides. For these reasons, and because several distinct subgeneric groups may be distinguished under it, the writers regard Clionites as an independent genus. While it probably had a common origin with Arpadites, -it is neither ancestor nor descendant of that genus, and therefore should have independent rank. 
The following groups of Clionites are represented in the Upper Triassic of California:

(1) Group of Clionites Fairbanksi Hyatt and Smith (Clionites s. str.).

(2) Group of Clionites compressus Hyatt and Smith (subgenus Shastites Hyatt and Smith) characterized by flattened sides, high whorls, narrower umbilicus, sigmoid ribs ending in knots, forming almost continuous ridges or keels bordering the ventral furrow. The spines are obsolescent, and are represented merely by short knots.

(3) Group of Clionites rugosus Hyatt and Smith (subgenus Stantonites Hyatt and Smith) characterized by extremely evolute whorls, with ribs broken up into strong knots, giving a rugose instead of spiny appearance to the shell.

(4) Group of Clionites robustus Hyatt and Smith (subgenus Traskites Hyatt and Smith) characterized by the rougher sculpture, strong spines, and square cross section.

(5) Group of Clionites californicus Hyatt and Smith (subgenus Neanites Hyatt and Smith), characterized by the low, broad, quadratic whorls in the adolescent stage, and the sudden change of form and sculpture at maturity, when the marginal spines become obsolete, and the venter becomes highly arched.

Clionites appears in the Karnic stage of the Upper Triassic, of which horizon it is characteristic in the Mediterranean region and in California. It is also found in the Noric stage, of which horizon it is characteristic in the Himalayas, and the Alpine province. In California. it is most abundant in the upper part of the zone of Tropites subbullatus. No species of this genus has previously been found in America. Clionites s. str., Stantonites, and Traskites, are each represented in the Upper Triassic of California by several species; Neanites has two species; and Shastites has but one, although there is another that seems to be transitional from Clionites s. str. to Shastites.

The species belonging to all these groups are very similar in the later larval stages, when they resemble Tirolites; also in the adolescent stages, when they correspond to Californites, which may thus be considered as the ancestor of the genus. Shastites has departed farthest from the ancestral characters, and as a result has reduced the Californites stage almost to a minimum. Clionites s. str. has also lost most of this stage, but retains somewhat more. Stantonites is more primitive in character, and the Californites stage is prolonged, as is also that corresponding to Tirolites. Still more primitive is Neanites, in which the Californites stage is retained until the beginning of maturity, when the sudden transition to adult characters takes place. Traskites retains many of the Californites characters through life, and shows its ancestry most plainly in its ontogeny; it is the least specialized of all these groups, and consequently the most useful in tracing the history of the genus. 
CLIONITES FAIRBANKSI Hyatt and Smith, sp. nov.

Pl. XL, figs. 1-11; Pl. XLI, figs. 1-14.

Evolute, discoidal, widely umbilicate, laterally compressed. Whorl low and increasing slowly in height, little embracing, and little indented by the inner volutions. The umbilical shoulders are abrupt, with steep inward slope; the sides are flattened, and slope gently outward, so that the whorl is slightly broader at the abdominal than at the umbilical shoulders. The cross section is subrectangular, the breadth of the whorl being five-sixths of the height. The abdominal shoulders occur at three-fourths of the height of the whorl, and slope abruptly to the rather high venter. The height of the whorl is slightly more than one-third of the total diameter of the shell, and the indentation is about one-tenth of the height. 'The umbilicus is wide and shallow, being two-fifths of the total diameter. The surface is ornamented with coarse radial ribs, beginning in knots on the umbilical shoulder, running nearly straight up the flanks, bending abruptly forward at the abdominal shoulders, and ending in knots on the sides of the ventral furrow. The alternate ribs bifurcate on the abdominal shoulder, so that the ventral ribs are finer than those on the flanks. On the ribs are spiral rows of short spines, five rows on the flanks, and two between the abdominal shoulder knots and the ventral furrow.

The septa are ceratitic, saddles all rounded and entire, lobes all serrated. The ventral lobe is divided by a short siphonal notch into two narrow, slightly serrated branches, which fall upon the external row of knots. The first lateral which falls on the abdominal shoulders is broader and deeper, with fine serrations; the second lateral is about one-third of the size of the first, usually trifid, and falls on the umbilical shoulder. On the umbilical slope, partially concealed by the involution, is a small auxiliary lobe only slightly serrated.

The length of the body chamber is nearly three-fourths of a revolution.

In old age the ribs come very much closer together, the spines become longer, and one or two additional rows of knots are intercalated on the flanks. The whorl becomes rounder, nearly as broad as high, and the abdominal shoulders cease to be angular. The species grew to a diameter of at least $80 \mathrm{~mm}$, , several broken specimens of that size having been found. Senile degeneration usually begins at the diameter of about $60 \mathrm{~mm}$., although on some specimens it begins prematurely at $40 \mathrm{~mm}$.

In the larval stage the whorl is broader than high; with trapezoidal cross section, narrow flanks, angular abdominal shoulders, and broad flattened venter. The surface is ornamented only with umbilical ribs, forming nodes on the abdominal shoulders. There are no spines, no ventral furrow, and the abdomen is smooth. This stage corresponds to Tirolites. 
At diameter of about $5 \mathrm{~mm}$. the ribs begin to extend beyond the shoulders, ending in a row of knots on each side of the center, although as yet there is no ventral furrow. At about $6 \mathrm{~mm}$. the furrow begins to show, and the shell enters the Californites stage. The whorl now grows steadily higher in proportion to its width, the rows of incipient spines begin to be visible, and at a diameter of about $10 \mathrm{~mm}$. the shell enters the Clionites stage, although it does not attain the characters distinctive of this species until a diameter of $25 \mathrm{~mm}$. is reached.

The nearest described species to Clionites Fairbanksi is $C$. Woodwardi Mojsisovics, ${ }^{a}$ from the Noric horizon of the Upper Triassic of India. But the Indian species has too few spiral rows of knots and a much wider ventral furrow. The dimensions and other characters of the two species appear to be identical.

Clionites spinosus Mojsisovics, from the same horizon in India, is more similar to the Californian species in its sculpture, but differs in its lower and broader whorl.

The type specimen, figured on PI. XL, figs. 1-4, gave the following dimensions:

Dimensions of the figured specimen.

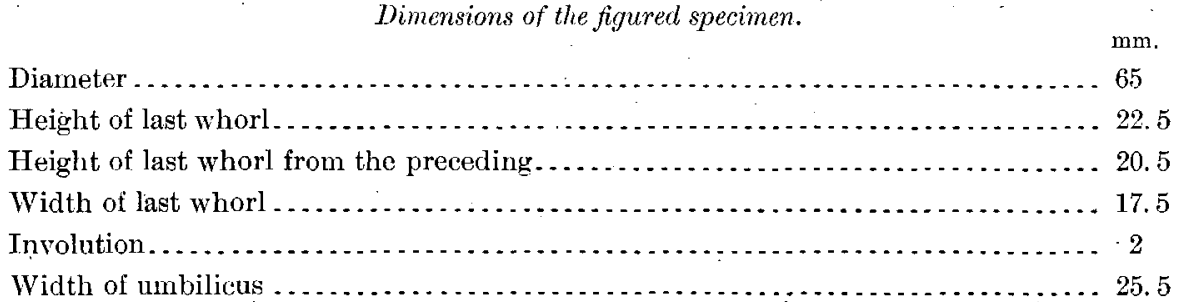

Dimensions in younger stages.

[In millimeters.]

\begin{tabular}{|c|c|c|c|c|c|c|}
\hline Diameter. & 7.50 & 10.20 & 14: & 17.5 & 32 & 47 \\
\hline Height of last whorl ...... & 2.60 & 3.40 & 5 & 6.3 & 11.5 & 18 \\
\hline Height of last whorl from preceding & 2.20 & 3.10 & 4.6 & 5.3 & 10.2 & 15.5 \\
\hline Tidth of last whorl. & 3.80 & 4. 70 & 5.2 & 7 & 10.3 & 13.5 \\
\hline ivolution $\ldots . . . . . . . .$. & .40 & .30 & .40 & 1 & 1.3 & 2.5 \\
\hline idth of umbilicus .. & 3.08 & 4.20 & 5.5 & 7 & 13 & 18 \\
\hline
\end{tabular}

Clionites Fairbanksi was chosen, out of a large number of species present in the Californian Upper Triassic, as the most typical member of the genus in the American fauna. It is an exceedingly variable species, and it was found very difficult to draw the line between this and kindred forms. The young stages, especially, are more and more alike as they are smaller, so that it becomes nearly impossible to distinguish the young of this species from those of several others in the larval and early adolescent stages; and it is even difficult to distinguish the young of Clionites s. str.

a Obertriadischen Cephalopoden-Faunen des Himalaya: Denkschr. k. Akad, Wiss., Wien, vol, 63, p. 624, PI. XIII, figs. 4 and 5 . 
from those of the subgenera Traskites, Stantonites, and Shastites until the adolescent stage has begun.

Horizon and locality.--In the Upper Triassic, zone of Tropites subbullatus, of Shasta County, Cal., on the divide between Squaw Creek and Pit River, 3 miles east of Madison's ranch and one-half mile north of the trail to Brock's.

The specific name is given in honor of Dr. H. W. Fairbanks, the discoverer of this fauna.

Subgenus STANTONITES Hyatt and Smith, subgen. nov.

Type-Clionites rugosus Hyatt and Smith, sp. nov.

Evolute, little embracing, whorls low, and not increasing rapidly in height, cross section subquadratic. Inner whorls not concealed by the outer and scarcely indenting them. Umbilicus wide and shallow. Surface ornamented with coarse ribs, which are broken up into knots, which are the modifications of the spines of Clionites s. str. The ventral furrow is distinet, bordered by rows of knots, and there is a second row on the abdominal shoulder. Septa ceratitic. This is probably a phylogerontic modification of the group, for in old age the whorls scarcely touch. The rugose modification of the sculpture begins in early youth.

This subgenus is known only in the Upper Triassic, zone of Tropites subbullatus, of Shasta County, Cal.

CLIONITES (STANTONITES) RUGOSUS Hyatt and Smith, sp. nov.

Pl. XLI, figs. 15-26.

Evolute, discoidal, widely umbilicate, laterally compressed. Whorl low and increasing very slowly in height, little embracing, and scarcely indented by the inner volution. The eross section is subquadratic. The height of the whorl is slightly less than one-third of the total diameter of the shell, and the breadth is four-fifths of the height. The umbilicus is wide and shallow, being three-sevenths of the total diameter. The umbilical shoulders are abruptly rounded, with a steep inner slope. The sides are flattened and nearly parallel. 'The abdominal shoulders are square. The venter is low, the center being but little higher than the shoulders. The surface is ornamented with radial ribs, spiral rows of knots, and a ventral furrow. The ribs run straight up the sides to the shoulders, and then bifurcate, being continued obliquely forward by smaller ribs. Between the principal lateral ribs there is usually a smaller one that does not bifurcate. There are on each side six rows of knots, four small ones on the flanks, a large one on the abdominal shoulders, and another smaller one on each side of the ventral furrow. The unusual development of the abdominal shoulder knots is the chief characteristic of this subgenus. The form is extremely evolute. This character begins at a very early age and is a mark of degeneration, which also shows itself in the reduction of the spines to knots. 
The septa are ceratitic, saddles rounded and entire, lobes serrated, all of the usual. Clionites type, a small divided ventral lobe, large first lateral, small second lateral, and still smaller auxiliary on the umbilical slope.

The adolescent stages are so like the mature forms that no description of them is necessary. The larval stage is like that of Clionites Fairbanksi, and corresponds to Tirolites. It also passes through the Californites stage in early adolescence.

Horizon and locality. - In the Upper Triassic, zone of Tropites subbullatus of Shasta County, Cal., about 3 miles east of Madison's ranch, on the divide between Squaw Creek and Pit River, about 6 miles northeast of the Bully Hill mine.

Subgenus TRASKITES Hyatt and Smith, subgen. nov.

Type.-Clionites robustris Hyatt and Smith, sp. nov.

Evolute, little embracing, whorls low and broad, with quadratic cross section. Venter broad and flattened, with distinct rentral furrow, bordered by rows of spines. Sides ornamented with strong, straight ribs, provided with short spines from the umbilicus to the square abdominal shoulders, where there is a row of strong spines. Rows of spines also occur on the ribs where they cross the venter between the abdominal shoulders and the ridges bordering the furrow.

The young persist in the Californites stage of growth until late in life, and make the transition to the Traskites type of sculpture quite suddenly. Septa ceratitic. Body chamber short.

This group looks rery like Distichites Mojsisovics, but is distinguished by having ceratitic instead of ammonitic septa. It is known only in the Upper Triassic zone of Tropites subbullatus of Shasta County, Cal.

CLIONITES (TRASKITES) ROBUSTUS Hyatt and Smith, sp. nov.

Pl. XLII, figs. 1-19.

Form robust, thickset, evolute, discoidal. Whorl low, increasing slowly in ieight, little embracing, and little indented by the inner volution. Cross section subquadratic, with flattened sides, square abdominal shoulders, and low, little arched venter. Umbilical shoulders square, umbilical slope nearly vertical. The umbilicus is rather deep and wide, being two-fifths of the total diameter of the shell. The height of the whorl is one third of the diameter of the shell, the width is somewhat greater than the height, and the indentation is one-seventh of the height.

The sculpture is very marked, composed of strong radial pibs and spiral rows of spines. The ribs run straight across the flanks, the alternate ribs dividing into two or sometimes three smaller ones on the strong abdominal shoulder-knots. The intermediate ribs are usually undivided, but bend sharply forward on the shoulders, as do the others. There are three spiral rows of small spines on the flanks--a large row forming knots on the shoulders, a small row on the ventral slope, and another 
larger row on the ridge bordering the ventral furrow. The first row lies on the umbilical shoulders, and occasionally grows to considerable length, as do also those on the abdominal shoulders and the ventral ridge.

The septa are ceratitic, with entire saddles and serrated lobes; a divided ventral lobe, large first lateral on the abdominal shoulder, small second lateral on the flanks, smaller auxiliary on the umbilical slope, rather long undivided antisiphonal, and a pair of internal laterals.

In the larval stage the form and ornamentation are like those of Tirolites; the whorl is low, broad, with trapezoidal cross section, narrow flanks, provided with marginal spines, low flattened venter without furrow or other ornamentation. At the diameter of $5 \mathrm{~mm}$. the ventral furrow appears, and the shell then corresponds to Californites. At this size, too, the flanks grow higher and the marginal knots are prolonged into lateral ribs, which cease on the abdominal shoulders. At diameter of 8 $\mathrm{mm}$. the ribs begin to show on the venter and the row of spines appears on the ridge bordering the ventral furrow. This is the beginning of Traskites characters, although those of Californites persist until the shell is nearly mature. In fact, the subgeneric character of Traskites is the preservation, at maturity, of most of the Californites characters - the low, broad whorl, flattened venter, and strong marginal spines.

The young of Clionites Ares Mojsisovics" resemble the adult stage of $C$. (Traskites) robustus. This suggests that the European species, which occurs in the higher Noric beds, may have been developed out of the group of Traskites. There is, however, no mature form known anywhere else that might be compared with the Californian species.

Dimensions of the type specimen, figured on Pl. XLII, figs. 1-3.

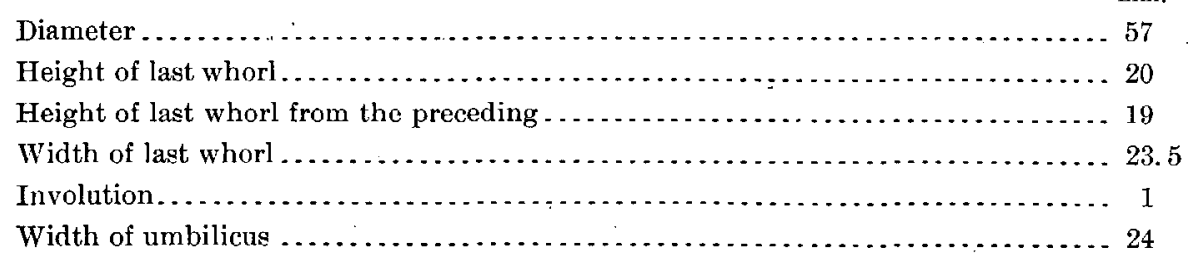

Dimensions of young stages, showing changes in development. [In millimeters.]

\begin{tabular}{|c|c|c|c|c|}
\hline 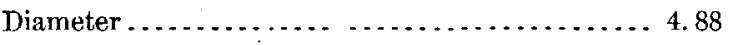 & 7.10 & 10.5 & 16 & 26 \\
\hline Height of last whorl $\ldots \ldots \ldots \ldots \ldots \ldots \ldots$ & 2.52 & 3.5 & 6 & 10.5 \\
\hline Height of last whorl from the preceding. & 2.04 & 3 & 5 & 9 \\
\hline Width of last whorl.. & 4.24 & 5.6 & 7.8 & 11 \\
\hline Involution...$\ldots \ldots \ldots \ldots \ldots \ldots$ & .48 & .5 & 1 & 1.5 \\
\hline Width of umbilicus . . . . . . . & 3.18 & 4.2 & 6.5 & 10.5 \\
\hline
\end{tabular}

These figures show the relative increase in the height of the whorl as maturity is approached. 
Horizon and locality. - In the Upper Triassic higher beds of the zone of Tropites subbullatus of Shasta County, Cal., on the divide between Squaw Creek and Pit River, 3 miles east of Madison's ranch and one-half mile north of the trail to Brock's ranch. This species is rather common in the lower beds of the Hosselkus limestonie, but above the strata in which Tropites subbullatus is most common.

Subgenus SHASTITES Hyatt and Smith, subgen. nov.

Type.--Olionites compressus Hyatt and Smith.

Whorls somewhat evolute, laterally compressed, higher than wide, rather deeply embracing, sides flattened, venter narrow. Umbilicus rather narrow. Sigmoidal ribs ending in knots, forming almost continuous ridges bordering the central furrow. Spines nearly obsolete, being represented only by tubercles on the ribs. The young retain the spines, but lose them early.

Septa ceratitic, as in Clionites s. str.

Shastites is known at present only in the zone of Tropites subbullatus, Upper Triassic of Shasta County, Cal.

CLIONITES (SHASTITES) COMPRESSUS Hyatt and Smith, sp. nov.

Pl. XLIII, figs. 1'-15.

Moderately evolute, discoidal, very much compressed laterally. Whorl increasing rather rapidly in height, embracing nearly half of the inner volution, but not deeply'indented by it. The height of the whorl is three-eighths of the total diameter and the width is three-fourths of the height. It is indented to oneninth of the height by the inner volution. The width of the umbilicus is threeeighths of the total diameter of the shell.

The surface is ornamented with slender sigmoidal radial ribs, which bend gently forward high up on the flanks, ending at the margins of the deep ventral furrow. There are on each side seven rows of small knots or rudimentary spines, four on the flanks, one on the indistinct abdominal shoulders, one on the arched sides of the venter, and one on the ridge bordering the ventral furrow. These spines become weaker as the shell grows larger, and are almost obsolete at maturity. They occur only on the ribs, never on the intervening depressions. The septa are ceratitic, of the usual Clionites type, consisting of a divided ventral, a large first lateral lobe, small second lateral, small auxiliary on the umbilical slope, narrow internal antisiphonal lobe, with a single lateral on each side.

In the young stage the shell is evolute with trapezoidal cross section, with no flanks and broad flattened venter, corresponding to Tirolites. At the diameter of $5 \mathrm{~mm}$. the ventral furrow begins, and the marginal nodes extend obliquely across the venter to the furrow. This stage corresponds to Californites. The flanks 
become gradually higher and the venter more rounded, until the Clionites stage is reached, which happens at the diameter of about $10 \mathrm{~mm}$. The lateral compression characteristic of this species does not become marked until the shell has attained a diameter of about $20 \mathrm{~mm}$. ; but even in the adolescent stages the fine sigmoidal ribs, almost wholly destitute of spines, would distinguish Clionites compressus from all other species.

Dimensions of the type specimen.

$\mathrm{mm}$

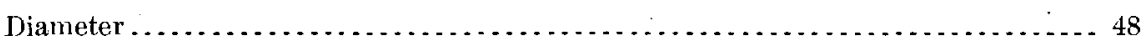

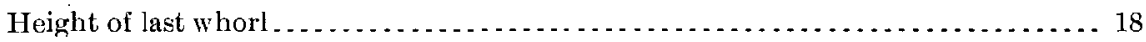

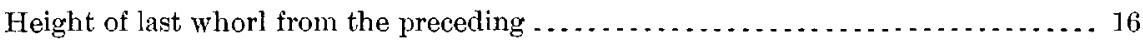

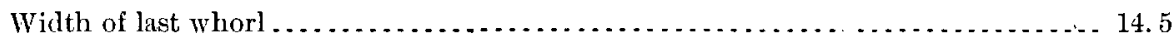

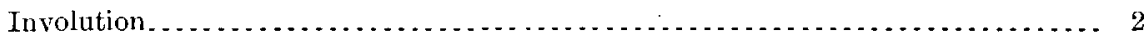

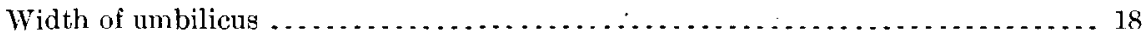

Clionites compressus differs from all other species of Clionites in the late larval and adolescent stages, in the fine sculpture and narrowness of the whorl, especially in contrast to similar stages of growth in Traskites, Stantonites, and Neanites. The subgenus Shastites has departed further from the Californites stock than any of the others, and, while it retains the Tirolites stage to an equal degree, has almost lost that corresponding to Californites. It further shows its acceleration of development in the early stage at which it takes on Clionites characters.

Horizon and locality.-Upper Triassic, zone of Tropites subbullutus, of Shasta County, Cal., on divide between Squaw Creek and Pit River, about 3 miles east of Madison's ranch and one-half mile north of the trail from Madison's to Brock's' ranch. This species is much less common than most other species of Clionites which occur in this bed. It is associated with the usual fossils of the upper part of the zone of Tropites subbullatus.

Subgenus NEANITES Hyatt and Smith, subgen. nov.

Type- - Clionites californicus Hyatt and Smith, sp. nov.

Evolute, little embracing, low-whorled, involute. Wide umbilicus, abrupt umbilical shoulders. Cross section subquadratic. Ventral furrow much reduced. Ribs run nearly straight from umbilicus to border of the ventral furrow; spines obsolete, represented only by small knots. Septa ceratitic. The chief character of this group is the persistence of the Californites stage until the end of the adolescent period, and then the sudden change to Clionites characters. In the adolescent stage the whorls are low and broad, with square abdominal shoulders provided with long spines and flattened venter. At maturity the venter is highly arched.

Neanites is known only from the Upper Triassic, zone of Tropites subbullatus, of Shasta County, Cal. 
CLIONITES (NEANITES) CALIFORNICUs Hyatt and Smith, sp. nov.

PI. LXXXIII, figs. 14-27.

Evolute, robust, widely umbilicate. Whorl subquadratic in cross section, height and breadth equal and about two-fifths of the total diameter of the shell. The whorl increases slowly in height, is little embracing and little indented by the inner volution. The umbilical shoulders are abrupt, with steep inner slope. The sides are flat and nearly parallel. The abdominal shoulder occurs at three-fourths of the height of the whorl, is gently rounded, and slopes gradually up to broad low venter. The umbilicus is wide and deep, the width being slightly more than one-third of the total diameter of the shell.

The surface is ornamented with a shallow ventral furrow, fine radial ribs bending forward on the abdominal shoulders, and spiral rows of knots, becoming almost obsolete at maturity. The ribs are close together and sigmoidal. The rows of knots are five in number, one on the umbilical shoulder, one, sometimes double, on the flanks a short distance above the shoulder, one on the abdominal shoulder, one halfway up the ventral slope, and one on the ridge bordering the ventral furrow. Both ribs and knots grow finer at maturity, the latter becoming nearly obsolete.

The septa are ceratitic, like those of all other Clionites. The most salient character of this species is the sudden change from the adolescent to the mature stage, when the whorl becomes subquadratic instead of trapezoidal in cross section, the venter becomes arched instead of flattened, and the strong row of marginal spines becomes obsolete.

In the larval stage the shell is evolute, with deep, wide umbilicus, and broad trapezoidal whorl. The flanks consist merely of a narrow angular umbilical ridge, and the venter is broad and nearly flat. The only ornamentation consists of rather strong marginal spines, which are prolonged in very faint ribs on the venter. This stage corresponds exactly with Tirolites, both in shape, ornamentation, and septa. At the diameter of slightly less than $5 \mathrm{~mm}$. the ventral furrow appears, the ribs begin to show more decidedly above the shoulders, and the flanks increase in beight. This stage resembles and corresponds to Californites in all its characters, the septa now being ceratitic, as in that genus. The Californites stage lasts until a diameter of about $25 \mathrm{~mm}$. is reached. Then suddenly the marginal spines disappear, the flanks become higher, the venter arches, and the radial sculpture grows weak. The form is then mature, and the characters of Neanites have been assumed.

Horizon and locality.-In the Upper. Triassic, zone of Trowites subbullatus, 
of Shasta County, Cal., on the divide between Squaw Creek and Pit River, about 3 miles east of Madison's ranch and one-half mile north of the trail leading to Brock's ranch.

Genus TRACHYCHRAS Lambe.

1869. Trachyceras, Laube, Ueber Ammonites Aon Münster und dessen Verwandte: Sitzungsber. K. Akad. Wiss., Wien, vol. 59, pt. 1, p. 7.

1869. Trachyceras, Laube, Die Fauna der Schichten von St. Cassian: Denkschr. K. Akad. Wiss., Wien, vol. 30,1869, p: 65.

1877. Trachyceras, Meek, U. S. Geol. and Geog. Explor. 40th Par., vol. 4, p. 116.

1879. Trachyceras, Mojsisovics, Vorläufige kurze Uebersicht der Ammoniten-Gattungen der Mediterranen und Juvavischen Trias: Verhandl. K.-k. geol. Reichsanstalt, Wien, p. 140.

1882. Trachyceras (pars), Mojsisovies, Cephalopoden der Mediterranen Triasprovinz: Abhandl, K.-k. geol. Reichsanstalt, Wien, vol. 10, p. 93 .

1889. Trachyceras, Hyatt, in Whiteaves, Fossils of the Triassic Rocks of British Columbia: Geol. and Nat. Hist. Survey Canada, Contributions Canadian Palæeontology, vol. 1, pt. 2, p. 142.

1893. Trachyceras, Mojsisovics, Cephalopoden der Hallstätter Kalke: Abhandl. K.-k. geol. Reichsanstalt, Wien, vol. 6 , pt. 2, p. 617 .

1896. Trachyceras, Mojsisovics, Beitr. Kennt. Obertriadischen Cephalopoden-Faunen des Himalaya: Denkschr. K: Akad. Wiss., Wien, vol. 63, p. 646.

1898. Protrachyceras, Tornquist, Neuere Beitr. Geol. und Pal. der Umgebung von Recoaro, etc.: Zeitschr. Deutsch. geol. Gesell., vol. 50, pt. 4, p. 659.

1904. Trachyceras, J. P. Smith, Comparative Stratigraphy of the Marine Trias of Western America: Proc. California Acad. Sci., $3 \mathrm{~d}$ ser., vol. 1, p. 387.

Type.-. "Ceratites" Aon Münster, Leonhard und Bronn's Neues Jahrbuch, 1834 , p. 13, Pl. I, figs. 4 and 5; and Mojsisovics, Cephalopoden der Mediterranen Triasprovinz, 1882, p. 129, Pl. XXI, tigs. 1-35, 37, and 38.

Form moderately involute, somewhat compressed laterally, deeply embracing, but usually showing the inner volutions. Whorls higher than wide, with abrupt umbilical shoulders, somewhat flattened convex sides, rounded abdominal shoulders, and proportionally narrow venters, with a distinct central furrow bounded by tubercles. Body chamber short, not exceeding two-thirds of the last volution.

The surface is ornamented with ribs radiating from tubercles on the umbilical shoulders, and running with gentle curves up the sides to the abdominal shoulders, where they curve forward. These ribs may bifurcate on the umbilicus, again on the sides, and more rarely on the shoulders. Their ends form the rows of tubercles that border the central furrow. On the ribs are spiral rows of spines or tubercles, which give a rugose appearance to the shell and suggested the name of the genus. The spines may become almost obsolete on very old shells, but are always present at early maturity. They show on the cast as well as on the shell, and, together with the central furrow, afford an easy means of identification of the genus. Con strictions or varices do not appear at all on the shell or on the cast, and contractions of the body chamber have not been obșerved. 
Septa ammonitic, but not deeply digitate, moderately dolichophyllic. The external lobe is always divided by a siphonal saddle, and there are always two lateral lobes present, but the auxiliary lobe is occasionally absent.

E. von Mojsisovics ${ }^{a}$ divided this genus into three groups or subgenera: Trachycercls s. str., characterized by having two rows of spines on each side of the central furrow; Protrachyceras Mojsisovics, with only a single row of spines on each side of the furrow, and Anolcites Mojsisovics, without a distinct furrow and with the ribs crossing the venter. Since Trachyceras Aon had the double spine rows, all Trachyceratea with this sort of ornamentation are placed under the typical section of the genus. This group is usually more involute and more compressed laterally, and seems to have originated from the group with the single row of spines bordering the furrow. Mojsisovies assumes that the genus Trachyceras in the broader sense developed out of Balatonites, and that this in turn came from Tirolites. There can be little doubt that not only Trachyceras, but also all the Trachyceratea, descended from Tirolites or some similar form, for they all go through such a stage. But it is more than doubtful if Balatonites is a connecting link in the series, for no intermediate mature forms are known, and no Balatonites stage is seen in the development of Trachyceras.

K. A. von Zittel ${ }^{b}$ placed this genus in the family Tropitidæ, but without assigning any reason for the change. It need hardly be said, however, that the development of the Trachyceratea is wholly unlike that of the Tropitide; that of the former points to an origin from the Prolecanitidæ, while the Tropitidæ seem to have come from the Glyphioceratidæ. Professor von Zittel was no doubt influenced by the resemblance of Sagenites to Trachyceras in placing the latter genus in the Tropitidæ, but this resemblance is purely external, and is one of the many puzzling convergencephenomena so often seen in the history of the ammonites, the young of the two groups being farther apart than the mature forms.

Trachyceras in the broader sense is characteristic of the Upper Triassic, beginning in the Ladinic stage, and becoming extinct in the middle Karnic horizon. Trachyceras in the limited sense is found only in the uppermost Ladinic, and the lower and middle Karnic. Anolcites ranges from the upper Muschelkalk to the middle Karnic. Protrachyceras ranges from the lower Ladinic (uppermost Muschelkalk) to the upper Karnic. It will thus be seen that the genus as a whole is intensely characteristic of the Upper Triassic, although two of the subgenera begin at the top of the Middle Triassic.

In the Alpine province the entire genus became extinct in the Middle Karnic, below the zone of Tropites subbullatus, but in the Himalayas in India and in Cali- 
fornia it lived on until a later period, and was a contemporary of the Tropites subbullatus fauna: In Shasta County, Cal., J. P. Smith found Trachyceras abundant in the beds in which Tropites subbullatus also occurred and even in the same hand specimen with that species, but these Californian species were all provided with only a single row of spines on each side of the ventral furrow, and thus would fall under the subgenus Protrachycerces.

Trachyceras seems to have been equally at home in the Mediterranean, the Oriental, and the American regions, although it is much more abundant in the first, and extremely rare in the second. It is difficult to explain on the basis of our present knowledge why this genus should be so common in the Alpine province and in western America and so scarce in the Oriental region, which must have been the connecting link between the two. But this is one of the unexplained facts in Triassic faunal distribution. The same thing was noted of Balatonites in the Middle Triassic, and suggests that some other connection may have existed between the European and western American waters.

The only American species that can be assigned to the artificial group of Trachyceras s. str, as restricted by Mojsisovics, is T. canadense Whiteaves, from the Upper Triassic of British Columbia. Protrachyceras is represented by T. Homfrayi Gabb, T. Lecontei Hyatt and Smith, and a large number of undescribed species, all in the Upper Triassic, and possibly by T. subasperum, Meek, of the Middle Triassic.

Anoloites is represented by T. Whitneyi Gabb, T. Meeki Mojsisovics, and by several undescribed forms, all from the Middle Triassic except one doubtful species from the Karnic horizon of California.

Subgenus PROTRACHYCERAS Mojsisovics.

1893. Protrachyceras, Mojsisovies, Cephalopoden der Hallstätter Kalke: Abhandl. K.k. geol. Reichsanstalt, Wien, vol. 6 , pt. 2 , p. 618 .

1896. Protrachyceras, Mojsisovics, Beitr. Kennt. Obertriadischen Cephalopoden-Fannen des Himalaya: Denkschr. K. Akad. Wiss., Wien, vol. 63, p. 646.

1898. Protrachyceras, Tornquist, Neuere Beitr. Geol. und Pal. der Umgebung ron Recoaro, etc.: Zeitschr. Deutsch. geol. Gesell., vol. 50, pt. 4, p. 659.

1904. Protrachyceras, J. P. Smith, Comparative Stratigraphy of the Marine Trias of Western America: Proc. California Acad. Sci., 3d ser., vol. 1, p. 387.

No type is expressly given by Mojsisovics for this subgenus, but the species first mentioned is Trachyceras chiesense Mojsisovics, Cephalopoden der Mediterranen Triasprovinz, p. 95, Pl. XXXIV, fig. 4, which is merely a fragment, and could hardly have been the typical form in the mind of the author. The first form deseribed under the new subgenus was-Protrachyceras Rudolphi Mojsisovics, Cepha-: lopoden der Hallstätter Kalke, pt. 2, 1893, p. 623, Pl. CLXVI, figs. 2 and 3, which 16918-No. $40-05-13$ 
is much more characteristic, but even this species is not nearly so common nor so well known as many others; if the author had chosen a species to be the representative form, for this subgenus it would most probably have been Protrachyceras Archelaus Laube, which is known in all its details, and is so common as to be chosen as a zone-fossil.

Irotrachyceras is characterized by its short body chamber, compressed but robust whorls, moderately involute form, open umbilicus, and central abdominal furrow.' The ribs are provided with spines arranged in spiral rows, and the ventral furrow is bounded by only a single row of tubercles on each side. This is the only character that distinguishes it from Trachyceras s. str., which possesses a double row of tubercies on each side. Most species of Protrachyceras are somewhat evolute, but this character is not constant.

In the opinion of the writers the character that served as the basis for the separation of this subgenus is a minor one, not of sufficient importance to distinguish more than merely a group of species. It has neither phylogenic nor stratigraphic value; but since this classification has been accepted in standard works, the writers can only use it as is now customary.

Protrachyceras begins in the upper part of the Middle Triassic, the lower Ladinic stage, and lasts until the upper Karnic stage, the middle horizon of the Upper Triassic. It is common in the Alpine province, and in Nevada in the lower Ladinic; in the Mediterranean region, and in California in the Karnic. It is found also in the Himalayas in the Karnic, but is rare there.

Trachyceras subasperum Meek is the only American species hitherto described that belongs to Protrachyceras, but this group is represented by a large number of undescribed species from the Upper 'Triassic of Shasta County, Cal., some of which may even be identical with European forms.

TRACHYCERAS (PROTRACHYCERAS) LECONTEI Hyatt and Smith, sp. nov.

Pl. XLIV, figs. 1 and 2; Pl. XLV, figs. 1-9; Pl. XLVI, figs. 1-15.

Form discoidal, involute, laterally compressed. Whorls narrow, high, deeply embracing, but not deeply indented by the inner volutions. Umbilical shoulders abruptly rounded, inner walls steep; umbilicus narrow, exposing very little of the inner whorls. Sides flattened, with the greatest width just above the shoulders, sloping with gentle convexity up to the margin. Venter very narrow, slightly flattened, and with shallow median furrow, bounded by a row of small tubercles. The beight of the whorl is more than twice its width, and nearly three-fifths of the total diameter. It is indented to one-fourth of its height by the inner volution, and conceals two-thirds of this volution. The width of the umbilicus of the 
adult is about one-eighth of the total diameter of the snell, while that of tho adolescent stages is much narrower proportionally, being only about one-tenth.

The surface is ornamented with very fine forward curving radial ribs, and coarser spiral ridges. These ridges number about twelve on the sides and form small tubercles where they cross the radial ribs. These spiral rows of tubercles are closer together near the ventral margin than on the flanks. On the umbilical shoulders there is a row of somewhat coarser knots.

The septa are ammonitic, lobes and saddles deeply digitate. The external lobe is divided by a small siphonal saddle into two short and broad divisions; the first lateral is broad and deep; the second lateral similar in shape to the first, but much shorter and not so deeply digitate. The auxiliary is broad and shallow, with several divisions. The external saddle is somewhat narrower than the first lateral lobe, and long; the second is somewhat longer, but not so deeply divided. The auxiliary saddle is shorter and broader in proportion to its length. The antisiphonal lobe is long and narrow, flanked by three internal laterals on each side.

The earlier larval stages are smooth, the radial ribs beginning as fine folds: at diameter of about $2.5 \mathrm{~mm}$. The spiral rows of tubercles appear at diameter of $4 \mathrm{~mm}$., at first with only a few rows and the tubercles wide apart.

The septa begin to be ammonitic at the diameter of $4 \mathrm{~mm}$., there being no ceratite stage intervening between the goniatite and the ammonite stages of development.

Until the appearance of the spiral rows of tubercles the whorls are evolute, low, and broad, but at this stage they begin to be involute and laterally compressed. The following are the dimensions of some specimens:

\begin{tabular}{|c|c|c|c|c|c|}
\hline \multicolumn{6}{|l|}{ [In millimeters.] } \\
\hline 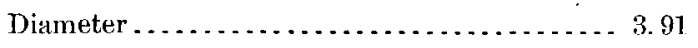 & 5 & 8.3 & 12 & 26 & 40 \\
\hline Height of last whorl $\ldots \ldots \ldots \ldots \ldots \ldots \ldots \ldots \ldots$ & 3.3 & 4.5 & 7 & 15 & 23.5 \\
\hline Height of last whorl from the preceding .... 1.70 & 2.5 & 3.6 & 5 & 12.5 & 18 \\
\hline Width of last whorl... & 3 & 4.5 & 5.5 & 10 & 13 \\
\hline Involution ........... & 8 & .9 & 2 & 2.5 & 5.5 \\
\hline Width of umbilicus.................... 76 & 1. & 1.4 & 1.7 & 2.5 & 4 \\
\hline
\end{tabular}

The type specimen, figured on Pl. XLIV, figs. 1 and 2 , has the following dimensions:

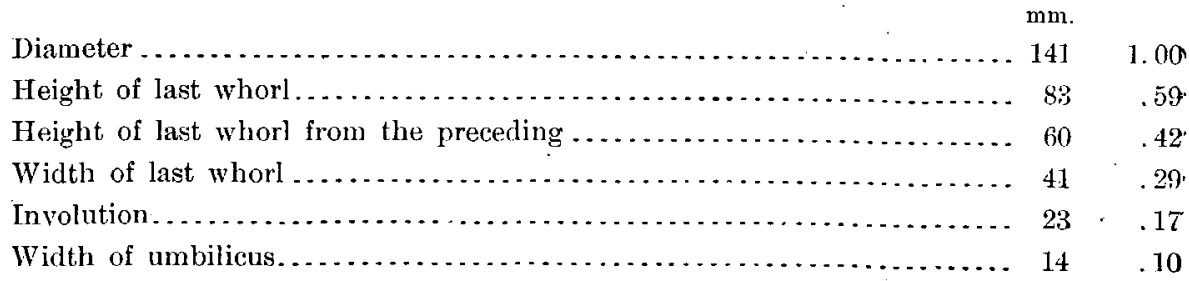


Trachyceras Lecontei resembles T. Attila Mojsisovics (Cephal. der Hallstätter Kalke, pt. 2, p. 633; Pl. CLXIX, figs. 6-9; Pl. CLXX, figs. 1 and 2), but differs from that species in its greater lateral compression, finer sculpture, more complex septa, and narrower umbilicus.

Horizon and locality.-Trachyceras Lecontei is not uncommon in the Upper Triassic, Karnic stage, of Shasta County, Cal., 3 miles east of Madison's ranch, between Squaw Creek and Pit River, one-half mile north of the trail from Madison's to Brock's ranch. It is associated with Tropites subbullatus, Paratropites Sellai, Discotropites sandlingensis, Halobia superba, and many other species characteristic of this horizon. In the same bed were found several other species of Trachyceras, all apparently new, but nearly related to Alpine forms.

Subgenus ANOLCITES Mojsisovics.

1893. Anolcies, Mojsisovics, Cephalopoden der Hallstätter Kalke: Abhandl. K.,k. geol. Reichsanstalt, Wien, vol. 6, pt. 2, p. 621 .

1904. Anolcites, J. P. Smith, Comparative Stratigraphy of the Marine Trias of Western America: Proc. California Acad. Sci., 3d ser., vol. 1, p. 388.

In naming this subgenus Mojsisovics did not select any species to serve the type, but the first mentioned under the diagnosis is "Trachyceras" doleritious Mojsisovics, Cephalopoden der Mediterranen Triasprovinz, 1882, p. 103, Pl. XIII, fig. 5; Pl. XXXVII, fig. 1.

Anolcites differs from Trachyceras s. str. in being more evolute, with wider umbilicus, and lower whorls. The ventral furrow is scarcely developed, and the ribs cross the venter, although a row of tubercles is developed on each side of the center, which gives a resemblance to Protrachyceras. The septa are usually ceratitic, the saddles being mostly rounded and entire. The ribs and spines are like those on Trachyceras s. str., and Protrachyceras.

This subgenus ranges from the upper Muschelkalk to the Middle of the Upper Triassic. In America it is known only in the upper part of the Middle Triassic of Nevada, where it is represented by T. Whitneyi Gabb, T. Meeki Mojsisovics, and several undescribed species.

TRACHYCERAS (ANOLCITES) MEEKI Mojsisovics.

Pl. XXIV, figs. 8-9; Pl. LIX, figs. 1-17; Pl. LXXIV, figs. 1-7.

1882. Trachyceras Meeki, Mojsisovics, Cephalopoden der Mediterranen Triasprovinz: Abhandl. K.-k. geol. Reichsanstalt, Wien, vol. 10, p. 108.

1877. Trachyceras judicaricum, Meek (not Mojsisovics), U. S. Geol. and Geog. Explor. 40th Par., vol. 4, p. 118, P1. XI, figs. 1 and 1a.

Form evolute, robust, deeply embracing, but not deeply indented by the inne: volution. Whorl increasing rather rapidly in height. Umbilicus wide and deep. 
Umbilical shoulders abrupt, flanks gently convex, abdominal shoulders gently rounded. Venter narrow, with deep central furrow. Surface ornamented with strong radial ribs and fine spiral rows of knots. The ribs bundle in knots on the umbilical shoulders, curve gently forward on the flanks, and cross the venter almost without interruption. There are rows of knots on the umbilical shoulder and the ridge bordering the ventral furrow, and three on the flanks. The strongest knots are on the venter.

The ribs do not bundle in threes, as shown in the rather diagrammatic drawing published of the type. There are usually two ribs branching from an umbilical tubercle, and the alternate ribs do not usually bifurcate. The knot bordering the ventral furrow do not lie opposite each other, but in alternate position.

At extreme maturity the ribs become weaker, and the knots stronger, until the appearance of the shell is greatly changed. In all probability the form described by Meek as Trachyceras judicaricum Mojsisovics, var. subasperum Meek, is only a prematurely old specimen of Anolcites Meeki.

The ventral furrow is quite distinct, although the ribs may still be traced across it. In the adolescent and early mature stages the furrow is little developed, and the ridges crossing the venter are strong. In this character the species under discussion is intermediate between Protrachyceras and Anolicites.

The septa are ceratitic, the saddles rounded and entire, the lobes deeply serrated.

Meek identified this species with Trachyceras (Anolcites),judicaricum Mojsisovies, from which it differs in its coarser and fewer ribs and knots. It is difficult to see why he did this, for it has little resemblance to that form, and the figures given by Mojsisovics of the European species are too poor to enable the identification.

The young stages of Anolcites Meeki are wholly unlike the mature form, being much more robust and evolute. The earliest stages seen bear a strong resemblance to Tirolites, much more so than in later, more specialized species of 'Trachycerata. The young stages figured in this paper were broken out of large characteristic specimens, to avoid confusion with the other species of the same group associated with them.

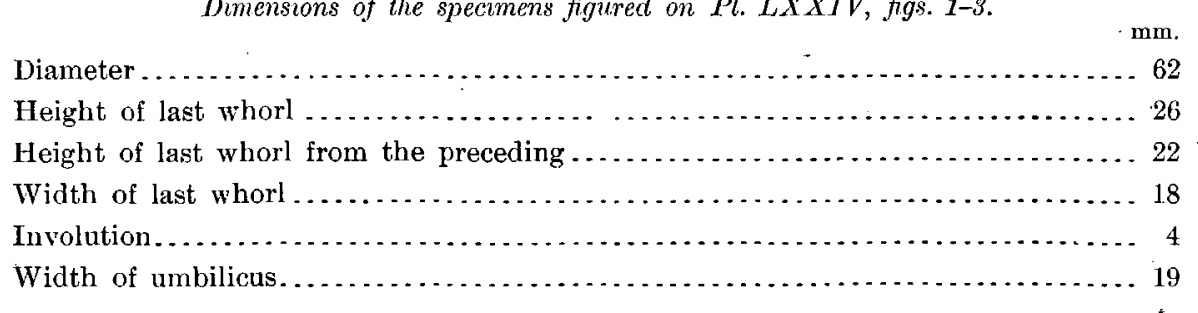


Horizon and locality. - Collected by U. S. Geol. and Geog. Exploration of the Fortieth Parallel in Middle Triassic, Cottonwood Canyon, West Humboldt Range, Nevada. J. P. Smith found it rather common at that place, near the "Lucky Dog" mine; also in the same horizon, on divide between Troy Canyon and South Fork of American Canyon, West Humboldt Range. In both places it was associated with Ceratites humboldtensis, Anolcites Whitneyi, Beyrichites rotelliformis, Gymnotoceras Blakei, Longobardites nevadanus, Joannites Gabbi, Daonella dubia, and many other species.

Genus SIRENITES Mojisisovias.

1893. Sirenites, Mojsisovics, Cephalopōden der Hallstätter Kalke: Abhandl. K.-k. geol. Reichsanstalt, Wien, vol: 6 , pt. 2 , p. 725 .

1896. Sirenites, Mojsisovies, Beitr. Kennt. Obertriadischen Cephalopoden-Faunen des Himalaya: Den'zschr. K. Akad. Wiss, Wien, vol. 63, p. 649.

Type--Ammonites senticosus Dittmar, Zur Fauna der Hallstätter Kalke: Geognost.-palæont. Beitr., von Benecke, etc., 1866, vol. 1, p. 375, Pl. XVII, figs. 8 and 9.

Involute; robust, laterally compressed, deeply embracing, and deeply indented by the inner whorls. Sides flattened-convex, whorls high, and increasing rapidly in height. Venter broad, with somewhat abrupt abdominal shoulders and distinct central furrow. Sculpture consisting of strong ribs that start out from the umbilicus and run nearly straight or with sigmoidal bend to the abdominal shoulders, where they bifurcate on strong knots and then bend sharply forward. There are also spiral rows of knots or spines on the lateral ribs. The septa ure ammonitic, like those of Trachyceras, from which Sirenites differs in the bifurcation of the ribs and forward bending at knots on the abdominal shoulders. The body chamber is short, and the other characters like those of Trachyceras or Protrachyceras, from which latter group Mojsisovics supposes Sirenites to have been dcrived. The various subgenera of this genus are not represented in the American region, so it is unnecessary to discuss them.

Sirenites is characteristic of the Upper Triassic, Karnic and Noric stages. In Anerica it is known only in the zone of Tropites subbullatus. The species described below is the only one known in America.

\section{SIRENITES LAWSONI Hyatt and Smith, sp. nov.}

Pl. XLVI, figs. 16 and 17 ; Pl. XLVII, figs. 1-9.

Involute, robust, somewhat compressed laterally. Whorls deeply embracing and deeply indented by the inner volutions. The height of the whorl is one-half of the total diameter; the breadth is four-fifths of the height, and the indentation is about one-sixth of the height. The greatest breadth is at the umbilical shoulders; the flanks converge steeply to the abdominal shoulders, where the width is reduced 
to one-half. The venter is arched, but low, rising but little above the shoulders. The umbilicus is deep and narrow, being only one-sixth of the diameter, but cxposing nearly all the inner whorls. The umbilical shoulders are abrupt, with nearly vertical inner slope. Although the outer whorl is deeply embracing, covering two-thirds of the inner, the two are scarcely in contact. The shell is uncoiling, for the young stages show much greater involution than is visible at maturity.

The sculpture consists of radial ribs, provided with short spines or knots, fine spiral lines on the outer shell, and a shallow ventral furrow. The ribs bend slightly backward on the flanks until they reach the shoulders, where they develop large knots, bifurcate, and turn abruptly forward, ending in a single row of knots on the margins of the ventral furrow. The alternate ribs also usually bifurcate on the flanks, not far above the umbilicus. The knots or spines are obscure on the flanks, but become very strong on the shoulders. There is a second smaller row above the shoulders, halfway between them and the row of knots on the margins of the furrow.

The septa are ammonitic, like those of Trachyceras, both lobes and saddles being strongly digitate.

The young stages are involute and globose in shape, with coarse radial ribs and rows of knots arranged in spiral lines. They resemble exactly the Brotheus stage in the development of Trachyceras, and do not retain any trace of Tirolites. At the diameter of $6 \mathrm{~mm}$. the alternate ribs become larger than the others, soon developing into prominent folds, with two or three ribs between them. At the diameter of $25 \mathrm{~mm}$. the folds lose their prominence, the shoulders and the shoulder knots are developed, and the shell enters the Sirenites stage, characterized by the furrow and the bifurcating ribs. The form now becomes more compressed laterally, and from this stage onward little change takes place except increase in size and relative height of the whorls.

Mojsisovics considered this genus as a descendant of Protrachyceras, and its development shows it to be nearly related to that subgenus. In fact, it is very doubtful whether such a minor character as the bundling of the ribs on the shoulders should be regarded as of generic importance. It, however, does not agree exactly with any of the species of Protrachyceras known in America, and therefore the writers have retained the name as it is customary to use it.

Horizon and locality.-In the Upper Triassic, zone of Tropites subbullatus, of Shasta County, Cal., on the divide between Squaw Creek and Pit River, 3 miles east of Madison's ranch, and one-half mile north of the trail to Brock's ranch. The young of this species are not uncommon in the limestone at this locality, but only one adult specimen was found.

The specific name is given in honor of Dr. A. C. Lawson. 
1893. Sandlingites, Mojsisovics, Cephalopoden der Hallstätter Kalke: Abhandl. K.-k. geol. Reichsanstalt, Wien, vol. 6, pt. 2, p. 70.

1896. Sundlingiles, Mojsisovics, Obertriadischen Cephalopoden-Faunen des Himalaya: Denkschr. K. Akad. Wiss., Wien, vol. 63, p. 648.

Type-Ammonites oribasus Dittmar, Zur Fauna der Hallstätter Kalke, p. 384, Pl. XVIII, figs. 8-10; and E. von Mojsisovics, Cephalopoden der Hallstätter Kalke, pt. 2, p. 706, Pl. CLXVII, figs. 5-7.

Evolute, little embracing, subquadratic whorls. increásing slowly in height. Umbilicus wide and rather shallow. Venter flattened, with shallow ventral furrow, not bounded by keels. Surface ornamented with smooth falcoid dichotomous ribs which cross the ventral furrow. In carly youth the form is like Tirolites, then like Protrachyceras, with spines on the ribs. Then toward maturity the spines become obsolete, and the ventral furrow almost disappears. The septa are ceratitic on all the forms known, and appear to be even goniatitic on some species.

This genus is made up wholly of dwarf forms, probably degenerates, and is confined largely to the Karnic horizon of the Upper 'Triassic, but a very few species are found in the Noric horizon.

In America this genus has been found only in the Karnic stage, zone of Tropites subbullatus, one species only, Sandlingites Andersoni Hyatt and Smith, sp. nov., having been found.

SANDLINGITES ANDERSONI Hyatt and Smith, sp. nov

Pl. XLVII, figs. 10-12.

Form evolute, laterally' compressed, with whorls little embracing, and little indented by the inner volutions. Cross section of whorl subquadratic, the height being equal to the breadth, and somewhat more than one-third of the total diameter of the shell. The flanks are flattened, the umbilical and abdominal sboulders abruptly rounded, and the venter is low. The umbilicus is shallow and broad, being more than one-third of the diameter of the shell. The surface is ornamented with radial ribs which begin in blunt spines on the umbilical shoulders, the alternate ones usually bifurcating there, run straight up the flanks, branch a second time on the abdominal shoulder-knots, and then cross the venter with a forward bend. On these ribs are on each side four rows of knots, or blunt spines, one on the abdominal shoulders, and a fourth on the venter. The ventral pair of spine rows do not stand opposite each other, but alternate.

The septa are ceratitic, only the lobes being weakly serrated; there is a small divided ventral, a large lateral lobe, small second lateral, and a smaller auxiliary at the umbilical suture. The body chamber seems to have been three-fourths of a revolution in length. 
The young portion of the shell shows a decided resemblance to Anolcites, which is, doubtless, the ancestor of Sandlingites.

Horizon and locality.-In the Upper Triassic, zone of Tropites subbullatus, of Shasta County, Cal., on the divide between Squaw Creek and Pit River, 3 miles east of Madison's ranch, and one-half mile north of the trail to Brock's ranch.

Only a single specimen was found in five seasons of collecting at this locality, where ammonites are extremely abundant in the lower beds of the Hosselkus limestone.

The specific name is given in honor of Mr. Frank M. Anderson, who assisted in collecting the rich fauna obtained at this place.

Genus POI YCYCLUS Mojsisovios.

1889. Polycyclus, Mojsisovics, Nachweis der Zone des Tropites subbullatus in den Hallstätter Kalken bei Hallein: Verhandl. K.-k: geol. Reichsanstalt, Wien, p. 281.

1893. Polycyclus, Mojsisovies, Cephalopoden der Hallstätter Kalke: Abhandl. K.-k. geol. Reichsanstalt, Wien, vol. 6 , pt. 2, p. 534 .

Type--Ammonites nasturtium Dittmar, Zur Fauna der Hallstätter Kalke: Geognost.-palaeont. Beitr, von Benecke, Schloenbach und Waagen, vol. 1, p. 358, PI. XIV, figs. 24-37; and Mojsisovies, Cephalopoden der Hallstätter Kalke, pt. 2, 1893, p. 535, Pl. CXXXII, figs. 27-36.

Evolute, little embracing, low whorls, laterally compressed, and increasing very slowly in height. Cross section oval, height greater than the breadth. Umbilicus wide and very shallow. Venter highly arched. Surface ornamented with simple, uncivided strong ribs that run from the umbilical shoulders nearly straight across the venter without interruption. Spines and constrictions are unknown in this genus.

The septa are usually goniatitic, but traces of sèrration are sometimes visible on the lateral lobe. . The ventral lobe is divided by a small siphonal notch; there are two laterals, of which the second may be considered as the auxiliary. 'Internal, antisiphonal, lobe long.

Polycychus appears in the Alpine province and in California in the Upper Triassic, zone of Tropites subbullatus; in the Alps it occurs also sparingly in the Noric stage. In California two species have been found, P. Henseli Oppel, and P. nodifer Hyatt and Smith, sp. nov.

POLYCYCLUS NODIFER Hyatt and Smith, sp. nov.

Pl. XXXVIII, figs. 1-18.

Evolute; discoidal, laterally compressed, widely umbilicate. Whorls low, and increasing very slowly in height, little embracing, and scarcely indented by the inner volution. The height of the whorl is one-third of the total diameter of the shell, and 
the width is three-fourths of the height. The umbilical shoulders are abruptly rounded, the flanks somewhat flattened, the venter low, rising but little above the abrupt abdominal shoulders. The umbilicus is wide and shallow, being about three-sevenths of the diameter of the shell.

The surface is ornamented with strong radial ribs, running from the umbilicus up the flanks and across the venter, and considerably broader than the intervening spaces. On the cast there is seen on the venter a slight furrow, not interrupting the ribs, but depressing them. On each side of this furrow the ribs are raised into low. knots. This seulpture is not visible on the outer shell.

The septa are goniatitic, except the first lateral lobe, which is very slightly ceratitic. The ventral lobe is divided by a small siphonal notch into two short narrow branches; the first lateral lobe is proportionally much larger; the second lateral and the auxiliary are exceedingly small; the internal or dorsal lobe is narrow and rather long, flanked on each side by a small internal lateral.

This species is most nearly related to Polycyclus Henseli Oppel, and especially to the variety directa, figured by Mojsisovics, Cephalopoden der Hallstätter Kalke, pt. 2, Pl. CXXXII, figs. 7-11. But P. nodifer is more evolute than the Tyrolian species, and its nodes on the ribs serve as distinguishing characters. All the other marks and the faunal association are the same. 'In the same beds with $P$. nodifer is a species that is almost undoubtedly identical with $P$. Henseli, and it is not unlikely that a transition between the two species may be traced.

In the young stages the shell is subglobose, but the umbilicus speedily widens and the whorl becomes relatively lower. The lateral ribs begin at the diameter of $1.6 \mathrm{~mm}$., at first as umbilical knots. The ventral knots and furrow begin at diameter of $3.2 \mathrm{~mm}$. The serration of the first lateral lobe begins at diameter of about $8 \mathrm{~mm}$. The largest specimens found had a diameter of about $25 \mathrm{~mm}$.

Horizon and locality.-Upper Triassic, zone of Tropites subbullatus, Shasta County, Cal., on the divide between Squaw Creek and Pit River, 3 miles east of Madison's ranch and one-half mile north of the trail to Brock's ranch.

\section{Genus RHABDOCHRAS ITauer.}

1860. Rhabdoceras, Hauer, Cephalopoden-Fauna der Hallstätter Kalke: Sitzungsber. K. Akad. Wiss.; Wien, vol. 41, p. 124.

1893. Rhabdoceras, Mojsisovics, Cephalopoden der Hallstätter Kalke: Abhandl. K.-k. geol. Reichsanstalt, Wien, vol. 6 , pt. 2, p. 570.

Type.-Rhabdoceras Suessi Hauer, Cephalopoden Fauna der Hallstitter Kalke, p. 125, Pl. II, figs. 9-16.

Shell consisting of a straight shaft, with marginal siphuncle, forward-pointing siphonal collars, and septa divided into lobes and saddles. 'The ventral lobe is 
divided, and there are two laterals and an undivided antisiphonal lobe. In Hauer's generic diagnosis it is stated that the lobes are clydonitic, unserrated, and the Californian species has similar septa.

The form probably had a larval coil at the beginning, but this has not yet been found.

This genus is distinguished from Bactrites by its forward-pointing siphonal collars and more complex septa; from Baculites it is distinguished by its simpler, goniatitic septa.

Rhabdoceras is known only from the Upper Triassic. In the Alpine province it occurs only in the Noric stage, and the beds of Plumas County, Cal., where it has been found, belong here also.

Rhabdoceras Suessi Hauer is the only European species of this genus, and R. Russelli Hyatt is the only other representative known.

\section{RHABDOCERAS RUSSELLI Hyatt.}

Pl. XLVII, figs. 13-15; Pl. LVI, fig. 26.

1892. Rhabdoceras Russelli, A. Hyatt, Bull. Geol. Soc. America, vol. 3, p. 398.

Shell straight, slender, increasing very slowly in size; cross section oval, with the venter more sharply rounded than the dorsum. Surface ornamented with cross ribs that run entirely around the shell, with gentle backward bend on the dorsum and the venter. The ribs are not prominent and are narrower than the interspaces.

Septa goniatitic, with long rounded saddles and linguiform lobes. The ventral lobe is divided by a long saddle into two slender branches; there are two tongueshaped laterals and a smaller undivided dorsal lobe.

This species resembles Rhabdoceras Suessi Hauer as described by Mojsisovics, but differs from the Alpine species in having the cross section more oval, the ribs not so stroing, and the lobes and saddles longer at the same size.

Horizon and locality.-In the Upper Triassic, Noric horizon, in the shales above the Hosselkus limestone, in the calcareous beds immediately above the Pseudomonotis shales. It was associated with Pseudomonotis subcircularis Gabb, Halorites americanus Hyatt, and Atractites sp. indet., along with many pelecypods.

J. P. Smith also found it in the Pseudomonotis beds of Muttleberry Canyon, West Humboldt Range, 8 miles southeast of Lovelock, Nev., associated with Pseudomonotis subcircularis Gabb, Arcestes Andersoni Hyatt and Smith, Placites humboldtensis Hyatt and Smith, Halorites conf. americanus Hyatt, Myophoria sp. indet., and other species not identified.

a Cephalopoden der Irallstätter Kalke: Abhandl. K.-k. geol. Reichsanstalt, Wien, vol. 6, pt. 2, p. 571, Pl. CXXXIII, figs. 10-17. 


\title{
BELEMNOIDEA.
}

\author{
Family BELEMNITID A.. \\ Genus ATRACTITHS Guembel.
}

1861. Atractites, Guembel, Geognostische Beschreibung des Bayrischen Alpengebirges, p. 475.

1871. Aulacoceras (pars), Mojsisovics, Ueber das Belemnitiden-Geschlecht Aulacoceras: Jahrb. K.-k. geol. Reichsanstalt, p. 41.

1880. Aulacoceras (pars), Branco, Beobachtungen an Aulacoceras: Zeitschr. Deutsch. geol. Gesell., p. 401.

1882. Atractites, Mojsisovics, Cephalopoden der Mediterranen Triasprovinz: Abhandl. K.-k. geol. Reichsanstalt, Wien, vol. 10, p. 299.

1887. Atractites, von Hauer, F., Cephalopoden des Bosnischen Muschelkalkes: Denkschr. K. Akad. Wiss., Wien, 54, vol. p. 3.

1896. Atractiles, Toula, F., Fine Muschelkalkfauna am Golie von Ismid in Kleinasien: Beitr. Pal. und Geol. Oesterreich-Ungarns und des Orients, vol. 10, pt. 4, p. 185.

1902. Atractites, Mojsisovics, Das Gebirge um Hallstatt, Supplement-Heft, p. 192.

The genus Atractites, as restricted by Mojsisovics, comprises belemnoid forms with long phragmocone and short guard. The phragmocone is chambered, long and slender, has simple concave septa, marginal siphuncle, backward-pointing siphonal collars, and a calcareous protoconch. The guard is the calcareous sheath that surrounds the phragmocone; in the Belemnites it makes up the greater part of the shell, but in Atractites it is little longer than the chambered part, and has neither ridges nor furrows.

The phragmocone is homologous with the shell of Bactrites, from which it probably descended. The guard, or ostracum, has no homology in any part of the shell of Bactrites, but is a coenogenetic character which reached its full development in the internal shell of Belemnites, and of which the pen of the squid is the sole remnant.

In Atractites we see the beginning of this character, for at least in some species the shell was several centimeters long before the guard began to be developed. It began as a thickening of the calcareous deposit around the lower end of the phragmocone and gradually enveloped the whole, until nothing could be seen on the outside but the prismatic secondary shell. This change probably took place when the chambered shell was enveloped by the mantle, and ceased to be the habitation of the animal when it passed from adolescence to maturity.

Atractites is most common in the Triassic, Muschelkalk and Upper Triassic, but is also found in the Lower Jurassic, where it has usually been described as Orthoceras. The species described below is the only one published from America, but there are several undescribed species in the Middle and Upper Triassic. 
ATRACTITES PHILIPPII Hyatt and Smith, sp. nov.

Pl. XIVIII, figs. 1-3.

Form long, slender, conical, with cylindrical cross section. Angle of increase very small. Phragmocone long and slender, with chamber walls set close together, marginal siphuncle, backward-pointing siphonal collars, short siphonal lobe, and calcareous protoconch. Guard thick and massive, not extending far beyond the small end of the chambered' internal shell, and not enlarged below the end, as is usually the case with Atractites.

The guard was not developed until the chambered shell was several centimeters long, for specimens of this size were found without any trace of the ostracum.

Horizon and locality-Common in the upper part of the zone of Tropites subbullatus, Upper Triassic, Shasta County, Cal., on the divide between Squaw Creek and Pit River, 3 miles east of Madison's ranch; also in the same horizon, on Bear Mountain, about 20 miles northeast of Redding, in the same association.

The specific name is given in honor of Dr. E. Philippi.

\section{NAUTILOIDEA.}

Genus PROCLYDONAU'IILUS Mojsisovies.

1902. Proclydonautilus, E. von Mojsisovics, Cephalopoden der Hallstätter Kalke, Supplement-Heft, p. 207 .

Type.-Nautilus Griesbachi Mojsisovies.

Form involute, with high, rounded whorls, nearly smooth shell, narrow umbilicus, and nearly central siphuncle. The septa are divided into numerous lobes and saddles. The broad ventral saddle is divided by a shallow funnel-shaped lobe; there is also a broad and deep lateral lobe. ' The internal part of the septum shows no lobes nor saddles. The young stages are like the Carboniferous genus Coloceras (Nautilus globatus Meek and Worthen), and the transition from the Paleozoic to the Triassic type of septa is very gradual. Mojsisovics ${ }^{a}$ formerly assigned Nautilus triadicus to his genus Clydonautilus, from which, however, it may be distinguished by having one less lateral lobe, a rounded instead of angular whorl, and the shape of the inner volutions. The writers are very doubtful if Proclydonautilus triadicuis belongs to the same group with Clydonautilus.

a Cephalopoden der Mediterranen Triasprovinz: A bhandl. K.-k. geol. Reichsanstalt, Wien, vol. 10, p. 281. 
1873. Nautilus triadicus, E. von Mojsisovics, Cephalopoden der Hallstitter Kalke: Abhandl. K.-k. geol. Reichsanstalt, Wien, vol. 6, pt. 1, p. 27, Pl. XlV, figs. $1-4$.

1882. Clydonautilus triadicus, E. von Mojsisovics, Cephalopoden der Mediterranen Triasprovinz: Abhandl. K.-k. geol. Reichsanstalt, Wien, vol. 10, p. 281.

1902. Proclydonautilus triadicus, L. von Mojsisovics, Das Gebirge um Hallstatt, Abtheil I, SupplementHeit, p. 209.

Involute, somewhat compressed laterally, high whorled, with broadly rounded flanks and venter without any angle on either. Umbilicus completcly closed; broadly rounded umbilical shoulders. The whorl is slightly broader than it is high, the greatest breadth being even with the projection of the top of the inuer whorl. The height of the whorl is two-thirds of the total diameter. The siphuncle lies a little below the center. The surface is smooth, having no ornamentation except the exceedingly fine radial strix of growth, which bend backward on the venter, forming a broad hyponomic sinus.

The septa are sinuous, showing both lobes and saddles; the broad and deep ventral saddle is divided by a narrow and shallow abdominal lobe; the lateral lobe is long and rather broad; on the umbilicus there is a second lateral lobe, shallow and broad. There is no internal lobe.

Relative dimensions of the adull shell.

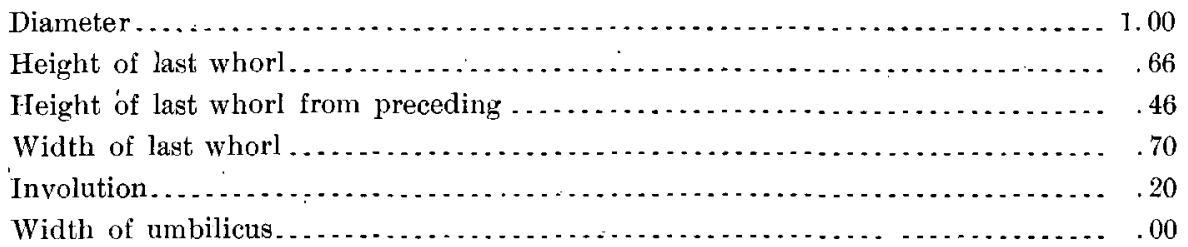

The largest specimen found had a diameter of $97 \mathrm{~mm}$; the average size of mature specimens was about $70 \mathrm{~mm}$. In the youngest stages there is no lobe nor saddle, the septum being straight, and the shape is globose; at this stage the shell corresponds to the Carboniferous genus Coloceras Hyatt (Nautilus globatus Meek and Worthen). At the diameter of $7 \mathrm{~mm}$. the ventral lobe begins to develop, and at $10 \mathrm{~mm}$. the lateral lobes and saddles are visible; at this stage the whorl ceases to be globose and becomes higher. At $25 \mathrm{~mm}$. the shell has all the characters of maturity, and from then forward changes only in size. In the ontogeny of this species we are able to connect a highly specialized Mesozoic group with the Paleozoic radicle:

Horizon and locality.-Upper Triassic, zone of Tropites subbullatus, Shasta County, Cal., on the divide between Squaw Creek and Pit River, 3 miles east of 
Madison's ranch and one-half, mile north of the trail to Brock's ranch. This is one of the commonest cephalopods in these beds.

Genus COSMONAUTILUS Hyatt and Smith, gren. nov.

Type.-Cosmonautilus Dilleri Hyatt and Smith.

Form involute, high whorled, laterally compressed, with narrow flattened venter and distinct abdominal shoulders. Surface at maturity smooth with only the striæ of growth. Septa very sinuous, with broad rounded ventral lobe, long principal lateral, and a shallow small lobe outside of the umbilicus. The internal septum has no lobe. Siphuncle, above the center.

In the adolescent stage this genus resembles Metacocercs ( $M$. cavatiforme Hyatt, Geol. Survey Texas, Second Ann. Rept., 1890, p. 334, figs. 30-33). In these stages the whorl is broad, much lower than at maturity, with simple septa, and a strong row of tubercles on the angular abdominal shoulders. The phylogeny of this group seems to be as follows:

Temnocheilus-Metacoceras-Cosmonautilus. Clydonautitus Mojsisovics is evidently a descendant of this genus, for $C$. Quenstedti Mojsisovics ${ }^{a}$ in its youth goes through a stage exactly like Cosmonautilus. This genus is distinguished from its descendant in lacking one pair of lateral lobes and in the primitive character of its young, the simplicity of the septa, and the strong marginal tubercles.

Cosmonautilus is known only in the Triassic, being represented in California by several new species. Clydonantilus biangularis Mojsisovics, of the Upper Triassic of the Himalayas in India, appears to belong to this genus, as may also some of the European species assigned by Mojsisovics to Clydonautilus.

COSMONAUTILUS DILLERI Hyatt and Smith, sp. nov.

Pl. LI, fig. 1; Pl. LII, fig. 1; Pl. LIII, figs. 1 and 2; Pl. LIV, fgs. 1-4; Pl. LV, figs. 1-11.

Form involute, high whorled, somewhat compressed laterally, deeply embracing, and deeply indented by the inner volutions. Greatest breadth of the whorl at a point even with the projection of the inner volution. The height of the whorl is two-thirds of the total diameter of the shell, the width is six-sevenths of the height, and the indentation by the inner volution is less than one-third of the height. The whorl is broadly convex, and slopes up from the widest point to the abruptly rounded abdominal shoulders; the venter is flattened and its width between the shoulders is less than one-third of the greatest breadth of the whorl. The siphuncle is above the center of the chamber.

The septa are sinuous, divided externally into complex lobes and saddles. The long ventral saddle is divided by a broad $U$-shaped ventral lobe, forming two very

a Cephalopoden der Hallstätter Kalkc: AbhandJ. K.-k. geol. Reichsanstalt, Wien, vol. 6, pt. 1, p. 22, Pl. IX, tigs. 1 and 3 . 
narrow tongue-shaped saddles on the abdominal shoulders; there is a deep and broad principal lateral lobe, with rounded extremity, and a small shallow lateral on the umbilical slope. The internal septum has no lobe nor saddles. The surface of the shell is smooth at maturity, having only fine cross striæ of growth.

In youth, up to the diameter of $8 \mathrm{~mm}$., the whorl is subglobose and perfectly smooth, with simple straight septa. At this size the abdominal shoulders begin to develop, and very soon faint tubercles begin to appear on the shoulders; this sculpture rapidly grows strong, until the shape, sculpture, and septa are very like those of Metacoceras Hyatt. But by the time a diameter of $12 \mathrm{~mm}$. is reached the septa already show the sinuous lobes and saddles characteristic of the mature form, except that they are not so complex. We thus find Metacoceras characters and those belonging to Cosmonautilus occurring simultaneously in the same individual, which may mean either that the Paleozoic characters are retarded in the development or that the Mesozoic characteristics are unduly accelerated in their appearance.

At the diameter of $35 \mathrm{~mm}$. the tubercles become obsolete and the shoulders lose their angularity. The shell is then entering on maturity, and from this time onward does not change in any essential characters, the whorls becoming proportionally higher and more compressed laterally, but retaining their general characters. J. P. Smith has found a specimen of $280 \mathrm{~mm}$. diameter that agreed in all essentials with those of about $100 \mathrm{~mm}$.

IIorizon and locality.-Upper Triassic, zone of Tropites subbullatus, Shasta County, Cal., on the divide between'Squaw Creek and Pit River, 3 miles east of Madison's ranch and one-half mile north of the trail to Brock's ranch. This species is not so common as Proclydonautilus triadicus, but is not uncommon. J. P. Smith also found it in the same horizon at Terrup-chetta (Cottonwood Flat), near Squaw Creek, about 6 miles north of the first locality. The specific name is given in honor of Mr. J. S. Diller.

$$
\text { Genus MOJSVAROCHRAS Hyatt. }
$$

1883. Mojscaroceras, Hyatt, Genera of Fossil Cephalopods: Proc. Boston Soc. Nat. Mist., vol. 22, p. 269. 1882. Temnocheilus, Mojsisovics, Cephalopoden der Mediterranen Triasprovinz: Abhandl. K:-k. geol. Reichsanstalt, Wien, vol. 10, p. 226.

(Not 1844. Temnocheilus, McCoy, Synopsis of the Characters of the Carboniferous Limestone Fossils of Ireland, p. 20.)

Type.-Temnocheilas Neumayri Mojsisovics, Cephalopoden der Mediterranen Triasprovinz, p. 267, Pl. LXXXVIII, figs. 1 and 2.

Form evolute, with low, broad quadrangular, little embracing whorls; wide, deep umbilicus; and two rows of lateral tubercles, one on the umbilical and one on the abdominal shoulders. The septa show broad, shallow ventral and lateral lobes, and a funnel-shaped dorsal or annular lobe. 
The primitive shape and septa strongly resemble the Paleozoic and early Mesozoic Foordiceras Hyatt, through which group it has probably descended from Temnocheilus. Most of the species assigned by Hyatt to Mojsvaroceras have been described under the name of Temnocheilus, but this genus will have to be restricted to the less specialized Paleozoic members of the group.

As thus defined, Mojsvaroceras is known only in the Triassic. In America the species described below is the only certain representative, but there are some forms in the Middle Triassic that may belong here.

\section{MOJSVAROCERAS TORNERI Hyatt and Smith, sp. nov.}

Pl. XLVIII, figs. 6-11.

Evolute, whorls subquadratic, low and broad, with flanks narrowing slightly to. the abruptly rounded abdominal shoulders. Whorls rather deeply indented by the inner volutions. Surface nearly smooth, but ornamented with weak tubercles on the flanks and on the abdominal shoulders. The umbilicus is deep and wide, the inner walls being very steep.

The dimensions of the type specimen are as follows:

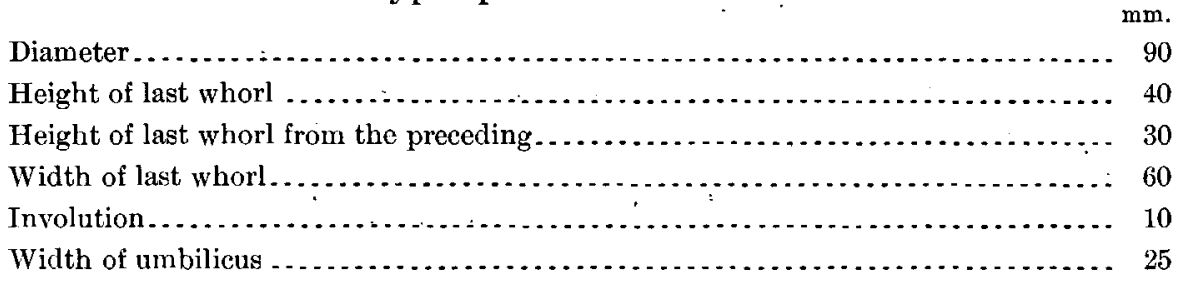

The septa are slightly sinuous, with a broad, shallow ventral lobe, and a similar lateral, and a funnel-shaped dorsal or annular lobe. The siphuncle is below the center of the whorl.

Horizon and locality. - Two specimens were found by J. P. Smith in the Upper Triassic, zone of Tropites subbullatus, of Shasta County, Cal., on the divide between Squaw Creek and Pit River, about 3 miles east of Madison's ranch and one-half mile north of the trail to Brock's ranch. The specific name is given in honor of Mr. H. W. Turner.

\section{Genus ORTHOCERAS Breyn.}

Shell straight or nearly so, tapering; siphuncle median or submedian, never marginal. Septa convex toward the apex, straight in cross section. This is the simplest and commonest member of the Orthoceratidæ; as thus defined the genus ranges from the lower Silurian to the Upper Triassic, with very little change. Species are distinguished by the angle of growth, the surface ornamentation, distance apart of the septa, position and size of the siphuncle. But these differences 
are so slight that it is extremely unsatisfactory to attempt to separate most species of this group. And it is still more unsatisfactory to try to identify or. compare species supposed to be identical, but occurring at different localities and in different association.

In America it has been found sparingly in the Lower Triassic, but it is very common in the Middle Triassic of Nevada, and occurs occasionally in the Upper - Triassic of California.

\section{ORTHOCERAS SHASTENSE Hyatt and Smith, sp. nov.}

Pl. XLVIII, figs. 4 and 5 .

Shell small, slender, angle of increase about six degrees. Cross section circular; siphuncle median. Surface smooth. Septa close together, distant about onie-half of the diameter of the shell.

This species resembles Orthoceras Blakei Gabb, from the Middle Triassic of the Humboldt Kange, Nevada, but differs from that species in its smaller angle of increase and its rather more distant septa.

Horizon and locality. $-A$ few specimens were found by J. P. Smith in the Upper Triassic, zone of Tropites subbullatus, of Shasta County, Cal., on the divide between Squaw Creek and Pit River, about 3 miles east of Madison's ranch, and one-half mile north of the trail to Brock's ranch. It was in the same beds with Tropites subbullatus, Discotropites sandlingensis, Sagenites Herbichi, Halobia superba, and many other species characteristic of this horizon. 


\section{BIBIIOGRAPHY.}

Arthaber, G. Yon. Die Cephalopodenfauna der.Reiflinger Kalke: Beiträge zur Paläontologie und Geologie Oesterreich-Ungarns und des Orients, Wien und Leipzig, vol. 10, 1896.

—_ Das jüngère Paläozoicum aus der Araxes-Enge bei Djulfa (Ueber das Paläozoicum in Hocharmenien und Persien, etc., by F. Frech and G. von Arthaber): Beitrïge zur Palïontologie und Geologie Oesterreich-Ungarns und des Orients, Wien und Leipzig, vol. 12, pt. 4, 1900.

Neue Funde in den Werfener Schichten und im Muschelkalke des südlichen Bakony, und Revision der Cephalopodenfauna des Muschelkalkes: Resultate der Wissenschaftlichen Erforschung des Balatonsees, vol. 1, pt. 1, 1903.

Beyrich, H. E. Ueber einige Cephalopoden aus dem Muschelkalk der Alpen und ïber verwandte Arten: Abhandl. K. Akad. Wiss., 1867.

Bовскі, J. Die geologischen Verhältnisse des südlichen Theiles des Bakony: Mittheilungen aus dem Jahrbuch der kön. ungarischen geologischen Anstalt, Budapest, vol. 2, 1872.

Branco, W. Beobachtungen an Aulacoceras: Zeitschr. Deutsch. geol. Gesell., 1880.

Diener, C. Cephalopoda of the Muschelkalk: Himalayan Fossils, vol, 2, pt. 2, 1895: Mem. Geol. Survey India, Pal. Indica, ser. 15.

- Triadische Cephalopodenfaunen der ostsibirischen Küstenprovinz: Mém. Com. géol., St.Pétersbourg, vol. 14, No. 3, 1895.

Cephalopoda of the lower Trias: Himalayan Fossils, vol. 2, pt. 1, 1897: Mem. Geol. Survey India, Pal. Indica; ser. 15.

Mittheilung über einige Cephalopodensuiten aus der Trias des südlichen Bakony: Resultate der Wissenschaftlichen Erforschung des Balatonsees, vol. 1, pt. 1, Pal. Anhang, 1899.

__ Die Triadische Cephalopoden-Fauna der Schiechlingshöhe bei Hallstatt: Beiträge zur Paläontologie und Geologie Oesterreich-Ungarns und des Orients, Wien und Ieipzig, vol. 12, 1900.

Dittman, A. von. Zur Fuuna der Hallstätter-Kalke: Geognost.-palaeont. Beitr., von Benecke, Schlœenbach und Waagen, vol. 1, 1866.

Frecr, F. Ueber Trias-Ammoniten aus Kaschmir: Centralblatt für Min., Geol. und Pal., vol. 3, No. 5, 1902.

- Die Dyas: Lethæa Palæozoica, Bd. 2, Lieferung 3, 1901, and Lieferung 4, 1902.

Lethæa Geognostica. II. Theil, Das Mesozoicum. Heft 1, Trias. Lieferung 1, Einleitung des Mesozoicum und der Trias, und Continentale Trias. 1903.

GABB, W. M. Description of the Triassic Fossils of California and the Adjacent Territories: Geol. Survey California, Palæontology, vol. 1, 1864.

- Descriptions of some Secondary Fossils from the Pacific States: Am. Jour. Conchol., vol. 5, 1870.

Griesbach, C. L. Palæontological Notes on the Lower Trias of the Himalayas: Records Geol. Survey India, vol. 13, 1880.

Guember, W. Geognostiche Beschreibung des Bayrischen Alpengebirges, 1861. 
HAAN, G. DE. Monographiæ Ammoniteorum et Goniatiteorum Specimen, 1825.

Hauer, F. von.' Die Cephalopoden des Salzkammergutes aus der Sammlung des Fürsten Metternich, Wien, 1846.

- Ueber neue Cephalopoden aus dem Rothen Marmor von Aussee: Haidinger's Naturwissenschaftliche Abhandlungen, vol. 1, 1847.

- Ueber neue Cephalopoden aus den Marmorschichteǹ von Hallstatt und Aussee: Haidinger's Naturwissenschaftliche Abhandlungen, vol. 3, 1849.

_ Beitrïge zur Kenntniss der Cephalopoden-Fauna der Hallstätter Schichten: Denkschr. K. Akad. Wiss., Wien, vol. 9, 1855.

_ Nachtrag zur Kenntniss der Cephalopoden-Fauna der Hallstätter Schichten: Sitzungsber. K. Akad. Wiss., Wien, vol. 41, 1860.

_- Cephalopoden aus der Unteren Trias der Alpen: Sitzungsber. K. Akad. Wiss., Wien, vol. 52, 1865.

- - Cephalopoden des Bosnischen Muschelkalkes von Han Bulog bei Sarajevo: Denkschr. K. Akad. Wiss., Wien, vol. 54, 1887.

- Beiträge zur Kenntniss der Cephalopoden aus der Trias von Bosnien: Denkschr. K. Akad. Wiss., Wien, vol. 59, pt. 1, 1892.

— Beiträge zur Kenntniss der Cephalopoden aus der Trias von Bosnien: Dẹkschr. K. Akad. Wiss., Wien, vol. 63, pt. 2, 1896.

Haug, E. Les Ammonites du Permien et du Trias: Bull. Soc. géol. France, ser. 3, tome 22, 1894.

— Études sur les Goniatites: Mém. Soc. géol. France, No. 18, 1898.

Holzaphel, E. Die Cephalopoden des Domanik im südlichen Timan: Mém. Com. géol., St.-Pétersbourg, vol. 12, No. 3, 1899 .

Hyatr, A. Genera of Fossil Cephalopods: Proc. Boston Soc. Nat. Hist., vol. 22, 1883.

- Jura and Trias at Taylorville, Cal.: Bull. Geol. Sóc. America, vol. 3, 1892.

- Cephalopoda: Text-book of Palæontology by K. A. von Zittel (translated by C. R. Eastman), 1900.

Karpinsky, A. Ueber die Ammoneen der Artinsk-Stufe, und einige mit denselben verwandte Carbonische Formen. Mém. Acad. imp. sci. St.-Pétersburg, - sér. 7, tome 37, No. 2, 1889.

KitTL, Ernst. Die Cephalopoden der oberen Werfener Schichten von Mué in Dalmatien, sowie von anderen dalmatinischen, bosnisch-herzegowinischen und alpinen Lokalitäten: Abhandl. K.-k. geol. Reichsanstalt, Wien, vol. 20, pt. 1, 1903.

Koninck, L. G. de. Descriptions of some Fossils from India, discovered by Dr. A. Fleming, of Edinburgh: Quart. Jour. Geol. Soc. London, vol. 19, 1863.

Laube, G. Die Fauna der Schichten von St. Cassian: Denkschr. K. Akad. Wiss., Wien, vol. 30, 1869.

__ Ueber Ammonites Aon Münster und dessen Verwandte: Sitzungsber. K. Akad. Wiss., Wien, vol. 59, 1869.

McCoy, F. Synopsis of the Characters of the Carboniferous Fossils of Ireland, 1844.

Meer, F. B. Palæontology: U. S. Geol. Explor. 40th Par., vol. 4, pt. 1, 1877.

Mojsisovics, E. vos. Beiträge zur Kenntniss der Cephalopoden-Fauna der Oenischen Gruppe: Jahrb. K.-k. geol. Reichsanstalt, Wien, 1870.

— Ueber die Entwicklung von Ammoniten in der Carbonischen Formation Indiens: Verhandl. K.-k. geol. Reichsanstalt, Wien, 1872.

- Das Gebirge um Hallstatt. Pt. 1. Die Mollusken-Faunen der Zlambach und Hallstätter Schichten: Abhandl. K.-k. geol. Reichsanstalt, Wien, vol. 6, pt. 1, 1873.

—. Die Dolomitriffe von Südtirol und Venetien, Wien, 1878. 
Mossisovics, E. vow. Vorläufige kurze Uebersicht der Ammoniten-Gattungen der Mediterranen und Juvavischen Trias: Verhandl. K.-k. geol. Reichsanstalt, Wien, 1879.

- (In Bittner's) Bericht über die geolog. Aufnahmen in Judicarien und Val Sabbia: Jahrbuch K.-k. geol. Reichsanstalt, Wien, 1881.

Die Cephalopoden der Mediterranen Triasprovinz: Abhandl. K.-k. geol. Reichsanstalt, Wien, vol. 10, 1882.

- Arktische Triasfaunen. Beiträge zur Paläontologischen Charakteristik der Arktisch-Pacifischen Triasprovinz: Mém. Acad. imp. sci. St.-Pétersbourg, sér. 7, tome 33, No. 6, 1886.

_-_ Ueber einige Japanische Trias Fossilien: Beiträge zu Paläontologie und Geologie OesterreichUngarns und des Orients, Wien und Liepzig, vol. 6, 1888.

_- Nachweis der Zone der Tropites subbullatus in den Hallstätter Kalken bei Hallein: Verhandl. K.-k. geol. Reichsanstalt, Wien, 1889.

Das Gebirge um Hallstatt. Pt. 1.- Die Cephalopoden der Hallstätter Kalke: Abhandl. K.-k. geol. Reichsanstalt, Wien, vol. 6, pt. 2, 1893.

Beiträge zur Kenntniss der obertriadischen Cephalopoden-Faunen des Himalaya: Denkschr.

K. Akad. Wiss., Wien, vol. 63, 1896.

- Das Gebirge um Hallstatt. Pt. 1. Die Cephalopoden der Hallstätter Kalke, Supplement-Heft: Abhandl. K.-k. geol. Reichsanstalt, Wien, vol. 6, pt. 1, I. Hälfte, 1902.

Muenster, G. Graf y. Ueber das Kalkmergel-Lager von St. Cassian in Tyrol, und die darin vorkommenden Ceratiten: Leonhard und Bronn's Neues Jahrbuch für Min., etc., 1834.

— Beiträge zur Geognosie und Petrifactenkunde des Südöstlichen Tirols, vol. 4, 1841.

Murchison, Verneulu and Keyserling. The Geology of Russia in Europe and the Ural Mountains: Palæontology, vol. 2, pt. 3, 1845 .

Noetung, F. Die Entwicklung der Trias in Oberschlesien: Zeitschr. Deutsch. geol. Gesell., vol. 32, 1880.

- Untersuchungen über den Bau den Lobenlinie von Pseudosageceras multilobatum Noetling: Palæontographica, vol. 51, 1905.

Neumayr, M. Die Ammoniten der Kreide und die Systematik der Ammoniten: Zeitschr. Deutsch. geol. Gesell., vol. 27, 1875.

Philippt, E. Die Ceratiten des Oberen Deutschen Muschelkalkes: Palæont. Abhandl. von Dames und Koken (Neue Folge), vol. 4, 1901.

Salomon, W. Geologische und Palæontologische Studien über die Marmolata: Palæontographica, vol. 42,1895 .

Sмrтн, J. P. The Metamorphic Series of Shasta County, Cal.: Jour. Geol., vol. 2, No. 6, 1894.

Classification of Marine Trias: Jour. Geol., vol. 4, No. 4, 1896.

Geographic relations of the Trias of California: Jour. Geol., vol. 6, No. 8, 1898.

The border-line between Paleozoic and Mesozoic in western America: Jour. Geol., vol. 9, No. 6, 1901.

- Ueber Pelecypoden-Zonen in der Trias Nord-Amerikas: Centralblatt für Min., Geol. und " Pal., 1902, pp. 689-695.

- The Carboniferous Ammonoids of America: Mon. U. S. Geol. Survey, vol. 42, 1903.

The Comparative Stratigraphy of the Marine Trias of Western America: Proceedings of the California Academy of Sciences, 3d ser., Geology, vol. 1, No. 10, 1904.

Smith, J. P., and Stuart Whluer. Prodromites, a New Ammonite Genus from the lower Carboniferous: Jour. Geol., vol. 9, 1901.

Suess, E. Ueber Ammoniten: Sitzungsber. K. Akad. Wiss., Wien, vol. 30, 1869. 
Tornquist, 4 . Neuere Beiträge zur Geologie und Paläontologie der Umgebung von Recoaro und Schio in Venetien: Zeitschr. Deutsch. geol. Gesell., vol. 50, pt. 4, 1898.

Toula, F. Eine Muschelkalkfauna am Golfe von Ismid in Kleinasien: Beiträge zur Paläeontologie und Geologie Oesterreich-Ungarns und des Orients, Wien und Leipzig, vol. 10, pt. 4, 1896.

WAAGEN, W. Productus Limestone Fossils: Salt Range Fossils, vol, 1, 1879: Mem. Geol. Survey India, Pal. Indica, ser. 13.

Preliminary Notice on the Triassic Deposits of the Salt Range: Records Geol. Survey India, vol. 25, 1892 .

Vorläufige Mittheilung über die Ablagerungen der Trias in der Salt Range: Jahrb. K.-k. geol. Reichsanstalt, Wien, vol. 42, 1892.

Fossils from the Ceratite Formation: Salt Range Fossils, vol. 2, 1895: Mem. Geol. Survey India, Pal. Indica, ser. 13.

Write, C. Fossils of the Jura-Trias of southeastern Idaho: U. S. Geol. and Geog. Survey Terr., vol. $5,1879$.

Contributions to Invertebrate Palæontology No. 5: Triassic Fossils of southeastern Idaho: U. S. Geol. and Geog. Survey Terr., vol. 12, pt. 1, 1880.

Whiteaves, J. F. Fossils of the Triassic Rocks of British Columbia: Geol. and Nat. Hist. Survey Canada; Contrib. Canadian Palæontology, vol. 1, pt. 2, 1889.

Zittel, K. A. von. Grundzüge der Paläontologie, 1895. 


\section{PLATES.}



PLATES I TO LXXXV. 


\section{PLATE I.}

\section{Flemingites Russeldi Hyatt and Smith (p. 121).}

Fugs. 1, 2, 3. Side and front views and septa.

From Lower Triassic (Meekoceras beds), 9 miles northeast of Wood Canyon, Aspen Ridge, Idaho. Collection United States National Museum.

\section{Clypites tentus Hyatt and Smith (p. 103).}

FIgs. 4, 5, 6. Side and rear views $(\times 2)$ and septa $(\times 3)$.

Figs. 7, 8. $\Lambda$ young specimen $(\times 3)$ of the same species, showing the Ambites stage of growth; diameter of $9 \mathrm{~mm}$. This species may prove to be merely the young of Hedenstramia Kossmati Hyatt and Smith.

From Lower Triassic (Meekoceras beds), 9 miles east, of Wood Canyon, Aspen Ridge, Idaho. Collection United States National Museum.

Columbites Parisianus Hyatt and Smith (p. 51).

FIGs. 9. 10, 11. Left side and front views (natural size) and septa ( $\times 3)$ of type specimen.

Figs. 12, 13, 14. Teft side, front, and rear views of an adolescent specimen; diameter of $33 \mathrm{~mm}$. (natural size).

From Lower Triassic (Columbites beds), 1 mile west of Paris, southeastern Idaho. Collection United States National Museum. 

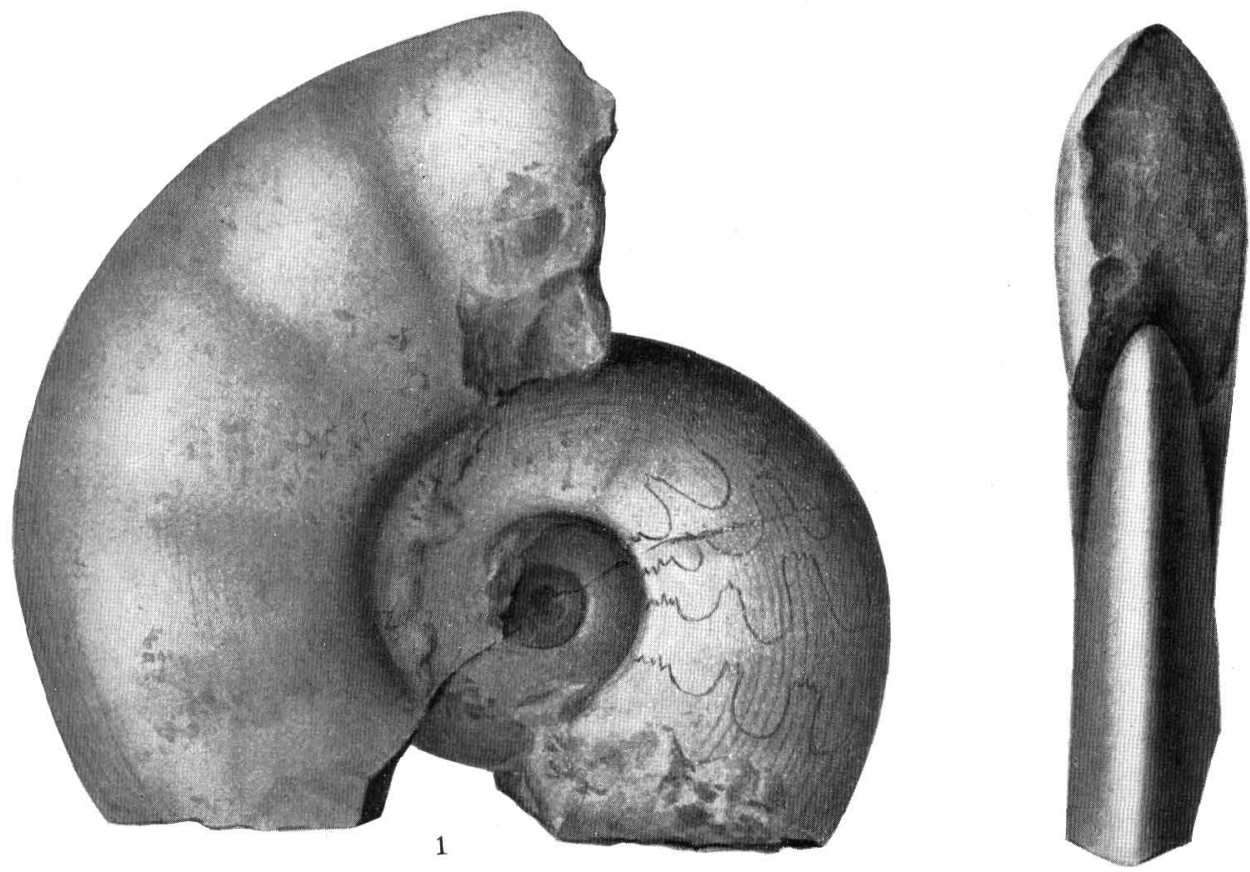

2
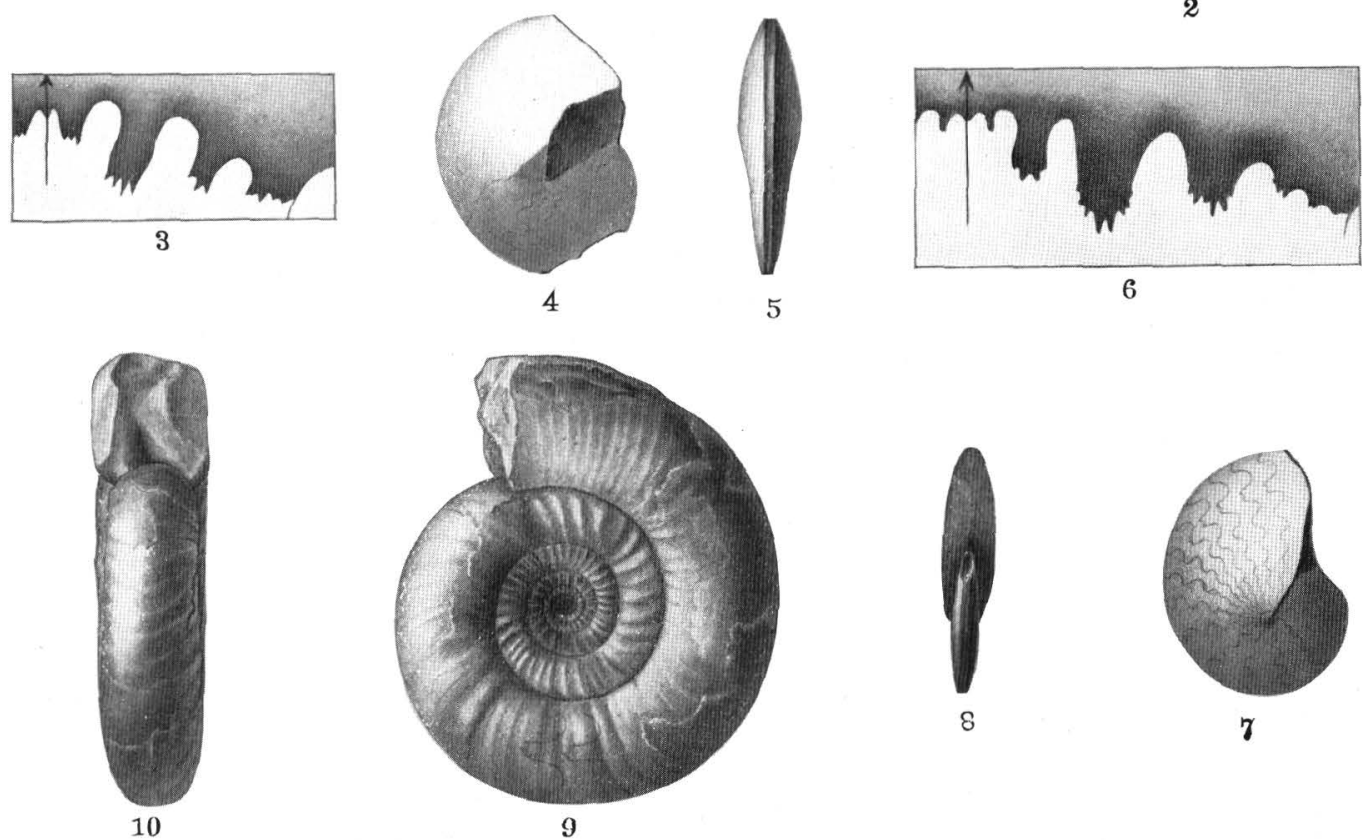

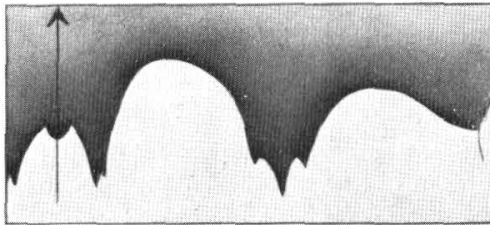

11

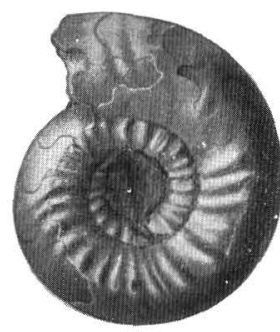

12
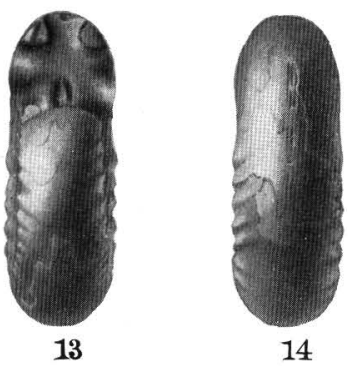

FLEMINGITES RUSSELLI, CLYPITES TENUIS, COLUMBITES PARISIANUS. 


\section{PLATE II.}

Cordillerites angulatus Hyatt and Smith (p. 110).

Figs. 1, 2, 3. Side and front views (natural size) and septa $(\times 2)$.

FIGS. 4, 5. Side and rear view of another specimen.

Figs. 7, 8. Side view and septa (both $\times 4$ ) of an adolescent specimen. Sicanites stage; diameter of $7 \mathrm{~mm}$.

Fra. 6. Side view $(\times 2)$ of an adolescent specimen, showing transition from Sicanites to Cordillerites. From Lower Triassic (Meekoceras beds), Wood Canyon, 9 miles east of Soda Springs, Aspen Ridge, Idaho. Collection United States National Museum.

\section{Aspenites acutus Hyatt and Smith (p. 96).}

Figs. 9, 10, 11. Side and front views $(\times 2)$ and septa $(\times 4)$ of an immature specimen.

FIGs. 12, 13. Left side view $(\times 2)$ and septa $(\times 4)$ of a larger specimen.

From Lower Triassic (Meekoceras beds), Wood Canyon, 9 miles east of Soda Springs, Aspen Ridge, Idaho. Collection United States National Museum. 

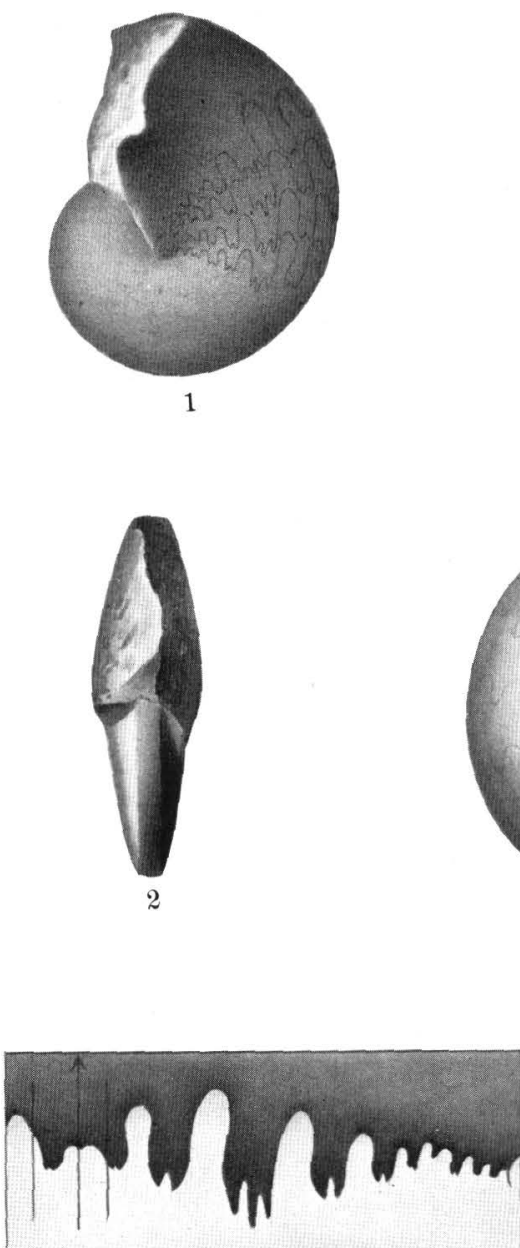

3

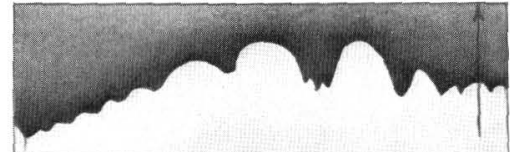

11

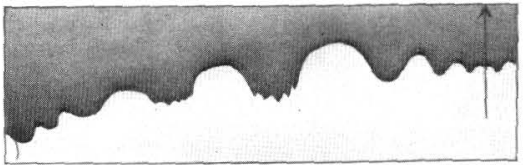

13
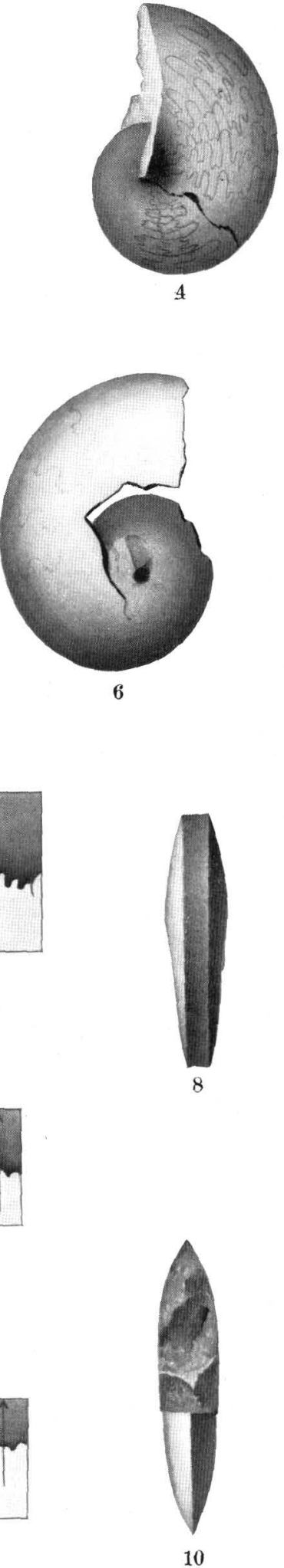
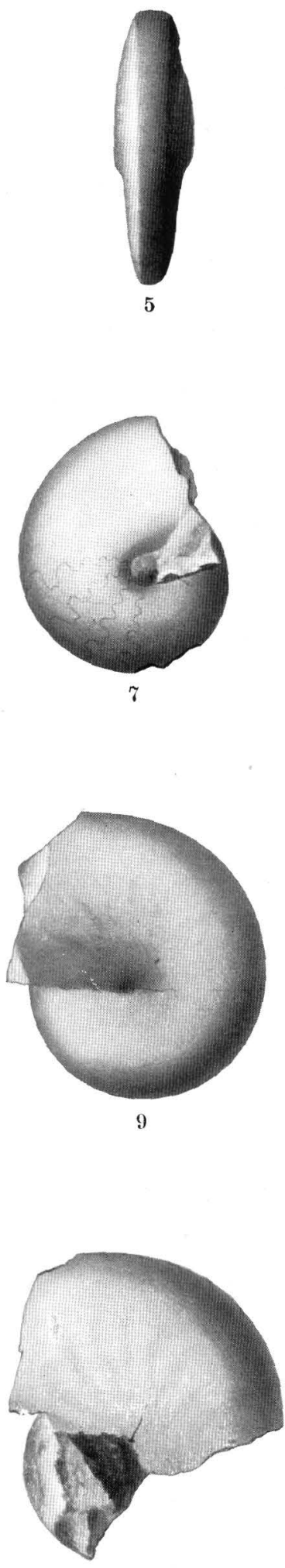

12 


\section{PLATE III.}

Asienites acutus Hyatt and Smith (p. 96).

Figs. 1, 2. Side and frnnt views of the type specimen.

Fig. 3. Side view of a larger specimen, showing the septa.

Fics. 4, 5. Side and rear views $(\times 6)$ of a young specimen; diameter of $4.5 \mathrm{~mm}$.

From Lower Triassic (Meekoceras beds), Union Wash, Inyo Ran e, California. Collection United States National Museum.

Ussuria compressa Hyatt and Smith (p. 89).

Figs. 6. 7. Side and front view of the type specimen.

Figs. 8, 9. Septa drawn from both sides of another specimen.

Figs. 10, 11. Side view (natural size) and septa $(\times 2)$ of a smaller specimen.

From Lower Triassic (Mcekoceras beds), Union Wash, Inyo Range, California. Collection United States National Museum. 


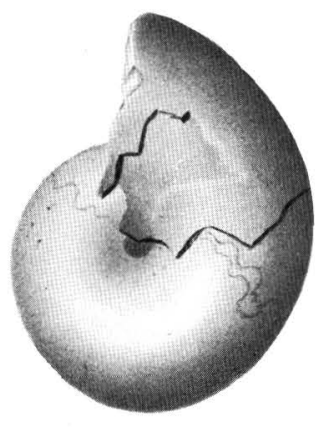

1

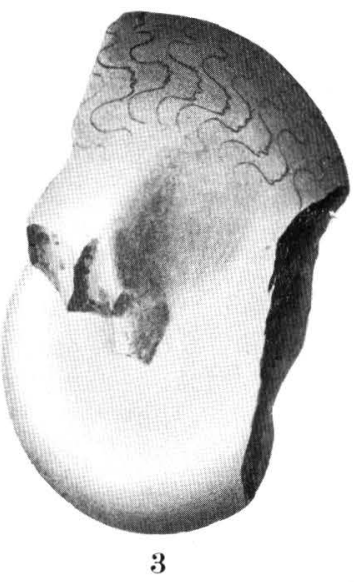

8
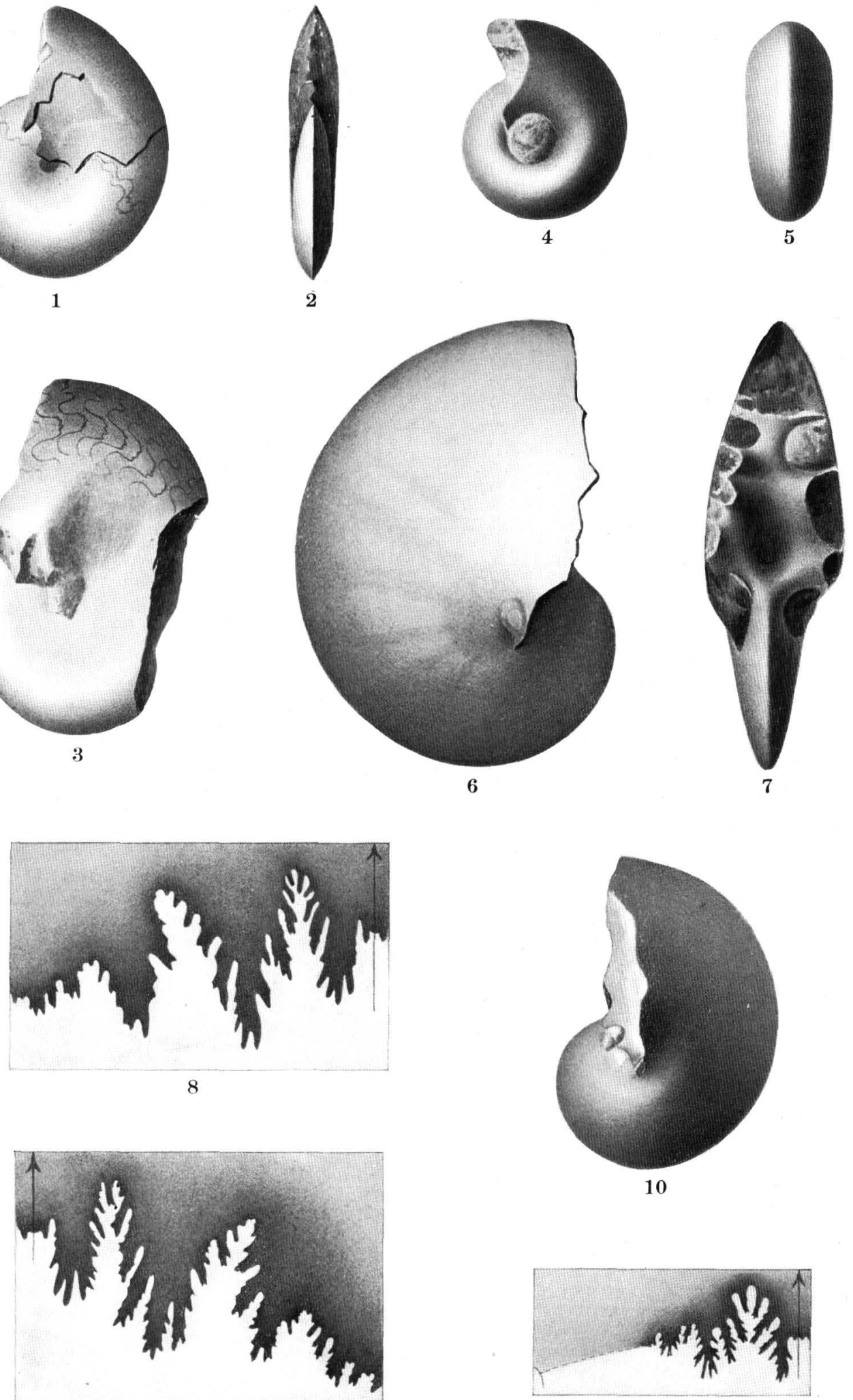

9
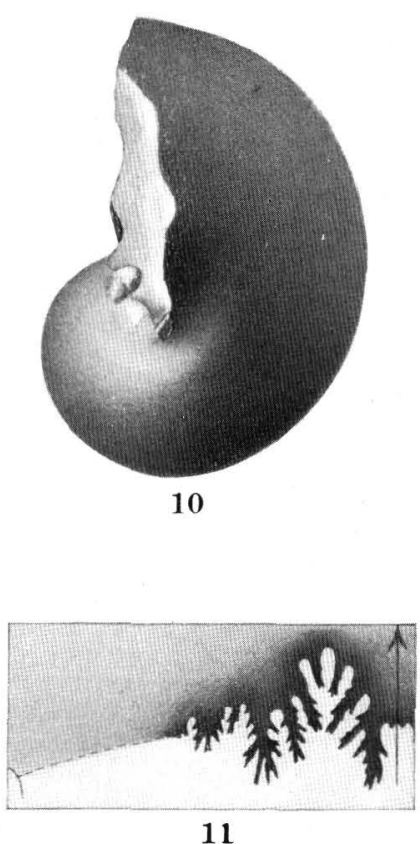


\section{PLA T E I V.}

Pseudosageceras in'termontanum Hyatt and Smith (p. 99).

Fics. 1, 2, 3. Side and front views and septa of the type specimen.

From Lower Triassic (Meekoceras beds), Wood Canyon, 9 miles east of Soda Springs, $\Lambda$ spen Ridge, Idaho. Collection United States National Museum.

Lanceolites compactus Hyatt and Smith (p. 113).

Figs. 4, 5, 6. Side and rear views (natural size) and septa $(\times 2)$.

FIG. 7. Septa $(X 3)$ of another specimen.

Figs. 8, 9, 10. Side and front views $(\times 3)$ and septa $(X 6)$ of a young specimen; diameter 12 $\mathrm{mm}$. All the specimens of Lanceolites compactus figures on this plate are immature, and have not yet acquired the lanceolate type of septa which is characteristic of maturity in this genus. The mature stage is shown on Pl. LXXVill, figs. 9, 10, 11.

From Lower Triassic (Meekoceras beds), Wood Canyon, 9 miles east of Soda Springs, Aspen Ridge, Idaho. Collection United States National Museum. 


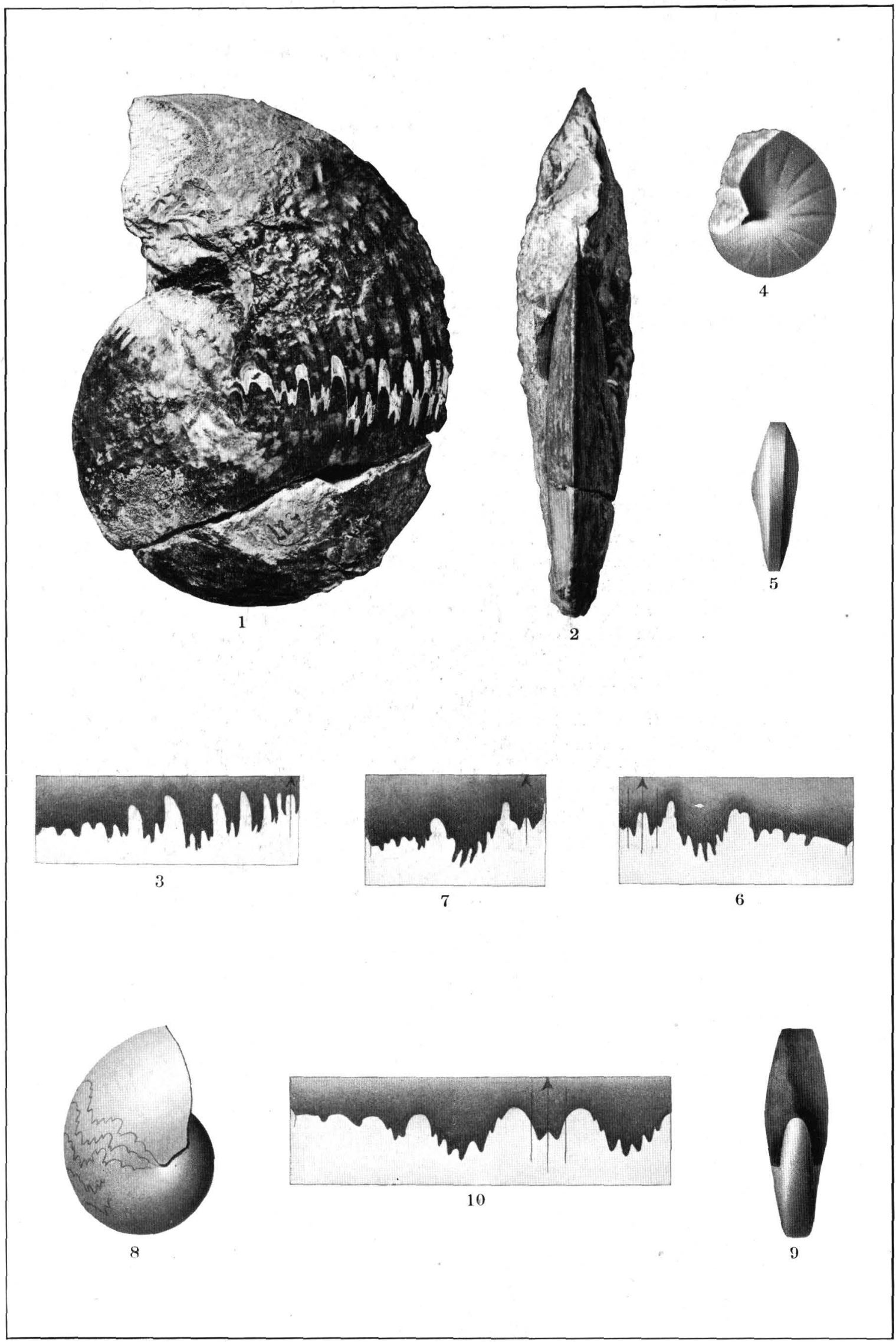

PSEUDOSAGECERAS INTERMONTANUM, LANCEOLITES COMPACTUS. 


\section{PLA TE V.}

Pseudosagechas intermontanum Hyatt and Smith (p. 99).

Figs. 1, 2. Side and front views of a large specimen.

Figs. 3, 4. Side view (natural size) and septa $(\times 2)$ of a smaller specimen.

Figs. 5, 6. View of ventral keel.

From Lower Triassic (Meckoceras beds), Union Wash, Inyo Range, Inyo County, Cal. Collection United States National Museum.

Lanceolites compactus Hyatt and Smith (p. 113).

Figs. 7, 8. Side view (natural size) and septa $(X 2)$ considerably modified by weathering.

Fig. 9. Septa $(\times 3)$ from a small specimen. Details of septa not quite correct and greatly modified by weathering. The specimens shown on this plate are immature and have not yet acquired the lanceolate type of septa that characterizes maturity. The mature stage is shown on Pl. LXXVIII, figs. 9-11.

From Lower Triassic (Meckoceras beds), Union Wash, Inyo Range, Inyo County, Cal. Collection United States National Museum. 


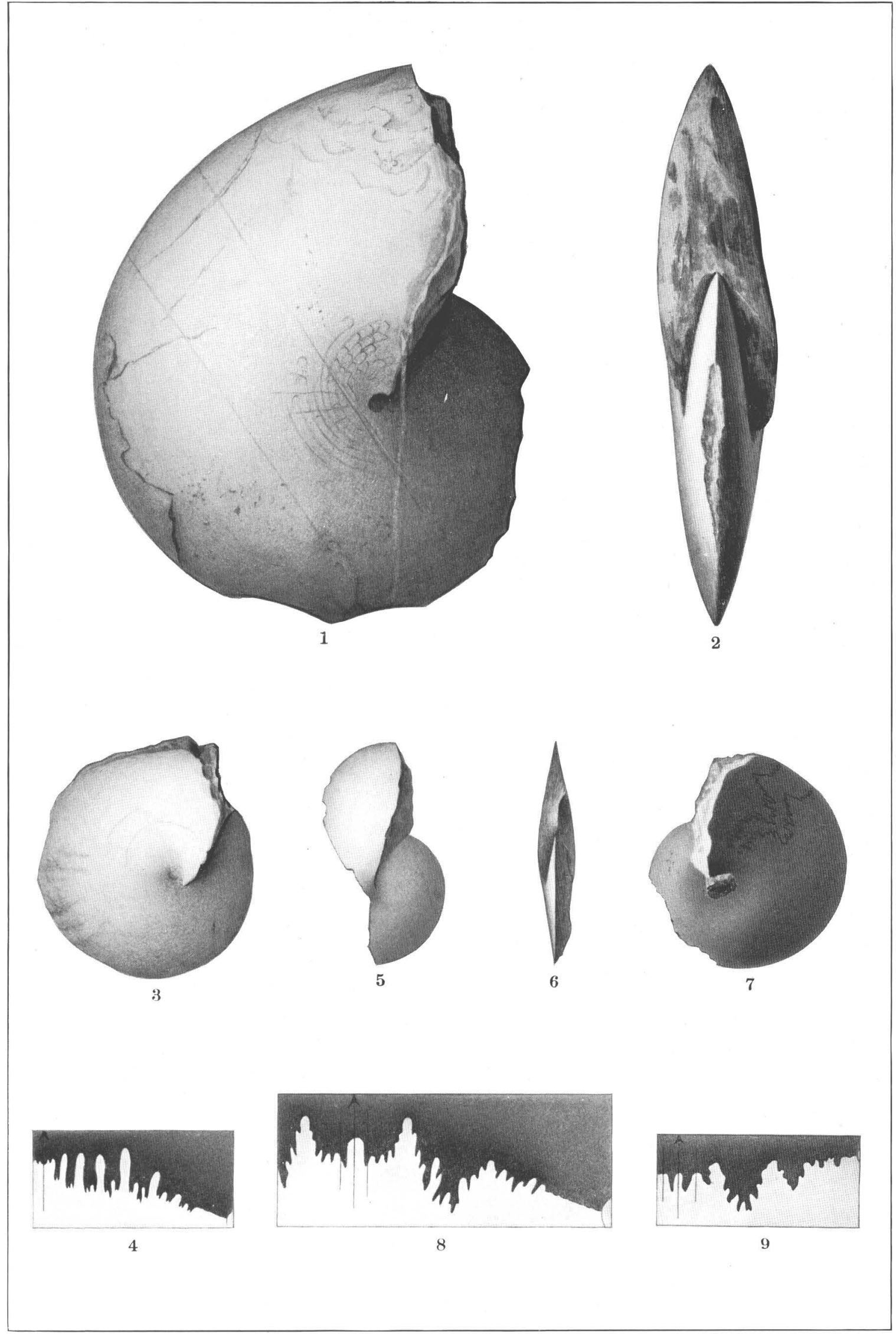

PSEUDOSAGECERAS INTERMONTANUM, LANCEOLITES COMPACTUS. 


\section{PLATE VI.}

InYoItes Oweni Hyatt and Smith (p. 134).

Fig. 1. Side view.

FIG. 2. Septa $(\times 2)$ drawn from a specimen of the same size as the above.

Frgs. 3, 4. Side and front views of a smaller specimen.

Fı́̆. 5. Septa $(\times 3)$ from a smaller specimen; diameter about $25 \mathrm{~mm}$.

Frg. 6. Side view of small specimen.

Figs. 7, 8. Front view and septa of a fragment of the whorl.

FIgs. 9, 10, 11. Side, front, and rear views of a fragment of whorl of young specimen; diameter about $15 \mathrm{~mm}$.

FIG. 12. Septa $(\times 3)$ external and internal, from the same specimen.

Fig. 13. Side view $(\times 2)$ of young specimen.

FIGs. 14, 15, 16. Side, front, rear, and septa (all $\times 12$ ) of larval specimcn; diameter $2.5 \mathrm{~mm}$.

From Lower Triassic (Meekoceras beds), Union Wash, Inyo Range, Inyo County, Cal. Collection United States National Museum. 


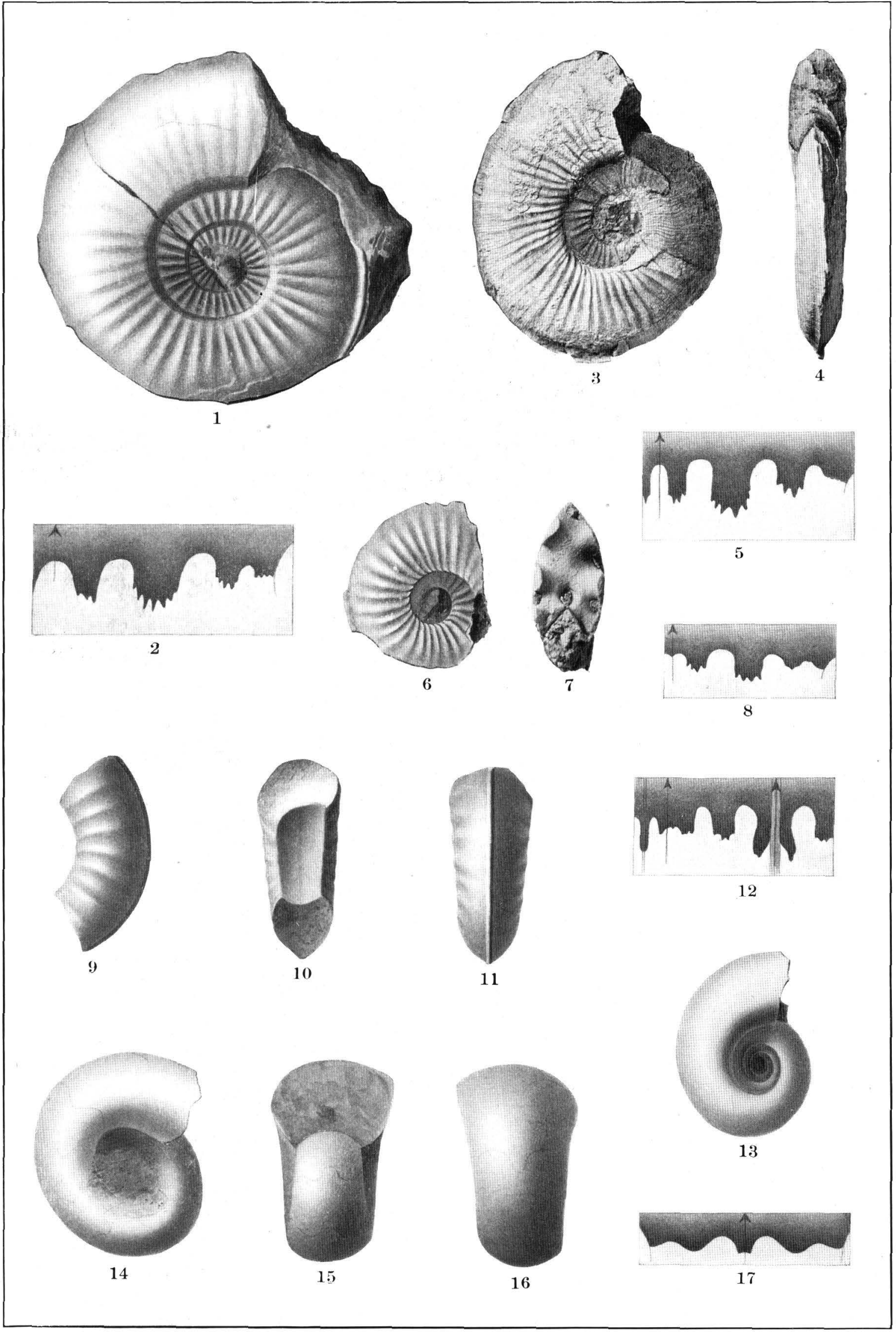

INYOITES OWENI. 


\section{PIATE VII:}

Prosiningites Austini Hyatt and Smith (p. 72).

Fics. 1, 2, 3, 4. Side, front, and rear views (natural size) and septa $(\times 2)$ of the type specimen. From Lower Triassic (Mcckoceras beds), Union Wash, Inyo Range, Inyo County,

Cal. Collection United States National Museum.

\section{Nannites Dieneri Hyatt and Smith (p. 79)}

Figs. 5, 6. Side and rear views.

Figs. 7, 8, 9. Side and front views (natural size) and septa $(\times 2)$.

Figs. 10, 11, 12, 13. Side, front, and rear views (natural size) and septa $(\times 2)$ of the type specimen. Fia. 14. Inside view of part of the body chamber broken from the specimen shown in figs. 10-13. Figs. 15, 16, 17, 18. Side, front, and rear views and septa (all $\times 2$ ) of an adolescent specimen; diameter $9.5 \mathrm{~mm}$.

FIGS. 19, 20, 21. Side, front, and rear views of an adolesecnt specimen, showing the shell (all $\times 6$ ). Fics. $22,23,24 ; 25$. Side, front, and rear views and septa (all $\times 12$ ) of a larval specimen having a diameter of $2.6 \mathrm{~mm}$.

From Lower Triassic (Meekoceras beds), Union Wash, Inyo Range, Inyo County, Cal. Collection United States National Museum.

Xenaspis Marcoui Hyatt and Smith (p. 116).

FIG. 26. Side view.

Figs. 27, 28. Side view and cross section of a broken whorl.

Figs. 29, 30, 31. Side view, cross section, and septa (all $\times 2$ ).

FiGs. 32, 33. Side and front views $(\times 2)$ of an adolescent specimen.

From Lower Triassic (Meekoceras beds), Union Wash, Inyo Range, Inyo County, Cal. Collection United States National Museum. 

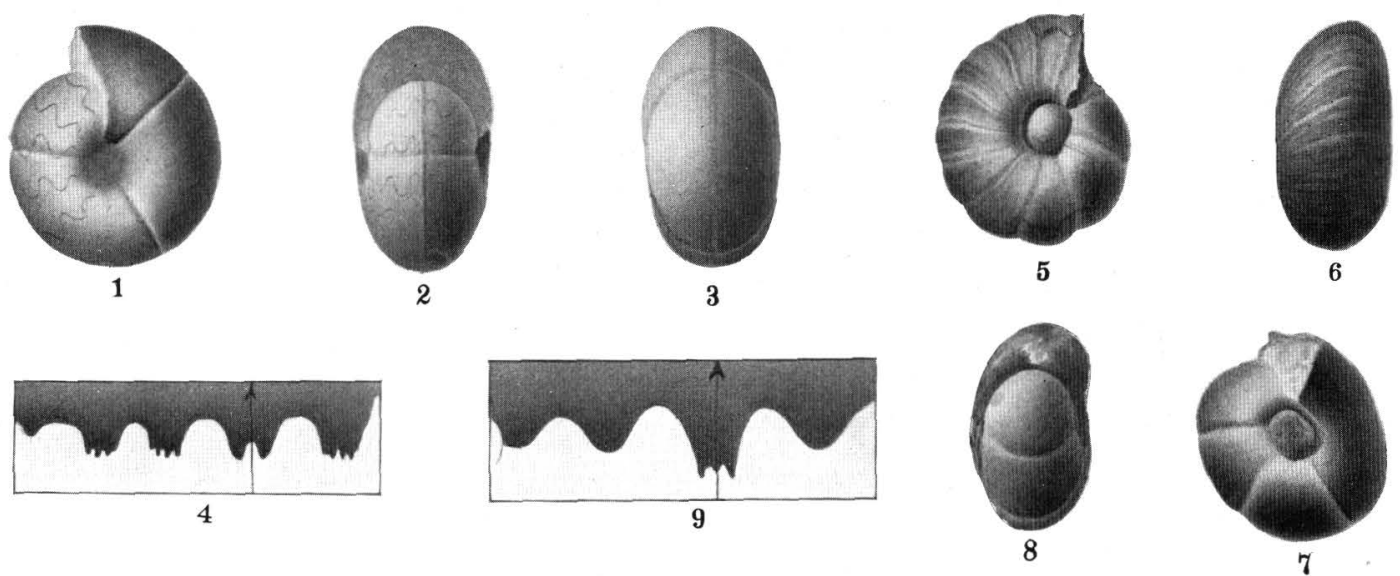

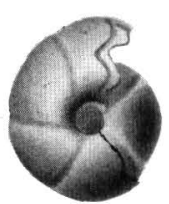

10
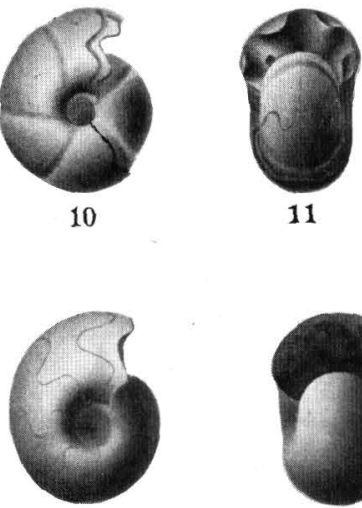

15

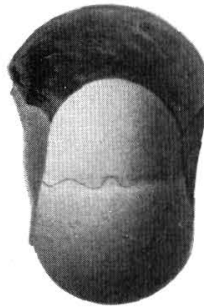

23

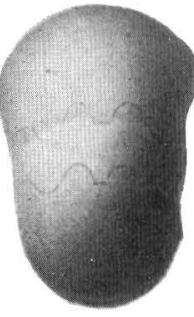

24

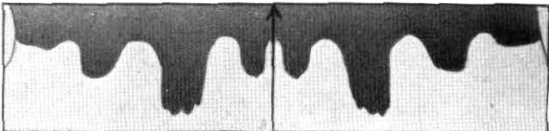

11

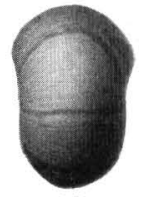

12
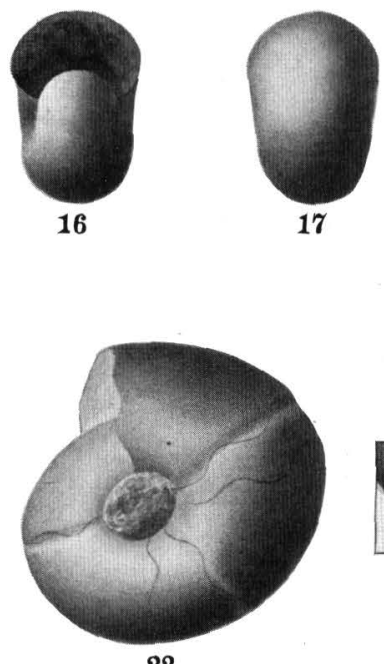

22

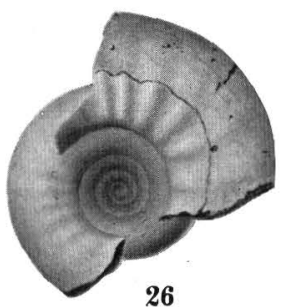

26
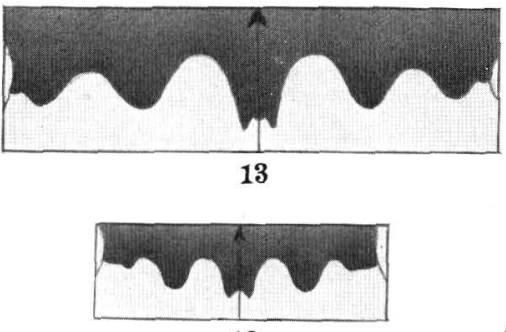

18
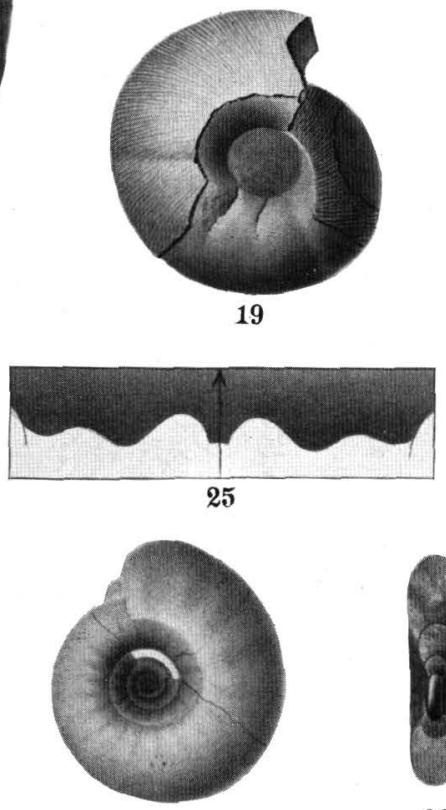

27

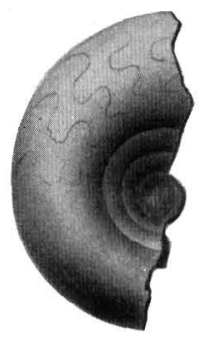

29

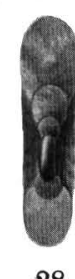

28

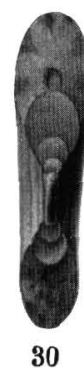

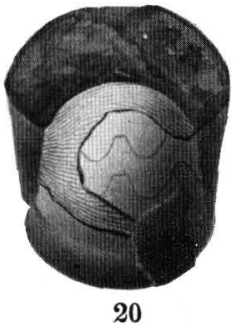

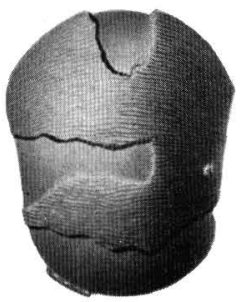

21

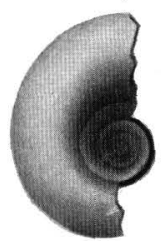

32

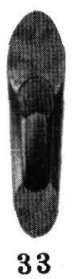




\section{PLATE VIII.}

\section{Paranannites aspenensis Hyatt and Smith (p. 81).}

Frgs. 1, 2, 3. Side and rear view (natural size) and septa $(\times 2)$ of a specimen of which the outline has been partly restored, as shown in the shading.

Figs. 4, 5, 6. Side, front, and rear views $(\times 2)$.

Fig. 7 . Septa of the same $(\times 3)$.

Fics. 8, 9, 10. Side, front, and rear view $(\times 3)$ of an adolescent specimen.

FIG. 11. Septa $(\times 6)$ from speciunen shown in figs. 8-10.

Figs. $12 ; 13$. Side and rear views $(\times 3)$ of an adolescent specimen; diameter $6 \mathrm{~mm}$.

FIgs. 14, 15. Side and rear views $(\times 6)$ of a specimen showing the transition from Aganides to Nannites; diameter $4 \mathrm{~mm}$.

From Lower Triassic (Meekoceras beds), Wood Canyon, 9 miles east of Soda Springs, Aspen Ridge, Idaho. Collection United States National Museum.

Ophickras Dieneri Hyatt and Smith (p. 118).

Figs. 16, 17, 18. Side and front views (natural size) and septa $(\times 4)$ of the type specimen.

Figs. 19, 20. Side and front views of a smaller specimen.

Fig. 21. Side view $(\times 2)$ of an adolescent specimen.

Figs. 22, 23. Side and rear views $(\times 3)$ of a spccimen; diameter $5.5 \mathrm{~mm}$.

FIf. 24. Septa $(\times 12)$ of the same specimen.

FiGs. 25, 26, 27. Side, front, and rear views $(\times 7)$ of young specimen; diameter $3.5 \mathrm{~mm}$.

FIgs. 28, 29. 'Side and rear view $(\times 7)$ of larval specimen; diameter $2.5 \mathrm{~mm}$.

From Lower Triassic (Meekoceras beds), Wood Canyon, 9 miles east of Soda Springs, Aspen Ridgc, Idaho. Collection United States National Museum. 


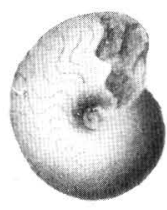

1

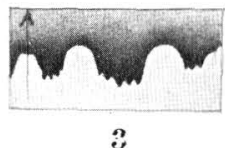

8

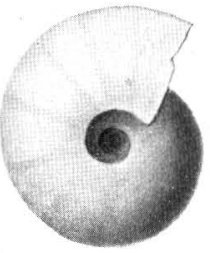

8

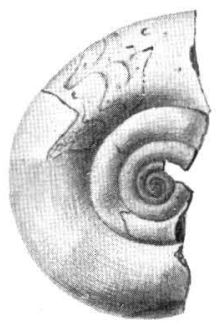

16

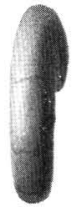

23
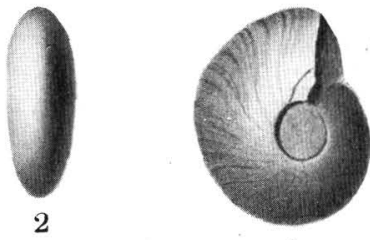

4

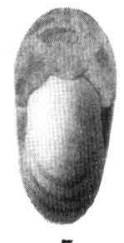

5

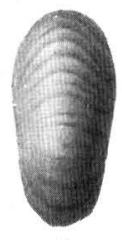

6
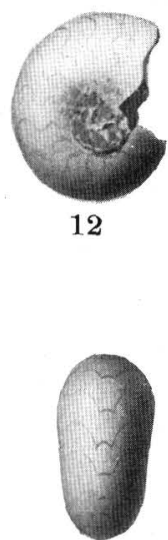

13

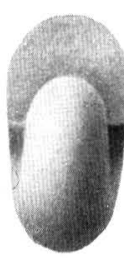

9

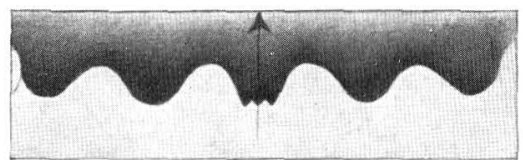

11
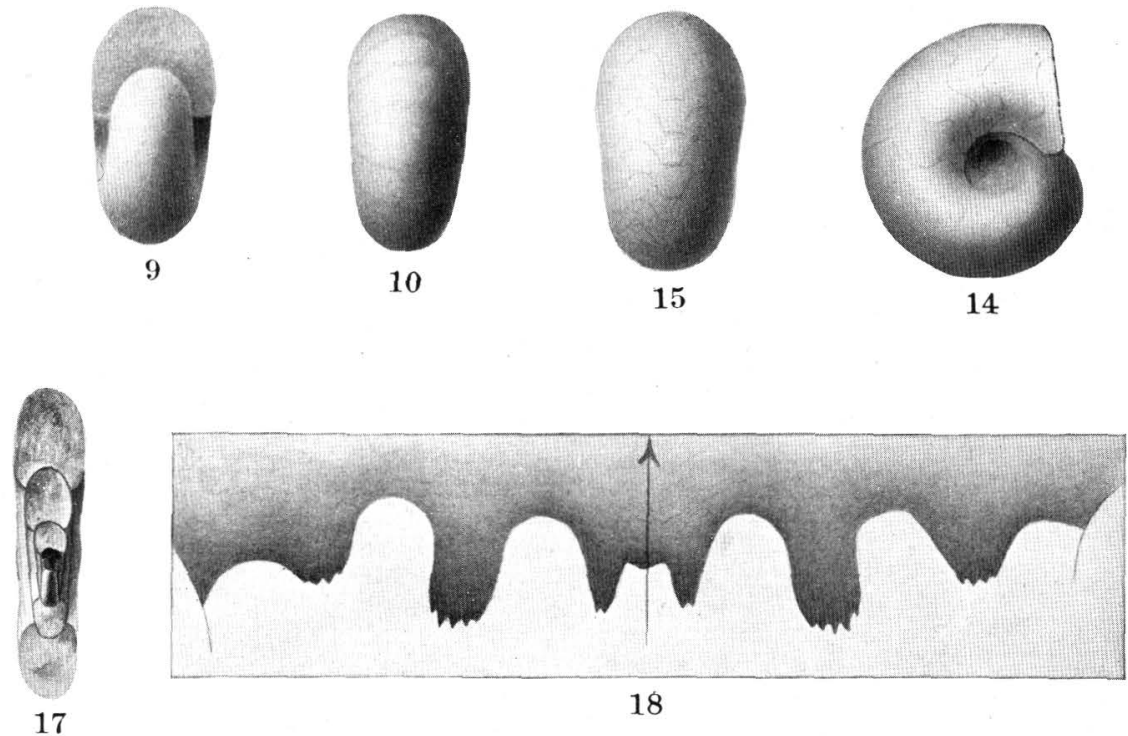

17
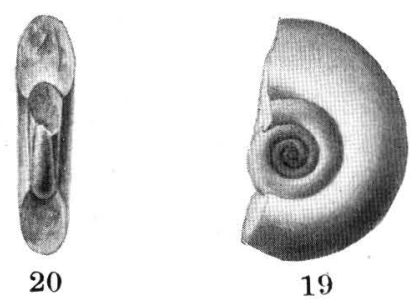

22

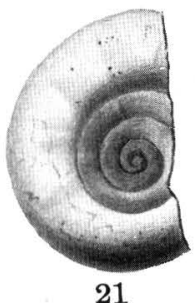

20
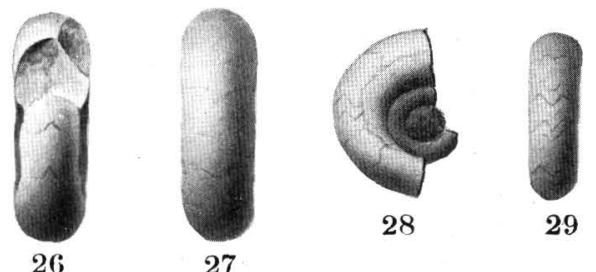

25

27

PARANANNITES ASPENENSIS. OPHICERAS DIENERI. 


\section{PLA TE IX.}

Sibinites Noftuingr Hyatt and Smith (p. 49).

Figs. 1, 2, 3. Side, front, and rear views.

From Lower Triassic (Meekoceras beds), Union Wash, Inyo Range, Inyo County, Cal. Collection United States National Museum.

Danubites Strongi Hyatt and Smith (p. 165).

Figs. 4, 5, 6. Side and front views (natural size) and scpta $(X 3)$ of the type specimen.

FIGs. 7, 8. Side and end views of a fragment of the body chamber, showing the normal shape of the cross section.

Figs. 9, 10. Side and front views of a smaller specimen.

From Lower Triassic (Meekoceras beds), Union Wash, Inyo Range, Inyo County, Cal. Collection United States National Museum.

LeCanites Knechti Hyatt and Smith (p. 138).

Figs. 11, 12, 13. Side and front views (natural size) and septa $(\times 4)$ of the type specimen.

Fias. 14, 15, 16. Side and from views (natural size) and septa $(X 6)$ of a smaller specimen.

From Lower Triassic (Meekoceras beds), Union Wash, Inyo Range, Inyo County, Cal. Collection United States National Museum. 

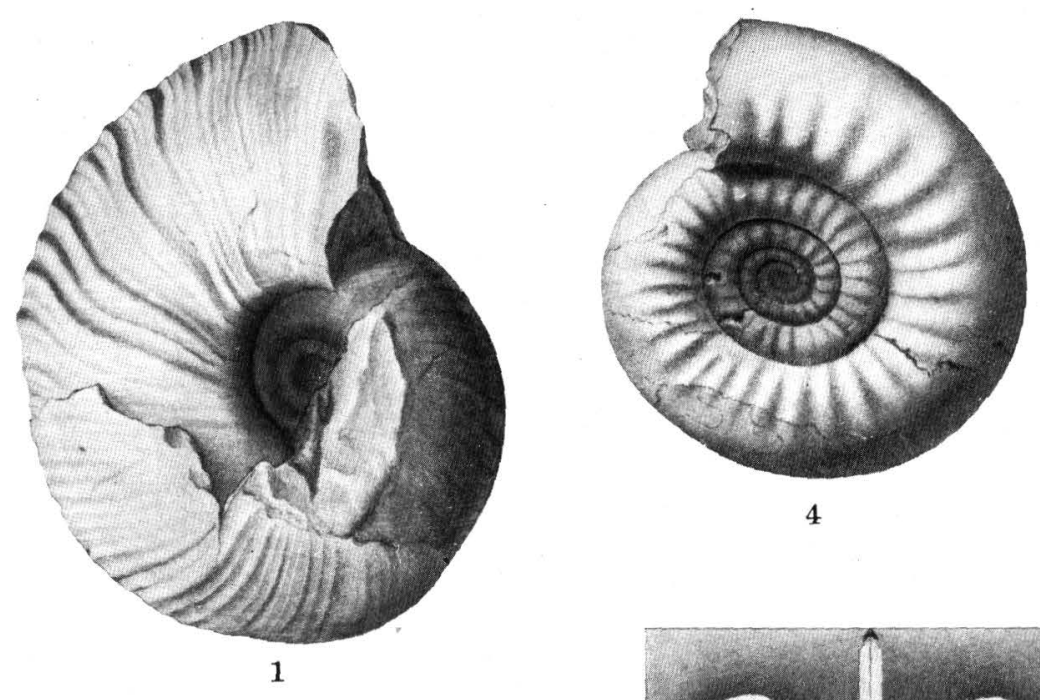

4
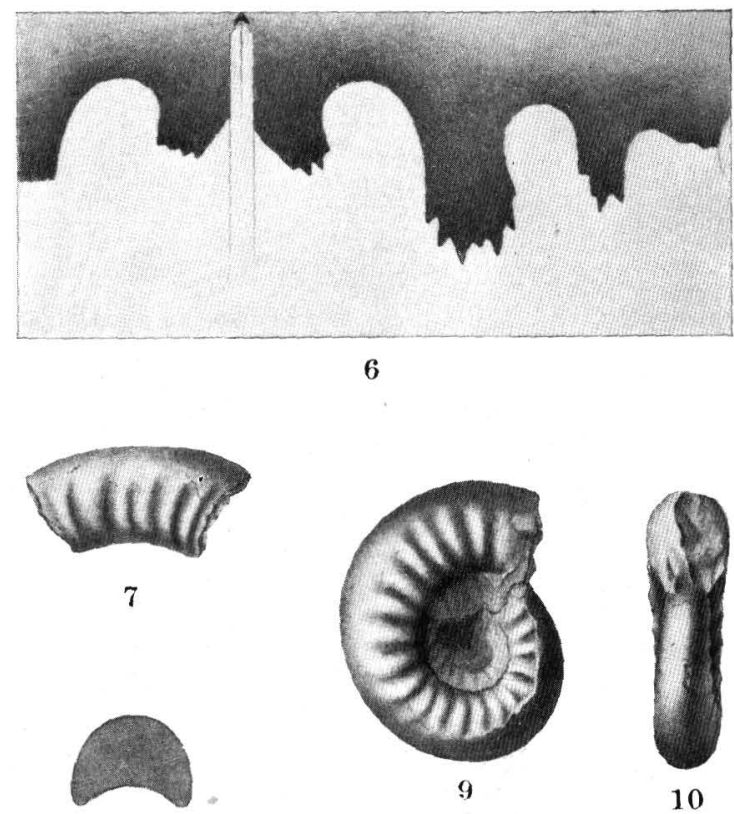

8

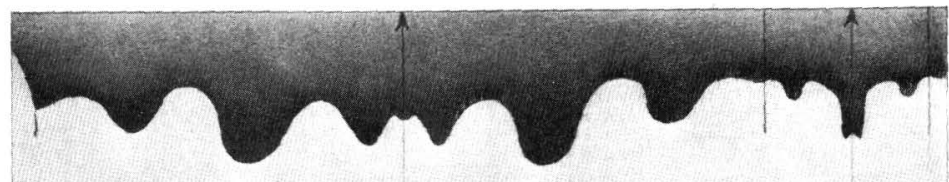

13

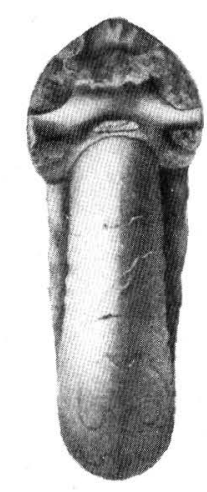

5
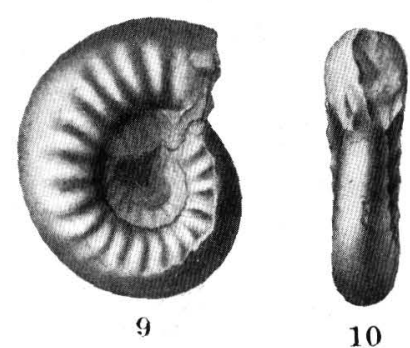

10
12

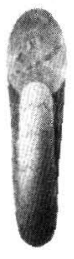

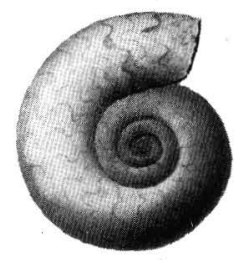

11

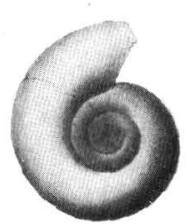

14
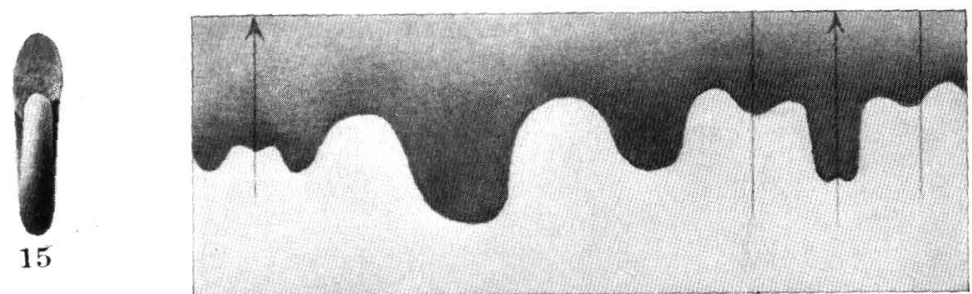

16

SIBIRITES NOETLINGI, DANUBITES STRONGI, LECANITES KNECHTI. 


\section{PLATE X.}

\section{Owenites Koeneni Hyatt and Smith (p. 83).}

Figs. 1, 2, 3, 4. Side, front, and rear views (natural size) and septa $(\times 3)$ of the type specimen.

Fics. 5, 6. Side and front views of a specimen showing only the body chamber in the last volution. Figs. 7, 8, 9, 10. Side, front, and rear views $(\times 2)$ and septa $(\times 4)$ of adolescent specimen, showing the transition from goniatite to ceratitic stage; diameter 15 mm.

Figs. 11, 12, 13. Side, front, and rear views $(\times 2)$ of an adolescent specimen, showing only the goniatite stage; diameter $9 \mathrm{~mm}$.

FIG. 14. Septa $(\times 4)$ from the same specimen.

Figs. 15, 16, 17. Side, front, and rear views $(X 4)$ of small adolescent specimen; diameter $5 \mathrm{~mm}$.

FIgs. 18, 19. Left side $(\times 8)$ and septa $(\times 16)$ of larval specimen, showing Nannites stage; diameter $2.4 \mathrm{~mm}$.

Figs. 20, 21, 21a, 22. Side, front, and rear views $(\times 8)$ and septa $(\times 16)$ of larval shell showing the Nannites stage; diameter $1.9 \mathrm{~mm}$.

From Lower 'Triassic (Meekoceras beds), Union Wash, Inyo Range, Inyo County, Cal. Collection United States National Museum. 

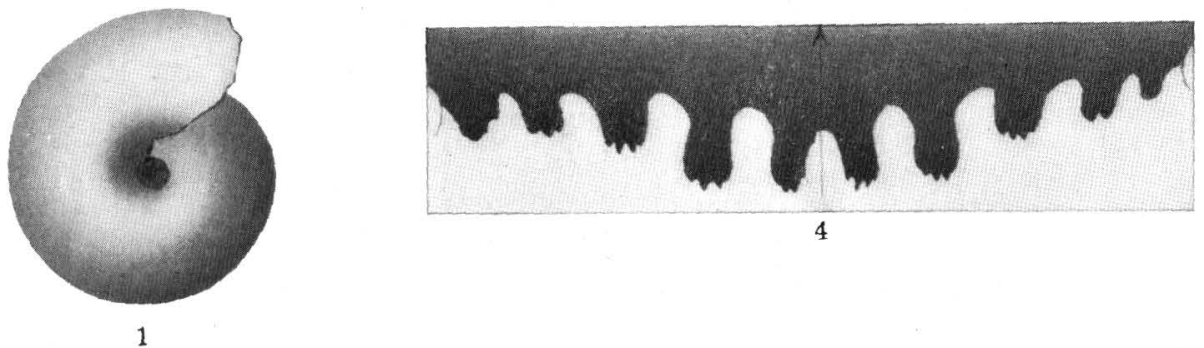

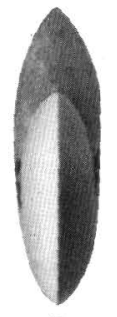

2
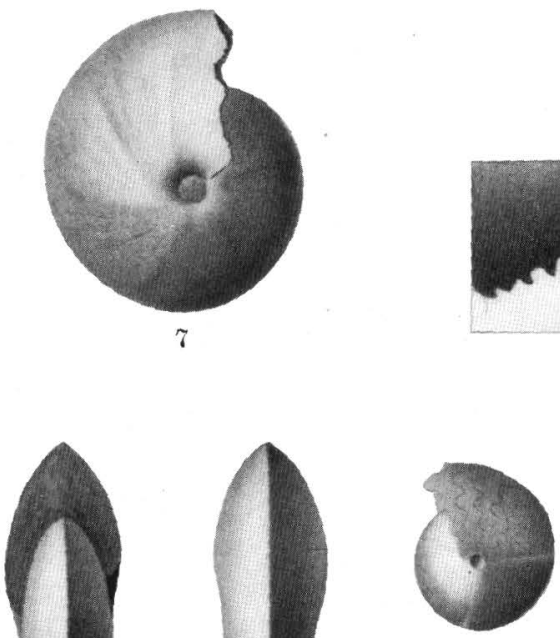

11

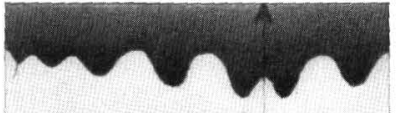

14

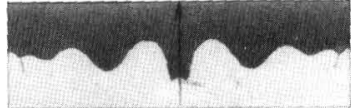

22

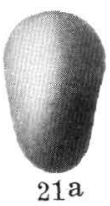

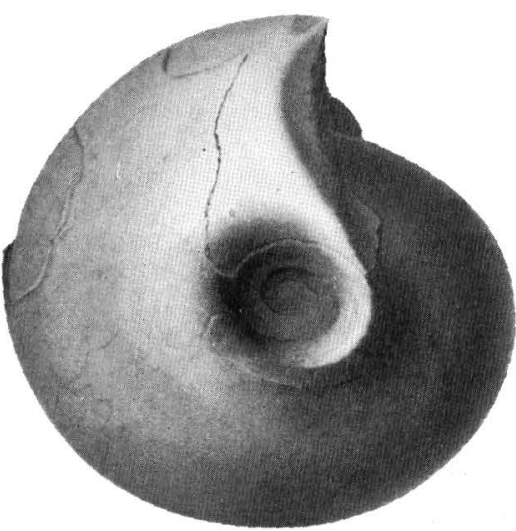

5

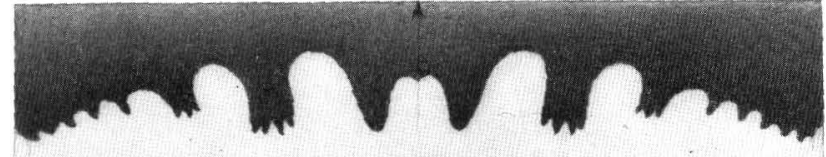

10
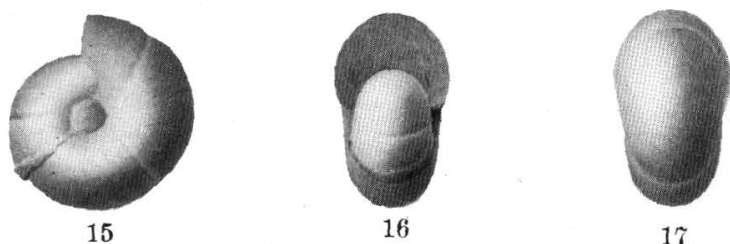

17
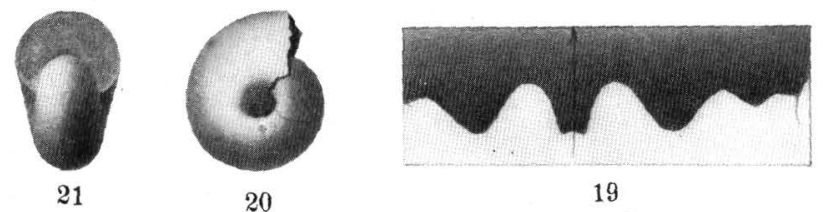

OWENITES KOENENI. 


\section{P L A T E X I.}

\section{Melkoceras (Grronites) aplanatum White (p. 146).}

FIGs. 1, 2, 3. Side and front views and septa of White's type specimen. (U. S. Geol. and Geog. Surv. Terr., vol. 12, pt. 1, .Pl. XXXI, figs. 1a, 1b, and 1d.)

Ficss. 4, 5, 6, 7. Side, front, and rear views (natural size) and septa $(X 3)$ of an adult specimen. Figs. 8, 9, 10. Side and front views $(\times 2)$ and septa $(X 3)$ of a fragment of the chambered shell. Figs. 11, 12. Side view $(\times 2)$ and septa $(\times 4)$ of an adolescent specimen, showing the Lecanites stage.

Figs. 13, 14. Side and cross section (both $\times 3$ ).

From Lower Triassic (Meekoceras beds), southeastern Idaho. Figs. 1-3, from locality No. 2 of White, 50 miles north of the Utah line and about 18 miles west of the Wyoming line; figs. 4-14, from Wood Canyon, 9 miles east of Soda Springs, Aspen Mountains, Idaho. Collection United States National Museum. 

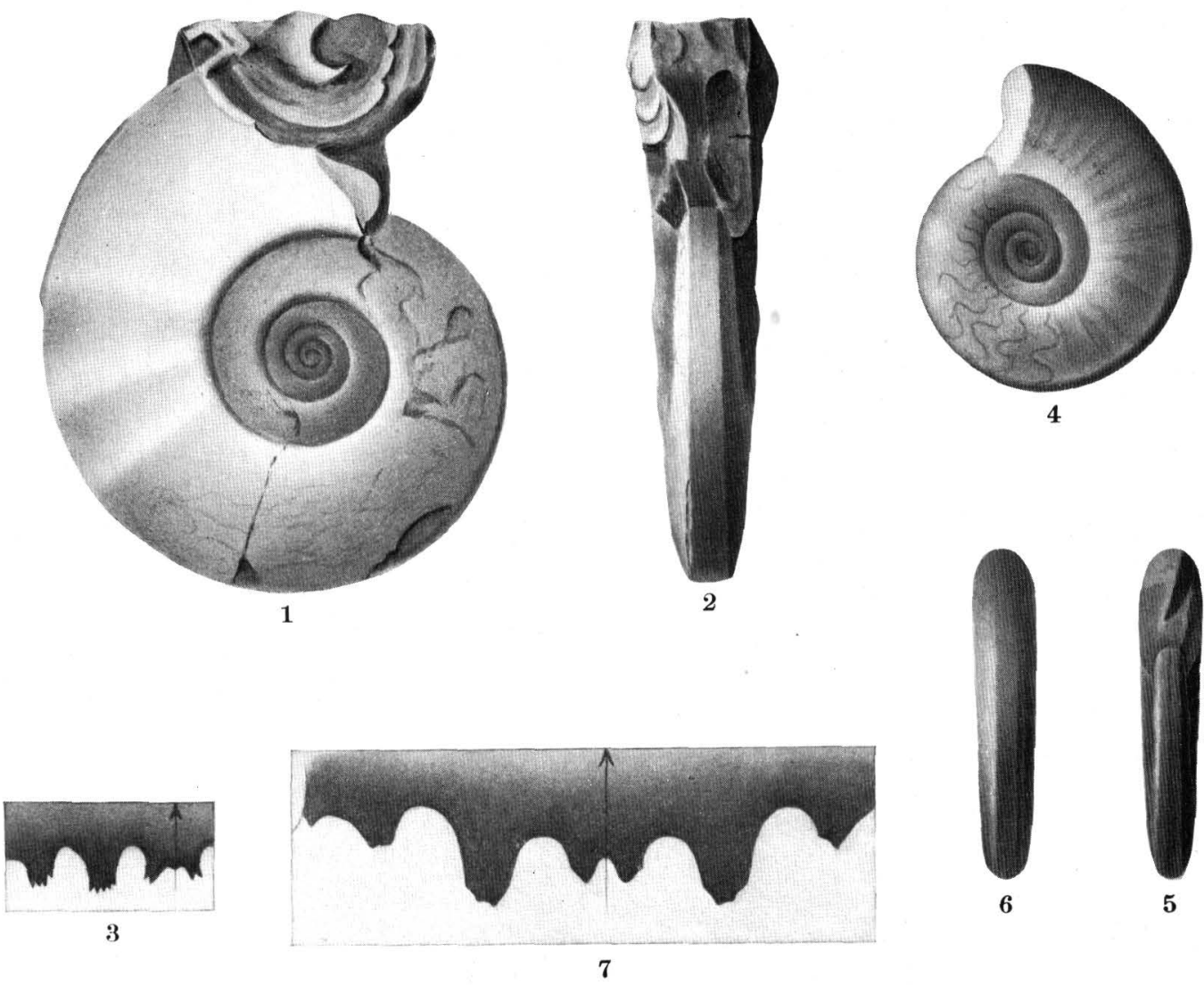

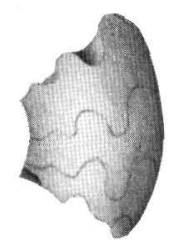

8
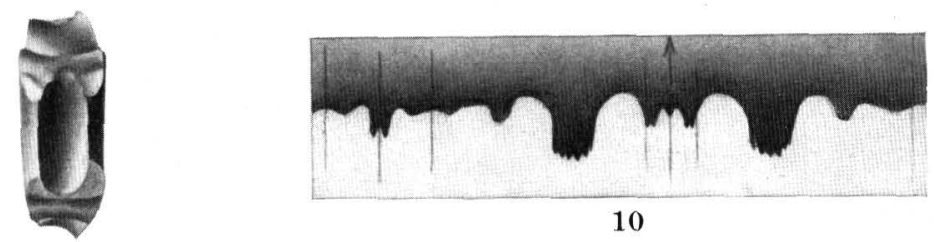

9

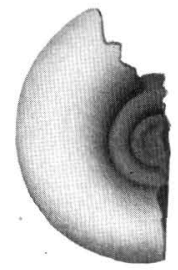

11

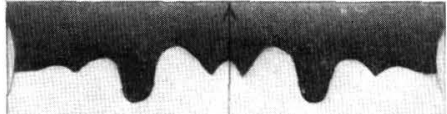

12

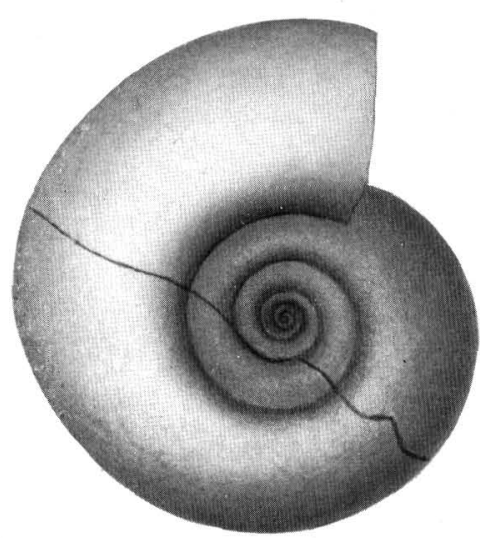

13

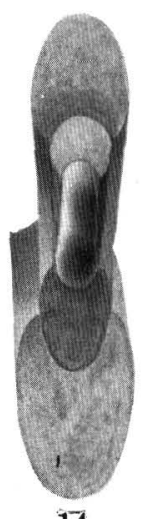

14 


\section{P'LA TE XI I .}

\section{Mefocenas gracilitatis White (p. 143).}

Fı́. 1. Side view of White's type specimen. (Copied from Pl. XXXI, fig. 2a of White, U. S. Geol. - and Geog. Surv. Terr., vol. 12, pt. 1.)

Fiss. 2, 3. Side and front views of a smaller specimen. (Pl. XXXI, figs. 2b and 2c of White.)

Fig. 4. Septa of a larger specimen. (Pl. XXXI, fig. $2 d$ of White.)

Figs. 5, 6. Side view and septa of a large specimen.

FIGs. $7,8,9,10$. Side, front, and rear views (natural size) and septa $(\times 2)$ of a smaller specimen.

Figs. 11, 12, 13. Side, front, and rear.

From Lower Triassic (Meekoceras beds), southeastern, Tdaho. Figs. 1-4, from locality No. 1 of White, 65 miles north of the Utah line and 18 miles west of Wyoming; figs. 5-13, from Wood Canyon, 9 miles cast of Soda Springs, Aspen Ridge, Idaho. Collection United States National Museum. 

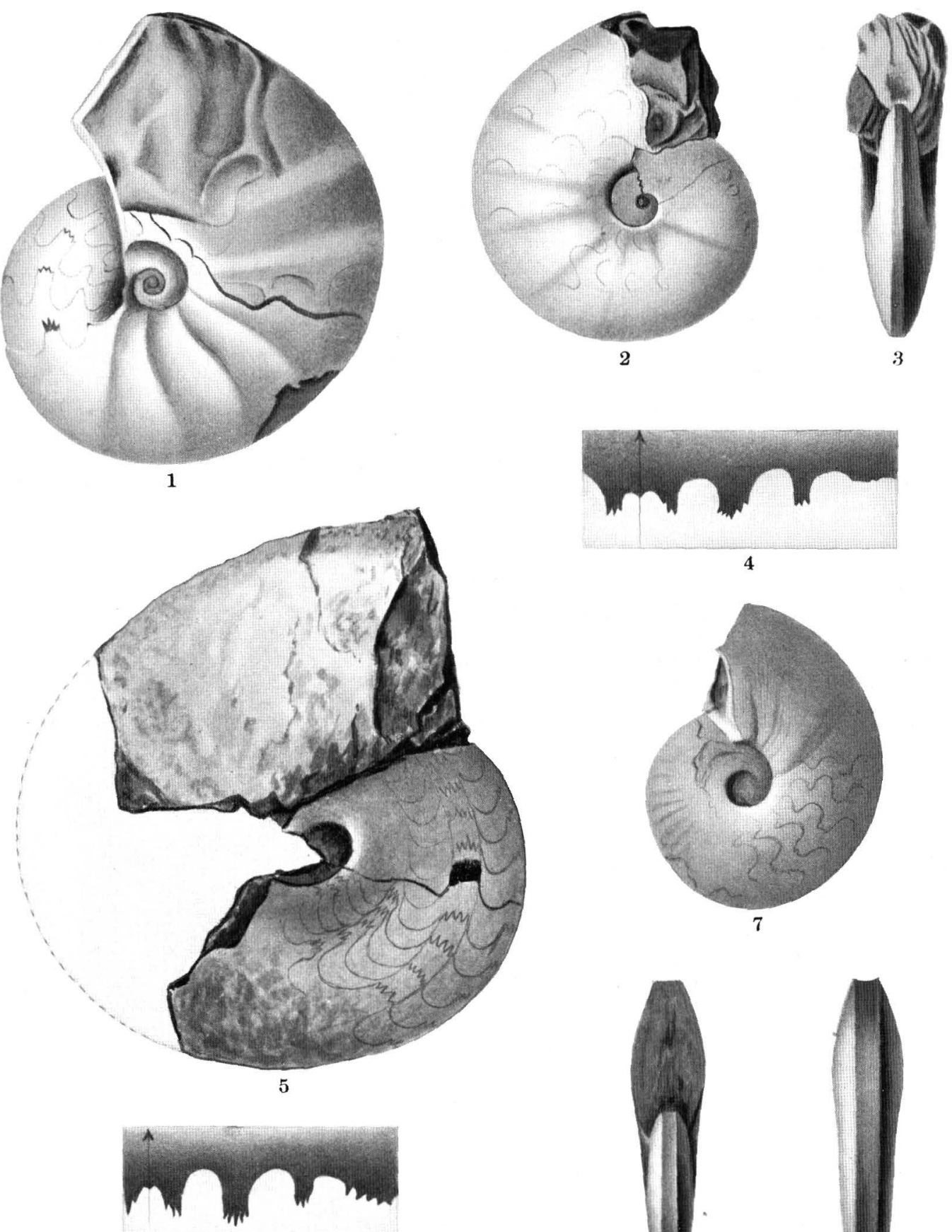

$$
6
$$
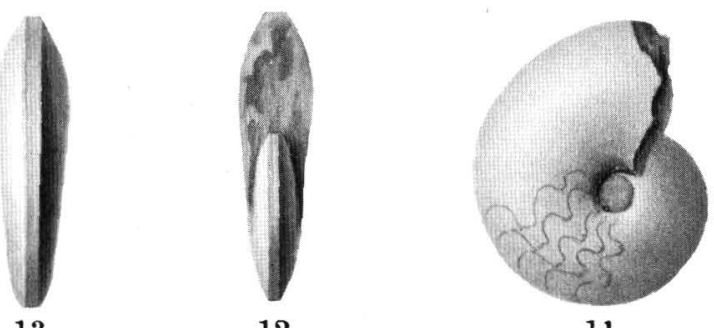

11
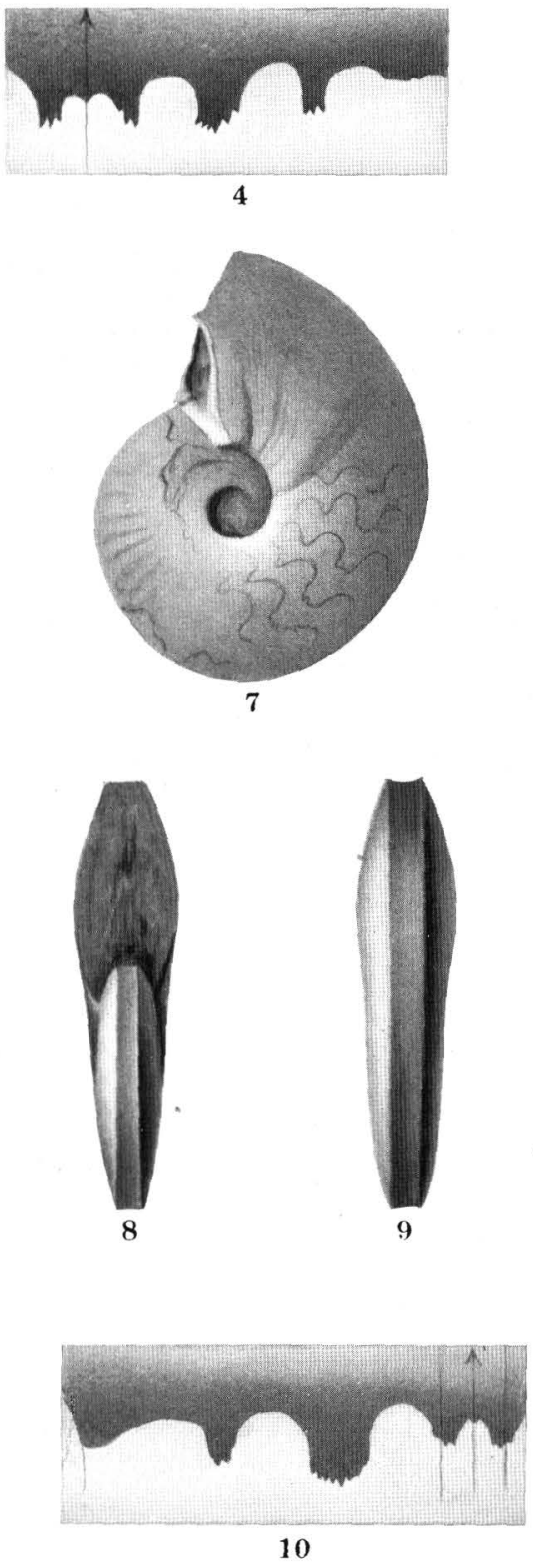


\section{PLA TE XIII.}

\section{Mekroceras gracilitatis White (p. 143).}

FIG. 1. Broken specimen showing cross section of the whorls (locality No. 1 of White).

Figs. 2, 3, 4. Side and front views $(\times 2)$ and septa $(\times 4)$; diameter $14.5 \mathrm{~mm}$.

FIG. 5. Side view $(\times 3)$ of the adolescent specimen, showing the end of the goniatite stage; diameter $12 \mathrm{~mm}$.

Fiss. 6, 7. Side and front views $(\times 6)$; diameter $5.5 \mathrm{~mm}$.

Figs. 8, 9. Side and front vicws $(X 6)$; diameter $4.5 \mathrm{~mm}$.

Frgs. 10, 11, 12. Side, front, and rear views $(\times 12)$; diameter $2.56 \mathrm{~mm}$.

Fias. 13, 14, 15. Side, front, and rear views $(\times 20)$ of larvel specimens; diameter $1.32 \mathrm{~mm}$.

Fras. 16, 17, 18. Front and top views $(\times 30)$; protoconch with two chambers attached; diameter $0.6 \mathrm{~mm}$.

From Lower Triassic (Meekoceras beds), Wood Canyon, 9 miles east of Soda Springs, Aspen Ridge, Idaho. Collection United States National Museum. 

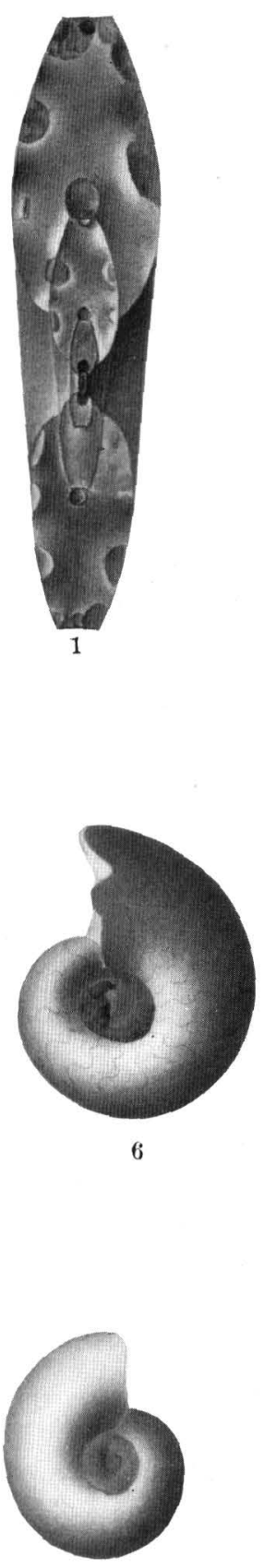

13
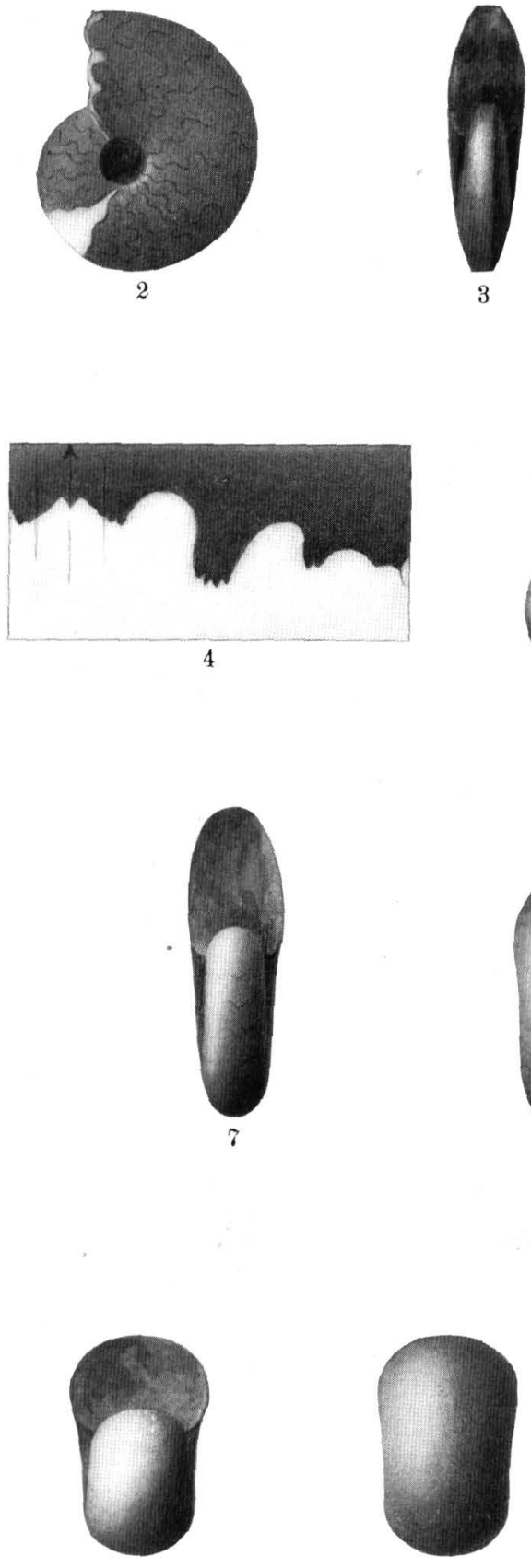

14

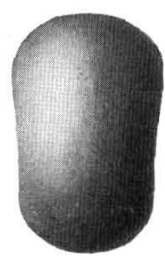

15

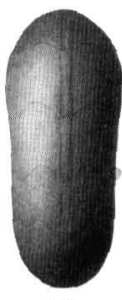

12

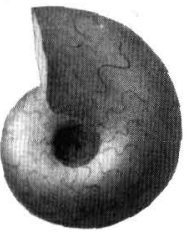

8
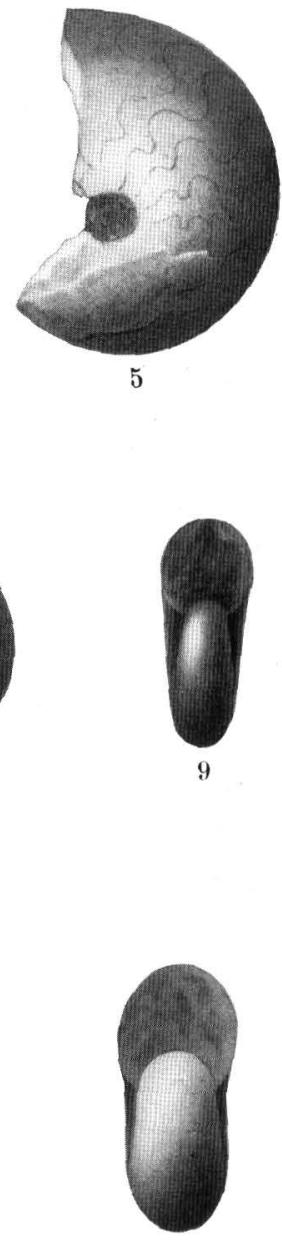

11
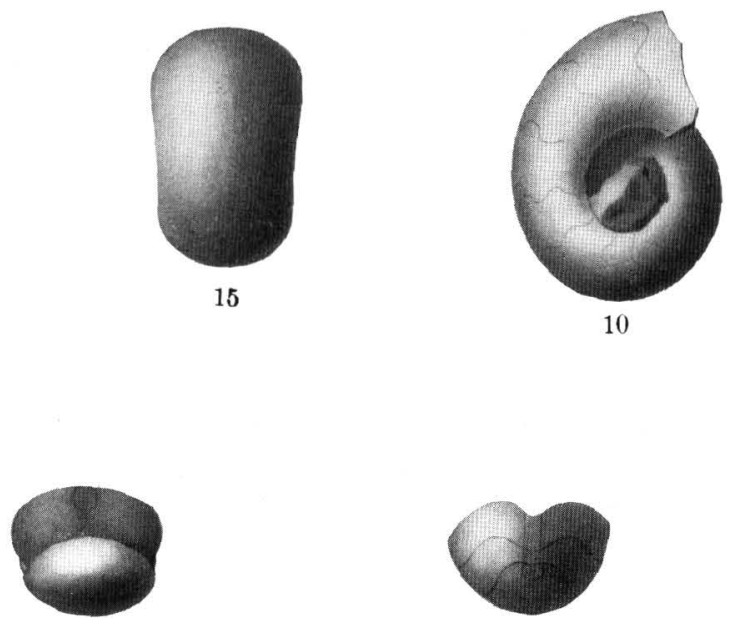

17

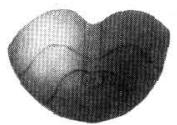

18 


\section{PLATE XIV.}

Mefkochras gracilitatis White (p. 143).

Figs. 1, 2, 3. Side, rear, and septa of a broken specimen, showing cross section of the younger whorls. Fics. 4, 5. Side and front views of a smaller specimen.

FIG. 6. Side view of a large specimen, showing the increasing evolution of the old whorl.

Figs. 7, 8. Side and front views of an adolescent specimen.

From Lower Triassic (Meekoceras beds), Union Wash, Inyo Mountains, Inyo County, Cal. Collection United States National Museum. 


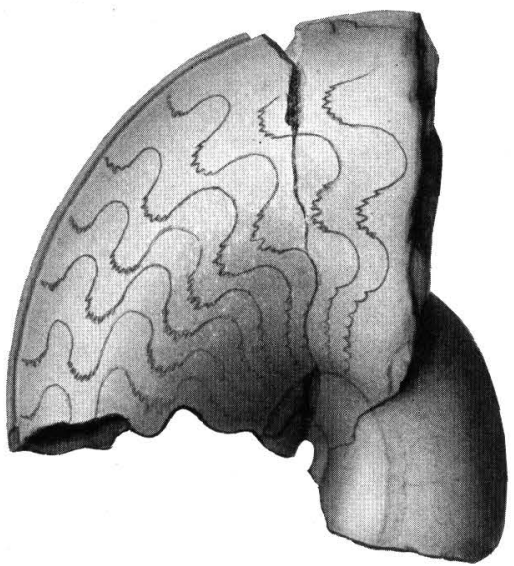

1
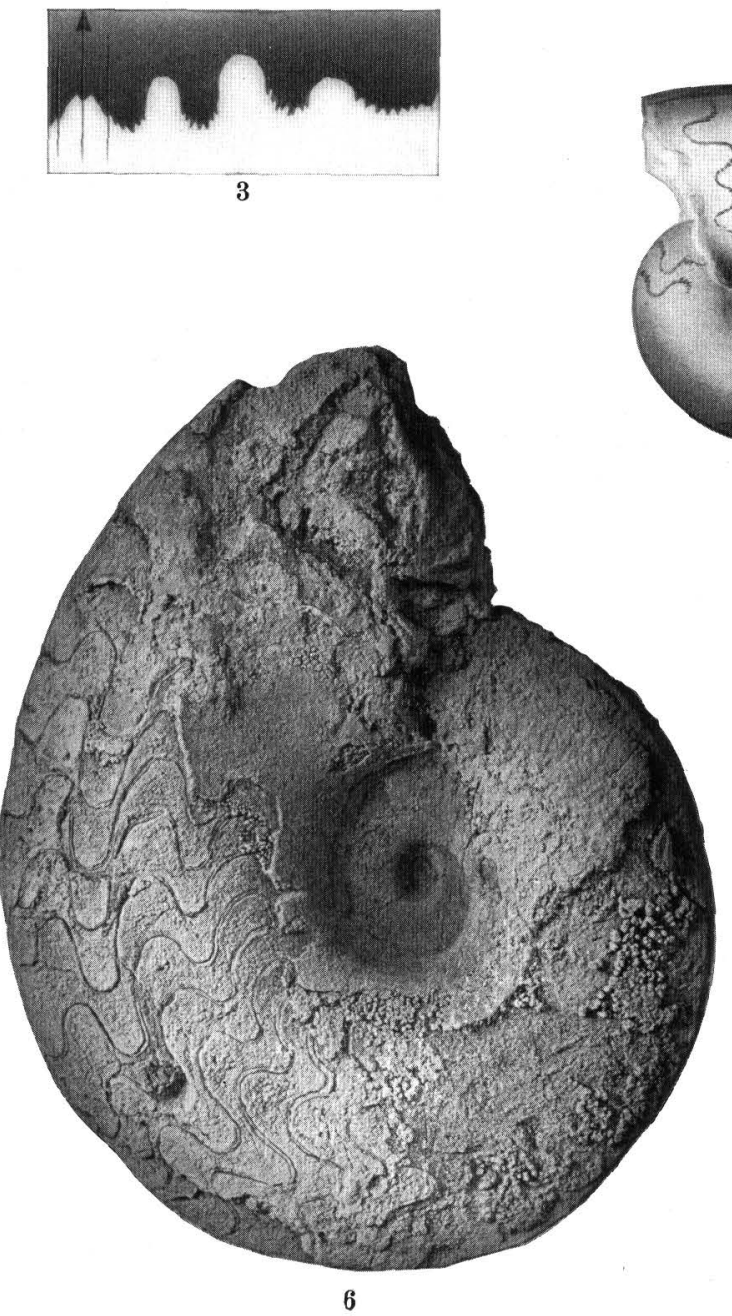
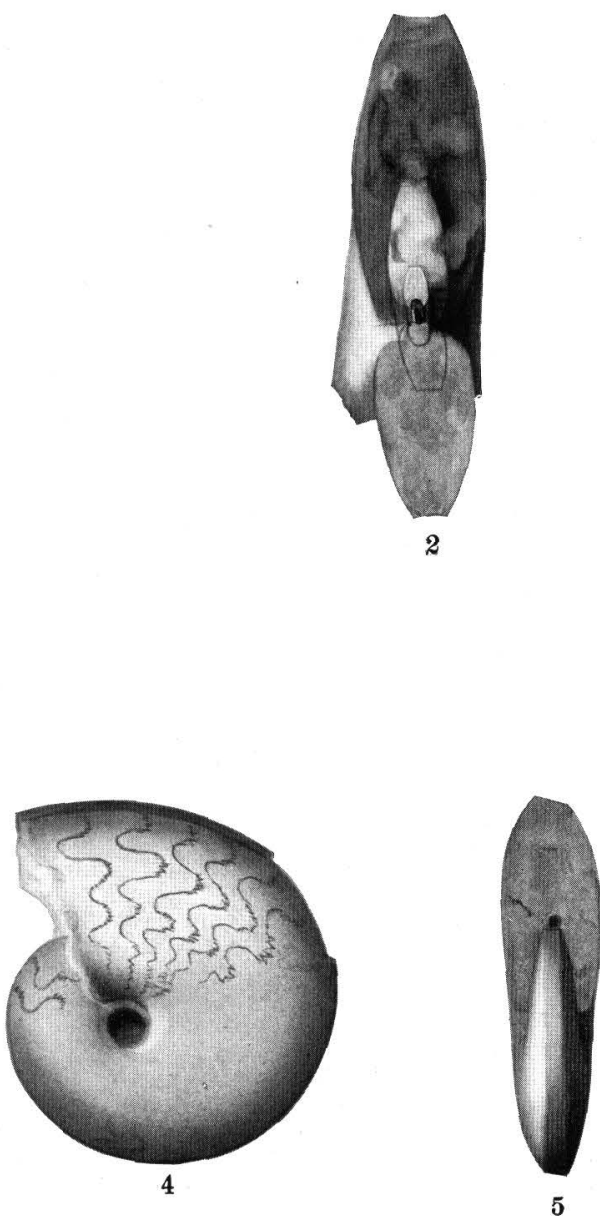

5
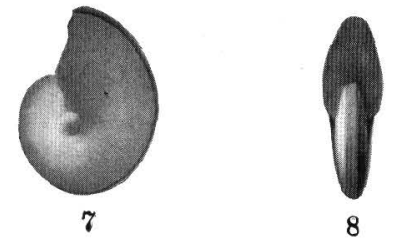


\section{P L A T E X V.}

Meekoceras (Koninckites) mushbacilanum White (p. 149).

FIGs. 1, 2, 3. Side, frunt, and cross section of White's type specimen, after Pl. XXXI of White, figs. $1 \mathrm{a}, 1 \mathrm{~b}$, and $1 \mathrm{c}$.

FIg. 4. Septa from a larger specimen, after Pl. XXXI of White, fig. 1d.

Fias. 5, 6, 7. Side and rear views and septa of a sinaller specimen.

Figs. 8, 9. Side view and septa (both $\times 2$ ) of an adolescent specimen.

From Lower Triassic (Meckoceras beds), Aspen Ridge, Idaho. Figs. 1-4, from locality No. 1 of White, 65 miles north of the Utah line and 18 miles west of Wyoming; figs. 5-9, from Wood Canyon, 9 miles east of Soda Springs. Collection United States National Museum. 

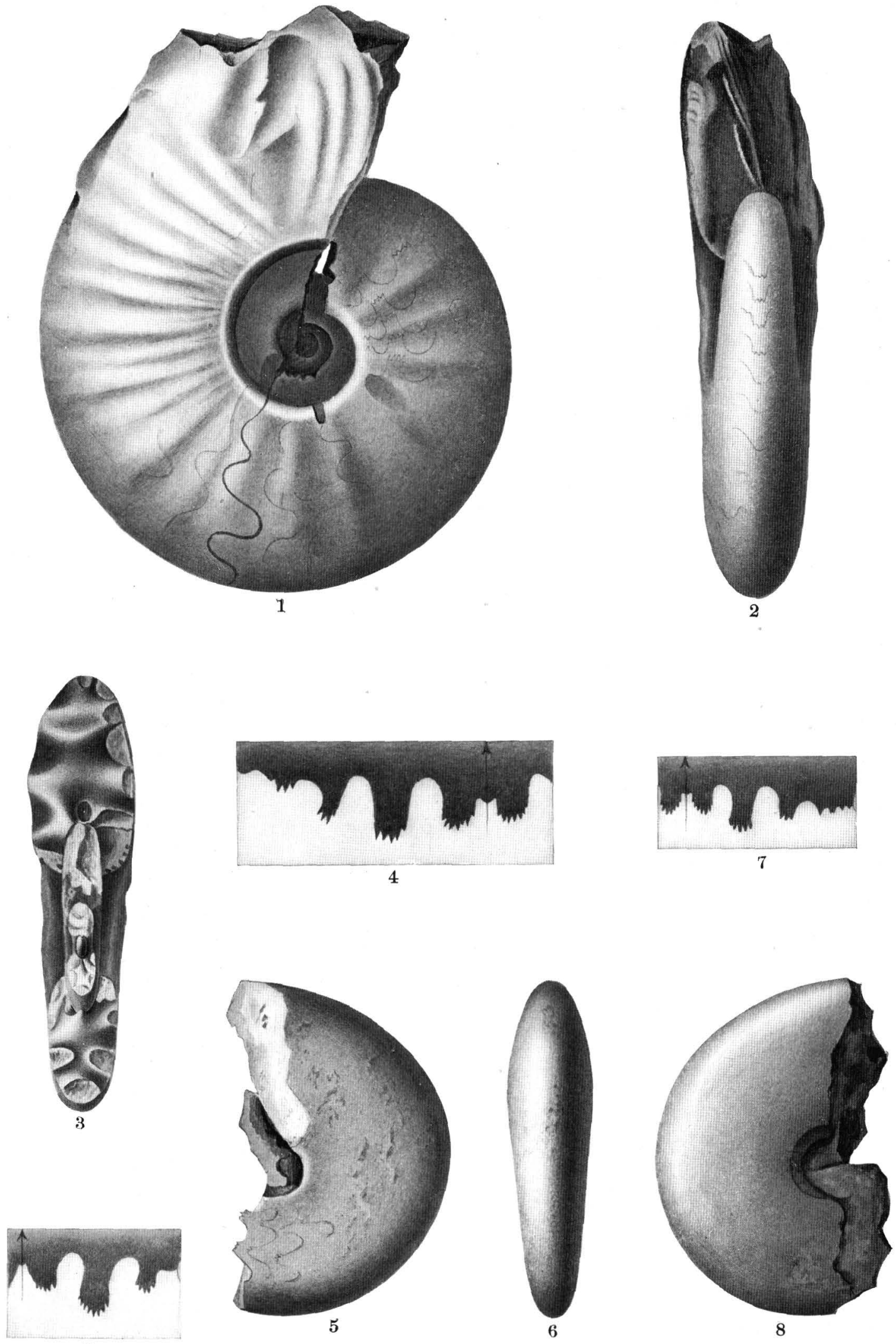


\section{PLA TE XVI.}

Meekoceras (Koninckites) mushbacilanum White p. 149).

FIGs. 1, 2, 3. Side views and septa (natural size) of a large specimen, showing the characteristic septa and shape of the whorl.

. From Iower Triassic (Meekoceras beds), southeastern Idaho, locality No. 1 of White, 65 miles north of Utah line, and 18 miles west of Wyoning. Collection United States Nationàl Museum. 

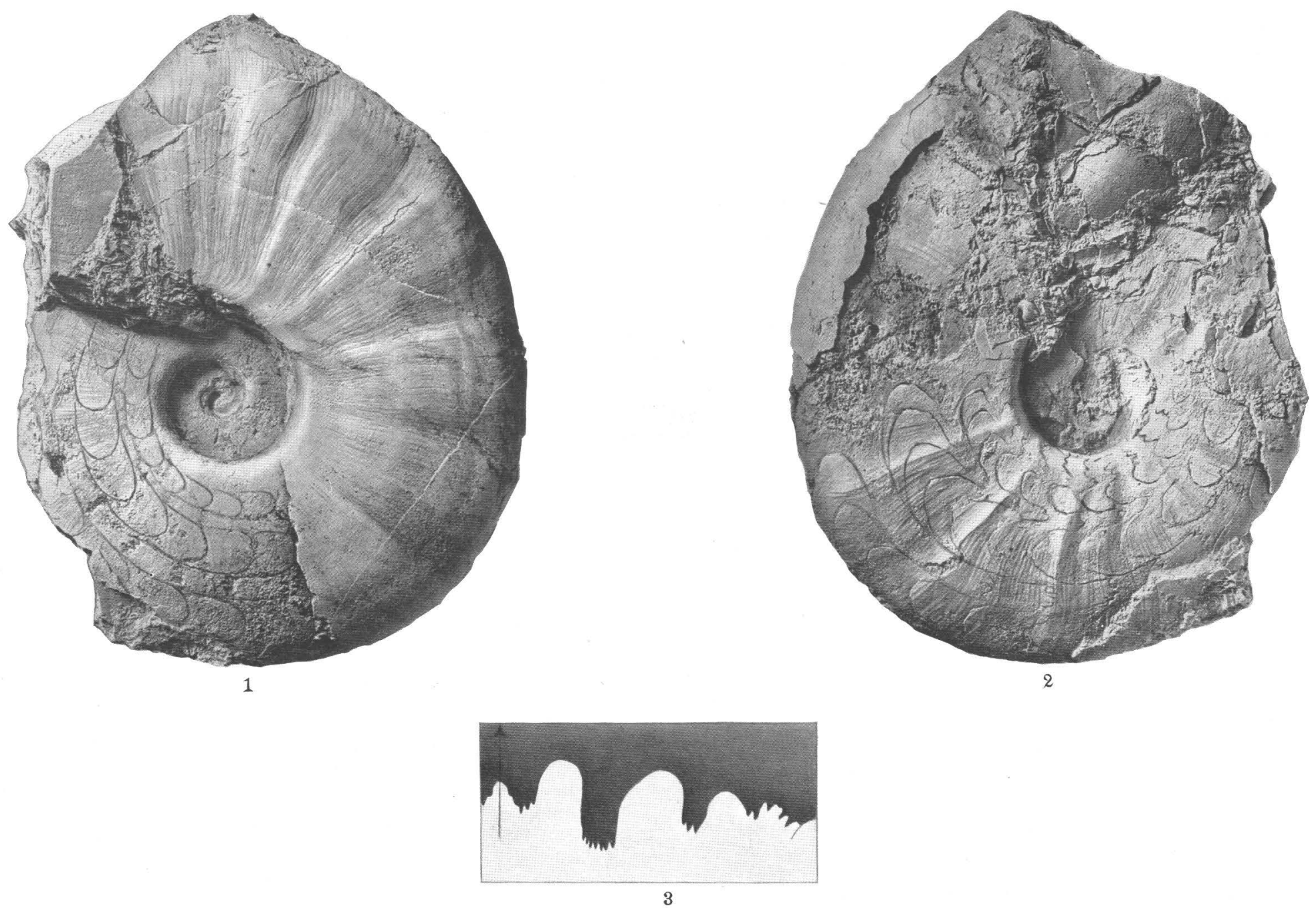

MEEKOCERAS (KONINCKITES) MUSHBACHANUM. 


\section{P L A TE X V I I.}

Aspidites Hooveri Hyatt and Smith, sp. nov. (p. 153).

Figs. 1, 2, 3. Side and rear views and septa of the type specimen. (Fig. 3, septa not correct in detail.)

Fics. 4, 5, 6. Side and front views (natural size) and septa $(\times 2)$ of an adolescent specimen.

FIGs. 7,8 . Side and front views $(\times 2)$ of a small specimen showing the Meekoceras stage.

Fic. 9. Septa $(\times 4)$ from the same specimen.

Fics. 10, 11, 12. Side and front views $(\times 3)$ and septa $(\times 6)$ of an adolescent specinen, showing the Lecaniles stage, broken ont of a larger specimen.

From lower Triassic (Meekoceras beds), Union Wash, Inyo Range, Inyo County, Cal. Collection United States National Museum. 

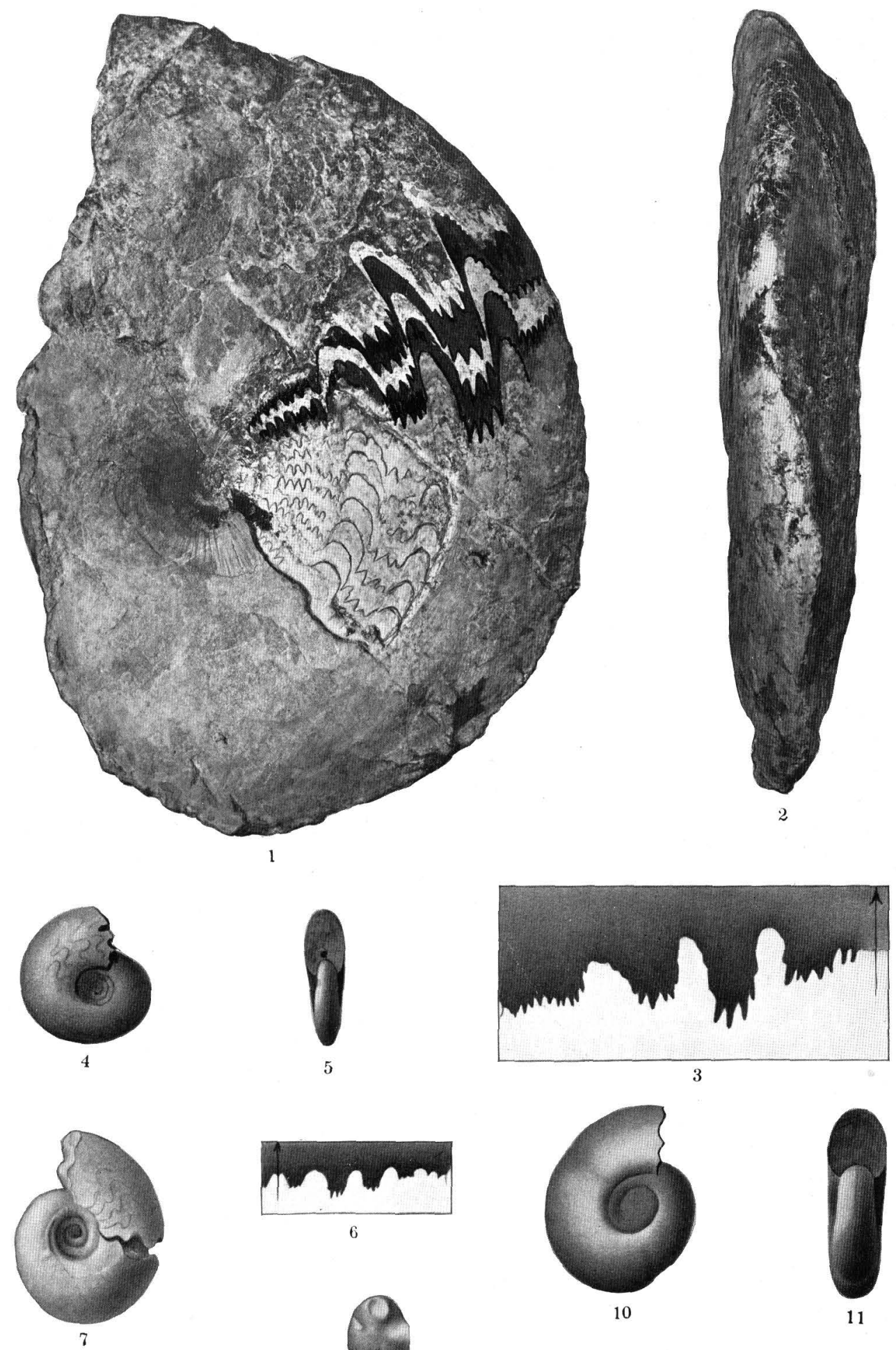

6
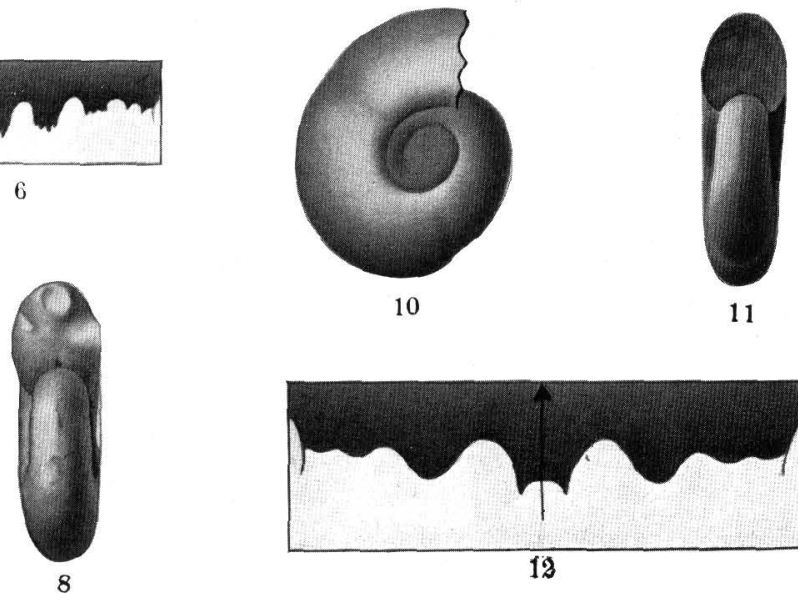

11

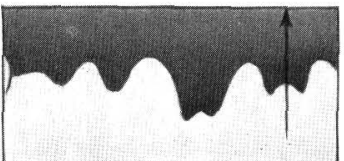

9

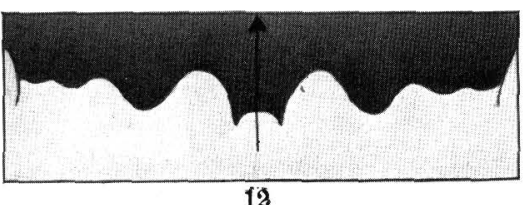




\section{PLATE XVIII.}

Méekoceras (Koningkites) mushbaciánum White (p. 149).

Figs. 1, 2. Side view and septa of a large specimen.

FIGs. $3,4,5$. Side, rear, and septa of a smaller specimen.

Figs. 6, 7. Side and front views of an immature specimen.

From Lower Triassic (Mcekoceras beds), Union Wash, Inyo Range, Inyo County, Cal. Collection United States National Museum.

252 


$$
0 \frac{m}{3}
$$




\section{PLATE XIX.}

Proptychites WalcotT Hyatt and Smith, sp. nov. (p. 85).

Figs. 1, 2, 3. Side and front views and septa of the type specimen.

FIGS. 4, 5, 6. Side and front views $(\times 3)$ and septa $(\times 6)$ of an interior specimen (broken out of the shell shown on fig. 7); diameter $10 \mathrm{~mm}$.

Fia. 7. Side view of a large shell out of which was broken the small specimen shown in figs. 4-6. From Lower 'Triassic (Meekoceras beds), Union Wash, Inyo Range, Inyo County, Cal. Collection United Stateg National Museum. 


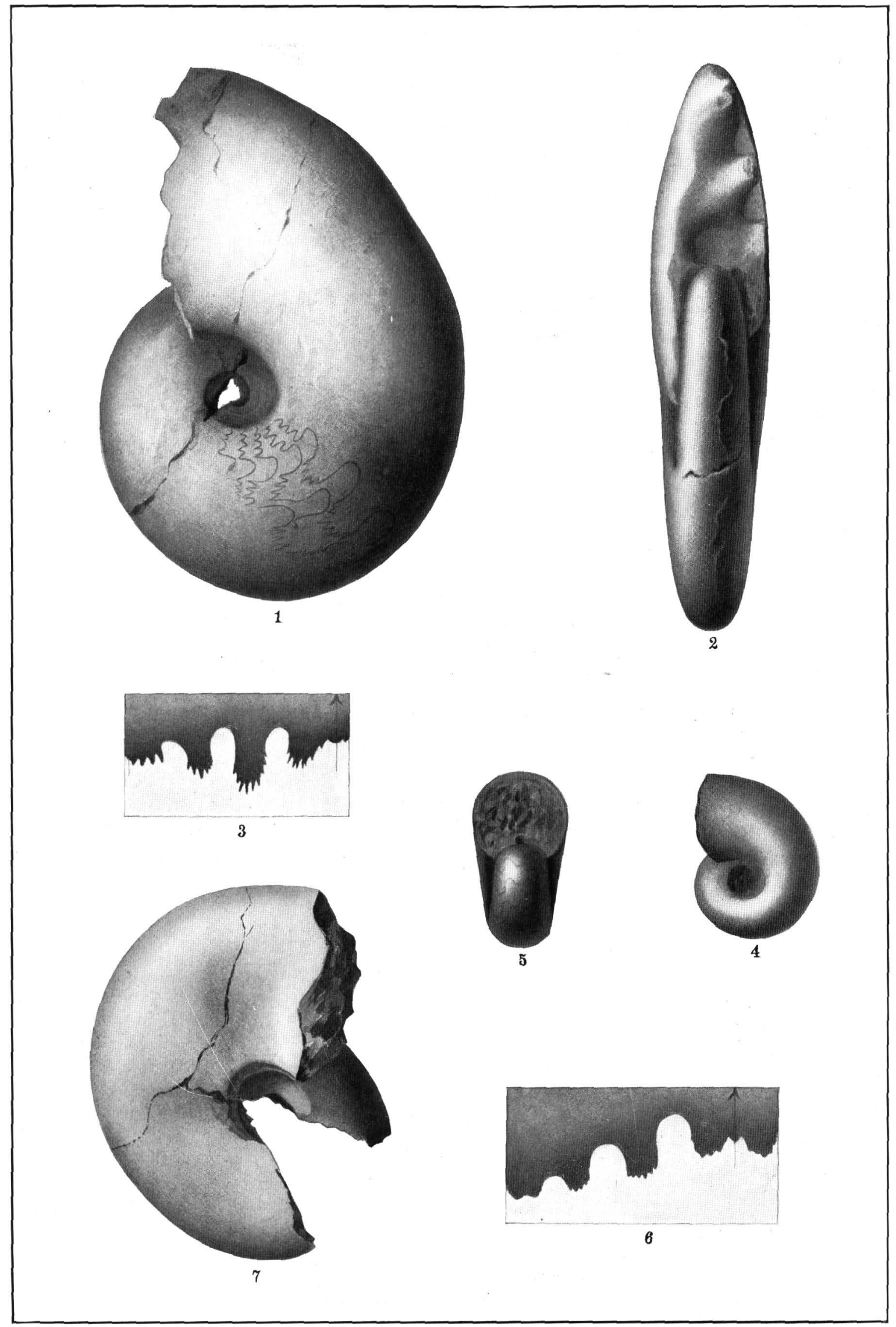

PROPTYCHITES WALCOTTI. 


\section{P LA TE X X.}

Hungarites Yatesi Hyatt and Smith (p. 129).

Figs. 1, 2, 3, 4. Side, front, and rear views (natural size), and septa $(X 4)$ of the type specimen. Outline restored, as shown by the shading.

From Middle Triassic, Union Wash, Inyo Range, 15 miles southeast of Independence, Cal. Collection United States National Museum.

Xenodiscus Bittweri Hyatt and Smith (p. 123).

Figs. 5, 6, 7. Side, front, and rear views of the type specimen, showing the outer shell.

Figs. 8, 9, 10. Side, front, and rear. views of a smaller specimen with shell removed, showing the septa.

Fig. 11: Septa $(\times 3)$ from the above specimen.

FIGs. 12, 13, 14. Side, front, and rear views $\left(\times 1 \frac{1}{2}\right)$ of an adolescent specimen.

Fig. 15. Septa $(\times 6)$ from the above specimen.

From Middle Triassic, Union Wash, Inyo Range, 15 miles southeast of Independence,

Cal. Collection United States National Museum. 

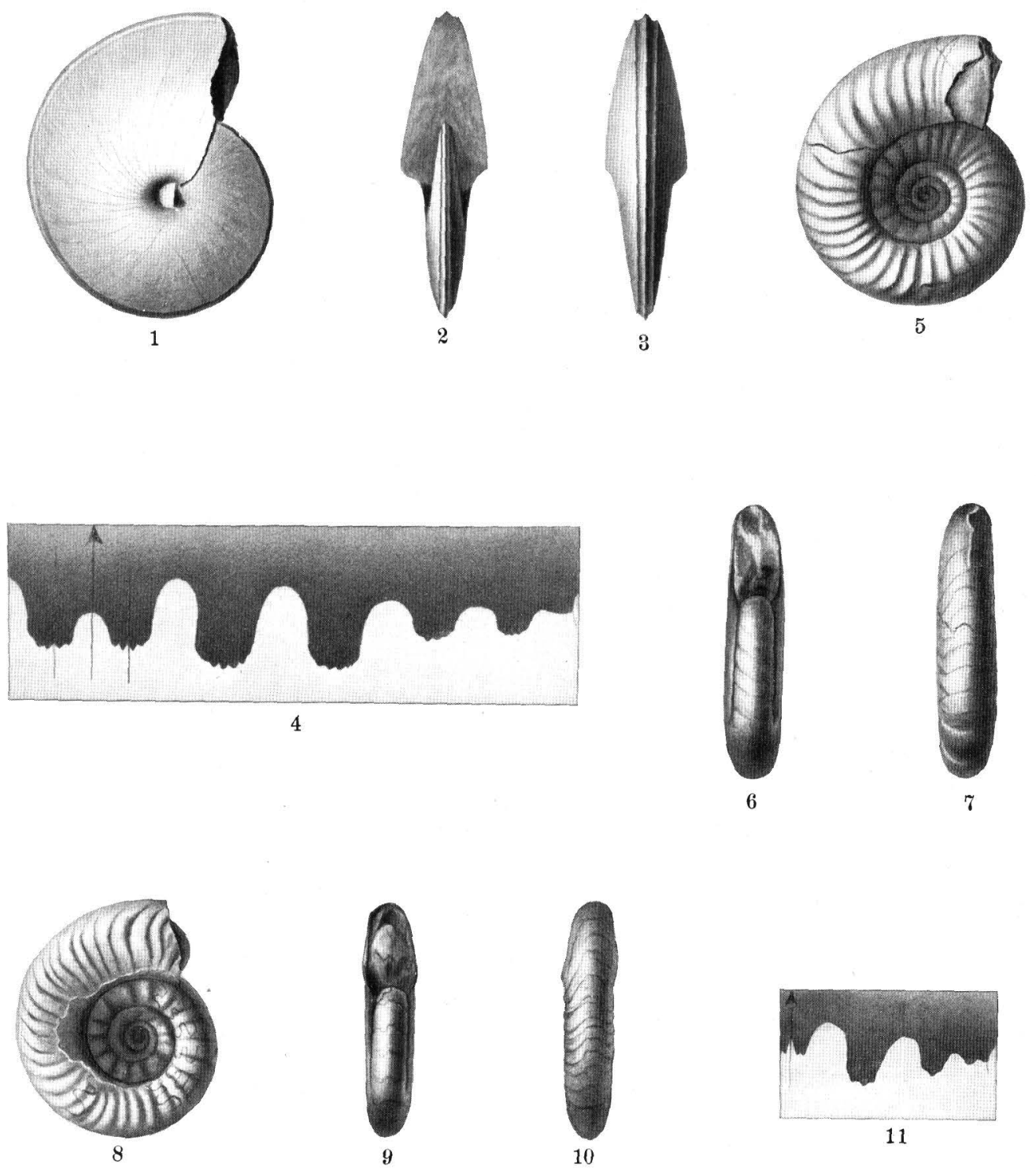

11
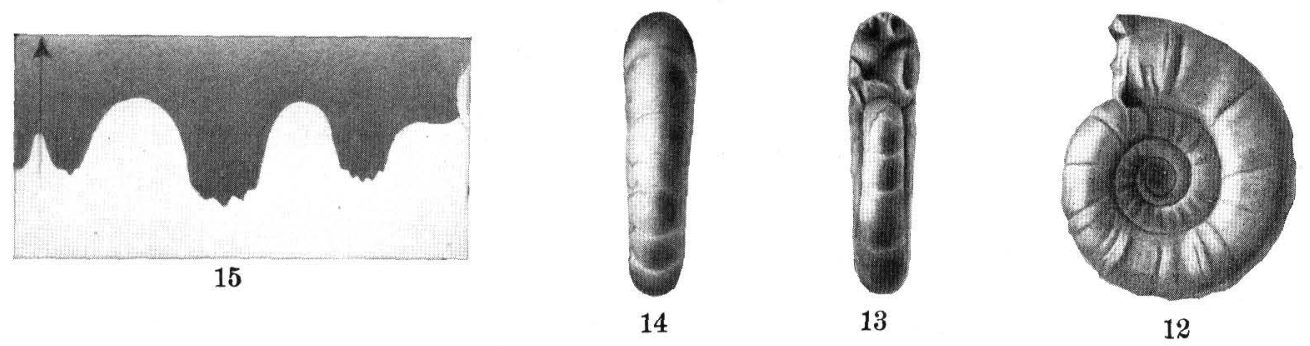


\section{PLATE XXI.}

Xenodiscus Bittnert Hyatt and Smith (p. 123).

Fics. 1, 2. Side and front views $(\times 6)$, beginning of adolescent stage, corresponding to Paralecanites; diameter $4 \mathrm{~mm}$.

Fia. 3. Septa $(\times 12)$ of the above specimen.

Figs. 4, 5. End of larval stage $(\times 12)$, corresponding to Prolecanites; diameter $2.20 \mathrm{~mm}$.

Fra. 6 . Septa $(\times 24)$ of the above specimen.

Fig. 7. Early larval stage; diameter $1.25 \mathrm{~mm}$.

Ficis. 8, 9. Adolescent stage $(\times 2)$; diameter $15 \mathrm{~mm}$.

Figs. 10, 11. Adolescent stage $(\times 3)$; diameter $9.5, \mathrm{~mm}$.

Figs. 12, 13. End of larval stage $(\times 4)$; diametcr $6.5 \mathrm{~mm}$.

From Middle Triassic, Union Wash, Inyo Range, Inyo County, Cal. Collection United States National Museum.

Tirom rces Pactricus Hyatt and Smith (p. 159).

Figs. 14, 15. Side and front views of the type.

Figs. 16, 17, 18. Side and front views $(\times 2)$ and septa $(\times 4)$.

From Middle T'riassic, Union Wash, Inyo Range, Inyo County, Cal. Collection United States National Museum: 

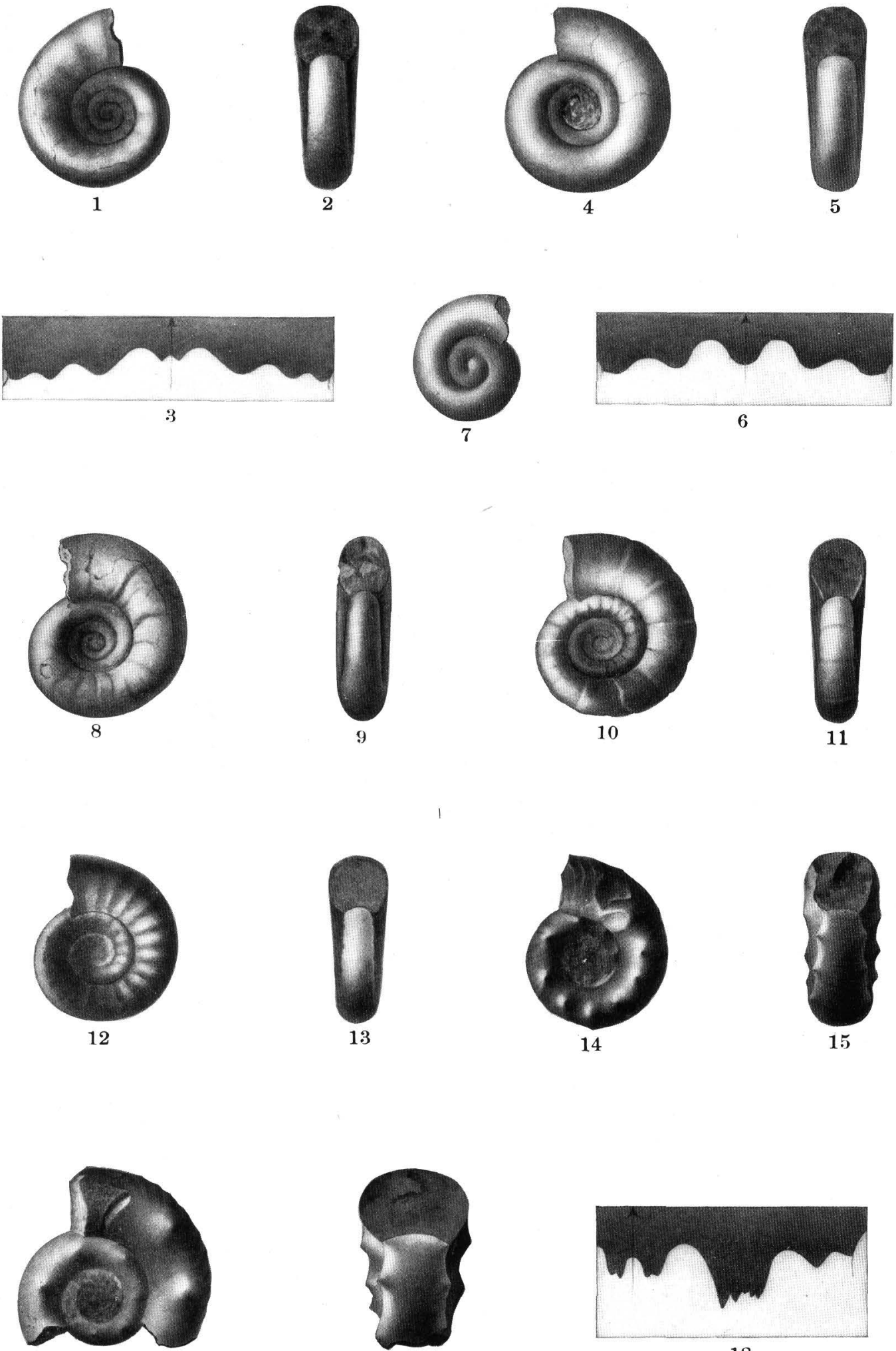

17

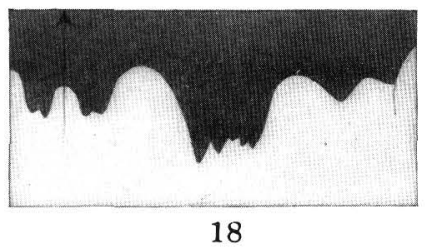




\section{PLATE XXII.}

\section{Cerattres (Gymnotochisas) Btakei Gabb (p. 173).}

Fics. 1, 2, 3. Side, front, and rear views of an adult specimen.

Figs. 4, 5. Side view (natural size) and septa $(\times 2)$ of an adult specimen.

From Middle Triassic, South Fork of American Canyon, West Humboldt Range, Nevada. Collection of J. P. Suith.

FIG. 6. Septa; diameter $35 \mathrm{~mm}$.

From Cottonwood Canyon. (No. 12512.) Collection United States National Museum.

Figs. 7, 8, 9. Side and front views (natural size) and septa $(\times 2)$; diameter about $30 \mathrm{~mm}$;

Figs. 10, 11. Side view (natural size) and septa $(\times 2)$ of an adolescent specimen; diameter $23 \mathrm{~mm}$.

Figs. 12, 13, 14 . Side, front, and rear views $\left(\times 1 \frac{1}{2}\right)$, adolescent stage; diameter $18 \mathrm{~mm}$.

Figs. 15, 16, 17. Side, front, and rear views $\left(X 1 \frac{1}{2}\right)$, adolescent stage; diameter $13 \mathrm{~mm}$.

Figs. 18, 19, 20. Side, front, and roar views $(\times 3)$, early adolescent stage; diameter $8 \mathrm{~mm}$. Corresponds to Dinarites.

Figs. 21, 22, 23. Side, front, and rear views $(X 4)$, larval stage; diameter $6.5 \mathrm{~mm}$. Corresponds to Tirolites.

From the divide between Troy Canyon and South Fork of American Canyon. Collection of J. P. Smith. 

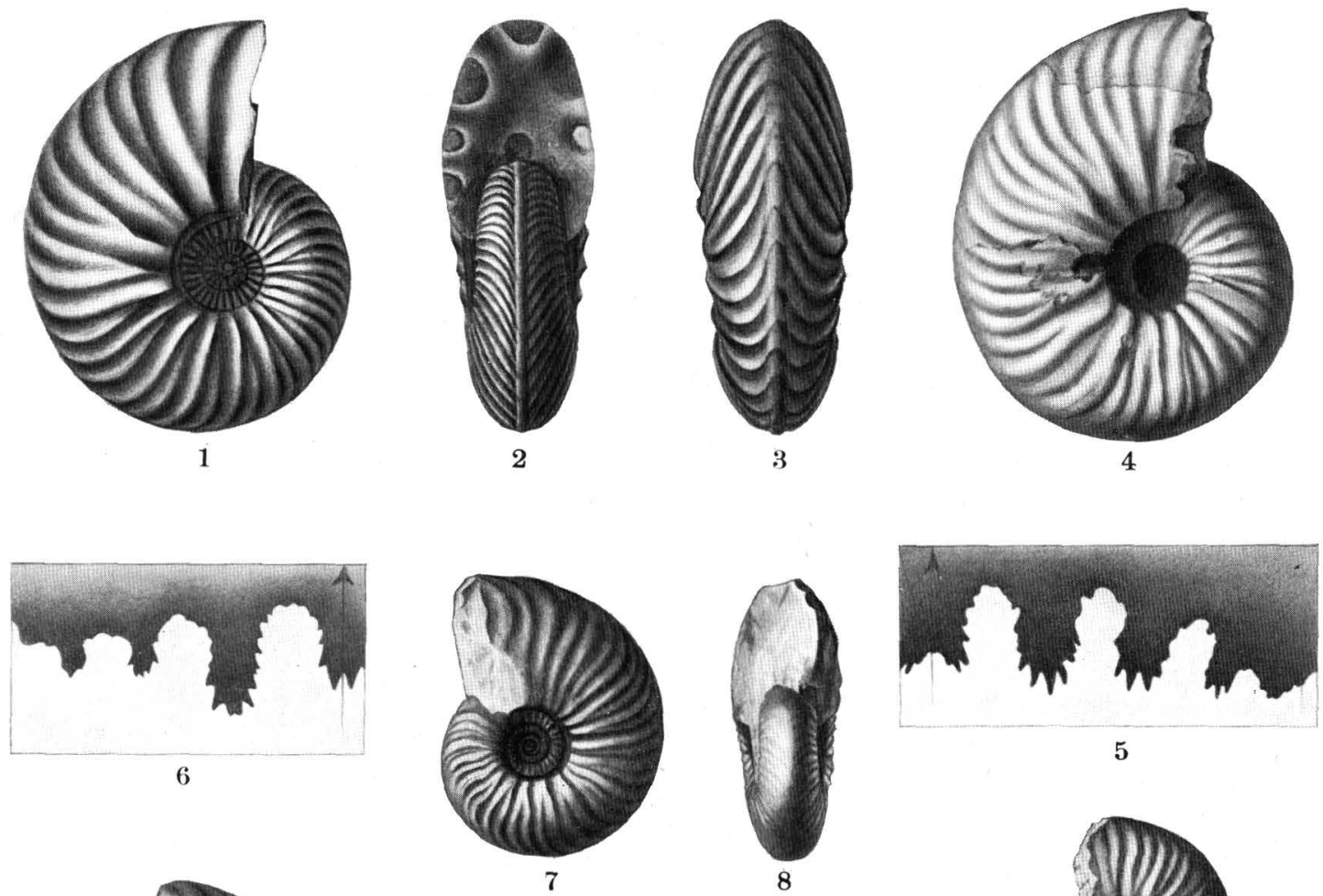

6

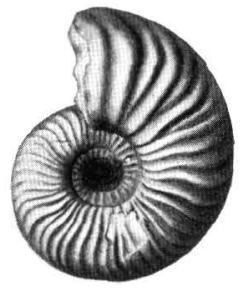

12
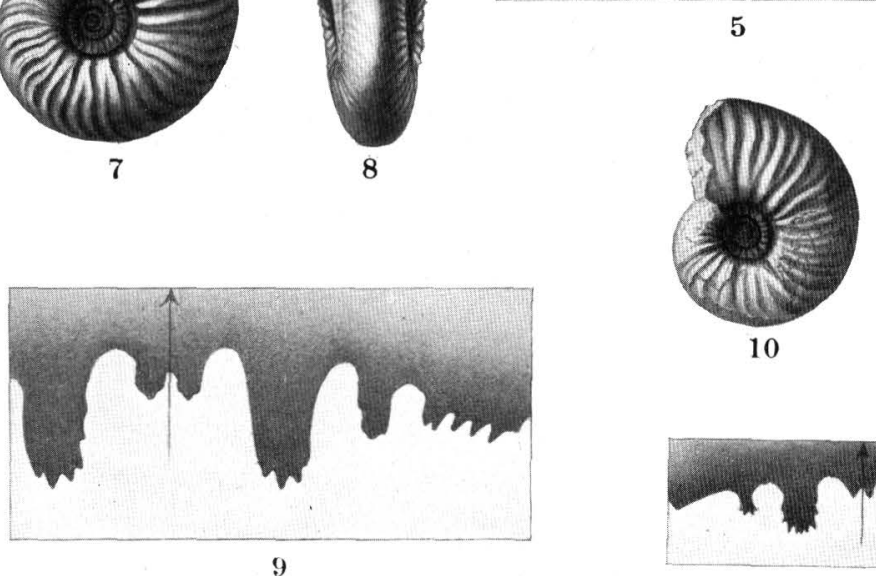

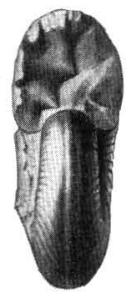

13
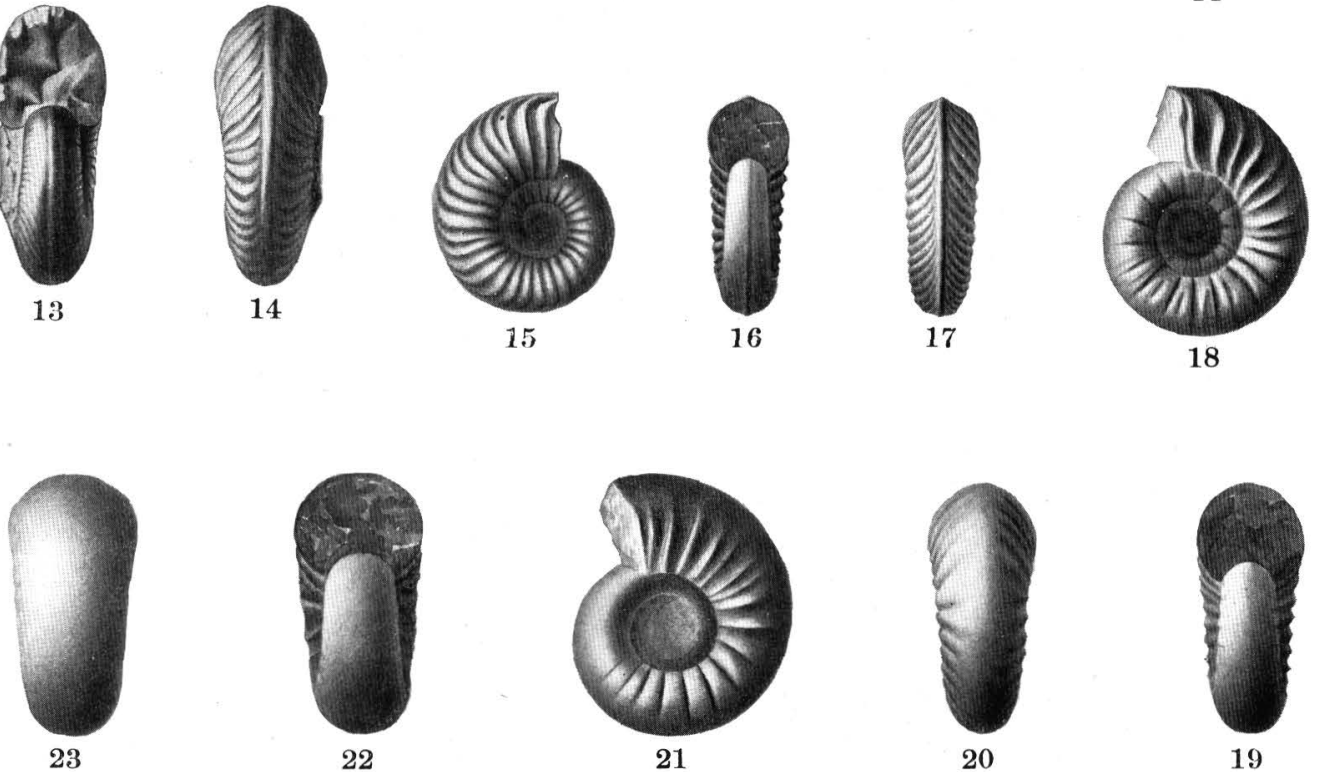

CERATITES (GYMNOTOCERAS) BLAKEI 


\section{PLATE XXIIT.}

\section{BeYrichites Roteldiformis Meek (p. 155).}

Figs. 1, 2. Side and front views of Meek's type (figured in U. S. Geol. Explor. 40th Par., vol. 4, pt. 1,

Pl, $X$, figs. 9 and $9-a)$.

Fics. 3, 4, 5. Side, front, and rear views of a young specimen.

Figs. 6, 7. Specimen showing the septa.

FIG. 7a. Septa of the same specimen.

From Middle Triassic, Nevada. Figs. 1-2, from Buena Vista Canyon, West Humboldt Range; figs. 3-7a from divide between Troy Canyon and South Fork of American Canyon, West Humboldt Range. Collection of J. P. Smith.

\section{Acrochordiceras IIyatti Meek (p. 178).}

Figs. 8, 9, 10, 11. Right and left sides, front, and septa.

From Middle Triassic, Shoshone Monntains, Nevada. Whitney Collection.

Balatonites shoshonensis Hyatt and Smith, sp. nov. (p. 167).

FIGs. 12, 13. Side and rear, views of the type.

From Middle Triassic, Nevada. Shoshone Mountains, longitude $117^{\circ} \mathrm{W}$. Whitney Collection.

262 

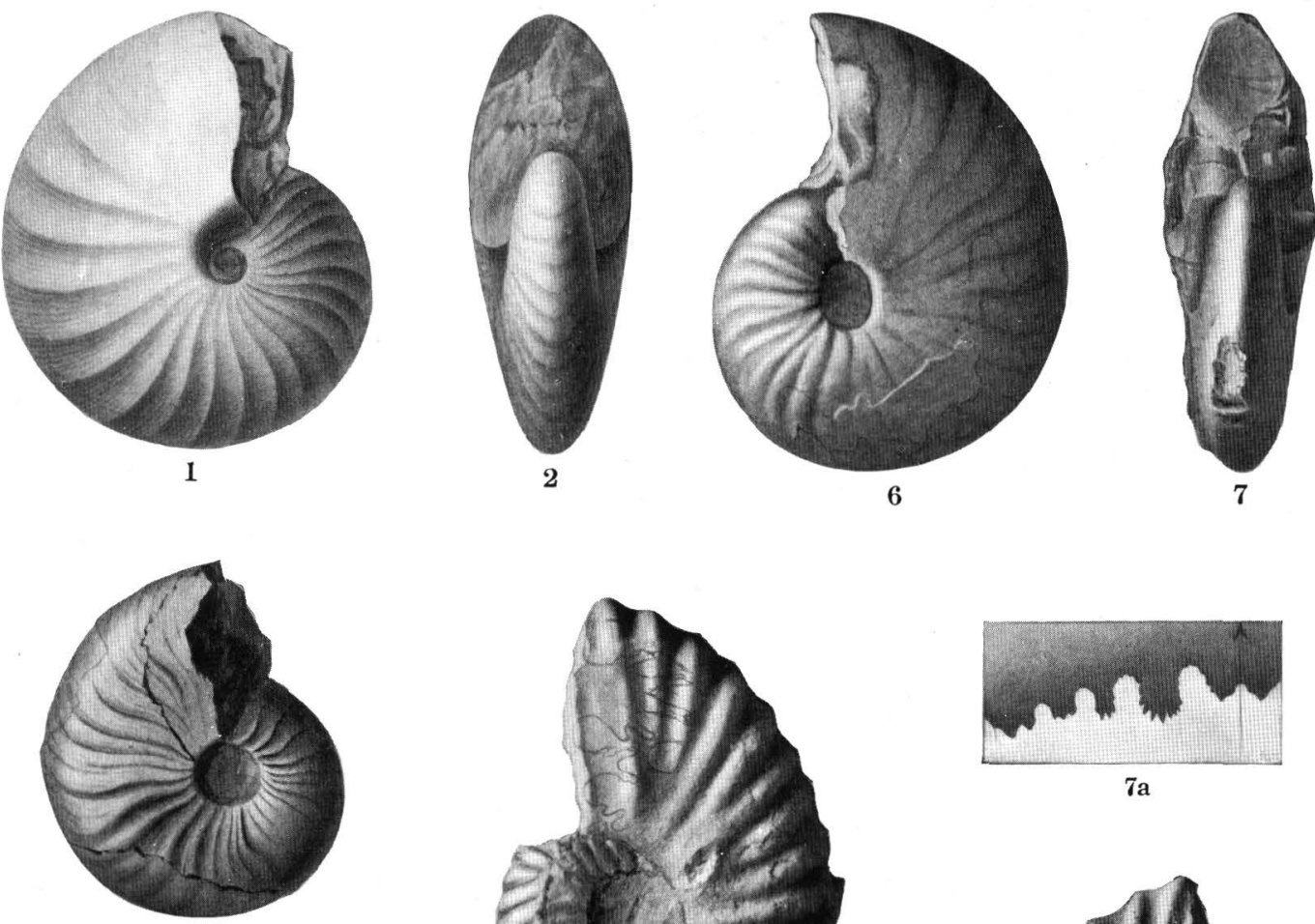

3
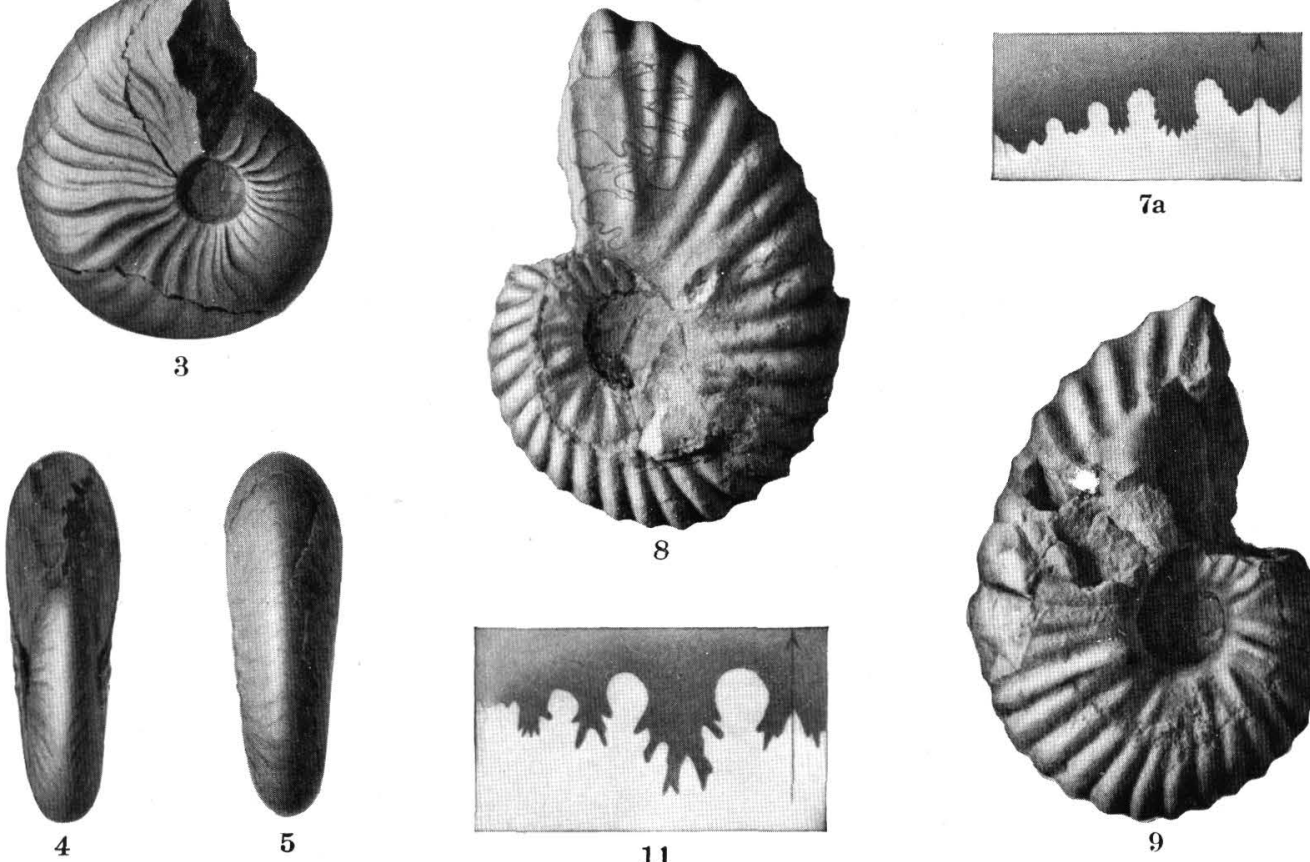

$7 \mathrm{a}$
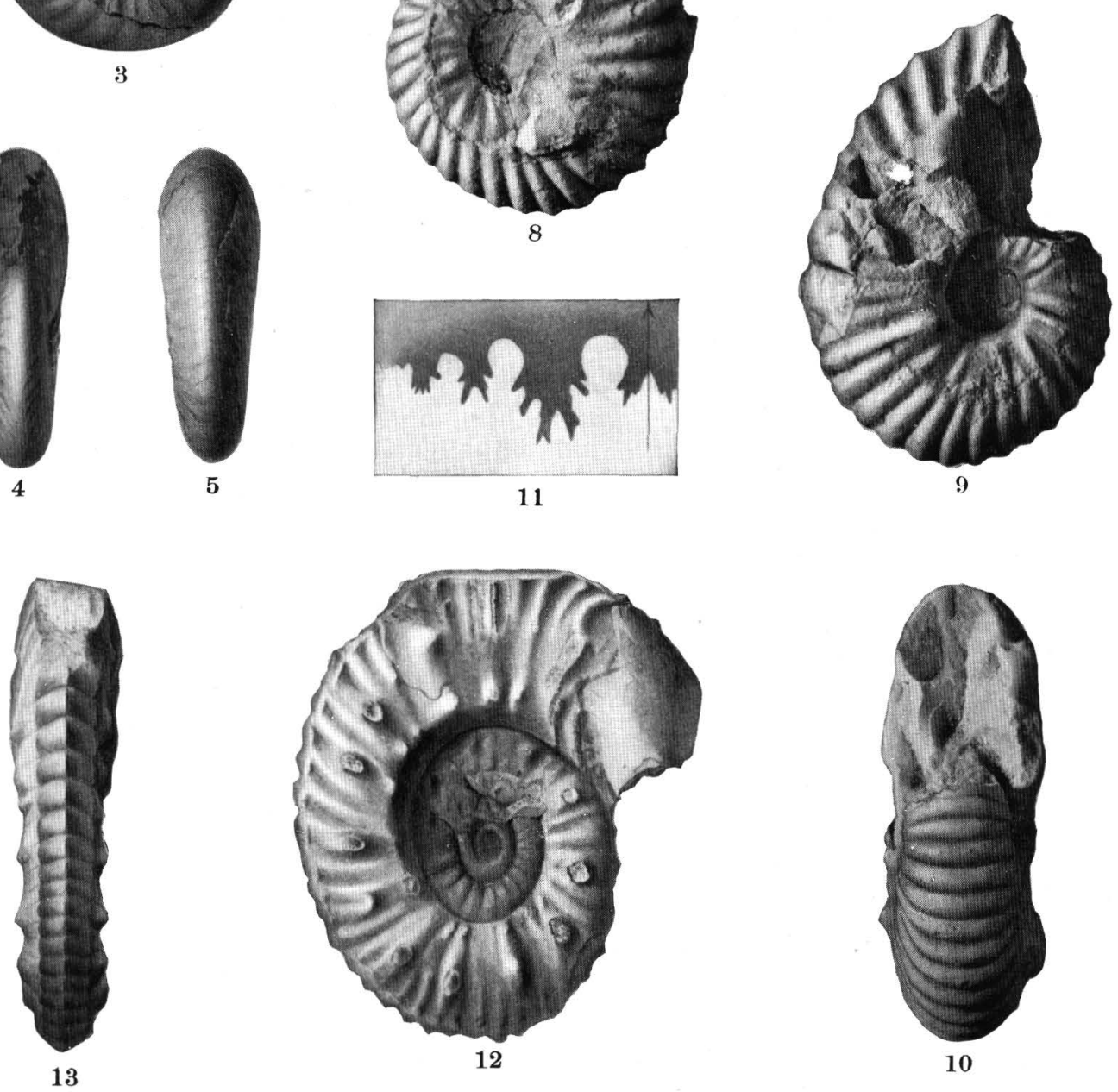


\section{P L A TE XXIV.}

\section{Eudiscocenas Gabir Meek (p. 179).}

Figs. 1, 2, Side and rear views, from U. S. Geol. Explor. 40th Par., vol. 4, pt. 1, Pl. XI, figs. 4 and 4 a. From Cottonwood Canyon, West Humboldt Range, Nevada.

Monophyllites Bithingstanus Gabb. (p. 94).

Figs. 3, 4. Side view and septa.

From Middle Triassic, East Range, Humboldt Mountains, Nevada. Whitney Collection.

\section{Joannites nevadanus Hyatt and Smith, sp. nov. (p. 76).}

Figs. 5, 6, 7. Side and front views and septa.

From Middle Triassic, Volcano, Nevada. Whitney Collection:

Trachyceras (Anolcites) Meeki Mojsisovics (p. 196).

Figs. 8, 9. After U. S. Geol. Explor. 40th Par., vol. 4, Pl. XI, figs. 1 and 1a.

From Middle Triassic, Cottonwood Canyon, West Humbolt Range, Nevada.

264 


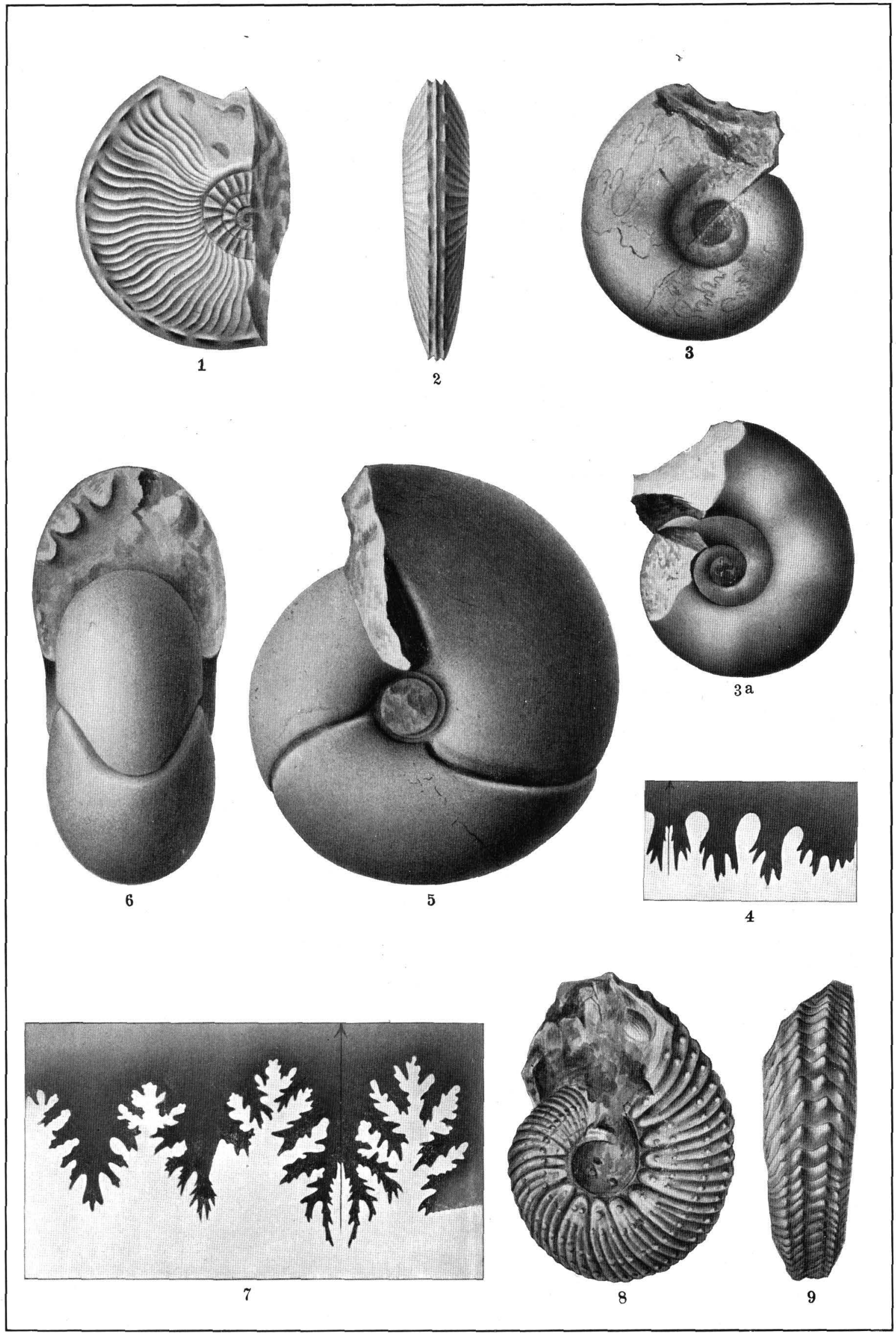




\section{PLATE XXV.}

Sagechras Gabbi Mojsisovics (p. 97).

Figs. 1, 2, 3. Side and front views and septa. (Copied from Paleontology of California, vol. 1, Pl. V, figs. 8 and 10.)

From Middle Triassic, West Humboldt Range, Nevada.

Celtitess Hatid Mojsisovics (p. 125).

Figs. 4, 4a. Side and front views (natural size).

Fra. 5. Right side (natural size) of another specimen.

Figs. 5a, 5b. Side view (natural size) and septa $(\times 3)$ of another specimen.

From Middle Triassic, on divide between north side of Troy Canyon and South Fork of American Canyon, Humboldt Range, Nevada. Collection of J. P. Smith.

Pтrchites Meeki Hyatt and Smith, sp. nov. (p. 87).

Figs. 6, 7, 8. Side and front views (natural size) and septa $(\times 2)$ of the type.

Fias. 9, 10. Side and front views of an adolescent specimen.

FIGs. 11, 12. Side and front views of a still smaller specimen.

From Middle Triassic, Star Canyon, West Humboldt Range, Nevada. Whitney collection, Harvard University.

Longobardites neVadanus Hyatt and Smith, sp. nov. (p. 132).

Fias. 13, 14, 15, 16. Side, front, and rear views $(\times 2)$ and septa $(\times 3)$ of the type specimen.

FIGs. 17, 18. Side view and septa (both $\times 3$ ) showing septa in the goniatite stage.

From Middle Triassic, New Pass, West Humboldt Range, Nevada. Whitney collection, Harvard Dniversity. 


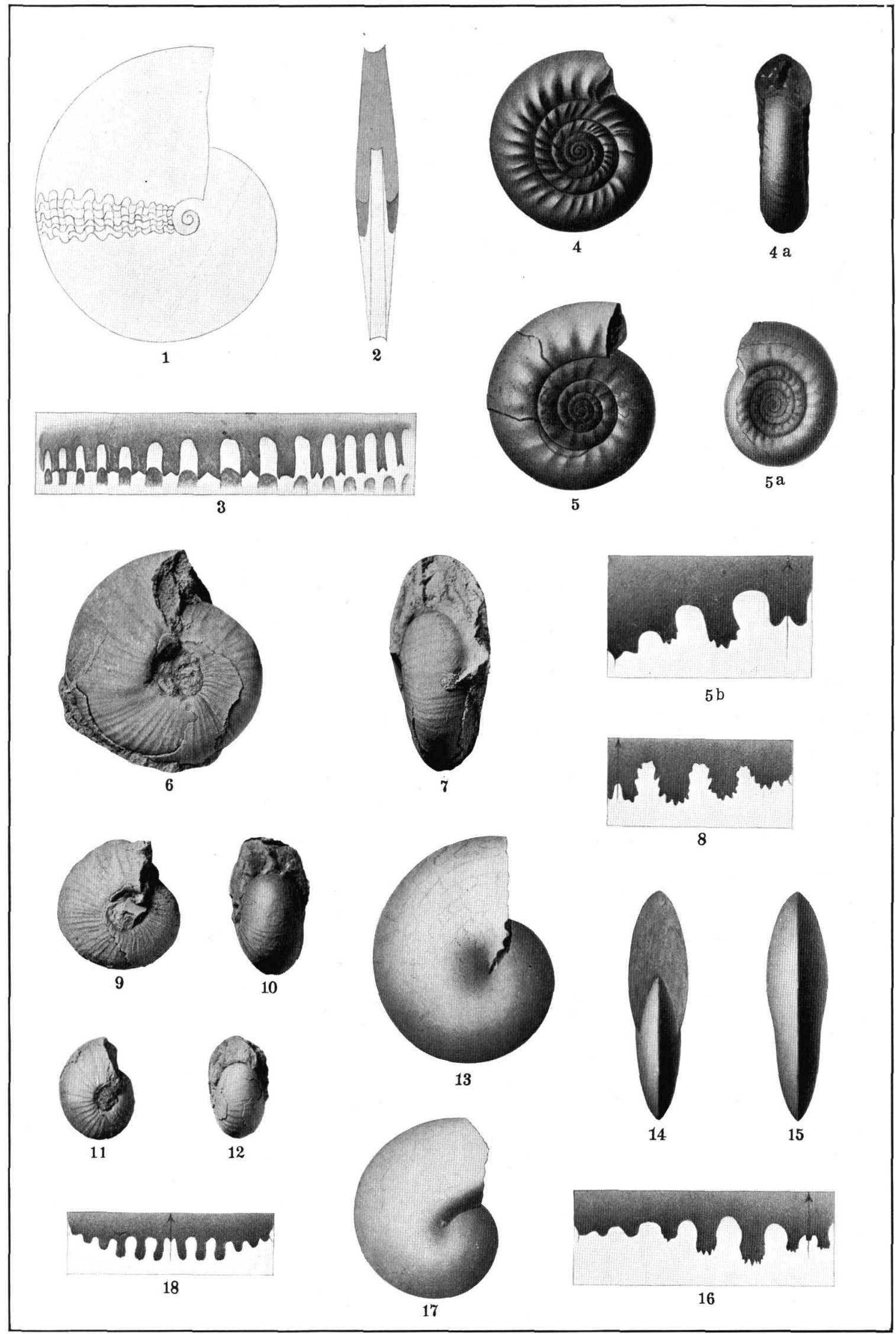

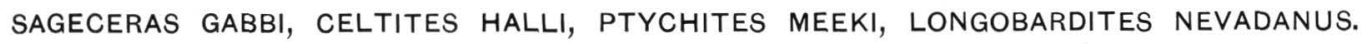




\section{PLATE XXVI.}

Sagenttes Herbichi Mojsisovics (p. 39).

Figs. 1, 2. Side and front views of a large specimen, showing the decrease of the spines and increase of the radial ribs in old age.

From Upper Triassic (Karnic stage), 3 miles east of Marison's ranch, between Squaw Creek and Pit River, Shasta County, Cal. Collection United States National Museum. 


$$
8
$$




\section{PLATE XXVII.}

Sagenites Herbichi Mojsisovies (p. 39).

Figs. 1, 2. Side view and septa of a specimen with the shell removed to show the smooth cast.

Figs. 3, 4. Side and front views, showing the shell at maturity.

Frum Upper Triassic (Karnic stage), 3 miles east of Madison's ranch, between Squaw Creek and Pit River, Shasta County, Cal. Collection of J. P. Smith. 


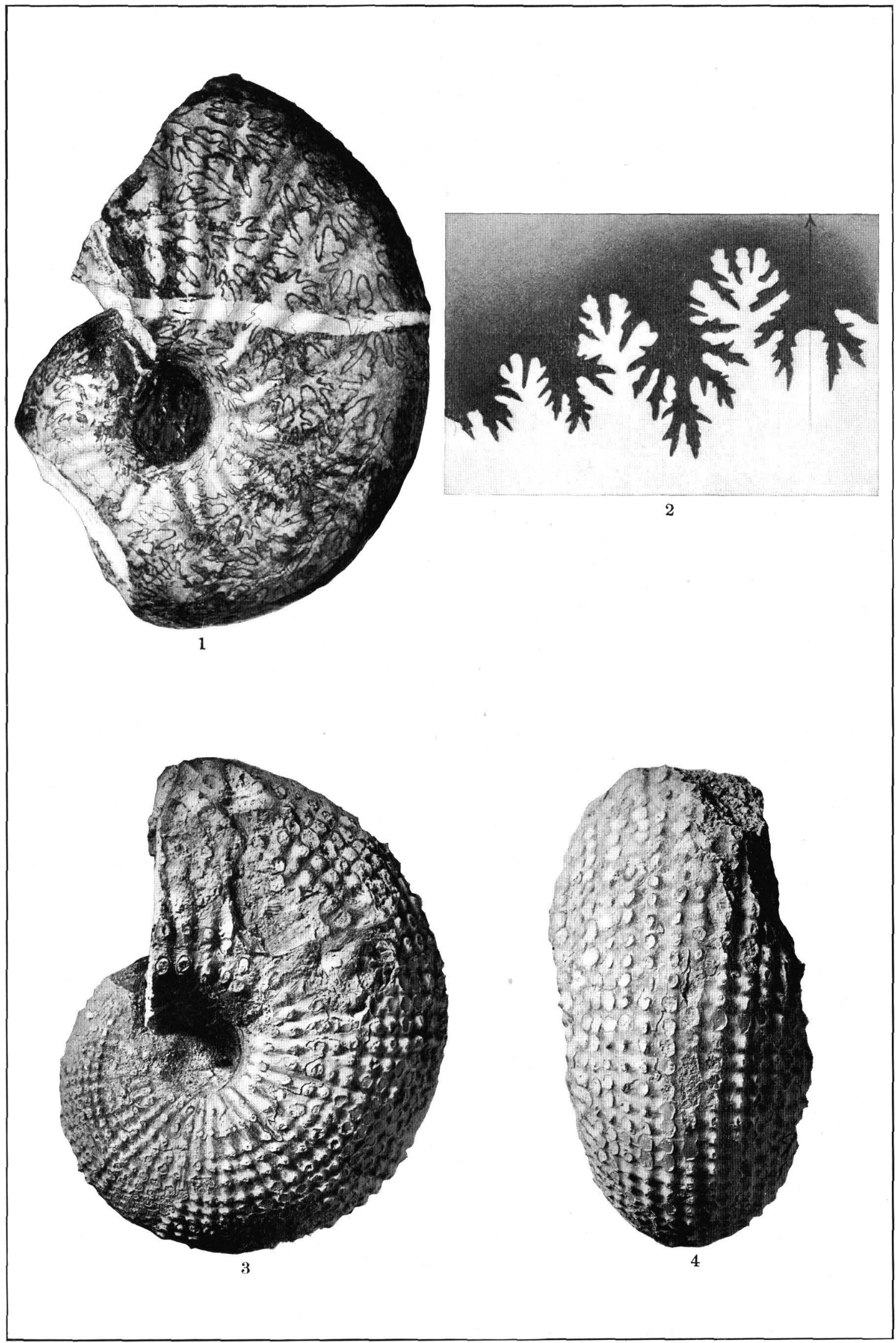




\section{PLATE XXVIII.}

\section{Sagenites Herbichi Mojsisovios (p. 39).}

Fias. 1, 2, 3. Side and front views and septa of an immature specimen; diameter $45 . \mathrm{mm}$.

Fias. 4, 5. Side and front views of an immature specimen, showing the shell at this stage; diameter $34 \mathrm{~mm}$.

Figs. 6, 7, 8. Side, front, and rear views $(\times 3)$ of an adolescent specimen, showing the beginning of the sculpture; diameter $9.5 \mathrm{~mm}$.

Figs. 9, 10. Side and front views $(\times 4)$ of a smaller adolescent specimen; diameter $6.5 \mathrm{~mm}$.

FIGs. 11, 12, 13, 14. Side, front, and rear views $(\times 4)$ and septa $(\times 6)$, showing the transition from goniatite to ammonite; diameter $4.8 \mathrm{~mm}$.

Figs. 15, 16, 17, 18. Side, front, and rear views $(\times 12)$ and septa $(\times 20)$, larval stage, corresponding to the goniatite ancestor of Sugenites; diameter $2.40 \mathrm{~mm}$.

From Upper Triassic (Karnic stage), 3 miles east of Madison's ranch, between Equaw Creck and Pit River, Shasta County, Cal, Collection of J. P. Smith.

\section{Homerites semiglobosus Hauer (p. 43).}

Figs. 19, 20. Side and rear views $(\times 2)$.

FIGs. 21, 22, 23. Side, front, and rear views.

Frg. 24. Septa $(\times 6)$ of same.

From Upper Triassic (Karnic stage), California. Figs. 19, 20, from divide between Squaw Creek and Pit River; figs. 21-24, from west bank of the North Fork of Squaw Creek, 3 miles north of Kelly's ranch, Shasta County, Cal. Collection of J. P. Smith. 


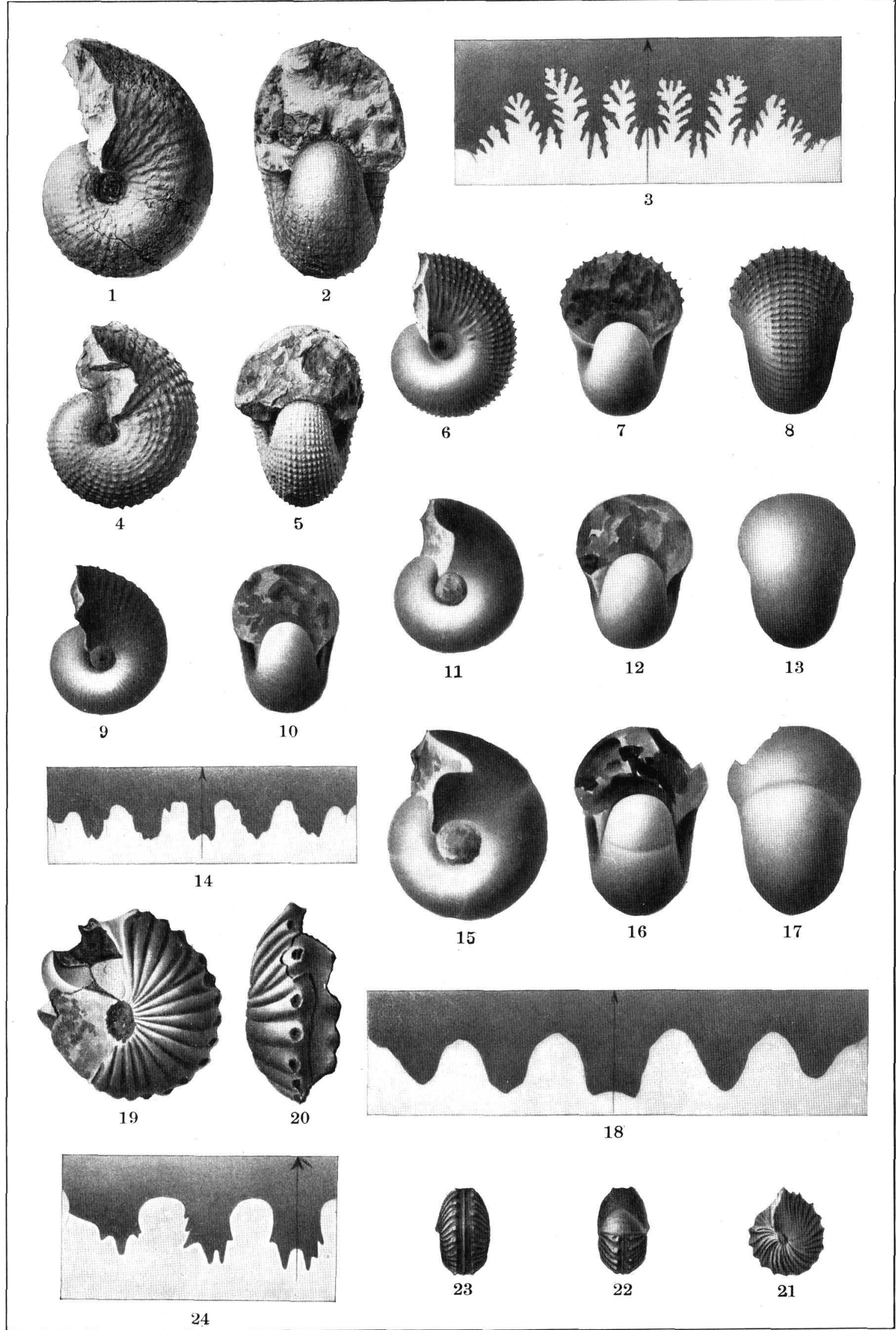




\section{PLA TE XXIX.}

\section{Halorites americanus Hyatt (p. 42).}

Figs. 1, 2. (Copied from Palæontology of California, vol. 1, Pl. III, figs. 21 and 21a.)

From Upper Triassic (Noric horizon, above the Hosselkus limestones) near Genesee, Plumas County, Cal.

Leconteia Californica Hyatt and Smith, sp. nov. (p. 36).

Fics. 3, 4, 5, 6. Side, front, and rear views (natural size) and septa $(\times 3)$ of the type specimen.

FIG. 7. Side view of another specimen, showing the constriction near the aperture.

Fig. 8. Cross section $(\times 2)$.

Fig. 9. Septa $(\times 2)$ drawn from a broken whorl.

Figs. 10, 11. Views from side and above of specimens, showing contraction of body chamber at the aperture.

Figs. 12, 13. Side and rear views of specimen with outer shell removed, showing the ventral rows of knots on the cast.

Ficis. 14, 15, 16. Side, front, and rear views $(\times 2)$ of an adolescent specimen, showing the beginning of the knots on the ribs; diameter $9 \mathrm{~mm}$.

Figs. 17, 18. Side and front views $(\times 10)$ of larval specimen; diameter $2.9 \mathrm{~mm}$.

Figs. 19, 20, 21. Side, front, and rear views $(\times 10)$ of larval specimen, to show the beginning of the umbilical ribs; diameter $2.5 \mathrm{~mm}$.

From Upper Triassic (zone of Tropites subbullatus), 3 miles east of Madison's ranch, between Squaw Creek and Pit River, Shasta County, Cal. Collection of J. P. Smith. 


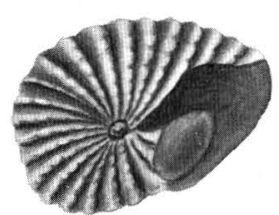

1

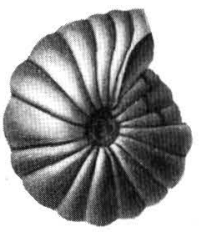

3

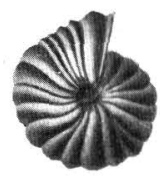

10

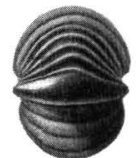

11

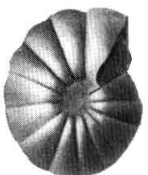

14

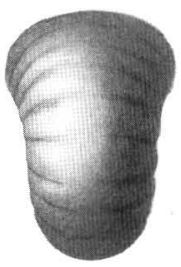

21

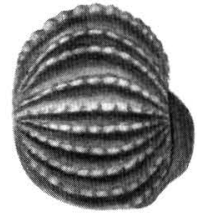

2

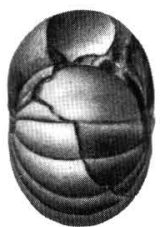

4
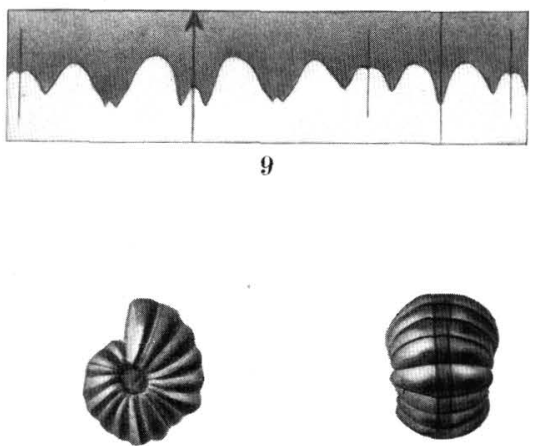

12

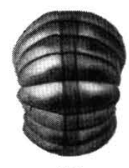

13
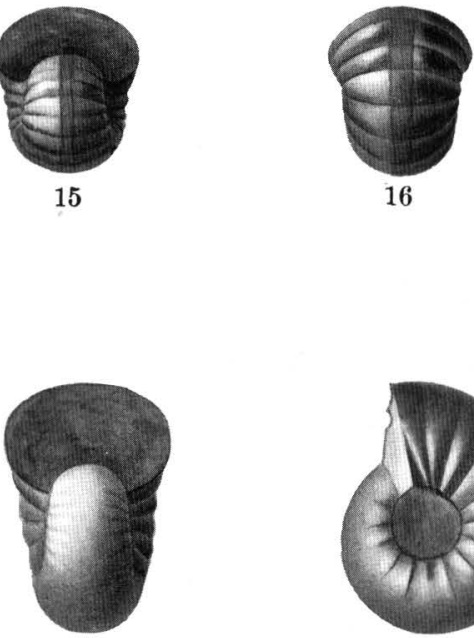

20

5

19

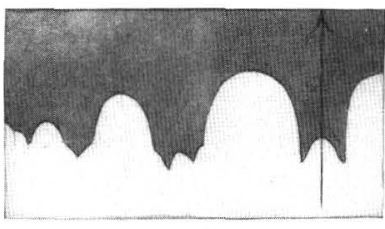

6
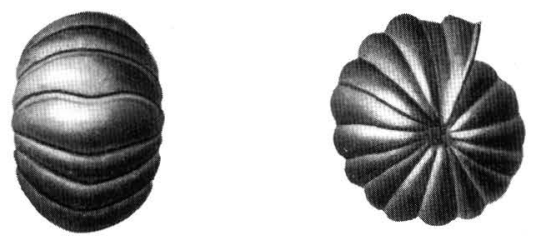

7
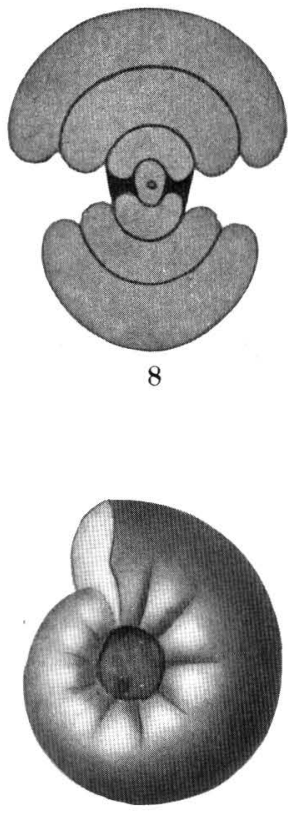

17
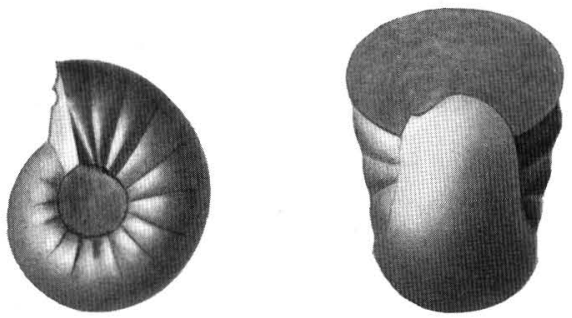

18 


\section{PLATE XXX.}

Juvatites subinterruptus Mojsisovics (p. 46).

Figs. 1, 2, Side and front views.

From Upper Triassic, near Terrup-chetta, 6 miles north of Madison's ranch, on divide between Squaw Creek and Pit River, Shasta County, Cal. Collection of J. P. Smith.

Juvavites subintermitens Hyatt and Smith, sp. nov. (p. 47).

Figs. 3, 4, 5. Side and front views (natural size) and septa $(\times 2)$.

From Upper Triassic, near Terrup-chetta, 6 miles north of Madison's ranch, on Squaw Creek, Shasta County, Cal. Collection of J. P. Simith.

Paratropités Selitai Mojsisovics (p. 54).

FIGs. 6, 7. Side and front views of an old specimen.

Figs. $8,9,10$. Side and front views and septa of a mature specimen.

From Upper Triassic, 3 miles east of Madison's ranch, between Squaw Creek and Pit River, Shasta County, Cal. Collection of J. P. Simith. 

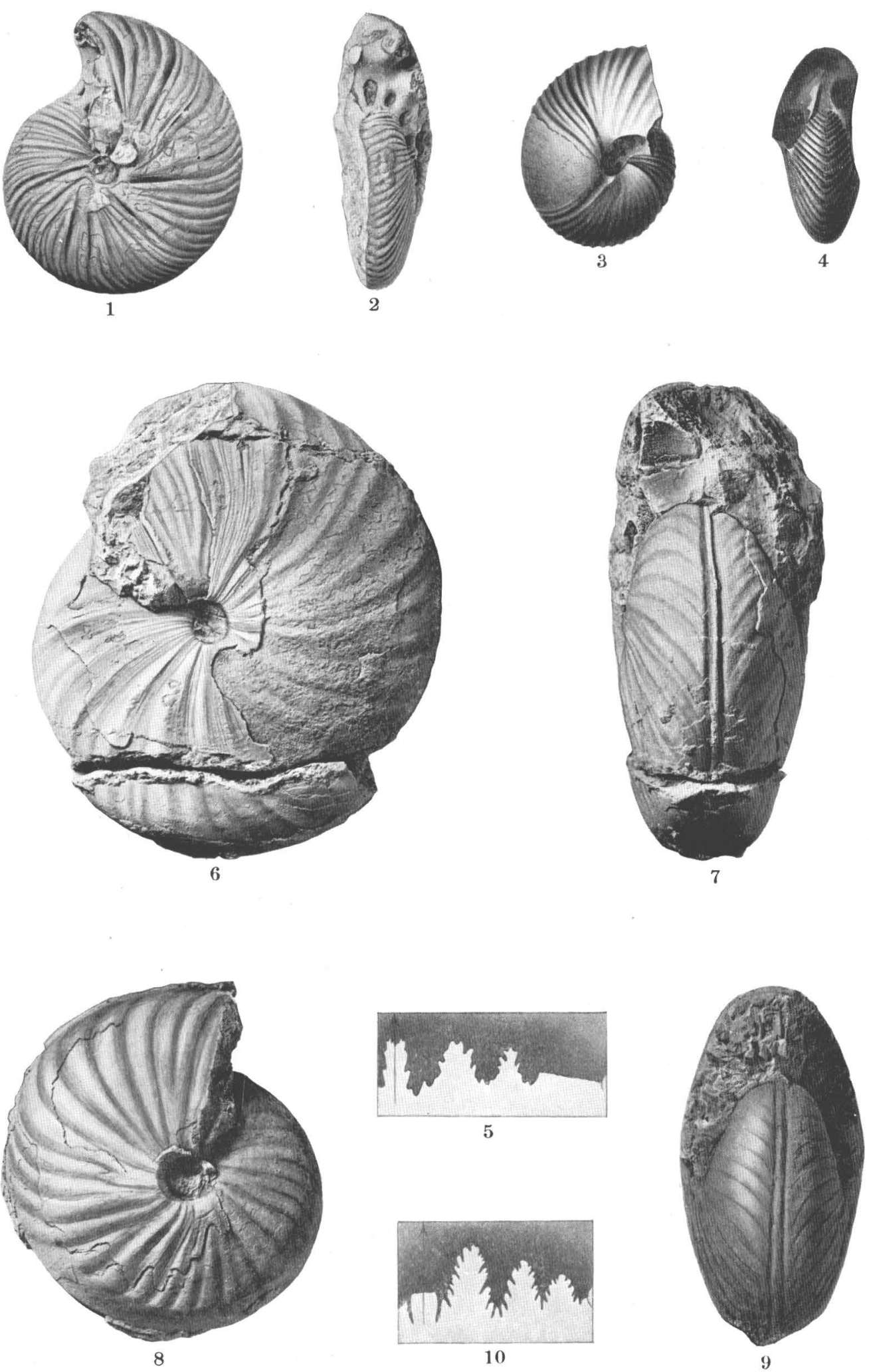

JUVAVITES SUBINTERRUPtUS, JUVAVITES SUBINTERMITTENS, PARATROPITES SELLAI. 


\section{PLATE XXXI.}

\section{Paratropites Sellai Mojsisovics (p. 54).}

FIG. 1. Septa $(\times 2)$ of a mature specimen.

Fias. 2, 3. Side and front views.

Ficis. 4, 5, 6. Side, front, and rear views.

Ficis. 7, 8. Side and rear views.

Figs. 9, 10. Side and front views; diameter $21 \mathrm{~mm}$.

Figs. 11, 12, 13. Side, front, and rear views $(\times 2)$; diameter $12 \mathrm{~mm}$.

Fics. 14, 15, 16. Side, front, and rear views; diameter $7 \mathrm{~mm}$.

Figs. 17, 18, 19, 20. Side, front, and rear views $(\times 4)$ and septa $(\times 10)$; diameter $4.98 \mathrm{~mm}$.

Figs. $21,22,23$. Side and front views $(\times 6)$ and septa $(\times 10)$; diameter $4 \mathrm{~mm}$.

FIGs. 24, 25, 26. Side and front views $(\times 10)$ and septa $(\times 15)$; diameter $2.3 \mathrm{~mm}$.

From Upper Triassic, 3 miles east of Madison's ranch, between Squaw Creek and Pit

River, Shasta County, Cal. Collection of J. P. Smith. 


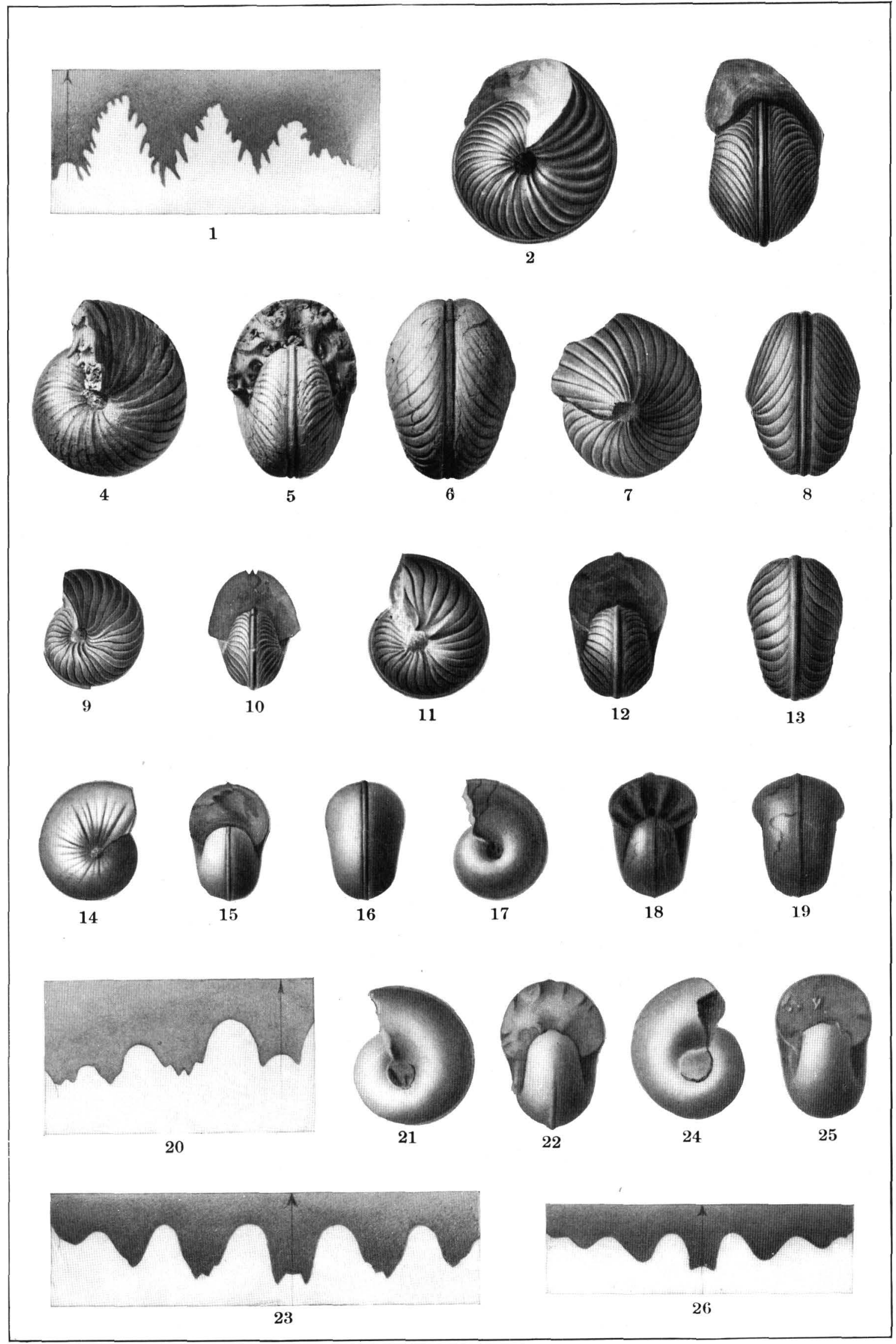




\section{PLA TE XXXII.}

Paratropites (Gimnotropites) americanus Hyatt and. Smith, sp. nov. (p. 56):

Figs. 1, 2. Side and front views $(\times 2)$ of the type specimen.

Figs. 3, 4, 5. Side, front, and rear views $(\times 2)$ and septa $(\times 4)$.

Figs: 6, 7. Side and front views $(\times 3)$; diameter $10 \mathrm{~mm}$. (Septa not exact; they should show a divided ventral lobe.)

Fig. 10. Side view $(\times 3)$; diameter $6.5 \mathrm{~mm}$.

From Upper Triassic, 3 miles east of Madison's ranch, between Squaw Creek and Pit River, Shasta County, Cal. Collection of J. P. Smith.

Tornquistites evolutus Hyatt and Smith, sp. nov. (p. 60).

Fias. 11, 12, 13, 14. Side, front, and rear views (natural size) and septa $(X 3)$ of the type specimen.

Fıgs. 15, 16. Side and front views.

Fias. 17, 18, 19. Side and front views (natural size) and septa ( $\times 3$ ).

Figs. 20, 21. Showing the keel on the inner volutions; diameter $7.5 \mathrm{~mm} .(\times 5)$.

From Upper Triassic, 3 miles east of Madison's ranch, between Squaw Creek and Pit River, Shasta County, Cal. Collection of J. P. Smith. 

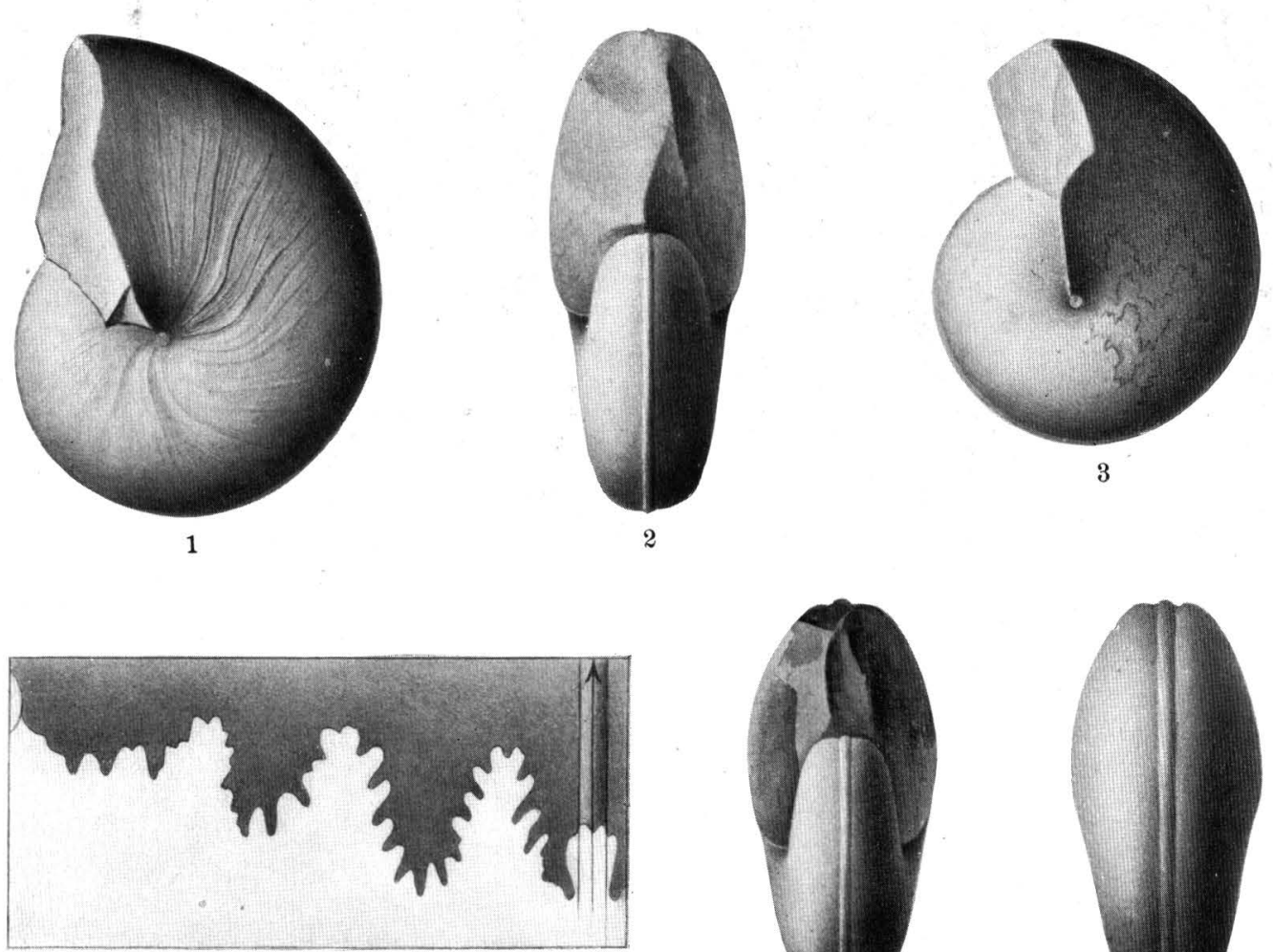

5
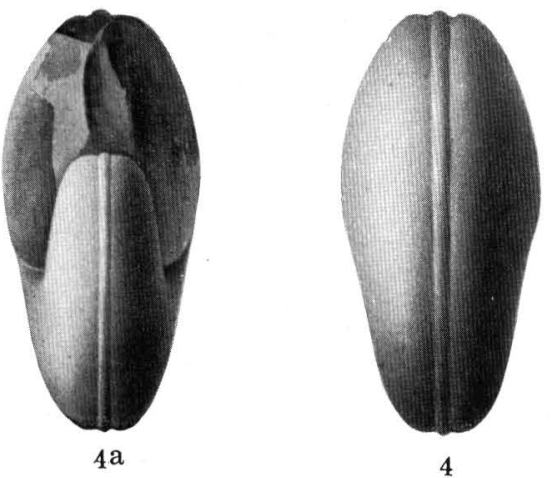

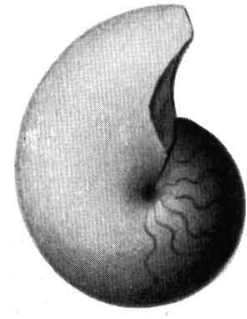

6

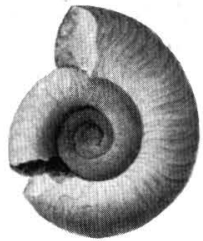

11

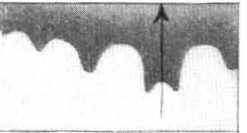

14
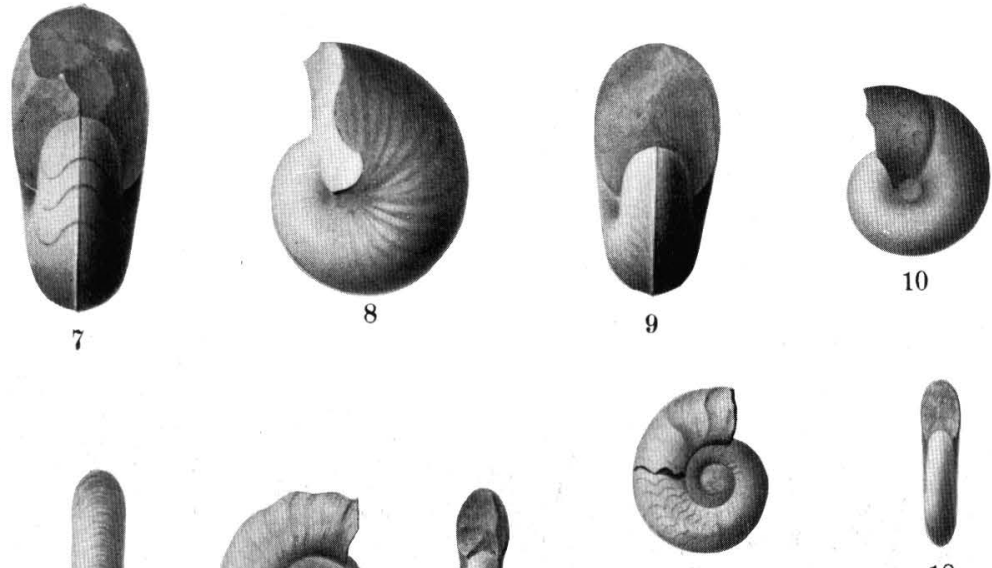

17
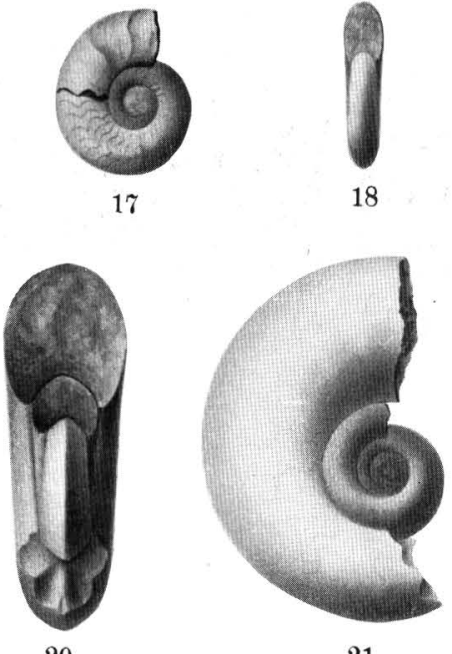

19 


\section{PLATE XXXII.}

Tropitras subbullatus Hauer (p. 67).

Fıcis. 1, 2, 3. Side, front, and reair views of an old specimen; diameter $83 \mathrm{~mm}$.

FIG. 4. Septa from another specimen.

Figs. 5, 6, 7. Side, front, and rear views of a smaller adult specimen.

From Upper Triassic (Karnic stage), 3 miles east of Madison's ranch, between Squaw Creek and Pit River, shasta County, Cal. Collection of J. P. Smith. 

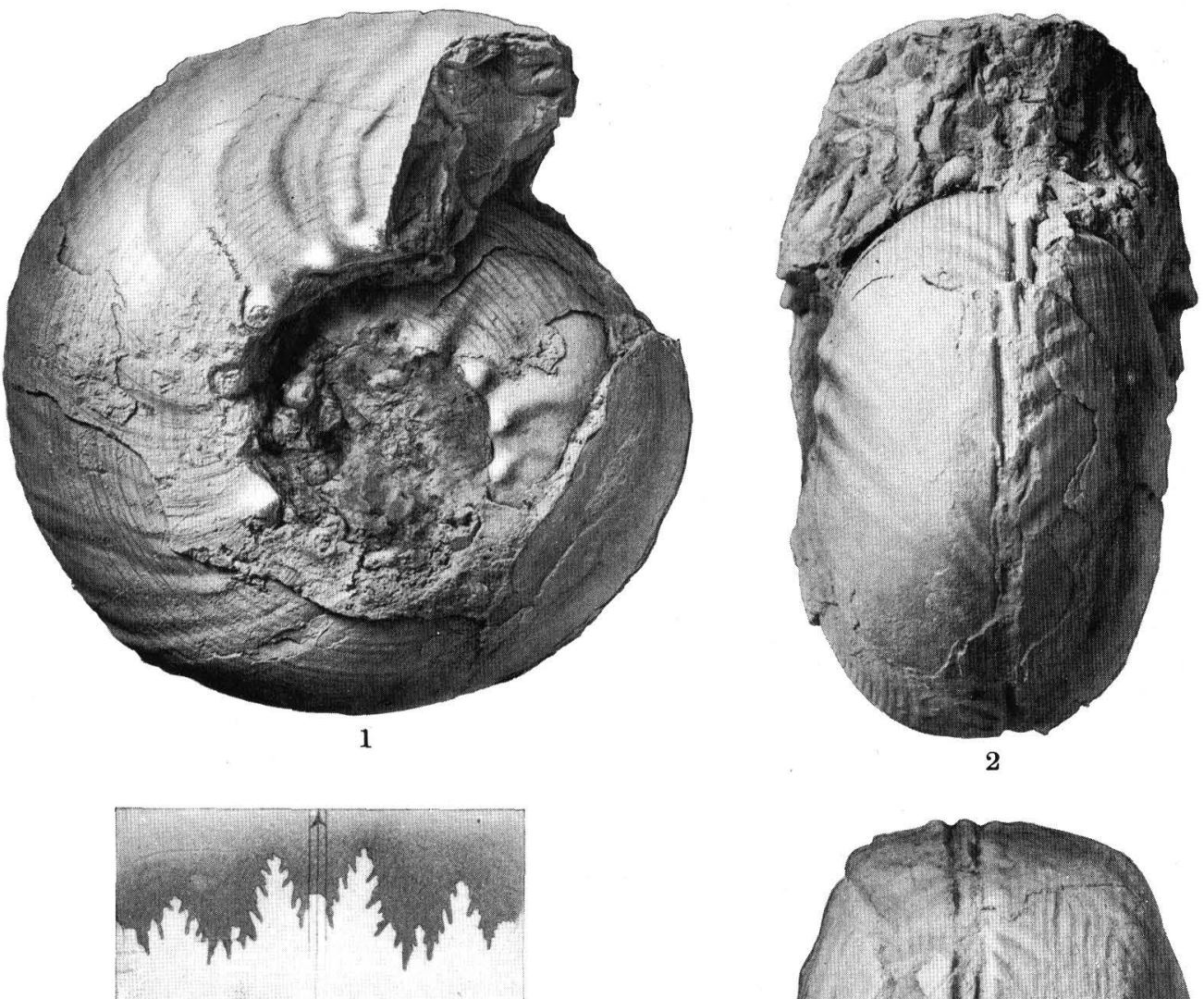

4
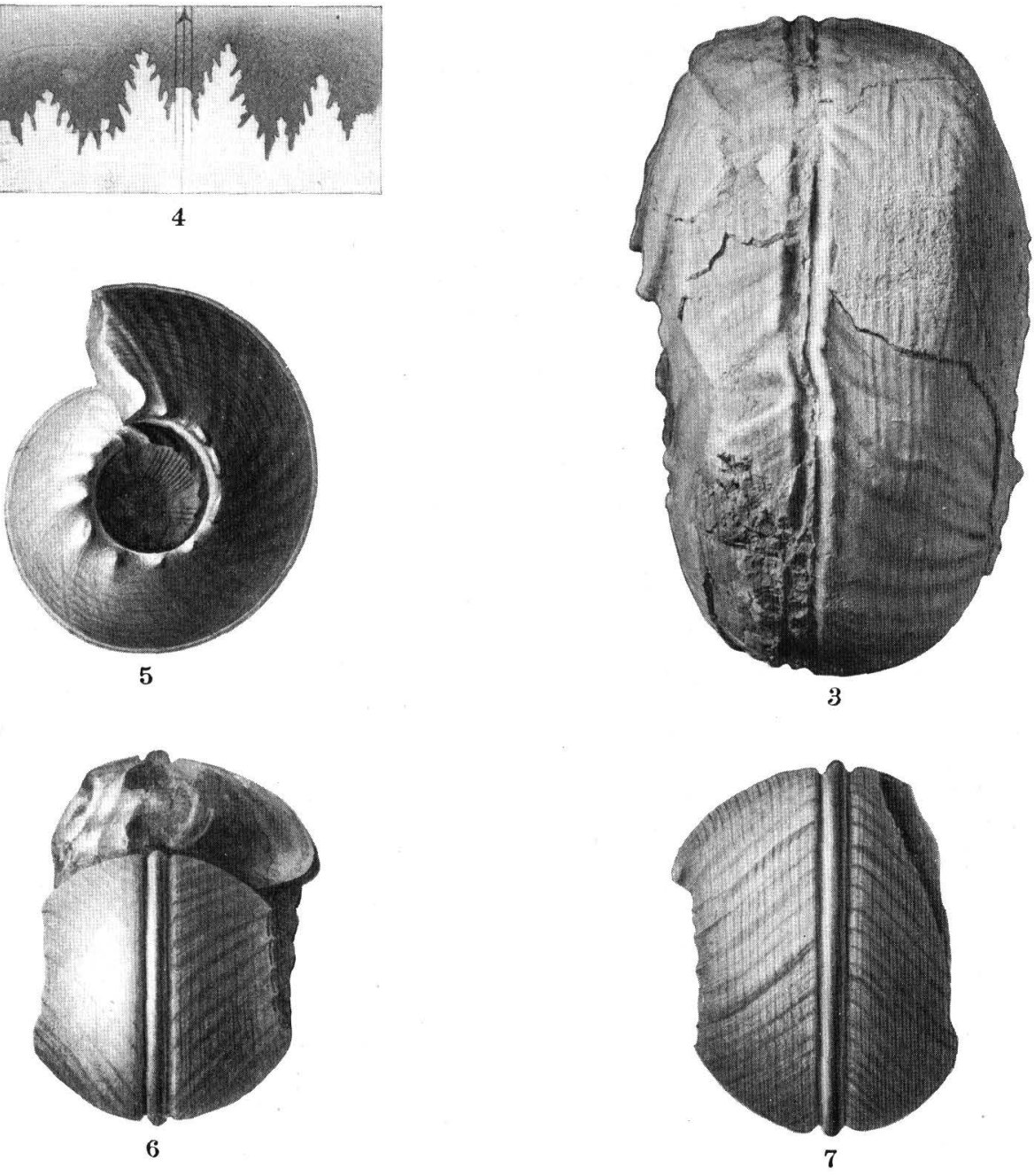

TROPITES SUBBULLATUS. 


\section{PLATE XXXIV.}

\section{Tropites subbullatus Hauer (p. 67).}

Figs. 1, 2. Side and front views of adult specimen.

Figs. 3, 4, 5. Side, front, and rear views of an adolescent specimen; diameter $27 \mathrm{~mm}$. FI is. 6, 7, 8. Side, front, and rear views ( $\times 2$ ), adolescent stage; diameter $17.5 \mathrm{~mm}$.

Figs. 9, 10, 11. Side, front, and rear views $(X 3)$, adolescent stage; diameter $9.5 \mathrm{~mm}$.

Fics. 12, 13, 14 . Side, front, and rear views $(X 3)$, adolescent stage; diameter $7 \mathrm{~mm}$.

From Upper Triassic, 3 miles east of Madison's ranch, between Squaw Creek and Pit River, Shasta County, Cal. Collection of J. P. Sinith. 

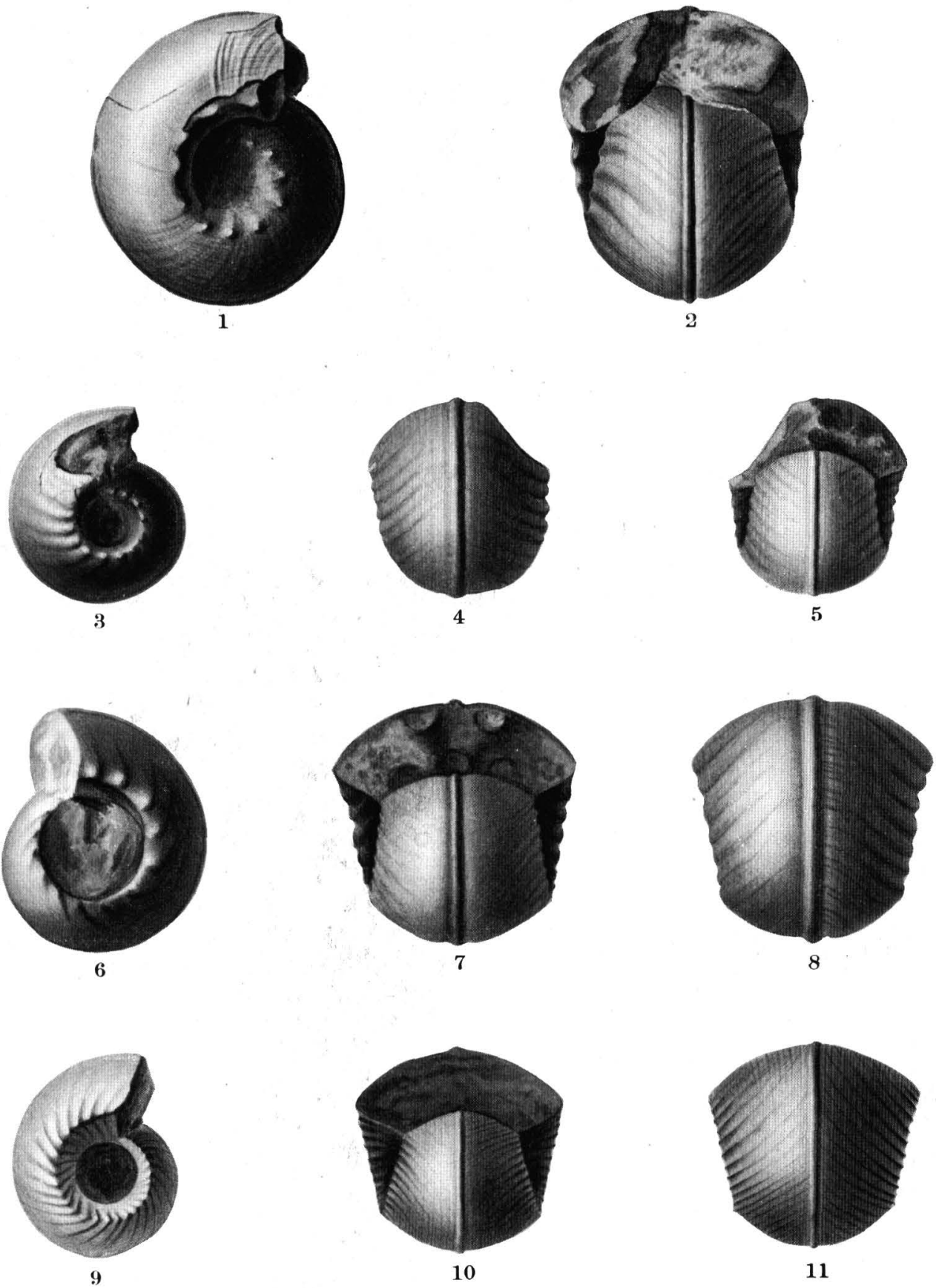

11

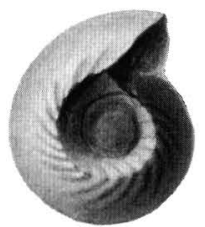

12
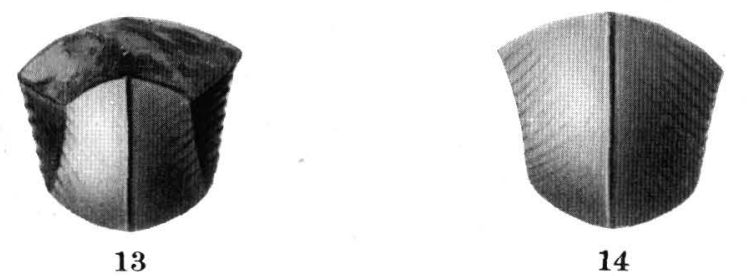


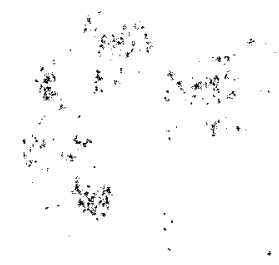

\section{PLATE XXXV.}

Discotropites sandingensis Hauer (p. 63).

Figs. 1, 2. Side view and septa of a large specimen, showing the hollow keel.

Figs. 3, 4, 5, 6. Side, front, and rear views and septa, with the onter shell removed, showing the low keel on the cast; diameter $48 \mathrm{~mm}$.

FIGs. 7, 8. Side and front views, showing the coarse sculpture.

Fra. 9. An artificial cast, showing the radial ribs, spiral lines, keel, and umbilical nodes.

Figs. 10, 11, 12. Side and front views (natural size) and septa $(\times 2)$; diameter $29.5 \mathrm{~mm}$.

From Upper Triassic, 3 miles east of Madisop's ranch, between Squaw Creek and Pit River, Shasta County, Cal. Collection of J. P. Smith. 

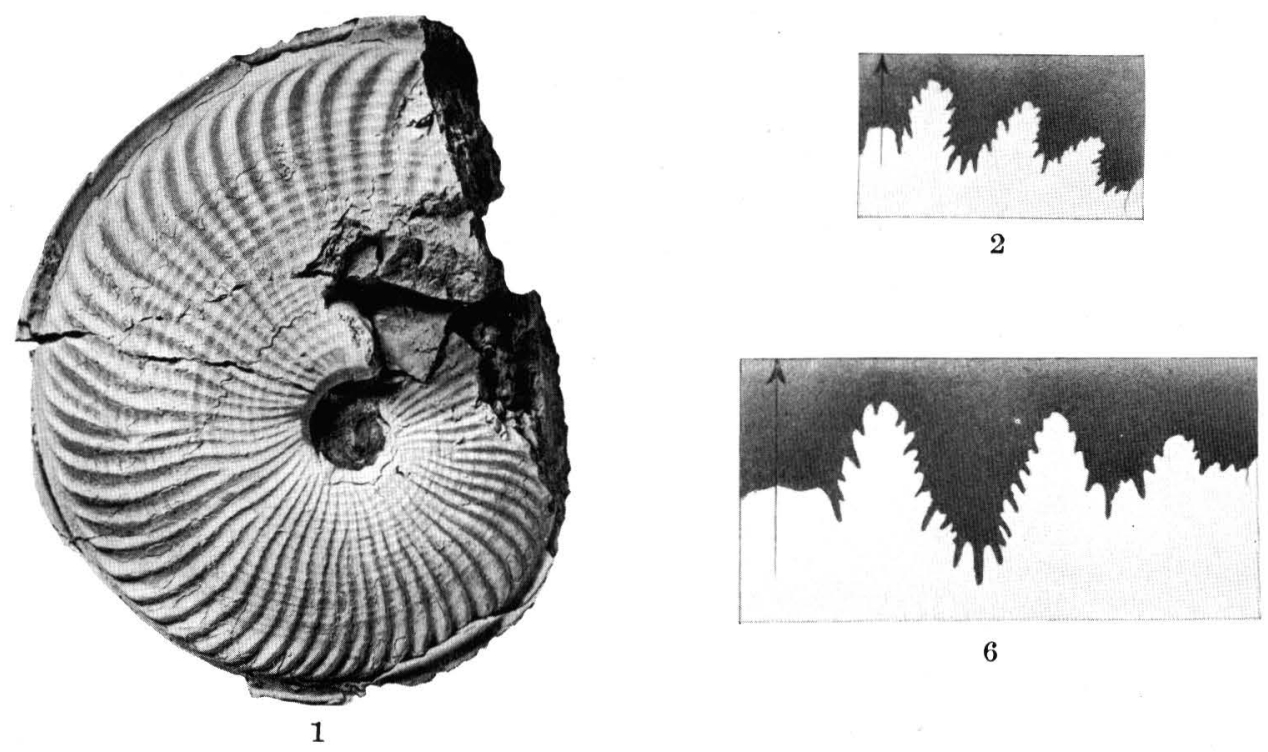

6
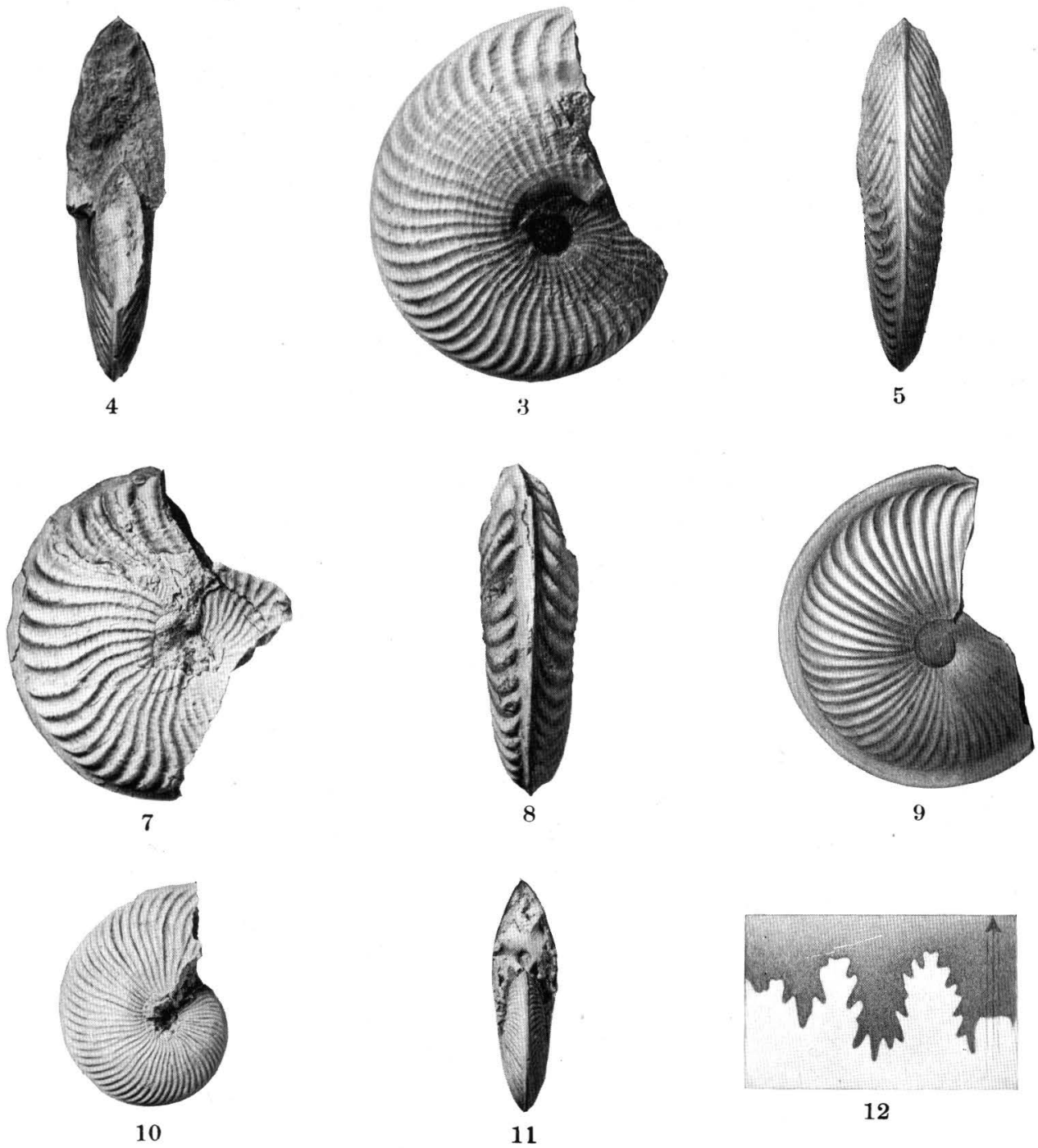

DISCOTROPITES SANDLINGENSIS. 


\section{P L A T E X X X V I.}

\section{Discotropites sandlingensis Hauer (p. 63).}

Figs. 1, 2, 3. Side, front, and rear views $(x 4)$ showing the beginning of the lateral ribs; diameter 5.5 $\mathrm{mm}$.

Fras. 4, 5, 6, 7. Side, front, and rear views $(\times 5)$ and septa $(\times 10)$; diameter 4.25 mm.

Fics. 8, 9. Fragment of whorl $(\times 10)$ and septa; diameter $3.20 \mathrm{~mm}$.

Fits. 10, 11, 12, 13. Side, front, and rear views, and septa (all $\times 10$ ), larval stage; diameter $2.68 \mathrm{~mm}$.

Figs. 14, 15, 16. Side, front, and rear views $(\times 20)$, larval stage; diameter $1.50 \mathrm{~mm}$.

FtGs. 17, 18. Side and front views, larval stage; diameter $1.36 \mathrm{~mm}$.

Figs. 19, 20, 21. Shell $(\times 2)$ and septa $(\times 4)$; diameter $15.5 \mathrm{~mm}$.

Fras. 22, 23, 24. Shell $(\times 2)$ and septa $(\times 4)$; diameter $10 \mathrm{~mm}$.

Figs. 25, 26. Outer shell and the keel; diameter $9 \mathrm{~mm}$.

From. Upper Triassic, 3 miles (ast of Madison's manch, between Squaw Creek and Pit River, Shasta County, Cal. Collection of J. P. Smith. 

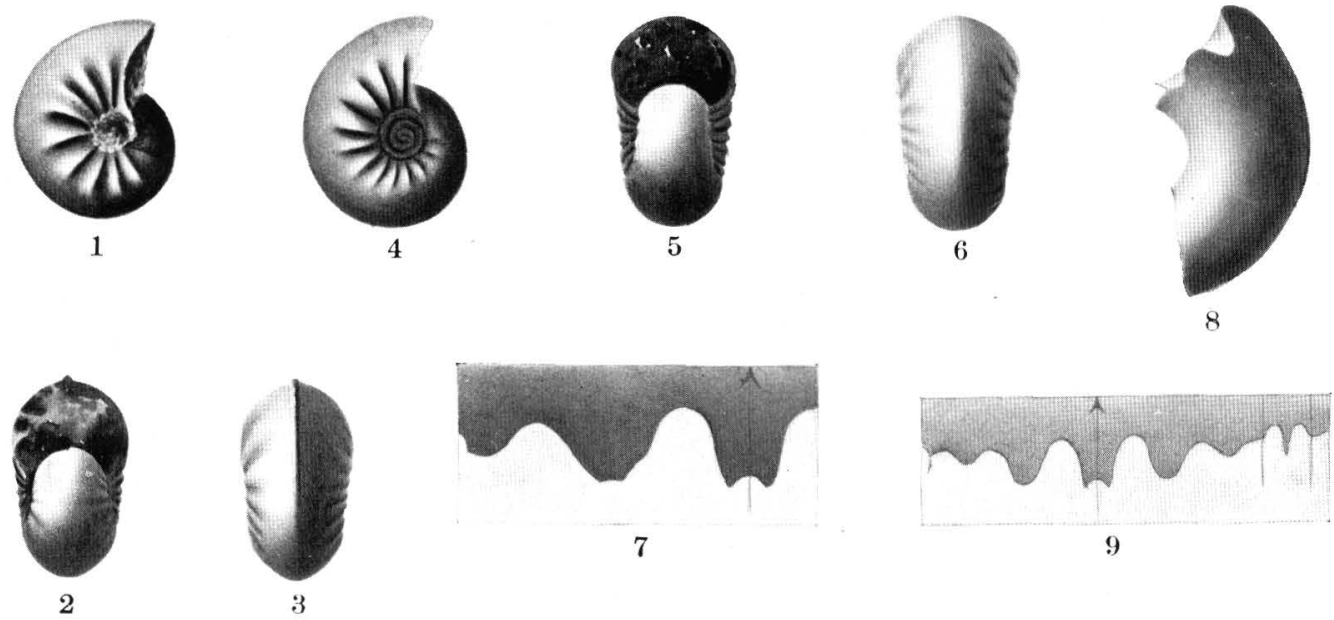
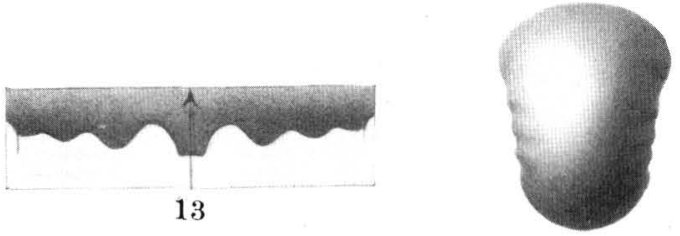

12

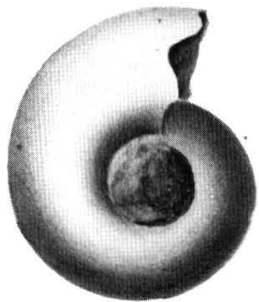

14

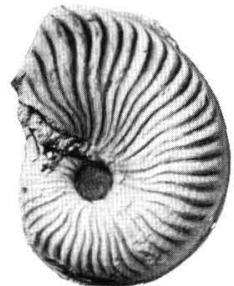

19

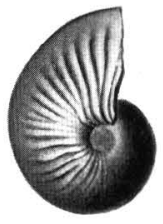

22

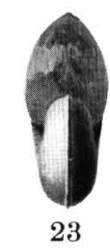

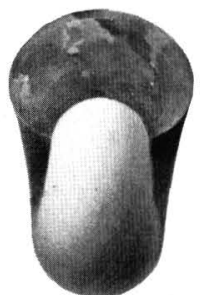

15

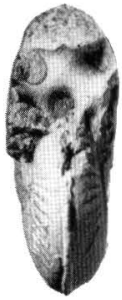

20

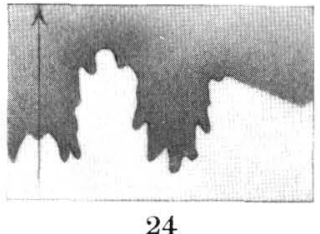

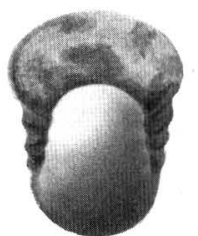

11

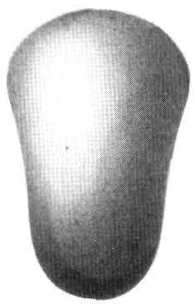

16
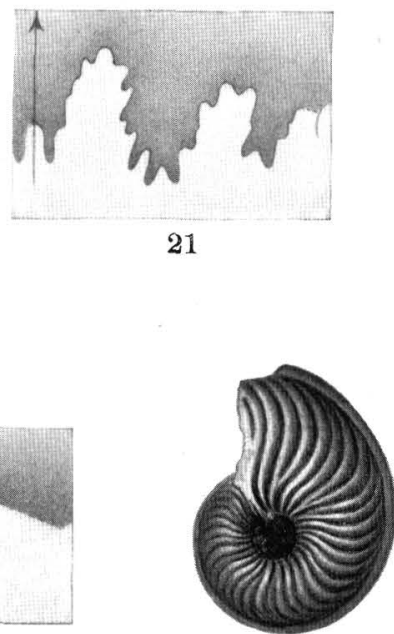

25
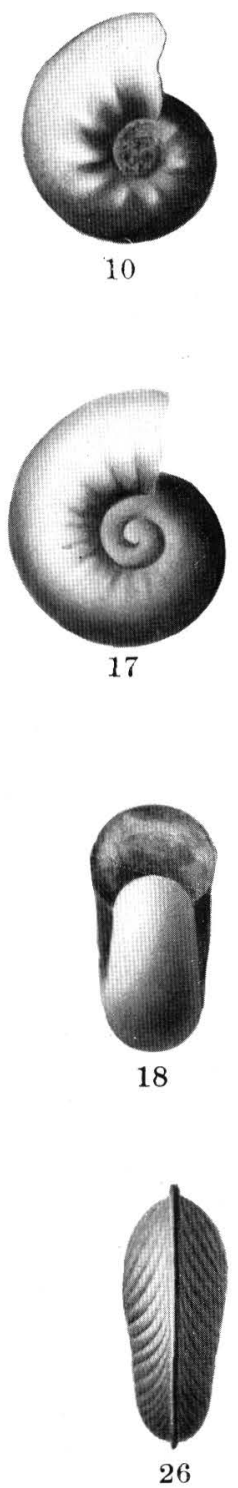


\section{PLATE XXXVII.}

Archstes (Proarcestes) pacificus Hyatt and Smith (p. 75).

Figs. 1, 2, 3. Side and front views $(X 10)$ and septa $(\times 15)$, Stacheoceras stage; diameter $2.97 \mathrm{~mm}$.

Frgs. 4, 5, 6. Side and front views $(\times 10)$ and septa $(\times 15)$, Popanoceras stage; diameter $2.16 \mathrm{~mm}$.

Figs. 7, 8, 9. Side and front views $(X 15)$ and septa $(X 20)$, Adrianites stage; diameter $1.7 \mathrm{~mm}$.

From Upper Triassic, 3 miles east of Madison's ranch, between Squaw Creek and Pit River, Shasta County, Cal. Collection of J. P. Smith.

Hautrites Ashleyi Hyatt and Smith (p. 104).

Figs. 10, 11, 12. Side and front views (natural size) and $\operatorname{septa}(\times 2)$.

From Upper 'Triassic, 3 miles east of Madison's ranch, between Squaw Creek and Pit - River, Shasta County, Cal. Collection of J. P. Smith.

Dieneria Arthaberi Hyatt and Smith (p. 106).

Figs. 13, 14. Side and front views $(\times 2)$; diameter $15 \mathrm{~mm}$.

Figs. 15, 16. Side view $(\times 2)$ and septa $(\times 4)$, showing the goniatitic character.

From Upper Triassic, 3 miles east of Madison's ranch, between Squaw Creek and Pit River, Shasta County, Cal. Collection of J. P. Smith. 

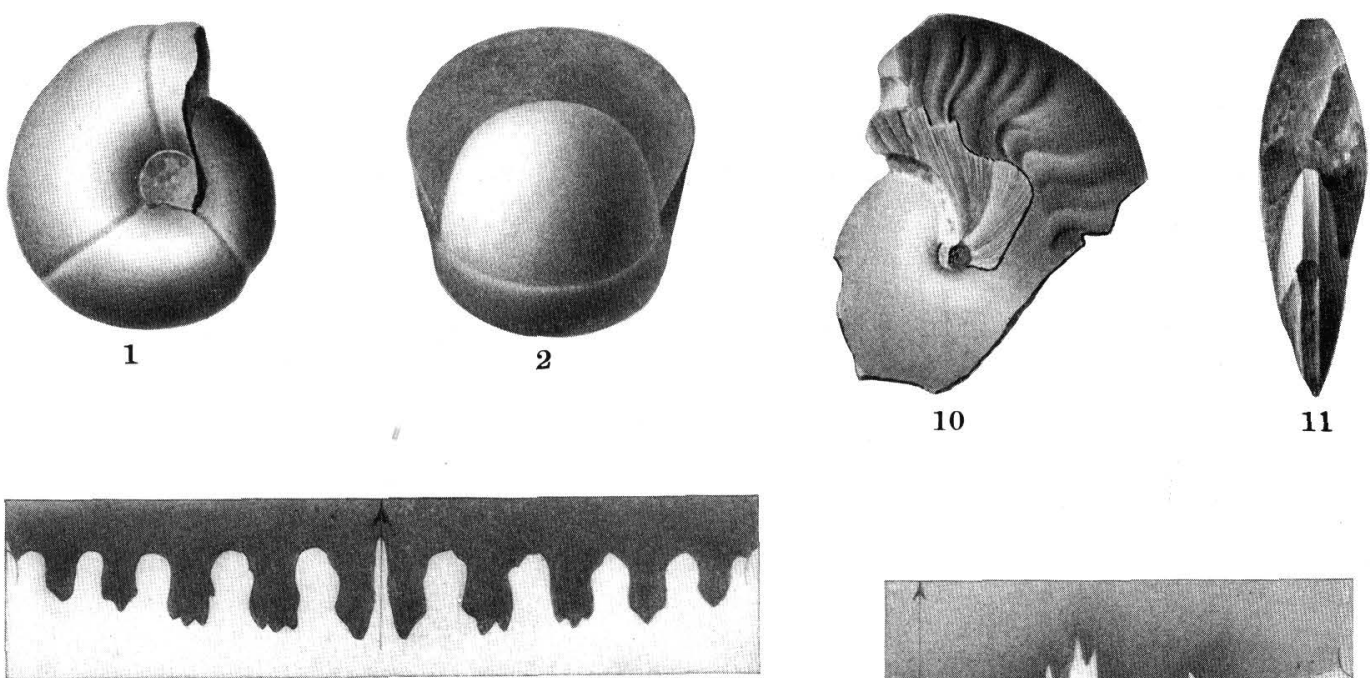

3
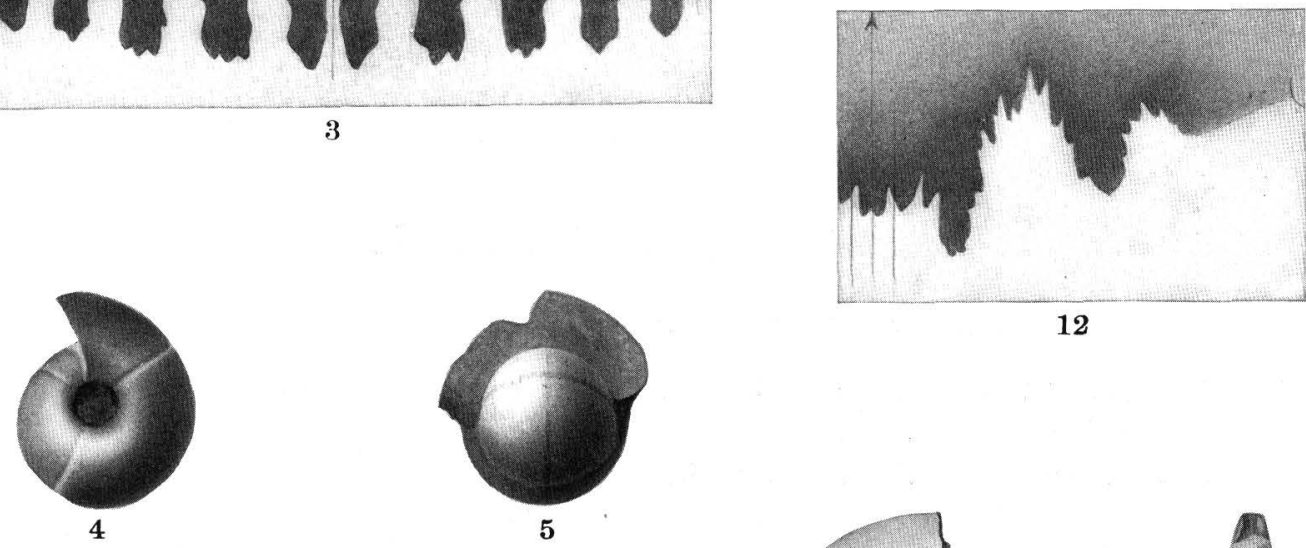

12
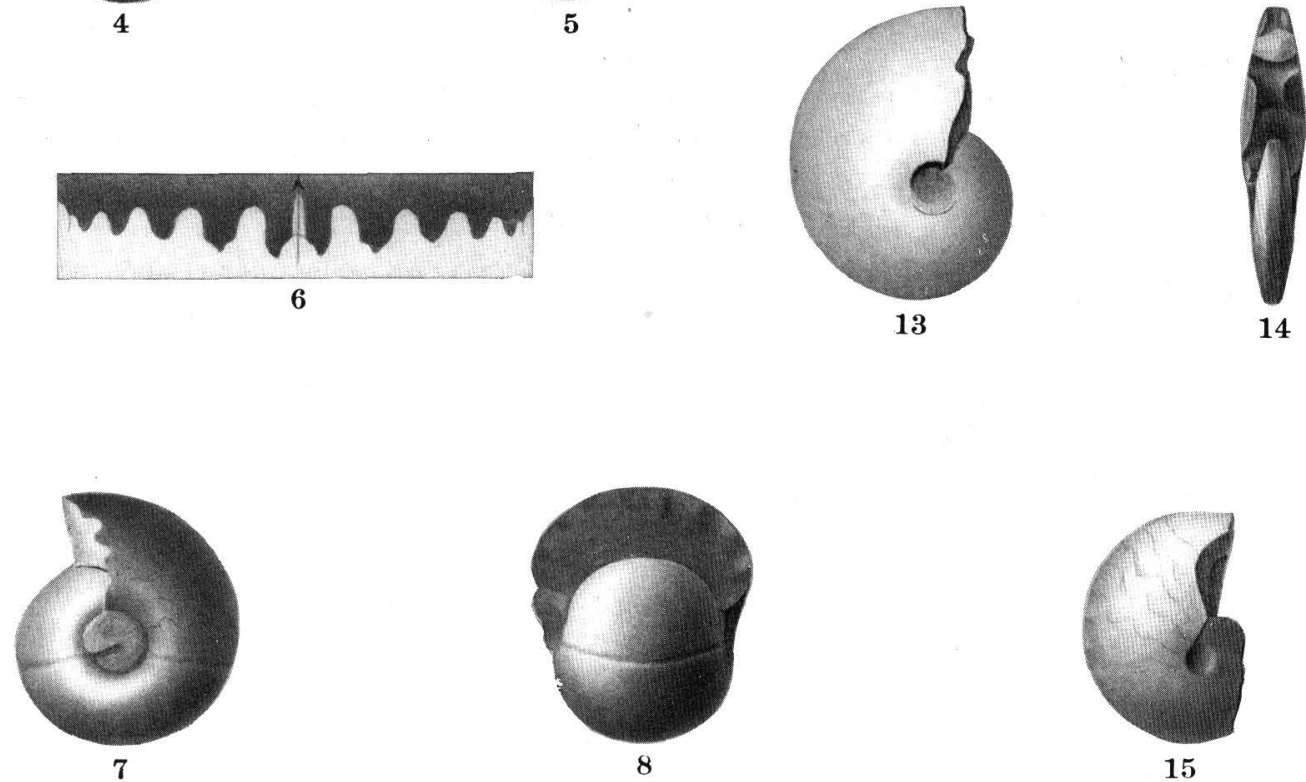

15
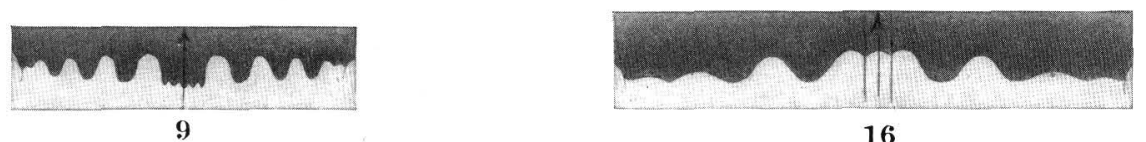

ARCESTES (PROARCESTES) PACIFICUS, HAUERITES ASHLEYI, DIENERIA ARTHABERI. 


\section{PLATE XXXVIII.}

\section{Polycyclus nodirer Hyatt and Smith (p. 201).}

FIGs. 1, 2, 3; 4. Side, front, and rear views (uatural size) and septa (X 4 ).

Figs. 5, 6. Side and front views.

Fics. 7, 8. Side and front views, showing the outer shell.

Fias. 9, 10. Side and front views, showing both shell and cast.

FIGs. 11, 12. Side and front views; diameter $10 \mathrm{~mm}$.

Figs. 13, 14, 15. Side and front views $(\times 5)$ and septa $(\times 10)$, adolescent stage; diameter $3.5 \mathrm{~mm}$.

Fras. 16, 17, 18. Side and front views $(\times 10)$ and septa $(\times 20)$, larval stage; diameter $2 \mathrm{~mm}$.

From Upper Triassic, 3 miles east of Madison's ranch, between Squaw Creek and Pit River, Shasta County, Cal. Collection of J. P. Smith. 

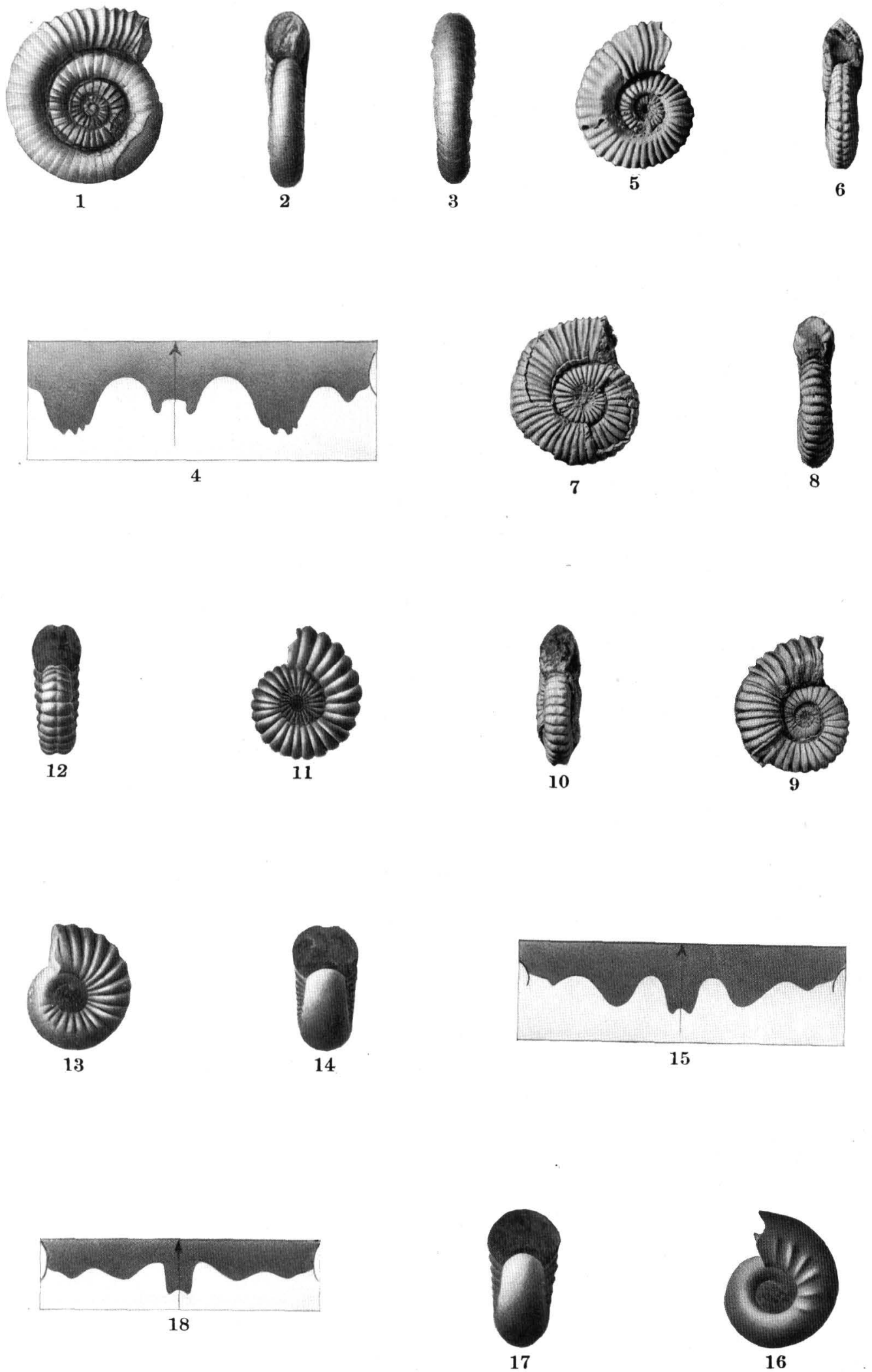


\section{PLATE XXXIX.}

Arpadites Gabib Hyatt and Smith (p. 175).

Figs, 1, 2, 3. Side and front views and septa.

Figs. 4, 5, 6, 7. Side, front, and rear views and septa (natural size).

Figs. 8, 9. Side and front views at early maturity.

Figs. 10, 11, 12. Side and front views $(\times 2)$ and septa $(X 4)$; diameter $18.5 \mathrm{~mm}$.

Figs. 13, 14. Side and front views $(\times 2)$; diameter $12.5 \mathrm{~mm}$.

Figs. 15, 16, 17. Side, front, and rear views $(\times 2)$, end of adolescent stage; diameter $10 \mathrm{~mm}$.

From Upper Triassic, 3 miles east of Madison's ranch, between Squaw Creek and Pit

River, Shasta County, Cal. Figs. 1-3, from collection United States National Museum; figs. 4-17, from collection of J. P. Smith. 

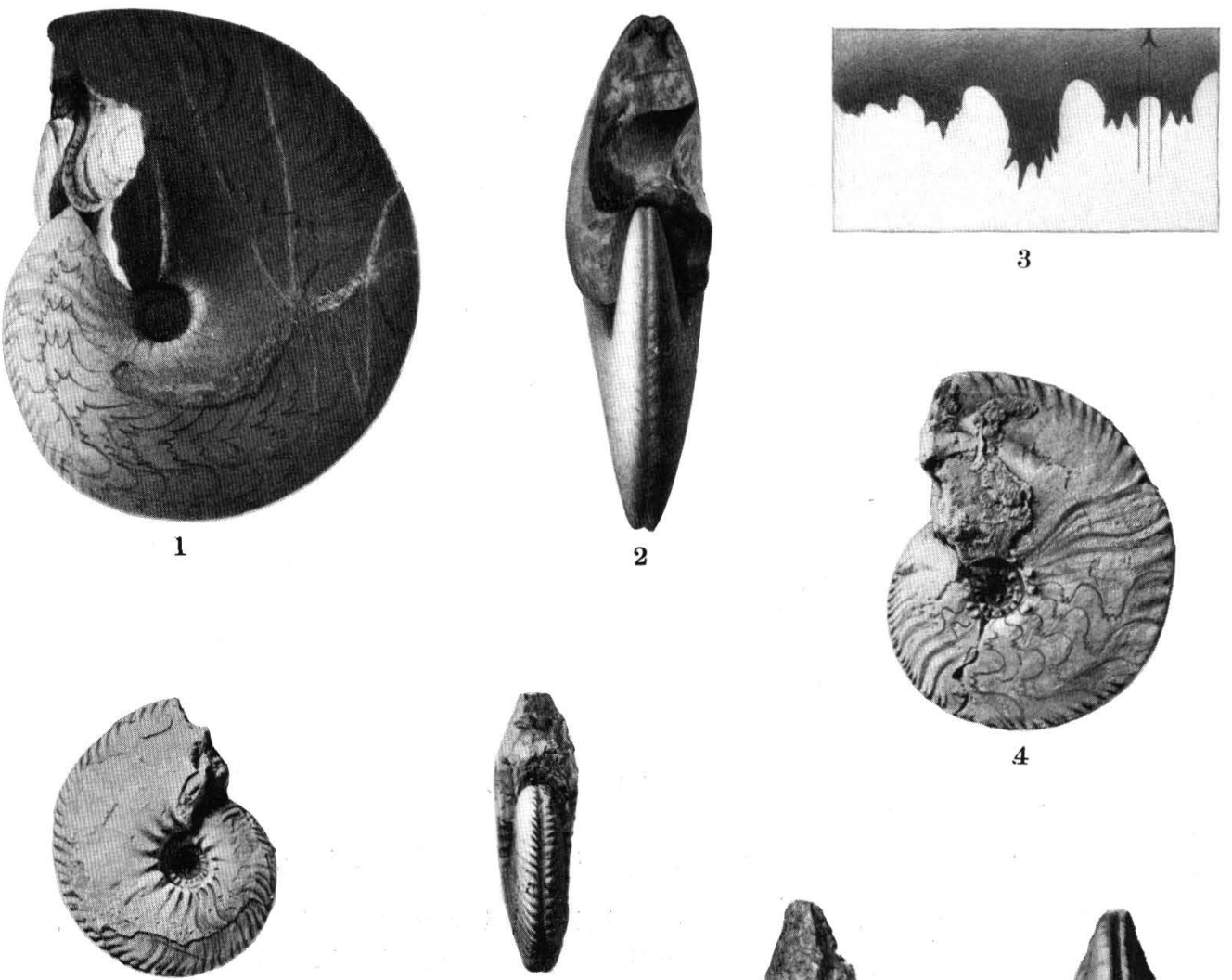

8

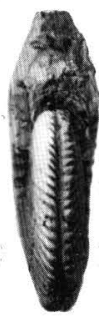

9
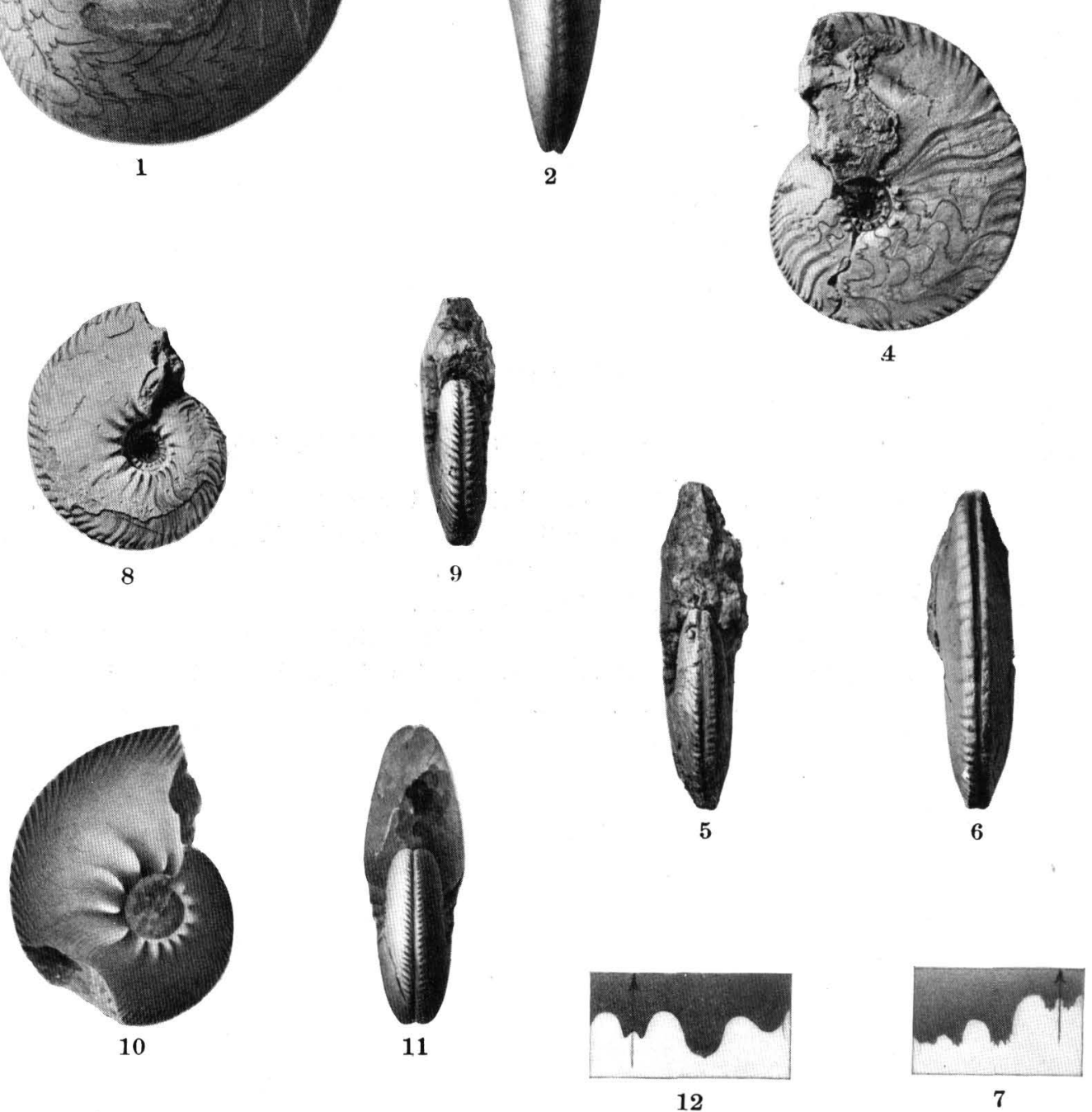

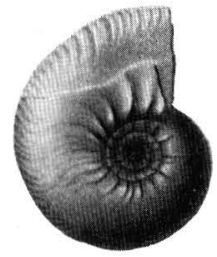

13

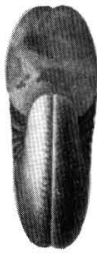

14

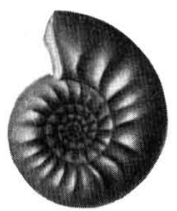

15
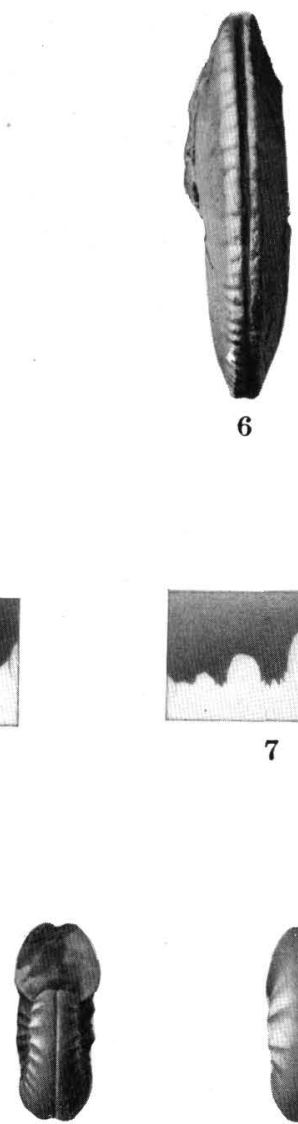

16

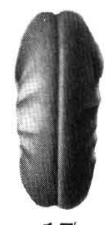




\section{PLA T E XL.}

Chionites Fairbanksi Hyatt and Smith (p. 183).

Figs. 1, 2, 3, 4. Side, front, and rear views (natural size) and septa ( $\left.\times^{2}\right)$ of the type specimen.

Fig. 5. Side view of an old specimen, showing the rough sculpture in old age.

Ficis. 6, 7, 8. Side, front, and rear views; dianeter $49 \mathrm{imm}$.

Figs. 9, 10, 11. Side, front, and rear views; diameter $32 \mathrm{~mm}$.

From Upper Triassic, 3 miles east of Madison's ranch, between Squaw Creek and Pit River, Shasta County, Cal. Figs. 1-4, collection of United States National Museum; figs. 5-11, collection of J. P. Smith. 


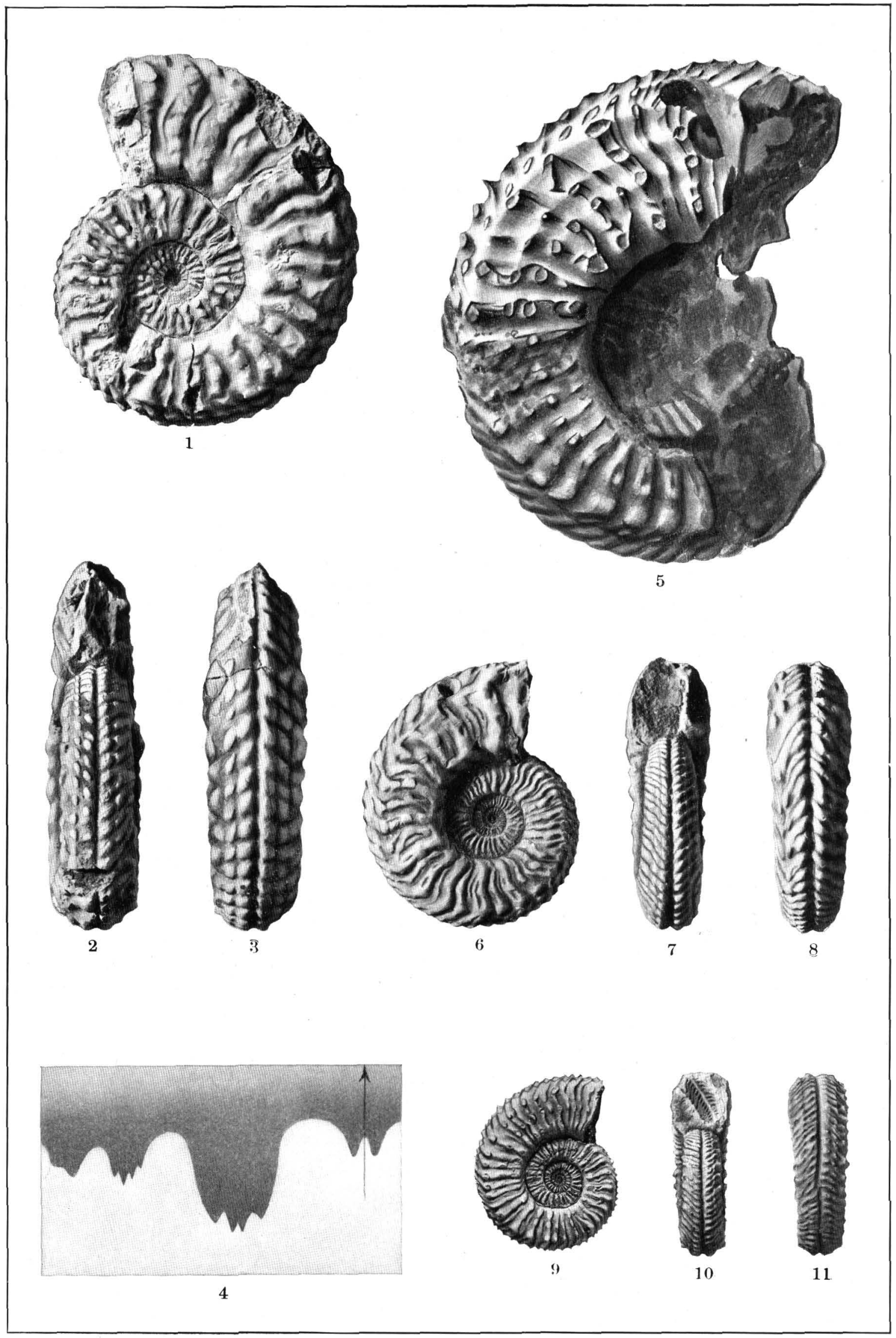




\section{P L A TE. X L I.}

\section{Clionites Fairbanksi Hyatt and Smith (p. 183).}

Figs. 1, 2. Side and rear views; diameter $17.5 \mathrm{~mm}$.

Figs. 3, 4, 5. Side, front, and rear views $(\times 2)$, adolescent stage; diameter $14 \mathrm{~mm}$.

Fias. 6, 7, 8. Adolescent stage $(\times 2)$; diameter $10.20 \mathrm{~mm}$

FIcis. 9, 10, 11. Adolescent stage $(\times 3)$; diameter $7.5 \mathrm{~mm}$.

Fias. 12, 13, 14. Adolescent stage $(\times 4)$; corresponding to Tirolites; diameter $5.08 \mathrm{~mm}$.

From Upper Triassic, 3 miles east of Madison's ranch, between Squaw Creek and Pit River, Shasta County, Cal. Collection of J. P. Smith.

Clionites (Stantonites) Rugosus Hyatt and Smith (p. 185).

Figs. 15, 16, 17. Side and front views (natural size) and septa $(\times 2)$ of type specimen.

Figs. 18, 19. Side and front viows (natural size).

Frgs. 20, 21. Side and front views, adolescent specimen; diameter $20 \mathrm{~mm}$.

Figs. 22, 23. Side and fronit views $(\times 2)$, adolescent stage; diameter $14 \mathrm{~mm}$.

Figs. 24, 25, 26. Side, front, and rear views $(X 5)$, Tirolites stage; diameter $4.5 \mathrm{~mm}$.

From Upper Triassic, 3 miles east of Madison's ranch, between Squaw Creek and Pit River, Shasta County, Cal. Collection of J. P. Smith. 

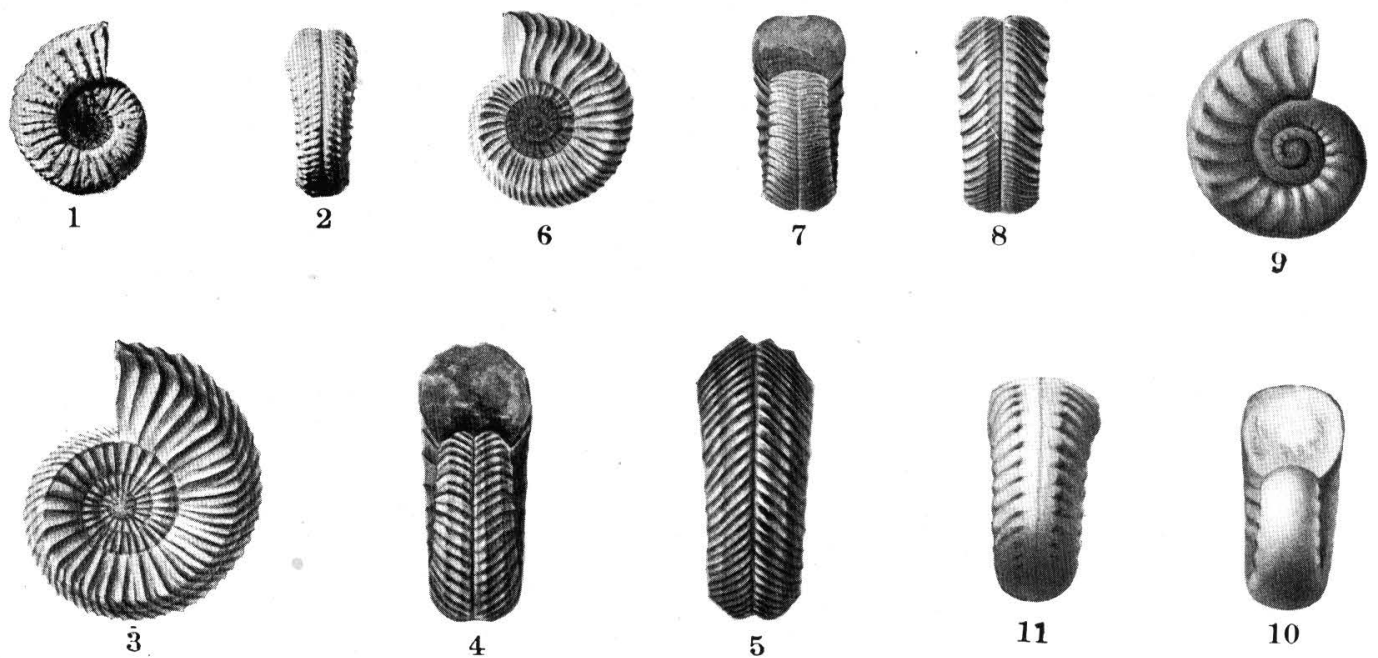

5

11

10
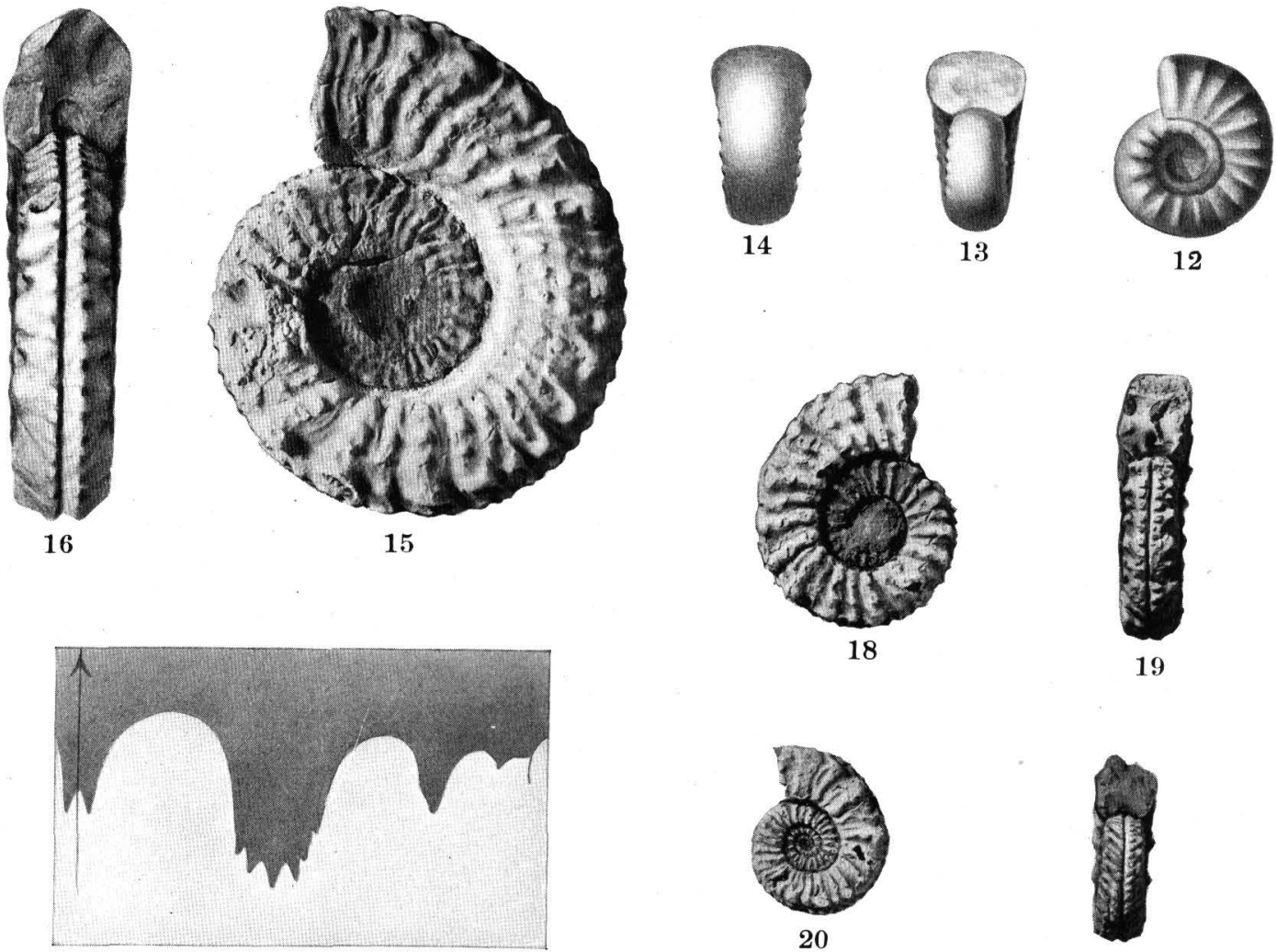

17
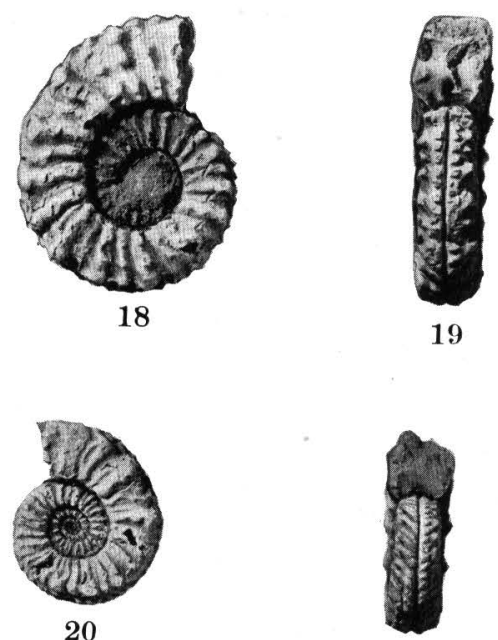

21
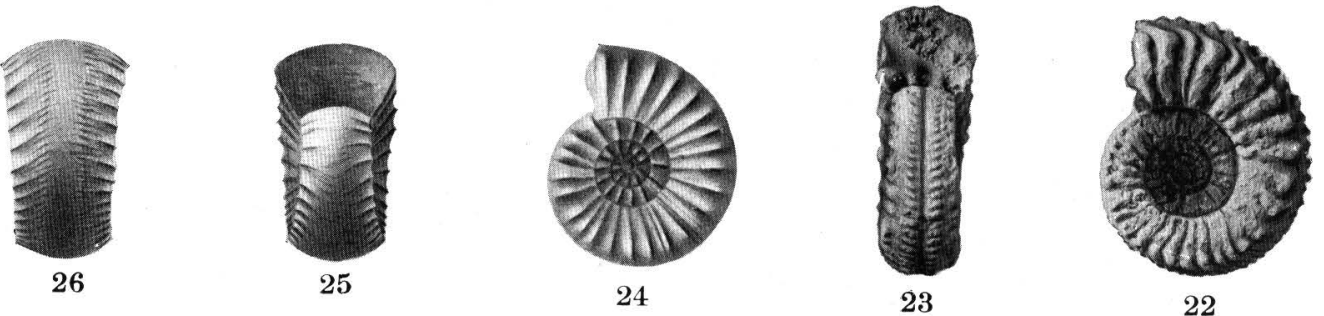

22

CLIONITES FAIRBANKSI, CLIONITES (STANTONITES) RUGOSUS. 


\section{PLATE XLII.}

\section{Chionites (Traskites) robustus Hyatt and Smith (p. 186):}

Fics. 1, 2, 3. Side, front, and rear views (natural size) of the type specimen.

Figs. 4, 5, 6. Side and front views (natural size) and septa $(\times 2)$.

Figs. 7, 8. Side and rear views (natural size). Transition from adolescence to maturity; diameter $31 \mathrm{~mm}$.

Fics. $9,10,11$. Side, front, and rear views $\left(\times 1 \frac{1}{2}\right)$, adolescent.stage; diameter $16 \mathrm{~mm}$.

FIGs. 12, 13. Side and front views $(\times 2)$, adolescent stage corresponding to Californites; diameter $10 \mathrm{~mm}$.

FIGs. 14, 15, 16. Side, front, and rear views $(\times 4)$, adolescent stage corresponding to Tirolites; diameter 6.5 min.

Figs. 17, 18, 19. Side, front, and rear views $(\times 5)$; Tirolites stage; diameter 4:5 mm.

From Upper Triassic, 3 miles east of Madison's ranch, between Squaw Creek and Pit River, Shasta County, Cal. Collection of J. P. Smith. 

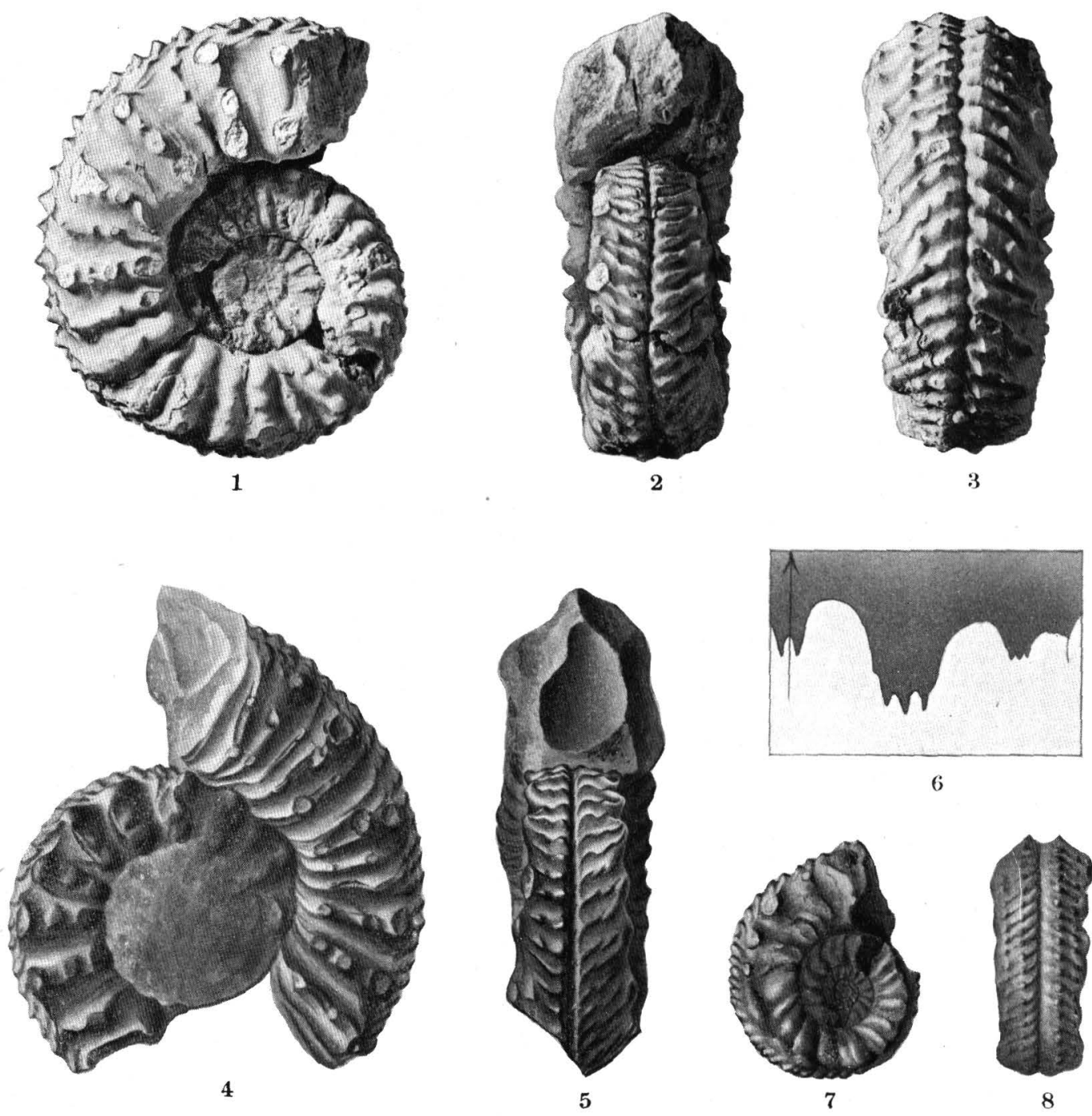

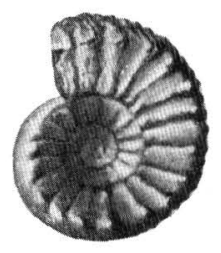

9

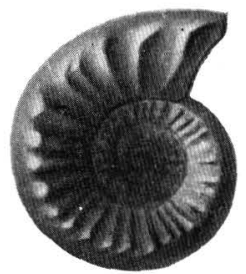

14

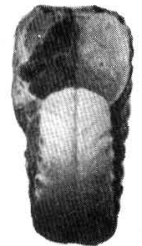

10

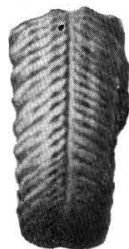

11

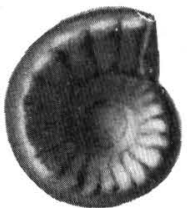

12

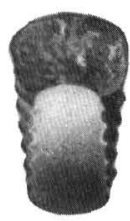

13
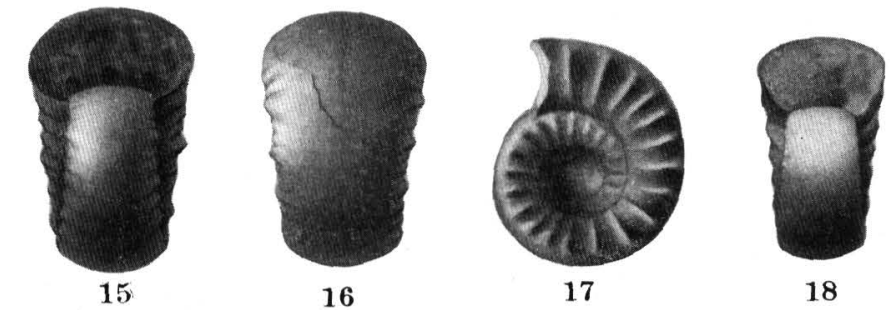

18

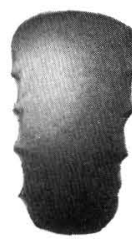

19 


\section{PLA TE XLIII.}

Clionites (Shastites) compressus Hyatt and Smith (p. 188).

Figs. 1, 2, 3, 4. Side, front, and rear views (natural size) and septa $(\times 2)$, of type specimen. Figs. 5, 6, 7. Side, front, and rear views; diameter $28 \mathrm{~mm}$.

Figs. $8,9,10$. Side and front views $(\times 2)$, adolescent stage; diameter $16 \cdot \mathrm{mm}$.

Figs. 11, 12, 13. Side, front, and rear views, adolescent stage; diameter $17 \mathrm{~mm}$.

Figs. 14, 15. Side and front views, adolescent stage corresponding to Tirolites; diameter $5 \mathrm{~mm}$. From Upper Triassic, 3 miles east of Madison's ranch, between Squaw Creek and Pit River, Shasta County, Cal. Collection of J. P. Smith. 

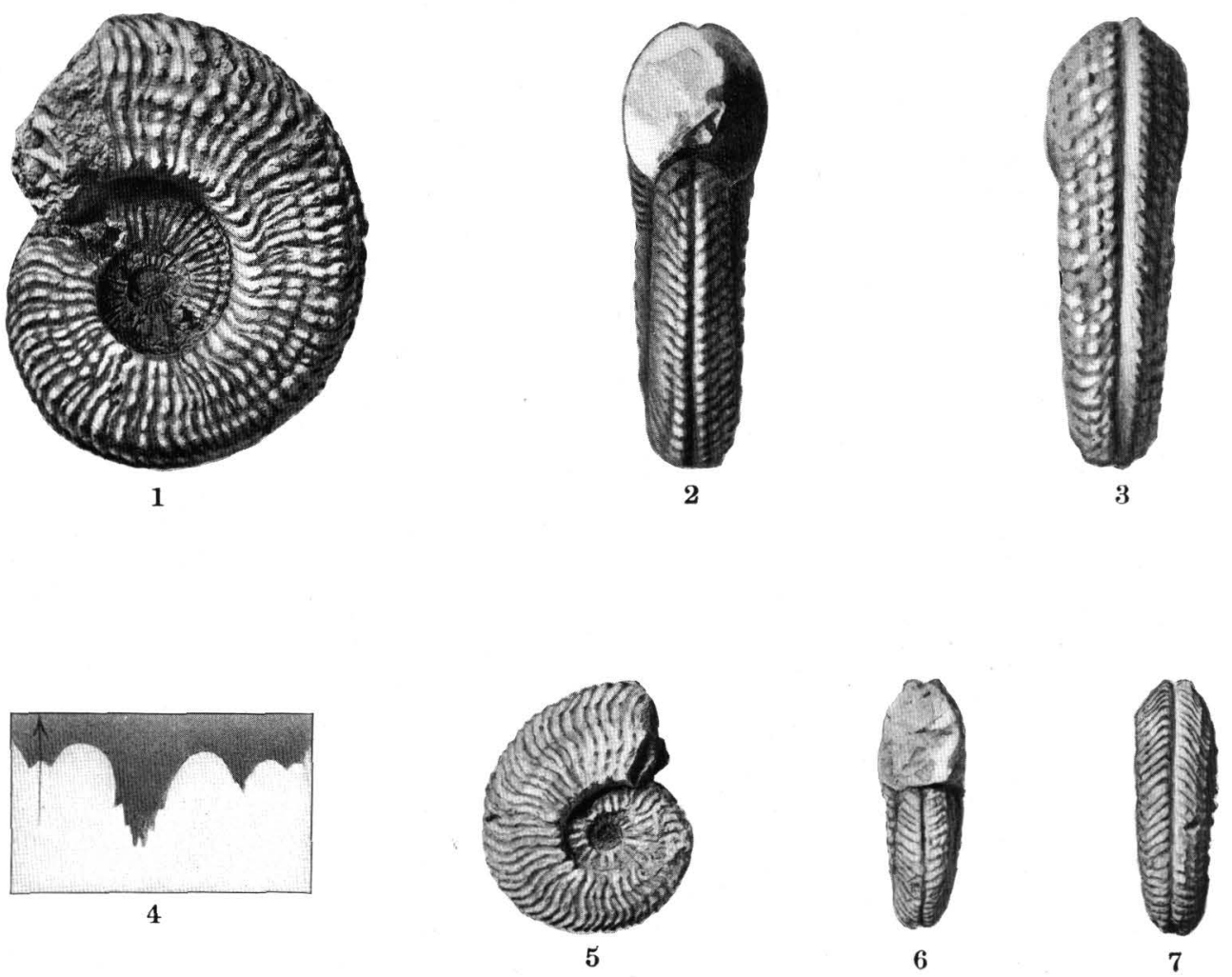

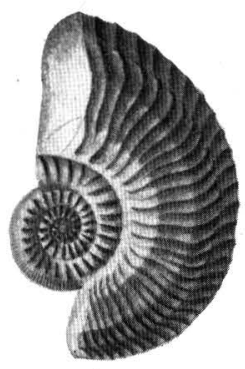

11

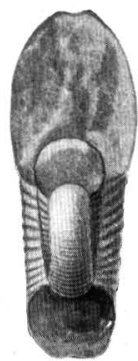

12

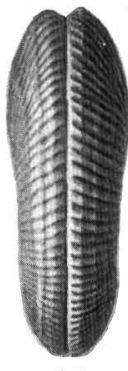

13
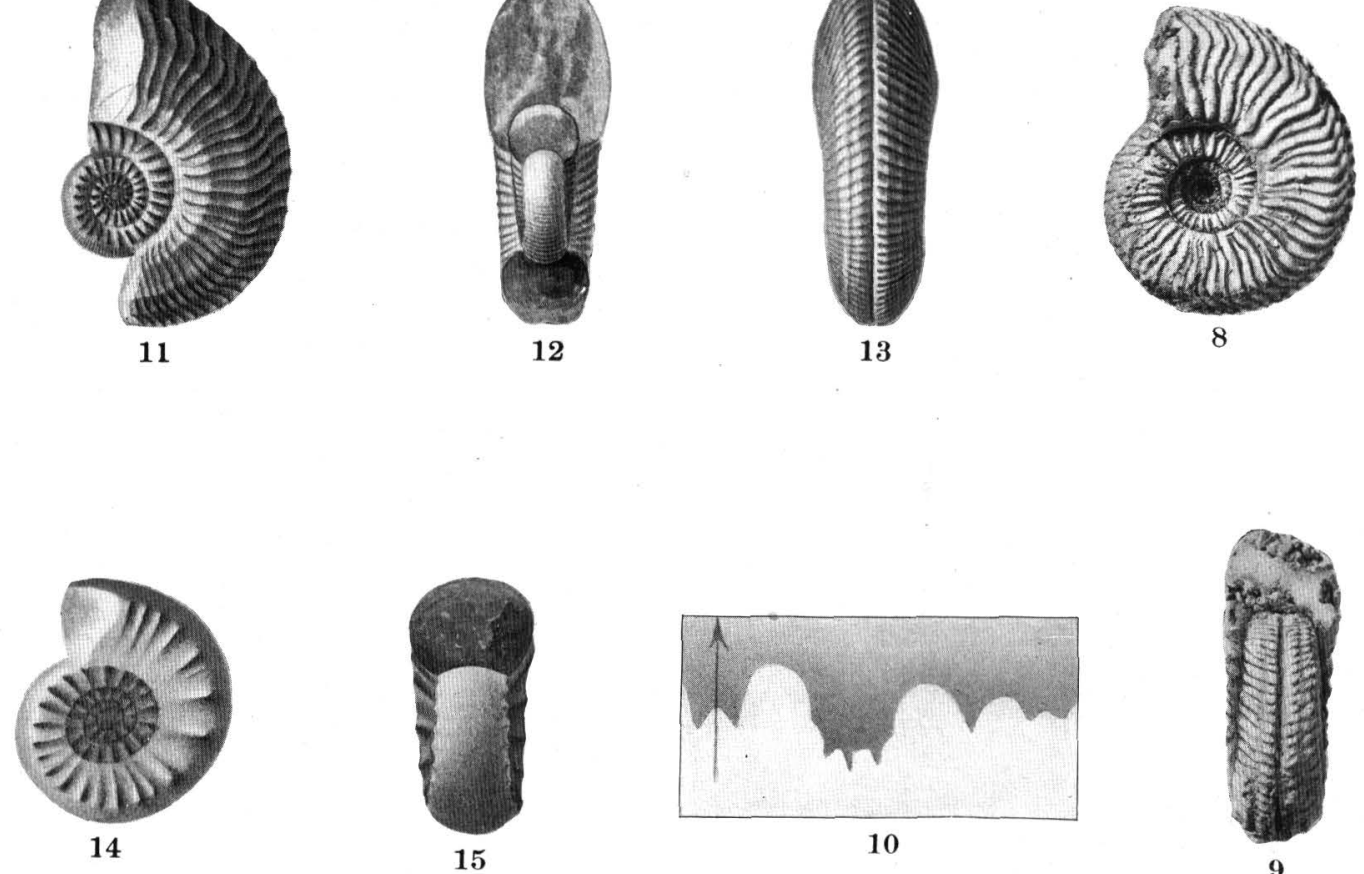

CLIONITES (SHASTITES) COMPRESSUS. 


\section{PLATE XLIV.}

Trachyceras (Protrachyceras) Lecontei Hyatt and Smith (p. 194).

Figs. 1, 2. Right and left sides, showing on the right the surface sculpture and on the left the septa, type specimen. (PI. XLV, figs. 1 and 2 ).

From Upper Triassic, 3 miles east of Madison's ranch, between Squaw Creek and Pit River, Shasta County, Cal. Collection of J. P. Smith. 

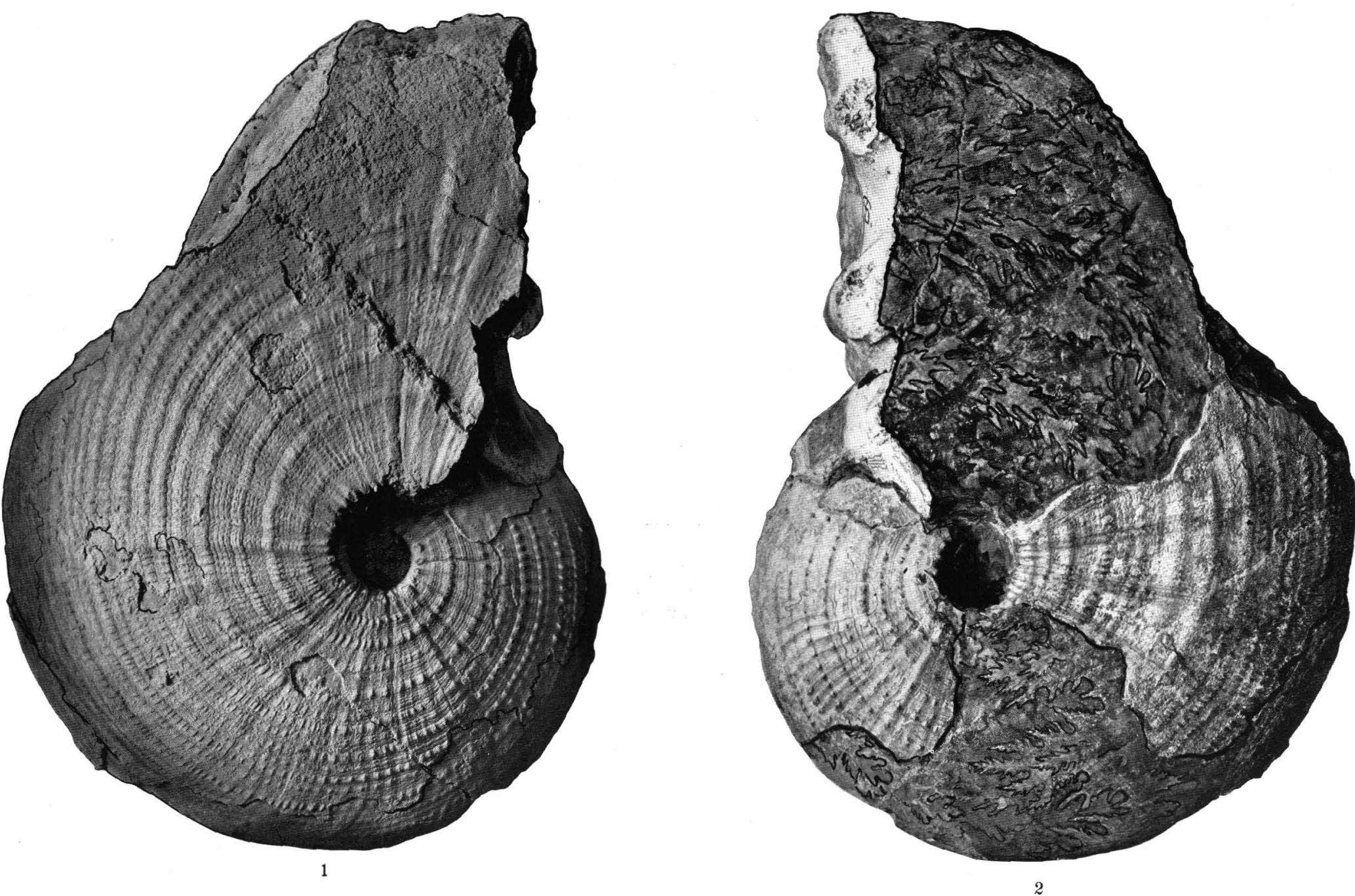

TRACHYCERAS (PROTRACHYCERAS) LECONTEI. 


\section{P L A T E X L V.}

Trachychas (Protrachyceras) Lecontei Hyatt and Smith (p. 194).

Figs. 1, 2. Front view and septa of the same specimen shown in PI. XLIV, figs. 1 and 2.

Figs. 3, 4. Side and front views of a smaller specimen; diameter $53 \mathrm{~mm}$.

Figs. 5, 6. Side view (natural size) and septa. $(\times 2)$; diameter $42 \mathrm{~mm}$.

Figs. 7, 8, 9. Side and front views and septa (all $\times 2$ ); diameter $26 \mathrm{~mm}$. (This specimen is the inner whorl of figs. 5 and 6.)

From Upper Triassic, 3 miles east of Madison's ranch, between Squaw Creek and Pit River, Shasta County, Cal. Collection of J. P. Smith. 

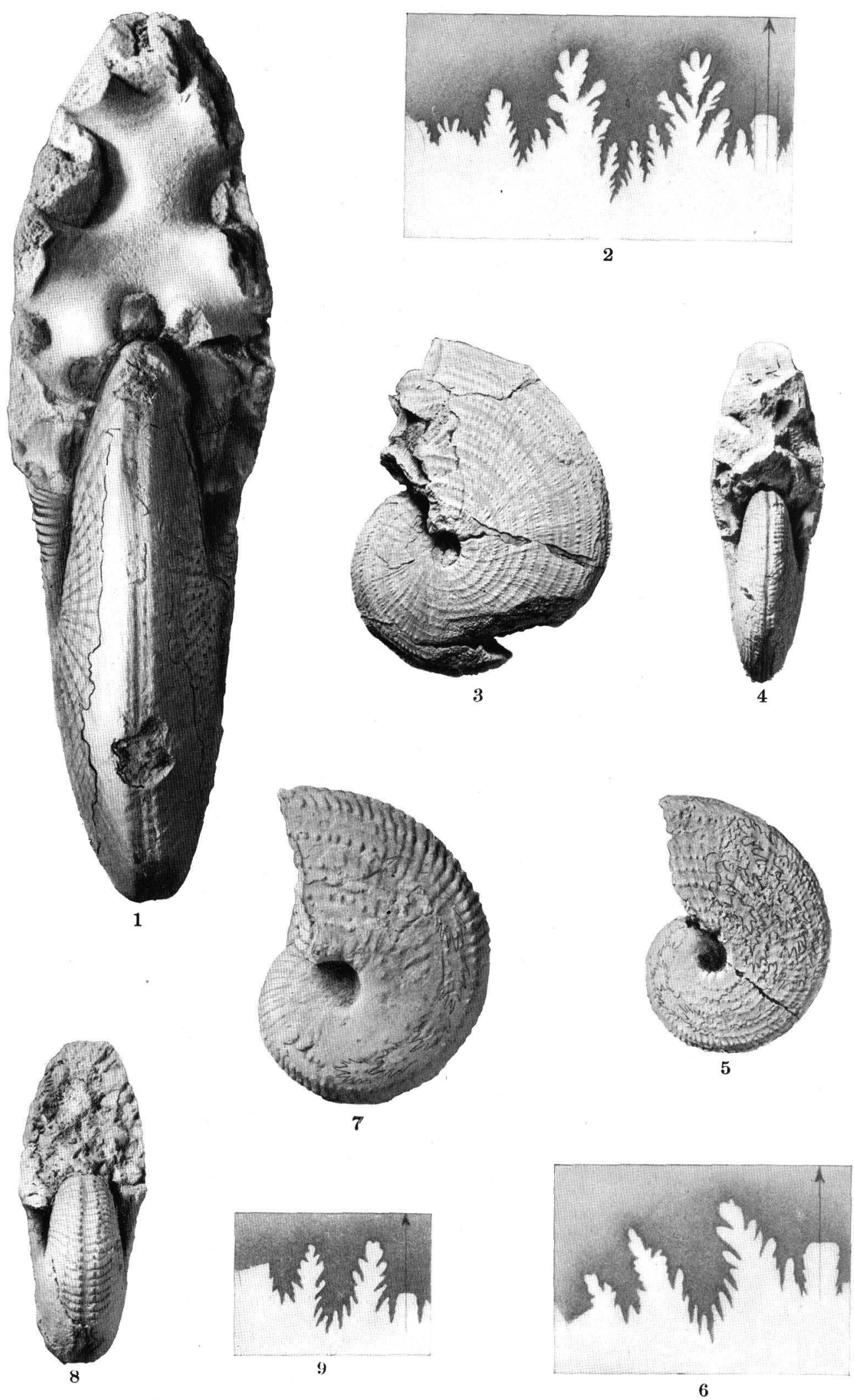


\section{PLATE XIVI.}

Trachyceras (Protrachyceras) Lacontei Hyatt and Smith (p. 194).

Figs. 1, 2, 3, 4. Side, front, and rear views $(\times 3)$ and septa $(\times 6)$, adolescent stage; diameter $12 \mathrm{~mm}$. Figs. 5, 6. Side view $(\times 3)$ and septa $(\times 6)$, adolescent stage; diameter $10 \mathrm{~mm}$.

Figs. 7, 8, 9. Side, front, and rear views $(X 3)$; diamèter $8 \mathrm{~mm}$.

Figs. 10, 11, 12. Side, front, and rear views $(X 5)$; diameter $5.5 \mathrm{~mm}$.

FIGs. 13, 14, 15. Fnd of larval stage, side, front, and rear views $(\times 6)$; diameter $3 \mathrm{~mm}$.

From Upper Triassic, 3 miles east of Madison's ranch, between Squaw Creek and Pit River, Shasta County, Cal. Collection of J. P. Smith.

\section{Sirenites Lawsoni Hyatt and Smith (p. 198).}

Figs. 16, 17. Side and front views (natural size) of the type. (See also Pl. XIVII, figs. 1-3, for septa and inner whorl of the same specimen.)

From Upper Triassic, 3 miles east of Madison's runch, between Squaw Creek and Pit River, Shasta County, Cal. Collection of United States National Museum. 

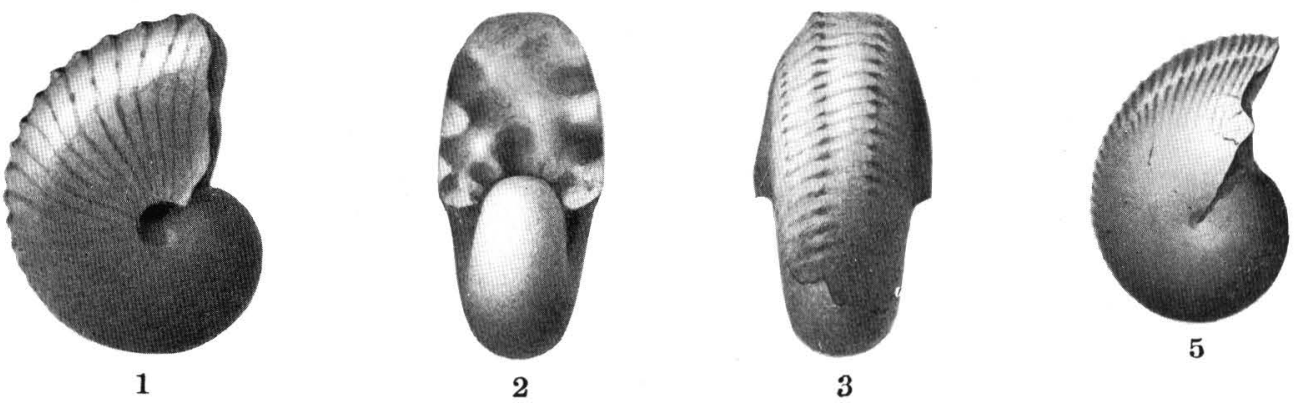

5

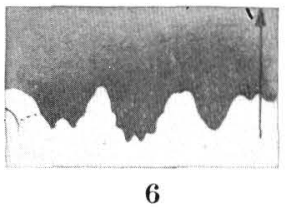

9

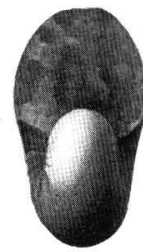

8
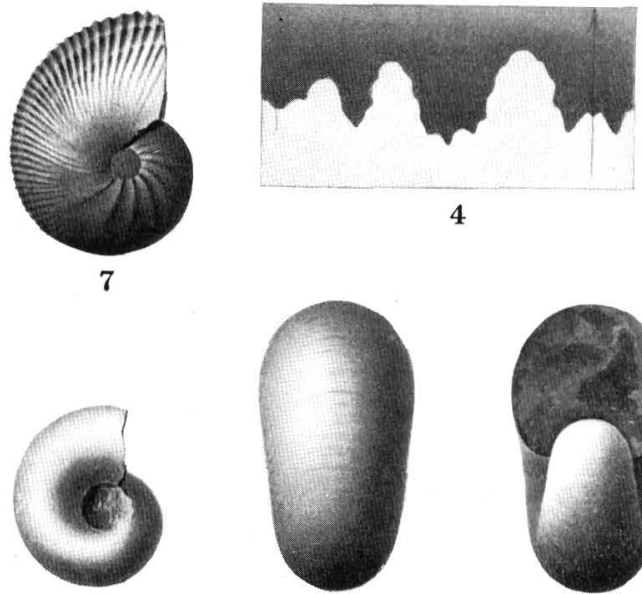

13

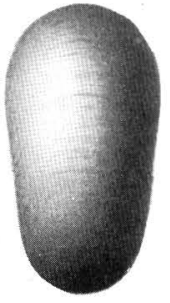

12

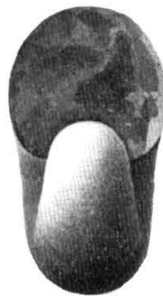

11

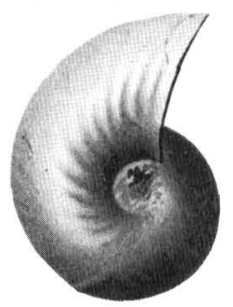

10

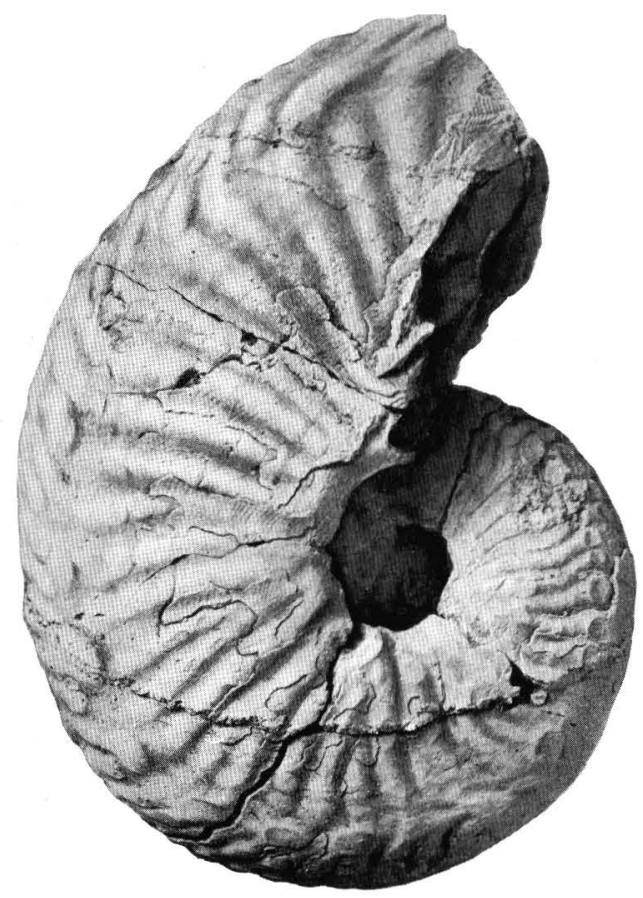

16

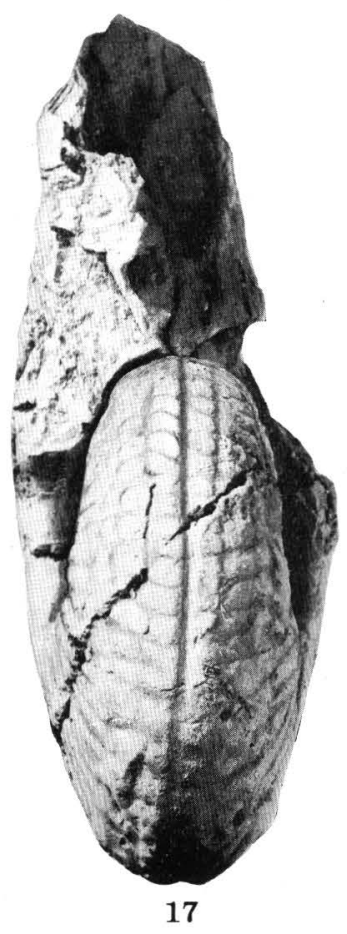

TRACHYCERAS (PROTRACHYCERAS) LECONTEI, SIRENITES LAWSONI. 


\section{PLA TE X L VII. \\ Sirenttrs IaAwsoni Hyatt and Smith (p. 198).}

FIGs. 1, 2, 3, 4. Side, front, and rear views and septa; inner whorl of specimen shown on Pl. XLVI, figs. 16 and 17.

Figs. 5, 6. Side and front views $(\times 2)$, adolescent stage; diameter $25 \mathrm{~mm}$.

Figs. 7, 8, 9. Side, front, and rear views $(\times 2)$, adolescent stage; diameter $17 \mathrm{~mm}$.

From Upper Triassic, 3 miles east of Madison's ranch, between Squaw Creek and Pit River, Shasta County, Cal. Collection United States National Museum.

Sandlingites Andersoni Hyatt and Smith (p. 200).

Fias. 10, 11, 12. Side, front, and rear views.

From Upper Triassic, 3 miles east of Madison's ranch, between Squaw Creek and Pit River, Shasta County, Cal. Collection of J. P. Smith.

Rhabdoceras Russelli Hyatt (p. 203).

Figs. 13, 14, 15. Side view and cross section (natural size), and septa $(\times 3)$.

From Upper Triassic, Noric horizon, near: Genesce, Plumas County, Cal. Collection United States National Museum. 

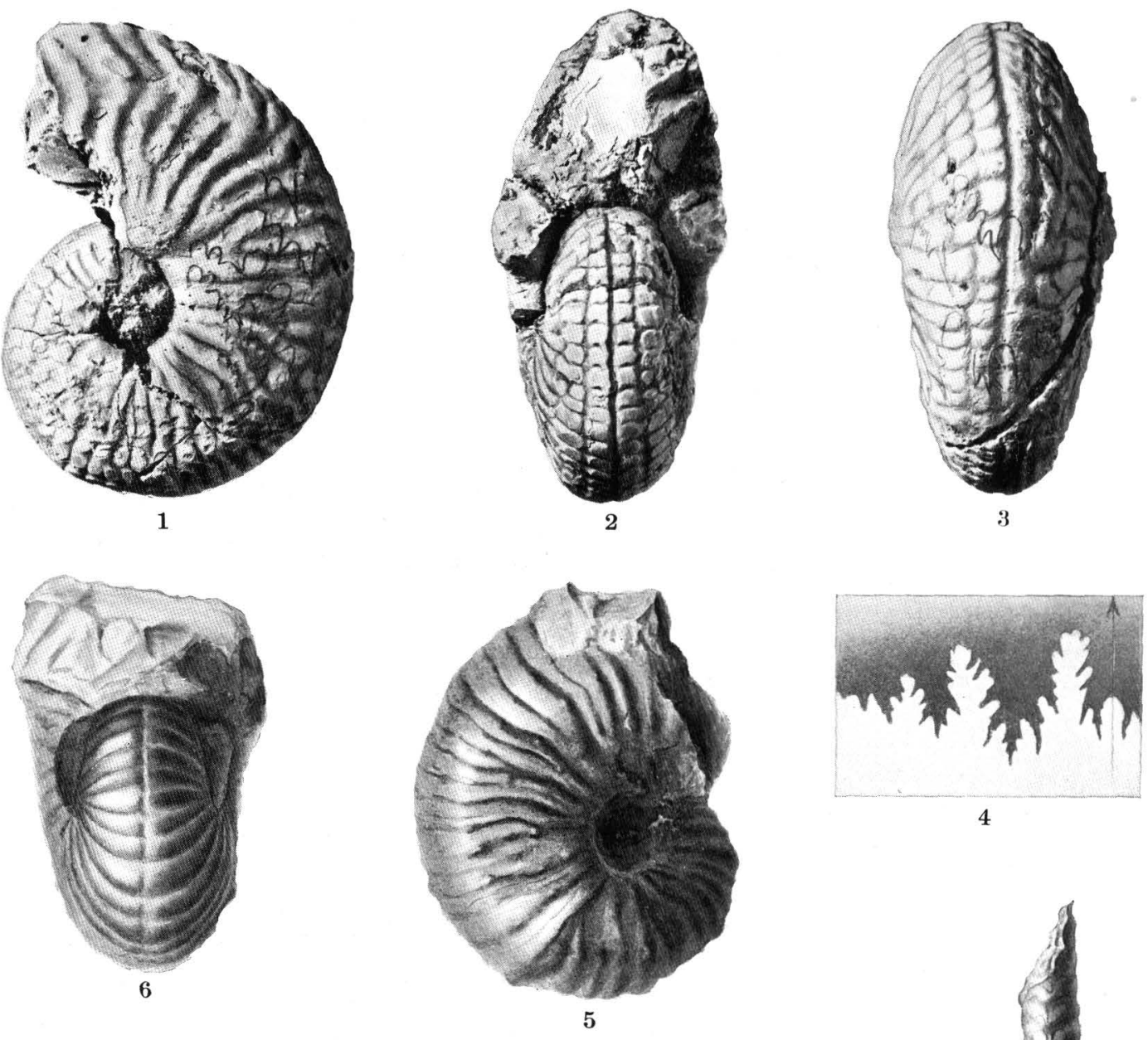

4
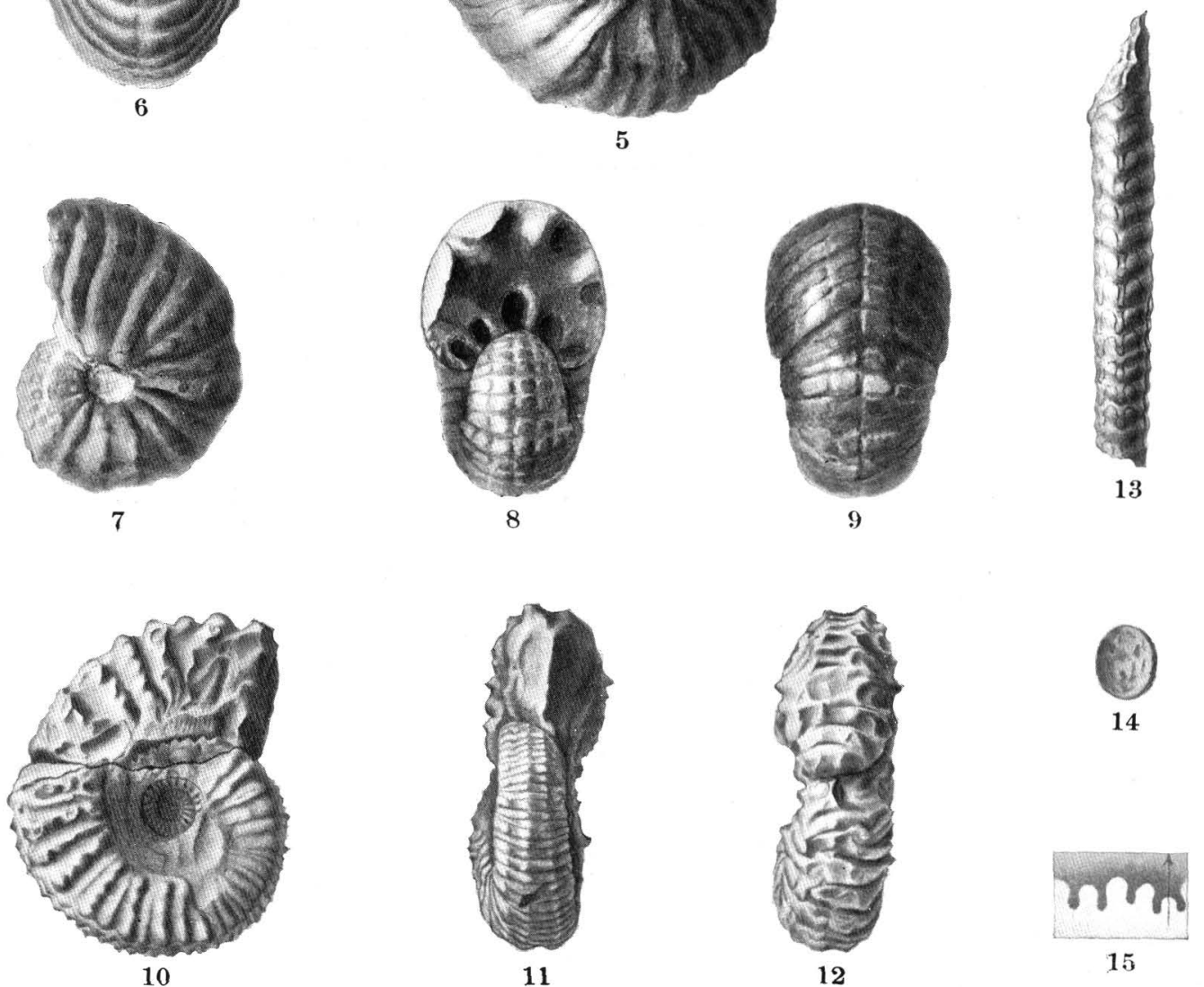

SIRENITES LAWSONI, SANDLINGITES ANDERSONI, RHABDOCERAS RUSSELLI. 


\section{PL A TE X L VIII.}

Atractites Philipeir Hyatt and Smith (p. 205).

Fia. 1. Specimen showing phragmocone and guard.

Fig. 2. Phragmocone $(\times 2)$ of the above.

Fig. 3. Phragmocone $(\times 2)$ of another ippecimen from Bear Mountain, Shasta County, showing the external siphuncle.

From Upper Triassic, 3 miles east of Madison's ranch, between Squaw Creek and Pit River, Shasta County, Cal. Collection of J. P. Smith.

Orthoceras shastense Hyatt and Smith (p. 210).

Figs. 4, 5. Side view and cross section (natural size).

From Upper Triassic, 3 iniles east of Madison's ranch, between Squaw Creek and Pit River, Shasta County, Cal. Collection of J. P. Smith.

Mojsvaroceras Turneri Hyatt and Smith (p. 209).

Figs. 6, 7, 8. Side and rear views and septa.

Figs. 9, 10. Side and rear views, adolescent stage.

Fia. 11. Small fragment $(\times 2)$ of inner whorl of the last specimen, showing the internal lobe and the siphuncle.

From Upper Triassic, 3 miles east of Madison's ranch, between Squaw Creek and Pit River, Shasta County, Cal. Collection of J. P. Smith. 

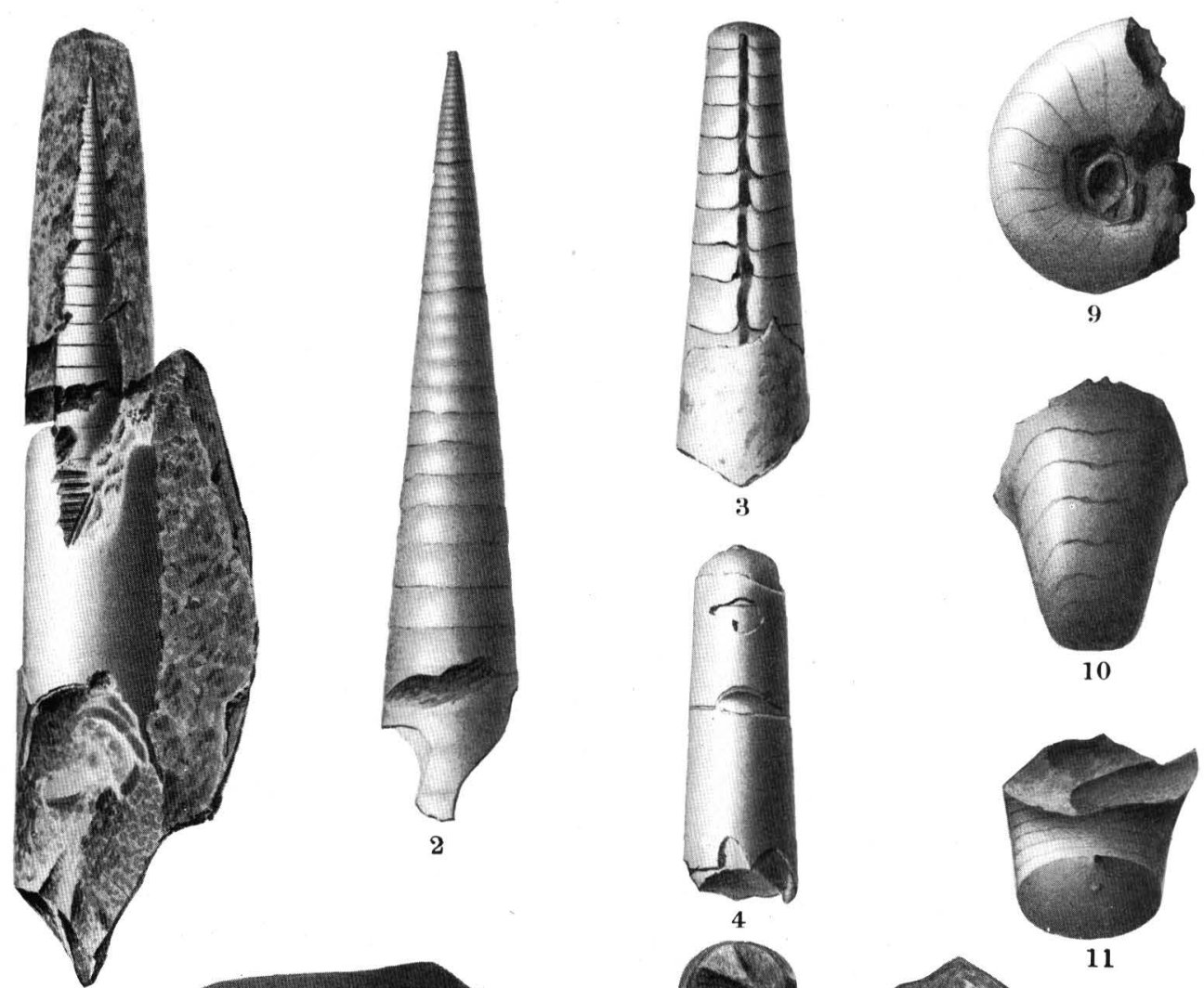

1
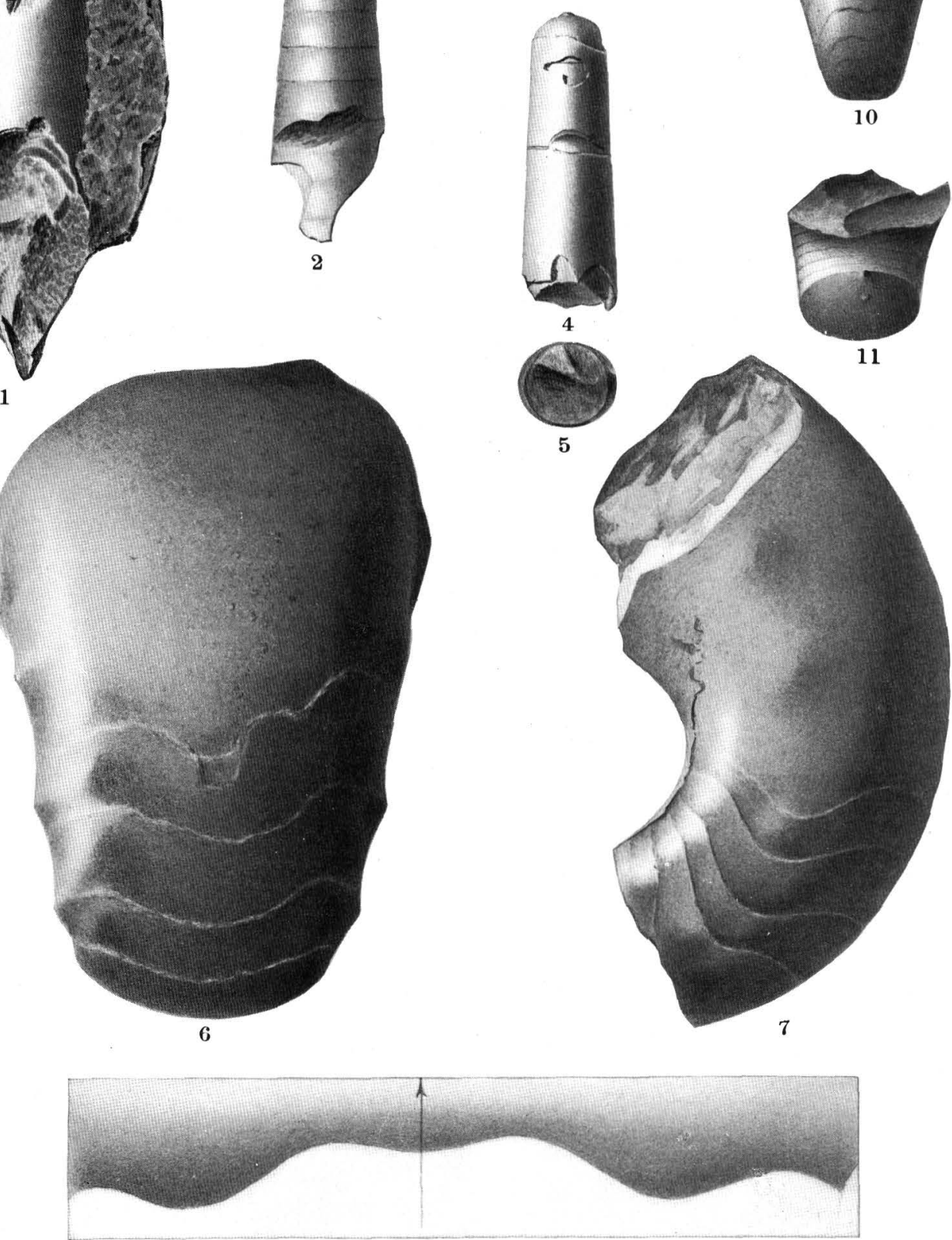


\section{PLATE XLIX}

Proclydonautilus triadicus Mojsisovics (p. 206).

Figs. 1, 2, 3. Side and front views and septa.

From Upper Triassic, 3 miles east of Madison's ranch, between Squaw Creek and Pit $\because \quad$ River, Shasta County, Cal. Collection of J. P. Smith. 

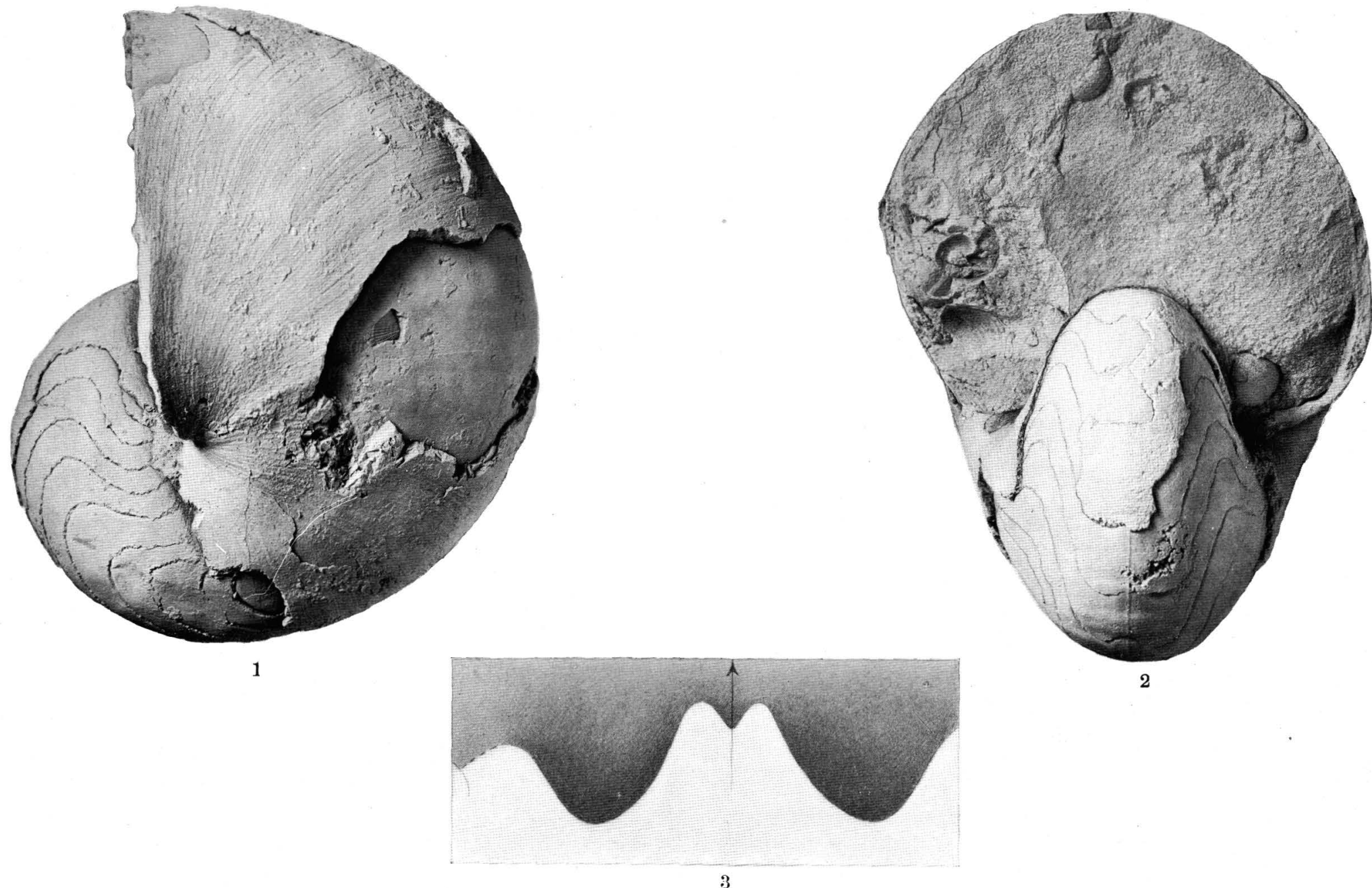

PROCLYDONAUTILUS TRIADICUS. 


\section{PLA TE L.}

Proclydonautilus triadicus Hyatt and Smith (p. 206).

Figs. 1, 2. Side and front views.

Figs. 3, 4, 5. Side and front views of an immature specimen, and a rear view of the inner whorls, shown by removing part of the onter whorl.

Figs. 6, 7, 8. Side, front, and rear views $(\times 2)$, adolescent stage; diameter $13 \mathrm{~mm}$.

Figs. 9, 10, 11. Side, front, and rear views $(\times 2)$, adolescent stage; diameter $12 \mathrm{~mm}$.

Figs. 12, 13, 14. Side, front, and rear views $(\times 3)$, adolescent stage, corresponding to Coloceras; diameter $7 \mathrm{~mm}$.

Fras. 15, 16, 17. Side, front, and rear views $(\times 6)$, larval stage; diameter $3 \mathrm{~mm}$.

From Upper Triassic, 3 miles east of Madison's ranch, between Squaw Creek and Pit River, Shasta County, Cal. Collection of J. P. Smith. 


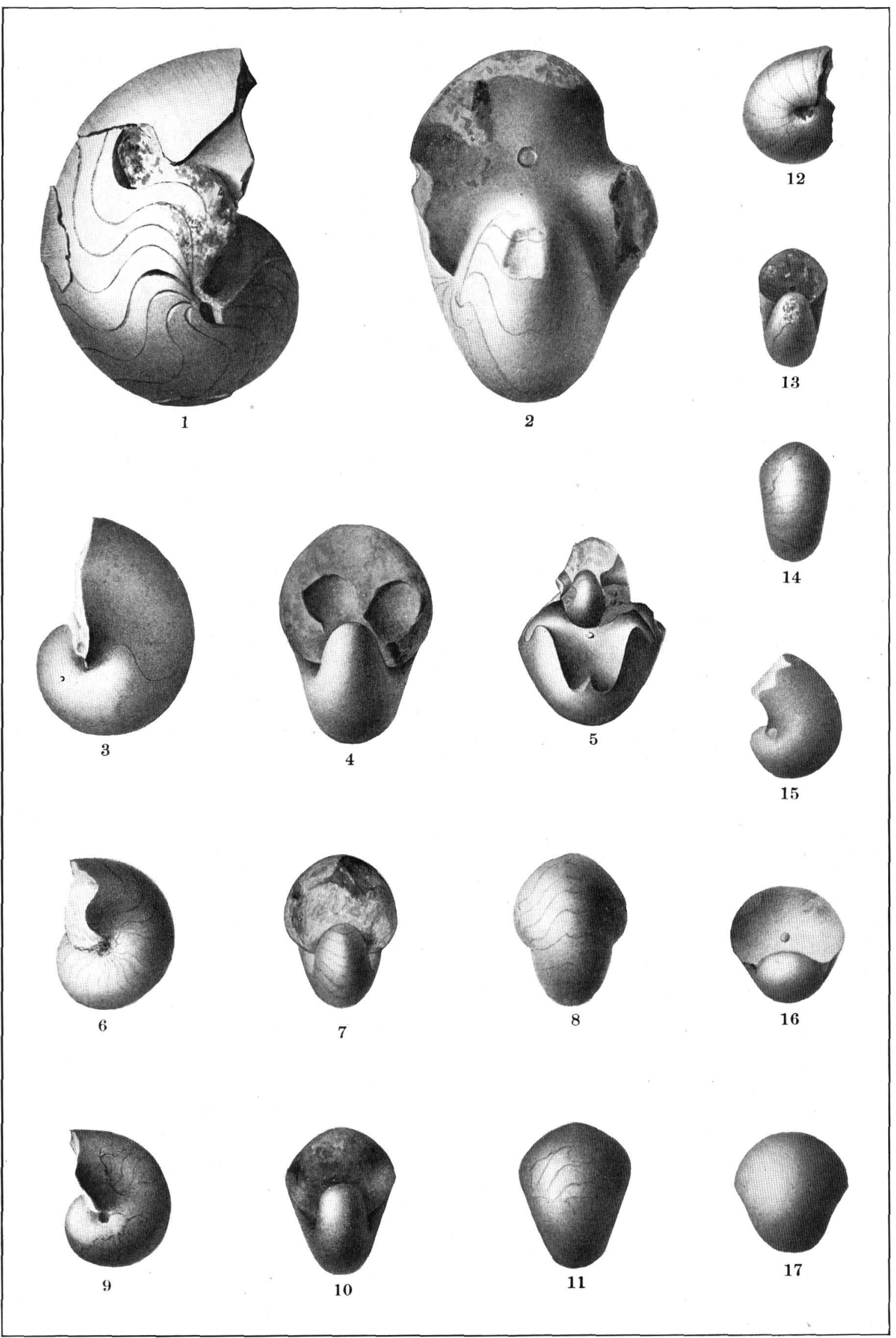

PROCLYDONAUTILUS TRIADICUS. 


\section{PLA TE L I.}

Cosmonautilus Dilleri Hyatt and Smith (p. 207).

FIG. 1. Side view; diameter $200 \mathrm{~mm}$. (See also PI. LII, fig. 1, for front view of the same specimen.) From Upper Triassic, 3 miles east of Madison's ranch, between Squaw Creek and Pit River, Shasta County, Cal. Collection of J. P. Smith. 


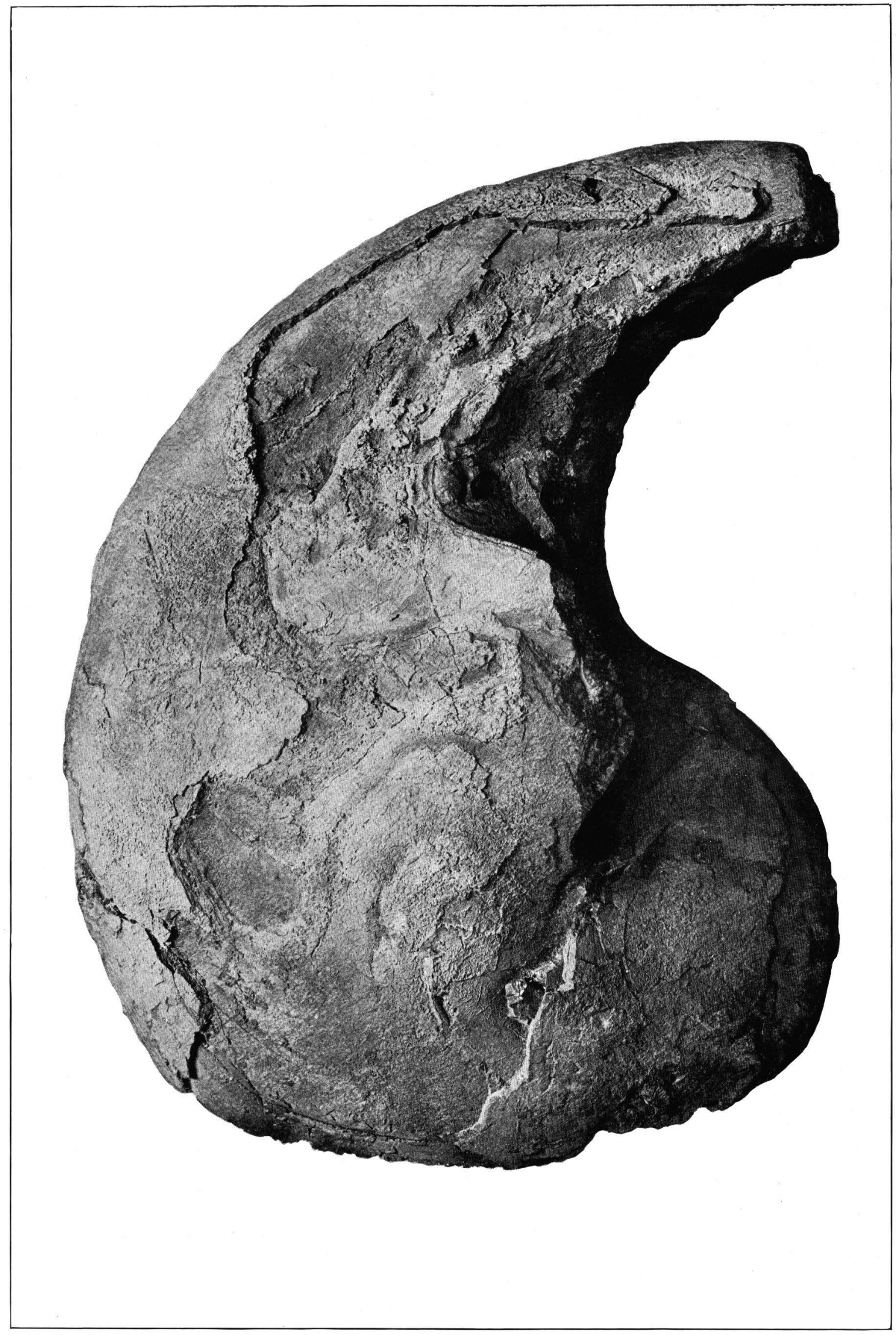




\section{P L A T E L II.}

Cosmonautilus Dilleri Hyattand Sinith (p.. 207).

Fia. 1. Front view; diameter $200 \mathrm{~mm}$. . (See Pl. LI, fig. 1; for side vièw.)

From Upper Triassic, 3 miles east of Madison's, ranch, between Squaw Creek and Pit River, Shasta County, Cal. Collection of J. P. Smith.

320

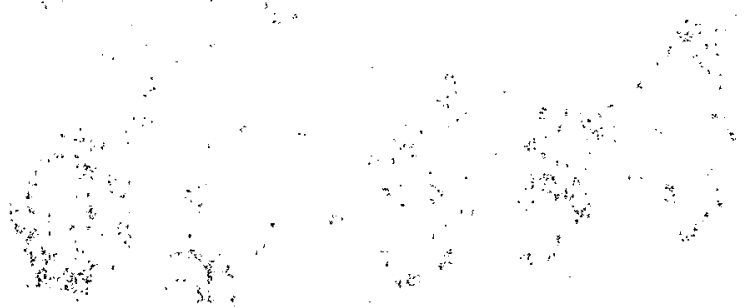




$$
1
$$




\section{PLATE LIII.}

Cosmonautilus Dilleri Hyatt and Smith (p. 207).

Fros. 1, 2. Side and front views; diameter $125 \mathrm{~mm}$. (see Pl. LIV, figs. 1 and 2, for rear view and septa).

From Upper Triassic, 3 miles east of Madison's ranch, between Squaw Creek and Pit River, Shasta County, Cal. Collection of J. P. Smith. 

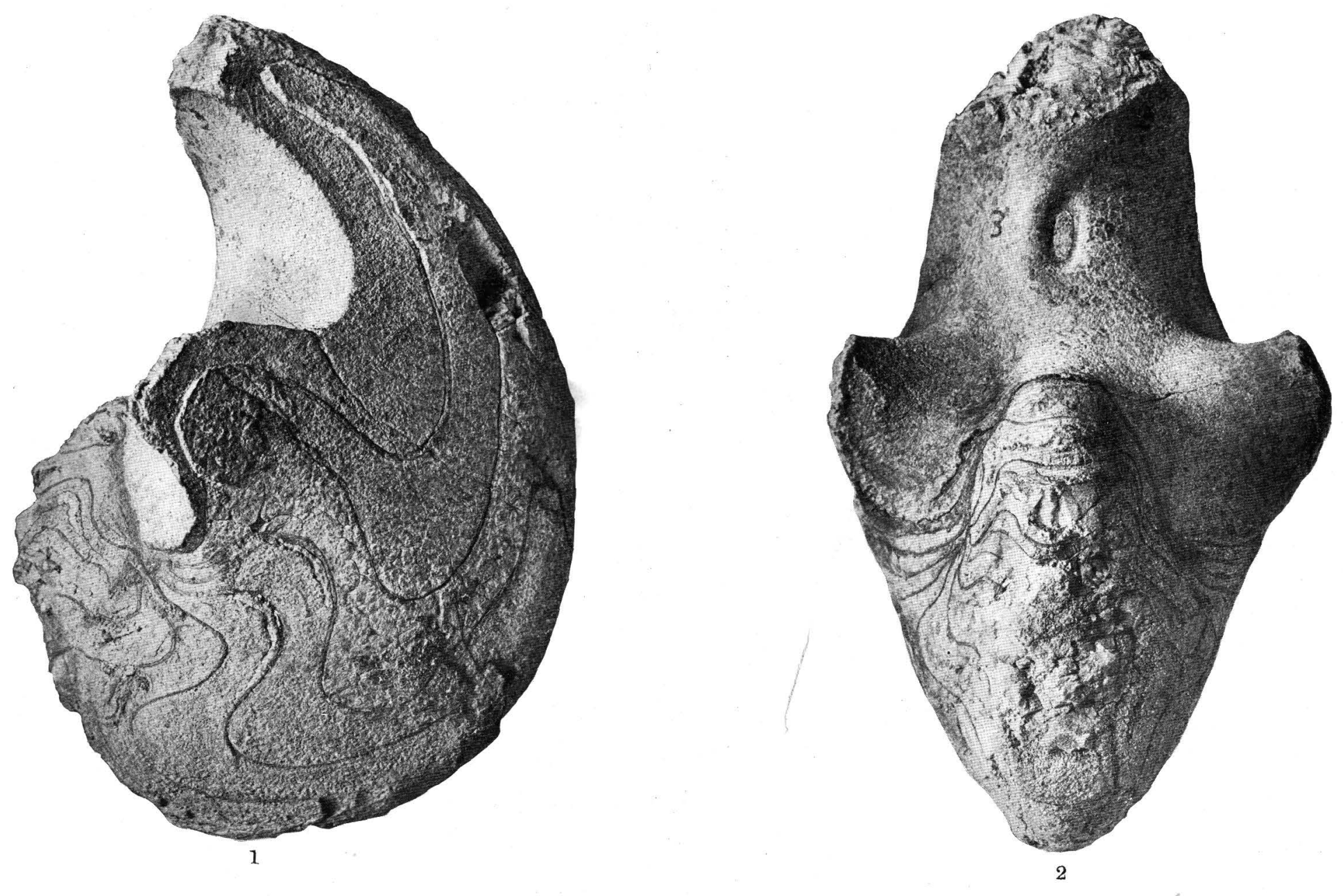
PLA T E L V.

Cosmonautilus Dilleri Hyatt and Simith (p. 207).

FIGs. 1, 2. Side and front views, early adult stage; diameter $95 \mathrm{~mm}$.

Figs. 3, 4, 5. Side, front, and rear views, adolescent stagc; diameter $40 \mathrm{~mm}$.

FIGs. 6, 7; 8. Side, front, and rear views $(\times 2)$, adolescent stage; diameter $24 \mathrm{~mm}$.

Figs. 9, 10, 11. Side, front, and rear views $(\times 2)$, larval stage; diameter $13 \mathrm{~mm}$.

From Upper 'Triassic, 3 miles east of Madison's ranch, between Squaw Creek and Pit River, Shasta County, Cal. Collection of J. P. Smith. 


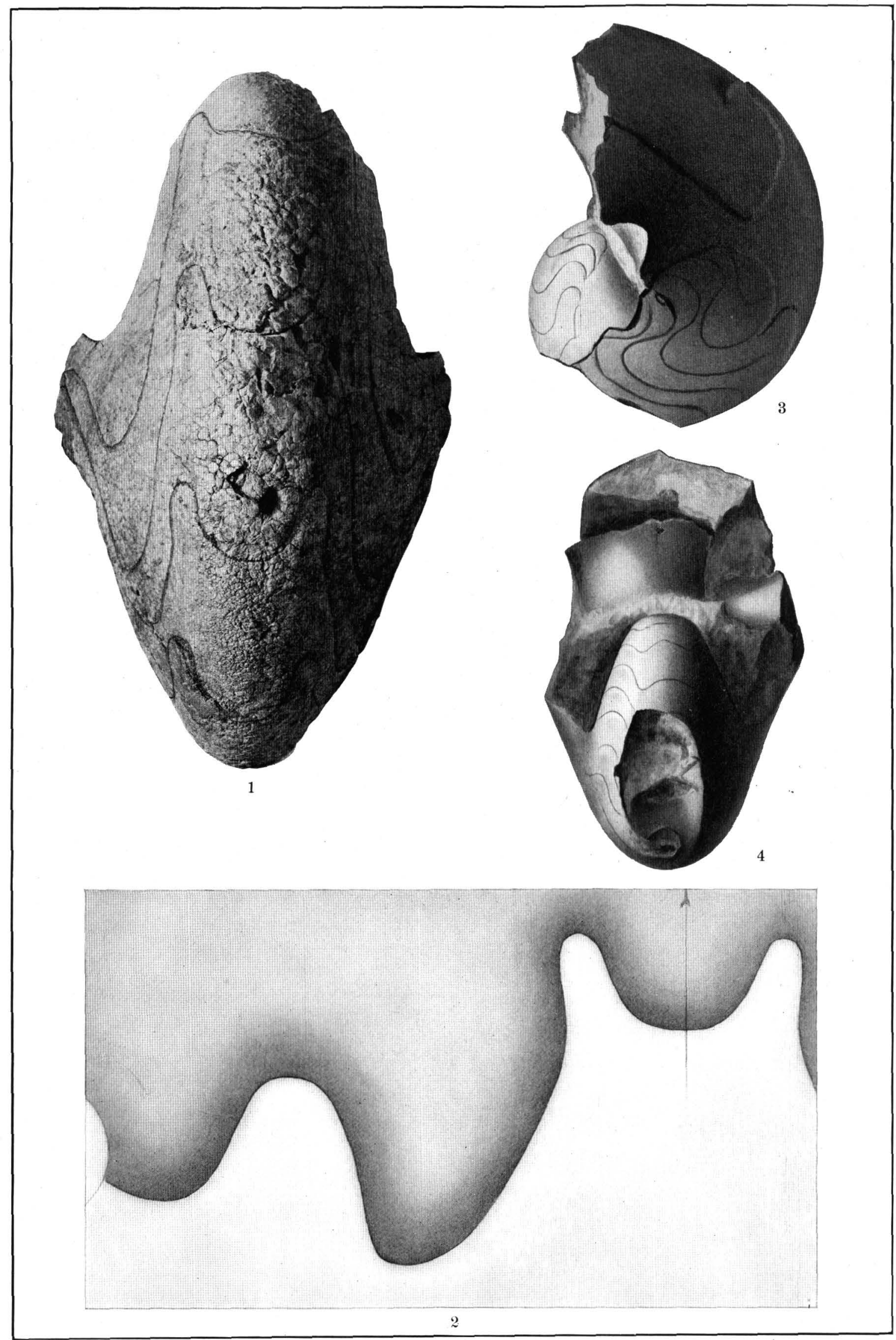

COSMONAUTILUS DILLERI. 
P L A T E L I V.

Cosmonautilus Dilleki Hyatt and Smith (p. 207).

Figs. 1, 2. Rear view and septa of specimen shown on Pl. LIII, figs. 1 and 2.

Figs. 3, 4. Side and front views, showing transition from adolescence to maturity; diameter $70 \mathrm{~mm}$. From Upper Triassic, 3 miles east of Marlison's ranch, between Squaw Creek and Pit River, Shasta County, Cal. Collection of J. P. Smith. 


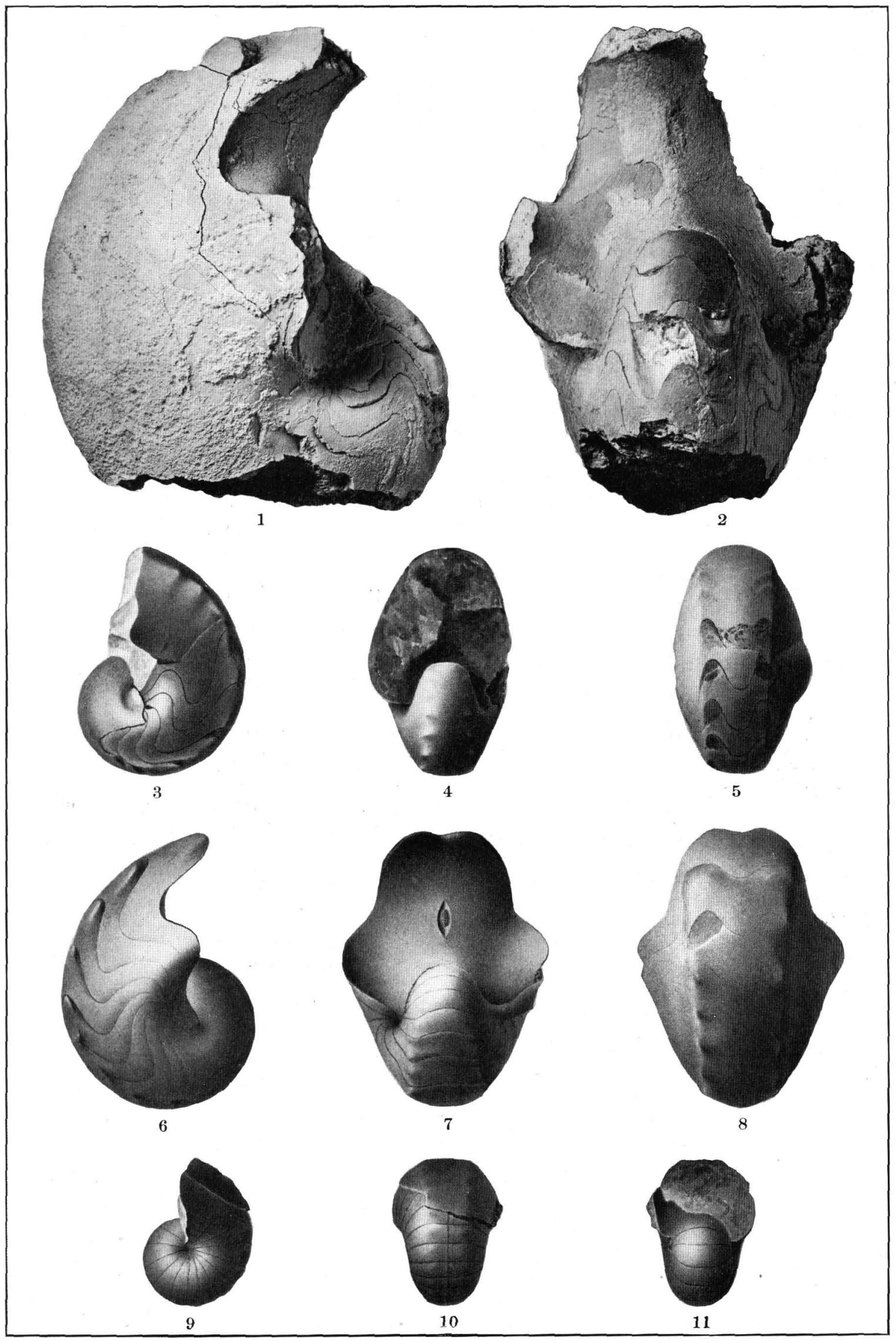




\section{P L A T E L V I .}

Arcestes Andersoni Hyatt and Smith, sp. nov. (p. 74).

Fugs. 1, 2, 3. Right side and front (natural size) and septa $(\times 2)$ of the type specimen.

Figs. 4, 5, 6. Right side and front (natural size) and septa $(\times 2)$ of a smaller specimen.

Figs. $7,8,9$. Side, front, and septa $($ all $\times 5$ ) of a young specimen; diameter 5 mm.

From Upper Triassic (Pscudomonotis beds), Muttleberry Canyon, 8 miles southeast of Lovelock, West Humboldt Range, Nevada. Figs. 1, 2, and 3, collection of F. M. Anderson, Berkeley, Cal.; figs. 4-9, collection of J. P. Smith.

Puacites humbolotensis Hyatt and Smith, sp. nov. (p. 107).

Fics. 10,11, 12; Left side and rear (natural size) and septa $(\times 4)$ somewhat weathered.

FI(s. 13, 14, 15. Right side and front views $(\times 3)$ and septa $(\times 6)$; diameter $9 \mathrm{~mm}$.

Frgs. 16, 17, 18. Left side and front views $(\times 5)$ and septa $(\times 10)$, early adolescent stage; diameter $.5 .5 \mathrm{~mm}$.

Figs. 19, 20, 21, 22. Left side, front, and rear views $(X 10)$ and scpta $(\times 20)$ larval stage, showing the siphuncle; diameter $3 \mathrm{~mm}$.

Figs. 23, 24, 25. Left side and front $(\times 2)$ and septa $(\times 3)$; diameter $15 \mathrm{~mm}$.

From Upper Triassic (Pseudomonotis beds), Muttleberry Canyon, 8 miles southeast of Lovelock, West Humboldt Range, Nevada. C̣ollection of J. P. Smith.

Rhabdoceras Russeldi Hyatt (p. 203).

FIG. 26. Side view $(\times 3)$.

From Upper Triassic (Noric stage), Muttleberry Canyon, 8 miles sontheast of Lovelock, West Humboldt Range, Nevada. Collection of J. P. Smith. 


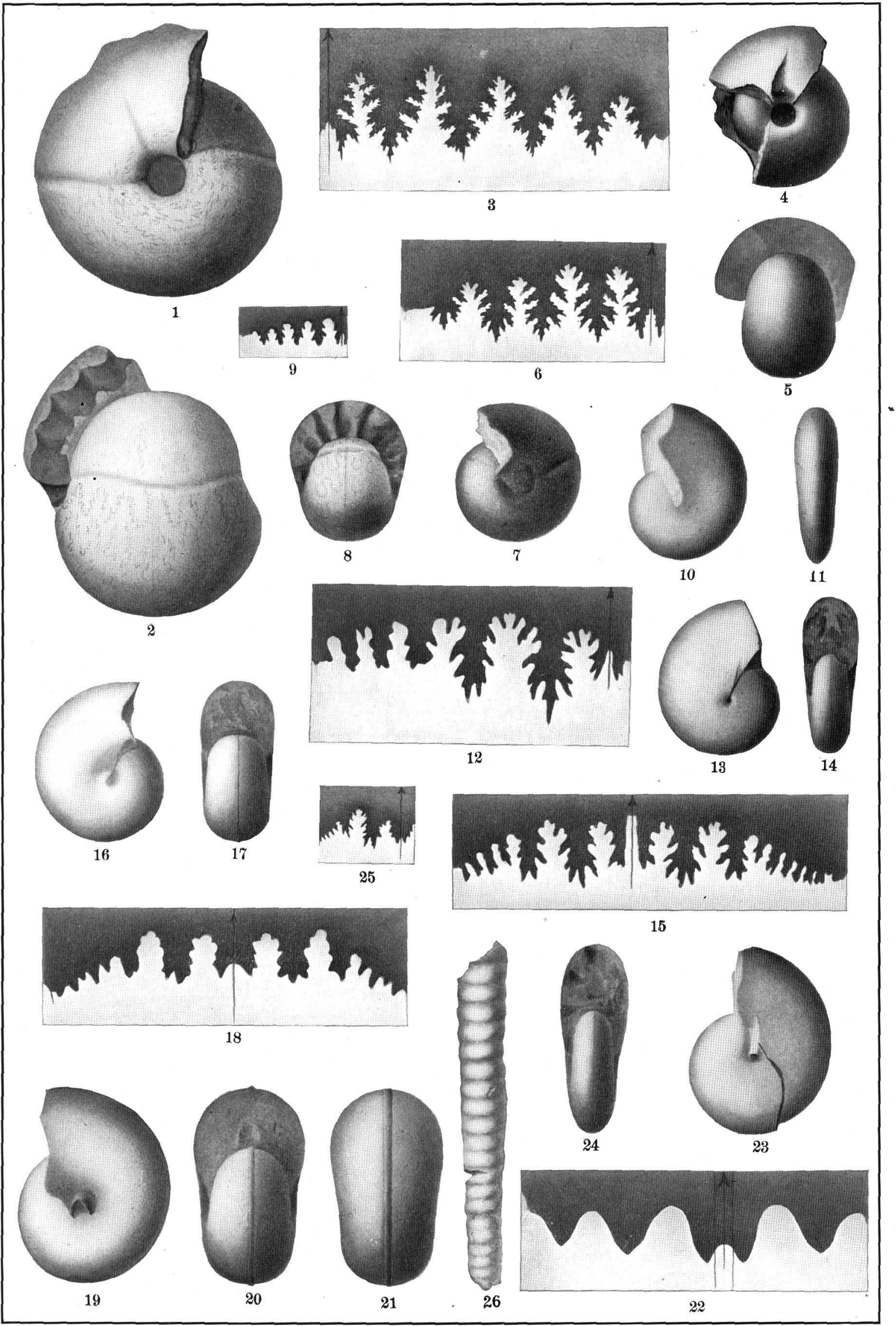

ARCESTES ANDERSONI, PLACITES HUMBOLDTENSIS, RHABDOCERAS RUSSELLI. 


\section{PLATE LVII.}

Ceratites humboldtensis Hyatt and Smith, sp. nov. (p. 170).

Figs. 1, 2, 3. Side, front, and rear views of an adult specimen, showing the beginning of the rough sculpture characteristic of maturity.

FIGs, 4, 5. Side view (natural size) and septa $(X 2)$ of a mature form.

Figs. 6, 6a, 7. Cross section and side view (from the same specimen), showing the increase in breadth and squareness of the whorls.

Figs. 8, 9, 10, 11. Side, front, and rear views (natural size) and septa $(\times 2)$, of a specimen at the beginning of maturity.

Fics. 12, 13. Side and rear views (natural size), showing the end of the adolescent stage.

FIGs. 14, 15, 16. Side, front, and rear views $\left(\times 1 \frac{1}{2}\right)$, adolescent stage; diameter $18 \mathrm{~mm}$.

Figs. 17, 18. Side and rear views $(\times 2)$, adolescent stage; diameter $13 \mathrm{~mm}$.

Figs. 19, 20, 21. Side, front, and rear views $(\times 3)$, early adolescent stage; diameter $8 \mathrm{~mm}$.

FIGs. 22, 23. Side and front views $(\times 5)$, larval stage; diameter $4.5 \mathrm{~mm}$.

From Middle Triassic (Daonella beds), on the divide between Troy Canyon and the South

Fork of American Canyon, West Humboldt Range, Nevada. Collection of J. P. Smith.

330 


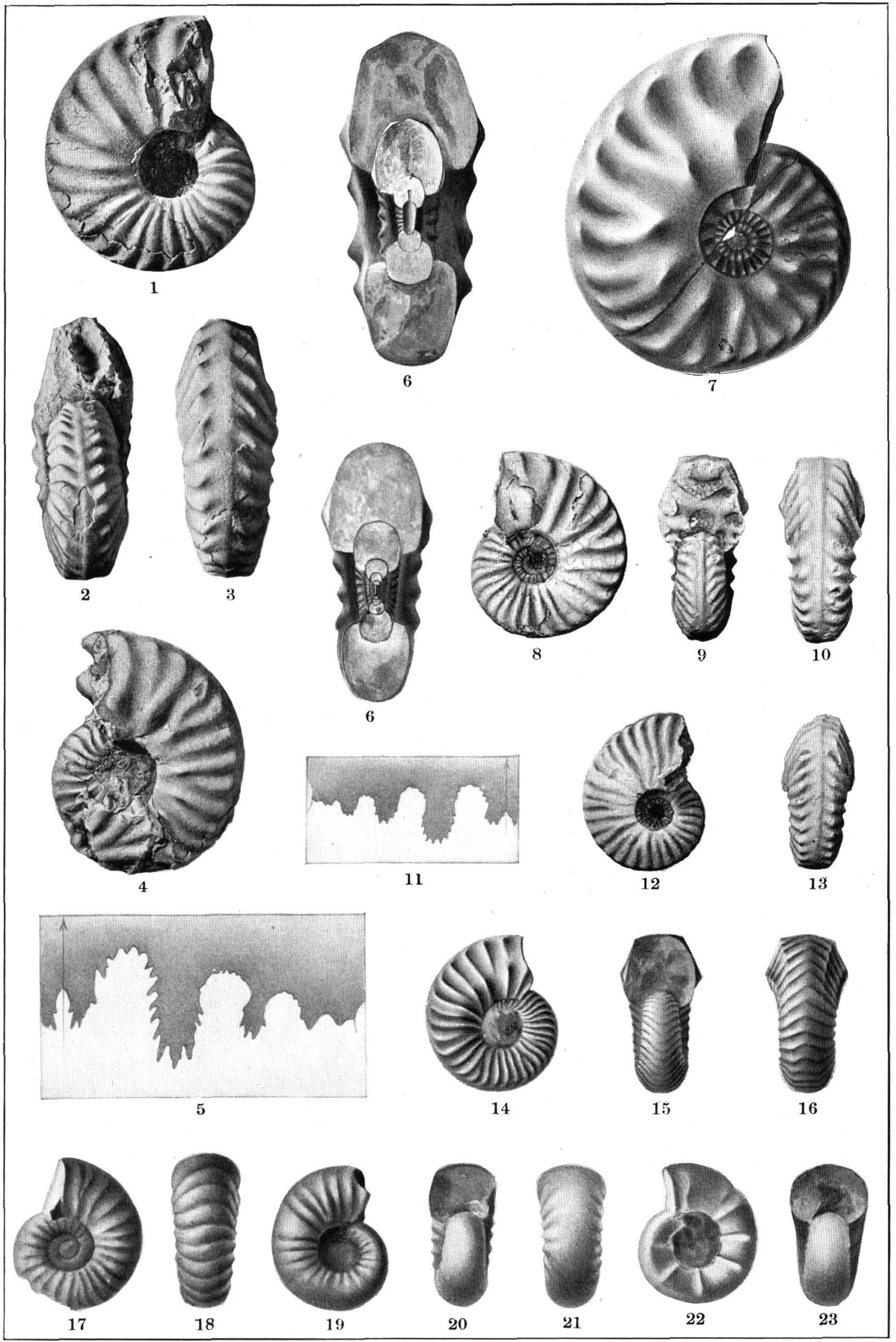

CERATITES HUMBOLDTENSIS. 


\section{PLA T E L V I I I.}

Beyrichites Ro'teilliformis Meek (p. 155).

FIGs. 1, 2, 3, 4. Side, front, and rear views and septa.

Figs. 5, 6. Side view (natural size) and septa $(\times 2)$ of an adolescent specimen; diameter $24 \mathrm{~mm}$.

Fics. 7, 8, 9. Side, front, and rear views $\left(\times 1 \frac{1}{2}\right)$, adolescent stage; diameter $15 \mathrm{~mm}$.

Figs. 10, 11, 12. Side, front, and rear views $(X 2)$, adolescent stage; diameter $11.5 \mathrm{~mm}$.

Figs. $13,14,15$. Side and front views $(\times 6)$ and septa $(\times 12)$, end of larval stage; diameter $3.4 \mathrm{~mm}$. From Middle Triassic, on divide between .Troy Canyon and South Fork of American Canyon, West Humboldt Range, Nevada. Collection of J. P. Smith.

Longobardites Nevadands Iyyatt and Smith, sp. nov. (p. 132).

Figs. 16, 17, 18. Side and front views (natura size) and septa $(\times 2)$.

FIas. 19, 20. Side view (natural size) and septa $(\times 2)$.

From Middle Triassic, on divide between Troy Canyon and South Fork of American Canyon, West Humboldt Range, Nevada. Collection of J. P. Smith. 

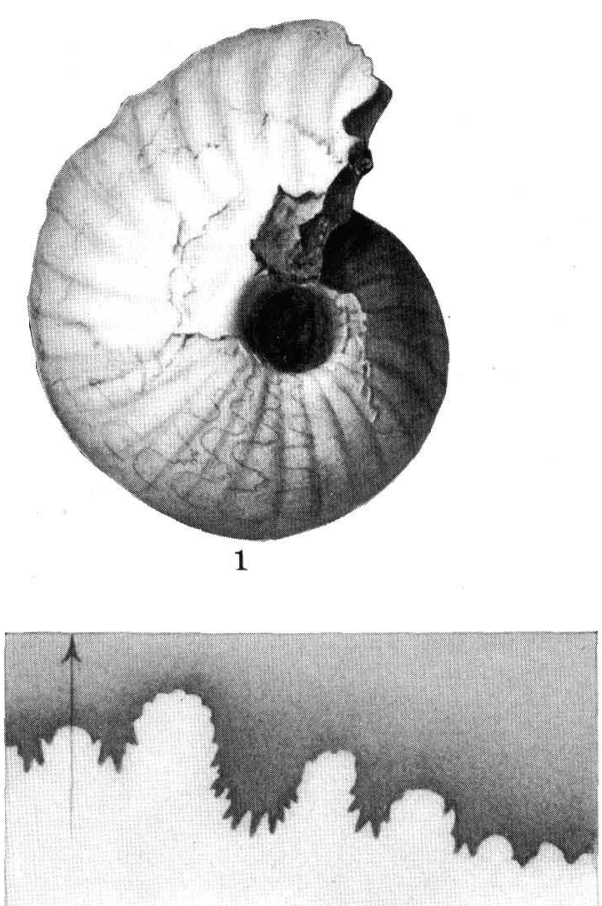

4
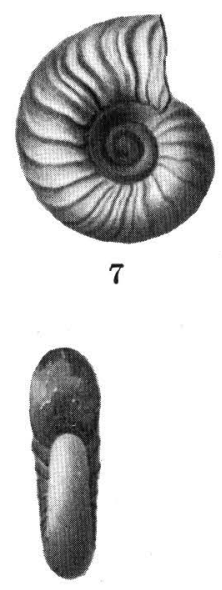

8
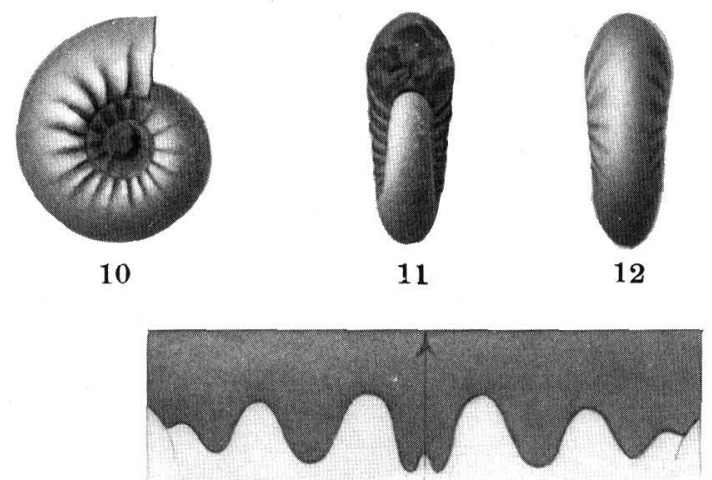

15
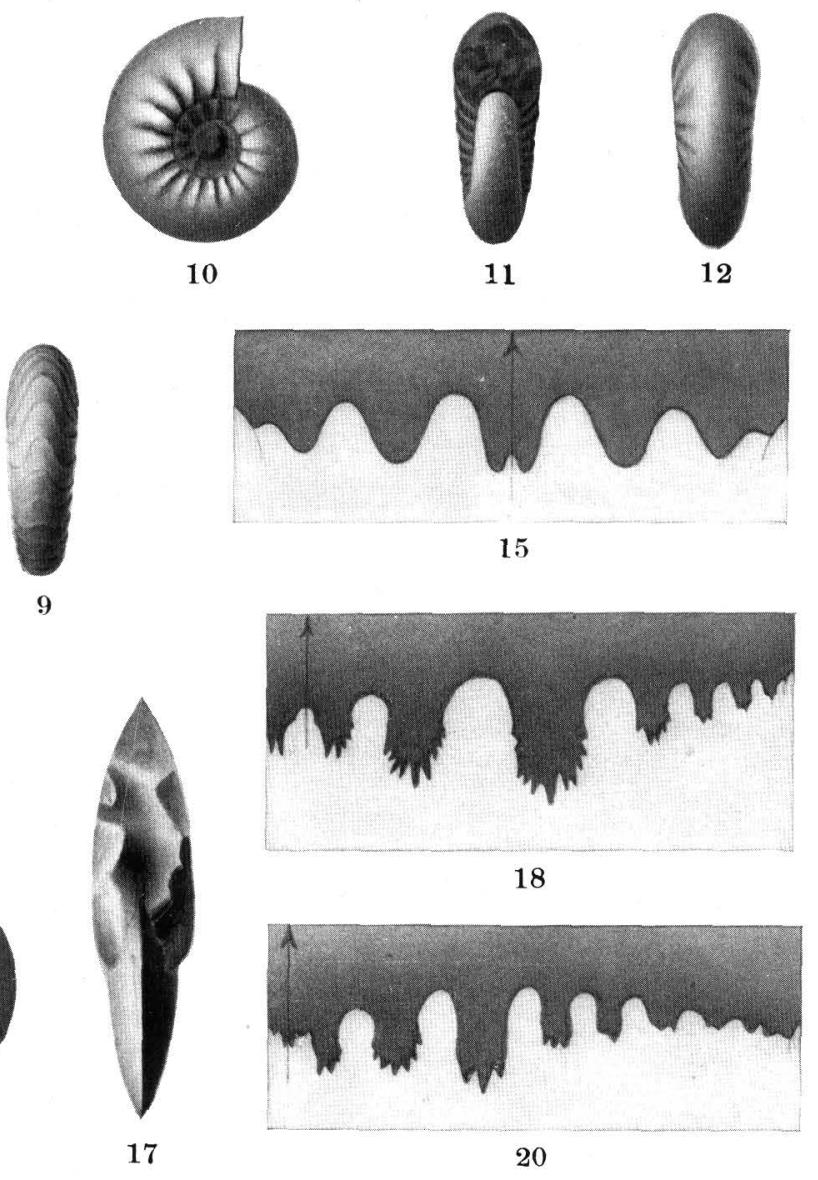
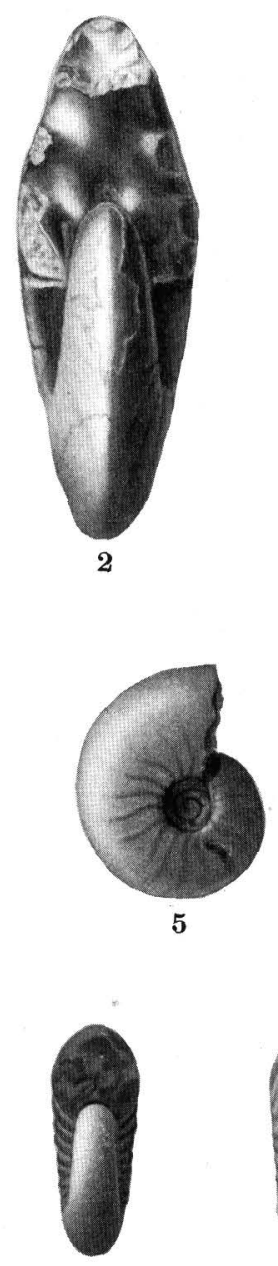

11

12

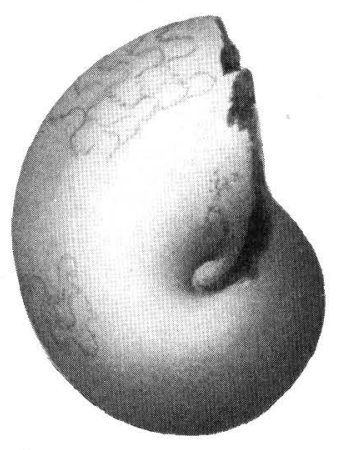

16
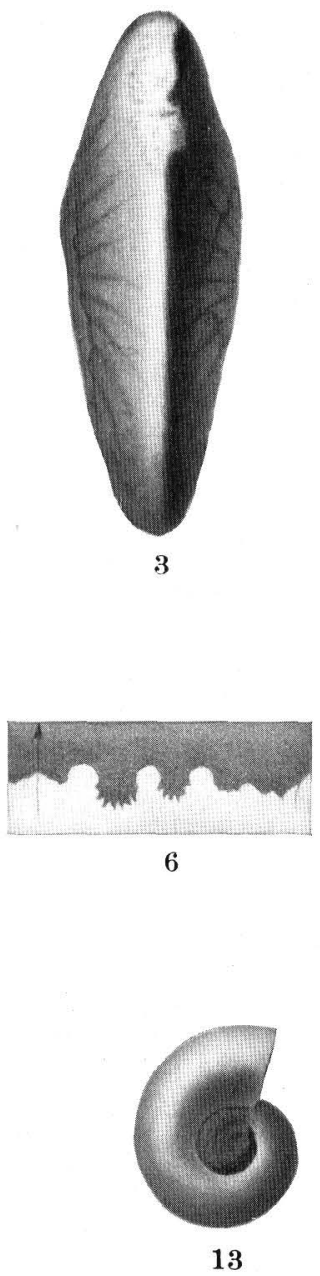


\section{PLATE LIX.}

Trachyceras (Anolcites) Meek M Mojsisovics (p. 196).

Ficis. 1, 2. Side and front views of an old specimen. This specimen shows the beginning of obsolescence of sculpture in old age.

Figs. 3, 4, 5, 6. Side, front, and rear views $(\times 2)$ and septa $(\times 3)$, adolescent stage; diameter $25 \mathrm{~mm}$.

FIGs. 7, 8, 9. Side, front, and rear views $(\times 2)$, adolescent stage; diameter $14 \mathrm{~mm}$.

FiGs. 10, 11, 12. Side, front, and rear views $(\times 2)$, adolescent stage; diameter $10 \mathrm{~mm}$.

Figs. 13, 14, 15. Side, front, and rear views $(\times 3)$, showing transition from larval to adolescent stage; diameter $6 \mathrm{~mm}$.

Figs. 16, 17. Side and front views $(\times 4)$, larval stage, corresponding to Tirolites; diameter $4.5 \mathrm{~mm}$.

From Middle Triassic (Daonella beds), West Humboldt Range, Nevada. Figs. 1 and 2, from Cottonwood Canyon, near "Lucky Dog" mine; figs. 3-17, from divide between Troy Canyon and South Fork of Ameriean Canyon. Collection of J. P. Smith. 

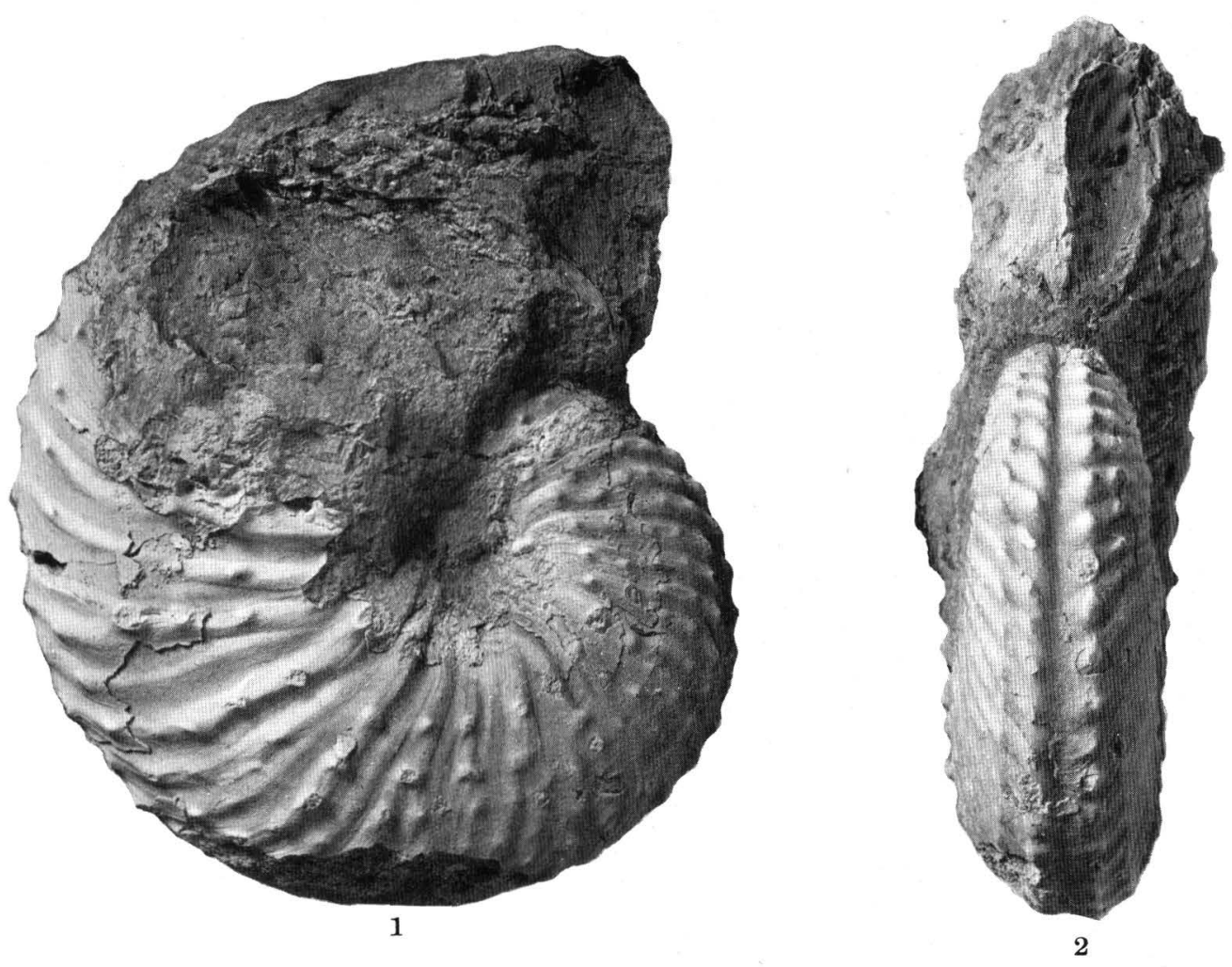

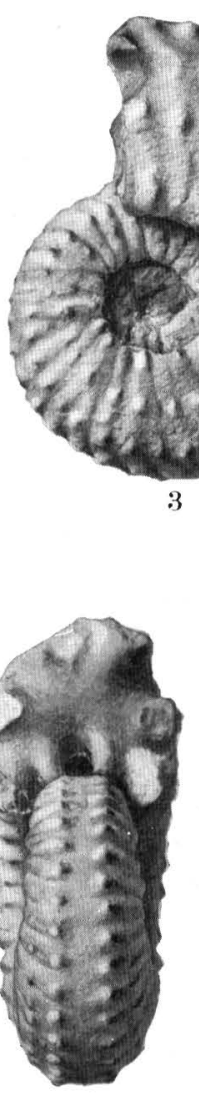

4

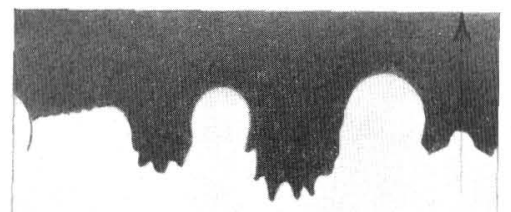

6
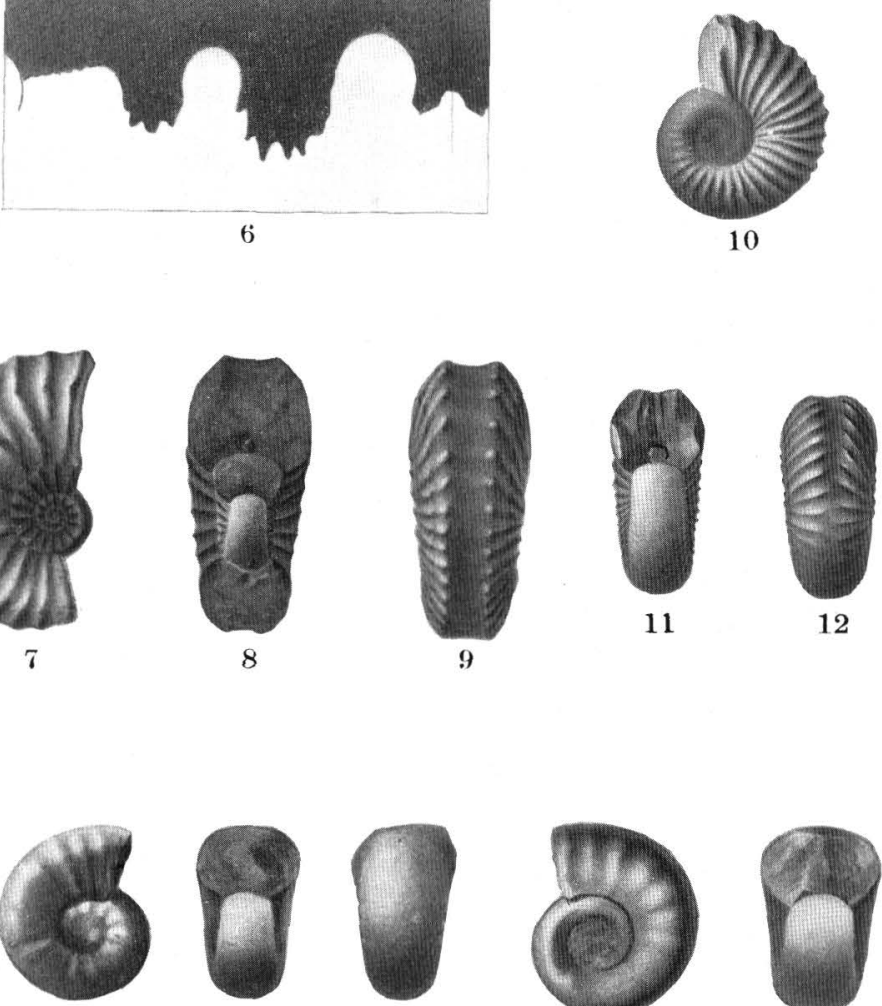

15

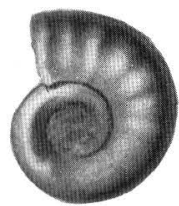

16

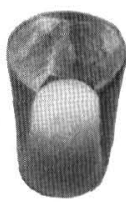

17 


\section{P L A T E L X .}

Dinarites BOnÆ-VISTA Hyatt and Smith, sp. nov. (p. 162.)

Fig. 1: Left side.

FIG. 2. Front.

FIG. 3. Rear view (natural size) of the type.

Fig. 4. Septa $(\times 2)$ of the same specimen.

Figs. 5, 6. Side and front views of a smaller specimen.

From Middle Triassic (Daonella beds), at Unionville, Buena Vista Canyon, West Humboldt Range, Nevada. Collection of J. P. Smith.

Eutomoceras Laubei Meck (p. 131).

Figs. 7, 8, 9. Right side, left side, and front views.

FIG. 10. Septa $(\times 2)$ of the same specimen.

FIG. 11. Right side view (natural size) of another specimen, showing the ornamentation.

From Middle Triassic (Daonella beds), on the divide between Troy Canyon and the South Fork of American Canyon, West Humboldt Range, 4 miles south of Foltz post-office, Humboldt County, Nev. Collection of J. P. Smith.

Lecanites Vogdesi Hyatt and Smith, sp. nov. (p. 139).

Figs. 12, 13, 14. Left side, right side, and front views (natural size) of type specimen.

Fig. 15. Septa $(\times 4)$ of the same specimen.

Figs. 16, 17. Side and front views of a smaller specimen, showing the greater evolution in youth.

FIGs. 18, 19. Side and front views (natural size) of a specimen just changing from adolescence to maturity; diameter $19 \mathrm{~mm}$.

Figs. 20, 21, 22. Adolescent specimens; diameter $15.5 \mathrm{~mm}$.

FIr. 20. Left side (natural size), whole specimen.

Fig. 21. Front view (natural size), whole specimen.

FIG. 22. Same specimen $(\times 3)$ with broken part of whorl removed, to show the cross section and the larval whorl inside.

From Middle Triassic (Daonella beds), on the divide between Troy Canyon and the South Fork of American Canyon, West Humboldt Range, 4 miles south of Foltz post-office, Humboldt County, Nev. Collection of J. P. Smith. 

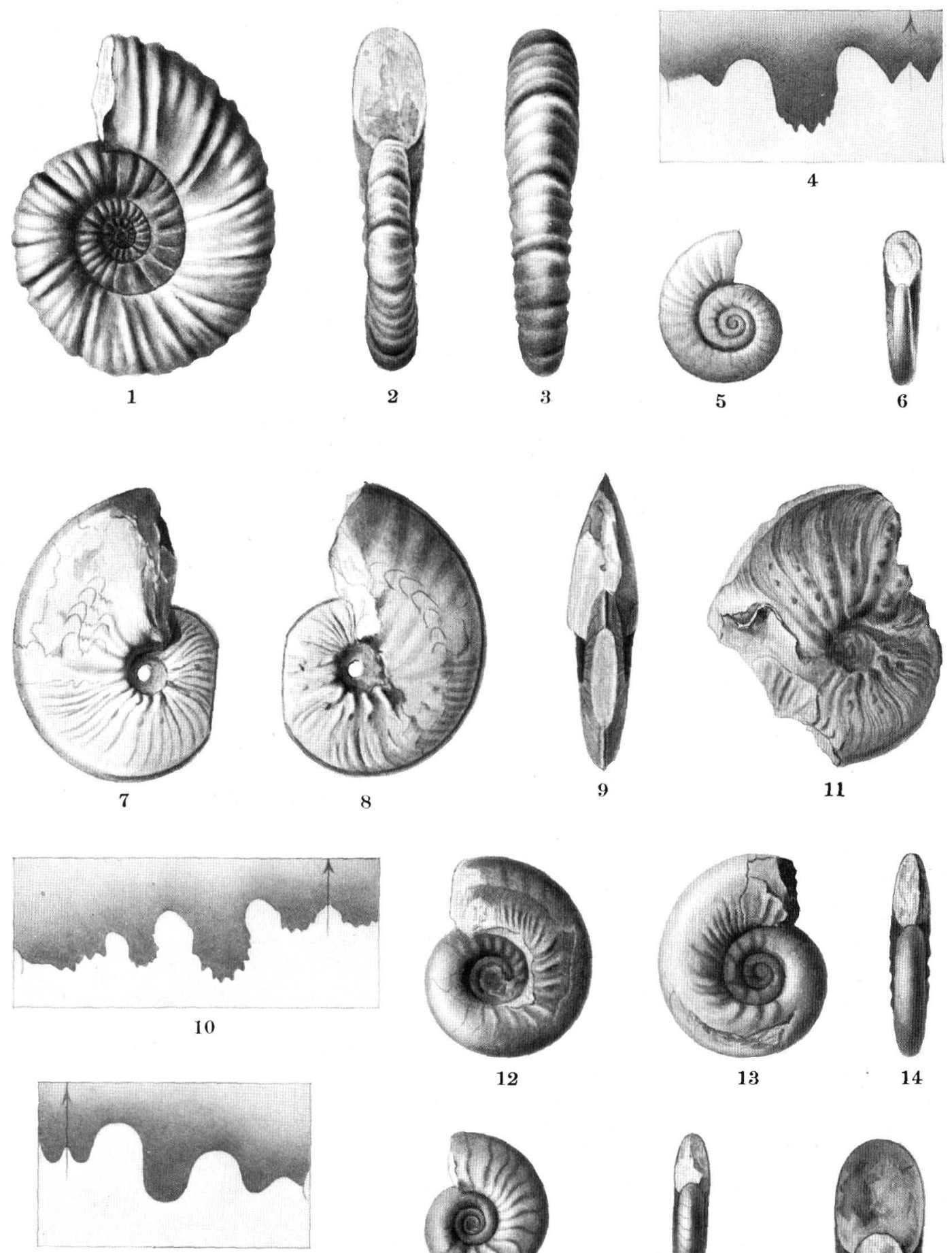

15
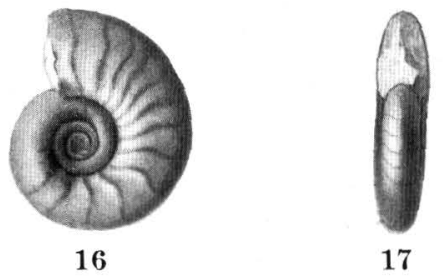

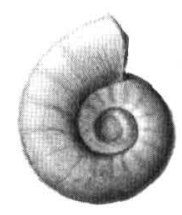

18

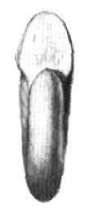

19

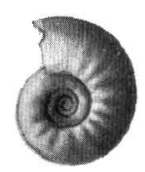

20

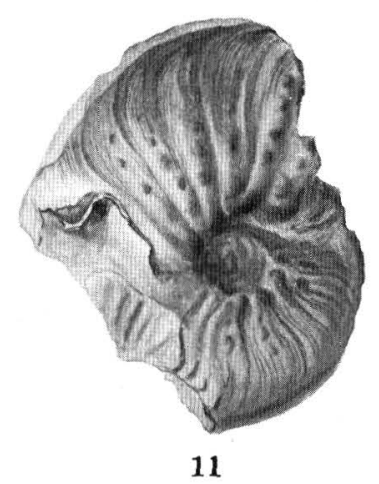

17

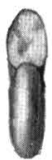

21

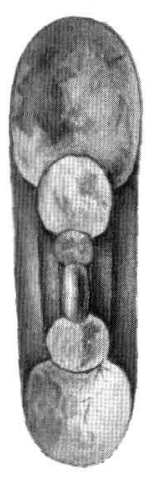

22 


\section{PLATE LXI.}

Colvmbites parisianus Hyatt and Smith, sp. nov. (p. 51).

Fig. 1. Mature specimen, showing the body chamber to be one revolution in length, also the obsolescence of sculpture at maturity.

Figs. 2, 3, 4, Side and front views (natural size), and septa $(\times 2)$, early maturity.

Figs. 5, 6, 7. Side, front, and rear views (natural size), to show the sculpture on both shell and cast.

FiGs. 8, 9. Side and front views (natural size), end of adolescent stage; diameter $33 \mathrm{~mm}$.

Fic. 10. Front view $(\times 2)$, broken, showing the inner whorl; diamster $28 \mathrm{~mm}$.

Figs. 11, 12. Side and front views (natural size) of whole specimen, adolescent stage; diameter $26 \mathrm{~mm}$. FIG. 13. Front view $(\times 2)$ of broken whorl of above specimen, showing the inner whorl.

Figs. 14, 15. Side and front views $(\times 2)$, showing Gastrioceras stage of growth, adolescent stage diameter-16 mm.

Figs. 16, 17, 18. Side and front views $(\times 2)$ and septa $(\times 5)$, early adolescent stage; diameter $10 \mathrm{~mm}$.

Figs. 19, 20, 21. Side, front, and rear views $(\times 6)$, early adolescent stage; diameter $3.32 \mathrm{~mm}$.

From Lower Triassic, 1 mile west of Paris, Idaho. (Locality 1981, U. S. Geol. Survey.) 


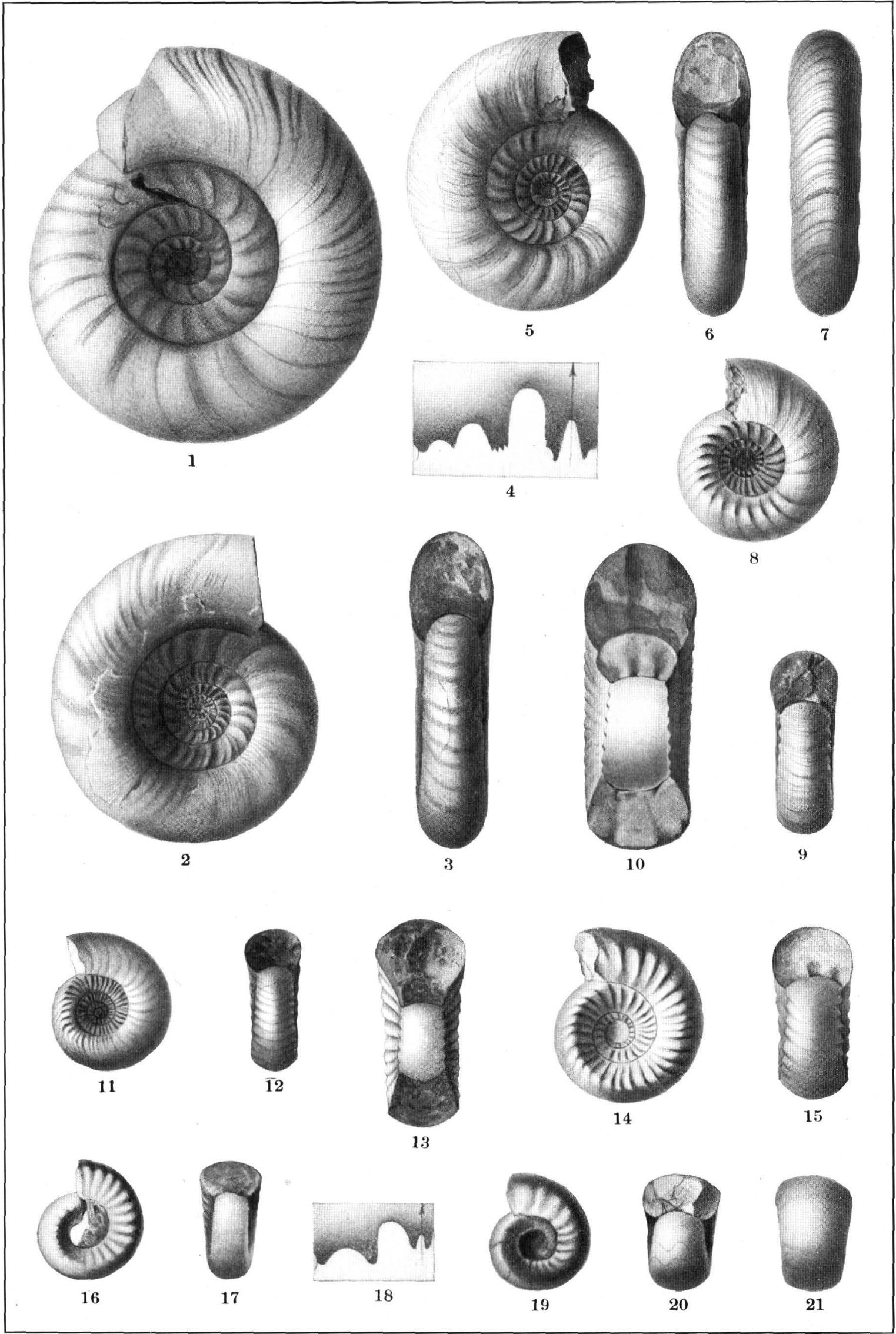




\section{PLA TE LXII.}

Ophickras Spencei Hyatt and Smith, sp. nov. (p. 119).

Figs. 1, 2, 3, 4. Side, front, and rear views (natural size), and septa $(\times 3)$. (The septa do not show the auxiliary lobes shown by mistake in the drawing).

FIGs. 5, 6, 7. Side and front views (natural size) and septa $(\times 2)$.

Figs. 8, 9, 10. Side, front, and rear views $(\times 5)$, early adolescent stage; diameter $5.5 \mathrm{~mm}$.

From Lower Triassic, 1 mile west of Paris, Idaho. Collection U. S: Geol. Survey.

Meekoceras (Prionolobus) Jacksoni Hyatt and Smith, sp. nov; (p. 151).

Figs. 11, 12, 13. Side and front views (natural size) and septa ( $\times 2$ ), of type specimen.

Fir. 14. Side view (natural size).

Figs. 15, 16. Side view (natural size) and septa $(\times 2)$, adult stage.

Figs. 17, 18. Side view (natural size) and septa $(\times 2)$, end of adolescent stage; diameter $25 \mathrm{~mm}$.

Figs. 19, 20, 21. Side, front, and rear views $(X 6)$, larval stage; diameter $3.2 \mathrm{~mm}$.

From Lower Triassic, 1 mile west of Paris, Idaho. Collection U. S. Geol. Survey. 


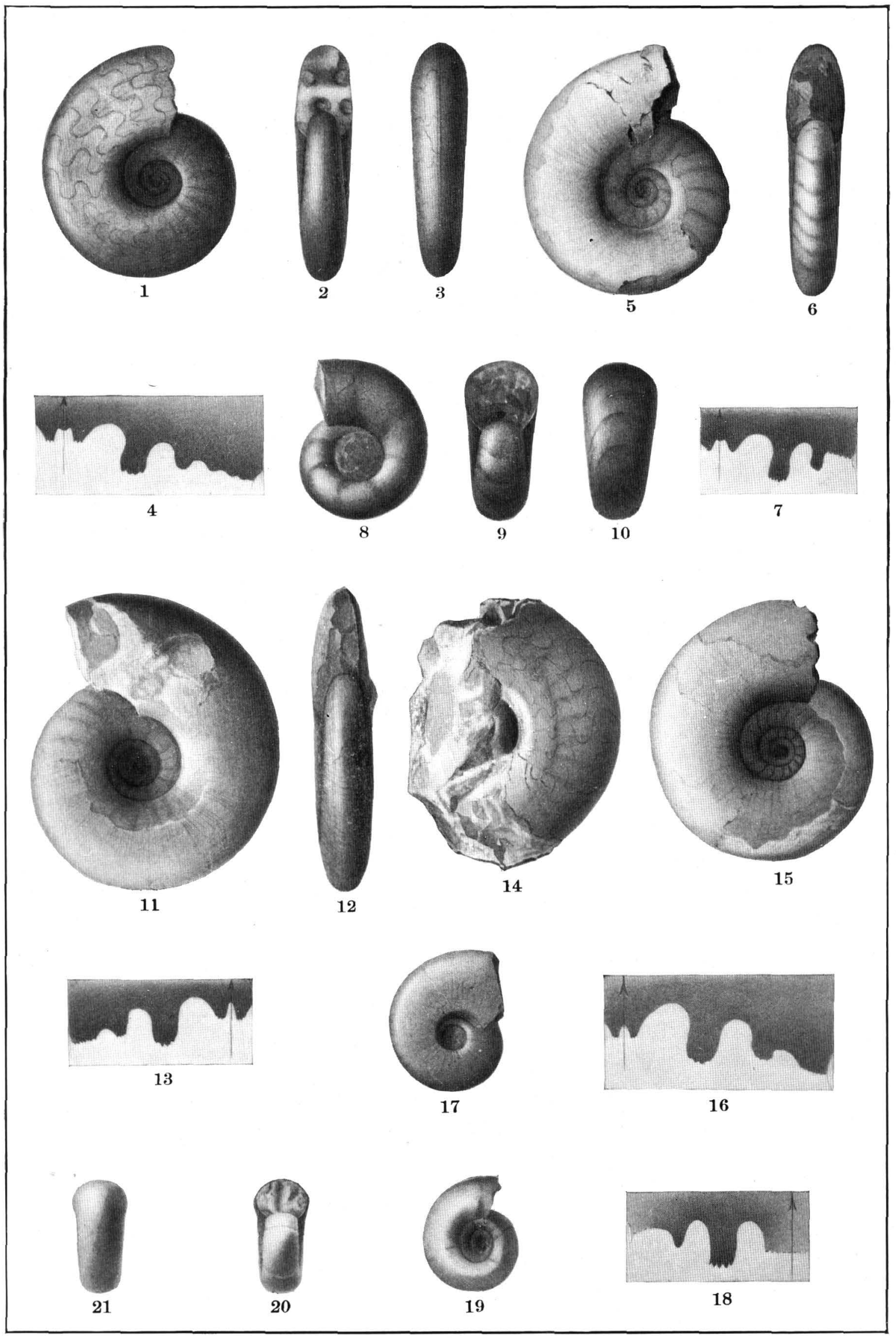

OPHICERAS SPENCEI, MEEKOCERAS (PRIONOLOBUS) JACKSONI. 


\section{PLATE LXIII.}

Pseudosageceras intermontanum Hyatt and Smith, sp. nov. (p. 99).

Figs. $1 a, 1 b$. Side and front views (natural size).

Fig. 1c. Septa $(\times 2)$.

Figs. $2 a, 2 b$. Side and rear views (natural size).

Fig. 2c. Septa $(\times 2)$ of same specimen.

From Lower Triassic, 1 mile west of Paris, Idaho. Locality No. 1981, U. S. Geol. Survey.

Meekoceras pilatum Hyatt and Smith, sp. nov. (p. 144).

FIGs. 3, 4. Side and front views (natural size).

Fia. 5. Septa (natural size) of the same specimen.

Fics. 6, 7, 8. Side, front, and rear views (natural size) of a smaller specimen.

Frg. 9. Septa $(\times 2)$ of the same specimen.

From Lower Triassic, 1 mile west of Paris, Idaho. Locality No. 1981, U. S. Geol. Survey. 

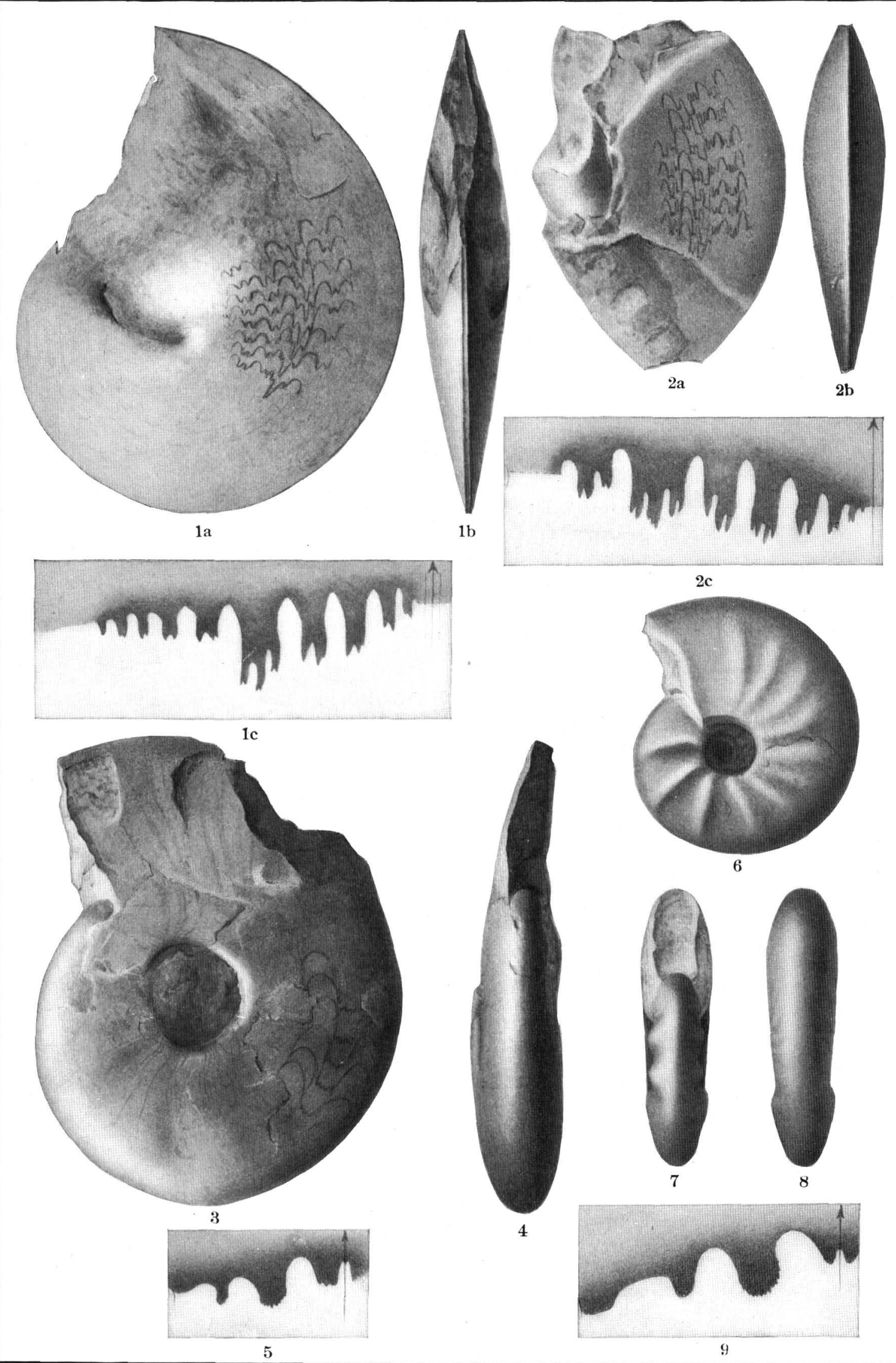

PSEUdOSAGECERAS INTERMONTANUM, MEEKOCERAS PILATUM. 


\section{P L A T E LXIV.}

Paralecanites Arnold Hyatt and Smith, sp. nov. (p. 136).

Fias. 1, 2, 3. Right side, front, and rcar views $(\times 2)$ of type specimen:

FIG. 4 . Septa $(\times 4)$ of the same.

Fig. 5. Cross section $\left(X^{2}\right)$.

Fics. 6, 7. Right side and front views $(\times 2)$, adolescent specimen; diameter $15 \mathrm{~mm}$.

Fig. 8. Septa $(x 4)$ of the same.

Figs. 9, 10, 11. Right side, front, and rear views $(X 3)$, adolescent stage; diameter $5 \mathrm{~mm}$.

Fig. 12. Septa $(\times 6)$ of the same.

Figs. 13, 14, 15. Left side, front, and rear views $(\times 3)$; diameter $3.36 \mathrm{~mm}$.

FIG. 16. Septa $(\times 6)$ of the same.

From Lower Triassic (Meekoceras beds), Wood Canyon, Aspen Ridge, 9 miles east of Soda Springs, Idaho.

Meekoceras (Grronites) aplanatum White (p. 146).

FIGs. 17, 18. Side and front views $\left(\times 1 \frac{1}{2}\right)$.

Fig. 19. Septa $(\times 4)$ of the same.

Figs. 20, 21. Side and front views $(\times 3)$, adolescent stage; diameter $14 \mathrm{~mm}$.

FIG. 22. Septa $(\times 6)$ of the same.

From Lower Triassic (Meekoceras beds), Wood Canyon, Aspen Ridge, 9 miles east of Soda Springs, ldaho. 


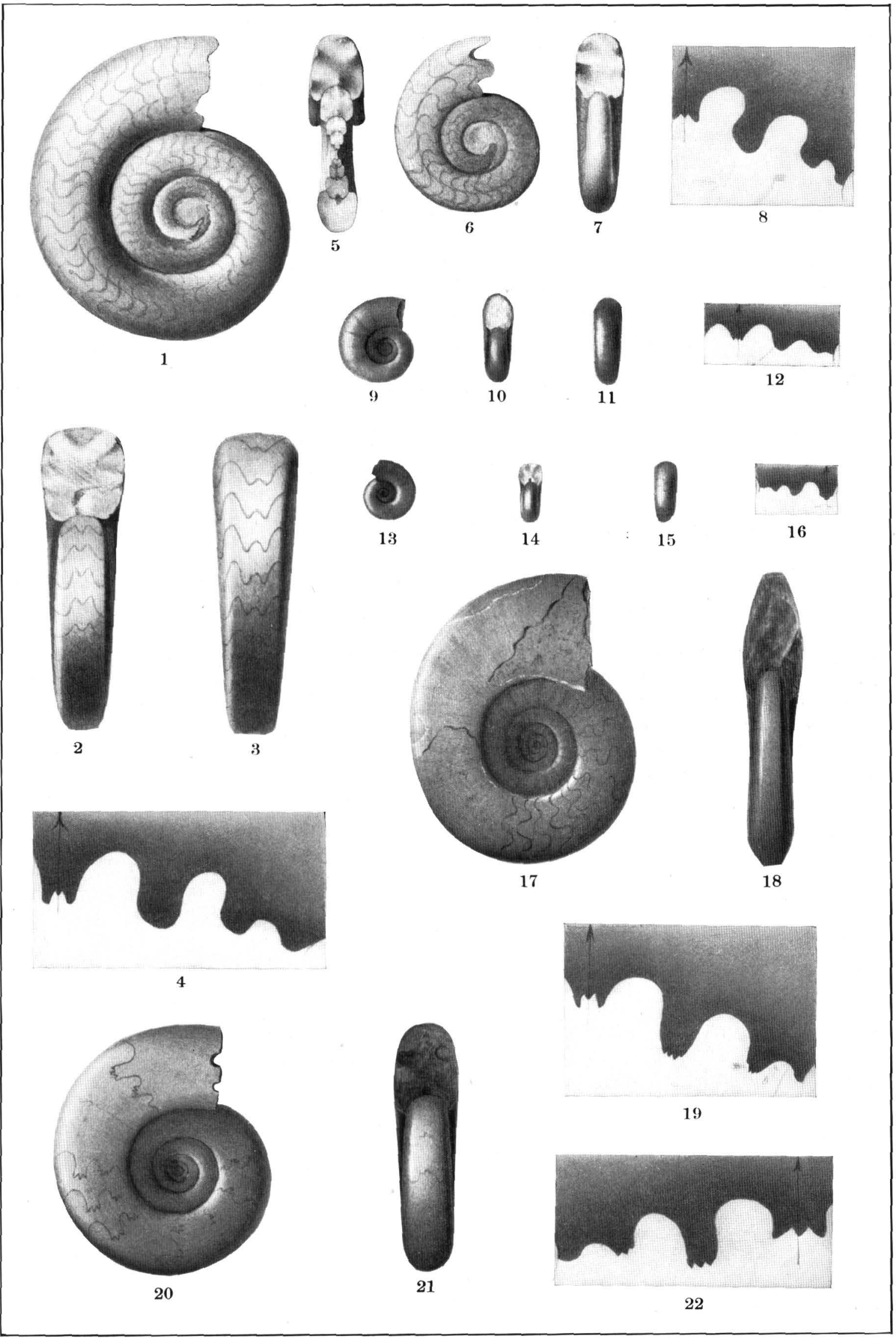

PARALECANITES ARNOLDI, MEEKOCERAS (GYRONITES) APLANATUM. 


\section{P L A T E L X V.}

Ussuria WaAgeni Hyatt and Smith, sp. nov. (p. 90).

FIG. 1. Side view of large specimen, showing the mature septa.

FIG. 2. Septa of the above specimen.

Frgs. 3, 4. Side and front views of a younger specimen; diameter $75 \mathrm{~mm}$.

Fra. 5. Septa of the same.

From Lower Triassic (Meekoceras beds), Wood Canyon, Aspen Ridge, 9 miles east of Soda Springs, Idaho.

346 


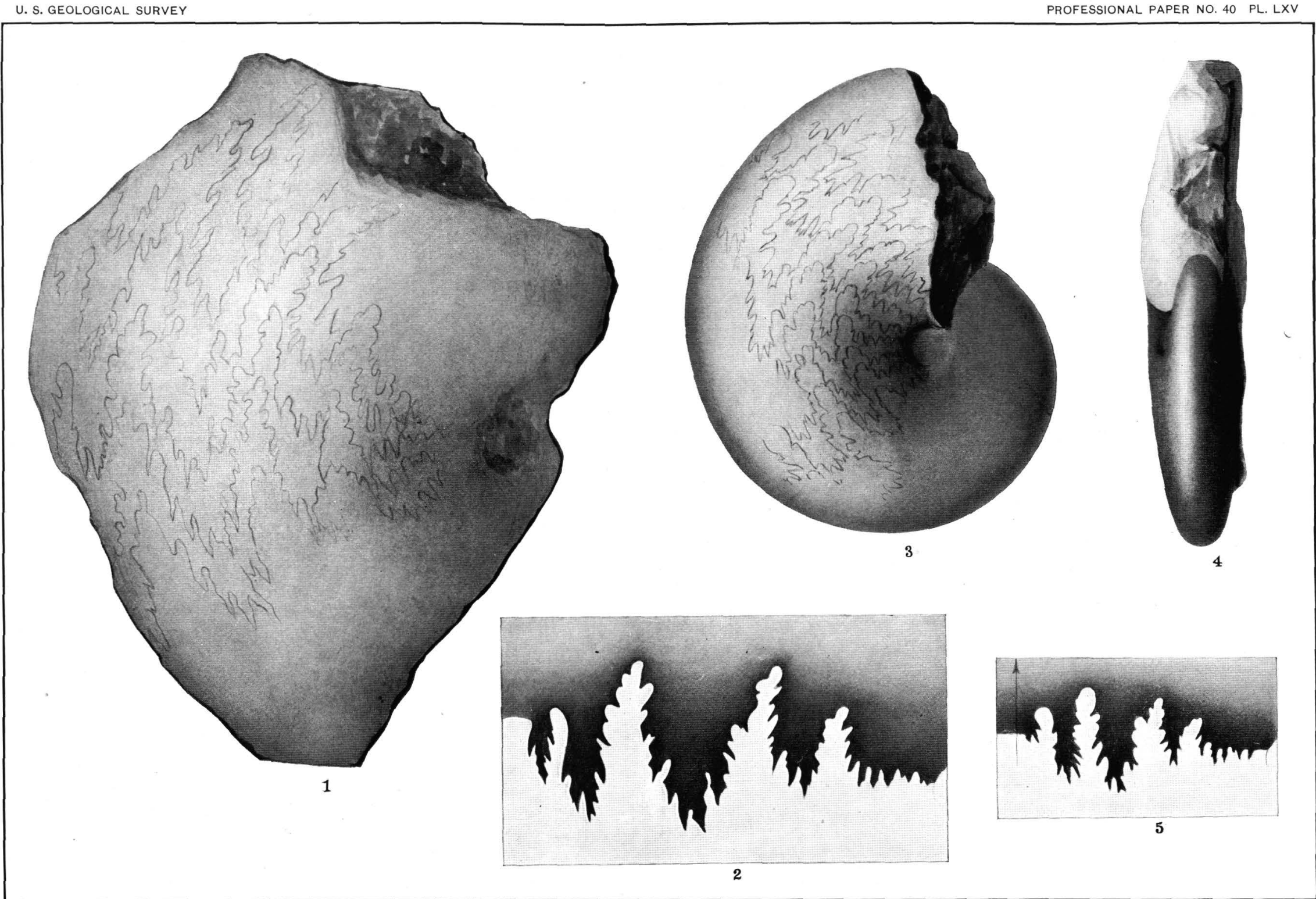

USSURIA WAAGENI. 


\section{PLA T E L X VI.}

Ussuria Waageni Hyatt and Smith, sp. nov. (p. 90).

Fics. 1, 2. Right side and rear views ( $\times 2$ ), adolescent stage, showing the early Ussuria stage; diameter 35 min.

Fiș. 3. Septa $(\times 2)$ of the same.

Figs. 4, 5. Right side and front views $(\times 2)$, adolescent stage; dianeter $30 \mathrm{~mm}$.

Fug. 6. Septa $(\times 2)$ of the same.

Figs. 7, 8. Side and front views, adolescent stage, showing transition from Thalassoceras to Ussuria; diameter $17 \mathrm{~mm}$.

FIG. 9. Septa $(\times 3)$ of the same.

FIgs. 10, 11. Right side and front views $(\times 3)$, Thalassoceras stage; diameter $13 \mathrm{~mm}$.

Fig. 12. Septa $(X \cdot 4)$ of the same.

From Lower Triassic (Meekoceras beds), Wood Canyon, Aspen Ridge, 9 miles east of Soda springs, Idaho. 


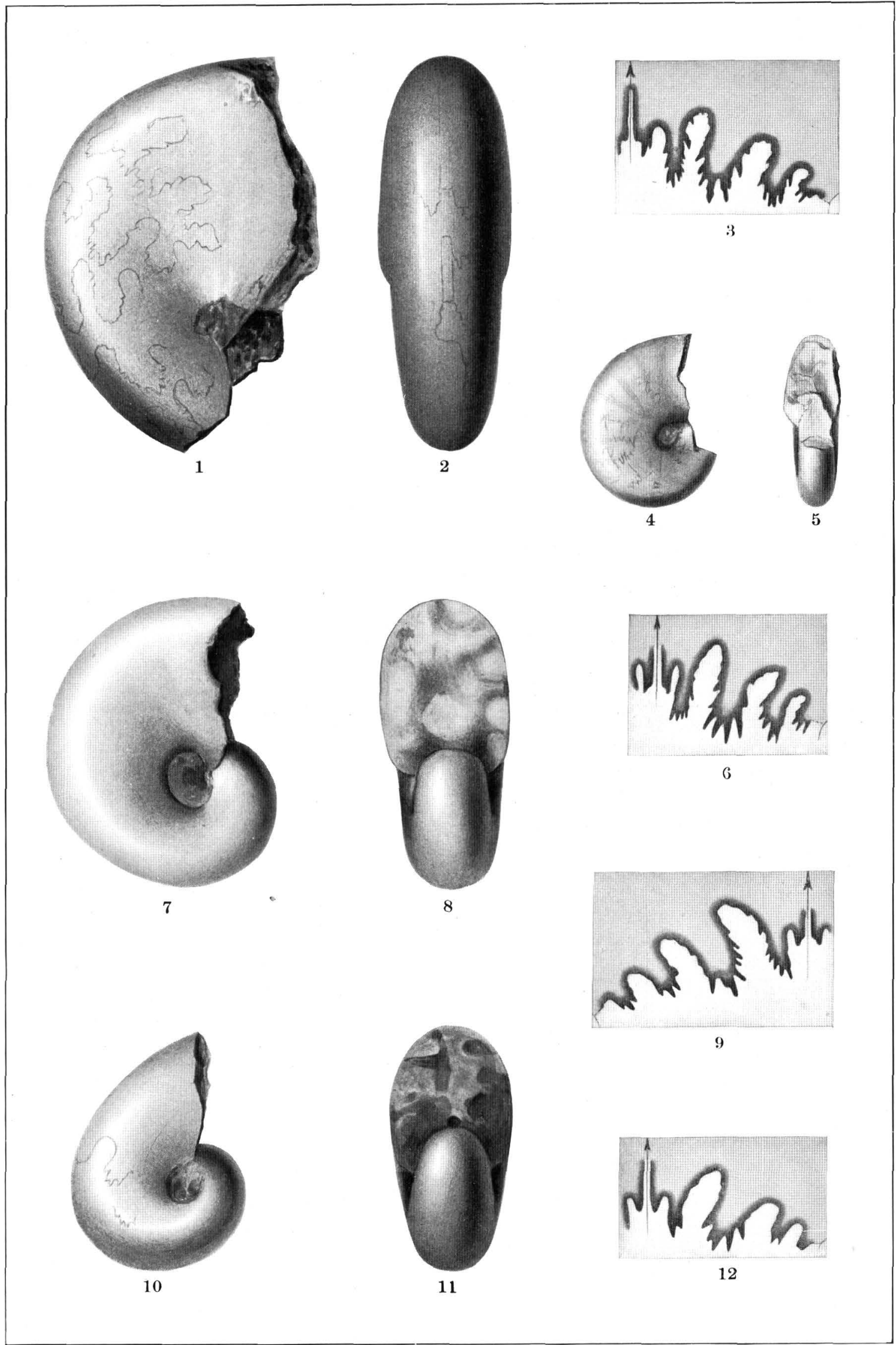

USSURIA WAAGENI. 


\section{PLA TE L X I I.}

Ussuria WaAgeni Hyatt and Smith, sp. nov. (p. 90).

Figs. 1, 2. Side and front views of a large specimen with the details of the septa somewhat obliterated by weathering.

From Lower Triassic (Meekoceras beds), Wood Canyon, Aspen Ridge, 9 miles east of Soda Springs, Idaho.

Hedenstromia Kossmati Hyatt and Smith, sp. nov. (p. 101).

-Figs. 3, 4, 5, 6. Left side, right side, front, and rear views of the type specimen.

Fia. 7 . Septa $(\times 2)$ of the same.

From Lower Triassic (Meekoceras beds). Wood Canyon, Aspen Ridge, 9 miles east of Soda Springs, Idaho. 


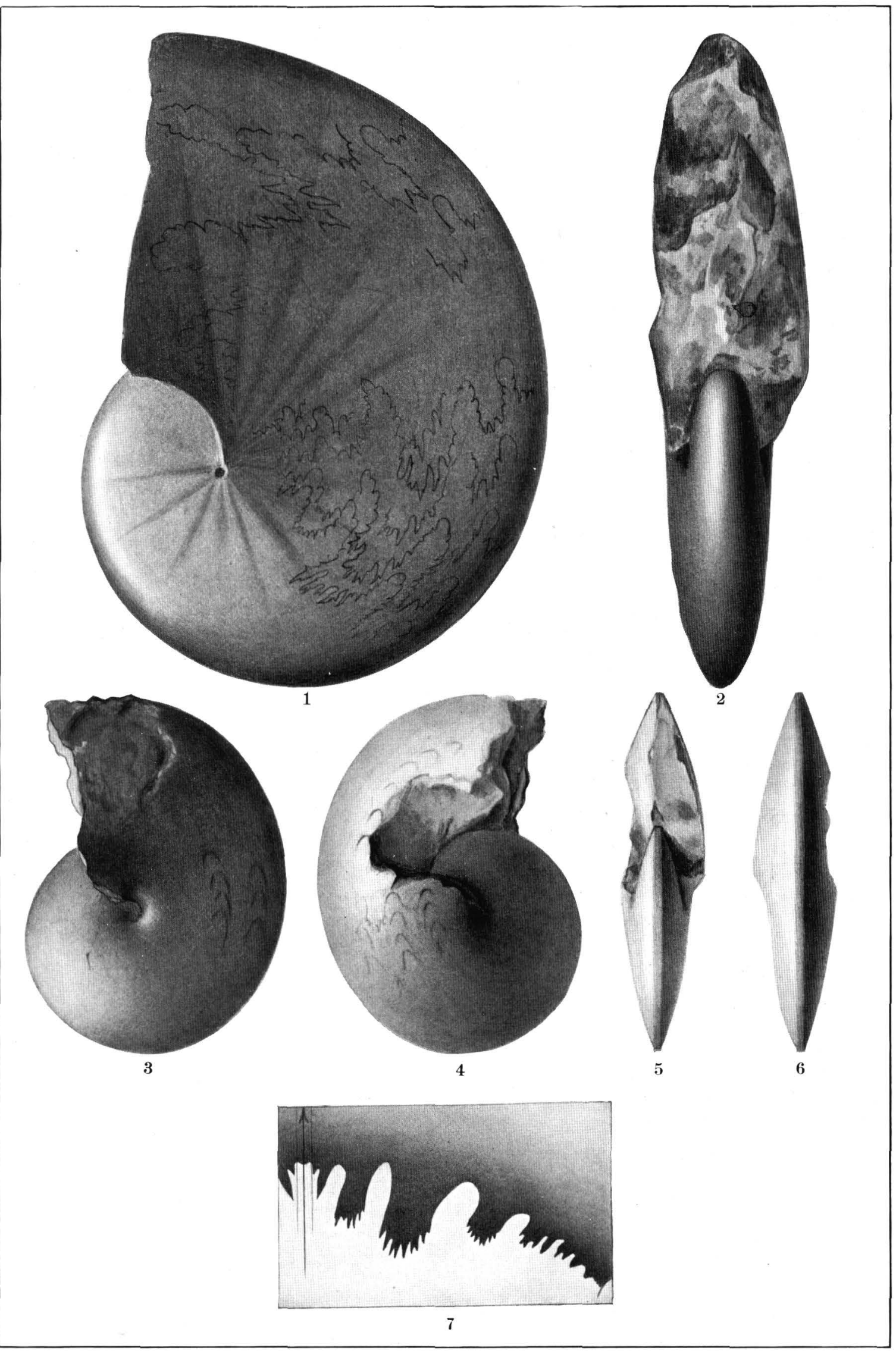

USSURIA WAAGENI, HEDENSTRCEMIA KOSSMATI. 


\section{PLA TE LX VIII.}

Cordillerites angulatus Hyatt and Smith, sp. nov. (p. 110).

Figs. 1, 2, 3. Side and front views and septa of a very large specimen; diameter $95 \mathrm{~mm}$.

FIGS. 4, 5, 6. Side view, front, and septa of a smaller specimen; diameter $80 \mathrm{~mm}$.

FIG. 7. Sirle view $(\times 3)$ of inner coil, inclosed in the above specimen; diameter about $20 \mathrm{~mm}$.

Figs. 8, 9. Right side and rear views $(\times 2)$, adolescent stage; diameter $25 \mathrm{~mm}$.

Fitr. 10. Septa $(\times 4)$ of the same.

From Lower Triassic (Meekoceras beds), Wood Canyon, Aspen Ridge, 9 miles east of Soda Springs, Idaho. 


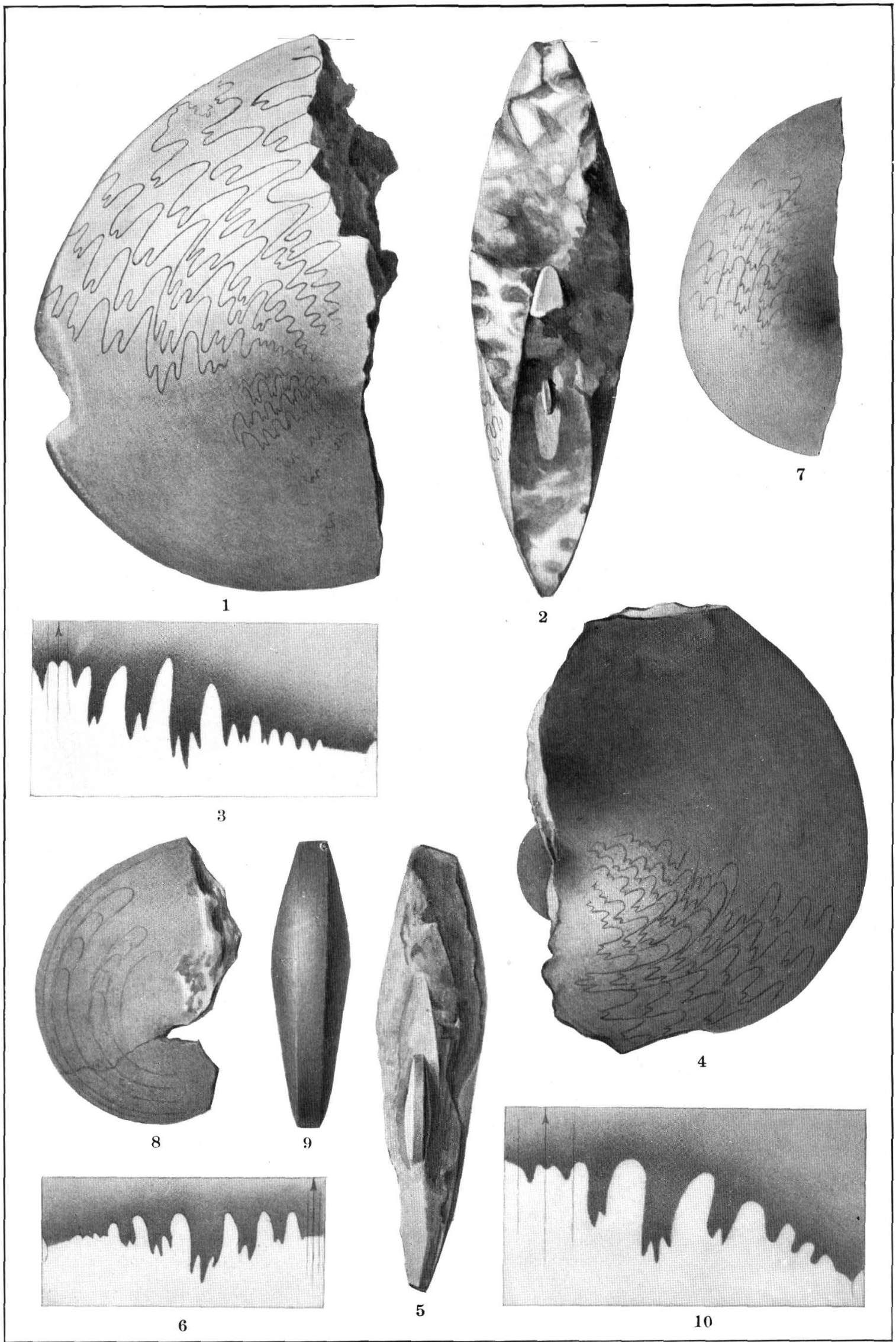




\section{PLA TE LXIX.}

InyotTes Oweni Hyatt and Smith, sp. nov. (p..134).

Fic. 1. Side view of large specimen showing the characteristic sculpture and the septa; diameter $90 \mathrm{~mm}$.

Ficis. 2, 3. Side and front views; diameter $72 \mathrm{~mm}$.

Figs. 4, 5, 6. Left side, front, and rear viuws $(\times 2)$, adolescent specimen; diameter $36 \mathrm{~mm}$.

Fics. 7, 8. Left side and front views $(\times 2)$, adolescent stage; diameter $27 \mathrm{~mm}$.

Fic. 9. Septa $(\times 4)$ of the same.

From Lower Triassic (Meckoceras beds), Union Canyon, 15 miles southeast of Independence, Inyo County, Cal.

$3 \tilde{4} 4$ 


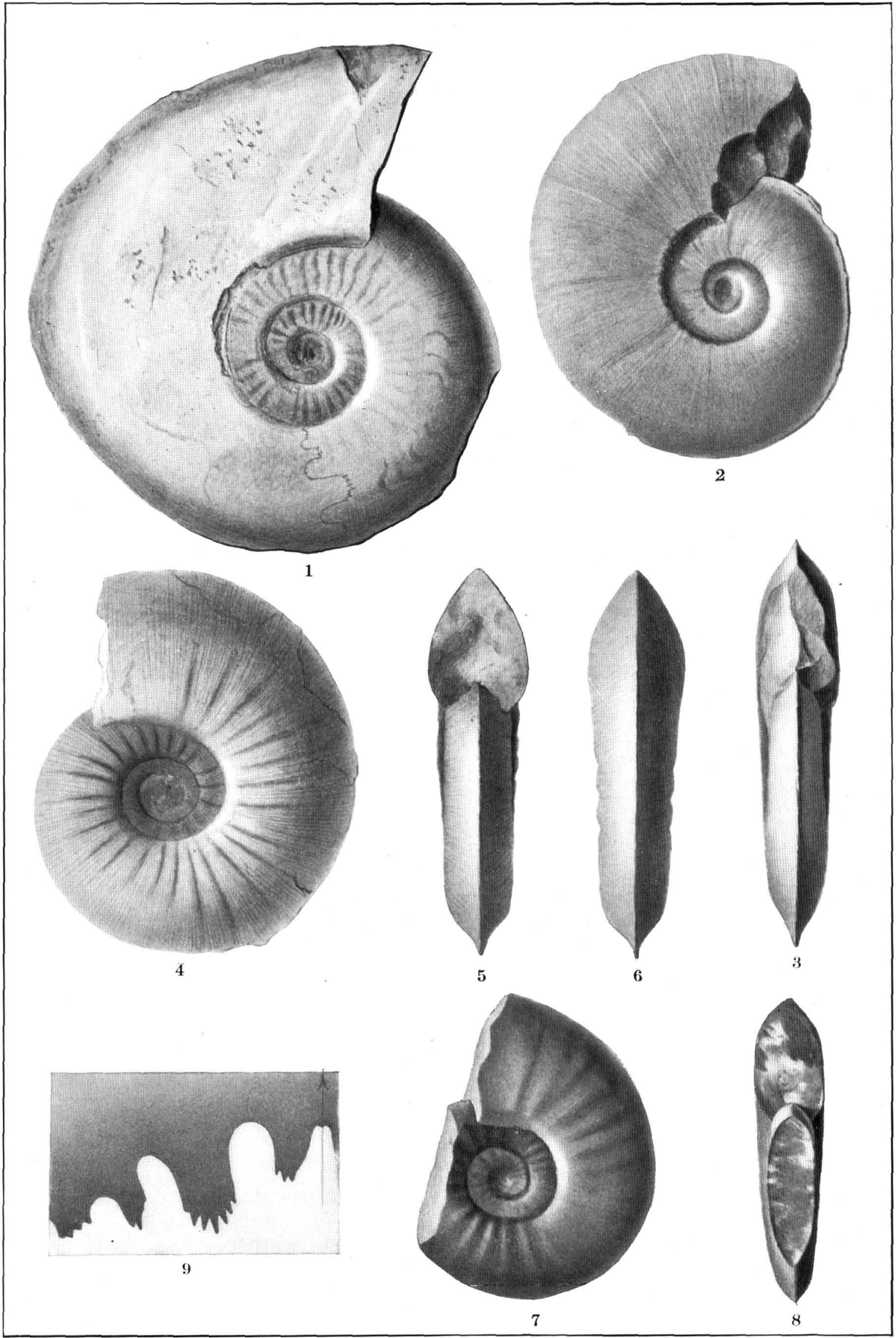

INYOITES OWENI. 


\section{PLATE LXX.}

Flemingites Russeld Hyatt and Smith, sp. nov. (p. 121).

Eıcs. 1, 2. Sirle and front views (natural size).

Fig. 3. Septa $(\times 2)$ of the same specimen.

From Lower Triassic (Meekoceras beds), Wood Canyon, Aspen Ridge, 9 miles east of Soda Springs, Idaho.

\section{Menooceras grachltatis White (p. 143).}

Figs. 4, 5. Side and front views, showing the full length of the body chamber; diameter $77 \mathrm{~mm}$.

Fris. 6, 7. Side and front views, showing the radial folds; diameter $67 \mathrm{~mm}$.

From Lower Triassic (Meekoceras beds), Wood Canyon, Aspen Ridge, 9 miles east of Soda Springs, Idaho.

Menkochras (Koninckites) mushiachanum White (p. i49).

Figs. 8, 9. Side and front views (natural size).

Fig. 10. Septa $(\times 2)$ of the same specimen.

From Lower Triassic (Meekoceras beds), Wood Canyon, Aspen Ridge, 9 miles east of Soda Springs, Idaho. 


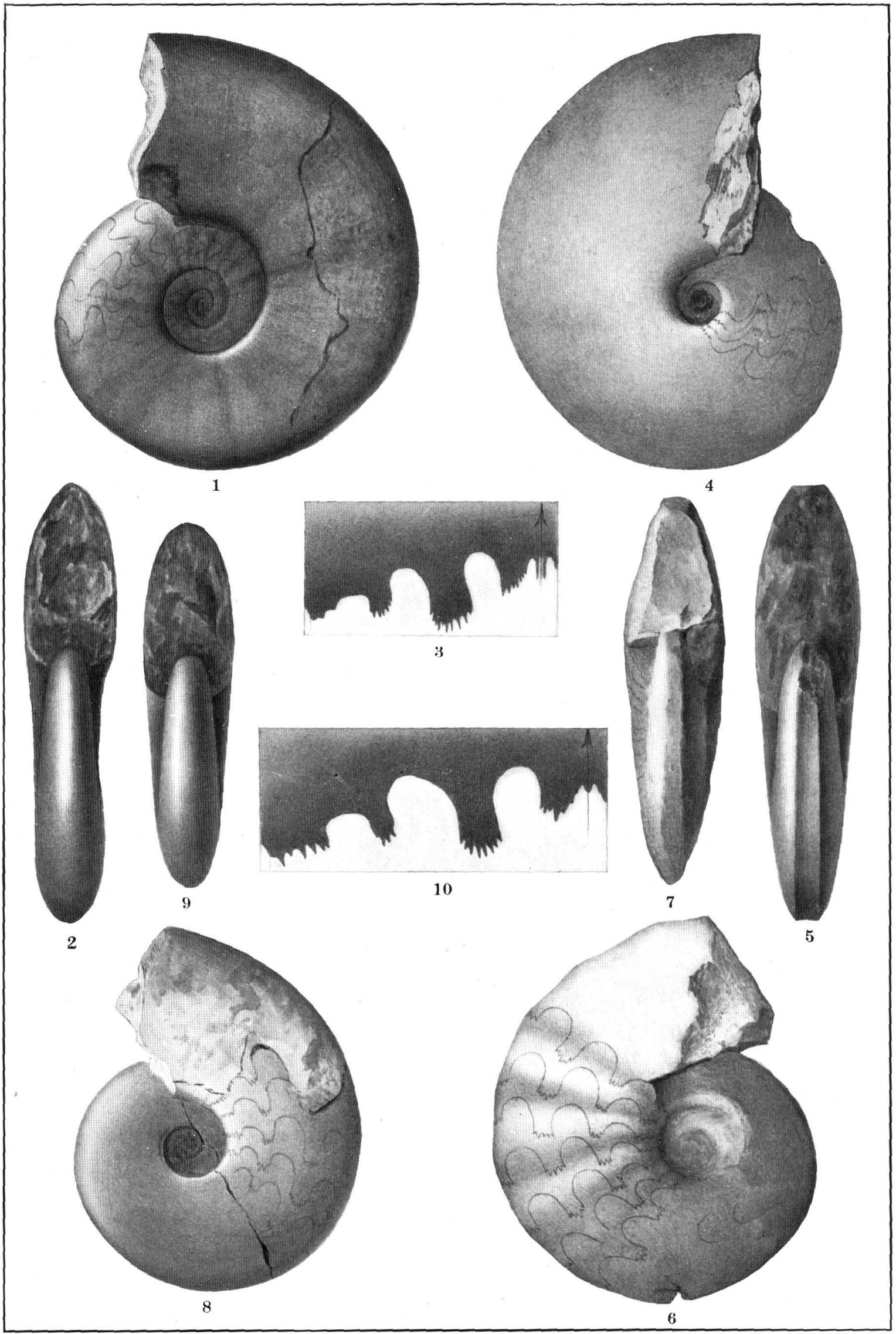

FLEMINGITES RUSSELLI, MEEKOCERAS GRACILITATIS, MEEKOCERAS MUSHBACHANUM. 


\section{PLA TE L X X I.}

Cordmlinites angulatus Hyatt and Smith (p. 110).

FIc. 1. Larval shell $(\times 8)$, showing development from Prolecanites to Pronorites stage; diameter $6.5 \mathrm{~mm}$.

FiG. 2. Septa $(\times 7)$, Sicanites stage; diameter $10 \mathrm{~mm}$.

Fic. 3. Septa $(X 7)$, showing Propinacoceras stage; diamster $11 \mathrm{~mm}$.

Fic. 4. Septa $(\dot{X} 7)$; diameter $12 \mathrm{~mm}$.

FIG. 5. Septa $(\times 7)$, showing transition from Propinacocerss to Cordillerites; diameter $17 \mathrm{~mm}$.

FIs. 6. Adult stage $\left(\times 1 \frac{1}{2}\right)$, showing Cordillerites characters.

From Lower Triassic (Meekoceras beds), Wood Canyon, 9 miles east of Sorla Springs, Idaho.

FIG. 7. Pronorites mixolobus, to show the tripartite first lateral .lobe of Pronorites (after de Koninek, Faune du Calcaire Carbonif. Belgique, II, p. 122, fig. 1).

Fic. 8, a.-h. Pronorites praepermicus Karpinsky, to show the development of the septa up to the Pronorites stage. (After Karpinsky, Ammoneen d. Artinsk-Stufe. Pl. I, fig. $2, f-n$. )

Fia. 9. Sicanites Mojscari Gemmellaro, to show the Sicanites stage, (after Frech, Lethrea Palaeozoica, Bd. 2, Lieferung 3, PI. LIX $d$, fig. $2 a$ ).

Fra. 10. Propinacoceras Beyrichi Gemmellaro, to show the Propinacoceras stage, (after Frech, Lethea Palæozoica, Bd. 2, Lieferung 3, p. 476, fig. 8).

358 

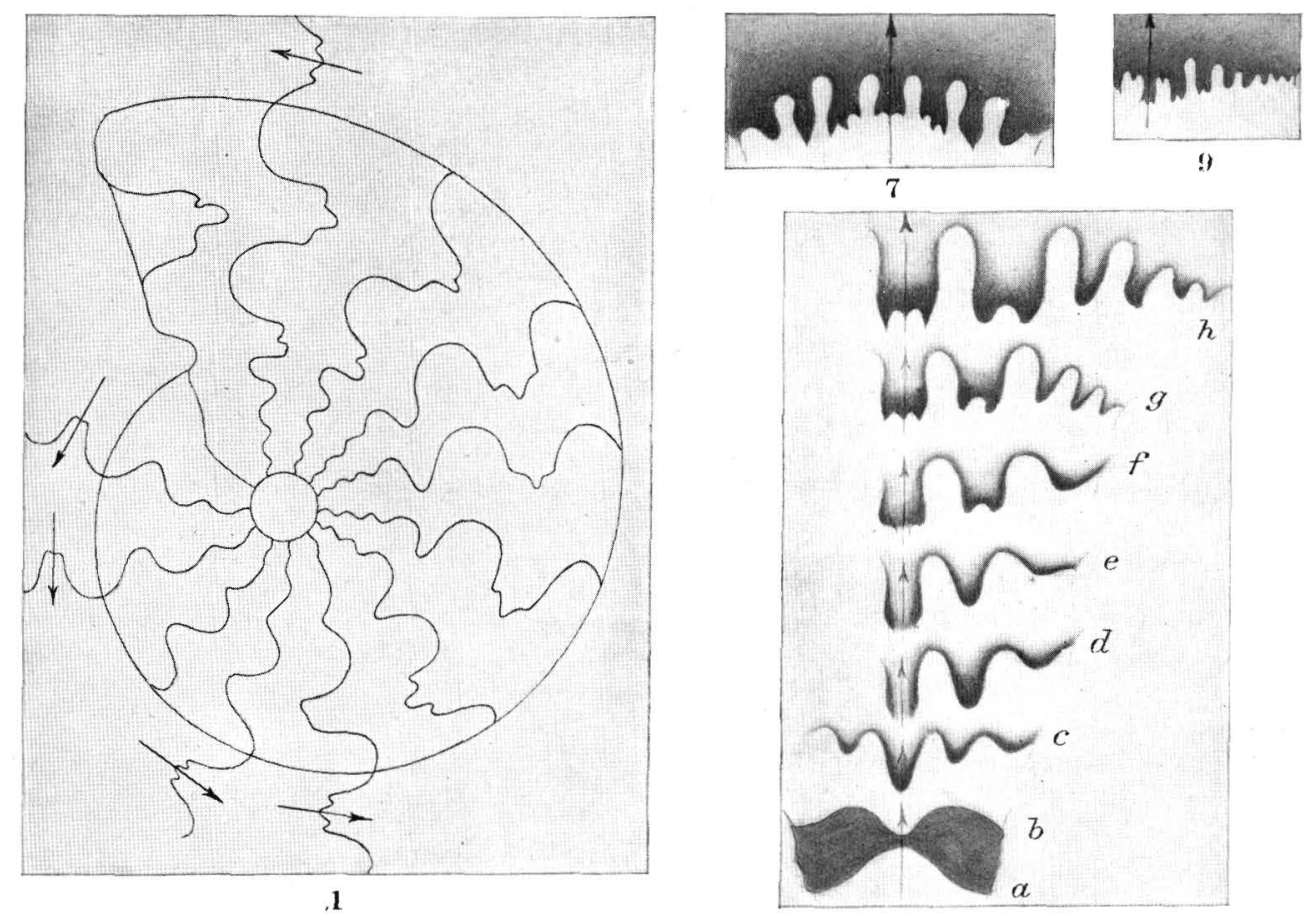

7

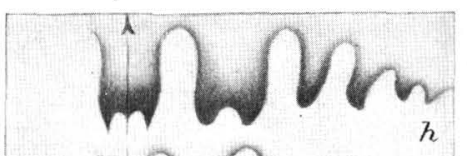

nhns
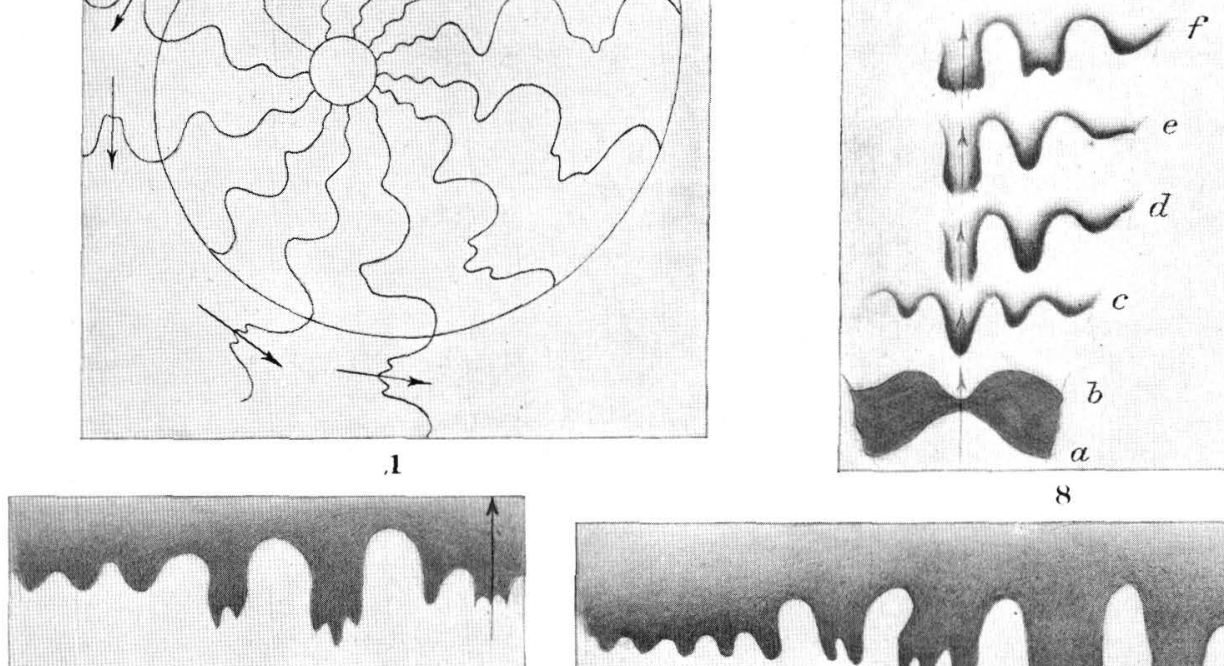

2

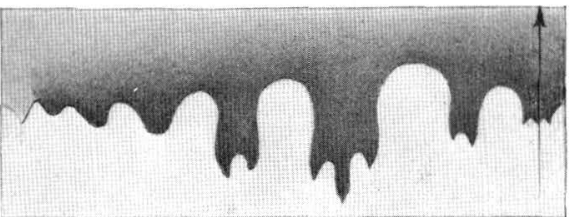

:3
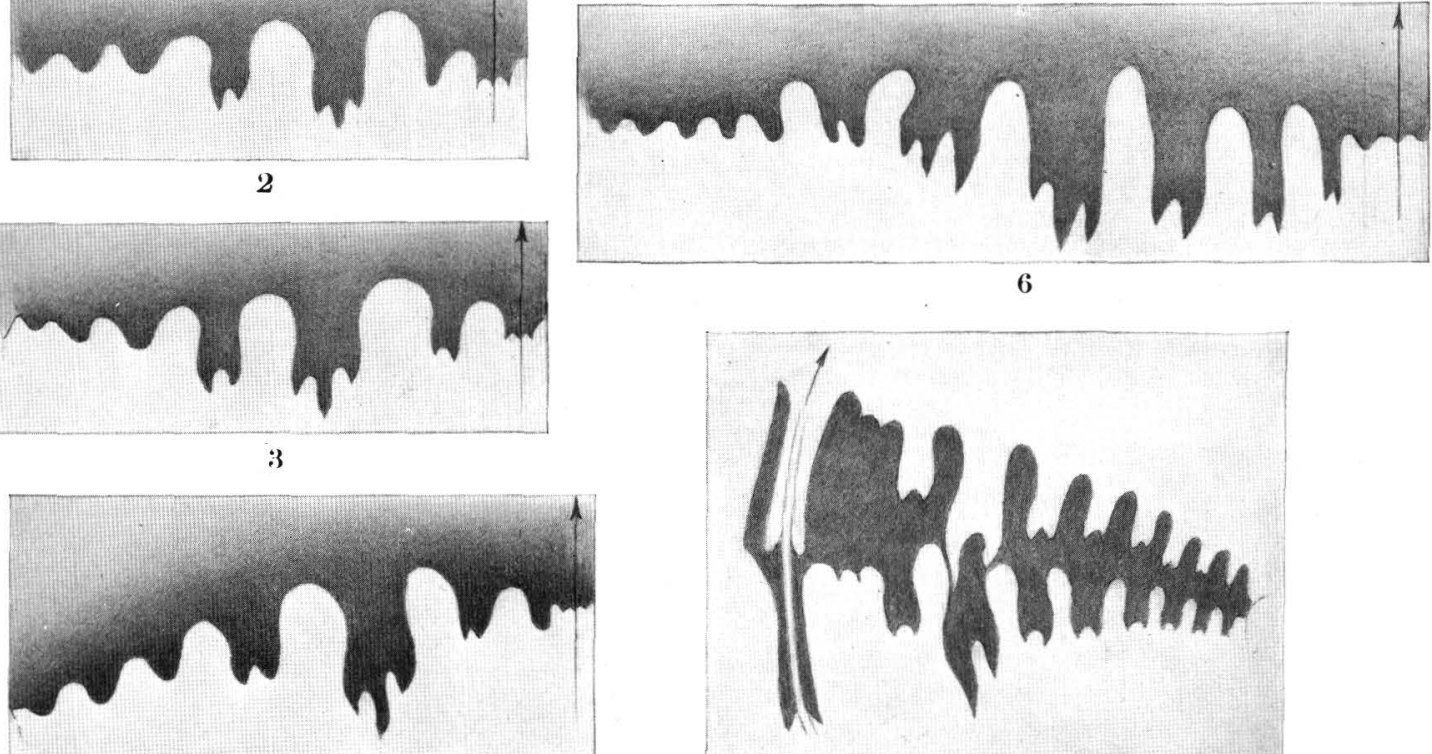

6

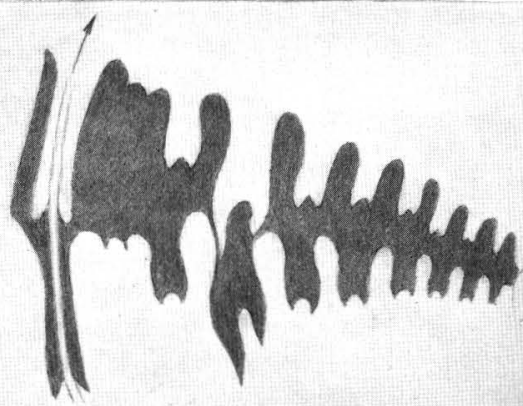

4

10

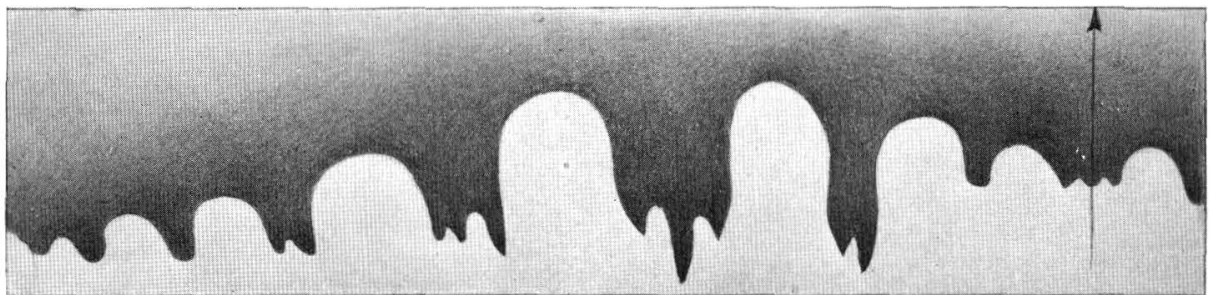

5 


\section{PLATE LXXII.}

Columbites Parisianus Hyatt and Smith, sp. nov. (p. 51).

Figs. 1, 2, 3, 4. Protoconch and three chambers $(\times 30)$; diameter $0.50 \mathrm{~mm}$. Fig. 1 from front, fig. 2 from right side, fig. 3 from below, and fig. 4 from above.

Figs. 5, 6. Protoconch and two-thirds of a revolution of the larval shell $(\times 30)$; diameter 0.75 mm. Fig. 5 from front, fig. 6 from right side.

Figs 7, 8, 9. Teft side, front, and rear views, larval stage; liameter $1.50 \mathrm{~mm}$.

Figs. 10, 11, 12. Right side, front, and rear views, larval stage; diameter $1.75 \mathrm{~mm}$.

Figs. 13, 14, 15. Right side, front, and rear views $(\times 10)$, larval stage; dianeter $3 \mathrm{~mm}$.

FIGs. $16,17,18$. Right side, front, and rear views $(X 4)$, adolescent stage; diameter $8.50 \mathrm{~mm}$.

Figs. 19, 20, 21. Left side, front, and rear views $(\times 3)$, adolescent stage; diameter $10 \mathrm{~mm}$.

Figs. 22, 23, 24. Left side, front, and rear views $(\times 2)$, adolescent stage; diameter $15 \mathrm{~mm}$.

From Lower Triassic (Colmmbites beds), 1 mile west of Paris, Idaho. Collection of U. S. Geol. Survey. 


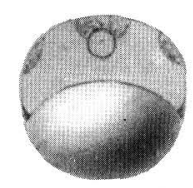

1
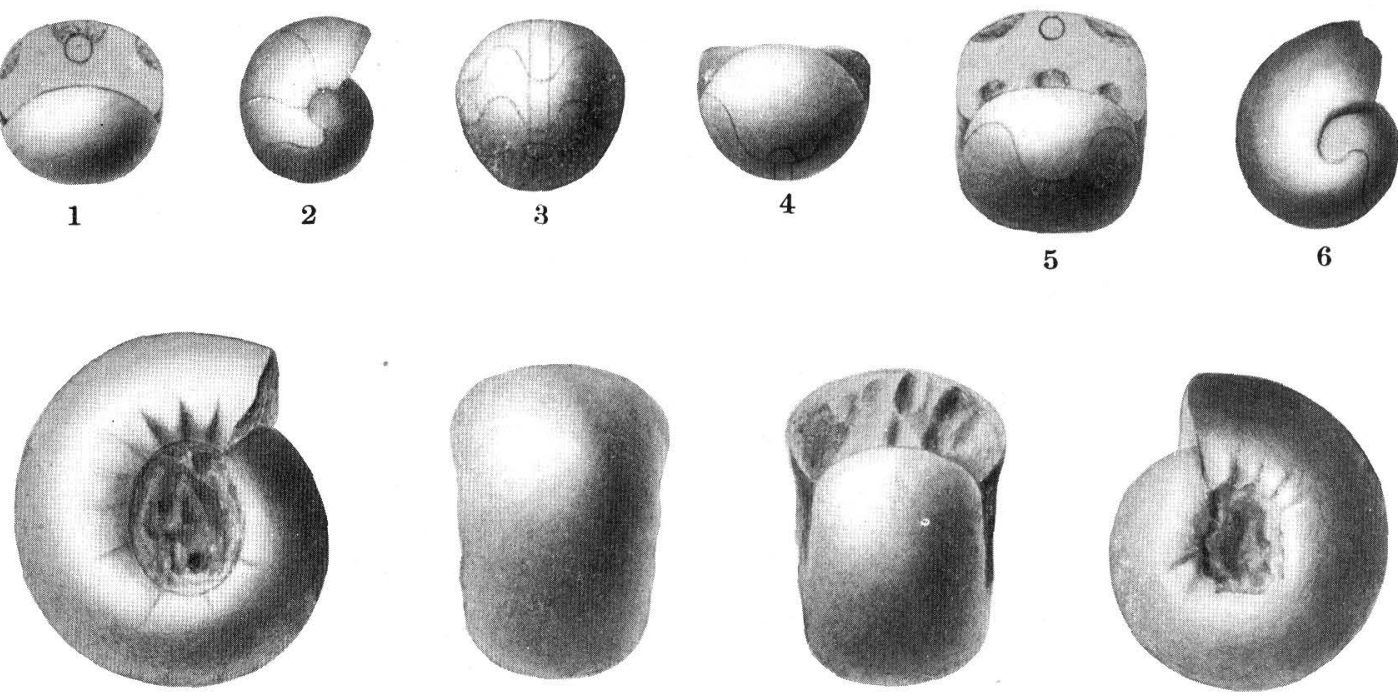

10

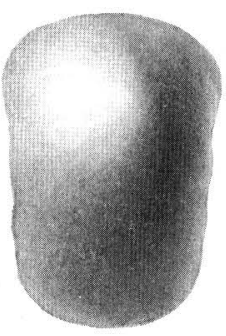

9

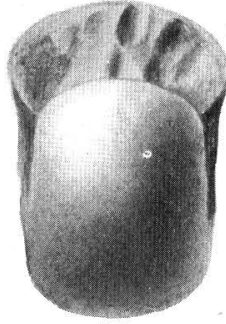

8

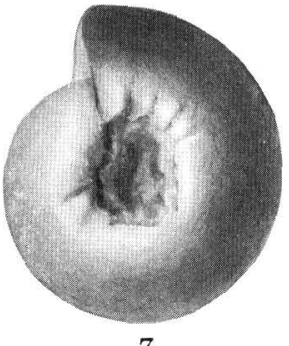

7

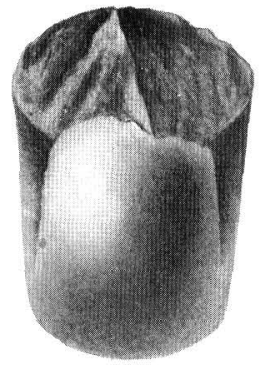

11

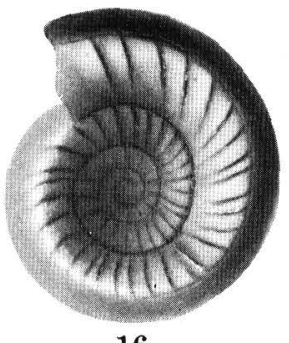

16
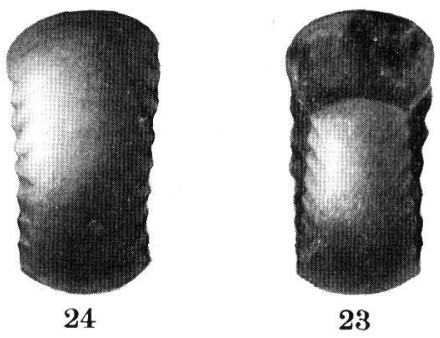

23

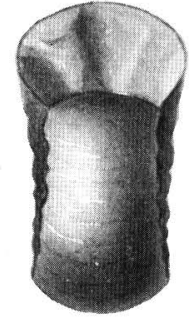

17
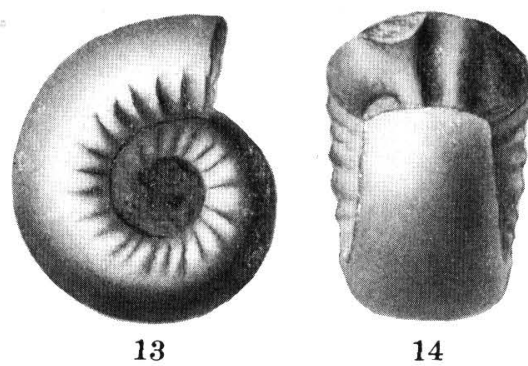

14

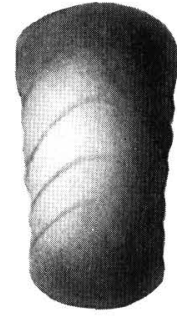

18

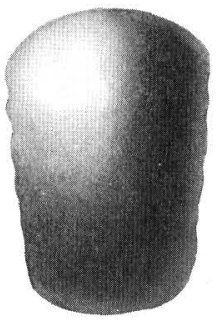

15

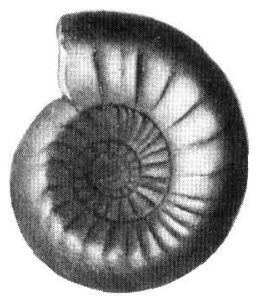

19 


\section{PLATE LXXIII.}

Paranannites aspenensis Hyatt and Smith, sp. nov. (p. 81).

Figs. 1, 2. Left side and front views $(\times 2)$ of the type specimen.

FIG. 3. Septa $(\times 4)$ from above specimen.

FIGs. 4, 5. Right side and front views $(X 2)$ of a smaller specimen.

Fig. 6. Septa $(\times 4)$ of the same specimen with the inner septa drawn frcm a piece broken off the coil.

Ficis. 7, 8. Ieft side and front views $(\times 2)$; diameter $12 \mathrm{~mm}$.

Fic. 9. Septa $(\times 4)$ from the above.

Figs. 10, 11. Right side and front views $(\times 3)$; diameter $9 \mathrm{~mm}$.

FIG. 12. Septa $(\times 6)$ of the same.

Fics. 13, 14, 15. Left side, front, and rear vicws $(\times 4)$, Nannites stage; diameter $7 \mathrm{~mm}$.

Fig. 16. Septa $(\times 6)$ of the same.

Figs. 17, 18. Right side and front views $(X 4)$, Nannites stage; diameter $5.5 \mathrm{~mm}$.

Figs. 20, 21. Right side and front views $(\times 5)$, Nonnites stage; diameter $3.88 \mathrm{~mm}$.

Fig. 22. Septa $(\times 10)$ of the same.

FIGs. 23, 24. Right side and front views $(\times 5)$, Pronannites stage; diameter $2.5 \mathrm{~mm}$.

Fic. 25. Septa $(\times 10)$ of the same.

FIas. 26, 27, 28. Right side, front, and rear views $(\times 30)$, transition from Parodoceras to Promannites stage; diameter $1.40 \mathrm{~mm}$.

Fias. 29, 30. Side and front views $(\times 30)$, early larval stage showing the latisellate first septum; diameter $0.5+$ num.

From Lower Triassic (Meekoceras beds), Wood Canyon, Aspen Ridge, 9 miles east of Soda Springs, Idaho. Collection of U. S. Geol. Survey. 


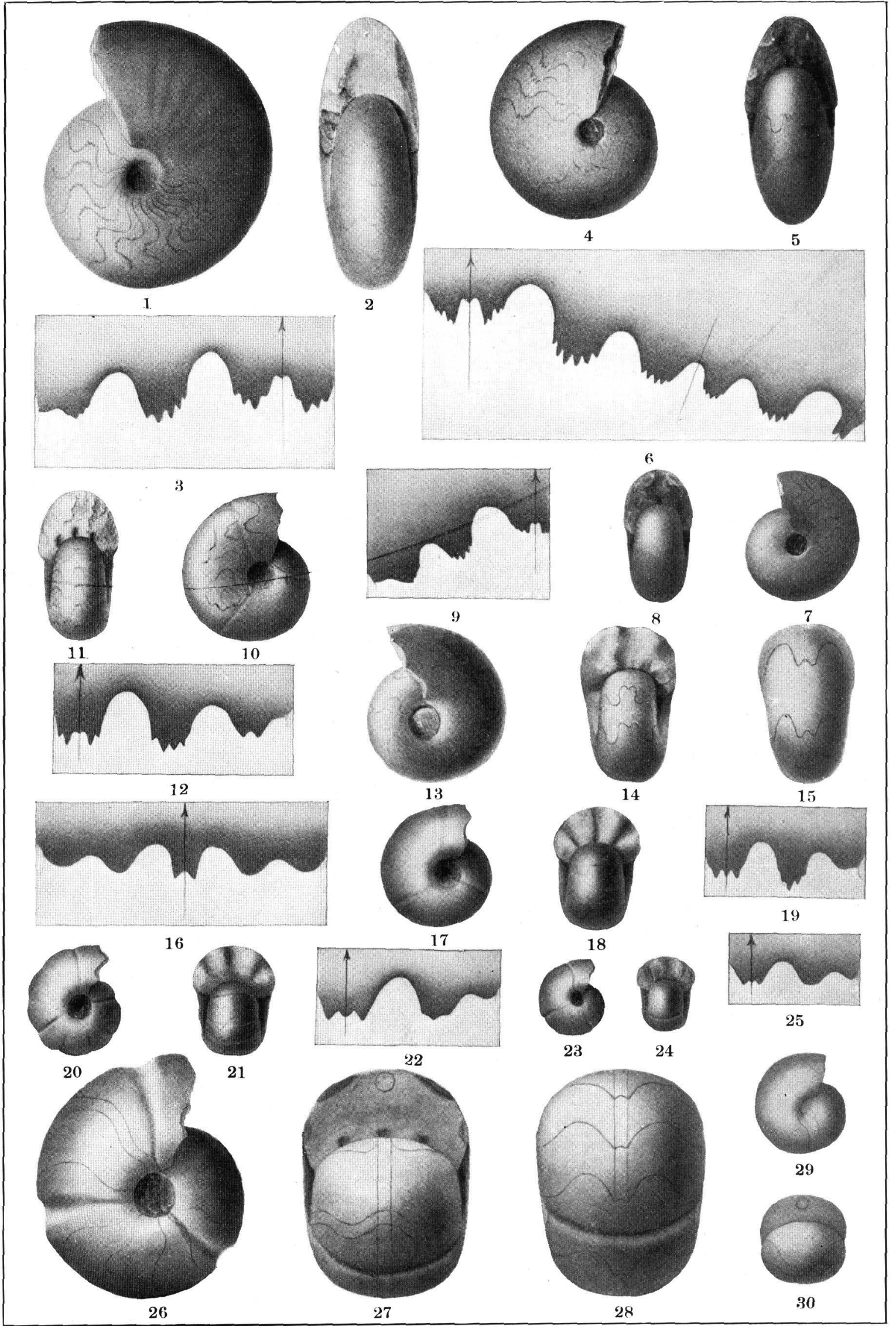

PARANANNITES ASPENENSIS. 


\section{PLATE LXXIV.}

Trachyceras (Anotaties) Meeki Mojsisovics (p. 196).

Figs. 1, 2, 3. Side, front, and rear views.

Figs. 4, 5. Side and rear views, adolescent stage; diameter $23 \mathrm{~mm}$.

Figs. 6,7. Side and front views $(\times 2)$, earlier adolescent stage, broken whorl, showing the larval stage inside; diameter $13 \mathrm{~mm}$.

From Middle Triassic, West IIumboldt Range, Nevada; figs. 1-3, from Cottonwood Canyon near "Lucky Dog" mine; figs. 4-7, from divide betwecn Troy Canyon and South Fork of American Canyon. Collection of J. P. Smith.

\section{Sagechras Gabbi Mojsisovies (p. 97).}

Figs. 8, 9. Side and front views of an old specimen.

From Middle Triassic, from divide between Troy Canyon and South Fork of American

Canyon, West Humboldt Range, Nevada. Collection of J. P. Smith.

Sibyllites Louderbacki Hyatt and Smith (p. 58).

Ficis. 10, 11. Side and front views (natural size).

FIG. 12. Septa $(\times 31)$.

From Middle Triassic, from divide between Troy Canyon and South Fork of American Canyon, West Humboldt Range, Nevada. Collection of J. F. Smith. 


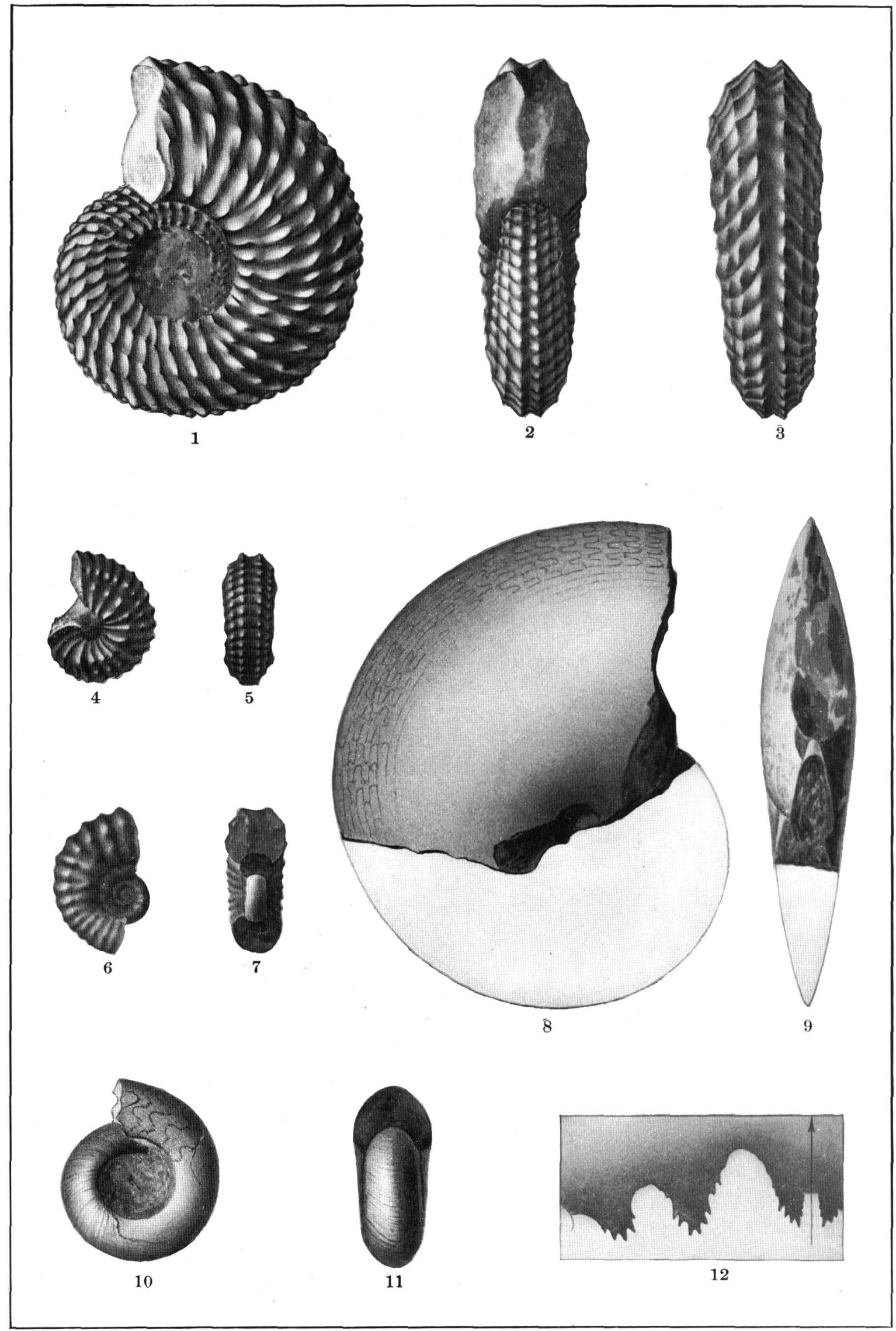

TRACHYCERAS MEEKI, SAGECERAS GABBI, SIBYLLITES LOUDERBACKI. 


\section{PLATE LXXV.}

\section{Celtites Halli Mojsisovics (p. 125).}

FIg. 1. Cross section (natural size), mature specimen.

Fig. 1-a. Inner whorls (enlarged) of the same.

Fias. 2, 3. Adolescent stage $(\times 2)$; diameter $13 \mathrm{~mm}$.

Figs. 4, 5. Adolescent stage $(\times 4)$; diameter $7 \mathrm{~mm}$.

From Middle Triassic, on the divide between Troy Canyon and the South Fork of American Canyon, West Humboldt Range, Nevada. Collection of J. P. Smith.

Longobardites nevadanus Hyatt and Smith (p. 132).

Fias. 6, 7. Enlarged twice.

Figs. 8, 9. Side view $(\times 6)$ and septa $(\times 12)$, larval stage; diameter $4 \mathrm{~mm}$.

From Middle Triassic, on the divide between Troy Canyon and the South Fork of American Canyon, West Humboldt Range, Nevada. Collection of J. P. Smith.

Lecanites Vogdesi Hyatt and Smith (p. 139).

Frc. 10. Side view, early adult stage; diameter $23 \mathrm{~mm}$.

Figs. 11, 12, 13. Side, front, and rear views $(\times 10)$, larval stage, corresponding to Paralecanites; diameter $2.36 \mathrm{~mm}$.

From Middle Triassic, on the divide between Troy Canyon and the South Fork of American Canyon, West Humboldt Range, Nevada. Collection of J. P. Smith.

Sagieceras Gabbi Mojsisovics (p. 97).

Fig. 14. Side view $(\times 2)$, adolescent stage; diameter $18 \mathrm{~mm}$.

Fig. 15. Septa $(\times 4)$ from the samé.

From Middle Triassic, on the divide between Troy Canyon and the South Fork of American Canyon, West Humboldt Range, Nevada. Collection of J. P. Smith. 

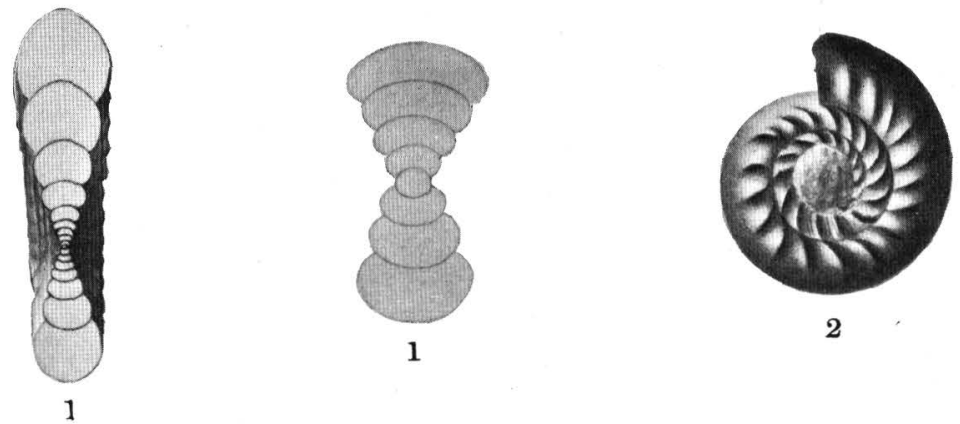

2
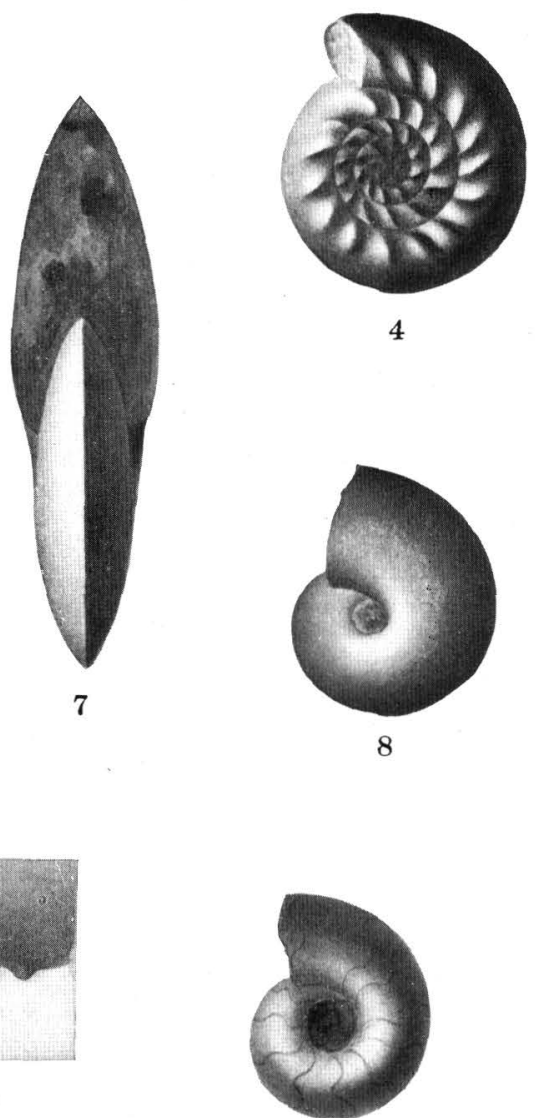

11

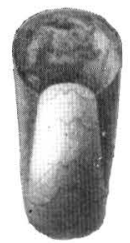

12

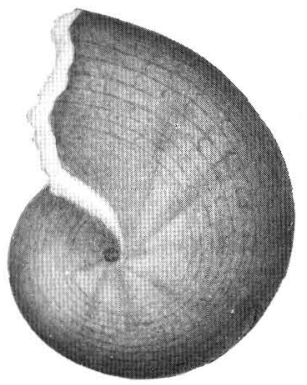

14
4
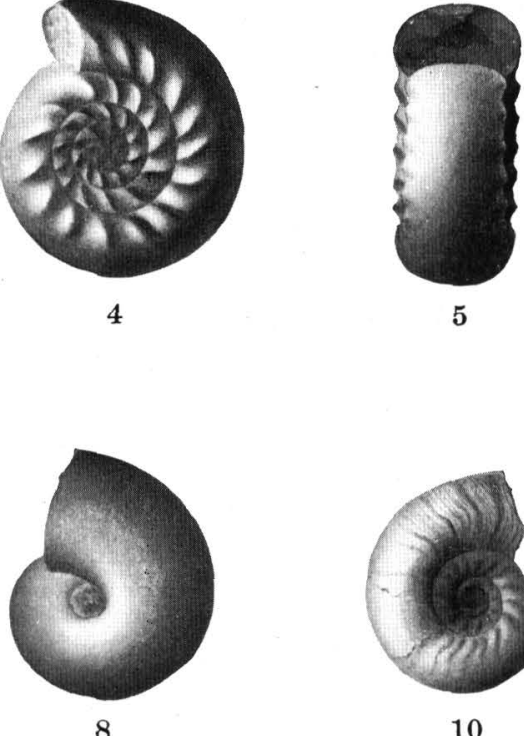

5

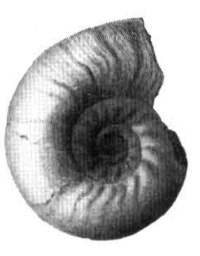

10

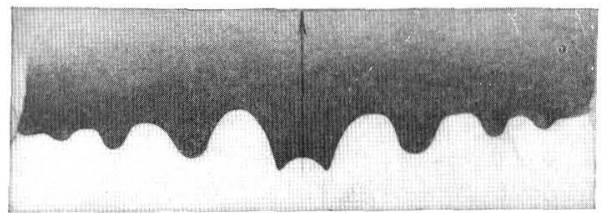

9

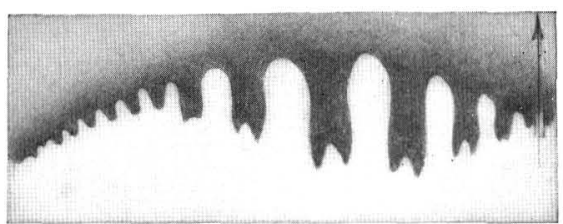

15

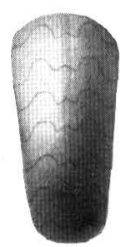

13

CELTITES HALLI, LONGOBARDITES NEVADANUS, LECANITES VOGDESI, SAGECERAS GABBI. 


\section{PLATE LXXVI.}

\section{Popanoceras (Parapopanoceras) Haugi Hyatt and Smith (p. 71).}

FIgs. 1, 2, 3. Side, frọt, and rear views.

FIG. 4. Septa $(\times 3)$ of another specimen.

- Figs. 5, 6. Side and front of a smaller specimen.

FiG. 7. Septa $(\times 3)$ of the above specimen.

Figs. 8,9 . Side and front $(\times 2)$ broken so as to show the inner whorls.

Fig. 10. Septa $(X 4)$ of the above specimen.

FIgs. 11, 12, 13, 14. Side, front, and rear views $(\times 3)$ and septa $(\times 6)$, adolescent stage, corresponding to Popanoceras; diameter $9.5 \mathrm{~mm}$.

FIGs. 15, 16, 17. Side and front $(\times 6)$ and septa $(\times 12)$, early adolescent (Adrianites) stage; diameter $4.5 \mathrm{~mm}$.

Figs. 18, 19, 20. Side and front $(X 10)$ and septa $(\times 20)$, larval (Paralegoceras) stage; diameter $2.88 \mathrm{~mm}$.

FIGs. 21, 22. Rear $(\times 10)$ and septa $(\times 20)$ larval (Gastrioceras) stage.

From Middle Triassic, Union Wash, Inyo Range, Inyo County, Cal. Collection United States National Museum. 

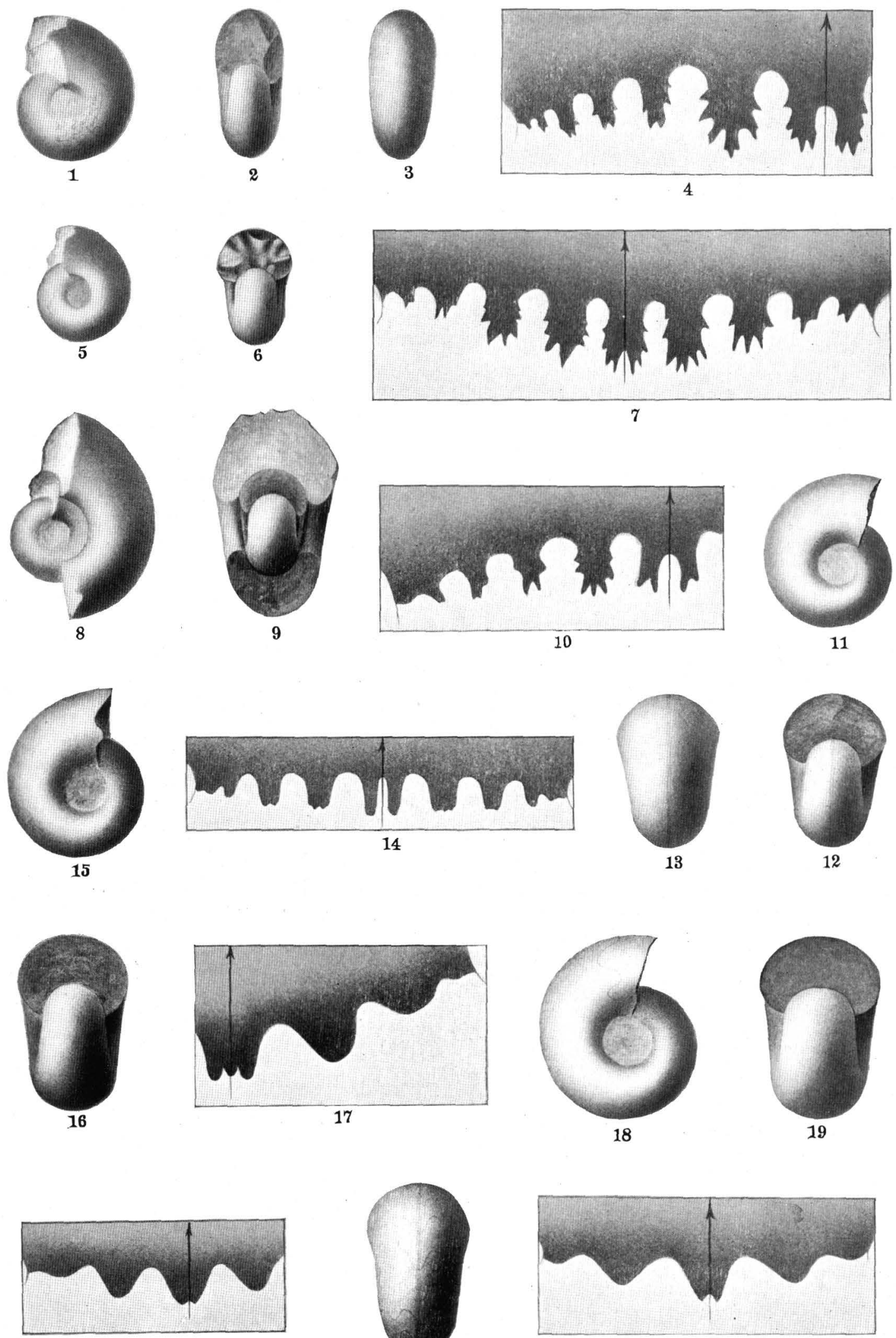

22
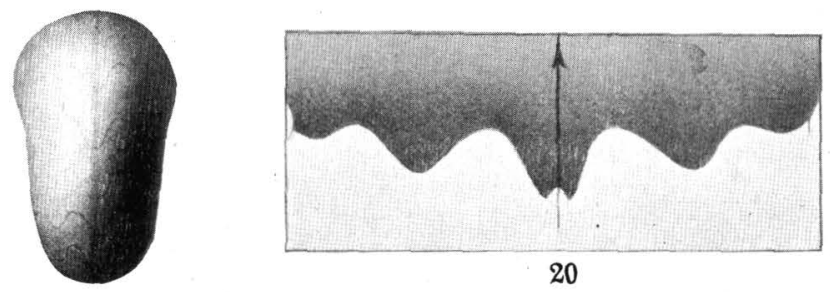

21

POPANOCERAS HAUGI. 


\section{P L A TE LXXVII.}

Mefooceras (Grronites) aptanatum White (p. 146).

Figs. 1, 2. Side view (natural size) and septa $(\times 2)$.

From Lower Triassic, Union Wash, Inyo Range, Inyo County, Cal. Collection United States National Museum.

Prionolobus Waageni Hyatt and Smith (p. 150).

Figs. 3, 4. Side and front view (natural size).

Fit. 5. Septa $(X 4)$ of the same.

Figs. 6, 7. Smaller specimen (natural size).

Fitr. 8. Septa $(X 4)$ of the same.

From Tower Triassic, Union Wash, Inyo Range, Inyo County, Cal. Collection United States National Museum.

Paralecanites Arnoldi Hyatt and Smith (p. 136).

Figs. 9, 10, 11. Adult stage $(\times 3)$.

Fia. 12. Septa $(\times 6)$ of the same specimen.

From Lower Triassic, Union Wash, Inyo Range, Inyo County, Cal. Collection United States National Museum.

370 

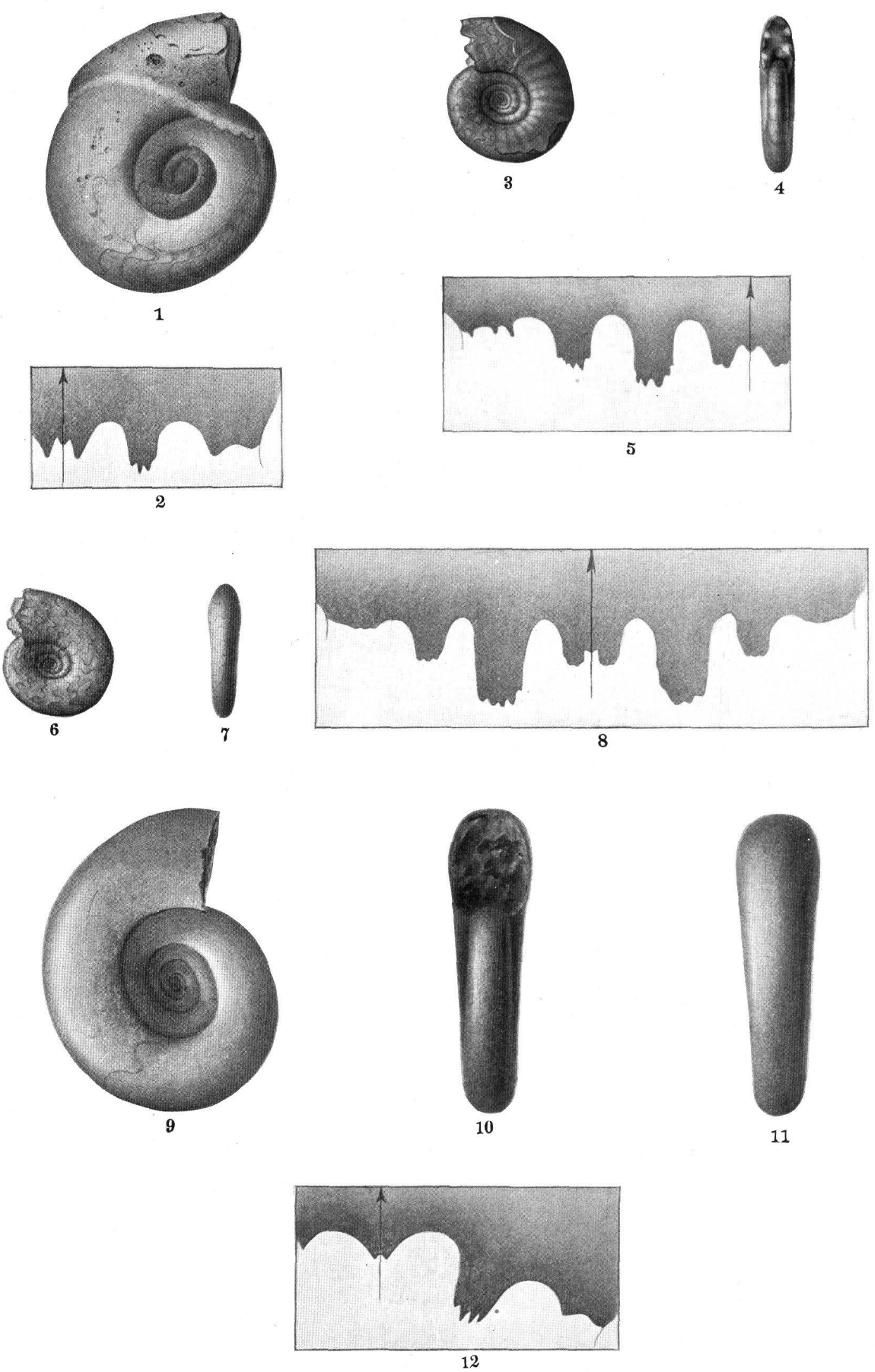

MEEKOCERAS APLANATUM, PRIONOLOBUS WAAGENI, PARALECANITES ARNOLDI. 


\section{PLA TE LXX VIII.}

InYoItes Oweni Hyatt and Smith (p. 134).

FIG. 1. Septa $(\times 3)$ of a young specimen; dianeter $3 \mathrm{~mm}$.

FIGs. 2, 3. Adolescent stage (natural size); diameter $33 \mathrm{~mm}$.

FIGs. 4,5. Above specimen $(\times 2)$, with one-third of a revolution removed, giving a diameter of $22 \mathrm{~mm}$.

Figs. 6, 7. The same specimen $(\times 3)$, with another third of a revolution removed, giving a diameter of $17 \mathrm{~mm}$.

Fig. 8. Septa $(\times 6)$ of the same.

From Lower Triassic, Union Wash, Inyo Range, Inyo County, Cal. · Collection United States National Museum.

Lanceolites compactus Hyatt and Smith (p. 113).

FIGs. 9, 10. Mature specimen (natural size); diameter $65 \mathrm{~mm}$.

FIG. 11. Septa $\left(\times 1 \frac{1}{2}\right)$ of the same specimen.

From Lower Triassic, Union Wash, Inyo Range, Inyo County, Cal. Collection United States National Museum.

372 

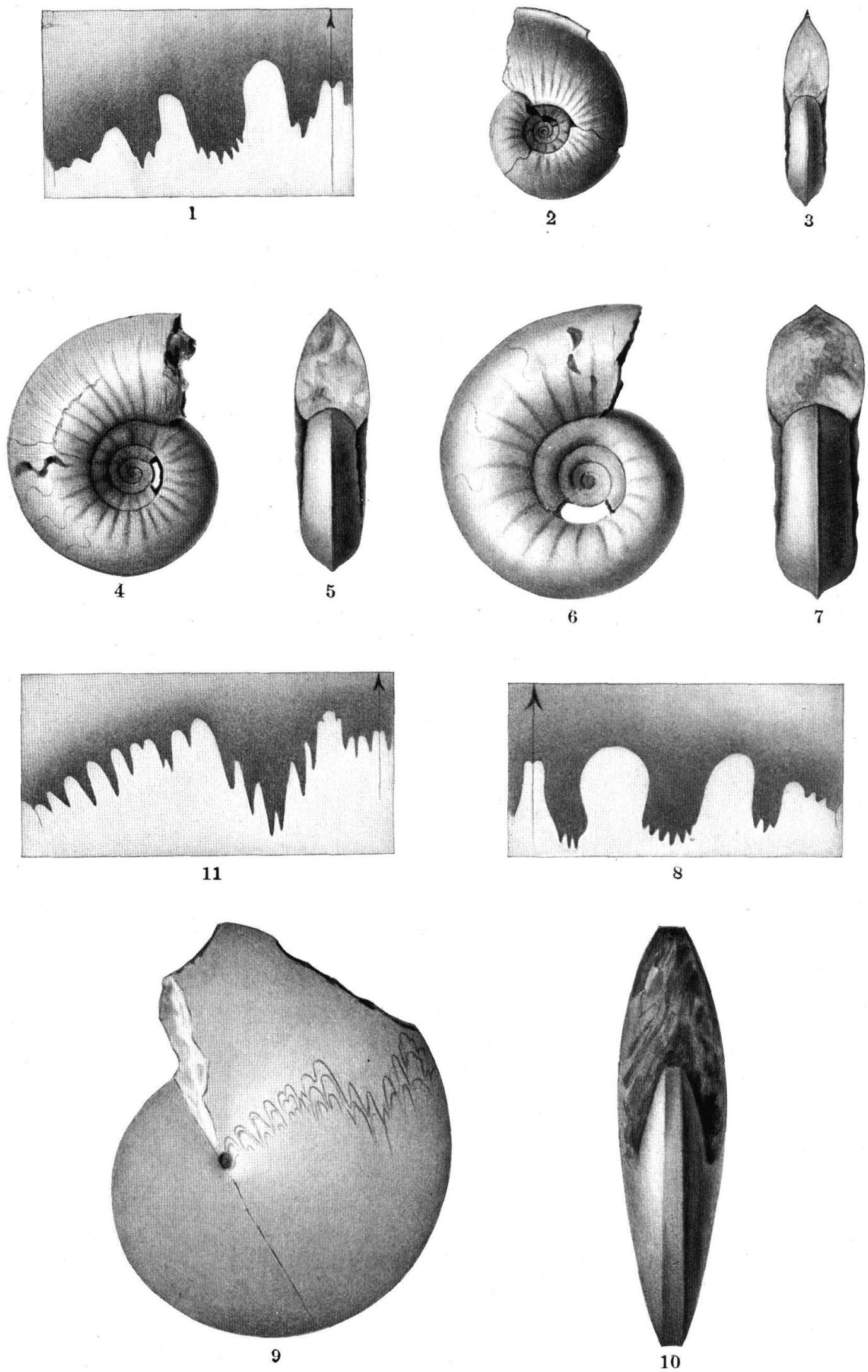

INYOITES OWENI, LANCEOLITES COMPACTUS. 


\section{PLA TE LXXIX:}

\section{Tropites subbullatus Hauer (p. 67.)}

Figs. 1, 2. Adolescent stage; diameter $4.6 \mathrm{~mm}$., showing the lobes becoming ammonitic at $4.5 \mathrm{~mm}$. (shell $\times 6)$ and septa $(\times 12)$.

Figs. 3, 4, 5, 6. Larval stage; dianeter $2.04 \mathrm{~mm}$., showing the goniatitic septa $(X 20)$ and the beginning of the keel at diameter of $2 \mathrm{~mm}$. (shell $\times 10$ ).

Fics. $7,8,9,10$. Larval stage; diameter $1.83 \mathrm{~mm}$, showing Gustrioceras stage (shell $\times 10)$ and septa $(\times 20)$.

From Upper Triassic (Karnic stage, zone of Tropites subbullatus), 3 miles east of Madison's ranch, between Squaw Creek and Pit River, Shasta County, Cal. Collection of J. P. Sinith.

Tardeceras parvum Hyatt and Smith (p. 44.)

Fras. 11, 12, 13. Type specimen $(\times 2)$; diameter $11 \mathrm{~mm}$.

Figs. 14, 15, 16. Smaller specimen $(X 3)$; diameter $7 \mathrm{~mm}$.

Figs, 17, 18. Shell $(\times 4)$ and septa $(\times 6)$; diameter $6 \mathrm{~mm}$.

Figs. 19. 20. Adolescent stage $(\times 6)$; diameter $3.44 \mathrm{~mm}$.

From Upper Triassic (Karnic stage, zone of Tropites subbullatus), 3 miles east of Madison's ranch, between Squaw Creek and Pit River, Shasta County, Cal. Collection of J. I. Smith. 

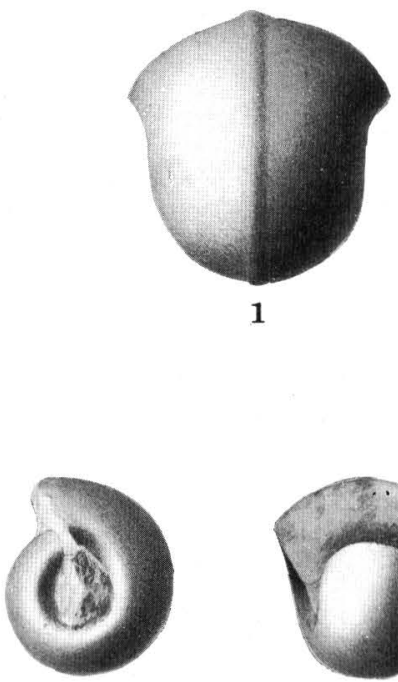

3

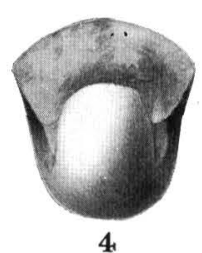

4

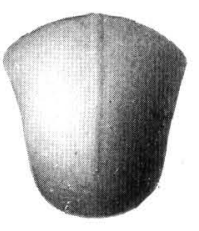

5
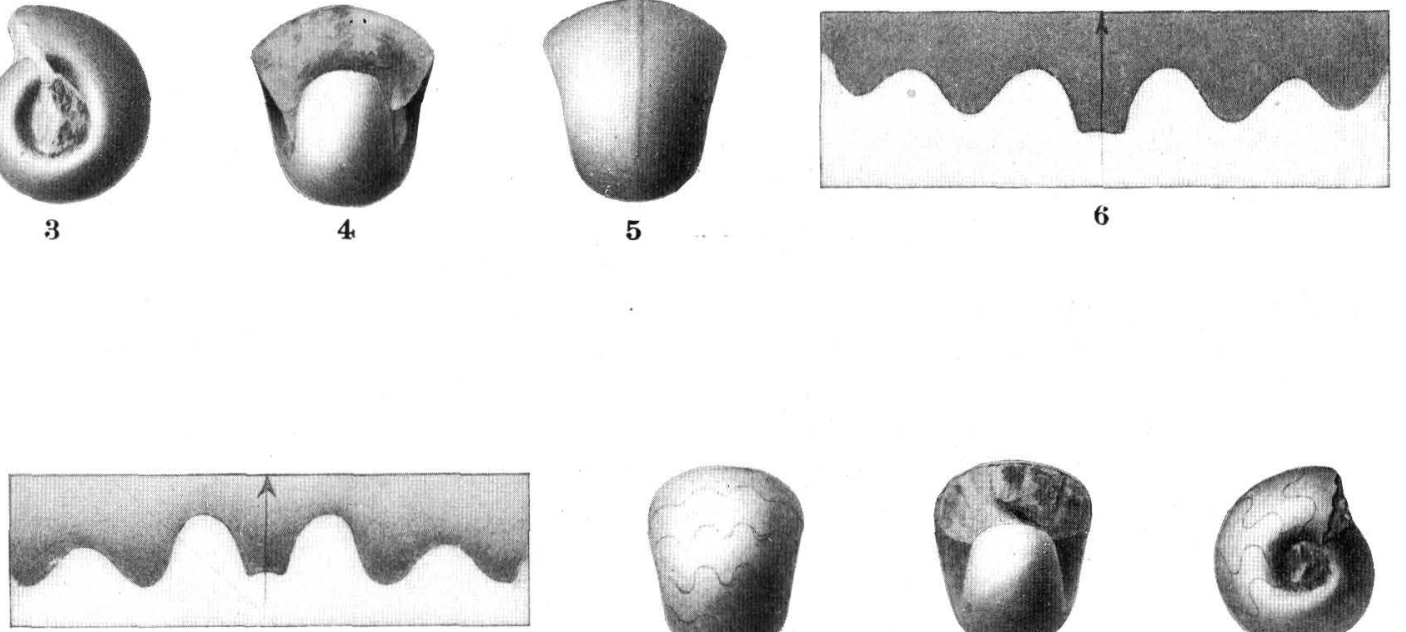

10
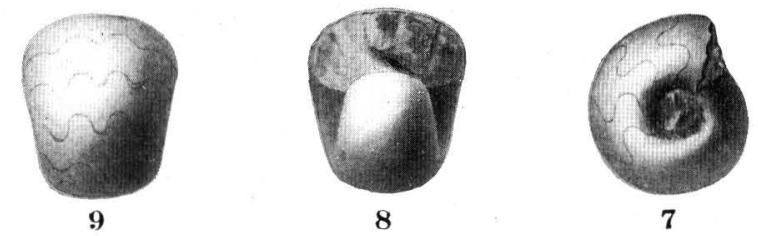

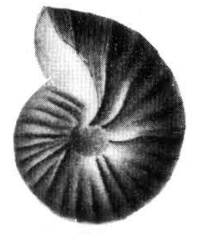

11

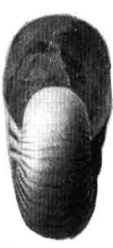

12

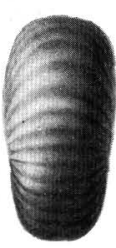

13

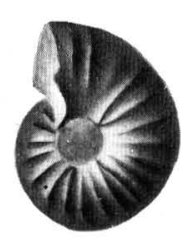

14

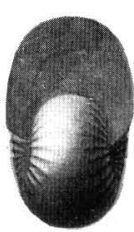

15
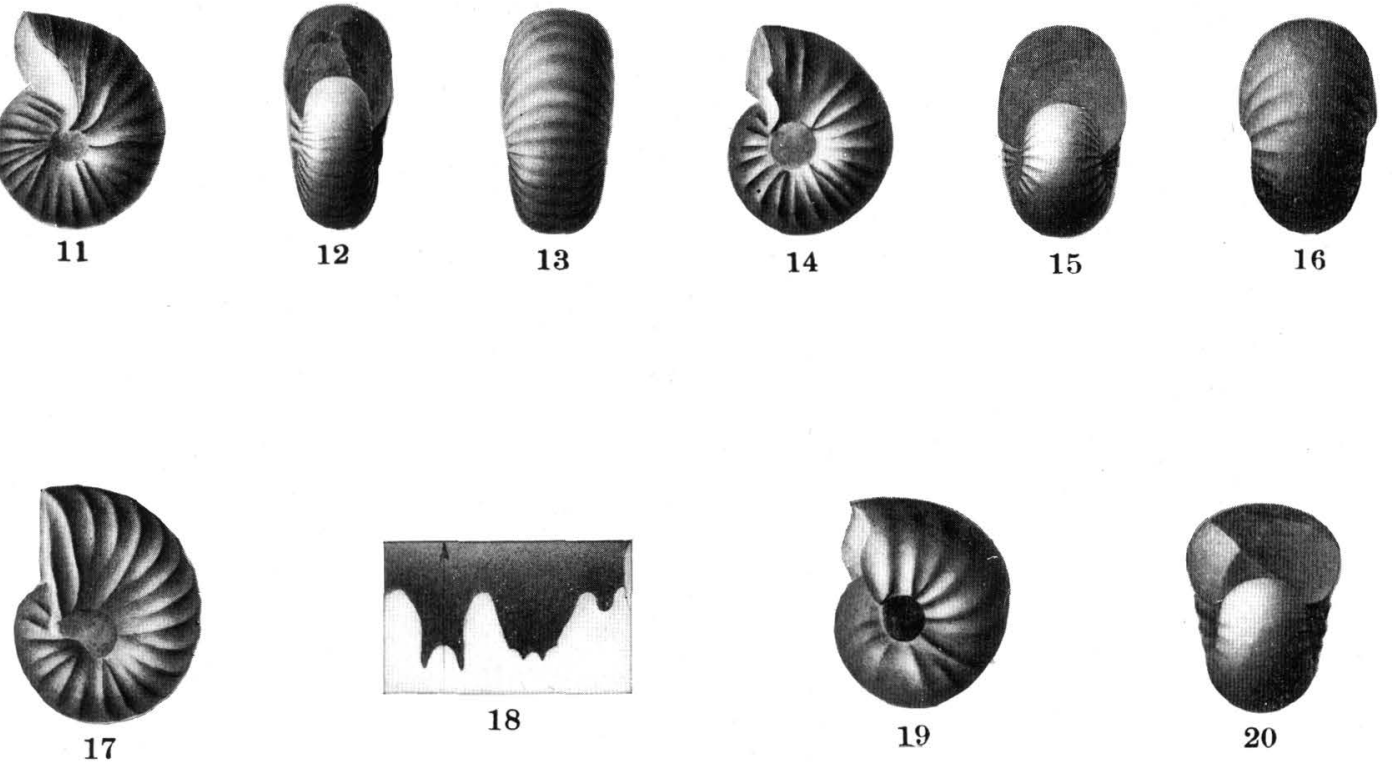

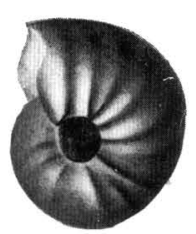

19

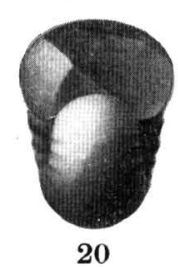

20

TROPITES SUBBULLATUS, TARDECERAS PARVUM. 


\section{P LA T E LXXX.}

Tropicrltites Frecird Hyatt and Smith (p. 59).

FIGs. 1, 2, 3. Natural size.

Figs. 4, 5. Natural size.

Figs. 6, 7, 8. Natural size.

FIG. 9. Septa $(\times 3)$ of the same specimen.

Figs. 10, 11. An old specimen showing change of sculpture.

From Upper Triassic (zone of Tropites subbullatus), 3 miles east of Madison's ranch. between Squaw Creek and Pit River, Shasta County, Cal. Collection of J. P. Smith,

Paraganides californicus Hyatt and Smith (p. 78).

Figs. 12, 13, 14. Shell $(\times 2)$ and septa $(\times 4)$ of type specimen.

FI(is. 15, 16. Enlarged twice.

Figs. 17, 18. Enlarged three times.

Fras. 19, 20, 21. 'Shell $(\times 6)$, and septa $(\times 12)$, adolescent stage; diameter $3.5 \mathrm{~mm}$.

From Upper Triassic (zone of Tropites subbullatus), 3 miles east of Madison's ranch, between Squaw Creek and Pit River, Shasta County, Cal. Collection of J. P. Smith. 

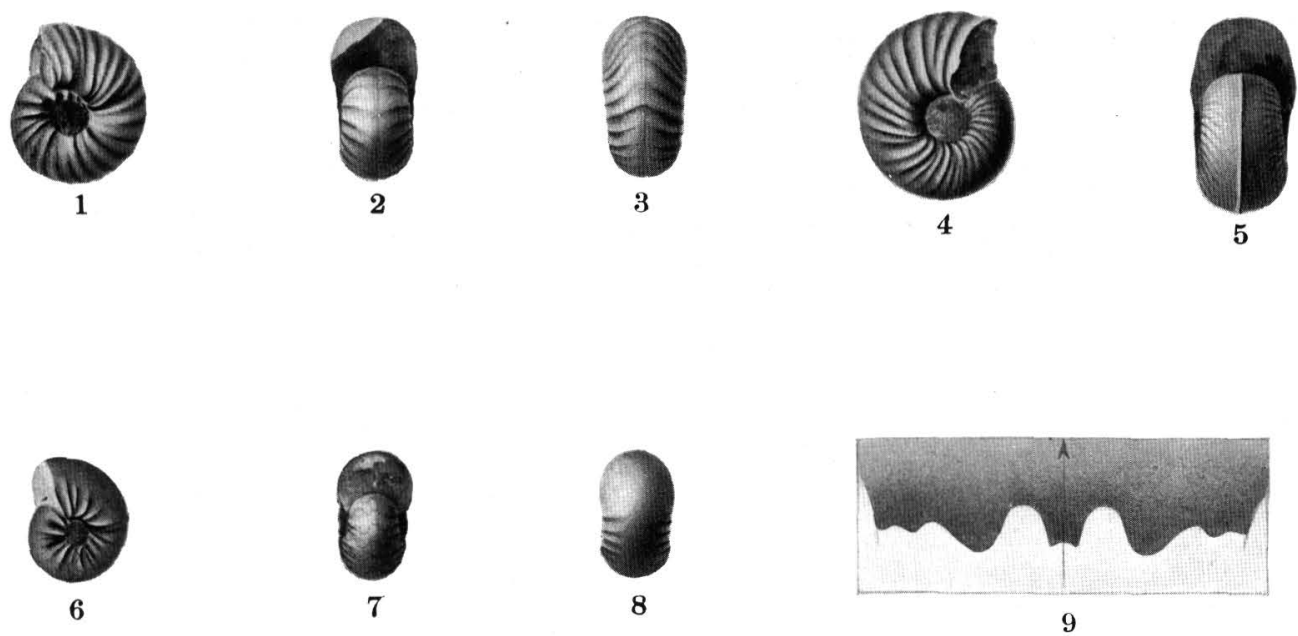

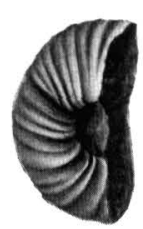

10

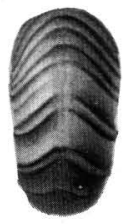

11
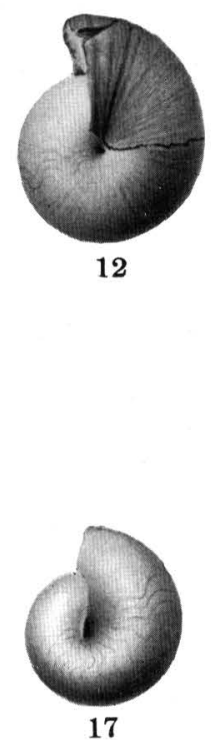

16
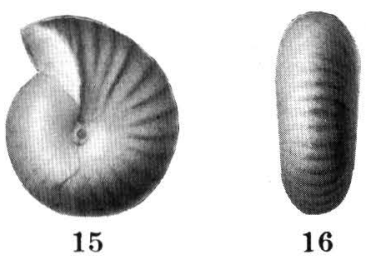
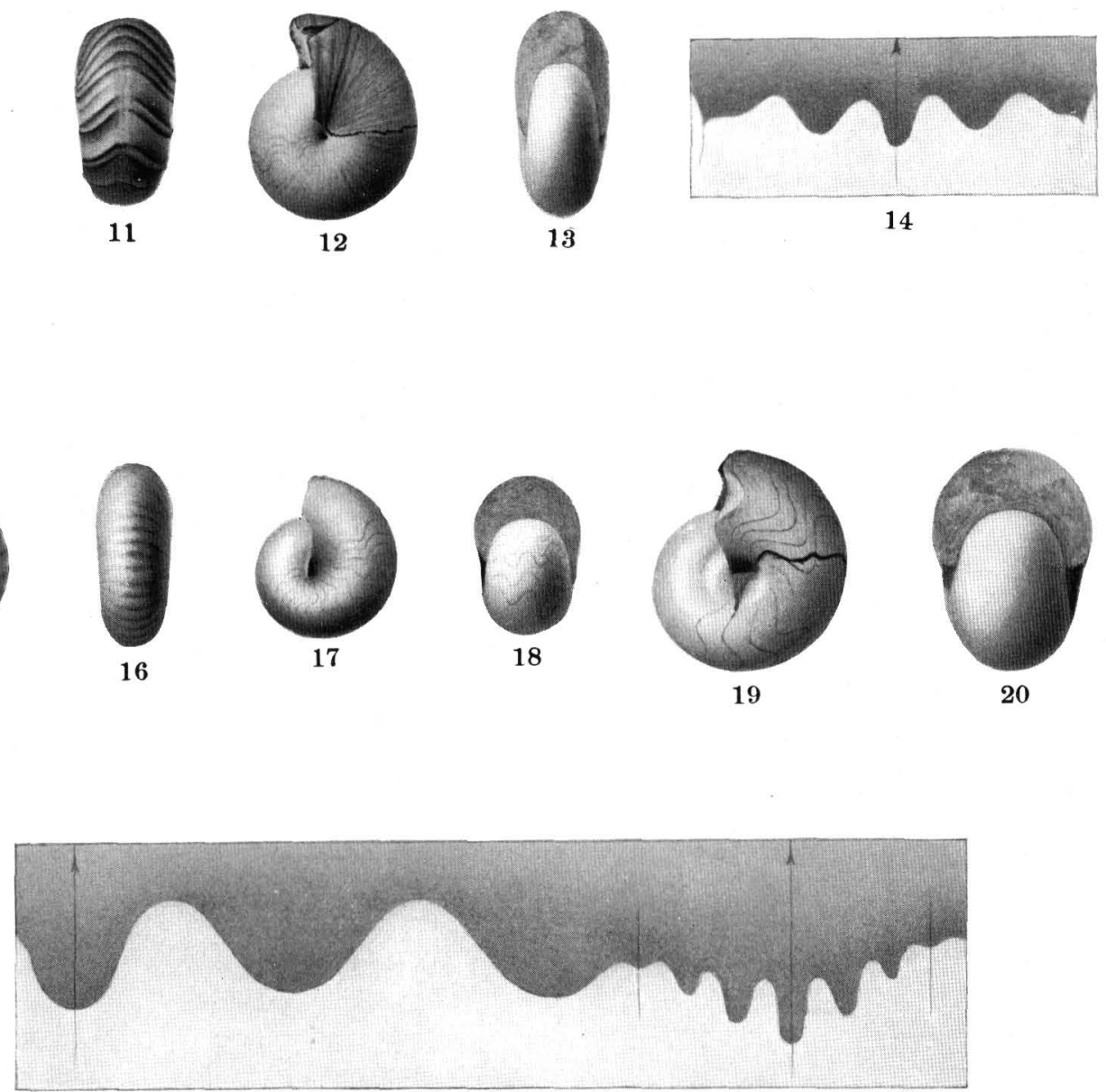

21 


\section{PLATE LXXXI.}

Aroestes Pacifious Hyatt and Smith (p. 75).

Fias. 1, 2, 3. Shell (natural size) and septa $(\times 2)$ of type specimen.

Figs. 4, 5, 6. Shell $(\times 3)$ and septa $(\times 4)$; diameter $11 \mathrm{~mm}$.

Figs. 7, 8, 9. Shell $(\times 5)$ and septa $(\times 6)$; diameter $5.34 \mathrm{~mm}$.

From Upper Trias (zone of Tropiles subbullatus), 3 miles east of Madison's ranch, between Squaw Creek and Pit River, Shasta County, Cal. Collection of J. P. Smith.

Dieneria Arthaberi Hyatt and Smith (p. 106).

Figs. 10, 11. Enlarged twice; diameter $10 \mathrm{~mm}$.

FiGs. 1:, 13, 14. Adolescent stage $(\times 3)$; diameter $7 \mathrm{~mm}$.

Figs. 15-18. Shell $(\times 6)$, septa $(\times 8)$, Ambites stage; diameter $3.6 \mathrm{~mm}$.

Figs. 19, 20. Larval stage $(\times 8)$; diameter $2.52 \mathrm{~mm}$.

Figs. 21, 22, 23. Larval stage $(\times 10)$; diameter $1.64 \mathrm{~mm}$.

Figs. 24, 25. Larval stage $(\times 20)$; diameter $0.66 \mathrm{~mm}$.

From Upper Trias (zone of Tropites subhullatus), 3 miles east of Madison's ranch, between Squaw Creek and Pit River, Shasta County, Cal. Collection of d. P. Smith. 


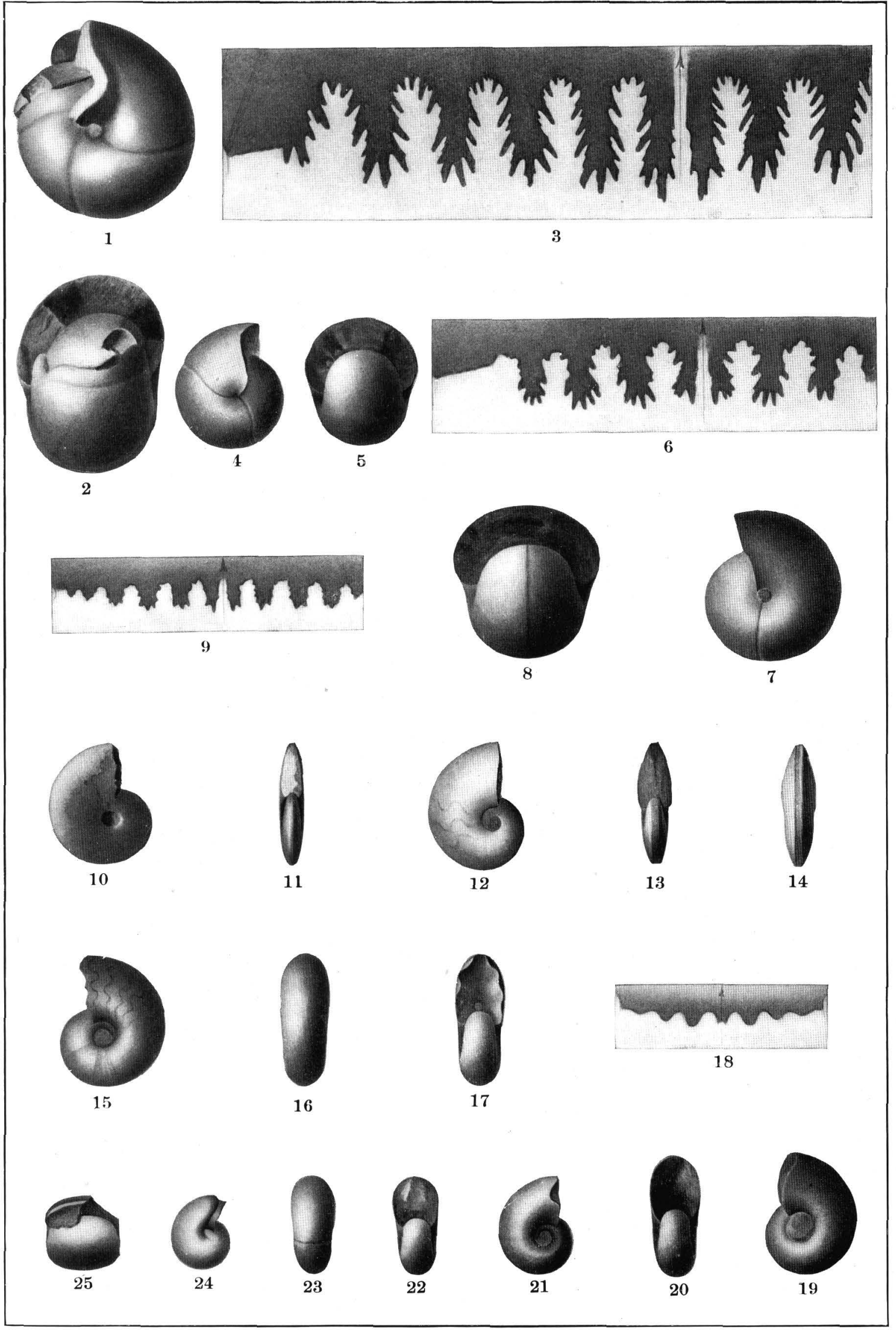

ARCESTES PACIFICUS, DIENERIA ARTHABERI. 


\section{PLA TE LXXXII.}

\section{Tirolites (Metatirolites) foliaceus Dittmar (p. 160).}

Figs. 1, 2. Enlarged twice; diameter $19.5 \mathrm{~mm}$.

Fias. 3, 4. Enlarged twice; diameter $17 \mathrm{~mm}$.

FIGs. 5, 6, 7, 8. Shell $(\times 2)$ and septa $(\times 4)$; diameter $13 \mathrm{~mm}$.

Figs. 9, 10. Enlarged twice.

From Upper Triassic (zone of Tropites subbullatus), 3 miles east of Madison's ranch, between Squaw Creek and Pit River, Shasta County, Cal. Collection of J. P. Smith.

Californites Merriami Hyatt and Smith (p. 180).

Fiss. 11, 12, 13, 14. Shell (natural size) and septa $(\times 4)$.

Figs. 15, 16, 17. Natural size.

Ficis. 18, 19, 20. Adolescent stage $(\times 2)$; diameter $10 \mathrm{~mm}$.

Figs. 21, 22, 23. Larval stage $(\times 4)$; diameter $4.5 \mathrm{~mm}$.

From Upper Triassic (zone of Tropites subbullatus), 3 miles east of Madison's ranch, between Squaw Creek and Pit River, Shasta County, Cal. Collection of J. P. Smith. 

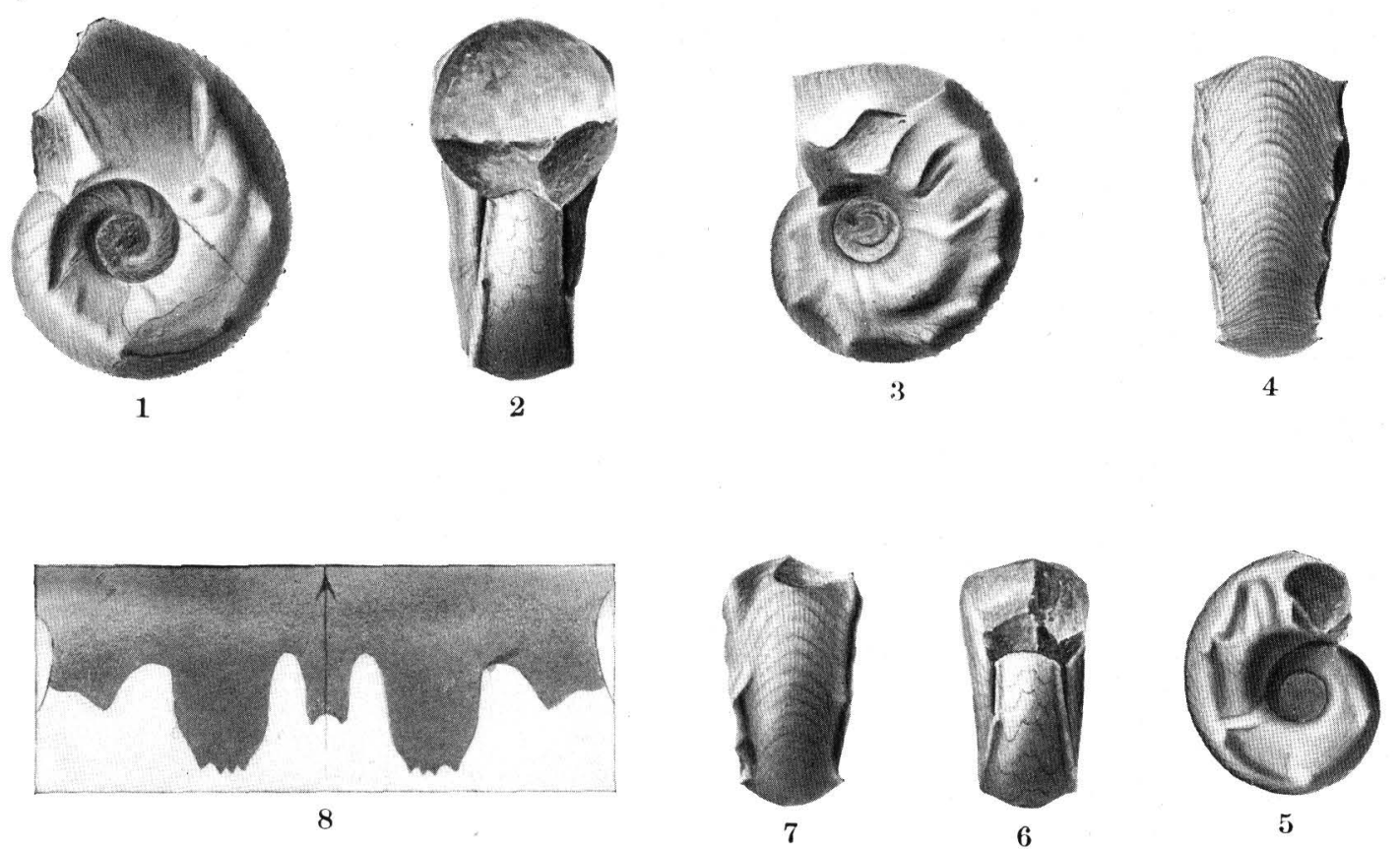

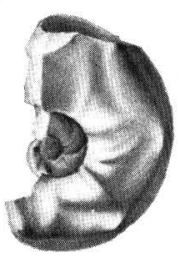

9

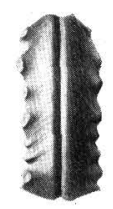

17
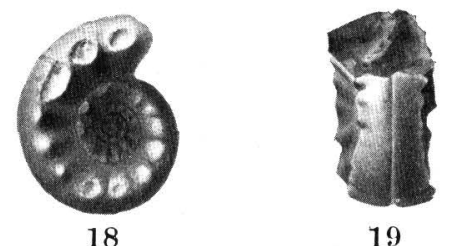

19

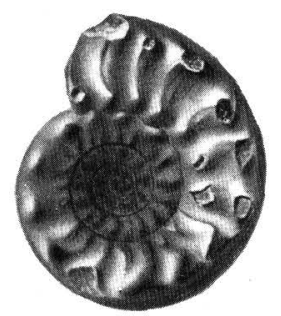

11

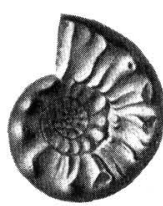

15

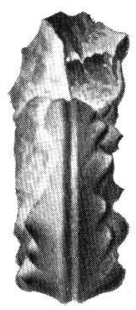

12

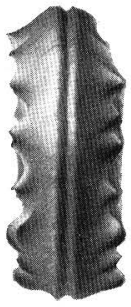

13

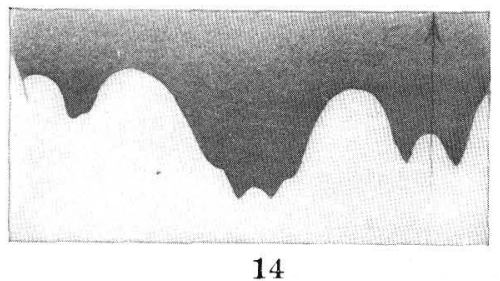

14

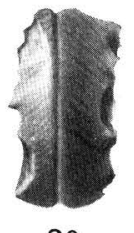

20

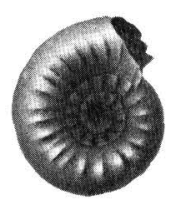

21

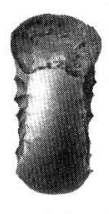

22

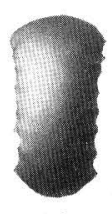

23 


\section{P L A T E L X X X I I I .}

\section{Arpadites Gabir Fyatt and Smith (p. 175).}

Fics. 1, 2, 3. Fnd of arlolescent stage, shell $(X 3)$ and septa $(\times 6)$; diameter $9.5 \mathrm{~mm}$.

Figs. 4, 5, 6. Dinarites stage $(X 5)$; diameter $4.6 \mathrm{~mm}$.

Figs. 7, 8, 9, 10. Dinarites stage, shell $(\times 5)$ and septa $(\times 10)$; diameter $3.46 \mathrm{~mm}$.

Figs. 11, 12, 13. Tirolites stage $(\times 10)$; diameter $2.19 \mathrm{~mm}$.

From Upper Triassic (zone of Tropites subbullo/us), 3 miles east of Madison's ranch, between Squaw Creek and Pit River, Shasta Connty, Cal. Collection of J. P. Smith.

Clionites (Neanites) californicus Hyatt and Smith (p. 190).

Figs. 14, 15, 16. Natural size.

Figs. 17; 18, and 18a. Californites stage $\left(\times 1 \frac{1}{2}\right)$.

FiGs. 19, 20, 21. Califormites stage $(\times 2)$, adolescent; diameter $13 \mathrm{~mm}$.

FIgs. 22, 23, 24. Tirolites stage $(\times 4)$, adolescent; diameter $6 \mathrm{~mm}$.

FIGs. 25, 26, 27. Tirolites stage $(X 5)$; diameter $4.5 \mathrm{~mm}$.

From Upper Triassic (zone of Tropites subbullatus, 3 miles east of Madison's ranch, between Squaw Creek and Pit River, Shasta County, Cal. Collection of J. P. Smith. 

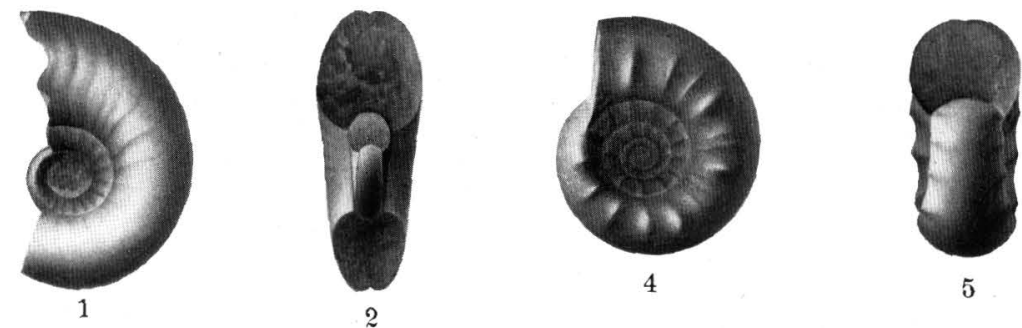

5
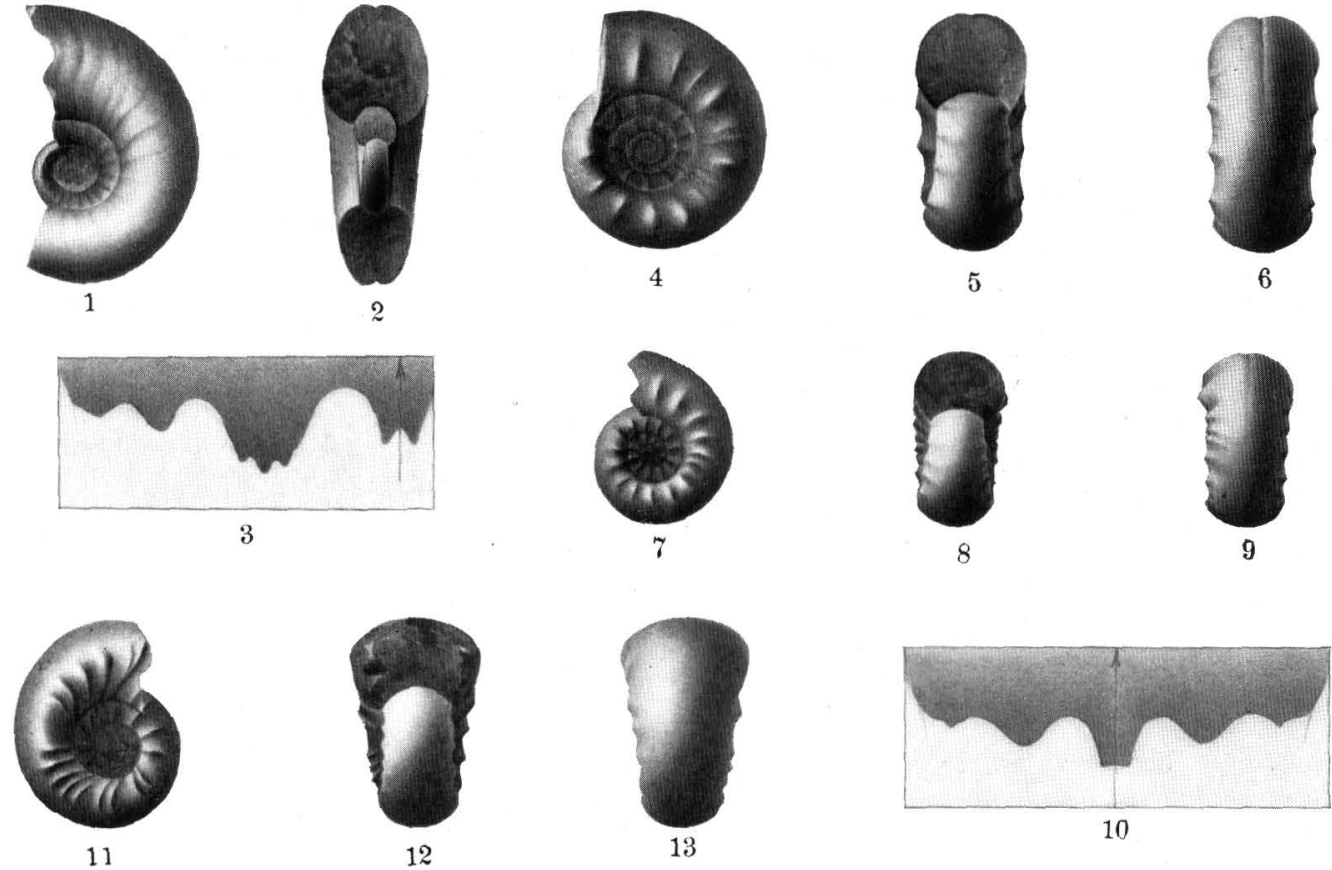

12
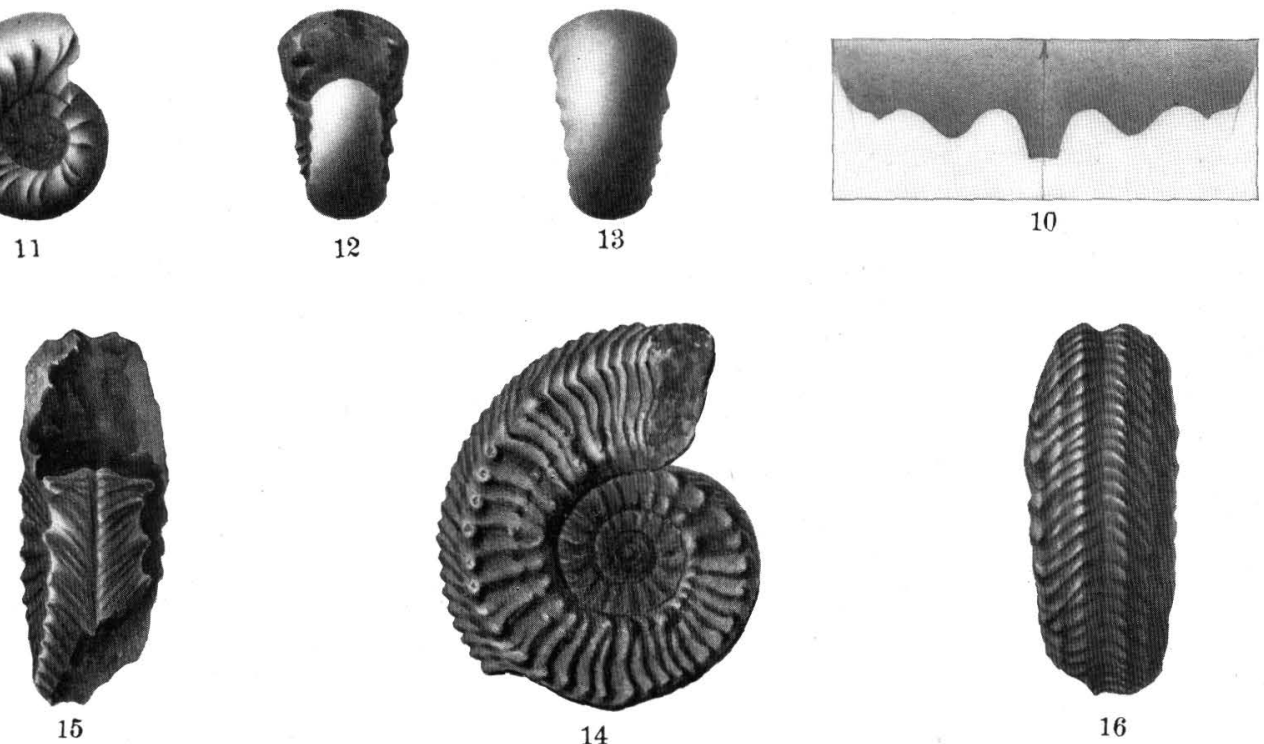

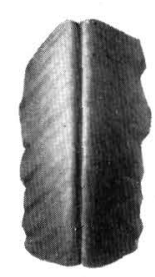

21

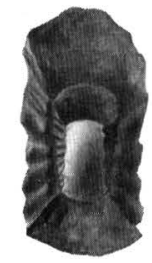

20

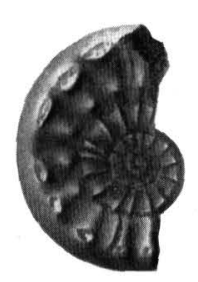

19
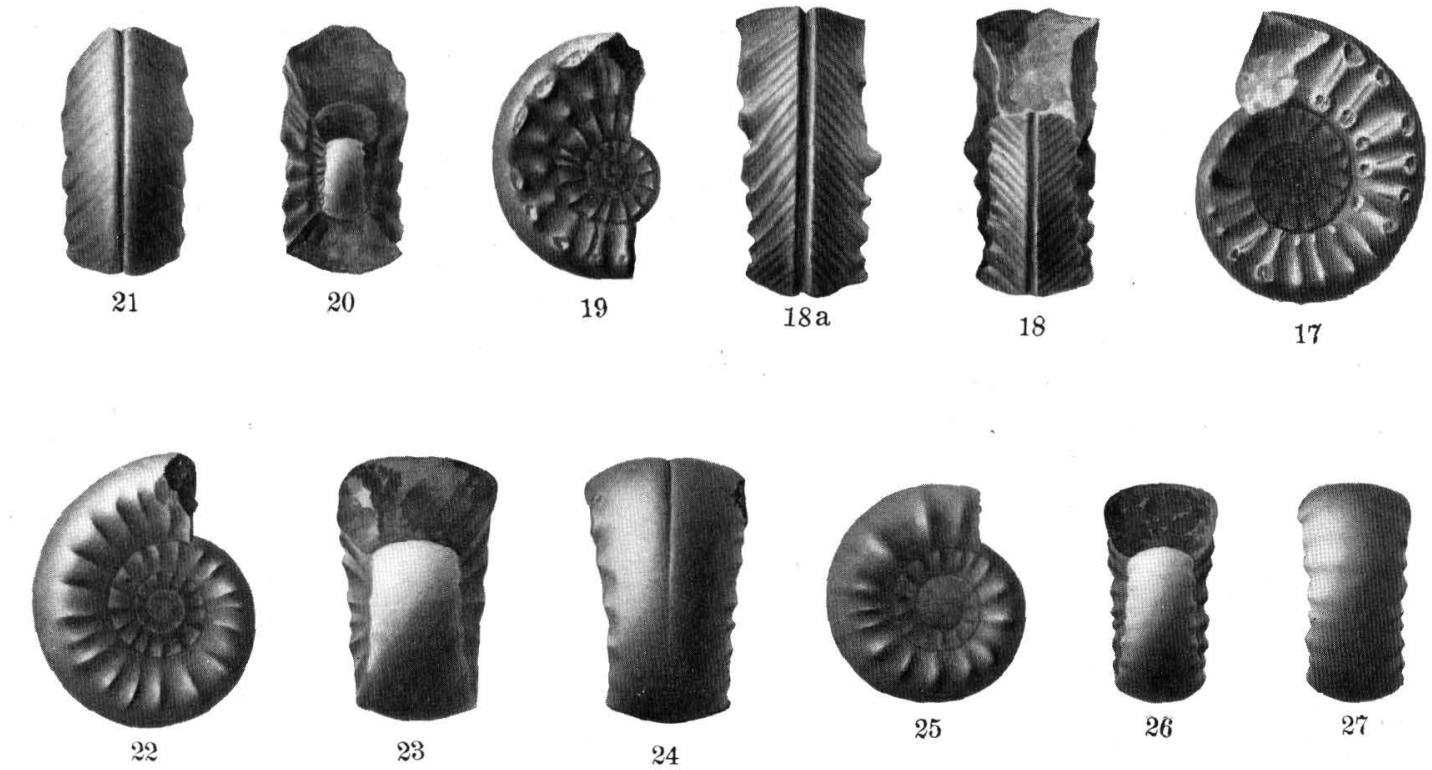

23

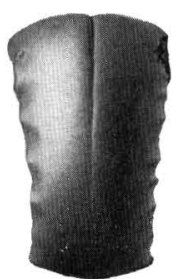

24
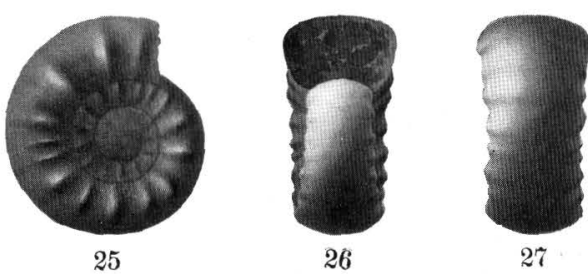

ARPADITES GABBI, CLIONITES CALIFORNICUS. 


\section{PLATE LXXXIV.}

Hedenstriema Kossmati Hyatt and Smith (p. 101).

Fic. 1. Side view of an adult specimen.

Fit. 2. Septa $(\times 2)$ of the above specimen.

Figs. 3, 4, 5. Adolescent stage $(\times 2)$; diameter $23 \mathrm{~mm}$.

Fig. 6. Septa $(\times 3)$ of the above specimen.

FIG. 7. Septa $(\times 3)$ of another specimen; diameter $20 \mathrm{~mm}$ :

Figs. 8, 9, 10. End of larval stage $(\times 6)$; diameter $5.5 \mathrm{~mm}$.

From Lower Triassic (Meekoceras beds), Wood Canyon, Aspen Ridge, 9 miles east of Soda Springs, Idaho. Collection of United States National Museum. 

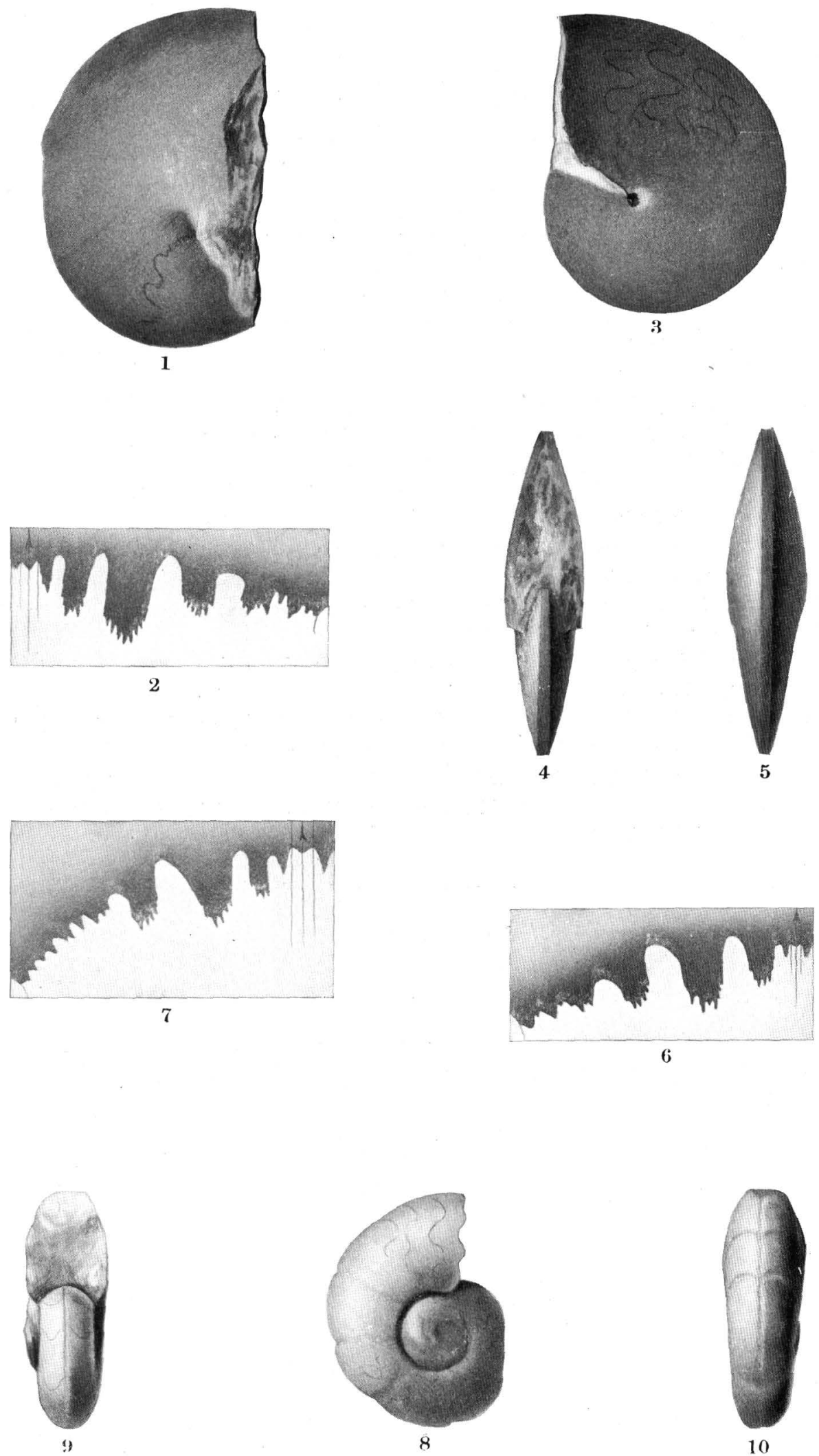


\section{PLATE L X X X V.}

\section{Ussuria Waageni Hyatt and Smith (p. 90.)}

Figs. 1, 2, 3. Left side, front, and rear views $(\times 3)$, transition from Dimorphoceras to Thalassoceras; diameter $11 \mathrm{~mm}$.

Fig. 4. Septa $(\times 4)$ of the same.

Figs. 5, 6, 7. Right side, front, and rear views $(\times 6)$, Dimorphoceras stage; diameter 5.5 mm.

Fig. 8. Septa $(\times 10)$ of the same.

From Lower Triassic (Meekoceras beds), Wood Canyon, Aspen Ridge, 9 miles east of Soda Springs, Idaho. Collection of United States National Museum.

Fig. 9. Septa of Thalassoceras Phillipsi Gemmellaro (for comparison), copied from Lethra Palacozoica, Bd. 2, Lieferung 3 , fig. 8 .

Fra. 10. Septa of Thalassoceras Gemmellaroi Karpinsky (for comparison), copied from A. Karpinsky, Ammoneen der Artinsk Stufe, Pl. IV, fig. 3c.

FIG. 11. Septa of Dimorphoceras atratum Goldfuss (for comparison), copied from F. Frech, Lcthæa Palcozoica, Bd. 2, Lieferung, 2, PI. 46b, fig. $11 \mathrm{~b}$.

Fig. 12. Septa of Dimorphoceras Gilbertsoni Phillips (for comparison), copied from Foord and Crick, Catal. Fossil Cephalopoda, British Museum, pt. 3, p. 221, fig. 105.

Fig. 13. Septa of Ussuria Iwanowi Diener (for comparison), copied from O. Diener, Triadische Cephalopodenfaunen der ostsibirischen Küstenprovinz: Mém. Com. géol., St.-Pétersbourg, vol. 14, No. 3, 1895, Pl. III, 1ig. 5.

\section{Cordillerites angulatus Hyatt and Smith (p. 110).}

Figs. 14, 15. Adolescent stage $(X 3)$; diameter $15 \mathrm{~mm}$.

Fig. 16. . Septa $(\times 4)$ of the above specimen.

Figs. 17, 18, 19 . Larval stage $(\times 8)$; diameter $6.5 \mathrm{~mm}$.

Fig. 20. Septa $(X 12)$ of the same specimen.

From Lower Triassic (Meekoceras beds), Wood Canyon, Aspen Ridge, 9 miles east of Soda Springs, Idaho: Collection of United States National Museum. 


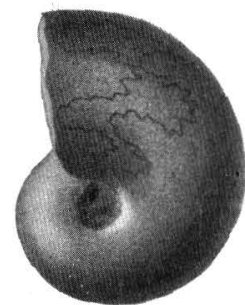

1

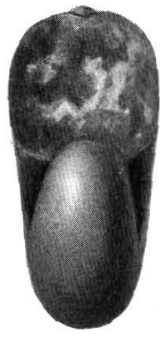

2

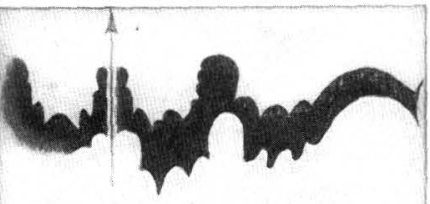

10
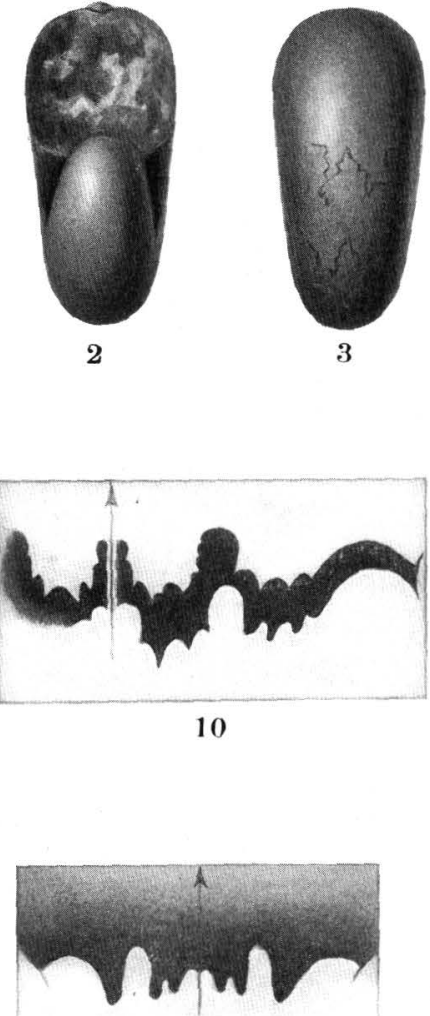

11

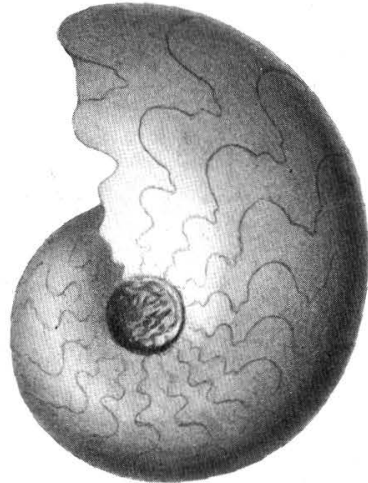

17
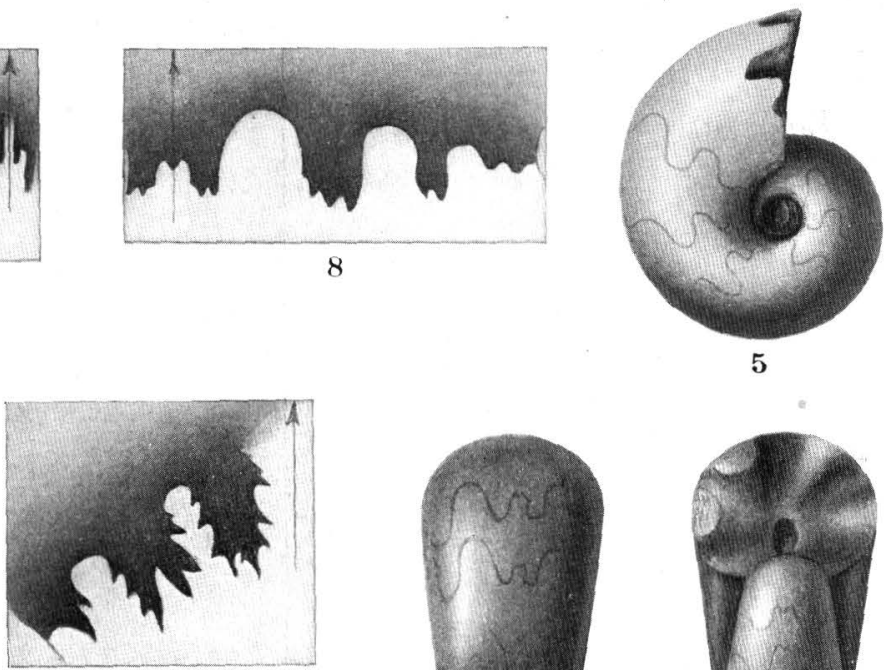

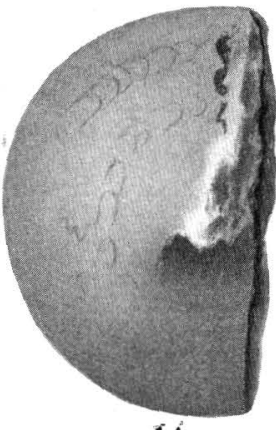

14

9

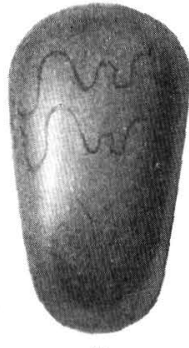

7
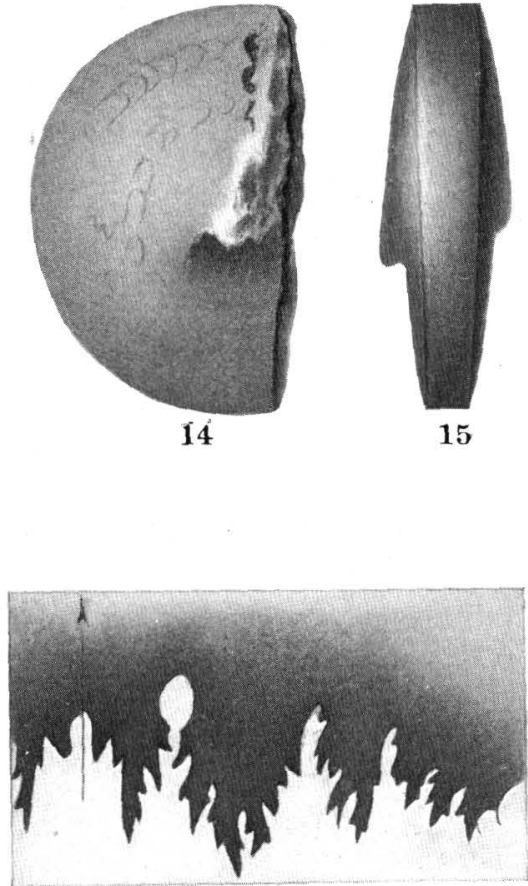

13

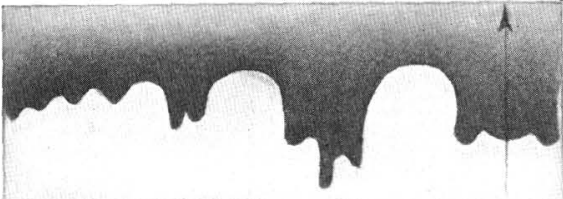

20

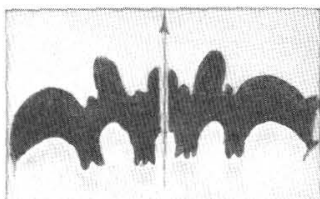

12

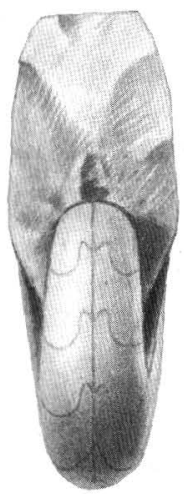

18

19

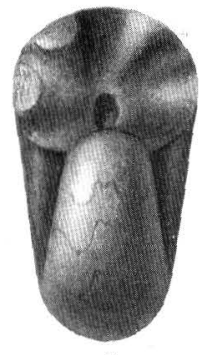

6

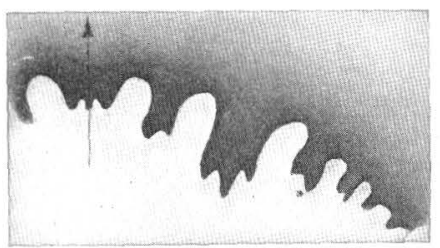

16

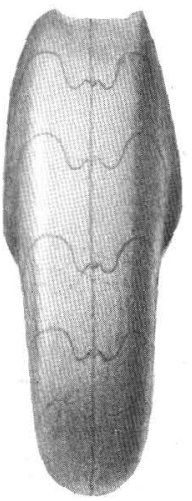

USSURIA WAAGENI, THALASSOCERAS PHILLIPSI, T. GEMMELLAROI, DIMORPHOCERAS ATRATUM, D. GILBERTSONI, USSURIA IWANOWI, CORDILLERITES ANGULATUS. 


\section{N D E X.}

Names in italic are synonyms; figures in black-face type denote pages on which descriptions appear; figures in italic denote illustrations.

A.
Acatenati.........................................
Sec also Halorites.

Ack nowledgments to those assisting $\ldots \ldots \ldots \ldots \ldots \ldots, \quad 12$

Acrochordiceras Hyatt ...................... 15 $17,22,33,44,123,129,158-159,177-178$ Hyatti Meek .. 22, 23, 131-132, 140, 156, 163, 172, 177, 178, 262 Acuti Mojsisovies. See also Balatonites.

Adrianites Gemmellaro .................. 29,72,75,368

Aquabiles Mojsisovies ......................... 66-67 See also Paratropites

Aganides...

Alaska, fossils from.............................. 17

Alpine provinee, fossils from................... $35,39,41,43,46,53-54,56,65,69,76,79,86,88$ $94,104,136,138,155,161,171,175,193-194$

Ambites Waagen ................... 104-106, 218, s78

America, fossils from

Triassic fossils of, relations of Paleozoic fossils and. $\quad 34$

See also Alaska, California, Idaho, Nevada, Wyoming.

Ammonites Arpadis Moj.

ausseeanus Gabb.

160

Blakci Gabb............................ 172-173

Ehrlichi Hau ...........................

erinaceus Ditt...............................

foliaceus Ditt.............................. 160

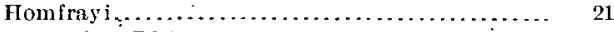

nasturtium Ditt $\ldots \ldots \ldots \ldots \ldots \ldots \ldots \ldots \ldots \ldots \ldots \ldots, \quad 201$

nodosus Brug . . . . . . . . . . . .

oribusus Ditt ............................. 200

Ramsaneri ............................ 21,41-42

rarestriatus Hau.......................... 104

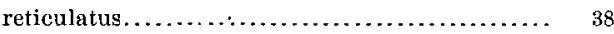

reuttensis Bey ............................ 154

sandlingensis $\mathrm{Hau} \ldots \ldots \ldots \ldots \ldots \ldots \ldots \ldots \ldots \ldots \ldots 6.61-62,65$

- Satumus Ditt .............................. 54

semiglobosus Hau .......................... 42

senticosus Ditt............................ 198

subbullatus Hau $\ldots \ldots \ldots \ldots \ldots \ldots \ldots \ldots \ldots \ldots \ldots \ldots .6,66,67$

Ammonoiden ............................31-33, 35-203

Anaholenstromia Hyatt ....................... 100

Anatomites Mojsisovics............... 24,31,46,47,47-48 subintermittens H. and $\mathrm{S} . \ldots \ldots \ldots \ldots \ldots \ldots 24,4 \mathbf{7}-48$ See also Juvarites.

Anatropites Mojsisoviç . See also Spinosi; Tropites.

Anderson; F. M., fossils found by $66^{\circ}$

fossil species named for
Anisic stage, fossils of $\ldots \ldots \ldots \ldots \ldots \ldots \ldots \ldots \ldots \ldots \ldots . .17$ Anolcites Mojsisovies .. 16, 17, 22,33, 158, 192, 196, 196-198, 20 Meeki Moj... 22-23, 126, 131, 133, 172, 193, 196-198, 9934,364 Whitneyi Gabb .......................... 22-23, See also 'Trachyceras.

$58,126,133,140,156,172,174,178,193,198,264$

Aploceras Hyatt.............................. 161 A rcestes Suess.............. 16, 17, 25, 29, 31, 72, 73-74, 74-75 Andersoni $H$, and $\mathrm{S} \ldots \ldots \ldots \ldots \ldots \ldots 26,42,74,108,203,328$ Bramantei ............................ 75

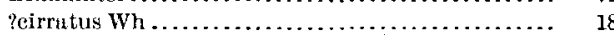
coloni................................. 73-74 cymbiformes .................................. 76

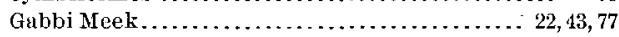
galeati ...................................

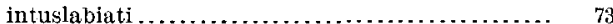
(Pron rcestes) pacificus H. and $\mathrm{S} . \ldots \ldots \ldots .24,5 \overline{5}, 990,878$ perplanus Meek........................... 84

A reestidæ......................... 29, 31, 7\$, 73-77 A rcestoidea ........................ 29,31, 70,70-77 Arietiformes ............................ 59, 166 Secalso Balatonites; Tropiceltites.

A rictites (Culoceras) nodotianus d'Orb'............ 26 Armenia, Triassic fossils from ................ 127-128 Arnioceltites................................ 59 Arniotites Hyatt. ........................... 165-166 Arnold, Ralph, fossil species named for .......... 137 Arpadites Mojsisovics. 16, 25, 33, 157-158, 174-175, 175-177, 181

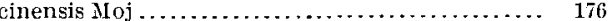
Gabbi $\mathrm{H}$. and $\mathrm{S} . \ldots \ldots \ldots \ldots \ldots \ldots . \ldots 24,17 \tilde{0}-177,294,382$ Arthaber, $(\dot{r}$. von, classification plan of . . . . . . . . . . 27 on Hungarites .............................. 128 on Judicarites .............................. 166 on Reiflingites........................... 174

Arthaberites Diener........................... 95, 109 Asia, fossils from...................... 17, 19,31-33 See also India, Siberia, Japan, Asin Minor.

Asia Minor, fossils from . . . . . . . . . . . . . . . . . . . 155 Aspen Ridge, Idaho, fossils of . . 17-19, 79, 81, 89, 92, 99-100, 102$103,110,112-114,118-121,137,148,150,218,220,224$, $232,298,240,242,246,248,34 /-352,356-358,362,984$

Aspenites Hyatt and Smith . . ............. 31, 95-96, 102, 108 acutus II. and $\mathrm{S} \ldots \ldots \ldots \ldots \ldots \ldots \ldots \ldots 19,20,95,96,220,22 \%$ Aspidites Freeh ........................ 84, 102, 148 Aspidites Waagen ....................... 15, 17,28,32, $92,103,113,119,135,142,15 \mathbf{5}-153,153-154$ Hooveri H. and $\mathrm{S} . \ldots \ldots \ldots \ldots \ldots \ldots \ldots .20, \mathbf{1 5 3 - 1 5 4}, 250$ superbus Waag ............................ 152

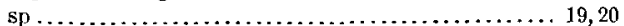
Atractites Guembel ...................... 16, 25, 33, 204, 205 Philippii H. and $5 . \ldots \ldots \ldots \ldots \ldots \ldots \ldots \ldots \ldots 24, \mathbf{2 0 5}, 31$ sp ................................ 22, 23, 26, 203 


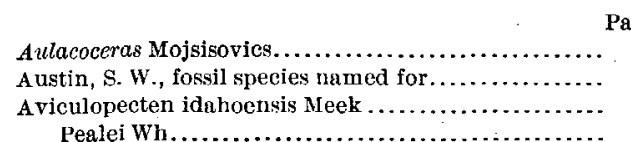

B.

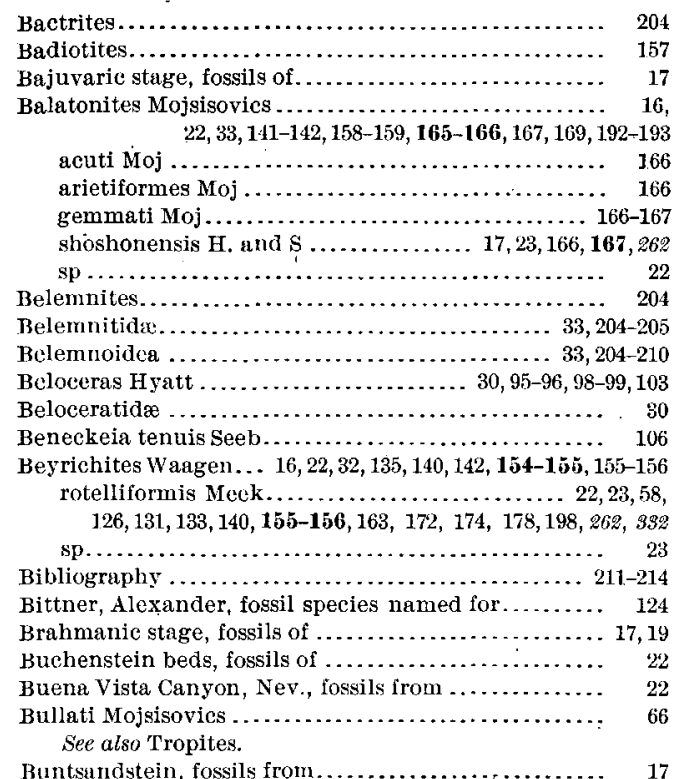

Buntsandstein, fossils from

\section{C.}

California, fossils from. $23-26,46,53,72,81-82,88,90,101,118,138$ $143,165,175,182,192-194,201,207,210$

Inyo County, fossils from See also Invo Range.

Plumas County, fossils from......... 17,25-26, 42, 274 section of ...

Shasta County, fossils from

$23-25,37,39$, $65,67,69,75,78,105,107,160-161,172,175$, 181, 185-186, 188-189, 191, 193-194, 196, $199,202,205-206,208-209,268,326,87_{4}-382$ section in............................ 24-25

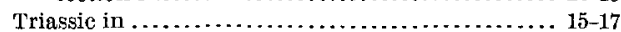
Californites Hyatt and Smith .................... 33

179-180, 180-182,184, 187-190,382

Merriami H. and $\mathrm{s} . \ldots \ldots \ldots \ldots \ldots \ldots .24,179, \mathbf{1 8 0}-181,380$ Caloceras nodotianus d'Orb ...................... 26 Carnites ................................... 95

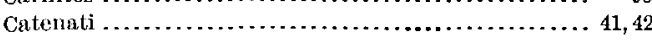
See also Halorites.

Celtites Mojsisovics. $17,32,50-51,52,122-123,125,125-126,141-142$

Floriani Moj......................... 164

Halli Moj ......... 22, 23, 195-126, 133, 156, 172, 266,866

lævidorsatus Hau ........................... 126 sp......................... 19,23,52,100, 120,151 Celtitidæ.............. 28, 30, 32, 114-116, 121-122, 122-126 Celtitine .................................... 122 Ceratite beds, fossils of $\ldots \ldots \ldots \ldots \ldots \ldots \ldots \ldots .17,19,22,128,162$
Page.

Ceratites de Haan ............. 15-17, 22, 28 $33,120,128-129,157-158,161,167-170,170-175,178$

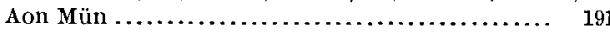
(Gymnotoceras) Blakei Gabb................ 22 $23,126,131,133,156,172,173-174,178,198,260$ carbonarius. ............................ 122-123 dalmatinus Hau ............................ 162 flemingianus de Kon ....................... 120 (Gymnotoceras) geminati ................... 172-17 glaucus Mue . . ................................ 137

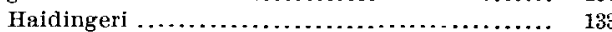

Hedenstromi Key ............................ 100

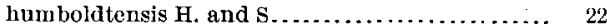
$23,25,58,126,131,133,140,156,170-172,174,198,390$ idrianus $\mathrm{Hau} \ldots \ldots \ldots \ldots \ldots \ldots \ldots \ldots \ldots \ldots \ldots . . \ldots \ldots$ lawrencianus de Kon ........................ 84 Mojsisovicsi Boeckh ........................ 127 nevadanus Moj ............................ 131

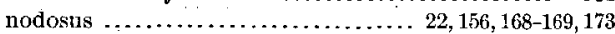
obsoleti............................... 117,123,164 planus Arth ........................... 23,172 subnodosus Moj ......................... 171,172

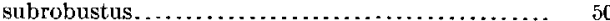
trinodosus Moj .................. 22, 23, 168, 171-172 Vogdesi Smith. . . . . . . . . . . . . . . . . . . . . . Ceratitidæ $\ldots \ldots \ldots \ldots \ldots \ldots \ldots \ldots \ldots \ldots \ldots \ldots \ldots 27,30,32-33$, $36,37,104,114-117,122-123,128,150-158,158-203$ Ceratitoidea.........29, 30,32,62,65,82,83, 114-115, 115-203 Choristoceras .............................. 157 Circumplicati Mojsisovics .................... 162-168 See also Dinarites.

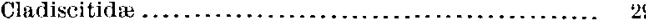

Classification, schemes of .................. 12, 20-28 Clionites Mojsisovics .. 16, 25, 33, 157-158, 180, 181-182, 183-191 angulosus Moj......................... 181 Ares $M o j$.................................. 187 (Neanites) californicus H. and S. 24, 181, 189, 190-191, 382 (Shastites) compressus H. and S ... 24, 181, 188-189,302 Fairbanksi H. and S ........... 24, 182, 183-185, 296, 298 ('Truskites) robustus II. and S...... 24, 181, 186-188, 300 (Stantonites) rugosus H. and S .... 24, 181, 185-186, 298 spinosus Moj................................. 184 Woodwardi Moj ........................... 184

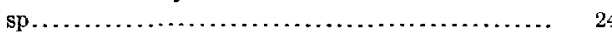

Clydonautilus Mojsisovics...................... 205

biangularis Moj ............................ 207

Quenstedti Moj ............................. 207 triadicus Moj . ................................ 206

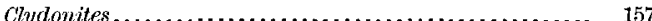
lavidorsatus Meek ........................ 125, 16t Clypites Wargen ...................... 32, 95, 102-108,152

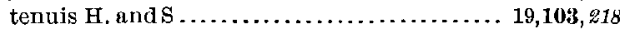
typicus Waag.......................... 102 Cochloceras.................................. 157

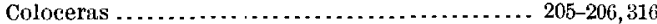
Coloni .......................................... See also Arcestes.

Columbites Hyatt and Smith.... 15, 17, 29, 31, 48, 50-51, 51-52 parisianus Hyatt and Smith ................. 19 $50,51-52,100,120,145,151,218,338,360$

Coliumbites beds, fossils of . . . . . . . . . . 19, 100, 145, 218,860 Continui Mojsisovies ........................... 45 See also Juvavites.

Cordillerites Hyatt and Smith................ 15, $30,32,95,101-102,108,109-110,110-114$ angulatus Hyatt and Smith ............... 19, $92,109,110-113,137,290.952,358,38$ 
Page.

Cosmonautilus Hyatt and Smith....... 16,33, 207, 207-208 Dilleri H. and S....... 24, 207-208, $318,320,322,224,326$ Costati Mojsisovics ....................... 58-59. See also Tropicelitites.

Cottonwood Canyon, Nev., fossils from

Cyclolobida.

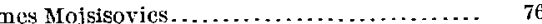
See also Arcestes.

Cymbospondylus Leidy.

$16,22,23$

Cyrtopleurites.

D.

Dalmatites Kittl

82

Danubites Mojsisovies ......................... 15-17, $32,50,89,92,113,117-119,123-124,146,157-158,163-165$

Holli Moj - ...... 125-126,164

himalayanus Gries ....................... 124

Strongi $H$, and $S \ldots \ldots \ldots \ldots \ldots \ldots \ldots \ldots, 20,52,126,165,294$

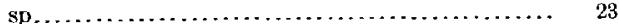

Dqonella..................................... 16,17

dubia Gabb... 22-23, 126, 131, 133, 140, 156, 172, 174, 178, 198

Lommeli Wiss ............................ 22, 23

Daonella beds, fossils of ..................... 17 $21,126,131-132,140,174,880,38 /, 386$

Darælites Gemmellaro........................

Desatoya Mountains, Nev., fossils from .............. 132

Diener, C., classification, plan of

fossil species named for

on Arthaberites.

on Danubites $\ldots \ldots \ldots . . . .16$

on Meekocerus......................... 142, 144, 146

on Meekoceratidæ .......................... 135

on Proptychites.

Dieneria Hyatt and Smith ............. 16,32, 105, 106-107 Arthaberi H. and S........... 24, 105, 106-107, 290, 378

Diller, J. S., fossil species named for.............. 208 Dimorphi Mojsisovies.

See also Juvavites.

Dimorphites ............................... $\quad 45$

Dimorphoceras ........................ 29, 87-88,91-92 atratum fold $\ldots \ldots \ldots \ldots \ldots \ldots \ldots \ldots \ldots \ldots \ldots \ldots . . \ldots 1,884$ Gilbertsoni Phil ......................... 91, 384

Dine ric stage, fossils of $\ldots \ldots \ldots \ldots \ldots \ldots \ldots \ldots \ldots \ldots . .17$

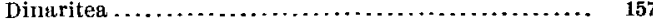

Dinarites Mojsisovics ..................... 16, 32, 104, $124,139,155,157-158,161-162,162-163,168,171,175,382$ avisianus Moj.

bonke-vistæe $\mathrm{H}$, and $\mathrm{s} \ldots \ldots \ldots \ldots \ldots \ldots \ldots .22,162-169,396$

circumplicati Moj ....................... 162-163

evolutus Waag ........................... 1124

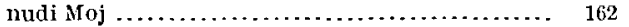

ornatus .............................. 163

spiniplicatus Moj............................ 50

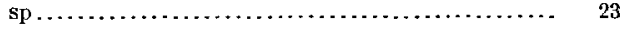

Dinaritinæ............................... 157

Discotropites Hyatt and Smith................ 16,

sindlingensis Hau $25,41,56,62,63-65,160-161,177,196,210,286,288$

Distichites . . ............................ 157 Dunn, L. F., fossil locality found by ............. 23

\section{$\mathrm{E}$.}

East Humbold t Range, fossils from............. 94, 264 Ectolcites.

Encrinus sp.
Page.

Eremites. ......................... 157

Eudiscoceras Hyatt........................ 33, 158,179 Gabbi Meek........................ 22, 179,264

Eumicrotis curta ............................... 18

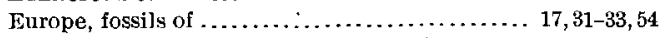
fossils of. See also Alpine provinee; Armenia; Hungary; Mediterranean region; Sicily; Spain; Spitzbergen.

Eutomoceras Hyatt ........ 16, 32, 61-62, 65, 129-131, 131-132 acutum $\mathrm{Moj} \ldots \ldots \ldots \ldots \ldots \ldots \ldots \ldots \ldots \ldots \ldots \ldots, 130$

denudatum Moj ........................ 62, 130 Dunni Smith .......................... 130 Laubei Meek .. 23, 62, 65, 126, 129-130, 131-132, 135, 172, 836

Lauræ Moj ............................... 130

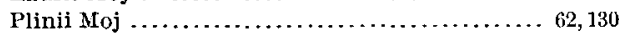
punctatum Moj....................... 62, 30 quinquepuntatum $\mathbf{M o j} \ldots \ldots \ldots \ldots \ldots \ldots \ldots \ldots . \quad 130$ sandlingense Moj...................... 62-63, 130 Sengeli Moj ........................ 62, 130

Theron Ditt............................ 62,130

Eutomocerata punctata ....................... 62

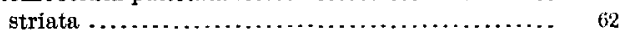

F.

Fairbanks, H, W., fossils found by ............... 69 fossil species named for . . . . . . . . . . . . . . . 185 Flemingites Waagen...... 15, 17,32, 81, 102, 117, 119, 120-121 Russelli Hy ............. 19,92, 113, 121, 137, 144, 218, 356

Flemingites beds, fossils of . ..................... 102

Florianites Hyatt ............................ 163-164

Foltz, Nev., fossils from near . . . . . . . . . . . . . . . . . $22-23$

Foordiceras Hyatt ........................... 209

Frech, F., classification plan of .................. 27-28 on Ammonites............................... 116 on Koninckites ........................... 148 on Meekoceratidæ....................... 135, 142

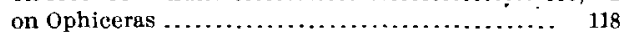
on Paralecanites........................... 136 on Proptychites............................ 84 on Pseudosageceras........................ on Ussuria ................................. 92

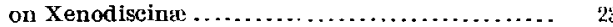

G.

Gabb, W. M., fossils determined by ............... 21, 26 on Celtites ................................ 126 on Halorites ............................ 42 on Sageceras............................. 98

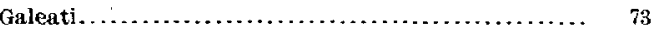
See also Arcéstes.

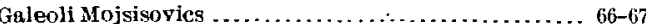
See also Nicrotropites.

Gastrioceras $\ldots \ldots \ldots \ldots \ldots \ldots .37,39,44,50,52,53,55,64,368,374$ Geminati Mojsisovies........................ 172-173 see also Gymnotoceras.

Gemmati Mojsisovics .......................... 166 See also Balatonites.

Genesee Valley, Cal., section in ..................... 26 Geological survey of Austria, acknowledgments to.... 11 Geph yroceratidæ ........................... 30. Glyphioceratidæ........ 27, 29, 35, 37,39, 50, 53, 81, 122, 168, 192 . Gonictites Haidingeri Gabb .................... 97

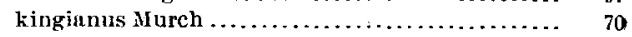
levidorsatus Gabb............................. spurius Muen ............................. Griesbach, C. I., on Proptychites ................... 84 Gymnites Mojsisovics................... 115, 120,122, 141 


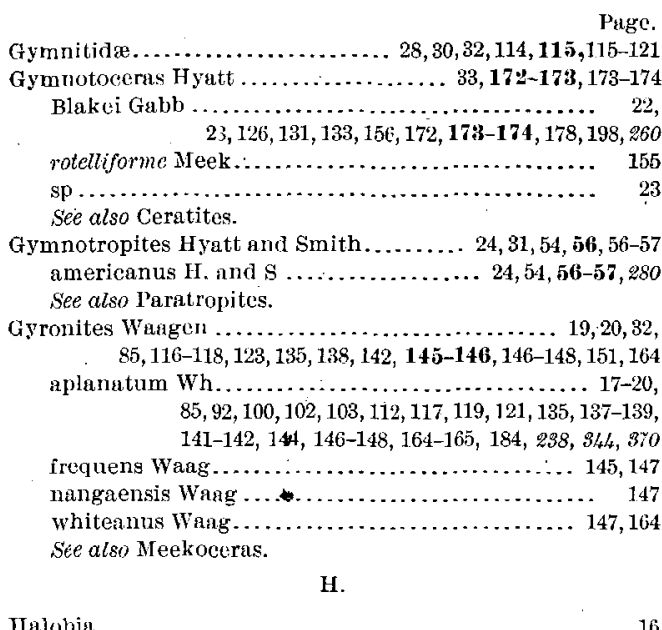

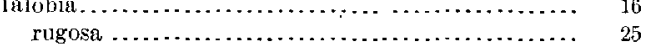
superba $\mathrm{Moj} \ldots \ldots \ldots \ldots 17,24-26,39,56,160-161,177,196,210$

Halobia superba beds, fossils of . . . . . . . . . . . . 17, 25-26

Halorites Mojsisovics................. 16, 31, 39,41,42-43 acatenati Mojsisovies ...................... 42 americunus..................... 26,41,49, 203,274 catenati Mojsisovics ................... 41,42 (Homerites) semiglobosus Hau............... 24

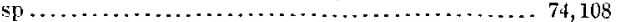
Haloritidi . . . . . . . . . . . . . . . . . . . . . 29,31,35,35-48

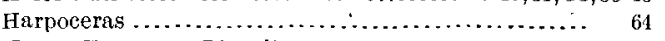
Hauer, F. von, on Dinarites . . . . . . . . . . . . . . . . 163

Hauerites Mojsisovics . .............. 16,32, 104, 104-105 Asculapii Moj ............................. 105 Ashleyi H. and S................. 24, 104-105, 106, 290

Iraug, F, classification plan of .................. 27 on Parapopanoceras ......................... 71

Hedenstromia Waagen ... 15, 32, 95, 100-101, 101-103, 119, 141 Hedenstrcemi............................ $10 \mathrm{~J}$ Kossmati H. and S ...... 19,92, 101-102, 137, 218, 350,38 Mojsisoviesi Dien........................ 101-102 Hedenstrœmia beds, correlation of ................. 19 Helictites ...................................

Heraclitea ................................. 157

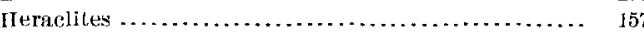

Himulayas, fossils from ....................... 35 $39,46,68,69,79,85-86,88,101,104,121,152,192,194,207$

Homerites Mojsisovics................... 24,31, 42-48 semiglobosus Hat1..................... 43, 272 See also Halorites.

Hoover, 'l. J., fossil species named for ............ 154 Hosselkus limestone, fossils from . .. 16-17, 24-25, 39, 56, 69, $20 \mathrm{~s}$ Hungarites Mojsisovies .................. 15, 16, 22,32, $62,65,82-83,123,127-129,130-131,141-142,158-159,166,168$ Prudoi Vern ................................ 129

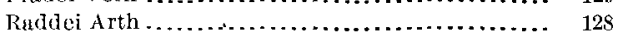

Yatesi $H$, and $s \ldots \ldots \ldots \ldots \ldots \ldots \ldots 17-20,129,250$ Hnongaritide.......28,30,32,94, 114-115, 122-123, 126, 126-135 Hungary, fossils from

Humboldt Mountains, Nev., fossils of See also East Humboldt Range: West Humboldt Range.

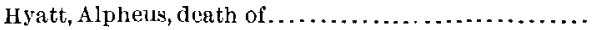
on Arniotites . on Florianites .
, Page.

yatt, Alpheus, on Meekocerus............... 142, 147 work of .................................... 11-12 Hydaspic stage, fossils of $\ldots \ldots \ldots \ldots \ldots \ldots \ldots \ldots \ldots$ it

\section{I.}

Ichthyosauridxe. .................... 24

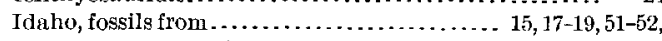
$88,96,101,122,136,143-145,148-149,151,159,164,218$ Sce ulso Aspen Ridge; Paris.

1ndependence, Cul., fossils from near. See Union Wash, Cal.

India, fossils from.................... 15, 17, 19,54,76 $82,102,123,135,138,143,155,159,162,164,170,175,184$ See also Salt Range; Himalayas.

Inermes Mojsisovics. See also Sagenites.

Intermittentes Mojsisovics ....................... 45-46 See also Juvavites.

Tnterrupti Mojsisovics .......................... See also Juvavites.

Intuslabiati... See also Arcestes.

Inyo Range, Cal., fossils from................... 15 $20,49,82-83,89,96,99,113-114,116,150,153,372$ See also Union Wash, Cal.; Union Spring, CaJ.

Inyoites Hyatt and Smith ..................32, 134, 134-135 Oweni H. and $\$$............... 20, 134-135, 298, 354,372 Isculites Mojsisovics.

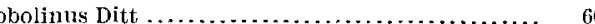

\section{J.}

Jackson, R. T., fossil species named for ............. 152 Jakutic stage, fossils of ...........................

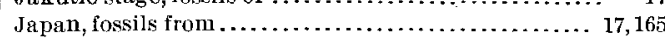
Japonites sp .................................. 22

Jounnites Mojsisovies ................. 16, 31, 76,76-77 cymbiformis Wulf .......................... 76 Gabbi Meek........................ $76,126,198$ nevadanus $H$. and $\mathrm{s} . \ldots \ldots \ldots \ldots \ldots \ldots \ldots .23,76-7 \mathbf{7}, 264$ sp........................................ 25 John Gray's Lake, Idaho, fossils from .......... 144, 148-149 section at ............................... 18 Judicarites Mojsisovies ......................... 166 Juvavites Mojsisovics.......... 16, 25, 31, 14, 45-46, 46-48, 178

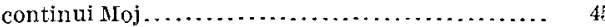
dimorphi Moj............................... 45

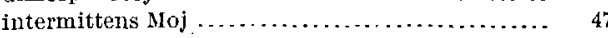
intermittentes $\mathrm{Moj} \ldots \ldots \ldots \ldots \ldots \ldots \ldots \ldots \ldots \ldots, 45,47$ interrupti...................................... rotundus Moj................................ 46 scissi Moj ............................. 45 (Anatomites) subintermittens H.and S... 24,47-48, 27O subinterruptus $\mathbf{M} 0 \mathrm{j} \ldots \ldots \ldots \ldots \ldots \ldots \ldots .24,46-47,276$ Juvavites beds, fossils of ............................ 17,25 $\mathrm{K}$.

Karnic stage, fossils of ................... 17, 24-26, $35,38-39,46-47,53-54,56,59,67,69,76,104,107$ $160,175,182,192-194,196,198,200,266-272,974$ Karpinsky, A., on Pronoritidx .................. 108 Keuper stage, fossils of ...................... 17 Keyserlingites Hyatt ........................ 50 Kingites Waugen ...................... 135, 142, 144 Kittl, E., on Dalmatites ........................ 82

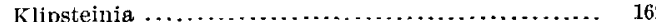
Knecht, C. E., fossil species narned for................ 139 
Page,

Koninckites Waagen ...... 19, 20,32,85, 135, 142, 148-149,152 mushbachanum Wh ....... $92,100,102,103,112,117,119,121,135,137,139$, $141-142,144,148,149,154,165,246,248,252,356$

vetustus Wàng See also Meekoceras.

Kymatites

\section{I.}

Labiati Mojsisovies Sce also Tropites.

Ladinie stage, fossils of $\ldots \ldots \ldots \ldots \ldots \ldots \ldots 17,25,87,192,194$ Laeves Mojsisovics...... Sce also Tropiceltites.

Lanceolites Hyatt und Smith ..... 30,32,95,108, 113,113-114 compactus $\mathrm{H}$. ands

20,$11 ;-114,224,226,372$

Lawson, A. C., fossil species named for ............. 199 Le Conte, Joseph, fossil species named for.

Lecanites Mojsisovics ................... 15, 16,30,32 $60,114,123,135,137-138,138-140,147,154,157-158,238$ gangeticus de Kon....................... 138 glaucus Muen. . ............................... 138 Knechti H, and s . ................. 20, 138-139, 234

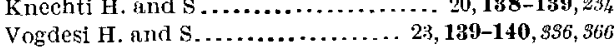
econteia Hyatt and smith............... 16, 29,31,35-36 californica $\mathrm{H}$. and $\mathrm{S} . \ldots \ldots \ldots \ldots \ldots .24,31,35, \mathbf{3 6}-\mathbf{3 7}, 27 \%$ Leiost raca . . . ................ 26-27, 114, 120, 122, 128, 168 Lingula sp.................................... 19

Lobites ..................................... 36

Longobardites Mojsisovies.............. 32, 98, 132, 132-133 breguzzanus Moj nevadanus $\mathrm{H}$. and $\mathrm{S} . . . \ldots \ldots \ldots \ldots . . . . . . .22$, $23,126,131,132-133,172,198,266,332,866$ Zsigmondyi Boeckh ........................ 133 Louderback, G. D., fossil species named for.......... 58 Ly toceratidæ ..................... 29, 30, 32, 92, 98-9.4 Lytoceratoidea $\ldots \ldots \ldots \ldots \ldots \ldots \ldots \ldots \ldots .29,32, \mathbf{9 2 - 9 3}, 93-94$

M.

Mediterancan region, fossils from ................. 54, $57,88,159-160,162,166,170,182,193-194$ Medlicottia Wagen ..................30,95, 108,110, 137 Meek, F. B., fossils determined by on Trachyceras

. , 99, 101,123, 135, 137, 140-143,143-152, 155, 250 (Gyronites) aplanatum Wh

$85,92,100,102,103,112$, $121,135,137-139,141-142,144,146-$ $148,149,154,164-165,238,344,970$

gracilitatis Wh $28,85,92,99-104,112,117,119,121$, $135,137,139,141-143,143-144,145$, $149,151,153-154,165,240,242,244,356$ (Koninckites) mushbachanum Wh........... 17-20, $85,92,100,102,103,112,117,119,121,135,137,139$, $141-142,144,148,149,154,165,246,248,259,956$

boreale Dien....

furcatum Moj

(Prionolobus) Jucksoni $H$. and $s \ldots \ldots \ldots \ldots \ldots \ldots$. $20,52,100,119-120,145,151-152,840$
$\ldots \ldots \ldots \ldots \ldots \ldots \ldots \ldots \ldots \ldots$

Khanikofi Opp maturum Moj.

pilatum $H$. and $\mathrm{S}$. $19,100,120,144-145,151,948$ reutense Bey............................ 155 (Prionolobus) Waageni H. and $\mathrm{S} . \ldots \ldots \ldots \ldots .20,150-151$. sp................................... 19, 20,52
Mickoceras beds, fossils of................. Page. $73,80-83,85,89-90,92,96,100-103,110$ $112-119,121,124,129,134,137-138,144$ $147,151,153-154,165,218-258,344-358$ Meekoceratidæ.. 28, 30́, 32, 94, 114-116, 122-123, 128, 135,136-156 Merriam, J. C., fossil species named for ............. 181 Metacoceras ............................... 207-208

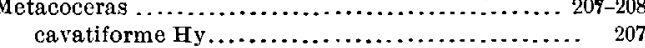
Metatirolites Mojsisovics.... 16, 24, 32, 123, 159, 160, 160-161, 380 foliaceus $\mathrm{Moj} . \ldots \ldots \ldots \ldots \ldots \ldots \ldots \ldots \ldots \ldots .24,160-161$ See also Tirolites.

Microtropites Mojsisovics........................ $\quad 66$ See also Tropites; galeoli.

Mojsisovies, E. von, classification scheme of ........ 26 on Ammonites............................. ${ }_{62}$

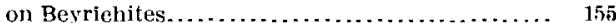
on Celtites ................................. 126 on Ceratites............................... 167-170 on Coratitidx ............................. 157 on Clionites.............................. 181 on Danubites ............................. 164 on Dinarites ............................. 162 on Discotropites ......................... $63-65$ on Eutomoceras .......................... 130 on Gymnotoceras ....................... 172 on Hgloritiđæ. . . . . ........................... 35 on Hanerites. . . . . . . . . . . . . . . . . . . . . . . 104 on Hedenstromia ......................... 101 on Humboldt fanna.......................... ${ }_{22}$ on Juvavites............................. 60

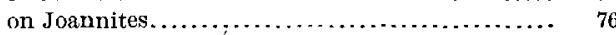
on Longobardites.......................... 132 on Meekoceras............................. 141 on Para popanoceras ........................ $7_{71}$ on Pinacoceratoidea......................... 94-95 on Proptychites............................. 84 on Sagenites $\ldots \ldots \ldots \ldots \ldots \ldots \ldots \ldots \ldots \ldots \ldots \ldots . \ldots \ldots, 40$ on Sirenites.................................. 199 on Tellerites............................... 101 on Tirolites .............................. 159 on Tornquisites....................... $\quad 60$ on Trachyceras............................ 192 on Tropiceltites.......................... 58

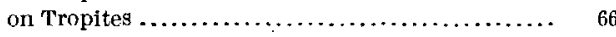
on Xenodisctus........................ 117, 122-123

Mojsvaroceras Hyatt .................. 33, 208-209, 312

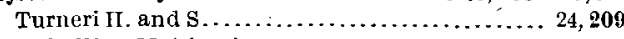
Monophyllites Mojsisovics.................. 32, 03-04

billingsianus Gabb .................... 23, 94, 264 Suessi Moj .................................. 98 Muschelkalk, fossils of ..................... 17, $21-23,25,128,155,163,171,175,192,196,204$ Museum of Comparative Zoology, loan by.......... 11 Muttleberry Canyon, Nev., fossils from.............. 26 Myophoria sp................................. 26

\section{N.}

Nannites Mojsisovies ....................... 15 $17,29,31,78-79,79-84,102,119,232,236,36^{2}$

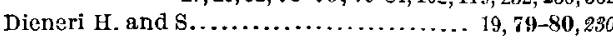
Herberti Dien ............................ 80

hindostanus Dien........................ 80

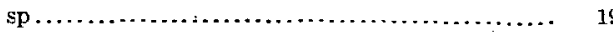
Nannitina Diener........................ $31,77,77-81$ National Museum, United States, loan by......... 11 Nautiloidea............................. 33, 205-210 Nautilus globatus M. and W. . . . . . . . . . . . . . . 205-206 Griesbachi Moj ............................ 205 
rage. utilus triadicus Mo (1050 -200 Whitneyi Gabb $24,33,182,189,190-191$ Neanites Hyatt and Smith californicus $\mathrm{H}$. and $\mathrm{s} . \ldots \ldots \ldots \ldots .24,181,189,190-191,38$ Sce also clionites.

Nevada, fossils from .... 21-23, 53, 57-i8, 72, 76-77,86, 94, 97, 107, $126,130,132,138,155-156,162,165-166,173,196,264$ fossils from. Sce also West Humboldt Runge; Desa toy Mountains; Shoshone Mountains

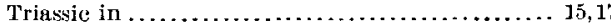
section

Nomismoceras.

Foric stage fossils of $\ldots \ldots \ldots \ldots .16,17 \cdot 25-26,35,38,41,46,59$ $74,104,107-108,182,184,198,200-201,203,274,829$

Norites.................................... 101 Noritidæ......................... 30, 95, 101, 104, 100

Nudi Mojsisovic: See also Dinarites.

0.

Obsoleti Mojsisovies See also Ceratites.

Olenek limestone, correlation of

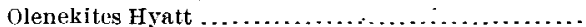

aplanatum $\mathrm{Fr}$ demissum Opp. $89,102,116,117-118,118-120,135,142,145-146,151$

Dieneri II. and S ............... 19,92,113, 118-119, 98 himalayanum Gries....................... $\quad 117$ ptychodes Dien ............................. 119 Spencei H. and S....... 19, 52, 100, 119-120,145, 151, 840

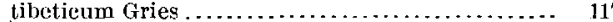
sp.................................... 20 Orthoceras Breyn .................... 33, 204, 209-210 Blakei Gabb ............................ 22,23, 210 shástense H. and $\mathrm{S} . \ldots \ldots \ldots \ldots \ldots \ldots \ldots \ldots . \ldots . \ldots, 24,210,312$

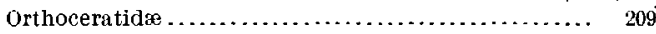
Orthopleuritea............................... 157 Otoceras ............................. 28,123,128,158 Woodwardi ..................................

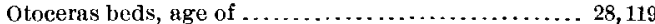
Owenites Hyatt and Smith................... 31,82,83 Kocneni $\mathrm{H}$. and $\mathrm{S} \ldots \ldots \ldots \ldots \ldots \ldots \ldots \ldots \mathbf{1 9}, 82, \mathbf{8 3}, \mathbf{g 3 6}$ Owens Valley, Cal, , fossils from. See Union Wash, CaI.

$$
\text { I. }
$$

Puleozoic fossils, relations of Triassic fossils and table

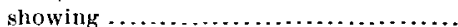
Paraganides Hyatt and Smith . . . . . . . . . 16, 29, 31, 77-78 californicus $\mathrm{H}$. and $\mathrm{s} \ldots \ldots \ldots \ldots \ldots \ldots \ldots 24,77,78,376$

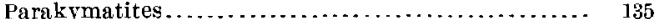

Paralecanites Diener ........................... 30 $32,114-115,123,136,136-137,140,157,168,258$ Arnoldi $\mathrm{H}$. and $\mathrm{S} . \ldots \ldots \ldots \ldots .19,20,113,136-137,344,870$ Paralegoceras . Paranannites Hyatt and smith . . . . . . . . . . 29, 31, 80-81 aspenensis $\mathrm{H}$, and $\mathrm{S} . \ldots \ldots \ldots . .80,81,92,113,137,282,36 \%$.

Purapopanoceras Haug ..... 15, 17, 29, 31, 70, 71, 71-72, 129, 159 Haugi $H$. and $\mathrm{s} . \ldots \ldots \ldots \ldots \ldots \ldots \ldots \ldots, 20,71-72,368$ See also Popanoceras.

Paraprolecanites....................30, 109-110

Paratropites Mojsisovies .. 16, 29, 31, 03-54, 54-57, 61, 64, 66, 173 (Gymnotropites) amerieanus $H$. and S.. 24, 54, $\mathbf{5 6 - 5 7 , 2 8 0}$ bidichotomus Moj. Dittmari Moj.
Page. ratropites saturnus Ditt.................. 53,55-06 Sellai Moj ......... 24-25,53, 54-56, 161,177, 196, 976,278 sp - . See also Tropites

Paris, Idaho, fossils from near. . 19, 52, 145, 151, $398,940, \$ 42,360$ Parodoceras ................................. $\quad 362$

Paulotropites Mojsisovies........................ 66 See also Tropites; Labiati.

Peale, A. C., fossils found by ................... 19, 144

Pelecypod beds, fossils of ........................ 17

Pericyclus Mojsisovies....................... 35

Phillippi, E., fossil species named for.............. 205

Phylloceratida................................ 89

Phylloceratide .......................... 29,92-98

Pinacoceras platyphyllum Moj ................. 107

Pinacoceratide. . . ..................... $50,32,95,95-108$

Pinacocerutoidea $\ldots \ldots \ldots \ldots \ldots \ldots \ldots, 29,30,32,94-95,95-114$

Pit ionmation, fossils of ...................... 17, 25

Placites Mojsisovies................... 16,32, $95,107,107-108$ humboldtensis II, and S..... 17, 26, 74, 107-108, 203, 32s

Plococeras Hyatt ................................. 161

Polyeyclus Mojsisovies...... . 16, 25, 38, 36, 157-158, 201,201-202

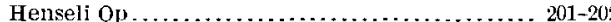
nesturtium. nodifor H. and S.................. 24, $201-202,292$ Popanoceras Hyatt.............. 31, 70,71-72, 75, 123, 290 (Parapopanoceras) Huugi $\mathrm{H}$. and $\mathrm{S} \ldots \ldots \ldots$ 20, 71-72,368

Popanoceratidæ..................... 29, 31, 70,70-7: Prionolobus Wargen ......... 28, $32,52,135,142,150,150-152$ gracilitatis Wh ............................. 143

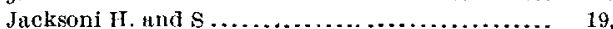
$20,52,100,119-120,145,151-1 \overline{0} 2,340$

- mushbachanus Frech....................... 149 Waugeni H, and S................. 25, 150-151,370 Sce also Meekoceras.

Proarcestes Mojsisovics................. 24, 29, 31, 74-7j

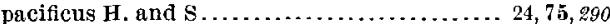
See also Arcestes.

Proceratites Kittl.......................... 11.5, 122

Proclydonautilus Mojsisovics............ 16, 33, 205, 206-207 triadicus Moj.............. 24,56, 206-207, 208, 314,316 Prodromites S. and W................ 30,95-96, 98, 103, 109 Prolecanites ..................... 30, 108-111, 157, 258, 358 Prolecanitidx ................ 27,39, 50,96, 122, 157, 168, 192 Pronannites.................................. 362 Pronorites Mojsisovies........................ 30,108

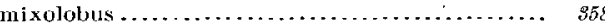
praepcrmicus .............................. 358 Pronoritidæ ..................... 30, 32, 95, 108-109, 109-114 Propinacoceras Gemmellaro................... 108-112

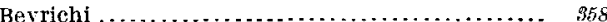

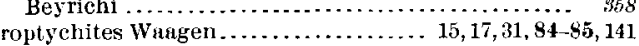

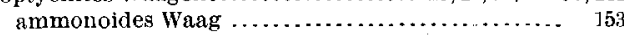
Walcotti H. and $\mathrm{S} \ldots \ldots \ldots \ldots \ldots \ldots \ldots \ldots \ldots, 20,85,254$ Proptychites beds, age of ....................... 28

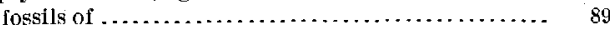
Prosphingites Mojsisovics.................. 31, 72,72-78

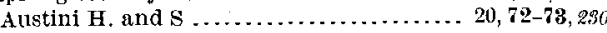
Czekanowskii Moj........................ 72 Iratophiceras Hyatt............................. 161 Protrachyceras Mojsisovics......................... 24 $33,158,191-192,193-194,194-196,198$ Archelaus Laube ............................. 194 chiesense Moj................................

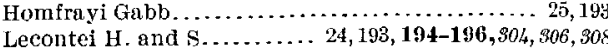
Rudolphi Moj ............................... 193 subasperum Meek ......................... 193-194 See also Trachyceras. 
Pseudodinarites Hyatt.

Page.

Pseudomonotis

idahoensis White. subcirularis Gabb......... 16,17, $21,24,26,42,74,108,203$ Pseudomonotis beds, fossils of ....16-17, 2 5-26, 74, 203, 928-930 Pseudosageceras Diener ...................... 15, $17,28,32,52,81,89,95,98-09,99-102,109,121$ intermontanum $\mathrm{H}$. and $\mathrm{S} . \ldots \ldots \ldots, 19,20,52,92,99-100$, $113,117,120,135,137,144,145,149,151,224,226, \$ 42$ Ptychites Mojsisovics........ 15, 16, 22, 31, 84, 86, 87, 115, 159 Heeki H. and s .......................23,87,266

? perplanus Meek. .......................... 22,23 Ptychitidœ Mojsisovics ....................... 29, $81,77,77-88,94,114-115,123,128,135,155$ Ptychitinæ ......................... 31,81-82, 82-87 Ptychitoiden...................... 29, 31-32, 7 7, 77-92 R.

Reiflingites Arthaber Reticulati Mojsisovics See also Sagenites. Rhabdoceras Hauer............ 16,33,41, 157-158, 202-203
Russelli ................. 17, 26,42,74, 108, 208, s10, 328 Suessi Hau............................... 202-208

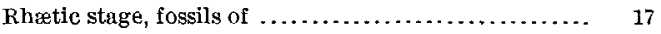
Rhynchonella sp ........................... 19

s.

Sageceras Mojsisovies. $32,95,97,97-98$ Gabbi Moj.......... 23, 97-48, 131, 133, 172, 266, 864,866 Haidingeri Hauer ........................ 98 hauerianum de Kon.

Sagenites Mojsisovics ... 16, 25. 29, 31, 36, 37-38,38-41, 192,272 erinaceus Ditt. (Trachysagenites) Herbichi Moj ............... $25,39-41,56,160-161,177,210,268,270,272$

inermes Moj . reticulati $\mathrm{Moj}$ spinosi Moj.

St. Cassian formation, fossils of. Salt Range, India, fossils from ......... 49 $85,97,103,116,121,138,152,178$ 24, $200-201,810$ Schistoceras $24,200-201,310$

Schuchertites Smith $\ldots \ldots \ldots \ldots \ldots \ldots \ldots \ldots \ldots \ldots \ldots \ldots,{ }_{95}$

Seissi Mojsisovics.............................. $45-46$ See also Juvavites.

Seythic stage, fossils of

Shastasaurus.... pacificus Merriam

Shastites Hyatt and smith......... 24,33,182, 185, 188, 188-189 compressus H. and S............. 24, 181, 188-189, 302 See also Clionites.

Shoshone Mountains, Nev, fossils from......... 167, 262 Shlimardites..

Siberia, fossils of .................. 15, 17, 19,49, 82, 86, $88-89,94,99,101,116,135,143,147,162,165,170,173$

Sibirites Mojsisovics................ 31, 44, 48-49, 49-50 hireinus Waag.

Noetlingi $H$. and $S \ldots \ldots \ldots \ldots \ldots \ldots \ldots \ldots .20,49-50,284$ pretiosus Moj.

Sibiritida $29,31,48,48-52$

Sibyllites Mojsisovics....................... $31,53,57,58$ Louderbacki $\mathrm{H}$. and $\mathrm{S} . \ldots \ldots \ldots \ldots \ldots \ldots \ldots \ldots \ldots . \ldots \ldots, 864$ planorbis Hau. tenuispinatus Moj. $0,108,110-112,220$ Sicily, fossils from ............................... 134 Sirenites Mojsisovics.............. 33, 157-159, 198, 198-199 Lawsoni $H$. and $\$$................. 24, 198-199, s08, $\$ 10$ Smith, J. P., classification plan of................. 28 collections made by ......... 11, 18-19,22, 25-26, 41, 83, 85 fossils determined by .................. Soda Springs, Idaho. See Wood Canyon.

Spain, fossils from . . ........................ 129 Spence, R.S., collections made by .............. 19, 100,145 fossil species named for . ..................... 120 Spinosi Mojsisovies......................... 38,66 See also Sagenites; Tropites; Metatirolites.

Spiriferina beds, fossils of .................... 17,25 Spitzbergen, fossils from ....................... 94 Stacheoceras Gemmellaro......................... 75,290 Stantonites Fyatt and smith ..... 24, 33, 182, 185, 185-186, 189 rugosus $\mathrm{H}$. and S................ 24,181, 185-186, 298 See also Clionites.

Star Peak limestone, fossils of ................. 16, 26

Stephanites Waagen........................44, 59

Strong, A. M., fossil species named for .............. 165

Sturia Mojsisovies ......................... 87-88, 117

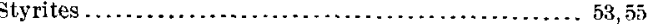

Reinischii Moj............................

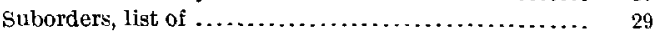

T.

Tardeceras Hyatt and Smith................ 31,44 parvum $H$, and $S \ldots \ldots \ldots \ldots \ldots \ldots \ldots \ldots \ldots \ldots, 24,44,87 / 4$

Tellerites Mojsisovics............................ 101

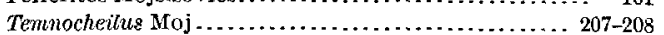
Neumayri Moj ............................ 208

Terebratula angustata Hall .................... 18 semisimplex White......................... 18

Thalassoceras Gemmellaro............ 29, 87-88, 91-92, 348 Gemmelharoi Karp ..................... 91,384 Phillipsi Gem........................... 91, 884

Thalassoceratide .................... 29, 32,87-88, 88-92 Timanites ................................ 30,96 Tirolíc stage, fossilis of $\ldots \ldots \ldots \ldots \ldots \ldots \ldots \ldots \ldots \ldots, 17,22$ Tirolites Mojsisovics ....................... 15, 17 $32,104,129,157-158,158-159,159-162,166,168,171$, $175,180,182-183,189-190,192,197,199-200,298,382$ cassianus Quen .......... 19, 159 (Metatirolites) foliaceus Ditt .......... 24, 160-161, 380 Haueri $\mathrm{Moj}_{\ldots} \ldots \ldots \ldots \ldots \ldots \ldots \ldots \ldots \ldots \ldots \ldots \ldots \ldots, 19$ pacificus $\mathrm{H}$. and $\mathrm{S} \ldots \ldots \ldots \ldots \ldots \ldots \ldots \ldots \ldots 20, \mathbf{1 5 9 , 2 5 8}$ Smiriagini Moj ........................... 19

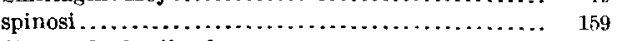

Tirolites beds, fossils of ......................... 159

Tirolítine ............................... 157, 159

Tornquist, Alexander, fossil genus named for ......... 60 on Ccratites. ............................ 169 on Humboldt fauna ............................. 22

Tornquistites Hyatt and Smith.......... 31, 59-60, 60-61 evolutus $H$. and $S \ldots \ldots \ldots \ldots \ldots \ldots \ldots \ldots 24,59,60-61,280$

Toula, F., on Hungarites....................... 87

Trachyceras Jaube .......................... $25,33,38-39,157-159,166,168,191-193,193-199$

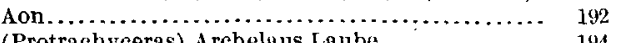
(Protrachyceras) Archelaus Laube............. 194 Brotheus ................................ 199 canadense Whit $. . \ldots \ldots \ldots \ldots \ldots \ldots \ldots \ldots \ldots \ldots, 193$ (Protrachyceras) chiesense Moj............... 193

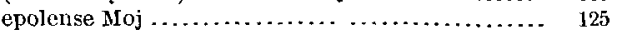
(Protrachyceras) Homfrayi Gabb . . . . . . . . . . 25, 193 
Trachyceras judicaricum Meek

193, 194-196, 304, 306,308 (Anolcites) Mecki Moj. $126,131,133,172,193,196-198,394,964$

(Protrachyceras) Rudolphi Moj.

(Protrachyceras) subusperum Mcek............ 193-194 (Anolcites) Whitneyi Gabb................. 22-23,

. $\quad 58,126,133,140,156,172,174,178,193,198,264$

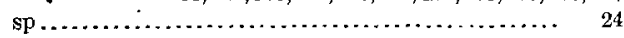

Trachyceras Homfrayi beds, fossils of................ 17,25

Trachycerata ........................... 157, 192, 197

Trachyostraca ....................... 26-27, 114,128

Trachysagenites Mojsisovics........... 24, 31, 38-39, 39-41 erinaceus Ditt ........................... 39 Herbichi Moj. 24-25, 39-41, 56, 160-161,177, 210, 268, 2970, 뭉ํㅇ See also Sagenites.

Traskites Hyatt and smith ...... 24, 33, 182, 185, 186, 186-189 robustus $\mathrm{H}$ and $\mathrm{S} . \ldots \ldots \ldots \ldots \ldots \ldots .24,181,186-188,300$ See also Clionites.

Triassic, fossils of, lists of. fossils of, relations of palcozoic fossils and, figure showing ............................ 34 oceurrence and thickness of ................... 15

Triassic, Lower, occurrence and fossils of ....... 15, 17, 18-20

Triassic, Middle, occurrence and fossils of.... 15-17, 20-23, 25

Triassic, Upper, occurrence and fossils of....... 16-17, 23-26

Tropiceltites Mojsisovies. .............. 31, 55, 58-59, 59, 64

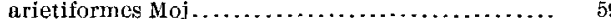

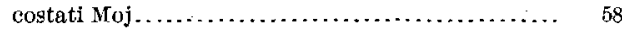

Frechi H. and $s \ldots \ldots \ldots \ldots \ldots \ldots \ldots \ldots \ldots \ldots 24,69, \$ 76$

laeves $\mathrm{Moj}$................................. 58

rotundus................................. 58,59

Tropites Mojsisovies ........................ 16, $25,29,31,50-51,54-55,64,65 \sim 67,67-69,117,178$

æquabiles Moj .

bullati Moj .......................... 62,66

Dilleri $\mathrm{Sm}$............................... 24

galeoli Moj .............................6, $66-67$

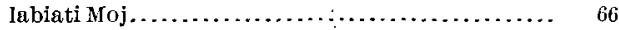

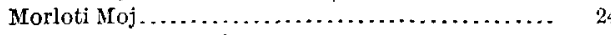

(Paratropites) Sellai Mloj.

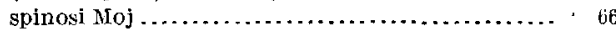

subbullatus Hau.... 16, 17, 25, 26, 36-37, 39, 41, 43-44, 56, 61, 67-69, 160-161,177, 188, 198, 196, 210,282,284, 37/

torquillus $\mathrm{Moj} \ldots \ldots \ldots \ldots \ldots \ldots \ldots \ldots \ldots \ldots 24,67,177$

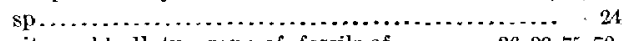

Tropites subbullatus, zone of, fossils of ....... $36,39,75,78$, $105,107,160,175,181,185-186,188-190$, $198-203,205-206,208-209,274,974-38$

Tropitidæ.... 29,31, 52-53, 53-69, 114, 122-123, 128, 130, 173, 192 Tropitoíden............................ 29,31,35-69

Turner, H. W., collections made by........... 11, 123, 129 fossil species named for.

U.

Union Spring, CaI., fossils from near........ 20,135, 151, 165 Union Wash, Cal, fossils on.................. 72-73,80,85, $100,102,117,123-124,129,144,148-149,151$ $154,159,222,226-230,234,286,244,250-258$
Page.

Ussuria Diener . . ... 15, 17, ‘8, 29, 31, 87, 88-89, 89-92, 99, 102, 149 compressa H. and S............. 20,88, \$9.90,92,222 Iwanowi Diei ....................... 88,90-92,384 Schumaræ Dien. . . . . . . . . . . . . . . . . . . . . $90-92$

Waageni $\mathrm{H}$. and S... 19, 88, 90-92, 113, 144, $346,348,950,386$ Ussuritidæ Hyatt . . . . . . . . . . . . . . . . . . . . . .89 $\mathrm{V}$.

Vogdes, A. W., fossil species named for. 140

W.

Wuagen, W., classification scheme of ............... 27 fossil species named for...................... on Ambites ................................ 106

on Beyrichites............................. 155

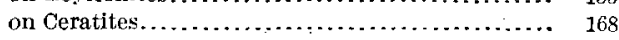
on Flemingites ............................ 120

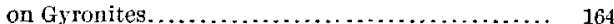

on Hedenstrœma ........................... 101

on Meckoceras............................. 142

on Meekoceratidæ ........................... 135

on Noritidx . . . . . . . . . . . . . . . . . .

on Proptychites.............................. 84

on Xenaspis ............................... 115

on Xenodiscus........................ 115, 118, 122 Waleott, C. D., fossils found by .................. 134 Werfen beds, fossils of ......................... 159

West Humboldt Range, Nev., fossils from...... 15-16, 21-22, $26,42,62,74,87,94,108,125-126,131$, $133,140,156,163,170,172-174,178-179$, $198,203,210,260-266,328-396,964,366$

White, C. A., fossils described by ................. 18 Whitney, J. D., collections by ........................ 138,174 Wood Canyon, Idaho, fossils from .............. 96, 144

Wyoming, fossils from ........................... 18 Wyomingites Hyatt....................... 140, 145, 147

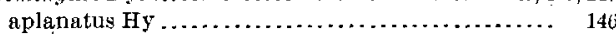
$\mathbf{x}$

Xenaspis Waagen............ $116-118,128,128,141-142,147,157-158$ aplanata Waag............................ 146 carbonaria Waag . . . . . . . . . . . . . . . . . . 117,122 Nareoni H. and S.................... 20, 116-117, 230 Xenodiscin ${ }^{2} \ldots \ldots \ldots \ldots \ldots \ldots \ldots \ldots \ldots \ldots \ldots . .28,123,128$

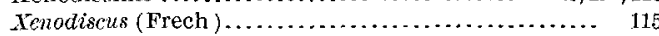
Xenodiscus Waagen............... 15,32, 50,115-116,118, 192-123, 123-124, 128-129, 137, 141-142, 146, 157-159 aplanatus Moj.............................. 146 Bittneri H. and S............ 17,20, 123-124,256,258 Karpinskyi Moj.......................... 117 plicatus Wuag ...................... 116-117, 122-123

r.

Yates, I. G., fossil named for.................. 129

Z.

7.jttel, K. A, von, on Trachyceras.................. 192 


\section{PUBLICATIONS OF UNITED STATES GEOLOGICAL SURVEY.}

[Professional Paper No. 40.]

The serial publications of the United States Geological Survey consists of (1) Annual Reports, (2) .Monographs, (3) Professional Papers, (4) Bulletins, (5) Mineral Resources, (6) Water-Supply and Irrigation Papers, (7) Topographic Atlas of the United States-folios and separate sheets thereof, (8) Geologic A tlas of the United States-folios thereof. The classes numbered 2, 7, and 8 are sold at cost of publication; the others are distributed free. A circular giving complete lists may be had on application.

Most of the above publications may be obtained or consulted in the foliowing ways:

1. A limited number are delivered to the Director of the Survey, from whom they may be obtained, free of charge (except classes 2,7 , and 8 ), on application.

2. A certain number are allotted every member of Congress, from whom they may be obtained, free of charge, on application.

3. Other copies are deposited with the Superintendent of Documents, Washington, D. C., from whom they may be had at practically cost.

4. Copies of all Government publications are furnished to the principal public libraries in the large cities throughout the United States, where they may be consulted by those interested.

The Professional Papers, Bulletins, and Water-Supply Papers treat of a variety of subjects, and the total number issued is large. They have therefore been classified into the following series: A, Economic geology; B, Descriptive geolugy; C, Systematic geology and paleontology; D, Petrography and mineralogy; E, Chemistry and physics; F, Geography; G, Miscellaneous; H, Forestry; I, Irrigation; J, Water storage; K, Pumping water; I, Quality of water; M, General hydrographic investigations; $\mathrm{N}$, Water power; O, Underground waters; P, Hydrographic progress reports. This paper is the fortyfifth in Series B, the sixty-eighth in Series C, and the twenty-eighth in Series $O$, the complete lists of which follow. (PP=Professional Paper; $\mathrm{B}=$ Bulletin; WS=Water-Supply Paper.)

SERIES C. SYSTENATIC GEOLOGY AND PALEONTOLOGY.

B 3. Fossil faunas of Upper Devonian, along the meridian $76^{\circ} 30^{\prime}$, from Tompkins County, New York, to Bradford County, Pennsylvania, by H. S. Willians. 1884. $36 \mathrm{pp.}$ (Out of stock.)

B 4. Mesozoic fossils, by C. A. White. 1884 . 36 pp., 9 pls. (Out of stock.)

B 10. Cambrian fammas of North America; preliminary studies, by C. D. Walcott. 1884.74 pp., 10 pls. (Ont of stoek.)

B 11. Quaternary and recent Mollusca of the Great Basin, with descriptions of ncw forms, by R, Ellsworth Call. Introduced by a sketeh of the Quaternary lakes of the Great Rasin, by G. K. Gilbert. 1884.66 pp., 6 pls.

B 15. Mesozoic and Cenozoic páleontology of California, by C. A. White. 1885. 33 pp. (Out of stock.)

B 16. Higher Devonian faunas of Ontario County, New York, by J. M. Clarke. 1885. 86 pp., 3 pls.

B 18. Marine Eocene, fresh-water Miocene, and other fossil Mollusca of western North America, by C. A. White. 1885.26 pp., 3 pls.

B 19. Notes on the stratigraphy of California, by G. F. Becker. 1885.28 pp. (Out of stock.)

B 22. New Cretaceous fossils from California, by C. A. White. 1885.25 pp., 5 pls. (Out of stock.)

B 24. List of marine Mollusca, comprising the Quaternary fossils and Recent forms from American localities between Cape Hatteras and Cape Roque, including the Bermudas, by W. H. Dall. 1885. $336 \mathrm{pp}$.

B 29. Fresh-water invertebrates of the North American Jurassic, by C. A. White. 41 pp., 4 pls.

B 30. Second contribution to the studies on the Cambrian faunas of North America, by C. D. Walcott. $1886.369 \mathrm{pp} ., 33$ pls. (Out of stock.)

B 31. Systematic revicw of our present knowledge of fossil insects, including myriapods and arachnids, by $\mathrm{S}$. H. Scudder. 1886. $128 \mathrm{pp}$.

B 34. Relation of the Laramie molluscan fauna to that of the succeding fresh-water Eocene and other groups, by $\mathbf{C}$. A. White. 1886.54 pp., 5 pls.

B 37. Types of the Laramie lora, by L. F. Ward, 1887.354 pp., 57 pls. 
B 41. Fossil faunas of the Upper Devonian-the Genesee section, New York, by II. S. Williams. 1887. 121 pp., 4 pls. (Out of stock.)

B 43. Tertiary and Cretaceous strata of the Tuscaloosa, Tombigbee, and Alabama rivers, by E. A. Smith and L. C. Johnson. 1887. $189 \mathrm{pp} ., 21 \mathrm{pls}$.

B 51. Invertebrate fossils from the Pacific coust, by C. A. White. 1889.102 pp., 14 pls. (Out of stock.)

B 56. Fossil wood and lignite of the Potomac formation, by F. H. Knowlton. 1889 . 72 pp., 7 pls.

B 63. Bibliogruphy of Paleozoic Crustacen from 1698 to 1889, including a list of North American species, and a systematic arrangement of genera, by $\mathrm{A}$. W. Vogdes. 1890. $177 \mathrm{pp.}$

B 69. Classed and annotated bibliography of fossil insects, by S. H. Scudder. 1890. 101 pp.

B 71. Index to known fossil insects of the world, including myriapods and arachnids, by S. H. Scudder. 1891.744 pp.

B 77. The Texan Permian and its Mesozoic types of fossils, by C. A. White. 1891. 51 pp., 4 pls.

B 80. Correlation papers-Devonian and Carboniferous, by H. S. Williams. 1891. 279 pp. (Out of stock.)

B 81. Correlation papers-Cambrian, by C. D. Walcott. 1891.447 pp., 3 pls. (Out of stock.)

B 82. Corrolution papers-Cretaceous, by C. A. White. 1891.273 pp., 3 pls. (Out of stock.)

B 83. Correlation papers-Eocene, by W. B. Clark. 1891. 173 pp., 2 pls.

B 84. Correlation papers-Neocene, by W. H. Dall and G. D. Harris. 1892. 349 pp., 3 pls. (Out of stock.)

B 85. Correlation papers-The Newark system, by I. C. Russell. 1892. $344 \mathrm{pp} ., 13 \mathrm{pls.}$ (Out of stock, )

B 86. Correlation papers-Archean und Algonkian, by C. R. Van Hise. 1892.549 pp., 12 pls. (Out of stock.)

B 87 . Synopsis of American fossil Brachiopoda, including bibliography and synonymy, by Charles Schuchert. 1897. $464 \mathrm{pp}$.

B 88. Cretaceous Foraminifera of New Jersey, by R. M. Bagg, jr. 1898.89 pp., 6 pls.

B 93. Some insects of special interest from Florissunt, Colo., and other points in the Tertiaries of Colorado and Utah, by S. H. Scudder, 1892.35 pp., 3 pls. (Out of stock.)

B 97. Mesozoic Echinodermata of the United States, by W. B. Clark. 1893. 207 pp., 50 pls.

B 98. Flora of the outlying Carboniferous basins of southwestern Missouri, by David White. 1893.139 pp., 5 pls.

B 101. Insect fatuna of the Rhode Island coal field, by S. II. Scudder. 1893,27 pp., 2 pls.

B 102. Catalogue and bibliogruphy of North American Mesozoie Invertebrata, by G. B. Boyle. 1893.315 pp.

B 105. The Laramie and the overlying Livingston formation in Montana, by W. II. Weed, with report on flora, by F. $H$, Knowlton. 1893.68 pp., 6 pls.

B 106. Colorado formation and its invertebrate fauna, by T. W. Stanton. 1893. 288 pp., 45 pls. (Out ol stock.)

3 110. Paleozoic section in the vicinity of Three Forks, Mont., by A. C. Peale. 1893. 56 pp., 6 pls.

B 120. Devonian system of eastern Pennsylvania and New York, by C. S. Prosser. 1895. 81 pp., 2 pls. (Out of stock.)

B 121. Bibliography of North American paleontology, by C. R. Keyes. 1894.251 pp.

B 124. Revision of North American fossil cockroaches, by S. H. Scudder. 1895.176 pp., 12 pis.

B 128. Bear River formation and its characteristic fauna, by C. A. White. 1895.108 pp., 11 pls.

B 133. Contributions to the Cretaceous paleontology of the Pacifie coast: The fauna of the Knoxville beds, by $T$, W. Stanton. 1895. $132 \mathrm{pp}, 20 \mathrm{pls}$.

B 134. Cambrian rocks of Pentisylvania, by C. D. Walcott. 1896. 43 pp., 15 pls.

B 141. Eocene deposits of the middle Atlantic slope in Delaware, Maryland, and Virginia, by W. B. Clark. $1896.167 \mathrm{pp}$., 40 pls.

B 142. Brief contribution to the geology and paleontology of northwestern Louisiana, by T. W. Vaughan, $1896.65 \mathrm{pp} .4 \mathrm{pls}$

B 145. Potomae formation in Virginia, by W. N. Fontaine. 1896, 149 pp., 2 pls. .

B 1.51. Lower Cretaceous gryphæas of the Texas region, by R. T. Hill and T. W. Vaughan. 1898.139 pp., 35 pls.

B 152. Catalogue of Cretaceous and Tertiary plants of North America, by F. H. Knowiton. $1898.247 \mathrm{pp.}$

B 153. Bibliographic index of North American Carboniferous invertebrates, by Stuart Weller. $1898.653 \mathrm{pp}$.

B 163. Fiora of the Montana formation, by F. H. Knowlton. 1900.118 pp., 19 pls.

B’173. Synopsis of American fossil Bryozoa, including bibliography and synonymy, by J. M. Nickles and R. S. Bassler. 1900. $663 \mathrm{pp}$

B 179. Bibliography and catalogue of fossil Vertebrata of North America, by O. P. Hay. $1902.868 \mathrm{pp.}$

B 191. North American geologie formation names: Bibliography, synonymy, and distribution, by F. B. Weeks. 1902. 448pp.

B 195. Structural details in the Green Nountain region and in eastern New York (second paper), by T, Nelson Dale. 1902. 22 pp., 4 pls.

B 204. Fossil flora of the John Day besin, Oregon, by F. H. Knowlton. 1902. 153 pp., 17 pls.

B 205. The Mollusea of the Buda limestone, by G. B. Shattuck, with an appendix on the corals of the Budu limestone, by T. W. Vaughan. 1903.94 pp., 27 pls.

B 206. A study of the fauna of the Hamilton formation of the Cayuga Lake section in central New York, by H. F. Cleland, 1903. 112 pp., 5 pls.

B 210. The correlation of geologicul faunas; a contribution to Devonian paleontology, by H. S. Williams. $1903.147 \mathrm{pp} ., 1 \mathrm{pl}$.

B 211. Stratigraphy and paleontology of the Upper Carboniferous rocks of the Kansas section, by G. I. Adams, G. H. Girty, und David White. 1903. 123 pp., 4 pls.

PP16. Carboniferous formations and faunas of Colorado, by G. H. Girty. 1903.546 pp., 10 pls.

PP 19. Contributions to the geology of Washington, by G. O. Smith and Bailey Willis. 1903. 101 pp., 20 pls.

PP21. The geology and ore deposits of the Bisbee quadrangle, Arizona, by F. T. Ransome. $1904.168 \mathrm{pp} ., 29 \mathrm{pls}$.

PP 24. Zinc and lead deposits of northern Arkansas, by G. I. Adams, assisted by A. H. Purdue and E. F. Burchard, with a section on the determination and correlation of formations, by E. O. Ulrich. 1904.118 pp., 27 pls.

PP 31. Preliminary report on the geology of the Arbuckle and Wiehita mountains in Indian Territory and oklahoma, by J. A. Taff; with an appendix on the reported ore deposits in the Wichita Mountains, by H. F. Bain. $1904.97 \mathrm{pp.,}$ 8 pls. 
PP 32. Preliminary report on the geology and underground water resources of the central Great Plains, by N. H. Darton. 1905. 433 pp., 72 pls.

B 244. Contributions to Dèvo sian paleontology, 1903, by H. S. Williams and E. M. Kindle. 1905. 137 pp., 4 pls.

PP 35. The geology of the Perry basin in southeastern Maine, by G. O. Smith and David White. 1905.107 pp., 6 pls.

PP 36. The lead, zinc, and fluorspar deposits of western Kentucky, by E. O. Ulrich and IV. S. T. Smith. 1905.218 pp., 15 pls.

B 257. Geology and paleontology of the Judith River beds, by T. W. Stanton and J. B. Hateher, with a chapter on the fossil plants, by F. H. Knowlton. 1905,174 pp., 19 pls.

B 266. Paleontology of the Malone Jurassic Formation of Texas, by F. W. Cragin, with stratigraphic notes on Malone Mountain and the surrounding region near Sierra Blanca, Texas, by T. W. Stanton. 1905. 172 pp., 29 pls.

PP 40. The Triassic cephalopod genera of America, by Alpheus Hyatt and J. P. Smith. 1905.394 pp., 85 pls.

Correspondence should be addressed to

The Director,

United States Geological Survey

OCTOBER, 1905.

Washington, D. C. 
